\title{
Leaving a Trail - revealing heritage in a rural landscape by
}

Maria Frances Rodgers 


\title{
Leaving a Trail - revealing heritage in a rural landscape
} by

Maria Frances Rodgers

\author{
A 120-point thesis \\ submitted to the Victoria University of Wellington \\ in partial fulfilment of the requirements for the \\ degree of Master of Landscape \\ Architecture
}

Victoria University of Wellington

School of Architecture

2016 


\section{Abstract}

'Leaving a Trail - revealing heritage in a rural landscape' investigates how landscape architecture can reveal heritage and connect Māori and Pākehā to the land and to the past in rural Aotearoa New Zealand. Our rural landscapes contain rich and varied stories, which, if interpreted and made stronger by being linked together, have the potential to create cultural and recreational assets as well as tourist drawcards.

A starting point for this research based in South Wairarapa was the six sites identified by the Wairarapa Moana Management Team as sites for development. The first design 'hunch' remained the touchstone of the project. With the six Wairarapa Moana Wetlands Park sites forming an 'inner necklace' the aim of this project became creating an 'outer necklace' of revealed heritage sites, a heritage trail.

This thesis was inspired by the depth of Māori connection to the land. Māori consider the natural world is able to 'speak' to humans. The method chosen for this design research is based on landscape architect Christophe Girot's 'Four Trace Concepts in Landscape Architecture'. Girot is interested in methods and techniques that expand landscape projects beyond the amelioration of sites towards the reactivation of the cultural dimensions of sites. As part of this research is to enable connection with the cultural dimensions of sites, or to 'hear the site speak', his method was chosen as a starting point. It was adapted and shaped by previous experience and the experience of this research to form a new method, 'Four Listening Acts in Landscape Architecture'. Through such methods landscape architects can grow their relationship with the land and so better design with the land and for the landscape and its people.

After research, the sites were chosen and grouped into four major routes, Māori, Pākehā settlement, natural system and military, so as to appeal to people with a variety of interests. Of the twenty six trail sites most are already marked and eleven are unmarked. Research into how to reveal these unmarked sites saw three different approaches used. Sites with spaces had their essence intensified to become places. Other sites had objects designed for them directly related to the landscape. The significance of the rest is shown with numbered markers. These three different methods of revealing a site's significance are threaded together into a series, a necklace, creating a trail that contributes a cultural, recreational and tourist resource to South Wairarapa. 
"Landscape is never finished or completed, like a can of preserves; it is an accumulation of events and stories, a continuously unfolding inheritance."

Georges Descombes - "Shifting Sites" 


\section{Acknowledgements}

There are many who have helped me in completing this thesis and who I wish to thank: Greater Wellington Regional Council, for financial support; Tim Porteous and the Wairarapa Moana Management Team, for being partners in this project and generously sharing their time and appreciation of the area; Christine Barnett, archaeologist and South Wairarapa resident, who was a fount of knowledge during the early stages of the project; Wairarapa archivists Gareth Winter and Neil Frances, whose knowledgeable voices were often sought, in person or through books; David Hancock, Destination Wairarapa General Manager, who shared his insight into what the trail could become, and, Rawiri Smith, Ngāti Kahungunu, and his hapū - Ra was there when I first met the lake and has walked alongside me ever since.

Many Wairarapa residents shared their love of their place with me. I wish to thank in particular, the hapū of Pāpāwai, Kohunui and Hurunuiorangi Marae; Joseph Potangaroa and his hapū, who made me welcome at the workshop with Rob McGowan (and thanks to Rob, authority on rongoā Māori, traditional Māori medicine); Reuben Raihania Tipoki, of Lake Ferry, who shared his dreams for Lake Onoke; Kate Mead, Katie Beattie and Emily Greenberg, passionate Featherstonians; John Hodder and Derek Hallett, who shared their passion for the Featherston Military Training Camp site; Phil Dittmer, who showed me around the Featherston Heritage Museum; Graham Hodder, who guided me around the fascinating remains of the Carkeek property; Jill Moon, descendant of Charles Tringham who owned the Pigeon Bush estate in 1896 when the picnic to celebrate the gifting of the lake was held there; Blyss Wagstaff of Heritage New Zealand, who helped in the early stages with the list in appendix C; and Bernard Jervis, chairman of the Featherston Camp Memorial Trust, who sadly died before seeing greater recognition of the camp realised.

Closer to home, my thanks go to Bruno Marques, my supervisor whose unerring positivity, encouragement and wisdom I feel I have benefitted from greatly. And thanks to my thesis group, Ashleigh, Kurt and Megan, who my son rightly called the dream team. Thank you to the rest of my class who have always been happy to help with my computer-related queries, and for your friendship. Thanks too are due to all the university staff who have contributed to my learning over the past five years. Special thanks to the unsung workers - the 'tech guys', the librarians and the administration staff.

Closer yet to home, thank you to my family, who have supported me in so many ways. Without you this truly would not have been possible

- aroha nui. 


\section{CONTENTS}

Introduction

1 The Back Story

4

Wairarapa Moana Wetlands Park 6

Challenges 6

The Preceding Project 10

Initial Design 'Hunch' 12

Landscape Architecture Expressing the Past 14

Relationships with Landscape in Aotearea New Zealand $\quad 16$

Māori Concept of Landscape 17

Making a Place from Space $\quad 20$

2 Girot's Method

3 Landing 26

Making Landing Images $\quad 31$

$\begin{array}{ll}\text { Emerging Patterns } & 40\end{array}$

$4 \quad$ Grounding 51

Seeking the Way $\quad 69$ 
5 Finding 75

Bringing Together the Threads $\quad 75$

Finding/weaving $\quad 88$

Design Principles and Precedent Examples $\quad 88$

Design Ideas Explored and Precedent Examples 99

After Girot's Method 106

6 Founding/Retelling 108

The Trail Markers $\quad 110$

Wairarapa Moana Heritage Trail 113

$\begin{array}{ll}\text { Trail Routes } & 173\end{array}$

Community Inhabitation of the Trail 182

7 Reflection 185

$\begin{array}{ll}\text { On Method } & 185\end{array}$

$\begin{array}{ll}\text { Leaving a Trail } & 187\end{array}$

$\begin{array}{lr}\text { Afterword } & 189\end{array}$

Glossary of the Māori Language - Papakupu o te Reo Māori 191

List of References 193

$\begin{array}{ll}\text { Additional Sources } & 198\end{array}$

$\begin{array}{ll}\text { Sources of Figures } & 200\end{array}$

$\begin{array}{ll}\text { Appendices } & 203\end{array}$ 


\section{INTRODUCTION}

In Europe there are no shortage of examples of landscape architecture interpreting heritage sites in rural as well as urban areas. In contrast, heritage sites in rural New Zealand are often not interpreted. This may be due to a number of factors: the low population of these areas and therefore low availability of funding; the tension between profitable and unprofitable land use; a lack of knowledge of the heritage sites or a lack of value put on them. Our rural landscapes contain rich and varied stories, which, if interpreted and made stronger by being linked together, have the potential to create a cultural and recreational asset as well as a tourist drawcard, e.g., the Otago Central Rail Trail.

This research seeks to answer a series of questions. The first is:

How can landscape architectural interventions reveal heritage and connect Māori and Pākehà to the land and to the past in rural Aotearoa New Zealand?

In order to investigate this, Māori and Pākehā relationships with the landscape in New Zealand will be explored. This research has been inspired by the depth of Māori connection to the land. What landscape architecture can learn from this connection will be discussed and the answer to the following question sought:

Can using Christophe Girot's 'Four Trace Concepts in Landscape Architecture' enable 'hearing the land speak' and the creation of a design that connects people to the land and to the past? 
This research is based in South Wairarapa which is at the bottom of the North Island of Aotearoa New Zealand. In 2008 the Wairarapa Moana Wetlands Project was set up. It is a joint initiative between the Greater Wellington Regional Council, the Department of Conservation, South Wairarapa District Council, Kahungunu ki Wairarapa and Rangitāne o Wairarapa Inc. The group's mission statement is, "We will work with the community to enhance the spiritual identity of Wairarapa Moana, and improve recreational and economic opportunities for the benefit of everyone" (Wairarapa Moana Wetlands Park). A starting point for this research will be the six sites identified by the Wairarapa Moana Management Team as sites they will be developing. Additional sites around the moana will be investigated. These heritage sites will be chosen from Māori sites, sites relating to early Pākehā farming and settlement, battle sites relating to the musket wars, World War One military training sites, natural environment sites and fell railway sites.

\section{How can the connection between the heritage of sites, the existing landscape and landscape processes be shown or made visible?}

This design-led research will endeavour to connect the sites together, forming a heritage trail that will contribute a cultural, recreational and tourist resource to South Wairarapa. 
Using Girot's 'Four Trace Concepts' method will mean a particular approach to designing. Initial site visits will occur without detailed research or site analysis in order to experience the site without predetermined ideas. The final research question is:

How can others be enabled to experience the 'discovery experience' that occurred in the research for this thesis?

Learning the stories and history of the site will come before detailed site analysis, as heritage, and its' interpretation, is to be the focus. Design may begin with the first visits to site - the initial response or impression may be the seeds of a design. Site visits are to continue throughout the research process so as to test the design and experience the site in different seasons and weather. Seeking feedback from stakeholders is an important part of the research process as it is vital both interventions and interpretations are relevant and appropriate for their South Wairarapa setting, the stakeholders and potential visitors.

Please note:

Every effort has been made to use Te Reo Māori correctly in this thesis document. English translations of Te Reo Māori used do not generally appear in the main text as there is a glossary on page 191. Sincere apologies in advance if there are any errors.

All figures not attributed ('Sources of Figures', page 200) are the author's own.

In order to undertake this research ethics approval was obtained from Victoria University Human Resource Committee, approval no. 21875.

The participant information sheet and consent form are to be found in Appendix G. 


\section{THE BACK STORY}

Wairarapa "occupies the south-eastern corner of the North Island [fig. 1.01], east of metropolitan Wellington and south-west of the Hawke's Bay region. It is lightly populated, having several rural service towns, with Masterton being the largest. It is named after its largest lake, Lake Wairarapa [see figs. 1.02 and 1.03]" (Wairarapa).

Fig. 1.01. The location of the maps on pages 4 and 5 on a map of New Zealand.

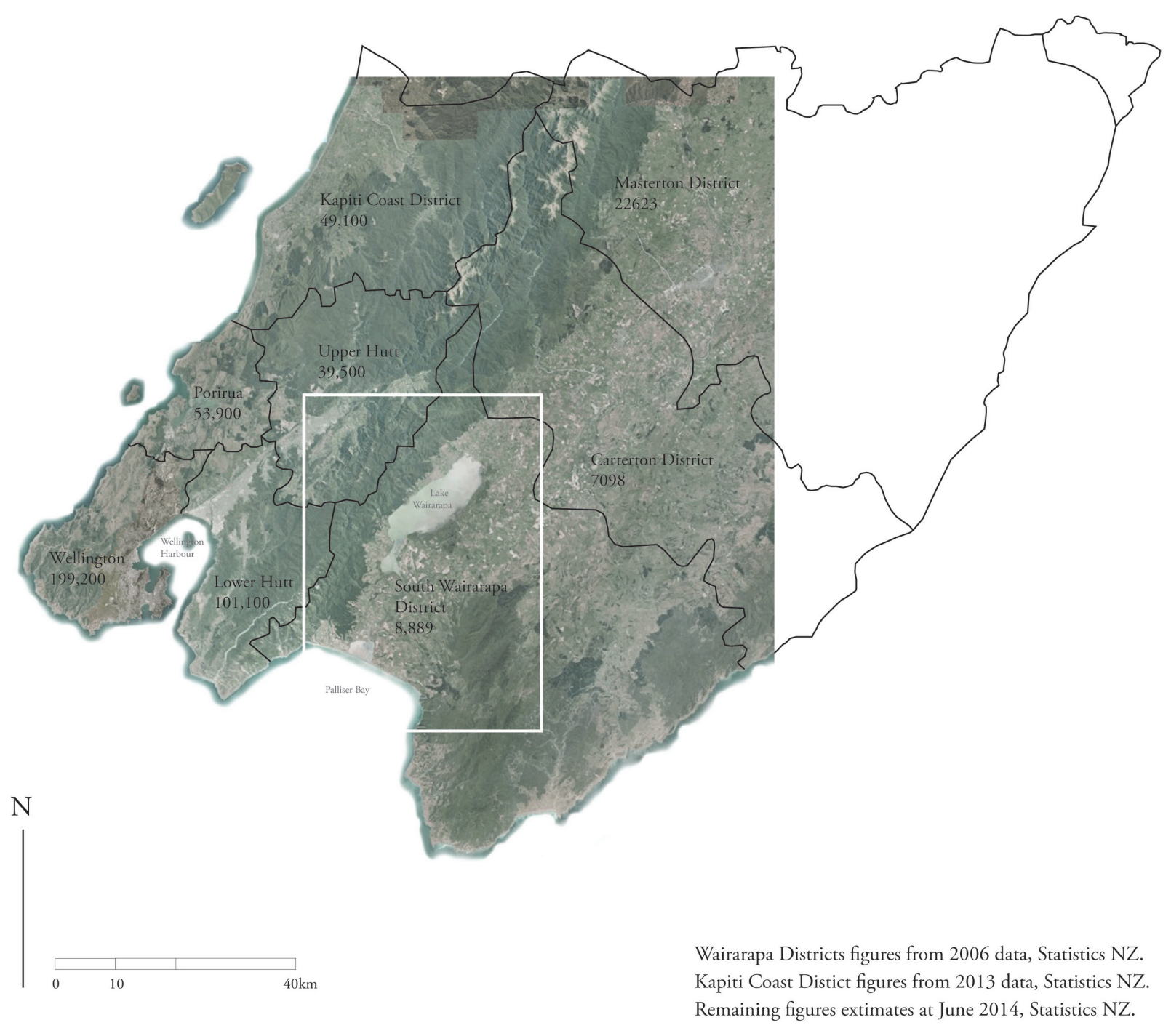

Fig. 1.02. Map showing the approximate current population of Wellington Region. 


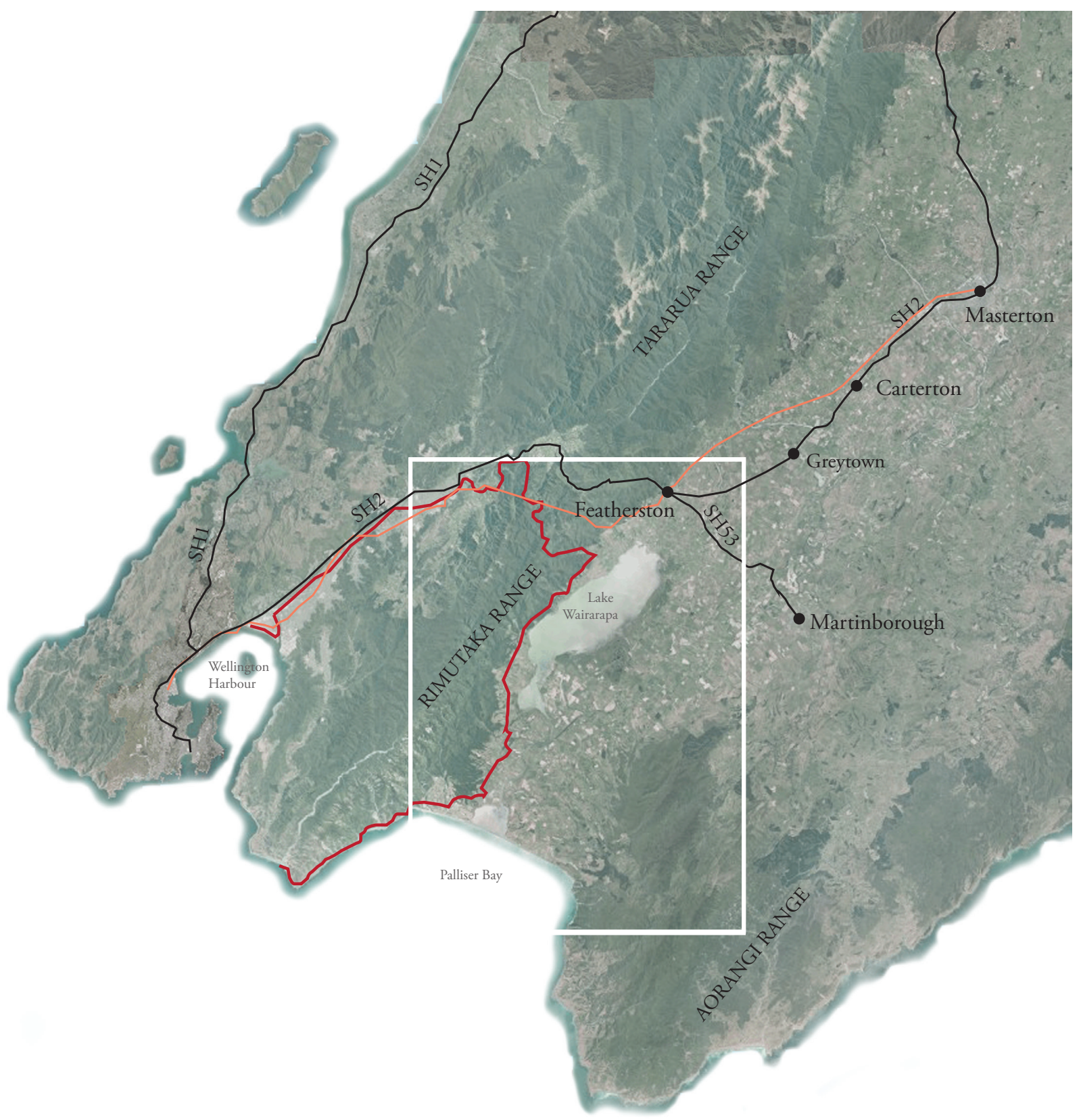

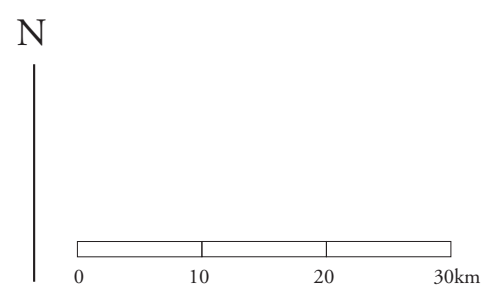

Fig. 1.03. Map showing the urban population and transport of Wairarapa.
Rimutaka Cycle Way, part of Nga Haerenga, The New Zealand Cycle Way

State Highways

Railway

Population figures, estimates at June 2014, Statistics NZ

Masterton 20,800

Carterton 4980

Featherston 2340

Greytown 2330

Martinborough 1550 


\section{Wairarapa Moana Wetlands Park}

The Wairarapa Moana Management Team, in plans for Wairarapa Moana Wetlands Park, decided to develop six sites around Lake Wairarapa and its related water bodies, with each site telling a different story. The sites are Lake Domain, Boggy Pond and Matthews Wildlife Reserve, Wairio Block, Lake Onoke, Onoke Spit and Wairarapa Lake Shore Scenic Reserve (see fig. 1.06). They are spread out around the moana and the aim is for them to be able to be visited singly or that visiting one will encourage visiting others. This research is a part of a thesis group working in partnership with the Management Team who were able to provide information and feedback (see figures 1.04 and 1.05).

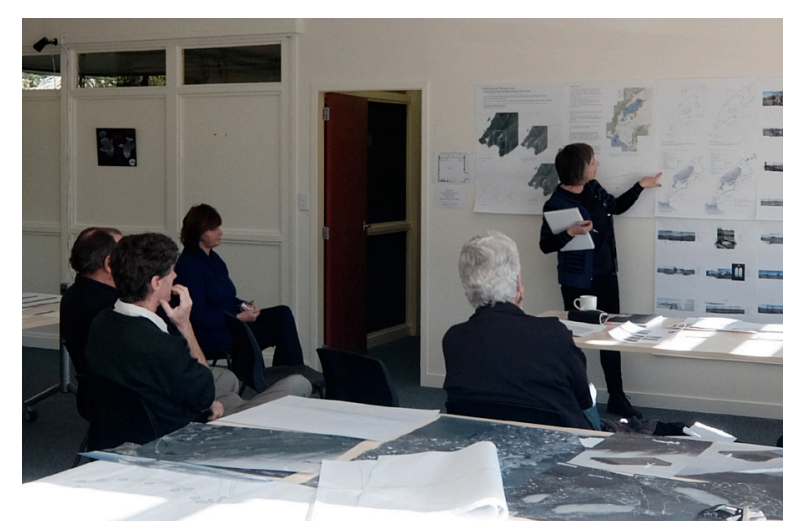

Fig. 1.04. The researcher presenting her design research to members of the Wairarapa Moana Management Team, Featherston, July 2015.

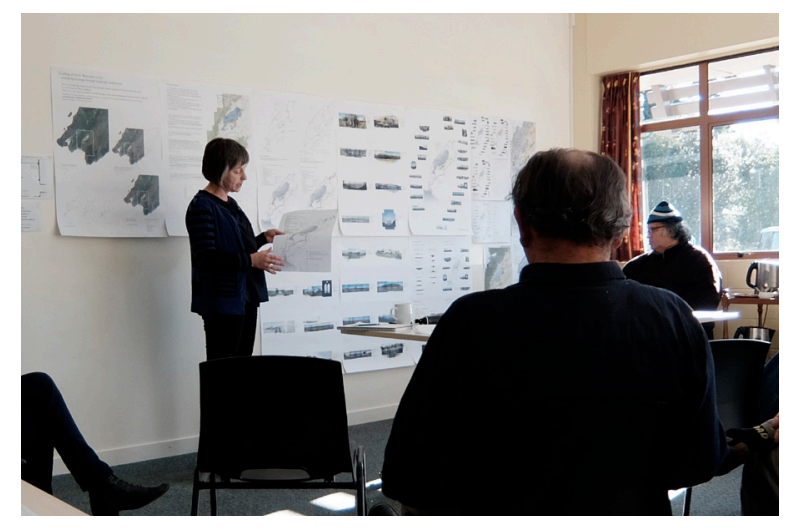

Fig. 1.05. as fig. 1.04 .

\section{Challenges}

There are a number of challenges to this thesis project. South Wairarapa has a low population and therefore a low amount of finance would be available for the construction and maintenance of any intervention limiting the size and cost of what should be designed. The environment is harsh and many of the natural systems are degraded. Many of the heritage site locations are isolated which may mean difficulty in them feeling connected to the rest of the trail. 


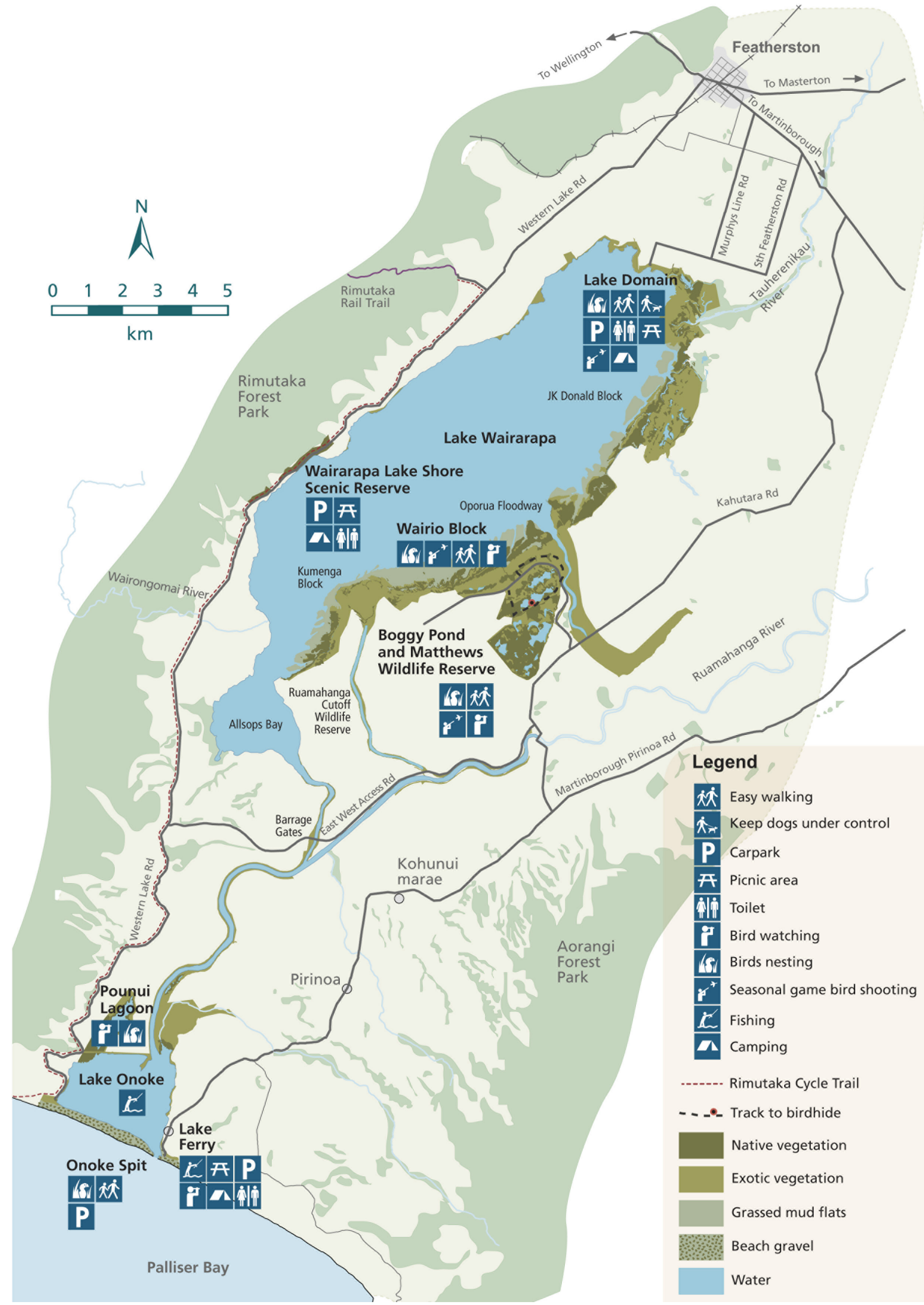

Fig. 1.06. Wairarapa Moana Wetlands Park. 
A further challenge is that many Featherston residents feel their town is seen and treated as a second class town and destination compared to other South Wairarapa towns, Greytown, with its boutique shopping and historic identity, and Martinborough 'wine village'. Perhaps revealing the area's heritage will help improve locals' pride in their surroundings and heritage. In addition, although the lake's name, Wairarapa, means 'glistening waters' painting an idyllic picture, the lake itself has a negative image for many (see figs. 1.07 and 1.08). It is seen as a large degraded area of water threatening to flood and blocking access between either side of the valley. When the lake levels are high, Pākehā see it as in flood and a problem to be alleviated, whereas Māori see the lake as full (Barnett).

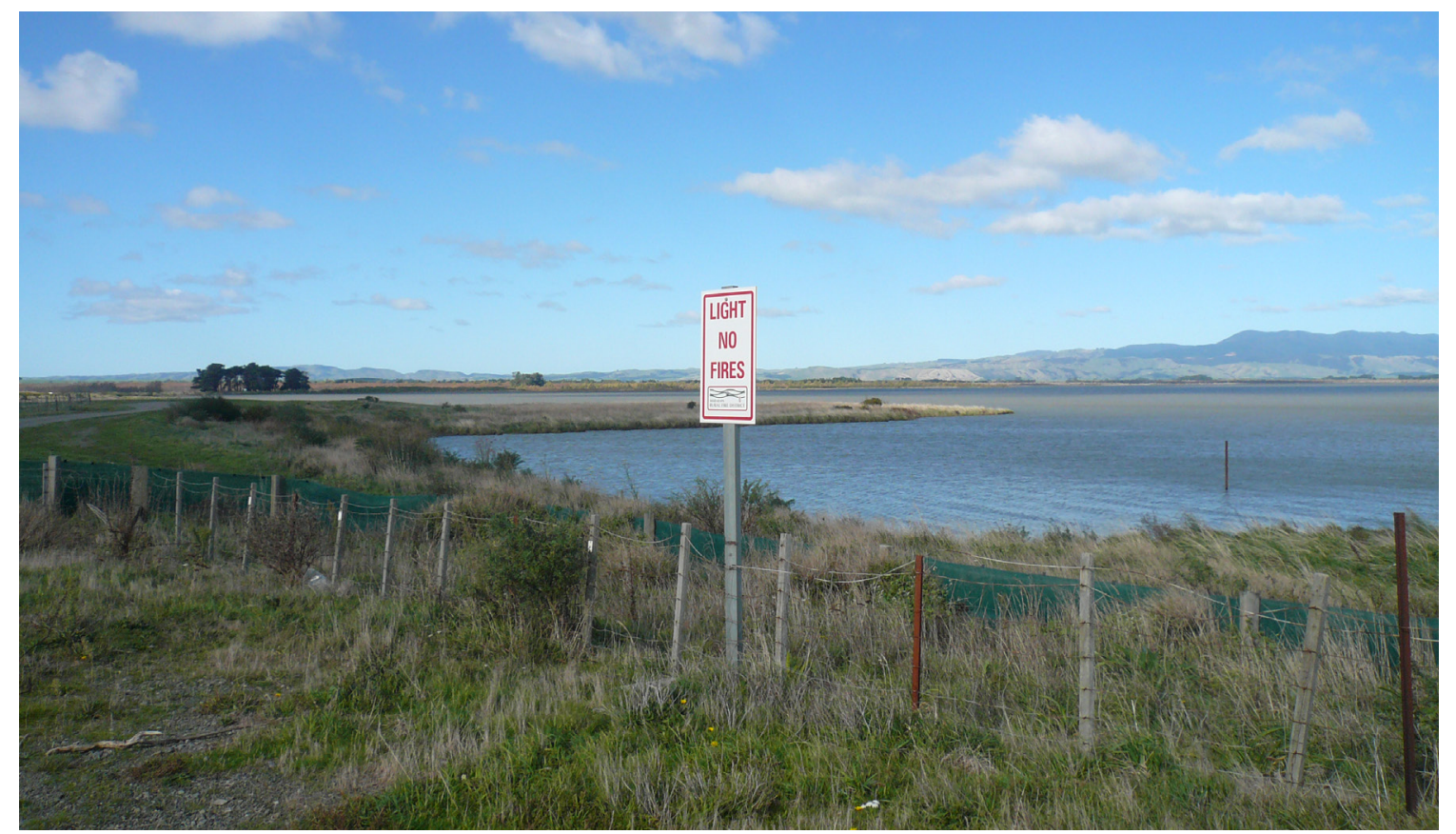

Fig. 1.07. Lake Domain Reserve looking eastward, May 2015. 
Alongside these challenges are existing riches. Wairarapa Moana is revered by Māori as a source of wellbeing for the region. It is the Wellington region's most significant wetland complex and has ecological, cultural and recreational values. A variety of recreational activities take place, including duck shooting, boating, walking, fishing, and there could be more.

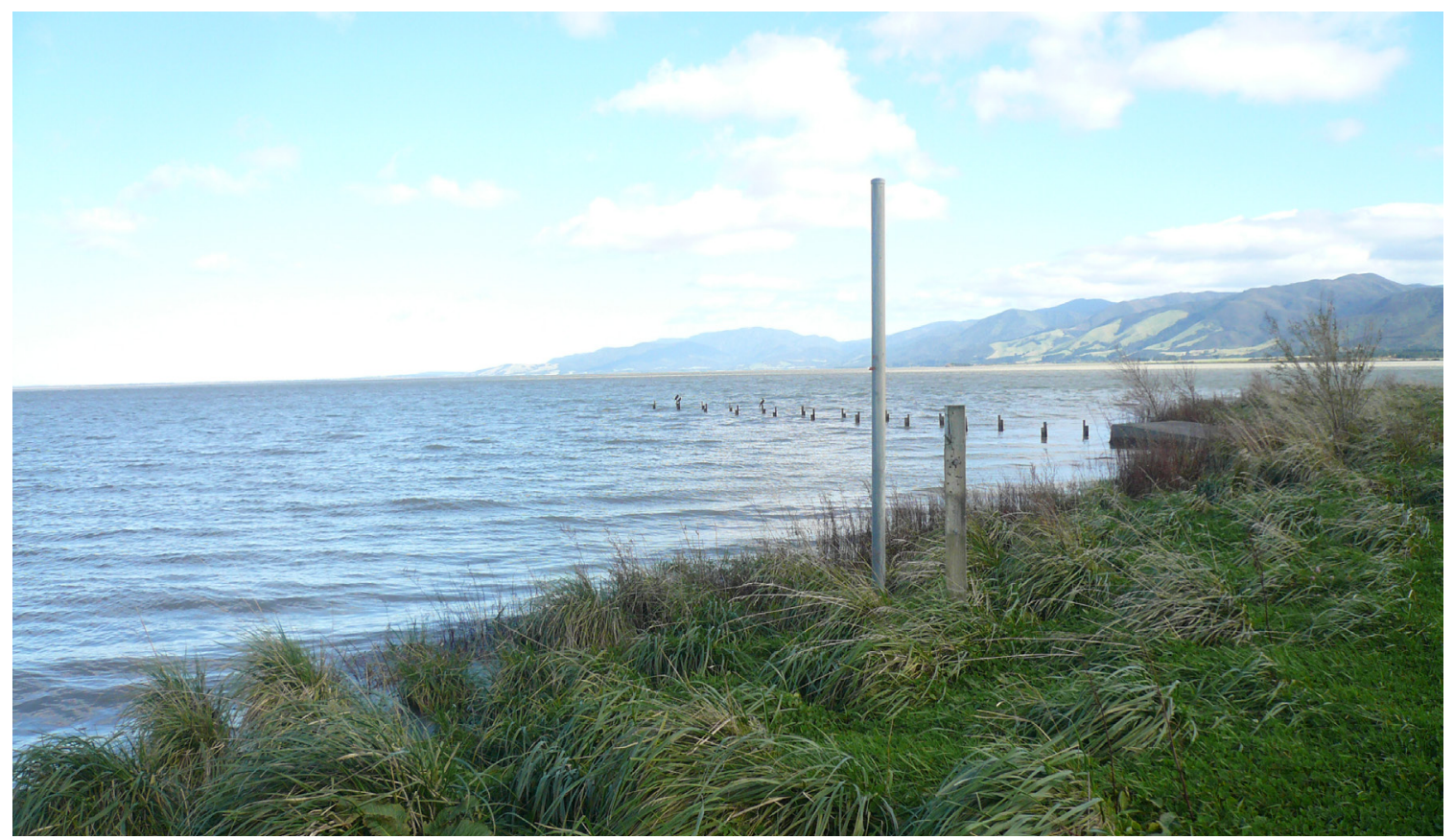

Fig. 1.08. Lake Domain Reserve looking southwest towards the Rimutaka Range, May 2015. 


\section{The Preceding Project}

The seed of this research was sown in a fourth year project in which the researcher designed a walkway from Featherston to the Featherston Military Training Camp and through the camp site (see figs. 1.09 to 1.12). The design explored ways planting could combine with the historical infrastructure to uniquely interpret the camp's stories. The camp has a mixed history. It was the largest World War One training camp in New Zealand, training about two thirds of those who served overseas. World War Two saw the site become a camp for Japanese Prisoners of War. In 1943 there was a tragic incident where 64 prisoners and one soldier were killed. (As it is included in the trail the complete design for the walkway is in Appendix A.)

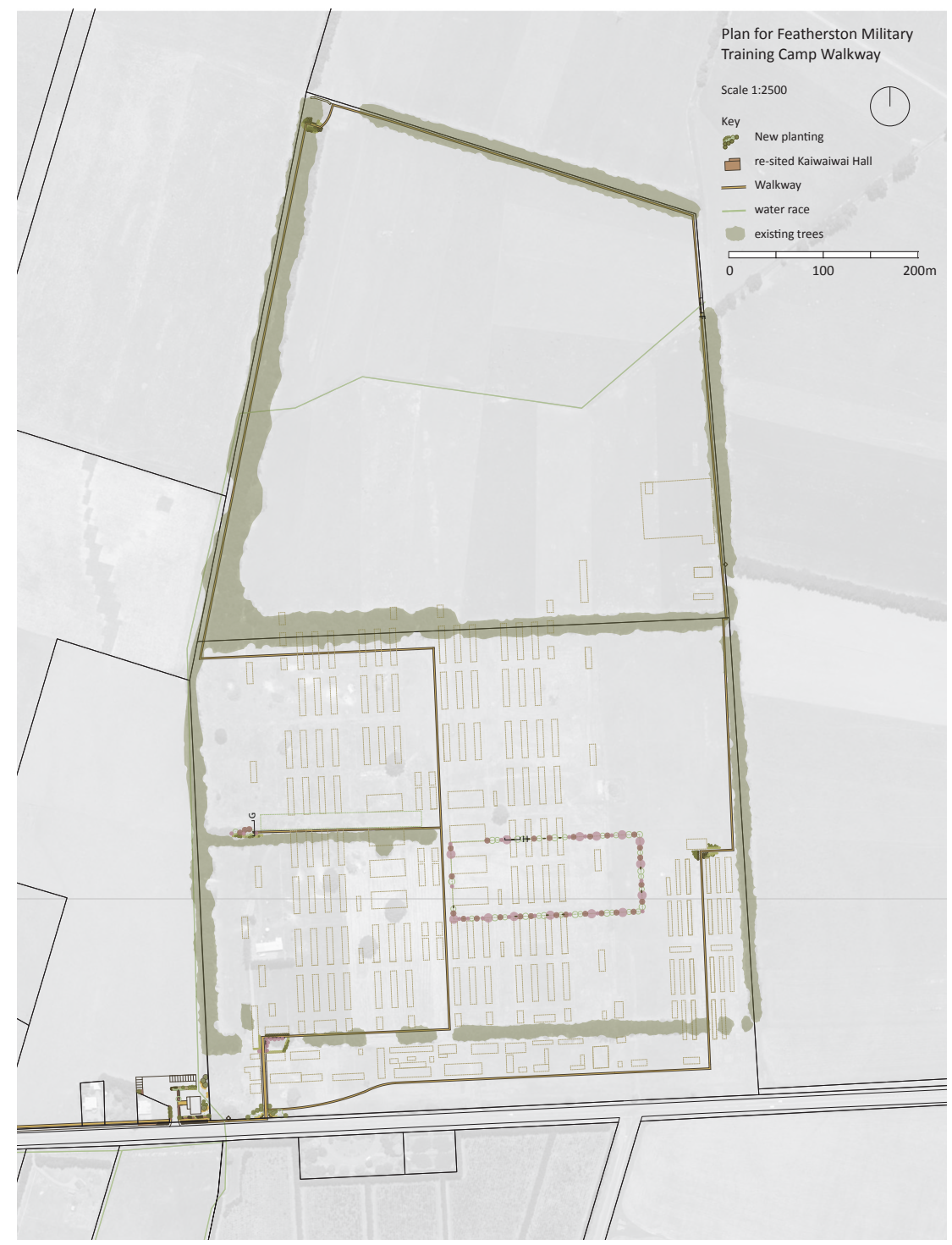

Fig. 1.09. Plan for the camp section of the Featherston Military Camp Walkway. 


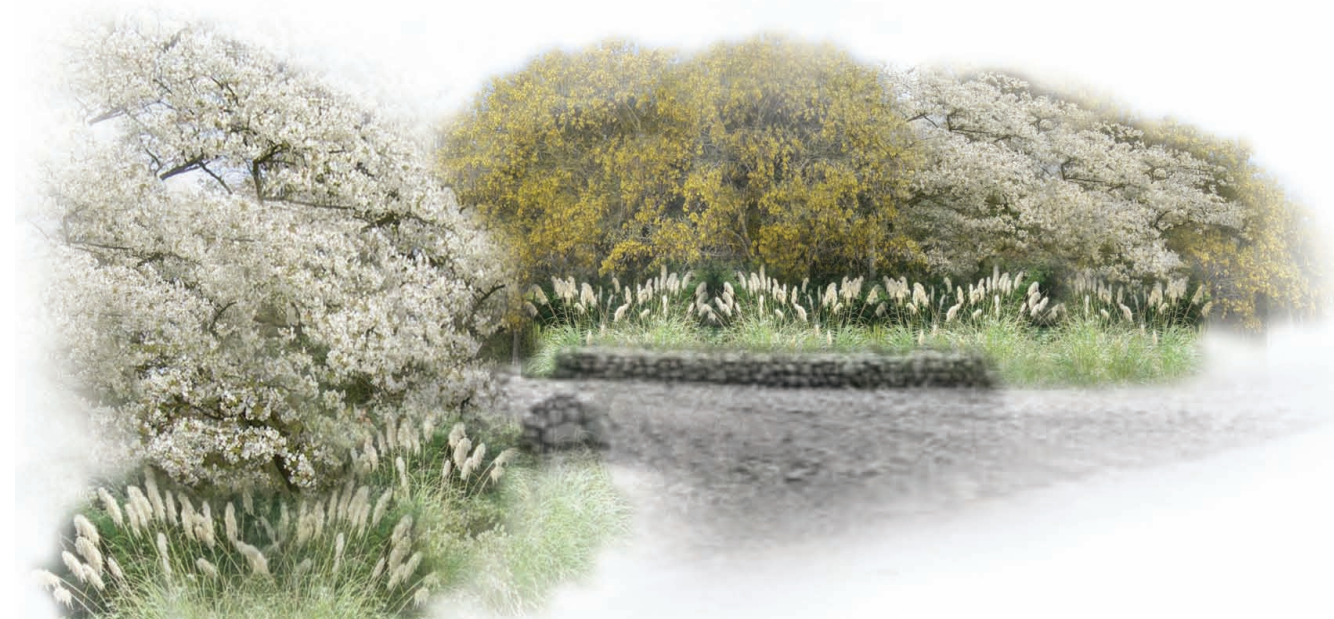

Fig. 1.10. The Camp Entrance - new curved stone walls of local stone replicate those of the prisoner of war camp entrance.

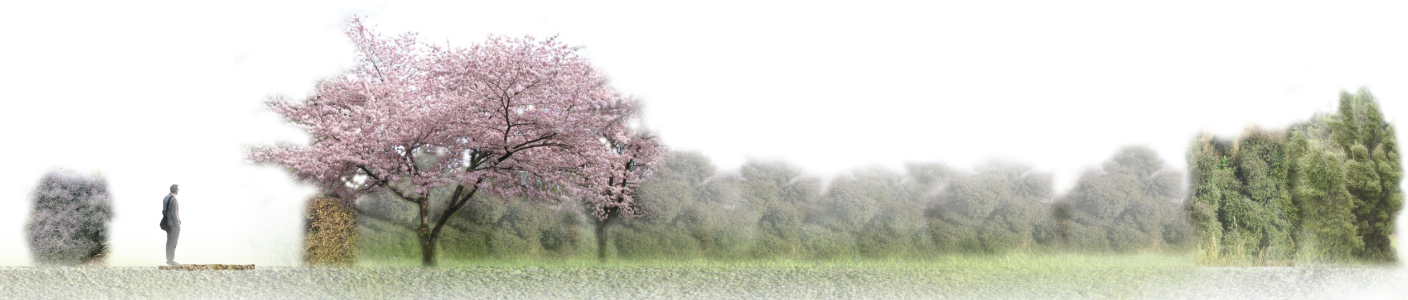

Fig. 1.11. The Gathering Area: flowering cherries reference the Japanese prisoner of war camp and some of the native divaricating plants resemble the men who once lived here and connect to the piles of barbed wire still on site.

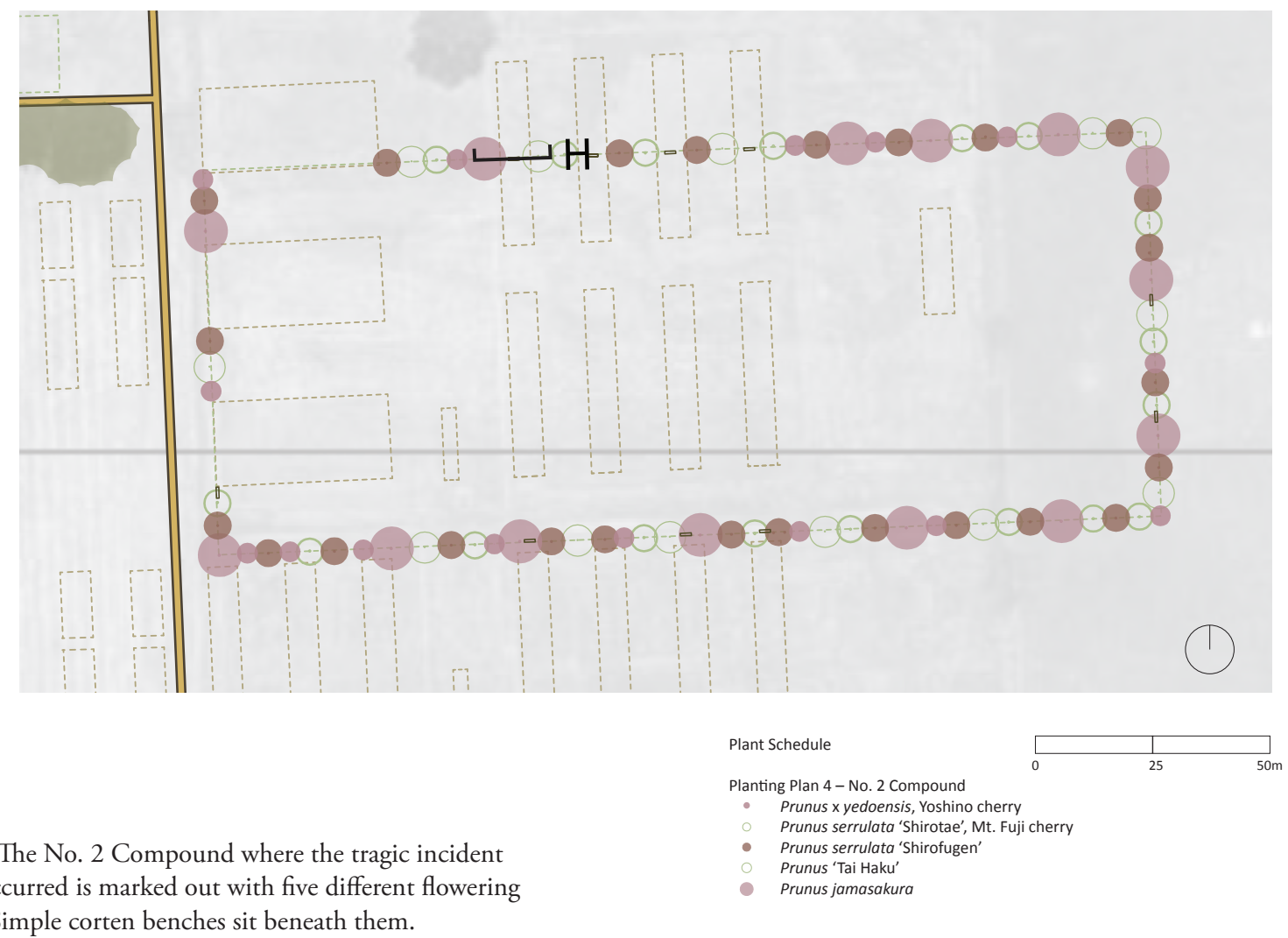
in 1943 occurred is marked out with five different flowering cherries. Simple corten benches sit beneath them. 


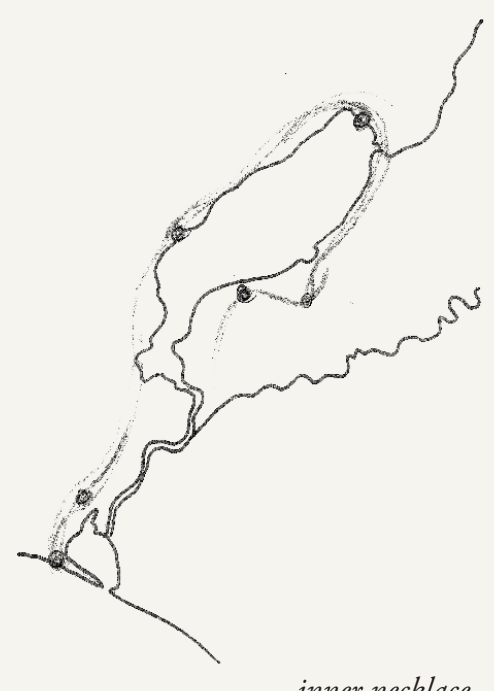

inner necklace

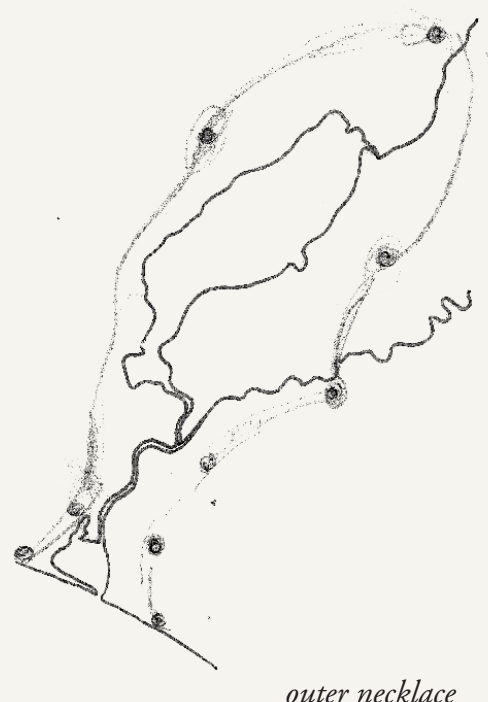

outer necklace

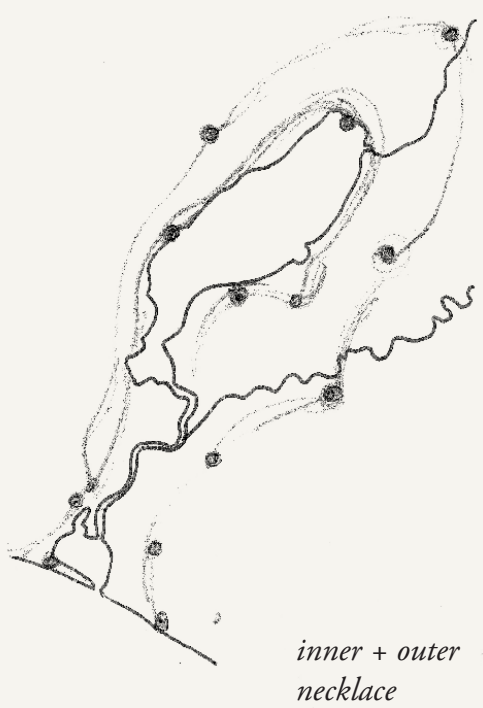

inner + outer

necklace

Fig. 1.13. Initial Hunch.

\section{Initial Design 'Hunch'}

The first design 'hunch' that occurred in this design research has remained the touchstone of the project. With the six Wairarapa Moana Wetlands Park sites forming an 'inner necklace' the aim of this project became creating an 'outer necklace' of interpreted heritage sites (see fig. 1.13). The term trail was used as an interim name with a view to developing another. However, once the Oxford Dictionary was consulted, the definition found of 'trail' asserted its place in the project. Trail, defined as "a mark or a series of signs or objects left behind by the passage of someone or something" (Definition of Trail in English), captures the intent of this research.

Linking sites and stories with a heritage trail has the support of current thinking amongst archaeologists and historians. Gavin McLean, senior historian for the Ministry for Culture and Heritage, and Ian Barber, 
associate professor of archaeology at University of Otago, wrote in 2000 that archaeologists and historians support a move away from interpreting single sites, objects and structures. Interpreting a cultural heritage landscape, relating to and interpreting history in a broad spatial context, and thinking thematically are now widely supported (105).

There are many landscape precedents that support this notion of strength in connection, with one of the most famous being Olmsted's 'Emerald Necklace' in Boston, shown in fig. 1.14. In 1894 he wrote, "the main distinctive characteristic of the Boston municipal system is its design as a series of parks, each possessing an individual landscape character and special re-creative functions, united by a chain of drives, rides and walks, forming a grand parkway of picturesque type" (Pressley).

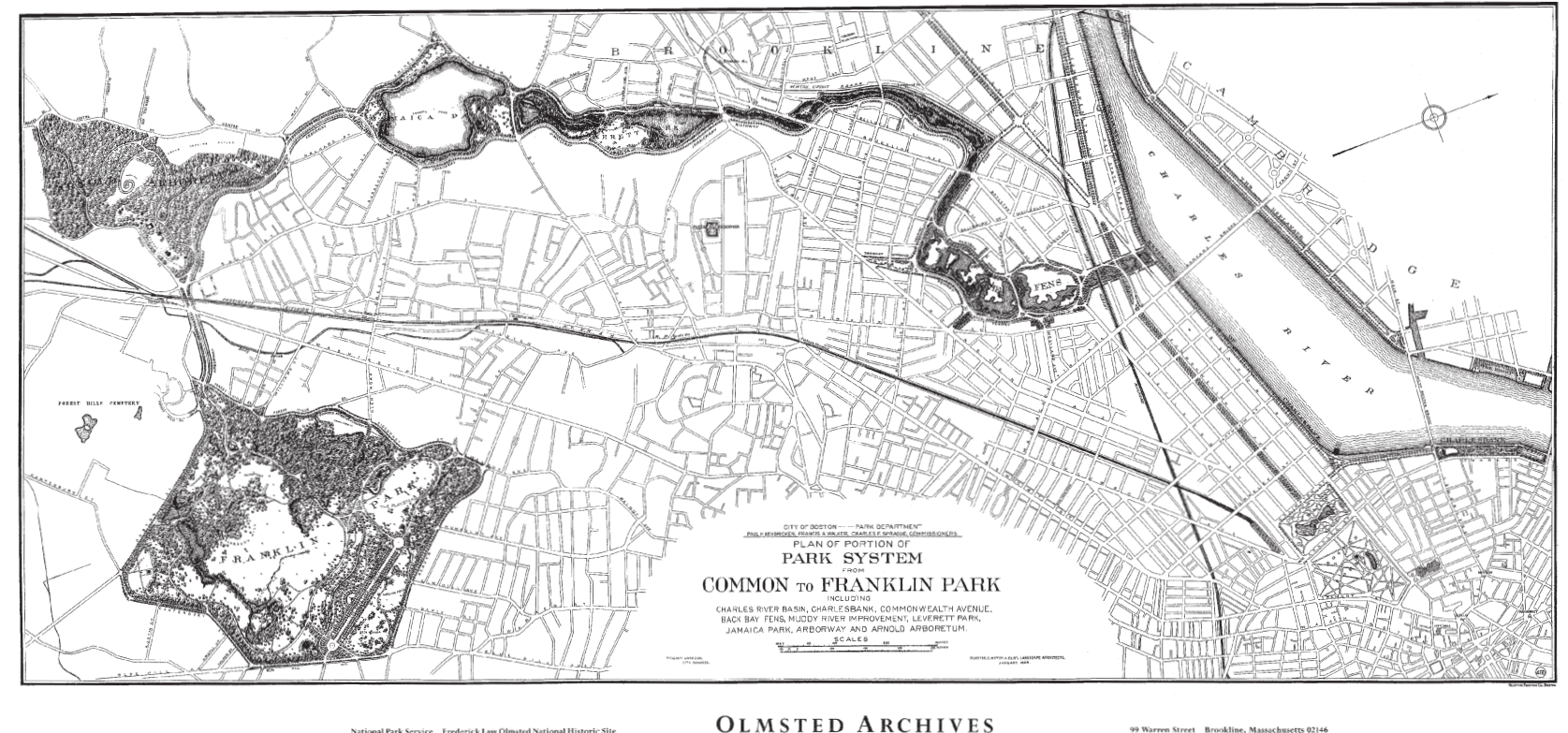

Fig. 1.14. The Emerald Necklace, by Frederick Law Olmsted, Boston. 


\section{Landscape Architecture Expressing the Past}

Landscape historian John Dixon Hunt, a professor at the University of Pennsylvania, considers that many landscape architects seek to express the past, but it is often not their priority. In his 2014 book 'Historical Ground: The Role of History in Contemporary Landscape Architecture' he suggests these possible reasons:

their own lack of interest in the past as opposed [to] something they can make that is new; their clients' concern to make a modern splash; a community committed, understandably, to seeing that its location responds to current needs ... [and] ... a lack of both opportunity and a suitable vocabulary to find some means of making history visible. (2)

Hunt goes on to say that a historian writing has control of the narrative and a film maker can direct the understanding of a story, but the landscape architect "can neither report objectively nor direct the telling of the tale" (4). Perhaps, however, the landscape architect need not fully tell the story of the site, but can instead create awareness of the site, revealing it as a place of significance (see fig.1.15).

Revealing the site is making a place from space. Social and cultural geographer Tim Cresswell, in attempting to define what links a variety of places, wrote, "they are all spaces which people have made meaningful. They are all spaces people are attached to in one way or another. This is the most straightforward and common definition of place - a meaningful location" (7).

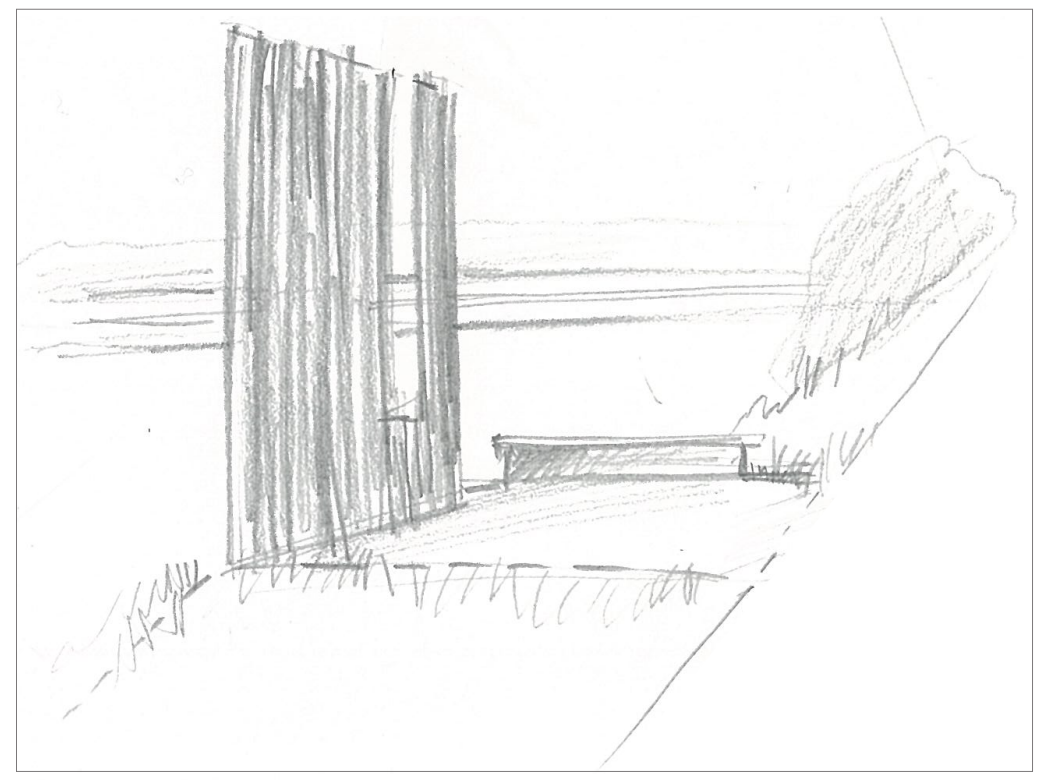

Fig. 1.15. Revealing the place as significant - the Cultural Landscape Path, Italy, by Archiplan. 
Marc Treib, Professor Emeritus of Architecture UC Berkeley, agrees that people make a space meaningful. "To my mind significance ultimately lies with the beholder and not in the place" (Treib, "Must Landscapes Mean?" 114). For an insignificant space to become significant, and a place, people need to be shown the hidden story. It need not be spelled out, but the significance of the site communicated in some way.

Swiss landscape architect Paolo Bürgi has said, "knowing something about the history of a landscape ... can change your perception of it and transform it into a very different place" (Hunt, "Historical Ground" 29). He has also said:

the perception of landscape is also subject to change depending on cultural memory and on the individual's own experiences... . imagine a beautiful seashore somewhere in the Mediterranean region that was the site of an important battle in the past [as in fig. 1.16] Your knowledge of its history can change your perception and appreciation of that place. Of course, you cannot see what happened, because there's nothing left except the landscape, but as soon as you know that a battle took place there, the landscape becomes different in your mind. (Gianetto 15)

In his address at the NZILA 2015 conference architect Rau Hoskins said, "Māori cultural landscapes are essential to supporting and reinforcing cultural identity and connection to place". Revealing the heritage stories of

Fig. 1.16. Preveli Beach where Allied soldiers evacuated from after the Battle of Crete in 1941.

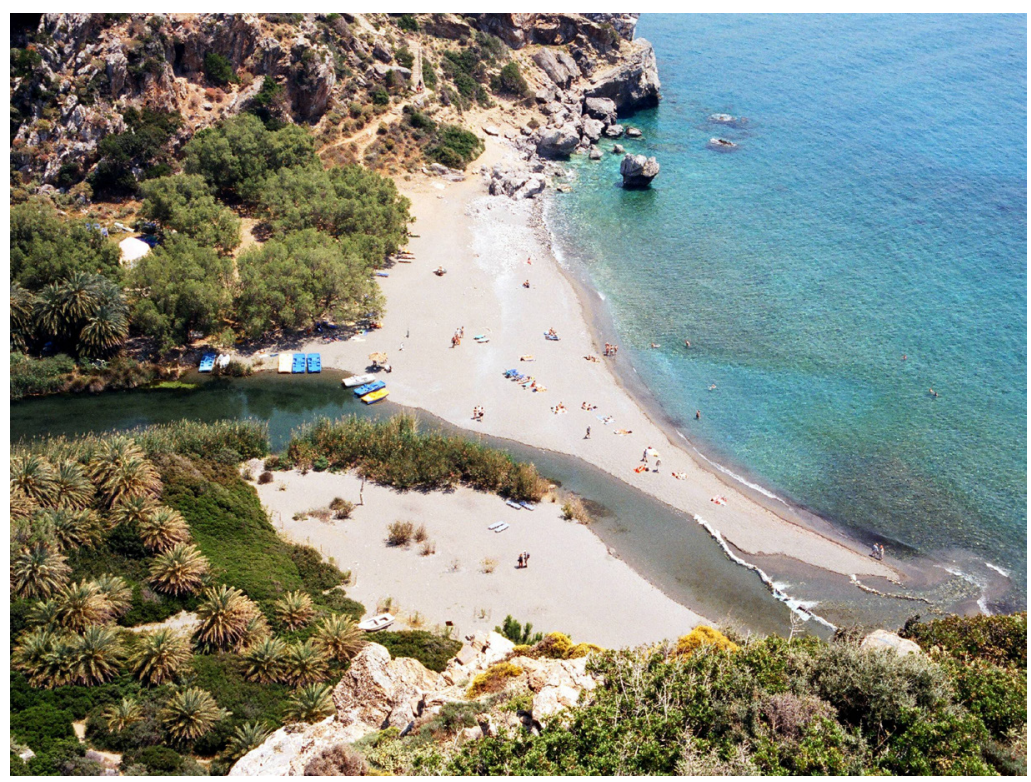


places in the landscape helps to restore and build connection to the land, to places, for all people, Māori and Pākehā. Learning the significance of a site, and being in the site, enables a richer association between people and place, making a space meaningful. It enables a deeper knowing, a directed looking, a richer seeing, a firmer rootedness, an experience to remember and an experience to share with others. It enables space to become a place.

\section{Relationships with Landscape in Aotearea New Zealand}

Tim Cresswell has written that the European idea of landscape, and therefore the idea held by many New Zealanders, dates back to Renaissance Venice and Flanders. Landscape painting emerged with the development of the merchant trader, the rediscovery of the science of 'optics' and new navigational techniques, for example, fig. 1.17. "Landscape referred to a portion of the earth's surface that can be viewed from one spot. It combined a focus on the material topography of a portion of land (that which can be seen) with the notion of vision (the way it is seen). Landscape is an intensely visual idea" (Cresswell 10).

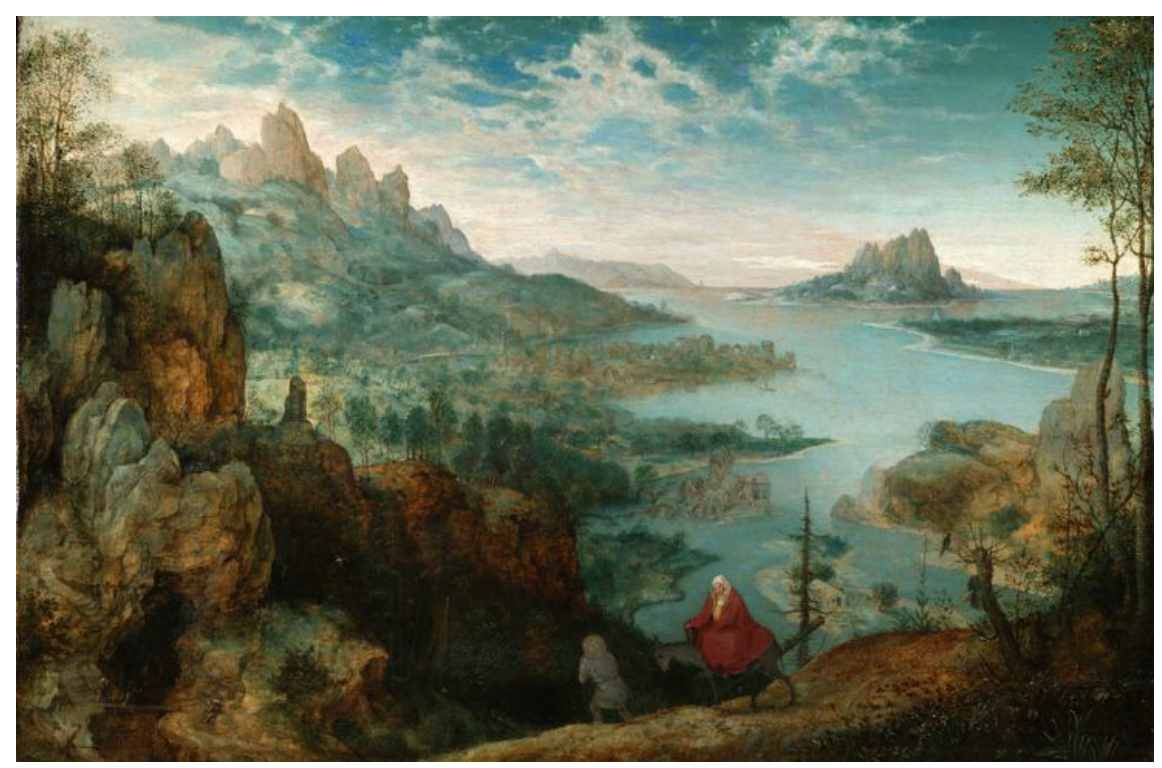

Fig. 1.17. Landscape with the Flight into Egypt by Flemish artist Pieter Bruegel the Elder. 


\section{Māori Concept of Landscape}

Brian Murton, geography professor at the University of Hawai' i, explores the understanding Māori have of landscape in 'Landscape in Language: Transdisciplinary Perspectives'. Māori had and continue to have a completely different relationship with landscape to the European one. Murton considers that "although Māori in the past did 'gaze' at their surroundings, and did have visual forms of representation, the concept of 'landscape' as it is commonly used in western scholarly and popular representation is inappropriate" (73).

The 'Te Aranga Māori Cultural Landscape Strategy', put together in 2008 to voice Māori interests and aspirations in the built environment, describes this relationship:

As Māori we have a unique sense of our 'landscape'. It includes past, present and future. It includes both physical, and spiritual dimensions. It is how we express ourselves in our environment. It connects whānau, flora, fauna, through whakapapa. It does not disconnect urban from rural. It transcends the boundaries of 'land'scape into other 'scapes'; rivers, lakes, ocean and sky. (Te Aranga Maori Cultural Landscape Strategy)

For Māori, land is a part of themselves and they are a part of the land and this is expressed in the content of a mihi or mihimihi.

A person will usually identify specific geographical features associated with their tribal area including their maunga (mountain), awa (river) and moana (sea).... This information is considered more important than the individual's own name which may be the last piece of information given in mihimihi (Mihimihi).

Recognition of the value of this acknowledgement of rootedness in landscape is increasing. "Mark Newdick, of Moorhead and Newdick Landscape Architects, won a time-pressured conmmission to bring new life to the Pipitea Marae site [see fig.1.18] partially on the strength of his own introductory greetings - his mihi” (Olsen 34). The researcher's own sense of the relevance of the mihi has grown with every marae visit that took place in the course of this research. 


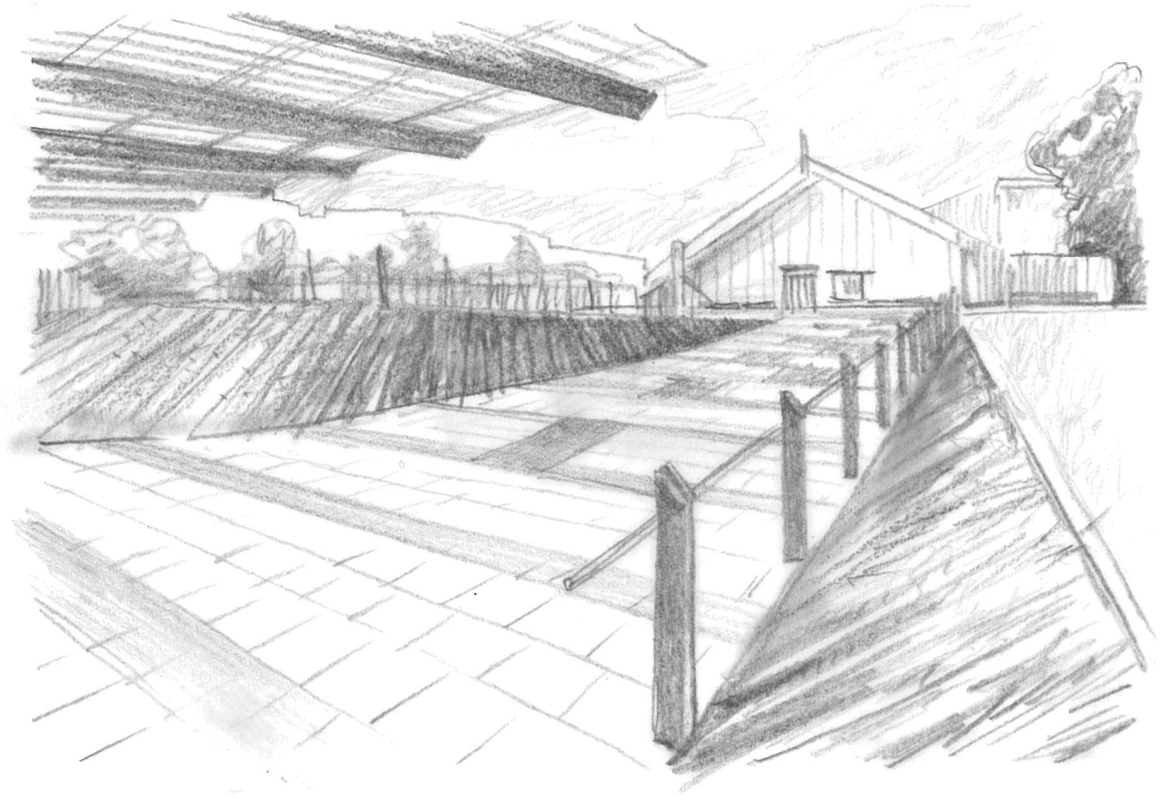

Brian Murton explains how being one with the land is expressed deeply in te reo Māori, the Mãori language, in which "the word whenua means both 'earth' and 'placenta', and as such metaphorically represents the connection of people to their origins, material, historical, and spiritual" (86). Māori bury both the placenta and the umbilical cord, pito, in the ground. This symbolically inserts the individual into the landscape reflecting the connection between place and people (Murton 86). Māori are tangata whenua of Aotearoa, 'people of the land'. At the NZILA Conference 2015 Rob McGowan (one of the foremost authorities on rongoā Māori, traditional Māori medicine) stated that a person is tangata whenua who draws life from the land, who can hear the land talking. Rawiri Smith of Ngāti Kahungungu told the researcher:

Tangata whenua is a Māori concept that defines people affected by land. Literally the structure for the Māori language is a noun followed by an adjective. Since our whenua is strong enough to affect all people, those who live on the land and are shaped by the land, listen to the land's korero [and] are in tune with the land's rhythm, these are tangata whenua. We can as New Zealanders all be tangata whenua.
Fig. 1.18. Pipitea Marae, Wellington, designed by Moorhead and Newdick Landscape Architects. 
Māori academic Ahukaramū Charles Royal has written that in Māori culture humans are so deeply connected to the land and to the natural world, that, "the natural world is able to 'speak' to humans and give them knowledge and understanding" (Royal 2). The notion of the natural world speaking, while not an idea commonly held in modern society, is not the sole preserve of Māori or other indigenous cultures. It has long been advocated in landscape architecture that the site be consulted prior to designing. Elizabeth Meyer, a landscape architect, theorist and critic, wrote in 1994: "The landscape does not sit silent awaiting the arrival of the architectural subject. The site speaks prior to the act of design" (31).

Philosophically this approach is deeply phenomenological and not without its adherents in other fields of thought. For Edmund Husserl, its founder, the philosophical movement of phenomenology "takes the intuitive experience of phenomena ... as its starting point and tries to extract from it ... the essence of what we experience" (Phenomenology). John Dixon Hunt considers that, due to his concern with place, landscape architect Paolo Bürgi seeks "what used to be called 'genius loci', .... he emphasizes his search for the essence of a place" ("Something Behind the Horizon" 136). Landscape architect Wendy Hoddinott in her journal article 'Passing Time: A Phenomenological Approach to Heritage Design' describes the design approach as "engaging perception and imagination in the experiential facets of space and place" (Hoddinott 42).

This research is inspired by the depth of Māori connection to the land. It seeks to design interventions that reveal heritage, make space a place, enable connection to the land and to the past, and deepen the feelings for, and relationship with, this land. Perhaps listening to and learning from Māori will enable better listening to the land and hearing it speak. Perhaps all landscape architects in Aotearoa should aspire to becoming tangata whenua. 


\section{Making a Place from Space}

Christophe Girot is Professor and Chair of Landscape Architecture at the Architecture Department of the ETH (Swiss Federal Institute of Technology) in Zürich. One of the questions this research seeks to answer is whether using a particular method, Girot's 'Four Trace Concepts in Landscape Architecture', enables the designer to 'hear the land speak', creates a design that connects people to the land and to the past, and makes space a place, as in figure 1.19. Tim Cresswell has written that, "in most definitions of landscape the viewer is outside of it. This is the primary way in which it differs from place. Places are very much things to be inside of" (10). People are connected to and a part of place, as Māori are a part of the land. Place is not just something to be looked at, not simply a landscape.

The experience of place has been called genius loci, which is defined as "the prevailing character or atmosphere of a place", or, literally in Latin, the spirit of the place (Definition of Genius Loci in English). Robyn Burgess, a registration researcher for NZ Heritage and a board member of ICOMOS New Zealand wrote an article in Heritage New Zealand magazine entitled 'Spirit of Place'. She states there are many interpretations of spirit of place: the Roman concept of genius loci meant a divine spirit intimately connected to a special place, but it can also mean engaging with a place, belonging to it and how we react to it. It can be constantly changing, it can combine the tangible and the intangible. Perhaps hearing the land speak is similar to connecting to the spirit of place, reflecting a widespread need to connect to place. Laurene Vaughan, Professor in Design and Communication in

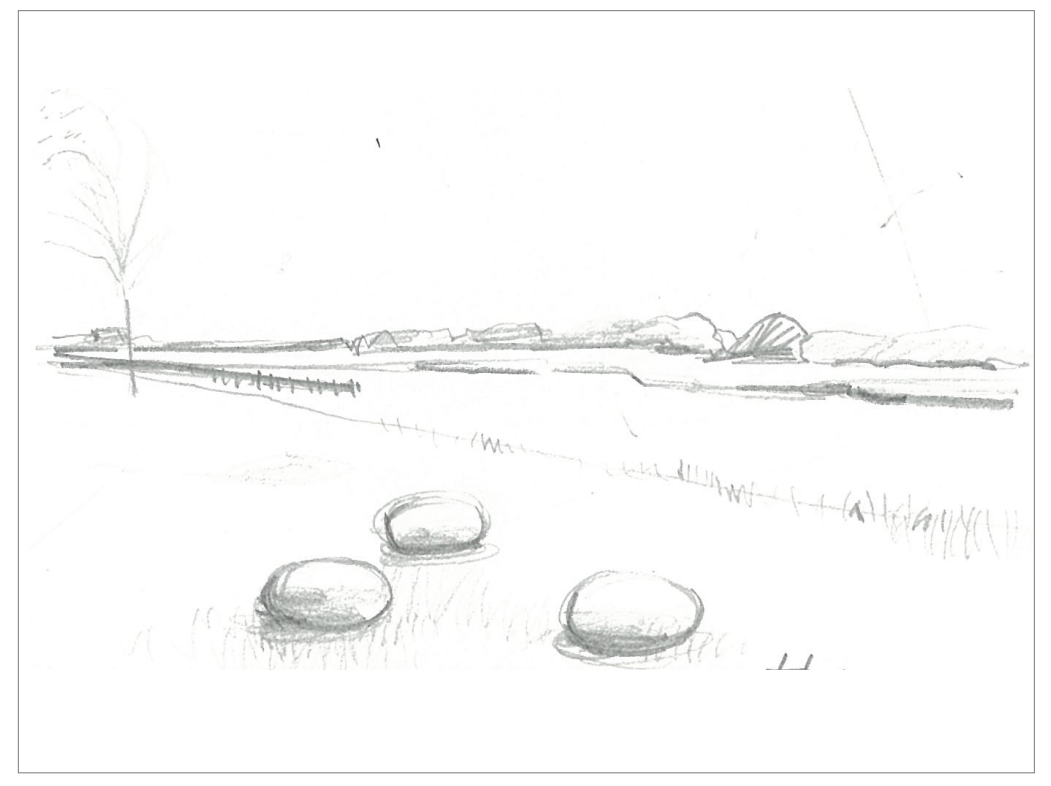

Fig. 1.19. Dorpsweide, the Netherlands, by Atelier Loos van Vliet. 
the School of Media and Communication, considers that, "Although each cultural grouping has its own unique ways of creating and reading place, there are also universal traits, qualities or values associated with place" (Vaughan 8).

Marc Treib in 'Must Landscapes Mean? Revisited' (2011) wrote: although the Latin term genius loci dates from ancient times, we know it as the Genius of the Place from Alexander Pope's "Epistle to Lord Burlington", in which he instructs m'lord to reject formalities such as allées and topiary. Instead, he should look more carefully at the site and use what it offers as the basis for improvement. (128)

The advice to look carefully at the site and use it as a basis for the design could be viewed as a form of listening to the land speak, of seeking the genius loci.

One of the aims of this research is for the design proposals to have a 'light touch' and not overwhelm what is present on site. The ICOMOS (International Council on Monuments and Sites) New Zealand Charter states: "Physical interventions for interpretation purposes should not detract from the experience of the place, and should not have an adverse effect on its tangible or intangible values" (8). John Dixon Hunt considers that as designers cannot be sure what people will bring to a place, they use "heavyhanded, overtly prescriptive narrative ... banal functionality or self-important solipsism" (Hunt "Something Behind the Horizon" 135-6).

Fig. 1.20. Terrace on the Forest, Switzerland, by Paolo Bürgi.

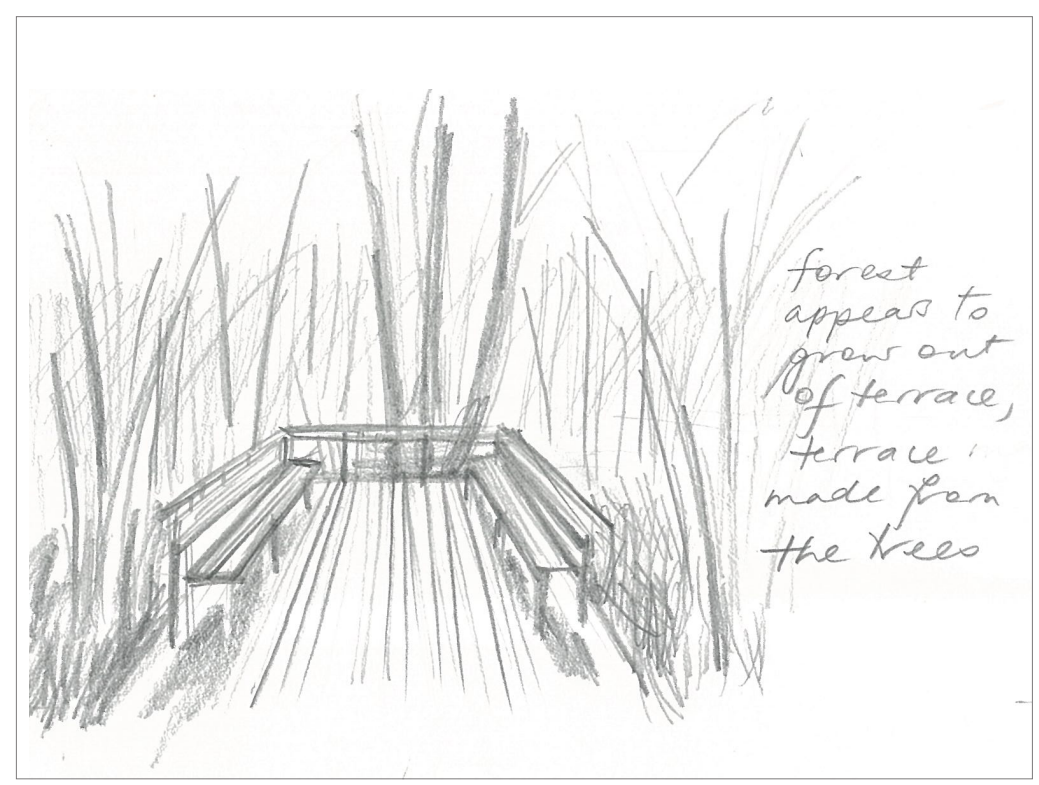


Hunt believes Paolo Bürgi (see fig. 1.20) avoids these due to:

His seizing of essence ... is painstaking and complex, physical and metaphysical, looking and feeling, researching and responding. It is, I suggest, the depth or richness of those initial approaches to his sites that ensures that whatever Bürgi subsequently proposes as physical interventions are rich; that richness in turn becomes a complex resource for the imaginations and knowledge of a wide range of people to connect with it at one level or another. ("Something Behind the Horizon" 136)

This research will seek to emulate Bürgi's search for the essence of a place, the genius loci, and seek to hear the natural, and as well the cultural, world speak. 


\section{GIROT'S METHOD}

The research method chosen for this design research is based on the landscape architect Christophe Girot's 'Four Trace Concepts in Landscape Architecture', as diagrammed in fig. 2.01. Girot writes that he is interested in methods and techniques that might expand landscape projects beyond "the simple amelioration of sites toward practices that also reactivate the cultural dimensions of sites" (59). As part of this research is to connect with, and to enable connection with, the cultural dimensions of sites, or 'to hear the site speak', this method has been chosen as a starting point.

Rather than systematically analysing the site from a distance, the trace concept method enables designers "to come to grips with their intuitions and experiences of place, allowing these impressions to direct the unfolding of the project." (Girot 65). Girot calls the four stages trace concepts "because they cluster around issues of memory: marking, impressing, and founding" (60). As designers are rarely from the place they are asked to design in, Girot believes his method helps address how designers can "acquire the understanding of a place that will enable them to act wisely and knowledgeably" (60). He considers this method to be an answer as "landing, grounding, finding, and founding each focus on particular gradients of discovery, inquiry and resolution. ... Each concept also designates a specific attitude and action that in turn nurtures a process of design and landscape transformation" (Girot 60). The physical, sensorial, intuition and analysis are blended together. Girot considers this intuitive and experiential approach draws as much as possible from the site, assessing which tangible or intangible landscape elements might be significant and might eventually contribute to the future design. The tangible elements might be stonework, archaeology or evidence of past flooding, the intangible a past event, story or song.

Girot's 'Four Traces' encourages careful listening to the site before any design moves and may be a tool we can use to 'hear the natural world speak'. This research aims to test whether Girot's method could be a way Pākehā might start to hear the natural world speak, so as to potentially connect to it as deeply as Māori can. The method had been tentatively but successfully employed in a previous design studio by the researcher who decided to test it more fully in this project. The results of this method are a very site-led 
Four Trace Concepts in Landscape Architecture - Christophe Girot

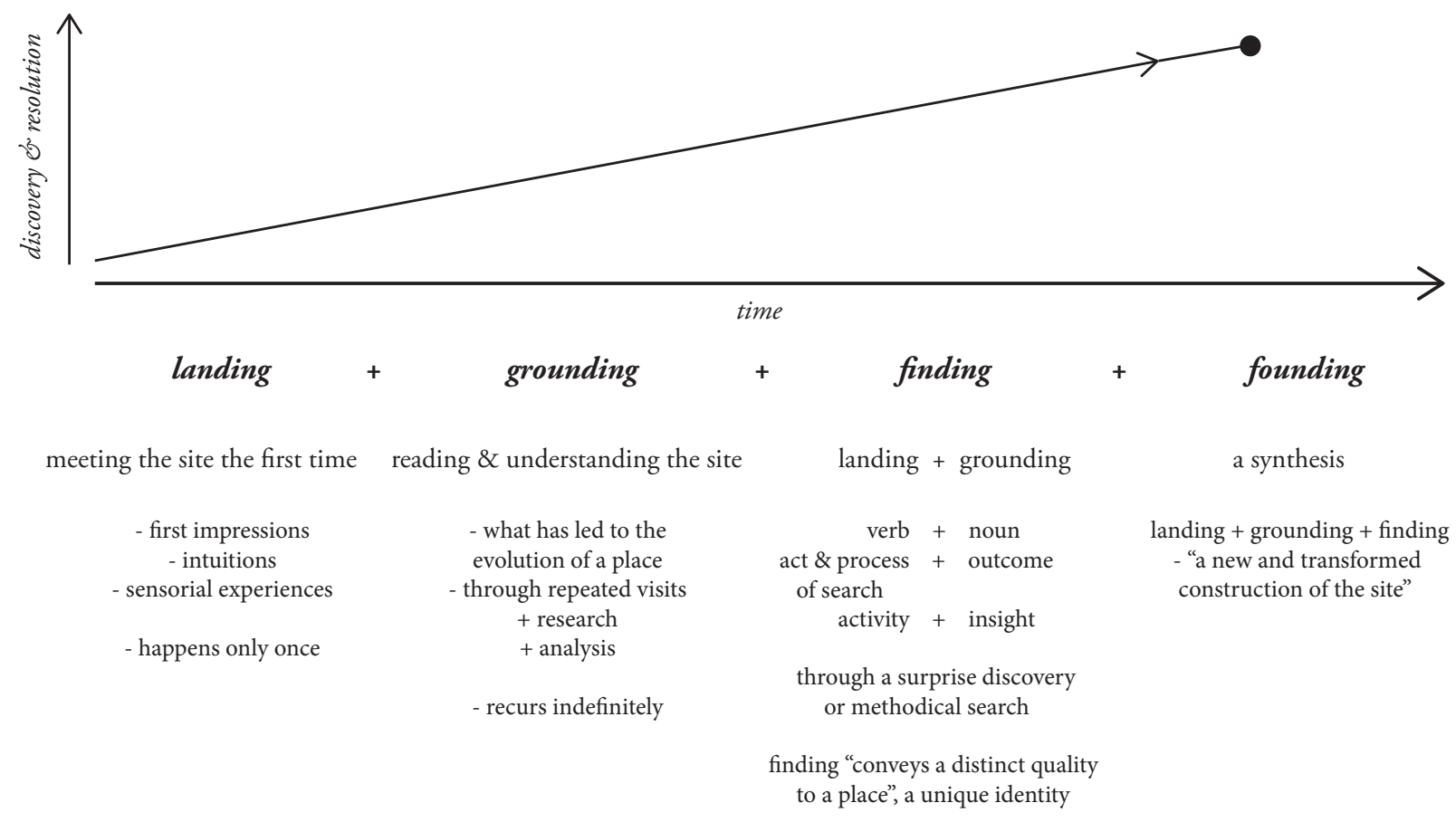

Fig. 2.01. Christophe Girot's 'Four

Trace Concepts in Landscape

Architecture' Diagram, authors own.

design, a respect for the site and its systems. The method shows deep respect for what has gone before, and for people for whom the landscape or site is special or important, Māori or Pākehā. Other writers call this reading the landscape, or reading of site. Marieke Timmermans, head of department of Landscape Architecture, Amsterdam School of the Arts, has written: this 'reading of a landscape' is the crux of meaningful analysis in our profession: to discover the non-physical, cultural characteristics and retrace their links to the spatial components of a landscape. There we find our levers for change. We look for context-based characteristics and select what is meaningful and valuable to keep. . .. we try to ... transcend the clinical analysis of layers and structures and to dig for the 'signs' of living - to learn 'landscape language' and how to read its stories. (Timmermans 21-22) 
Sébastien Marot, the French landscape scholar also stresses the importance of reading the site. He wrote in 1999 for "today's most interesting landscape architects.... the specific qualities of sites and their situations provide both the rationale and the raw material for making new projects" (49). Marot goes on to assert this further:

Without underestimating the importance of functional analysis or program performance standards, the landscape architectural reading of sites is not limited to quantities and capacities. Rather, it views the land and public space as an expression of ancient culture, or as a palimpsest that evidences all of the activities that contributed to the shaping of that particular landscape and no other. Upon the tracks overlaid by the march of time, site interpretation detects potentialities to be nurtured and passed on. The reading is thus that of an inheritance and the eventual project a bequest. $(49,50)$

Landscape architect Paolo Bürgi has spoken of reading the landscape for his project Cardada. "The question I posed myself was how to read the mountain, how to perceive it in a different way. . . . For instance, the birch wood at Cardada is a sign of emigration" (Gianetto 35). Bürgi explains how the birch trees were once removed so the land could be used for grazing. Now as many people have emigrated, the fields are no longer grazed and the birch have been left to grow, becoming a sign of reduced population. Bürgi considers this reading of the site part of design: "Once you dive into the history of a place, the creative process has already started" (Gianetto 22). 
Wairarapa Moana Wetlands

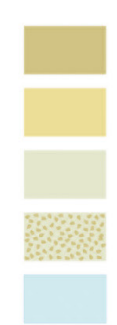

Native vegetation

Exotic vegetation

Grassed mud flats

Beach gravel

Water
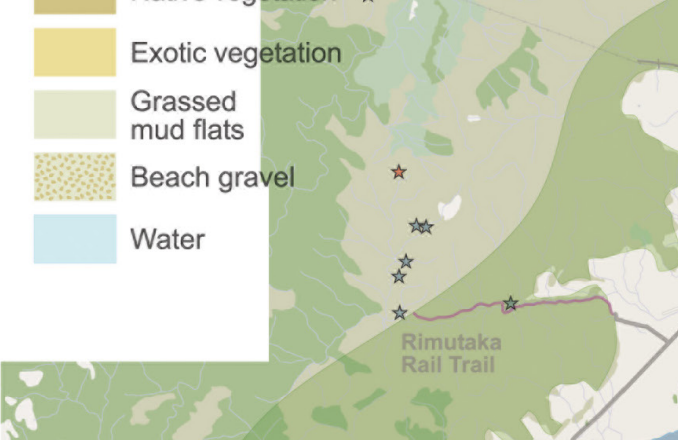

17

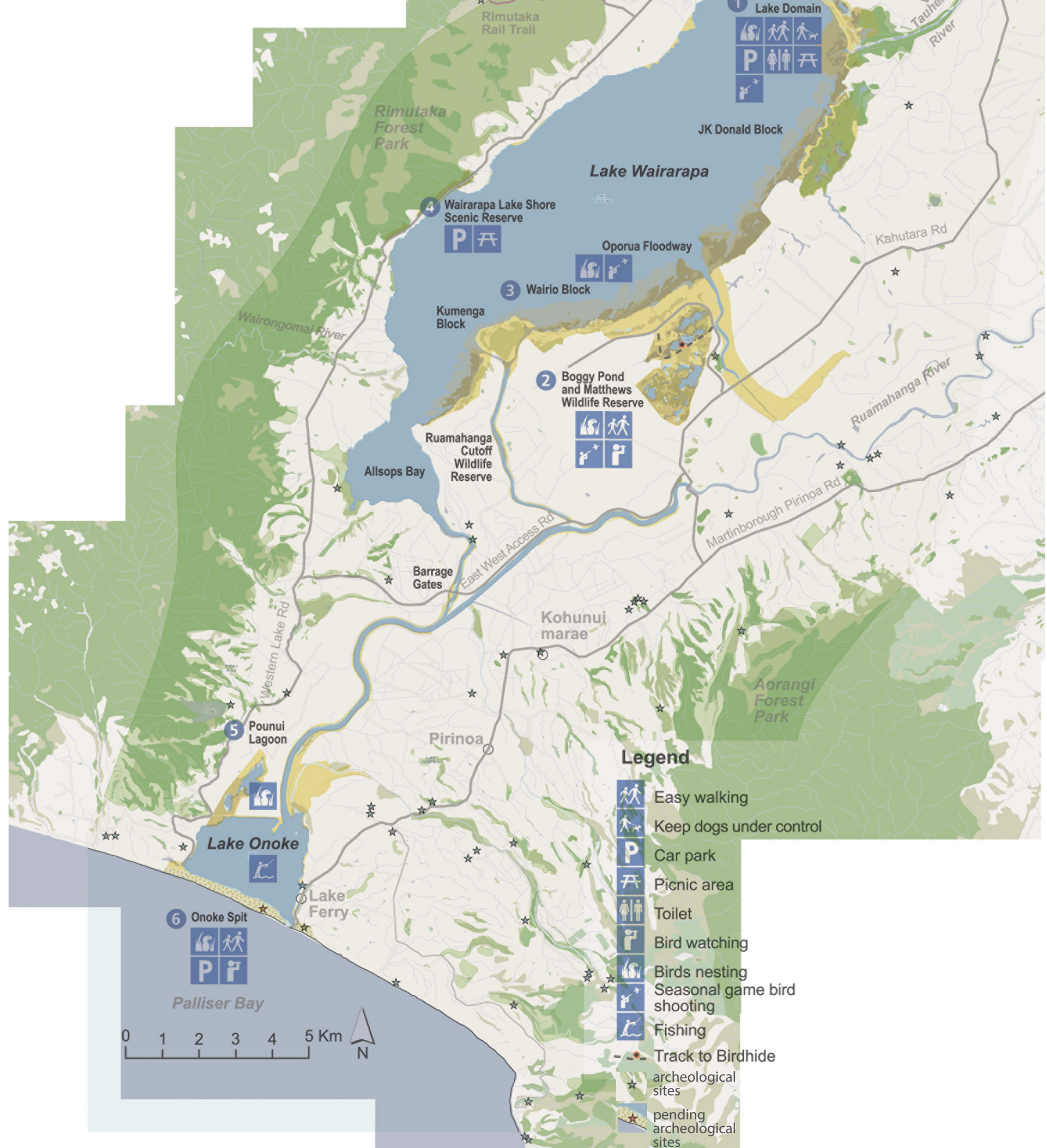

Fig. 3.01. The Wairarapa Moana

Wetlands Park Map layered with the map made from joined Arch Site Maps. 


\section{LANDING}

Seeking out the sites began with research into archaeological sites (see fig. 3.01 and Appendix B) and district plan heritage sites close to Wairarapa Moana Wetlands Park. The route of the trail was easily selected as there are few roads to choose from (see fig. 3.02). The first trail sites were chosen as they were close to, and so related, to the park.

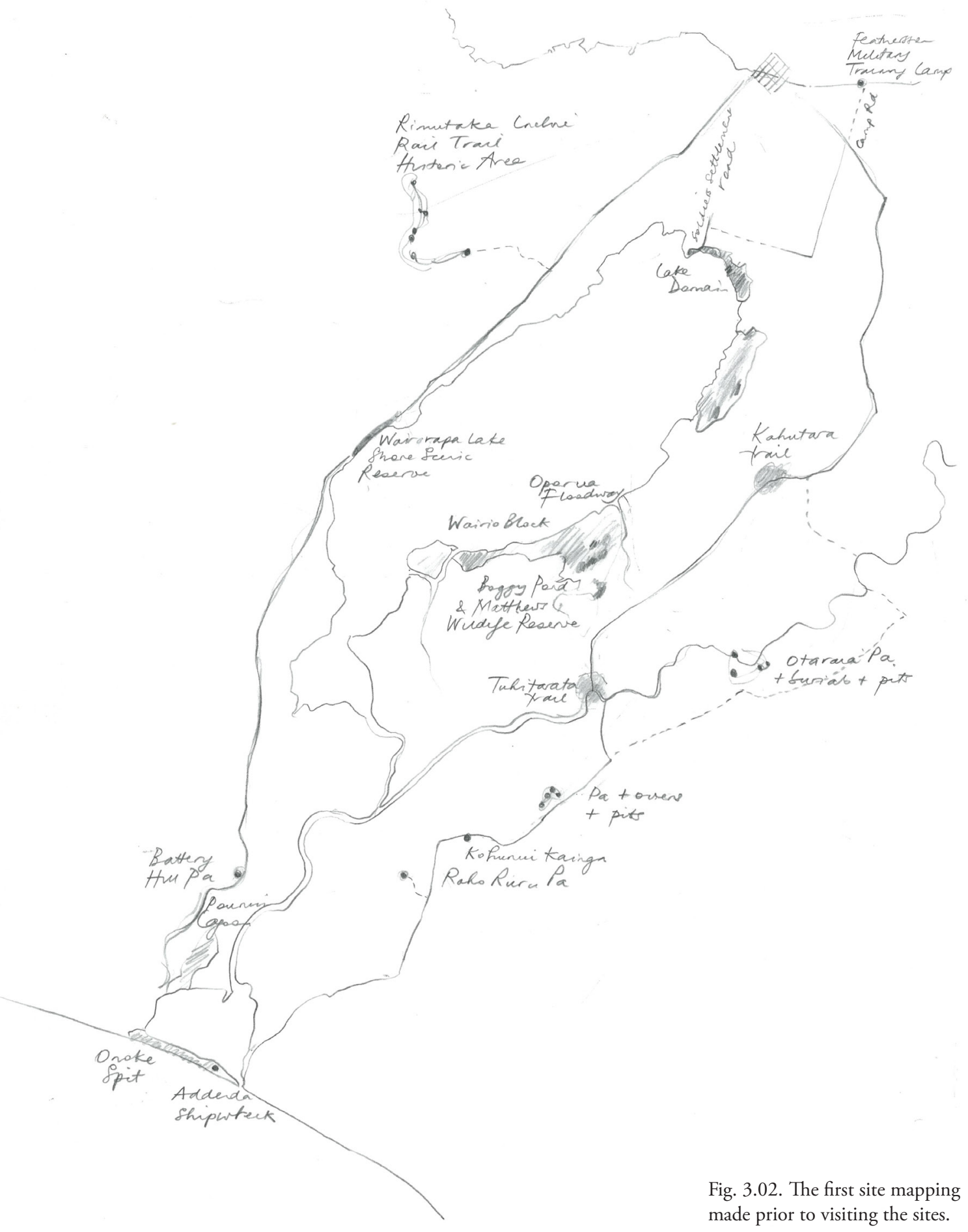


Additional sites were discovered during the first experience of the route (see fig. 3.03). Subsequent research followed into current and proposed NZ Heritage registrations and further sites were added (see appendix $\mathrm{C}$ ). The sites were then reduced to those that can be experienced from the roadside or are very important and the first draft trail map made (see fig. 3.04).

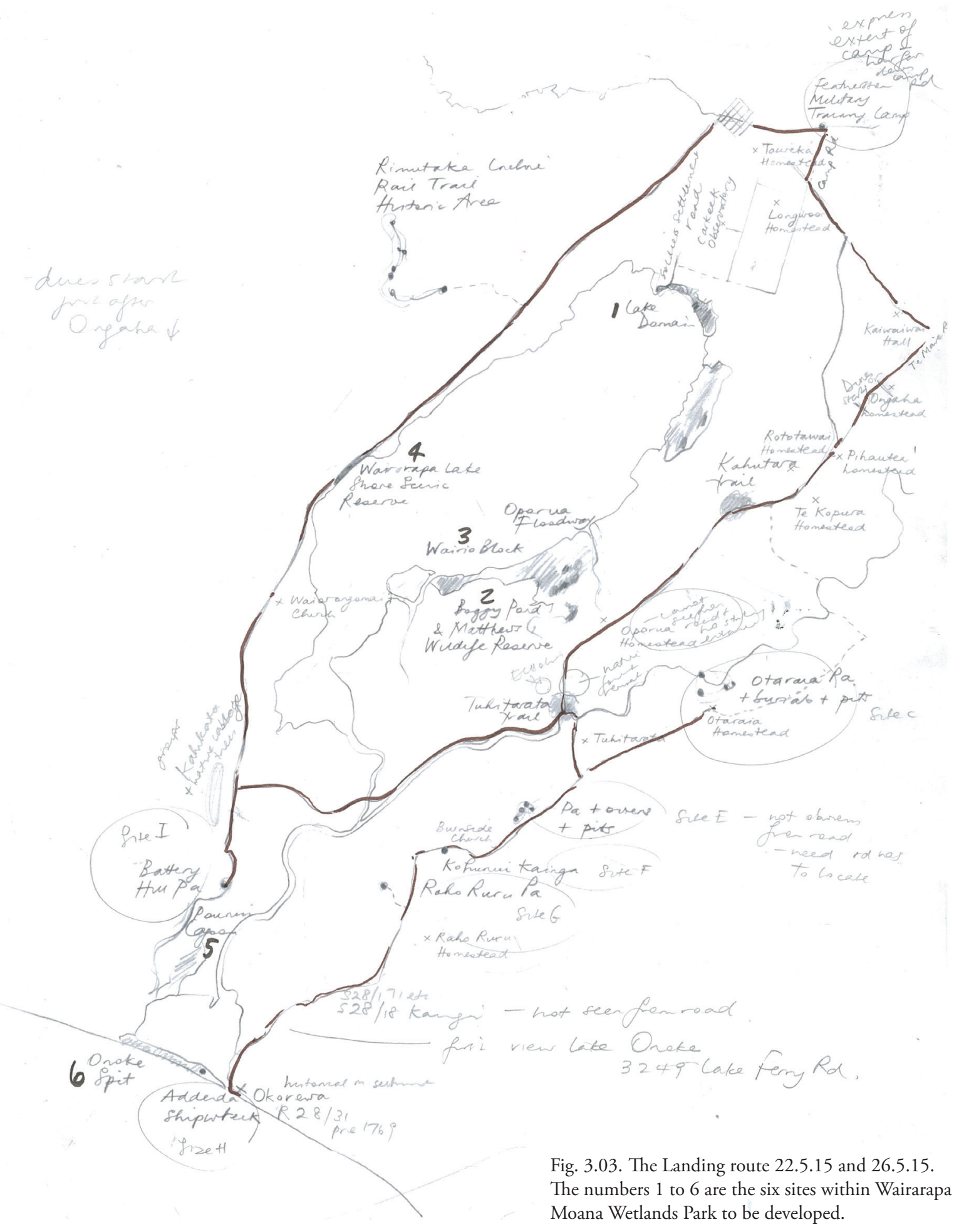


Carkeek Observatory

Lake Domain (Wairarapa Moana Wetlands Park)

Featherston

Featherston Military Training Camp

Kaiwaiwai Hall via Camp Rd

Historic homesteads + Kahutara Dunes

Boggy Pond \& Matthews Wildlife Reserve (WMWP)

Wairio Block (WMWP)

Native forest remnants around meeting

of Ruamahanga River and Kahutara Rd

Burnside Church

Kohunui Marae

Raho Ruru Pa

Okorewa kainga

Battery Hill Pa

Pounui Lagoon (WMWP)

Onoke Spit (WMWP)

Waiorongomai Church

Wairarapa Lake Shore Scenic Reserve (WMWP)

Rimutaka Incline Rail Trail Historic Area
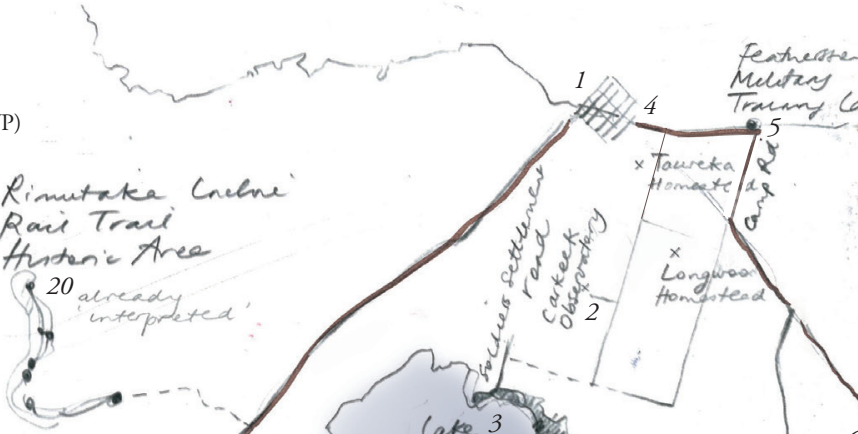
4 Trumy Lamp 
ROUTE

Featherston

Carkeek Observatory and house site

Wairarapa Lake Domain (Wairarapa Moana Wetlands Park)

Featherston

Featherston Military Training Camp

Kaiwaiwai Hall, via Camp Rd

Historic homesteads + Kahutara Dunes

Boggy Pond \& Matthews Wildlife Reserve (WMWP)

Wairio Block (WMWP)

Native forest remnants around meeting

of Ruamahanga River and Kahutara Rd

Burnside Church

Kohunui Marae

Raho Ruru Pa

Lake Onoke, at Lake Ferry

Okorewa kainga

Barrage Gates

Battery Hill Pa

Pounui Lagoon (WMWP)

Lake Onoke, Beach Road, western edge (WMWP)

View of Lake Onoke, Onoke Spit and Palliser Bay,

Wharekauhau Road

Waiorongomai Church

Views of lake from Western Lake Road

Wairarapa Lake Shore Scenic Reserve (WMWP)

Cross Creek, Rimutaka Incline Rail

Trail Historic Area

25. Pigeon Bush - the Wairarapa Fault;

Tipapaku (Pigeon Bush) the site

of the picnic to celebrate the

gifting of Wairarapa Moana,

January 1896

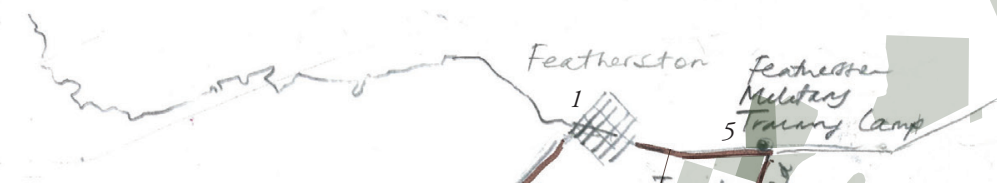

Rimutake Crelne

Raci Traci

Hustenic Area

I aiready intepreted

a cross ereek

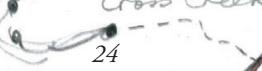

(a)

$\times$ toureta 2

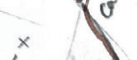

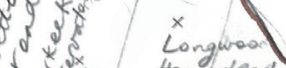
$183 x$ Aromgtead

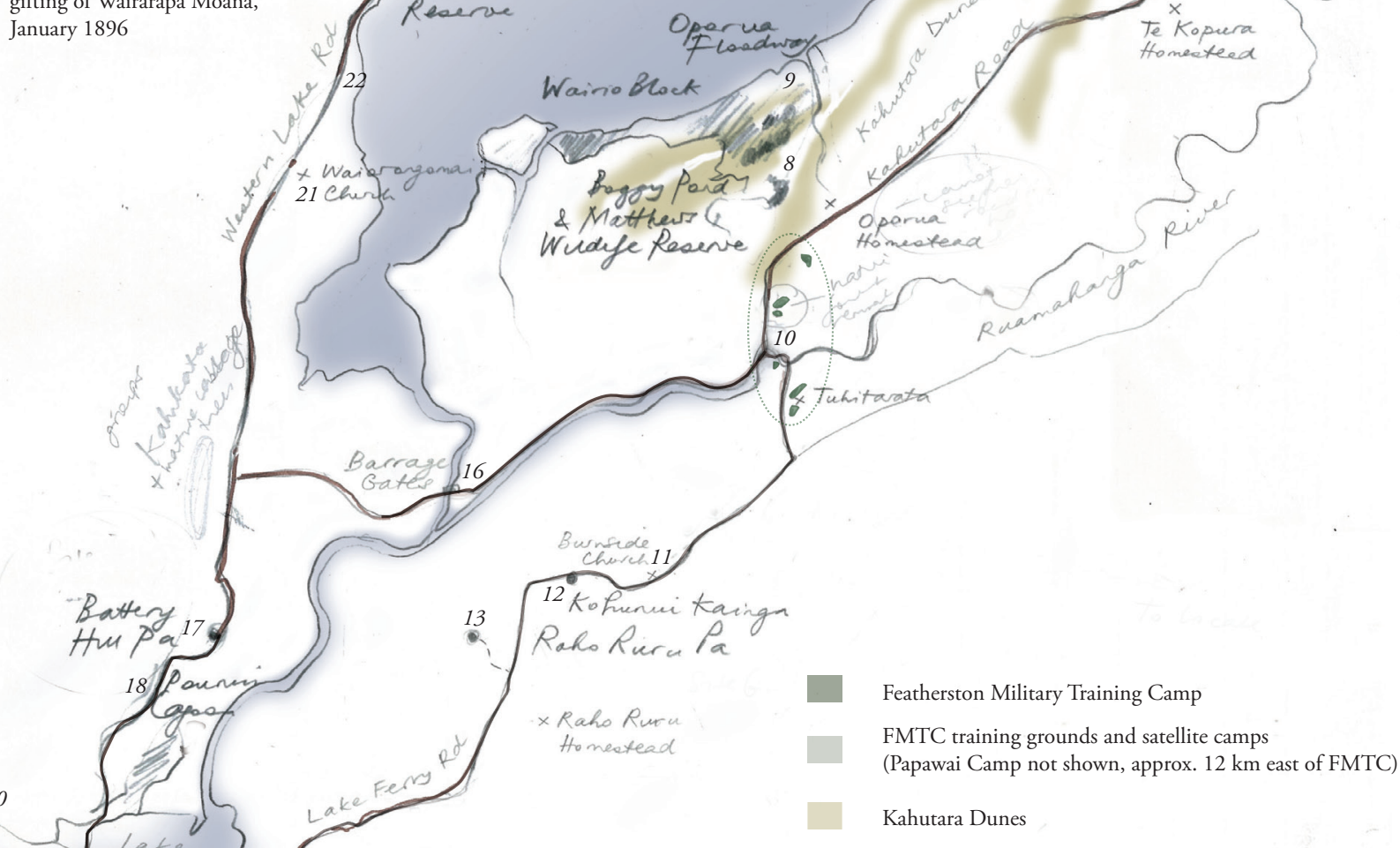

Native forest remnants around meeting of

Ruamahanga River and Kahutara Rd

Orake

spit

$14\left(\begin{array}{ll}\mathrm{La} \\ 15 \\ 0\end{array}\right.$

15 ferry

N

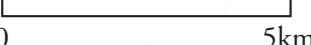

Fig. 3.05. The Second Draft Trail Map. 


\section{Making Landing Images}

The researcher usually sketches and photographs at site visits but the 'landing images' are a new departure, the result of wanting to capture what was experienced in landing. The landing images aim to express the result of what might be called listening to the site, or in Girot's words, 'where one feels before one thinks' and to establish a relationship with the site. This process helped focus and simplify impressions of the site, bringing out what Bürgi calls the site's essence.

Kaiwaiwai Hall landing

this hall

that beld

- at another (camp) site soldiers bravely set for war, is now sited alone and empty, waiting to re-serve

Fig. 3.06. Site 6 - Kaiwaiwai Hall landing image and text. 
Historic Homesteads +

Kahutara Dunes landing

dunes weave between

the homesteads built

by those who cleared,

drained

and farmed

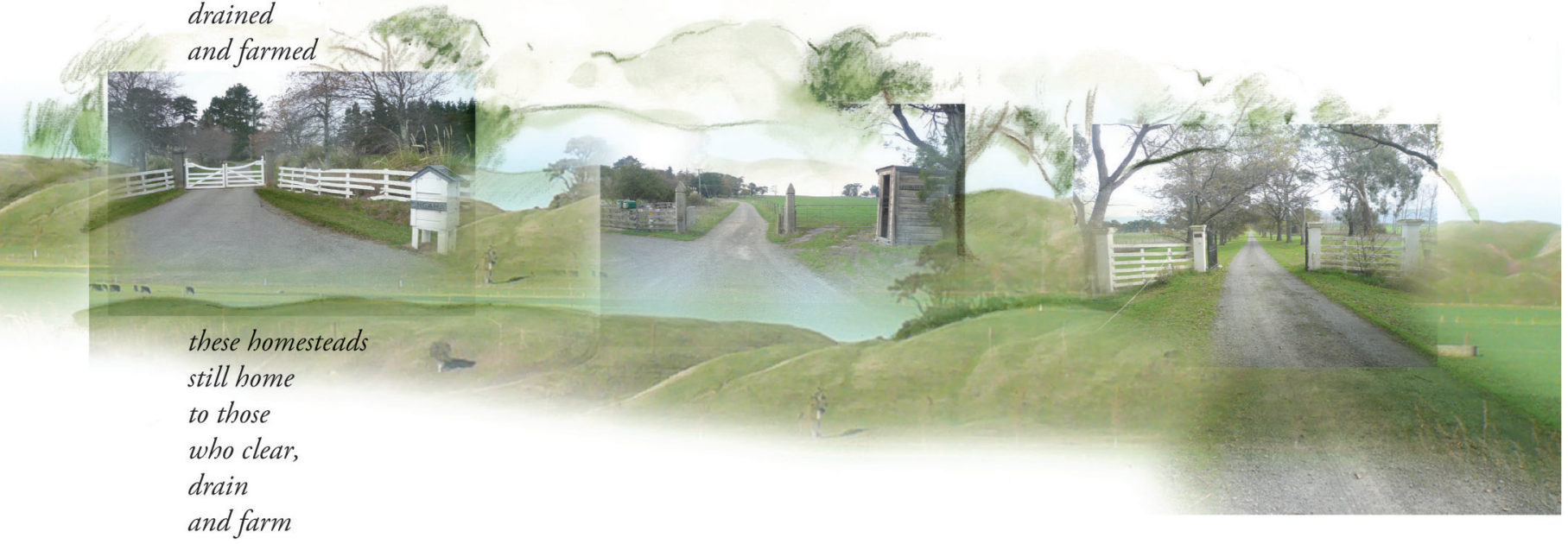

and farm

Fig. 3.07. Site 7 - Historic Homesteads + Kahutara Dunes landing image and text (this site became more correctly two separate sites,

Historic Homesteads + Marine Sediments and Kahutara Dunes).

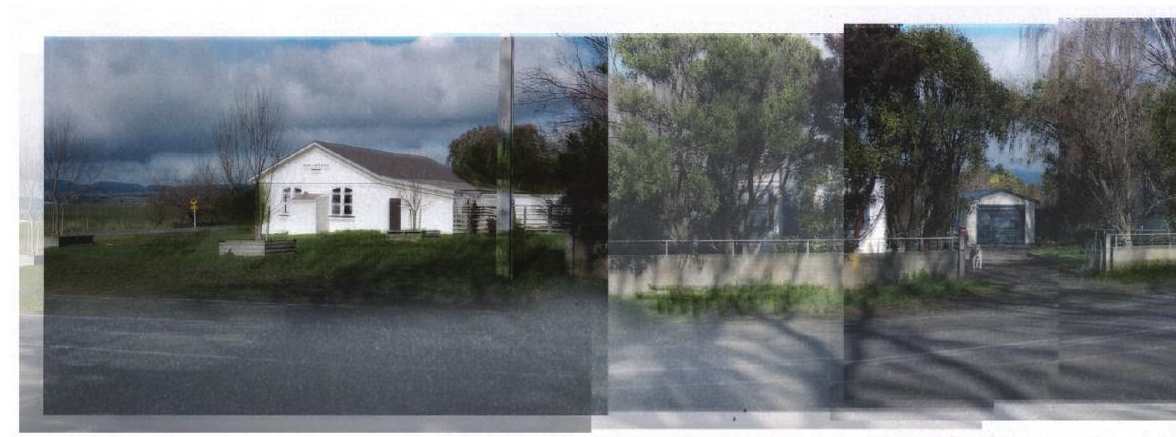

Fig. 3.08. Kahutara landing image and text (included in later draft of trail map). 
Kahutara and Kahutara Dunes were not included in figures 3.02 - 05. Their importance was discovered after these were made, but for completeness the landing images are included here.

Once the landing images were made there was a realisation there were connections back to previous images made by the researcher many years before, when, as an artist, images of landscapes were made that were not solely representational, but expressed a response to the essence of a particular landscape.

Kahutara Dunes

landing

raised spine rising from

flat green-of-paddock expanse

Fig. 3.09. Kahutara Dunes landing image and text (included in later draft of trail map). 


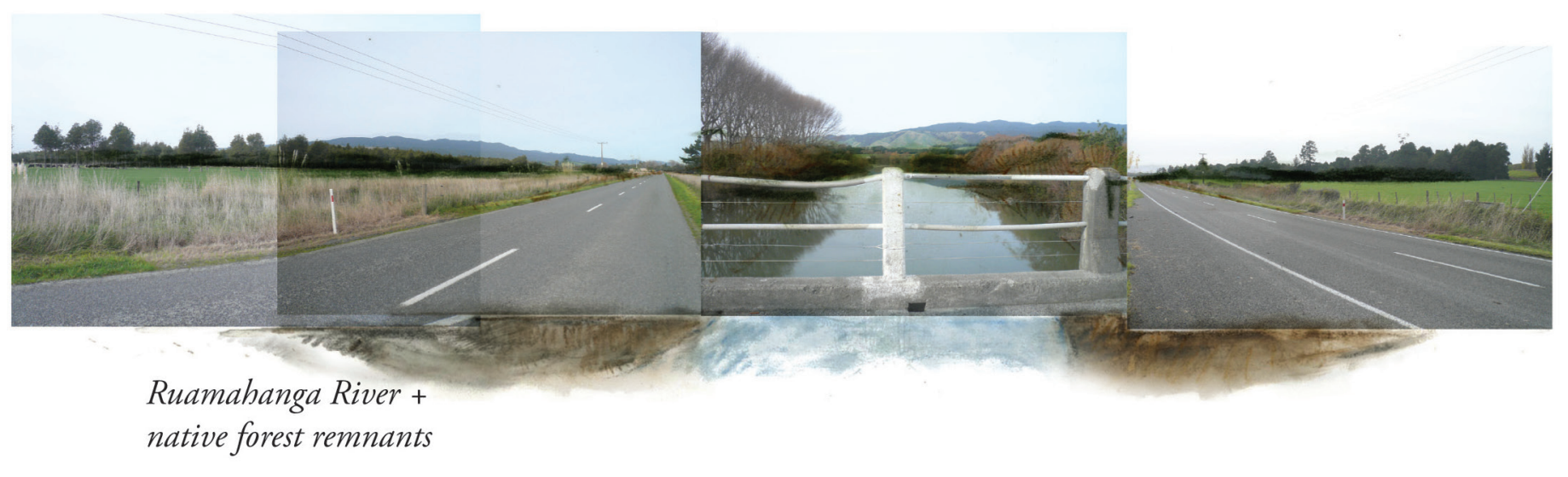

there is a gathering,

a coming together here,

of remnants of

Fig. 3.10. Site 10 - Ruamahanga River + native

what in the past

forest remnants landing image and text.

clothed this land

it is as if

they feel safer close

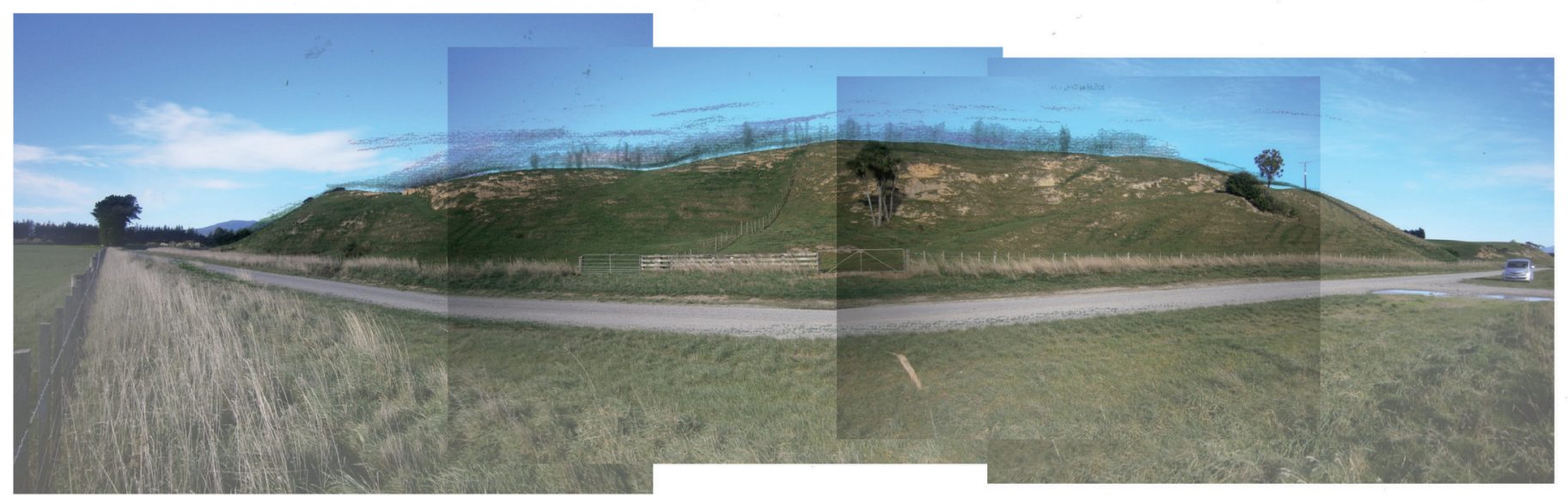

Raho Ruru Pa landing

hidden from my roadside view

Fig. 3.11. Site 13 - Raho Ruru Pa landing image those who held this high ground and text.

look down still 


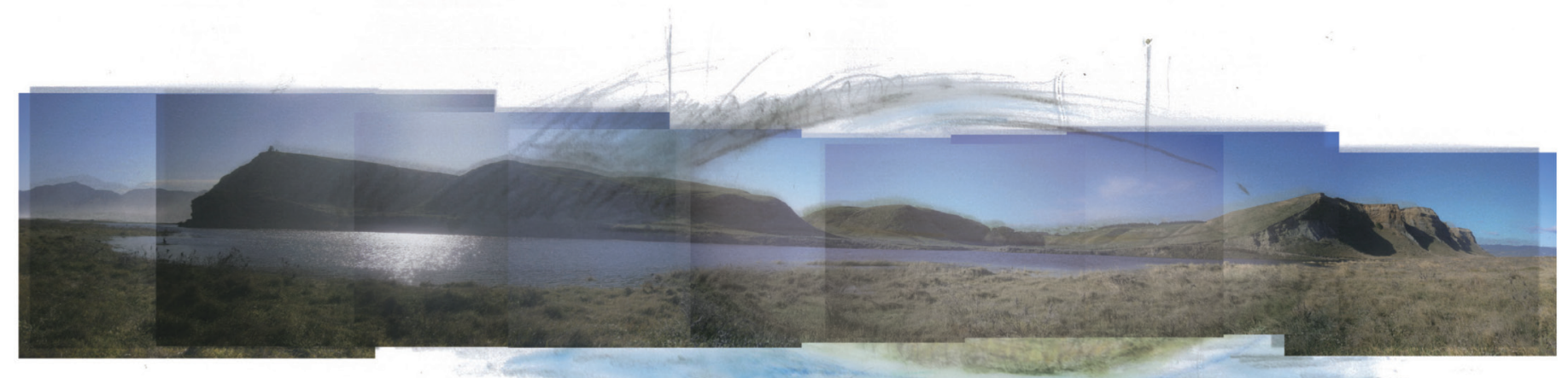

Okorewa kāinga landing

Fig. 3.12. Site 15 - Okorewa

kāinga landing image and text. the hills create a holding a slightly cupped hand, out of the north wind, and facing seaward and the sea's bounty 


\section{Kakahimakatea (Battery \\ Hill) Pa landing}

from the mass of Rimutaka

a finger of hill

points plainwards

from this mighty prow

all can be surveyed -

friend or foe,

taiaha or musket,

buia feather or grazing sheep
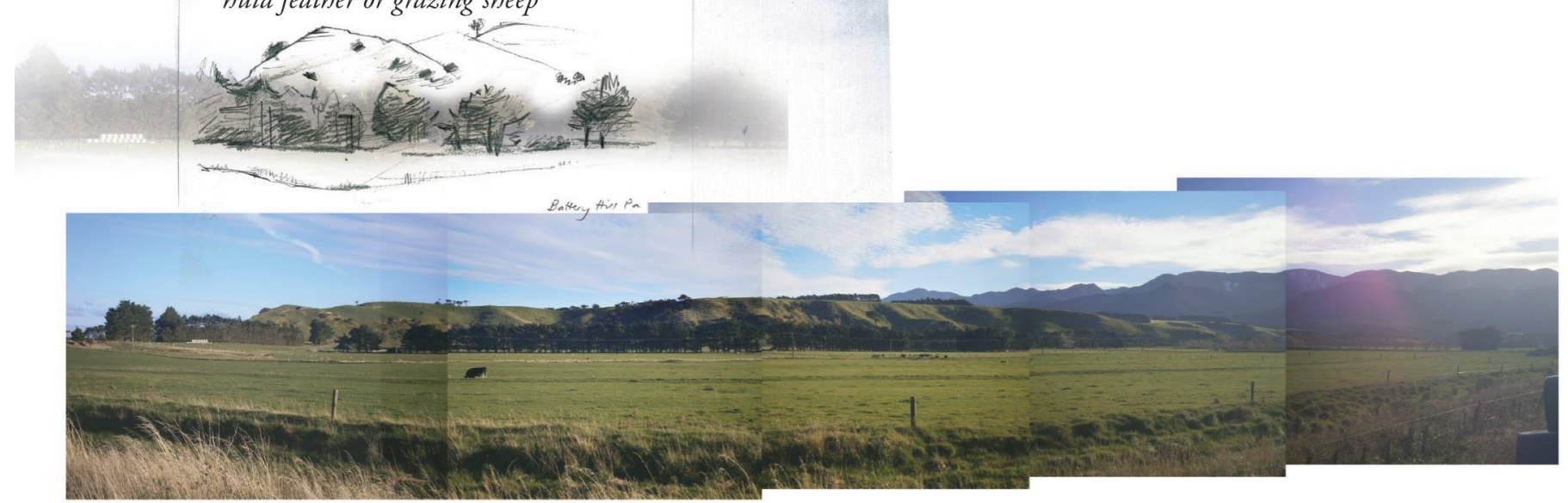

Fig. 3.13. Site 17 - Kakahimakatea (Battery Hill) Pa landing image and text.

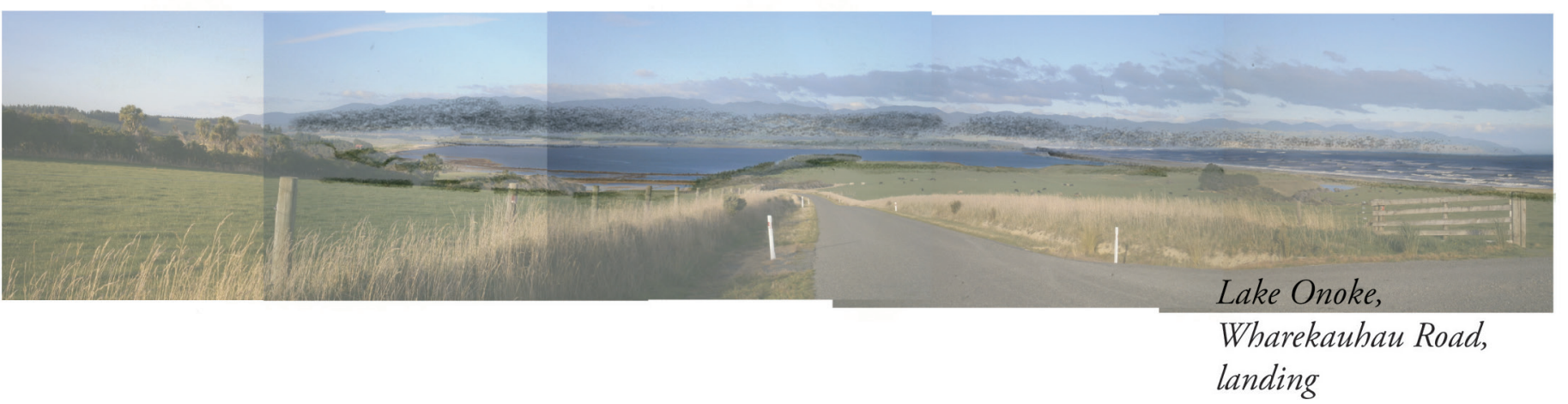

Fig. 3.14. Site 20 - View of Lake Onoke, Onoke Spit and Palliser Bay, Wharekauhau Road landing image and text (later became Wharekauhau Road Viewpoint). wide water view: calm lake to wild sea, mirror-flat blue to rushing white, divided by a line of grey 


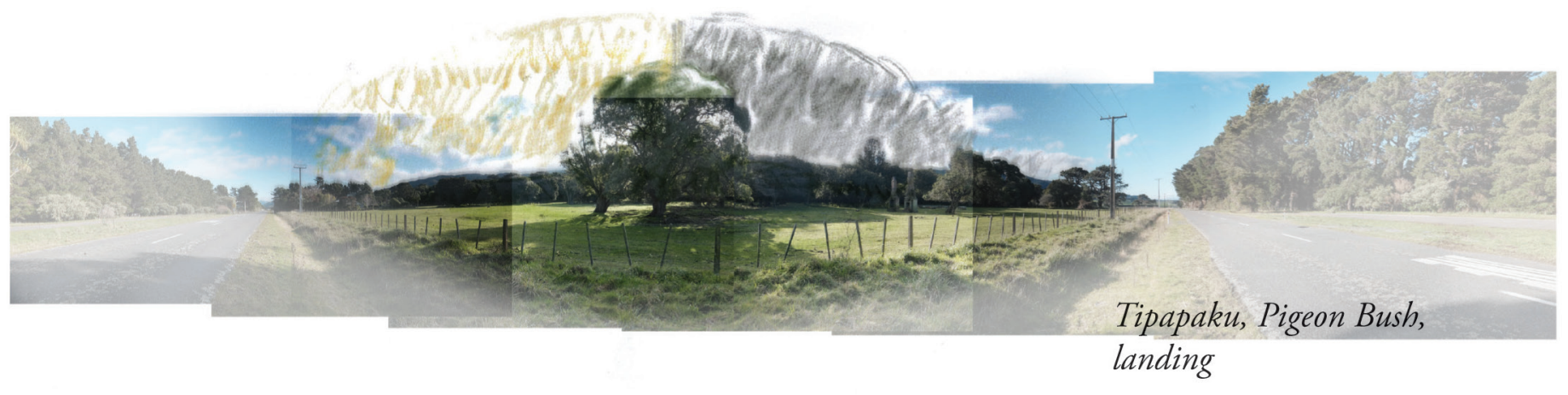

Fig. 3.15. Site 25 - Tipapaku, Pigeon Bush, landing image and text. here at

Tipapaku, Pigeon Bush, a picnic, hakari to celebrate the Maori gift, freely given

here at

Tipapaku, Pigeon Bush, Pakeha promises given, freely broken

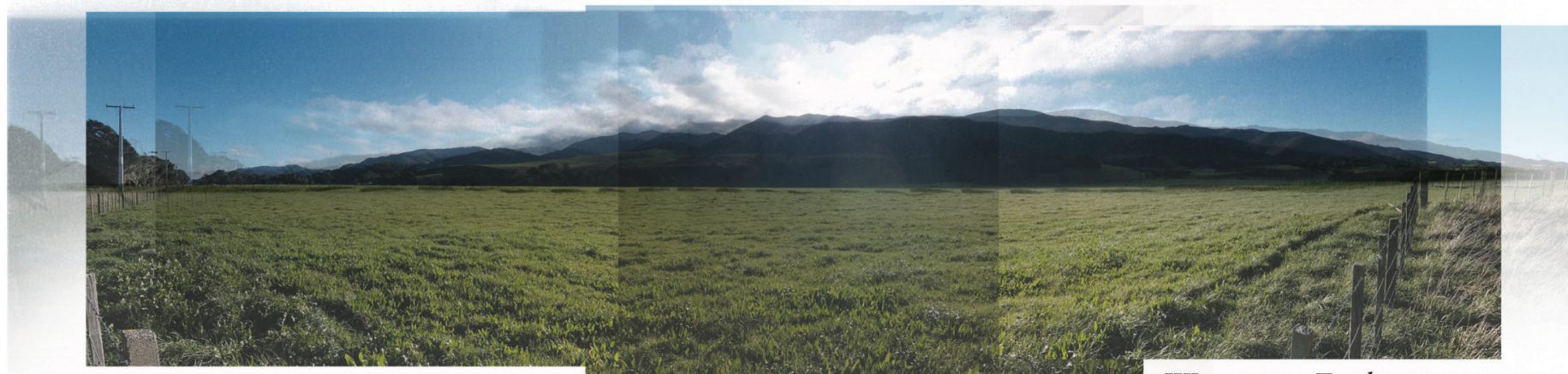

Wairarapa Fault, Pigeon Bush, landing

Fig. 3.16. Wairarapa Fault, Pigeon Bush landing image and text (included in later draft of trail map). at this line

- this fault -

plain and mountain meet abruptly, and part abruptly; part heading seawards, and part northwards 
After making these images the researcher discovered the writing of landscape architects Marc Claramunt and Catherine Mosbach. To them, the designer establishing a relationship with site is 'understanding a milieu' - this "is one of the reflexes in a landscaping project: as though, before using ones brain, there had to be a primitive relation between one and the landscape, reproduced by hand, or thanks to a camera, on paper through the act of drawing or of producing a picture" ( $\mathrm{p}$ 56). It is an instinctive reaction, or a reflex, for the designer to want to record the site for visual reference. The landing images and accompanying text made in response to visiting the sites for the first time were made as the result of an instinct to record the experience of landing at a site, to record the impressions of the first meeting, the beginning of the relationship. Landscape architect and academic Peter Connolly in reference to Claramunt and Mosbach calls this, "an expressive connection to the initial primitive relation.... This moment is not just experienced but is connected to in 'the act of drawing' or reproduction of a picture (83). This 'primitive relationship' with the landscape could be viewed as Girot's intuitions and experiences of place (65), or as Meyer's hearing the site speak (31). It could be what some call the genius of the place or genius loci, or, as Māori say, hearing the natural world speaking (Royal 2). 


\section{Emerging Patterns}

Peter Connolly considers that images such as the landing images could go on to inform later designing: "they point to what might, unsurprisingly, be called 'design expression' or 'landscape design expression', a future-oriented expression of an opening into the design of landscape" (83). The research to this stage was presented at the first design review in June 2015. It was felt by the reviewers that the landing images could be interpreted more fully and may then better inform design rather than primarily expressing the essence or unique identity of the site. It was suggested that the landing images themselves be reviewed and reassessed and that a collective view of the images may also inform design. The following questions were subsequently asked regarding the landing images: What is repeating? Are there patterns? What do they mean? Are there clusters or groups and are these close together or some distance apart? Can the sites be classified as primary or satellite sites. This instigated a deeper looking at the images and what they showed.

The subsequent exploration of the forms and the connections and patterns they unearthed asserted that drawing and making images does not simply mean making images to represent the so-called final design, but can be a way of finding, a method of discovery through the act of doing (see figs. 3.17 - 3.27). Andrea Kahn, architect and academic, has written, "in the most profound sense, representation is not about depicting reality, but about making knowledge" (Kahn 288). The two Pigeon Bush sites are not included in the following exploration until figure 3.22 as their importance emerged with ongoing research. 


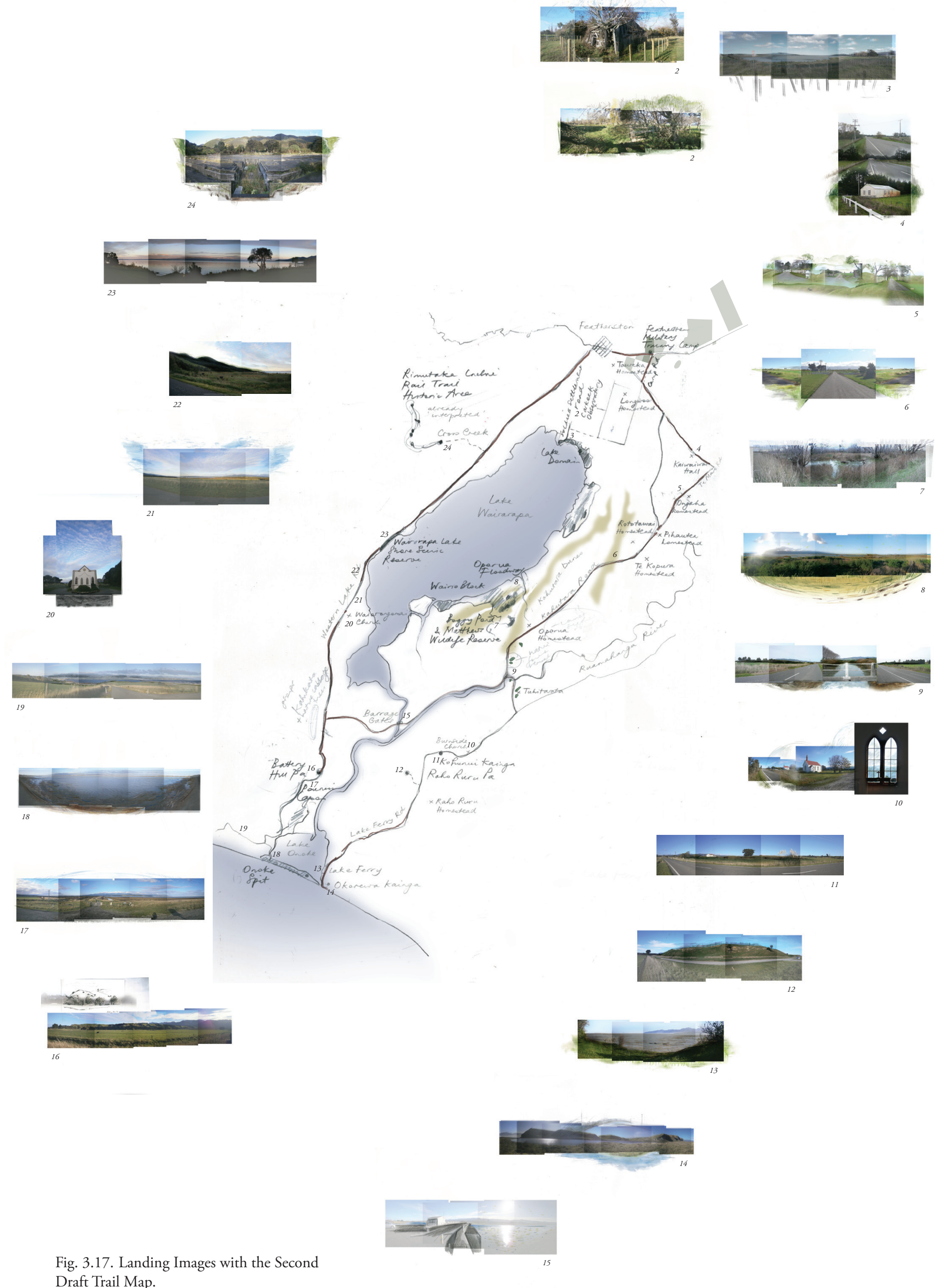




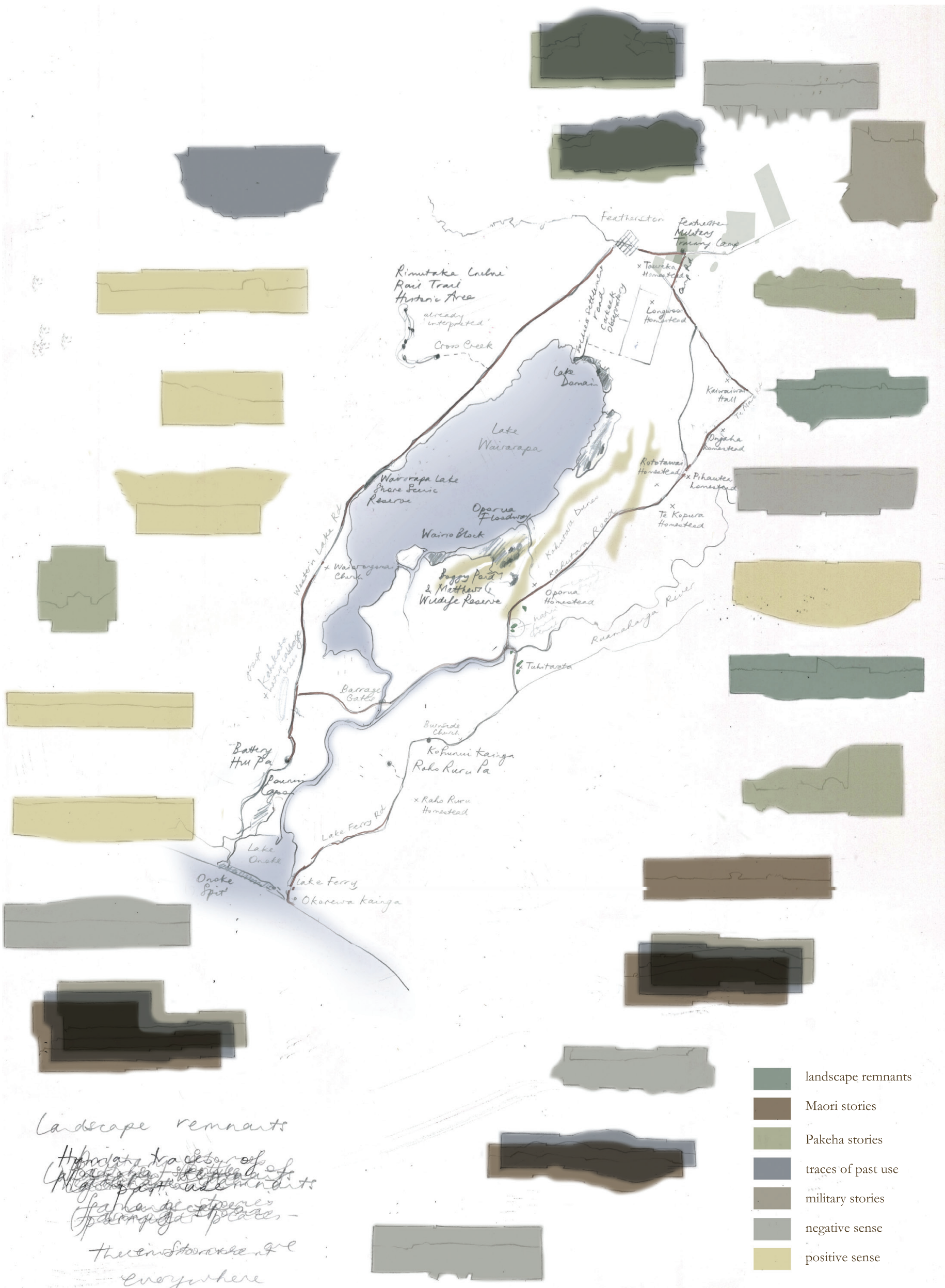

Fig. 3.18. The Different 'Stories' of the Sites, based on fig. 3.17. The term negative sense expresses the feeling 'this is a shame'. 


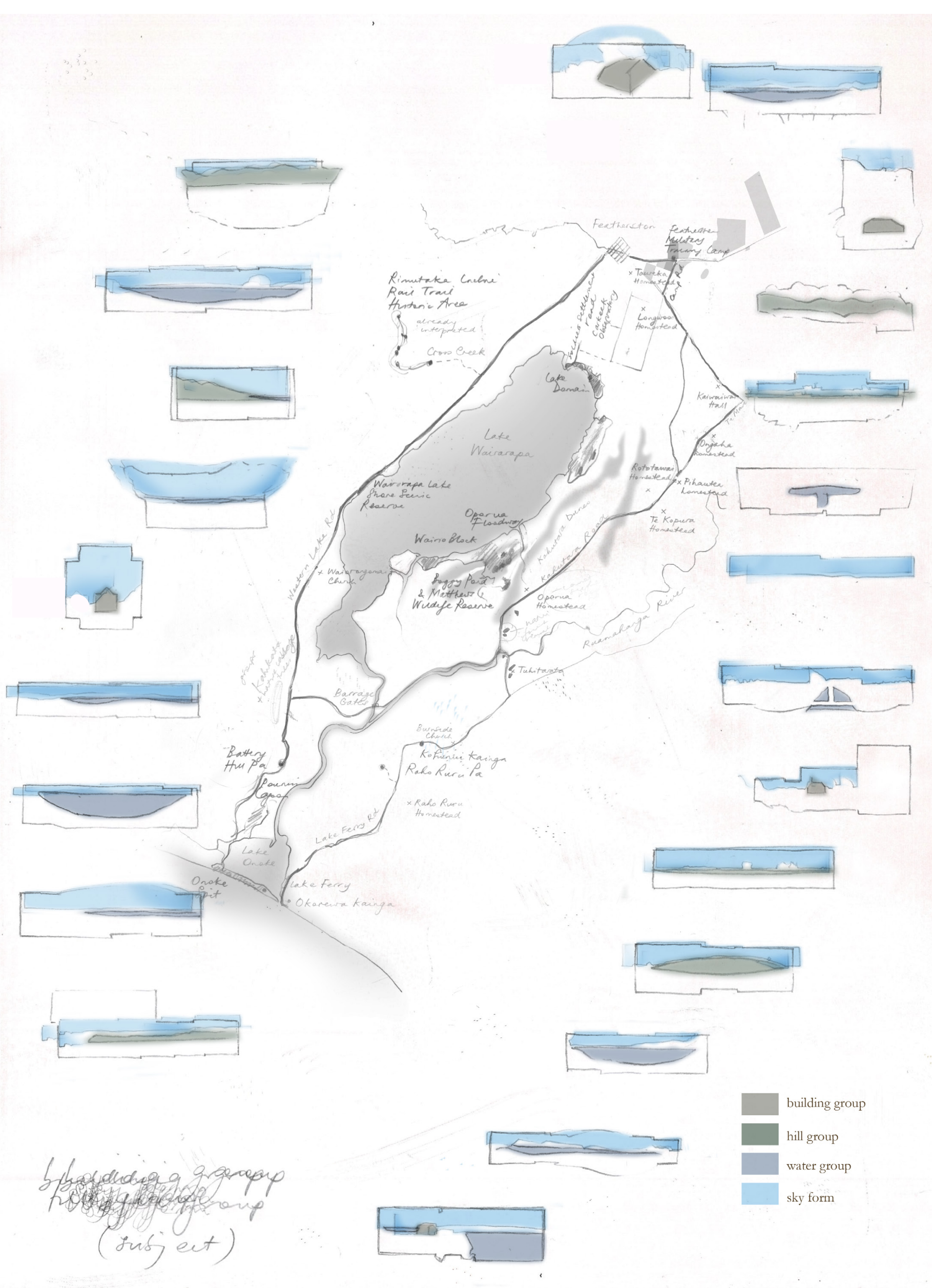

Fig. 3.19. The Different Landscape

Groups of the Sites, based on fig. 3.17. 

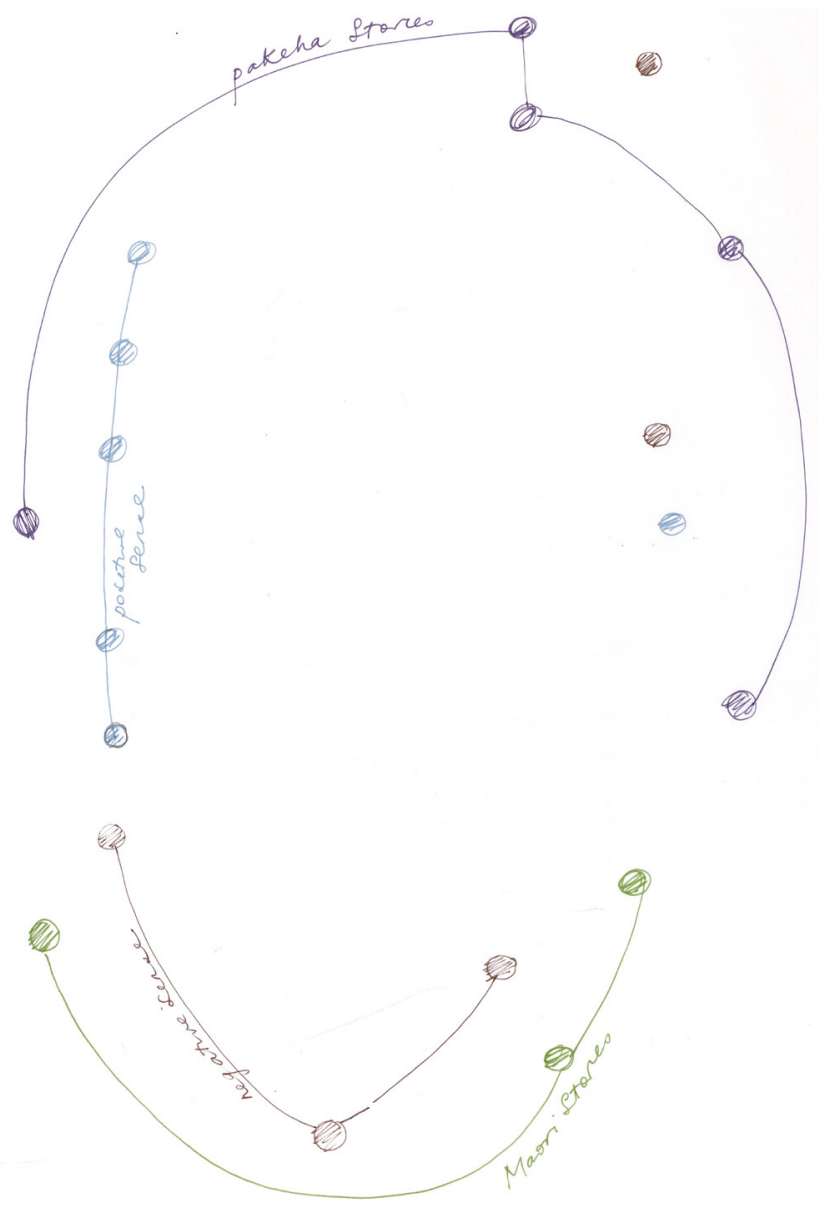

Fig. 3.20. Necklace Diagram of Story clusters.

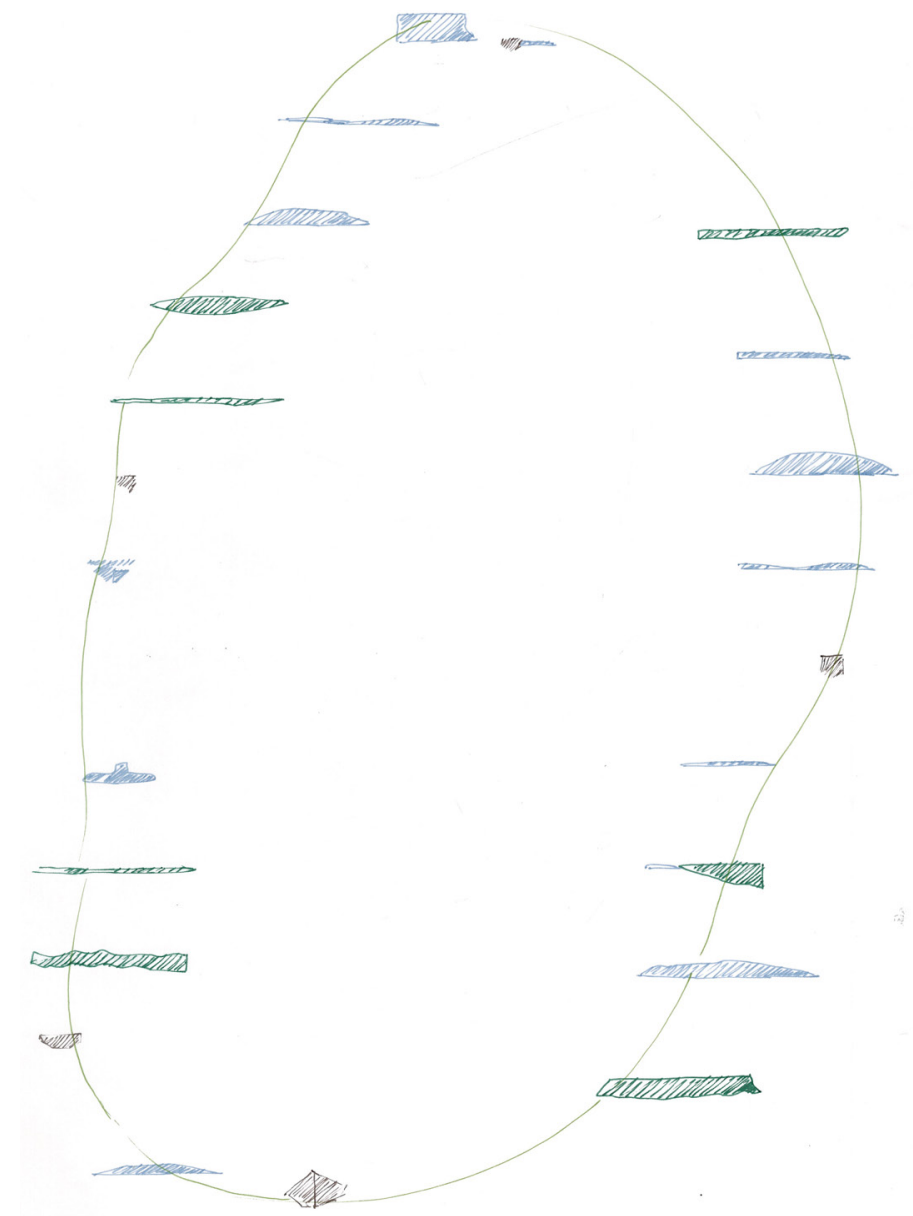

Fig. 3.21. Necklace Diagram of Landscape groups water, hill or building. 


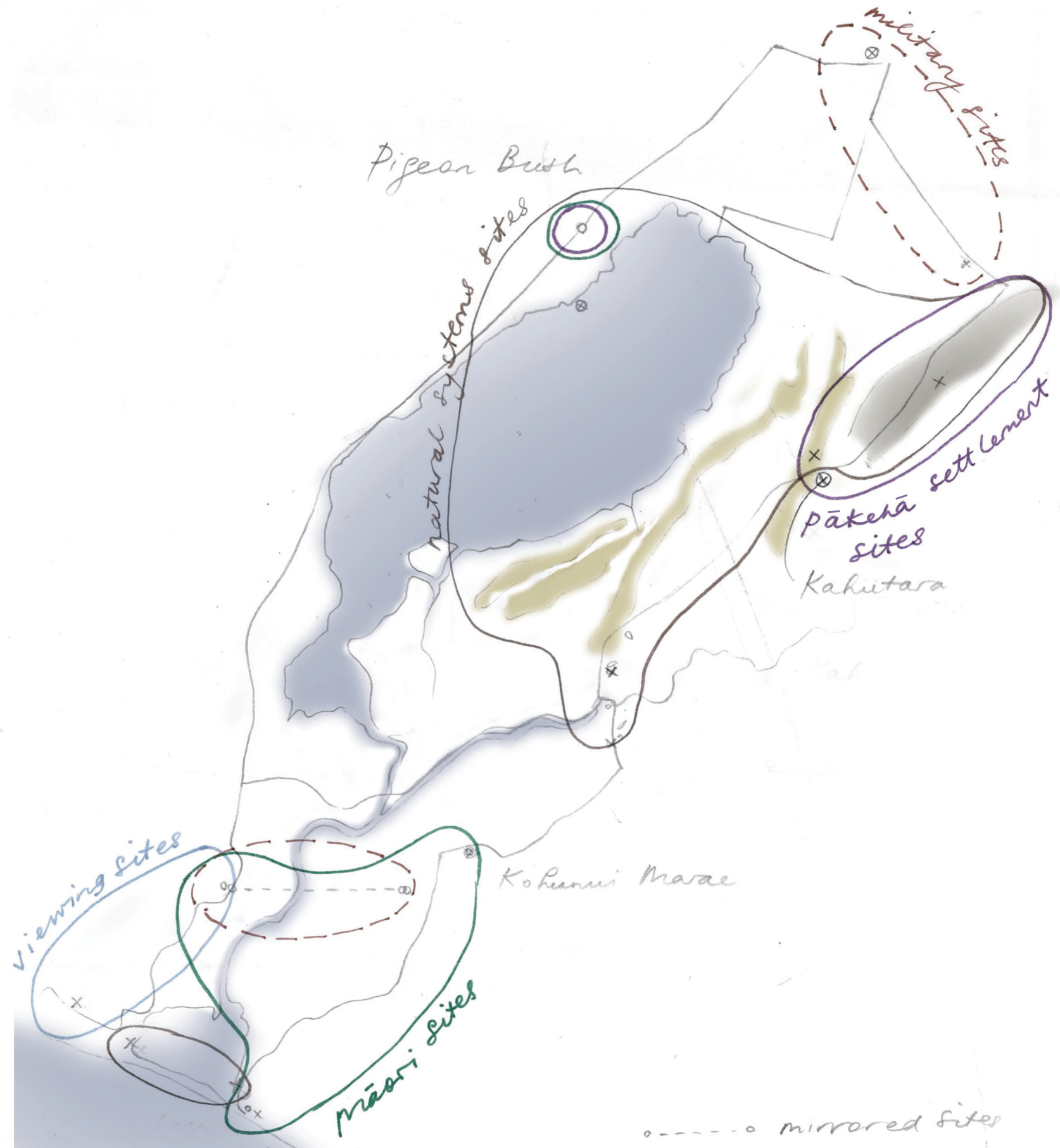

Fig. 3.22. Site Clusters. 


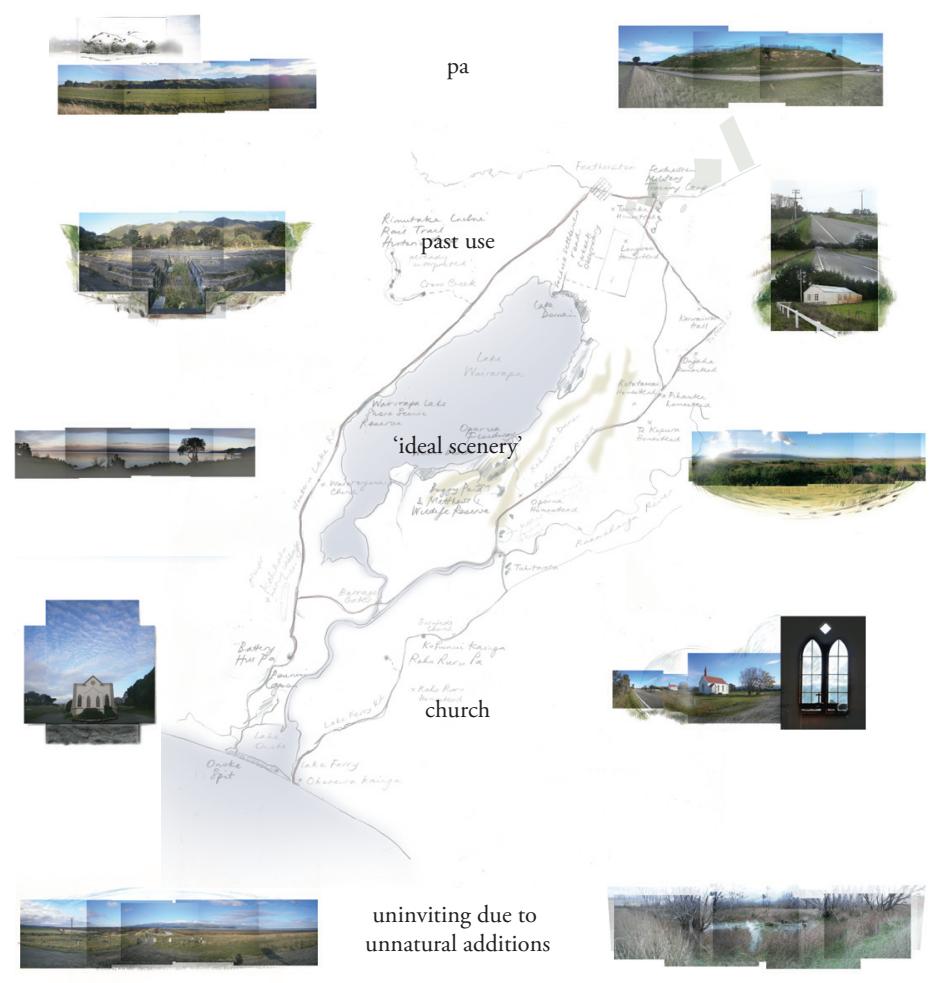

Fig. 3.23. Commonalities found in the landing images.

Horizontality in the landscape - linear form

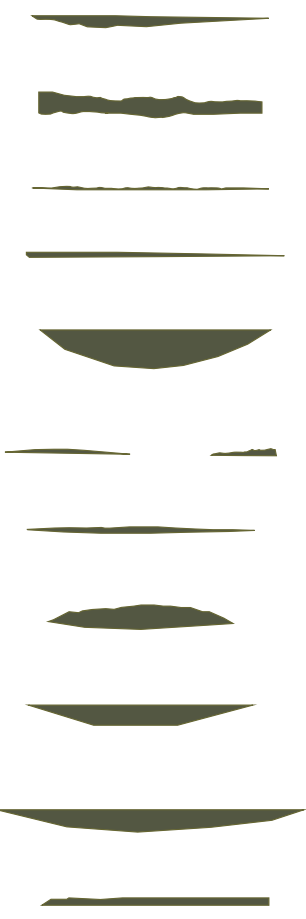

Fig. 3.25. Horizontality found in the landing images.
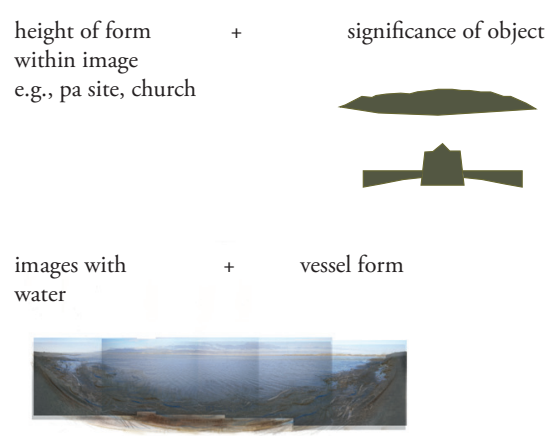

colour intensity $\quad+\quad$ positive sense of image
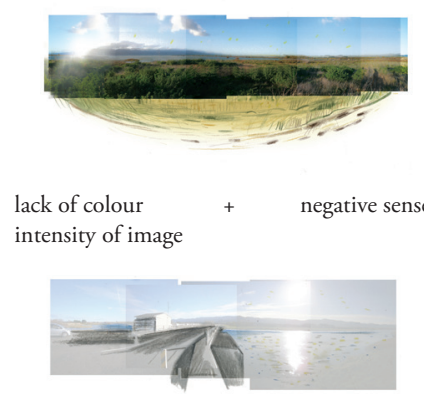

Fig. 3.24. Relationships found in the landing images.

Lake Domain

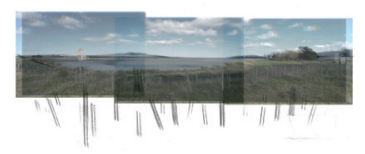

Barrage Gates

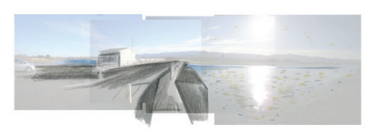

Cross Creek

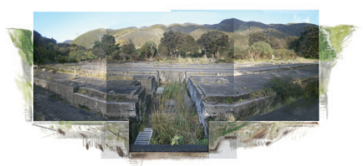

Lake Onoke, at Lake Ferry

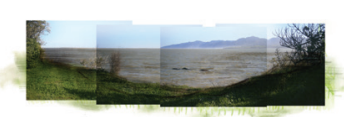

Fig. 3.26. High contrast within landing images expresses negative impact. 


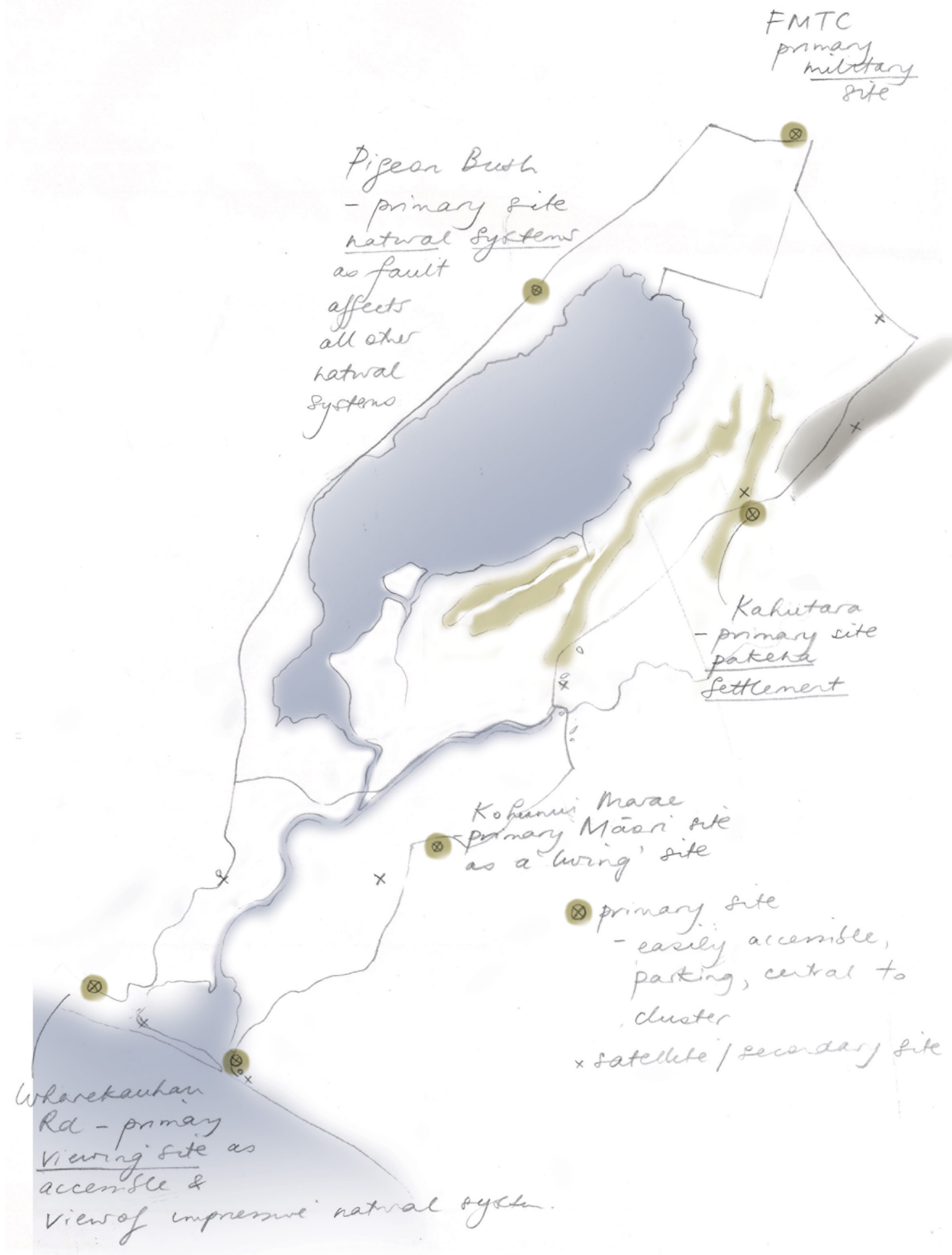

Fig. 3.27. Primary and Satellite Sites 


\section{SITES TO INTERPRET}

1. Kaiwaiwai Hall

2. Historic homesteads + marine sediments

3. Kahutara

4. Kahutara Dunes

5. Native forest remnants

6. Kohunui Marae

7. Raho Ruru Pa

8. Lake Onoke at Lake Ferry

9. Okorewa kāinga

10. Kakahimakatea (Battery Hill) Pa

11. View of Lake Onoke, Onoke Spit and Palliser Bay, Wharekauhau Road

12. Tipapaku (Pigeon Bush) 1896 picnic site

13. the Wairarapa Fault, at Pigeon Bush

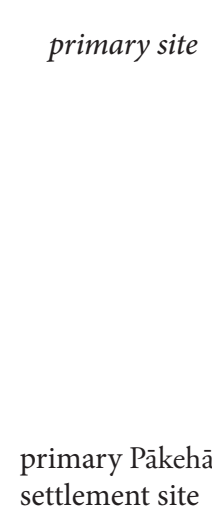

primary Māori

site

primary viewing

site

primary Māori + Pākehā site

primary natural systems site story cluster

landscape group

military

building

Pākehā settlement

hill

Pākehā settlement

buildings

natural systems

hill

natural systems

water

hill

Māori

Māori, military and traces of past use

hill

negative sense

water

Māori and traces

of past use

Māori, traces

of past use and viewing site

positive sense and viewing site

Māori + Pākehā site

building + hill + water

natural system

hill

Table 3.01 Sites to interpret with site grouping information. 


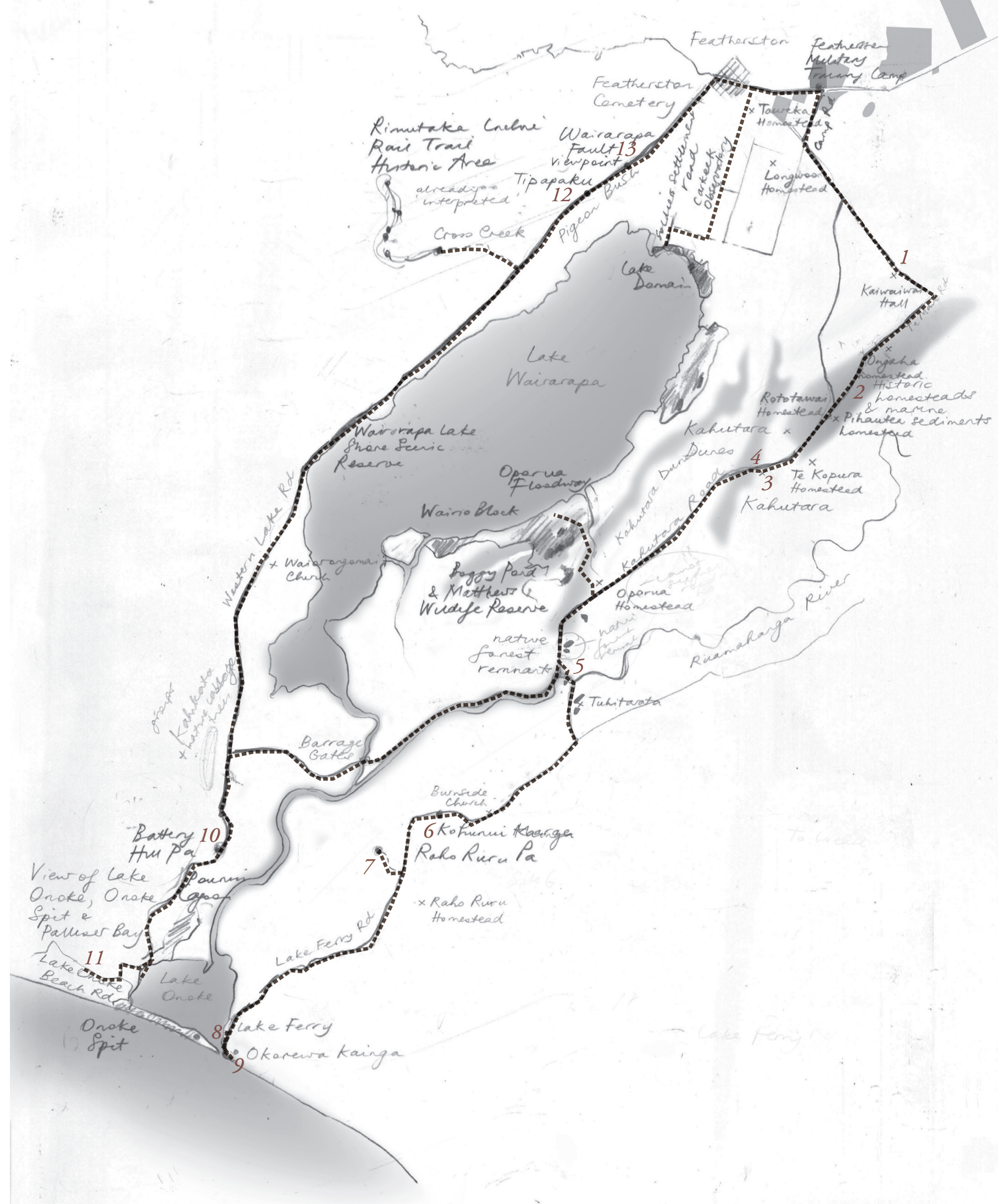

Fig. 3.28. Sites to Interpret, as in table 3.01. 


\section{GROUNDING}

Elizabeth Meyer, in discussing how Vaux and Olmsted changed the boundaries of Prospect Park to include three glacial formations that then could be reinforced as distinct landforms - the meadow, the ravine and the lake - ... argued that without knowledge of both geology and new landforms, the 'ground is silent'. (Hunt 33)

The second of Girot's trace concepts is grounding, or as he wrote, reading and understanding the site, which unlike landing can continue indefinitely (62). Girot says it "is a process implying successive layers, both visible and invisible ... it is not necessarily what remains visible to the eye that matters most, but those forces and events that undergird the evolution of a place" (63).

While limited site analysis was done in order to determine which sites to consider interpreting, systematic research into the landscape processes that have come together to form each site was done after reflection on the landing images. The information gathered was made into six analysis maps and the second draft trail map was layered on them (see figs. 4.05, 4.10, 4.13, 4.18, 4.23 and 4.28). In doing so the researcher's intuition that the character, story and location of each site was dependent on the landscape and the landscape processes that formed it was confirmed, for example, the settlement of Kahutara was established on land protected by the dunes from flooding. Further examples are illustrated in the photographs on the following pages (see figs. 4.01 to 4.27). Landscape elements and processes have woven together to make each site what it is and enabled the creation of the heritage that is to be interpreted, and are therefore an integral part of a site's heritage. 

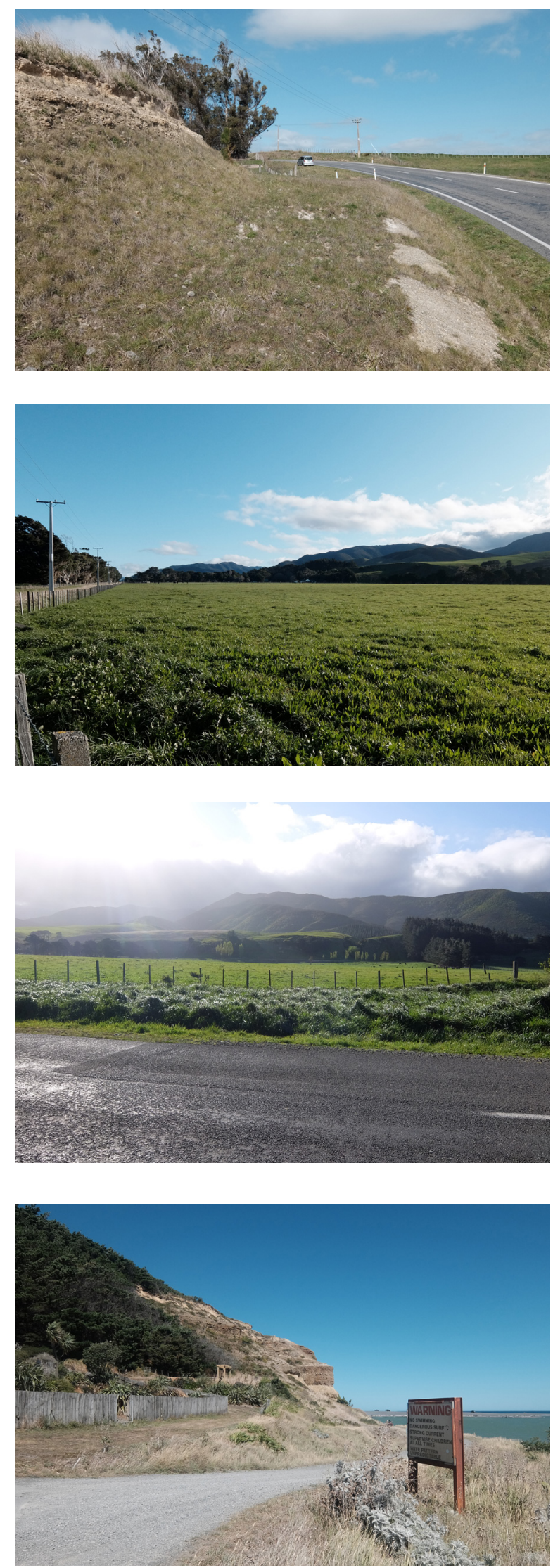

Fig. 4.01. Te Maire Road rises up onto the raised marine sediments, a reminder that the sea once reached much further inland.

Fig. 4.02. The Wairarapa Fault runs along the edge of the plain and has caused the dramatic change in topography.

Fig. 4.03. The Wairarapa Fault caused the 1855 earthquake that remains the most severe since 1840 - this picture was taken at a similar location to fig. 4.02 , just north of site 25 in fig. 4.05 .

Fig. 4.04. The headland just past Lake Ferry shown as limestone in fig. 4.05, with the fence of the Lake Ferry Hotel visible on the left. 

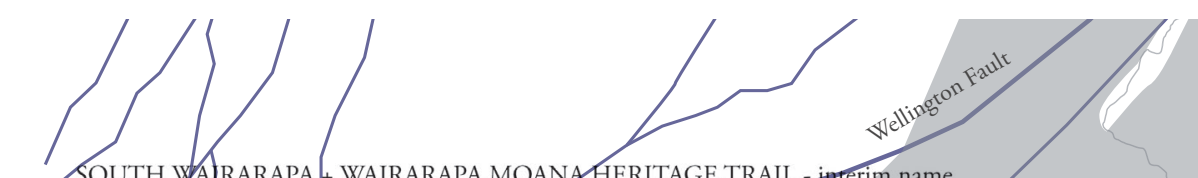

(n)

3. Wairarapa Lakervatory and house site

\section{Featherston} Featherston Military Training Camp Kaiwaiwai Hall, via Camp Rd

8. Boggy Pond \& Matthews Xildlife Reserve (WMWP)

9. Wairio Block (WMWD)

10. Native forest rem ants afound meeting of Ruamahanga River and Kahutara Rd

11. Burnside Church

12. Kohunui Marae

13. Raho Ruru Pa

14. Lake Onoke, at Lake Ferty

15. Okprewa kainga

16. Barrage fates

17. Battery Hill Pa

18. Pounui Lagoon (WMWP)

19. Lake Onoke, Beach Road, western edge (WMWP)

20. View of Lake Onoke, Onoke Spit and Palliser Bay, Whareleauhau Road

21. Waiorongoma Church

22. Views of lake from Western Lake Road

23. Wairarapa Lake Shore Scenic Reserve (WMWP)

24. Cross/Creek, Rimutaka Incline Rail Trail Historic Area

25. Pigeon Bush - the Wairarapa Fault;

Tipapaku (Pigeon Bush) the site
of the picnic to celebrate the of the picnic to celebrate the
gifting of Wairarapa Moana, January 1896
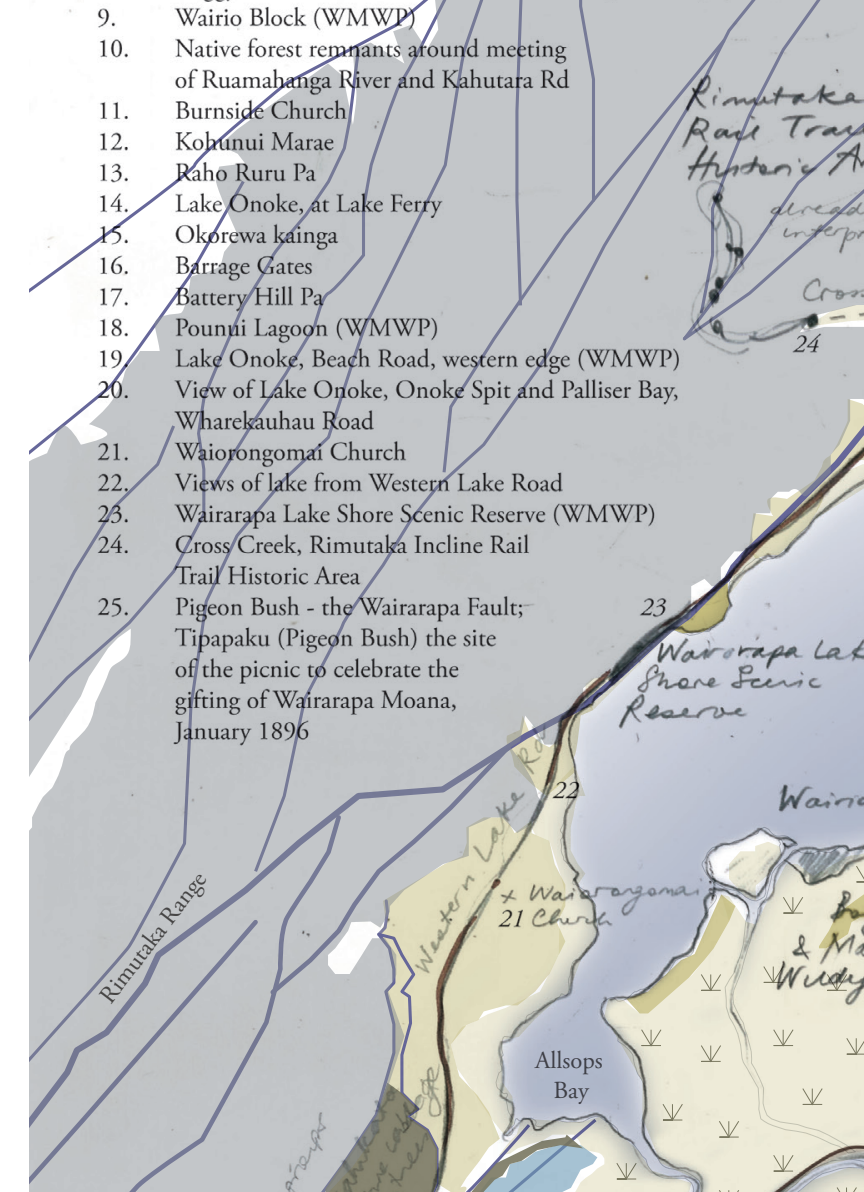
terim name 

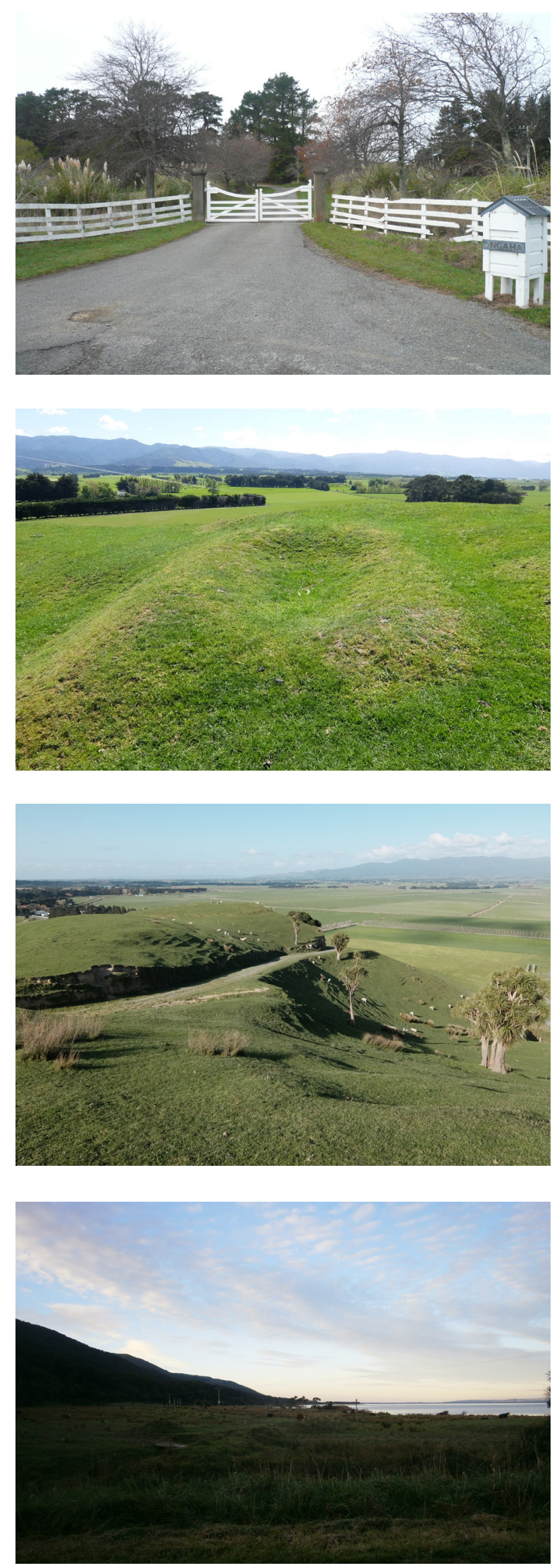

Fig. 4.06. The entrance to Ongaha Hometstead on Te Maire Road, safe from flooding above the plains.

Fig. 4.07. One of the fifteen raised rim pits of Raho Ruru Pa with wide views to the Rimutaka Range.

Fig. 4.08. The view from the opposite side of the valley to fig. 4.07. The terraces of Kakahimakatea Pa are clearly visible on the high ground above the farm road. The Aorangi Range is in the distance.

Fig. 4.09. The Rimutaka Range reaches down to Lake Wairarapa (site 22 on fig. 4.10). "As part of its proposed Treaty of Waitangi settlement package, Rangitāne o Wairarapa wants the name Rimutaka changed to Remutaka so that it finally makes sense. Rimutaka means nothing in Māori, whereas Remutaka translates as "place to sit" and describes how a chief took a rest while he was pursuing his wayward wife across the ranges to Wairarapa" (Fuller). 


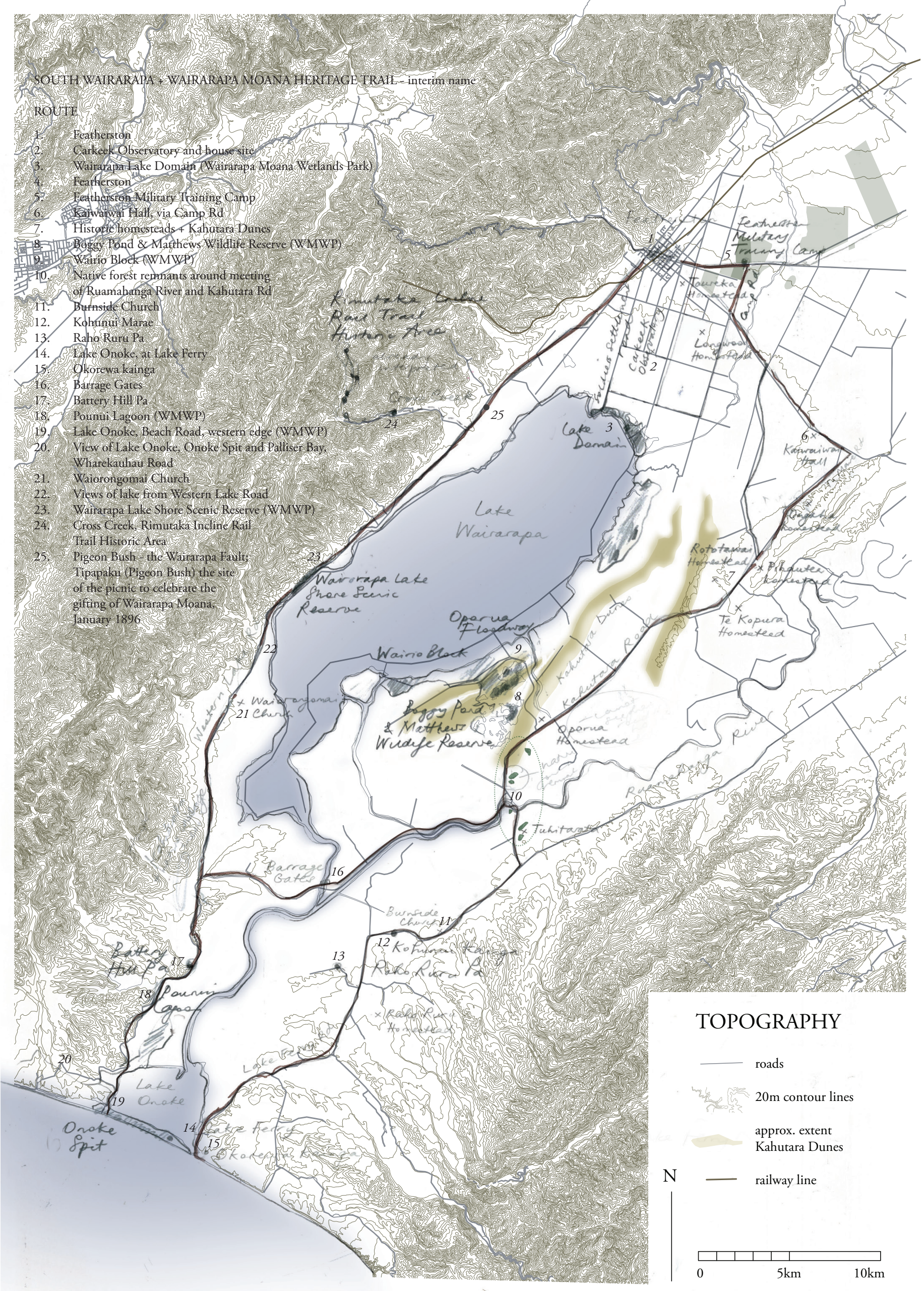

Fig. 4.10. Map showing the Topography of the Trail Area. 

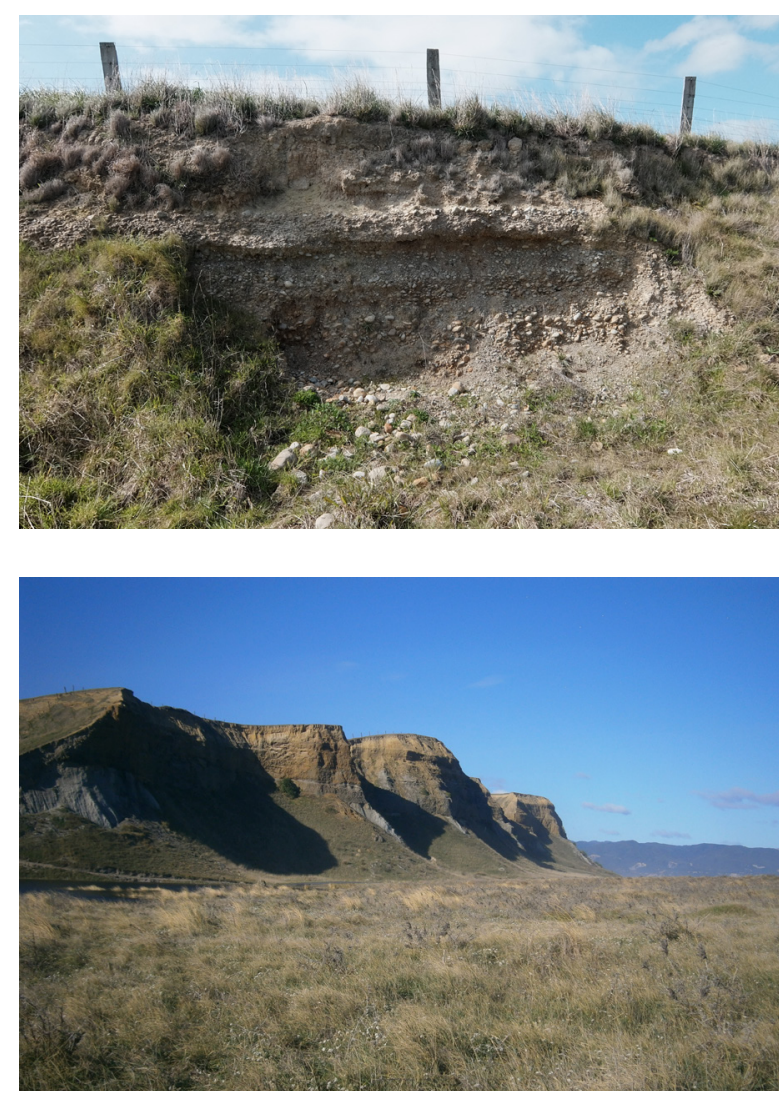

Fig. 4.11. A closeup of fig. 4.01 and the exposed marine sediments on Te Maire Road.

Fig. 4.12. The uplifted marine terraces east of Lake Ferry. 
$\sum^{3}$

\section{Y}

SOUTH WAIRARAPA + WAIRARAPA MOANA HERITAGE TRAIL - interim name ROUTE

1. Featherston

2. Carkeek $O$ bservatory and house-site

3. Wairatapanake Domain (Wairarapa Moana Wetlands Park)

4. Featherston 1 in

5. Featherstom Military Taining Camp

6. 管

7. Histonestomesteads Kahutara Dunes

F \& Ii 192. 1) Wáirio Bloce (WMWP)

F. Natiye forest remnants around meeting

F of Ruamahanga River and Kahutara Rd

11. Bumside Church

12. Kohunui Marae

13. Raho Ruru Pa

14. Lake Onoke, at LakêFerry

15. Okorewa kainga

16. Barrage Gates

_ 17. Battery Hill Pa

18. Pounui Lagoon (WMWP)

19. Lake Onoke, Beach Road, western edge (WMWP)

20. View of Lake Onoke, Onoke Spit and Palliser Bay,

Wharekauhau Road

21. Waiorongomai Church

22. Views of lake from Western Lake Road

23. Wairarapa Lake Shore Scenic Reserve (WMWP)

24. Cross Creek, Rimutaka Incline Rail Trail Historic Area

25. Pigeon Bush - the Wairarapa Fault; Tipapaku (Pigeon Bush) the site of the picnic to celebrate the gifting of Wairarapa Moana, January 1896
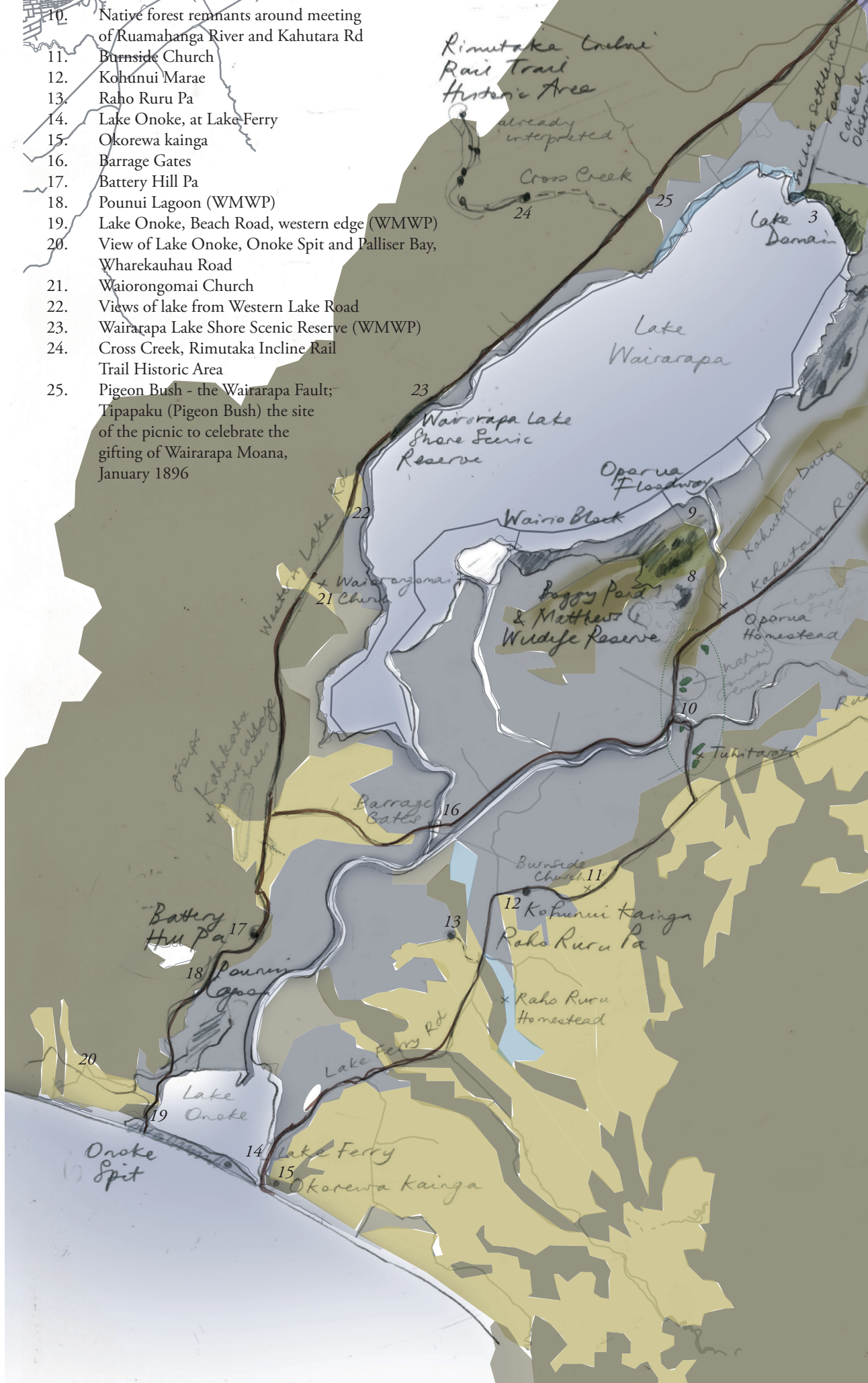
Raci Traci

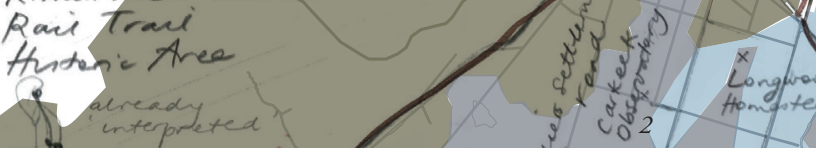

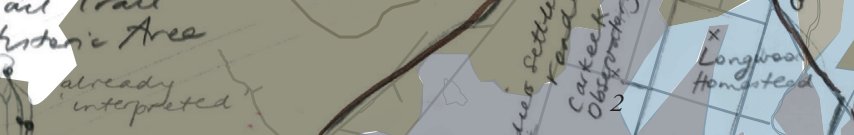

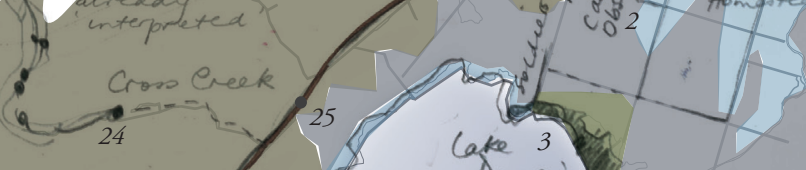

$$
\text { (1) }
$$



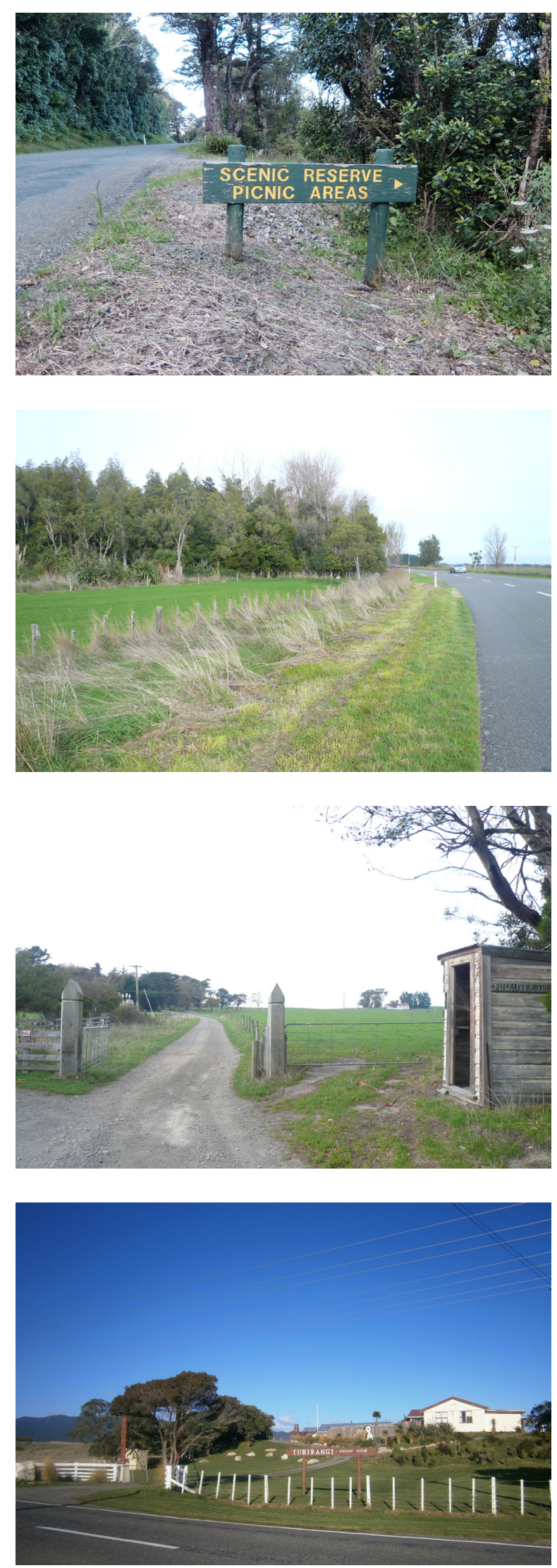

Fig. 4.14. The old DOC sign for Wairarapa Lake Shore Scenic Reserve on Western Lake Road, site 23 in fig. 4.18.

Fig. 4.15. E. C. Holmes Scenic Reserve on East West Access Road, part of the native forest remnants around the meeting of the Ruamahanga River and Kahutara Road, site 10 in fig. 4.18.

Fig. 4.16. The entrance to Pihautea Station on Kahutara Road, part of C. R. Bidwill's Pihautea. He began farming here in 1844, the first Pākehā settler west of the Ruamahanga River. In 1896 the run was divided for his sons into three blocks, Pihautea, Rototowai, and Tawaha.

Fig. 4.17. Kohunui Marae sits on a ridge that overlooks the plain. 


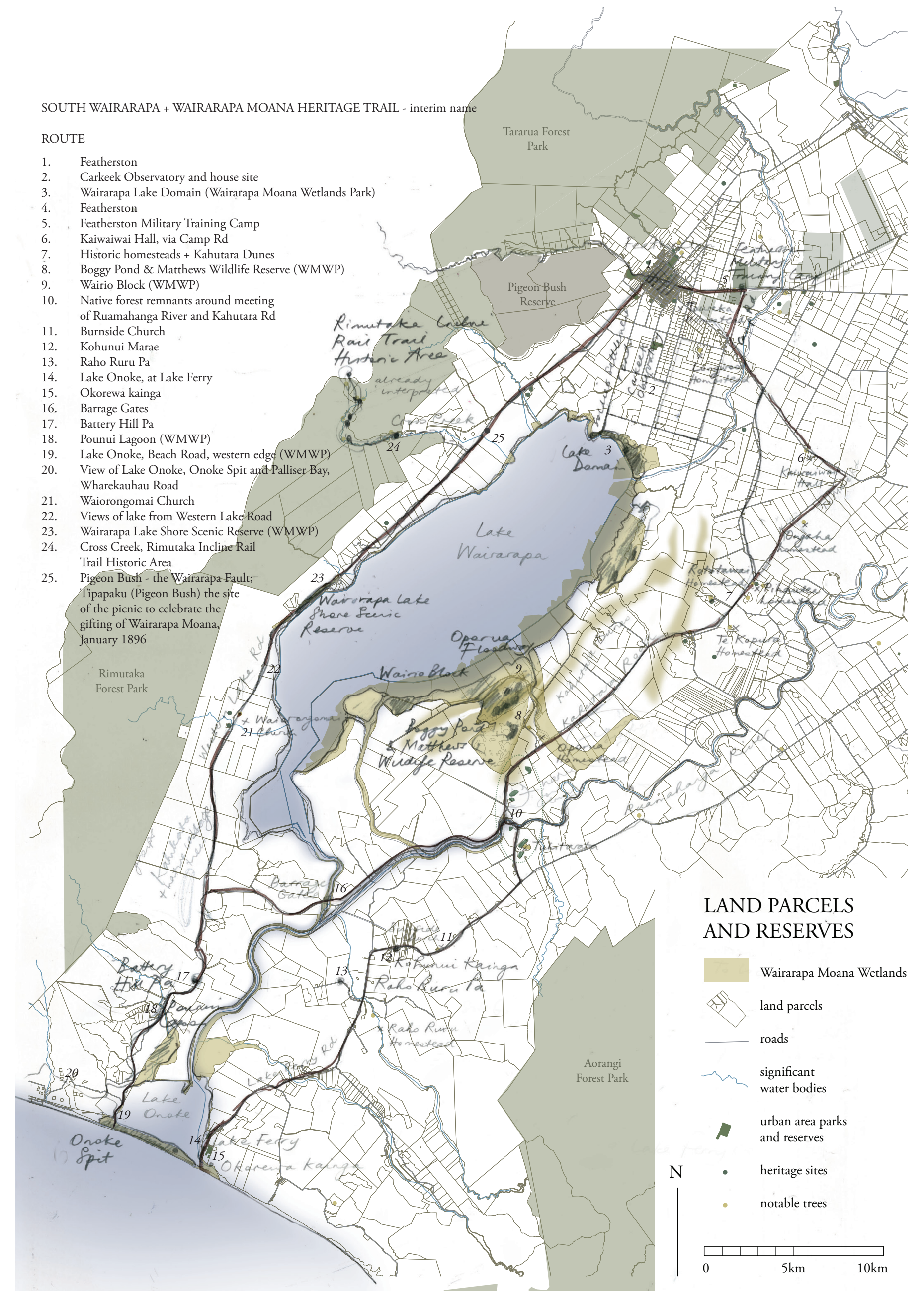

Fig. 4.18. Map showing the Land Parcels and Reserves of the Trail Area. 

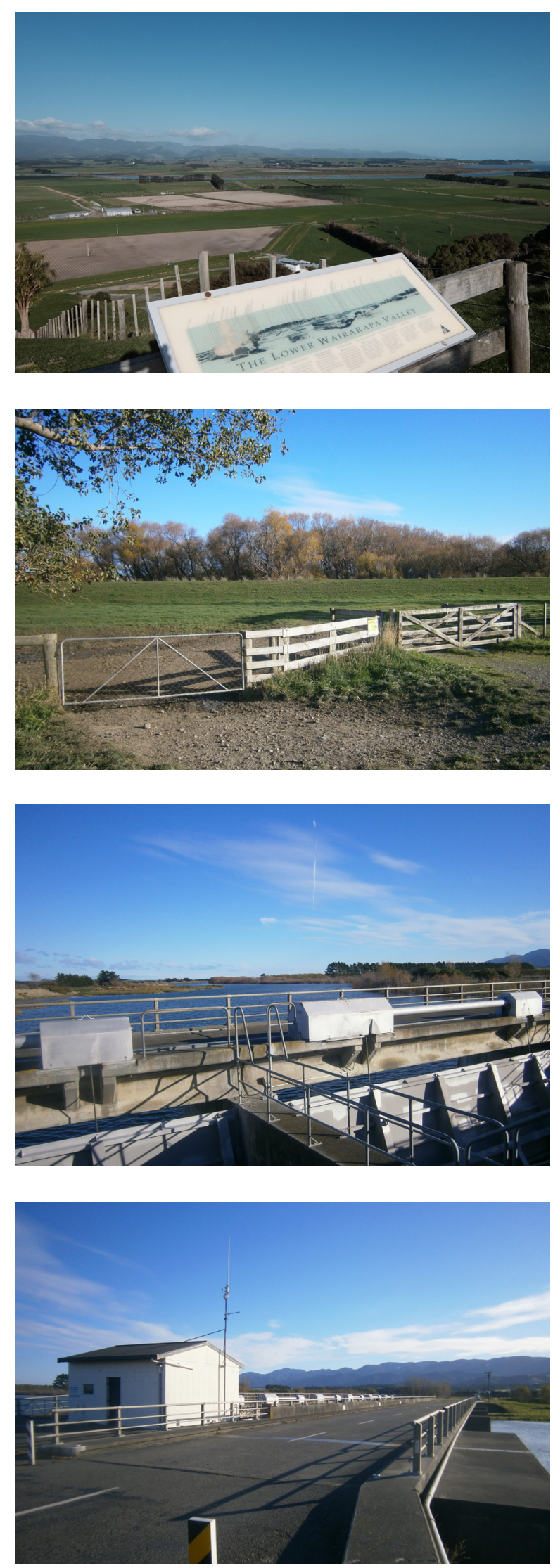

Fig. 4.19. This sign shows points of interest and sits on high ground above Kakahimakatea Pa (close to where fig. 4.08 was taken). The lower reaches of the Ruamahanga River and the effects of the flood protection scheme can be seen. "The Lower Wairarapa Valley Development Scheme is one of New Zealand's largest and most ambitious flood protection projects, benefiting a total land area of 31,500 hectares" (Lower Wairarapa Valley Development Scheme).

Fig. 4.20. The stopbank just north of the barrage gates runs alongside the Ruamahanga Diversion. "The Ruamahanga River was diverted from its direct course into Lake Wairarapa, across the Kumenga Peninsula and into the Lower Ruamahanga" (Lower Wairarapa Valley Development Scheme).

Fig. 4.21. The barrage control gates looking towards the sea. They "largely prevent all normal flows of the Ruamahanga from entering Lake Wairarapa. The barrage has also enabled levels of Lake Onoke to be raised quickly to either overcome impending blockage of the outlet or to aid in the formation of a new opening. This also means that the lake can be kept at a low level, ready to accept any flows from the Oporua Floodway" (Lower Wairarapa Valley Development Scheme).

Fig. 4.22. The East West Access Road runs across the barrage gates. The Rimutaka Range is in the distance. 
SOUTH WAIRARAPA + WAIRARAPA MOANA HERITAGE TRAIL - interim name ROUTE

Featherston

Carkeek Observatory and house site

Wairarapa Lake Domain (Wairarapa Moana Wetlands Park)

Featherston

Featherston Military Training Camp

Kaiwaiwai Hall, via Camp Rd

Historic homesteads + Kahutara Dunes

Boggy Pond \& Matthews Wildlife Reserve (WMWP)

Wairio Block (WMWP)

10. Native forest remnants around meeting

of Ruamahanga River and Kahutara Rd

Burnside Church

Kohunui Marae

Raho Ruru Pa

Lake Onoke, at Lake Ferry

Okorewa kainga

Barrage Gates

Battery Hill Pa

Pounui Lagoon (WMWP)

Lake Onoke, Beach Road, western edge (WMWP)

View of Lake Onoke, Onoke Spit and Palliser Bay,

Wharekauhau Road

Waiorongomai Church

Views of lake from Western Lake Road

Wairarapa Lake Shore Scenic Reserve (WMWP)

Cross Creek, Rimutaka Incline Rail

Trail Historic Area

25. Pigeon Bush - the Wairarapa Fault;

Tipapaku (Pigeon Bush) the site

of the picnic to celebrate the

gifting of Wairarapa Moana,

January 1896
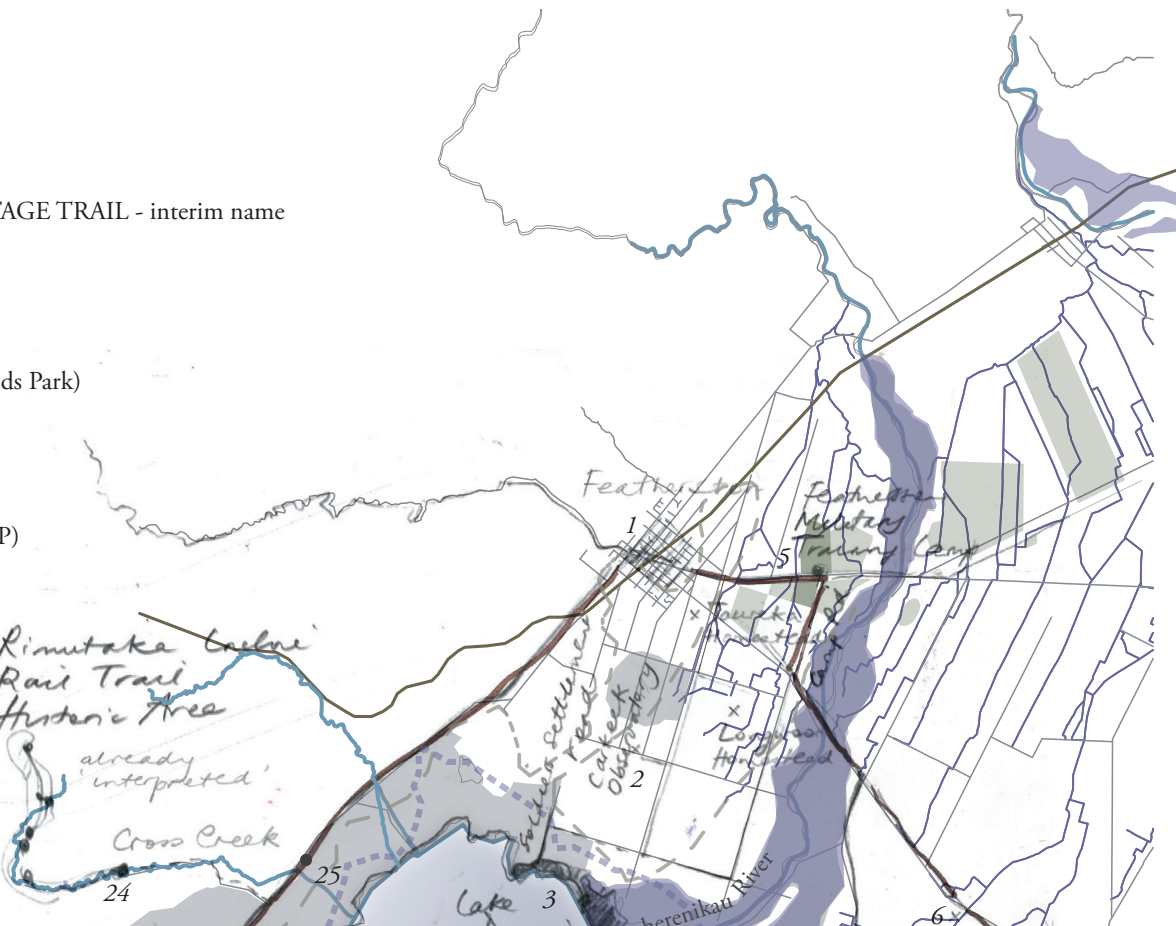

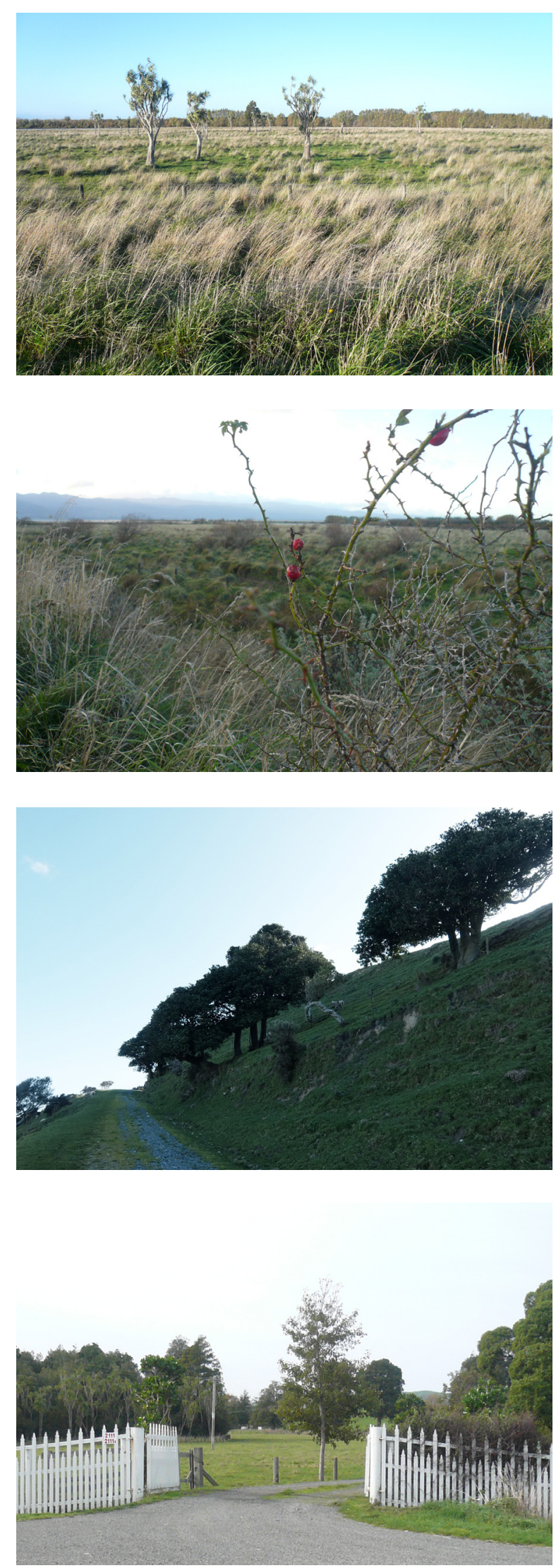

Fig. 4.24. Looking towards Oporua Floodway from the walkway atop the stopbank, Wairio Block. Ti kōuka, cabbage trees (Cordyline australis) dot the flat land - a sign of swampy ground.

Fig. 4.25. A wilding rose with red hips along the walkway towards the lake edge at Wairio Block may be a connection back to early Pākehā settlers.

Fig. 4.26. Karaka (Corynocarpus laevigatus) on the slopes below Kakahimakatea Pa. They or their forebears would probably have been planted by iwi for food.

Fig. 4.27. On either side of the entrance to Tuhitarata Estate on Kahutara Road are remnants of the swamp forest that once covered much of the land west of the Kahutara Dunes and on either side of the Ruamahanga River. 


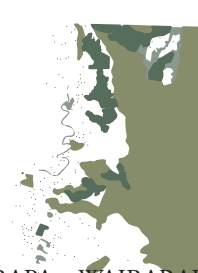

SOUTH WAIRARAPA + WAJRARAPA MOANA HERITAGETRAIL-interim name

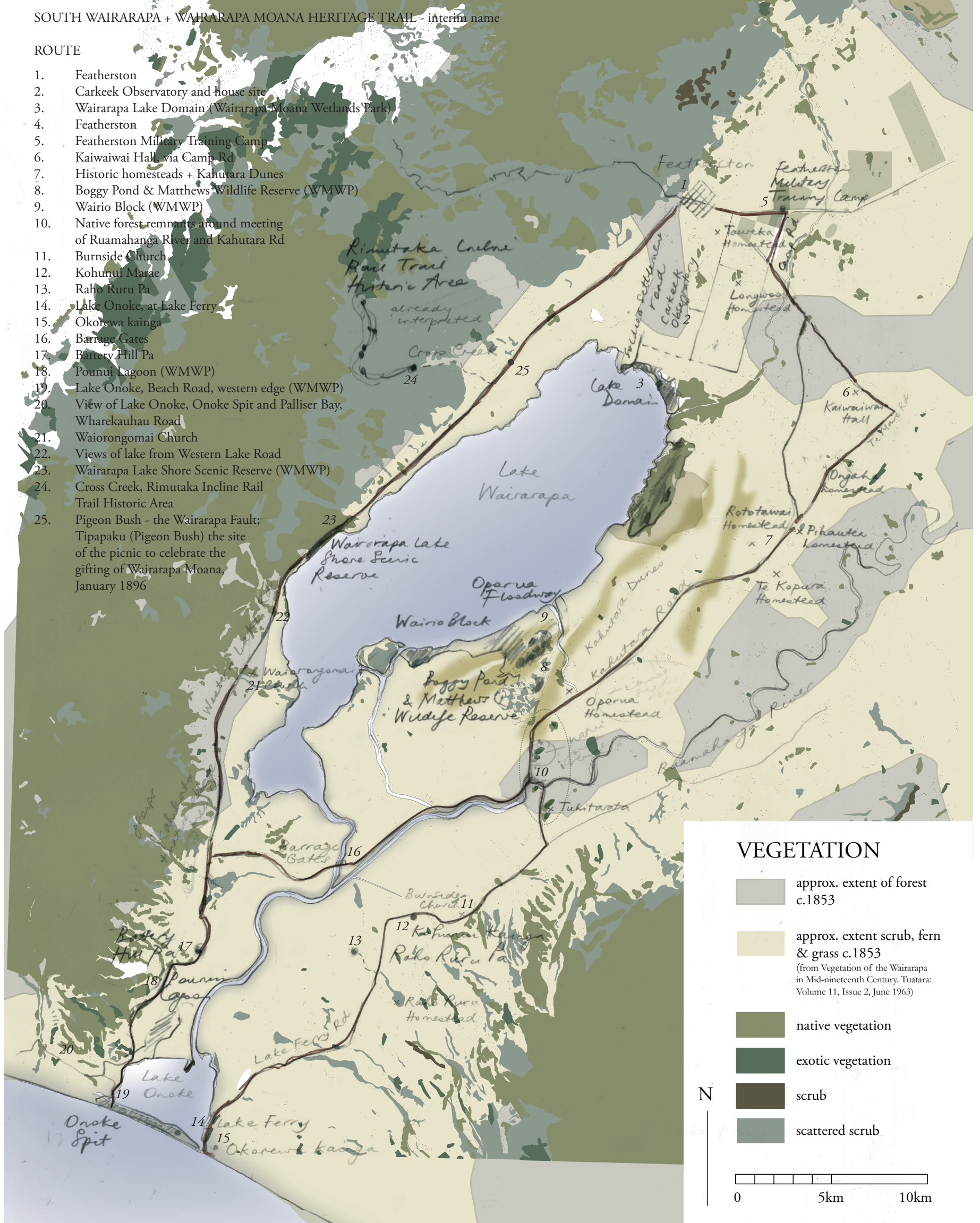

Fig. 4.28. Map showing the Vegetation of the Trail Area. 


\section{The Layers of the Trail Sites to be Interpreted - collated from analysis maps}

\section{Kaiwaiwai Hall}

\section{Historic Homesteads and \\ Marine Sediments}

Kahutara

scrub, fern and grass c. 1853

scrub, fern and grass c. 1853

gley soils - soils strongly affected by waterlogging which occurs in winter and spring, some soils remain wet throughout the year; in NZ large areas of gley soils have been artificially drained to form productive agricultural land (Soil Orders Of New Zealand) pallic soils - soils with weak structure and high density, in places that are dry in summer and wet in winter due to slow drainage; root extension limited (Soil Orders Of New Zealand) pallic soils - soils with weak structure and high density, in places that are dry in summer and wet in winter due to slow drainage; root extension limited (Soil Orders Of New Zealand) generally above flood hazard zone and hinurangi, protected by dunes and site location on relatively high ground generally above flood hazard zone and hinurangi, protected by dunes and site location on relatively high ground generally above flood hazard zone and hinurangi, protected by dunes and site location on relatively high ground high ground high ground on lower-lying area between Kahutara Dunes and area of Quaternary deposits, but higher than the lake side of dunes poor to moderately sorted gravels

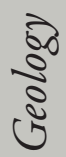

Quaternary deposits, marine sediments (from when lake was part of the sea) - in general shallow water deposits of sand and mud with shell beds and some limestone (barnacle coquina limestone specifically here) (Quaternary) alluvial deposits, well sorted floodplain gravels 
Kahutara Dunes

scrub, fern and grass c. 1853
Native Forest

Remnants

within area that was native

forest c. 1853
Kohunui Marae

scrub, fern and grass c. 1853 brown soils - summer dryness uncommon and not waterlogged in winter, rain usually $1000 \mathrm{~mm}+$ most extensive NZ soil (Soil

Orders Of New Zealand) recent-poorly drained soils

on or close to edge between pallic and recent-poorly drained soils generally above flood hazard zone and hinurangi, protected by dunes and site location on relatively high ground prior to the Lower Wairarapa Valley Development Scheme the remnants were part of a swamp/wetland above hinurangi on high ground relatively high ground low-lying land compared to surrounding land on edge of high ground adjacent to plain/low lying ground
Aoelian dunes - formed through wind action "non-coastal dunes formed by wind-deposited fine sediments exposed through fluctuating lake levels" (Extent and Significance of Wairarapa Moana Wetlands and Lake Pounui) alluvial deposits, well sorted floodplain gravels on ridge of gravel above alluvial deposits 
The Layers of the Trail Sites to be Interpreted - collated from analysis maps

Raho Ruru Pa

Lake Onoke, at Lake

Ferry

Okorewa kāinga

on or close to edge between pallic and recent-poorly drained soils on or close to edge between pallic and recent-poorly drained soils on or close to edge between pallic and recent-poorly drained soils

$\frac{\pi}{2}$

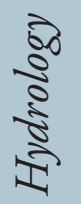

above hinurangi on high ground very close to sea level

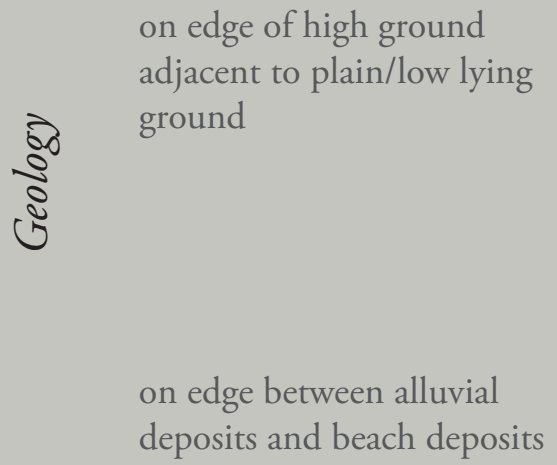

on edge of high ground adjacent to plain/low lying

thin line of gravel between lake and limestone

deposits and beach deposits on terrace overlooking coast on limestone, surrounded by beach deposits including marine gravel 


\section{Kakahimakatea \\ (Battery Hill) Pa}

scrub, fern and grass c. 1853
Lake Onoke, Beach

Road

scrub, fern and grass c. 1853
View of Lake Onoke, Onoke Spit and Palliser Bay, Wharekauhau Road

scrub, fern and grass c. 1853 on brown soils (close to recent-poorly drained soil on

flats); brown soils - summer dryness uncommon and not waterlogged in winter, rain usually $1000 \mathrm{~mm}+$, most extensive NZ soil (Soil Orders Of New Zealand) recent - poorly drained soils

pallic soils - soils with weak structure and high density, in places that are dry in summer and wet in winter due to slow drainage; root extension limited (Soil Orders Of New Zealand) above hinurangi on high

ground above hinurangi on high

ground on edge of high ground adjacent to plain/low lying ground very close to sea level

rery close to sea level

high ground, uplifted marine terrace (Boffa Miskell Ltd., 84) finger of mudstone extending from mountains, the end surrounded by alluvial and beach deposits coming together of gravels

from mountains and

beach/marine deposits alluvial deposits, well sorted floodplain gravels 
The Layers of the Trail Sites to be Interpreted - collated from analysis maps

\section{Pigeon Bush}

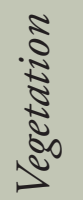

scrub, fern and grass c. 1853

edge of brown and

recent-poorly drained soils

$\frac{\tilde{s}}{\tilde{5}}$

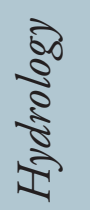

above hinurangi on high

ground

where foothills of ranges meet

the low land

on Wairarapa Fault and poor

to moderately sorted gravel

के from nearby ranges

Table 4.03 The Layers of the Trail Site to be Interpreted - Pigeon Bush,

collated from the site analysis maps figs. 4.05, 4.10, 4.13, 4.18, 4.23 and 4.28 


\section{Seeking the Way}

After the site analysis information was collated in tables 4.01 - 03 it was decided to remove Kohunui Marae and both Lake Onoke sites from the sites to be interpreted as they were already shown or interpreted in some way, the marae with prominant signage and Lake Onoke, Lake Ferry, with a Wairarapa Moana Wetlands Park sign installed in 2015. After further research and repeat visits Kahutara was added to the sites to be interpreted and the 'Historic Homesteads + Kahutara Dunes' became more correctly two sites, 'Historic Homesteads + Marine Sediments' and 'Kahutara Dunes'. Pigeon Bush also became two separate sites. A third draft trail map was made (fig. 4.29). While meeting with Wairarapa archivist Gareth Winter the researcher asked if the sites in this map expressed the stories of the area - he agreed that they did. 
SOUTH WAIRARAPA + WAIRARAPA MOANA HERITAGE TRAIL

\section{ROUTE + sites to interpret}

a. Featherston

b. Carkeek Observatory and house site

c. Wairarapa Lake Domain (Wairarapa Moana Wetlands Park)

Featherston

Featherston Military Training Camp (walkway to and around camp)

Kaiwaiwai Hall, via Camp Rd

Historic homesteads + marine sediments

\section{Kahutara}

Kahutara Dunes

Boggy Pond \& Matthews Wildlife Reserve (WMWP)

Wairio Block (WMWP)

Native forest remnants

Burnside Church

Kohunui Marae

Raho Ruru Pa

Lake Onoke, at Lake Ferry (WMWP)

Okorewa kainga

Barrage Gates

10. Kakahimakatea (Battery Hill) $\mathbf{P a}$

Pounui Lagoon (WMWP)

Lake Onoke, Beach Road (WMWP)

11. View of Lake Onoke, Onoke Spit and Palliser Bay,

\section{Wharekauhau Road}

Waiorongomai Church

m. Views of lake from Western Lake Road

n. Wairarapa Lake Shore Scenic Reserve (WMWP)

o. Cross Creek, Rimutaka Incline Rail

Trail Historic Area

12. Tipapaku (Pigeon Bush) - the site

of the picnic to celebrate the gifting of Wairarapa Moana, January 1896

13. the Wairarapa Fault, at Pigeon Bush

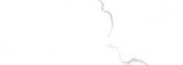
)

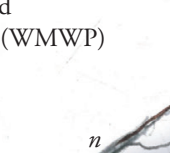




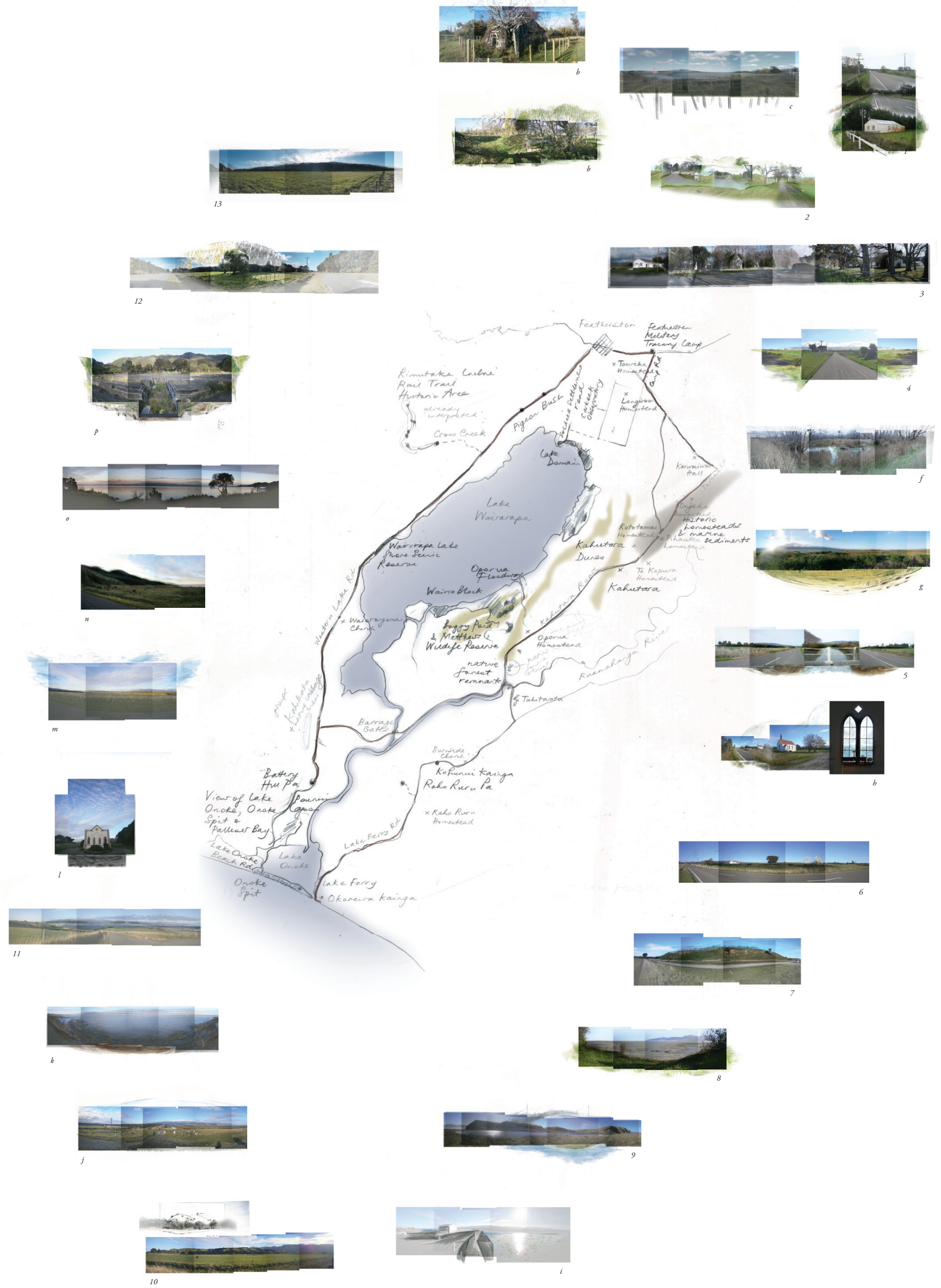

Fig. 4.30. Landing Images plus Third Draft Trail Map. 
Further changes were made. A cull after figure 4.29 was made removed the Carkeek Observatory and Homestead site. The researcher had visited these sites with the previous owner not long after ownership had changed to South Wairarapa District Council and found them evocative and intriguing. Due to this they continued to be kept on the trail until late in the research process. However, as they are not currently accessible to the public it was decided to remove them from the trail. The fourth draft trail map (see fig. 4.31) includes twenty six sites. Eleven sites are not readily visible and need to be marked or revealed.

Research was undertaken into how the trail would fit with existing trails, such as the Rimutaka Cycle Trail (see fig. 4.32). Destination Wairarapa lists as one of four key projects deriving "maximum benefit for the Wairarapa from the Rimutaka Trail” (Destination Wairarapa Strategic Plan 2014-16). The trail will also create connections between the six Wairarapa Moana Wetland Park sites. 


\section{ROUTE + sites to interpret}

Featherston

b. Carkeek Observatory and house site

Wairarapa Lake Domain (Wairarapa Moana Wetlands Park)

Featherston

Featherston Military Training Camp (walkway to and around camp)

Kaiwaiwai Hall, via Camp Rd

Historic homesteads + marine sediments

\section{Kahutara}

\section{Kahutara Dunes}

Boggy Pond \& Matthews Wildlife Reserve (WMWP)

Wairio Block (WMWP)

Native swamp forest remnants

Burnside Church

Kohunui Marae

6. Raho Ruru Pa

. Lake Onoke, at Lake Ferry (WMWP)

7.. Okorewa kainga

k. Barrage Gates

8. Kakahimakatea (Battery Hill) Pa

Pounui Lagoon (WMWP)

Lake Onoke, Beach Road (WMWP)

9. View of Lake Onoke, Onoke Spit and Palliser Bay,

Wharekauhau Road

Waiorongomai Church

Views of lake from Western Lake Road

Wairarapa Lake Shore Scenic Reserve (WMWP)

Cross Creek, Rimutaka Incline Rail

Trail Historic Area

10. Tipapaku (Pigeon Bush) - the site

of the picnic to celebrate the gifting of Wairarapa Moana, January 1896

11. The Wairarapa Fault, at Pigeon Bush
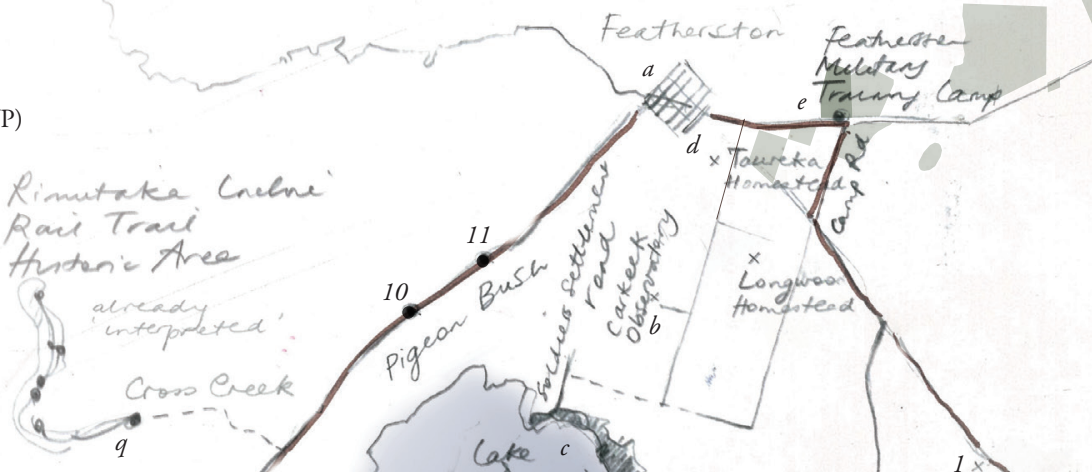

$\psi^{2}$

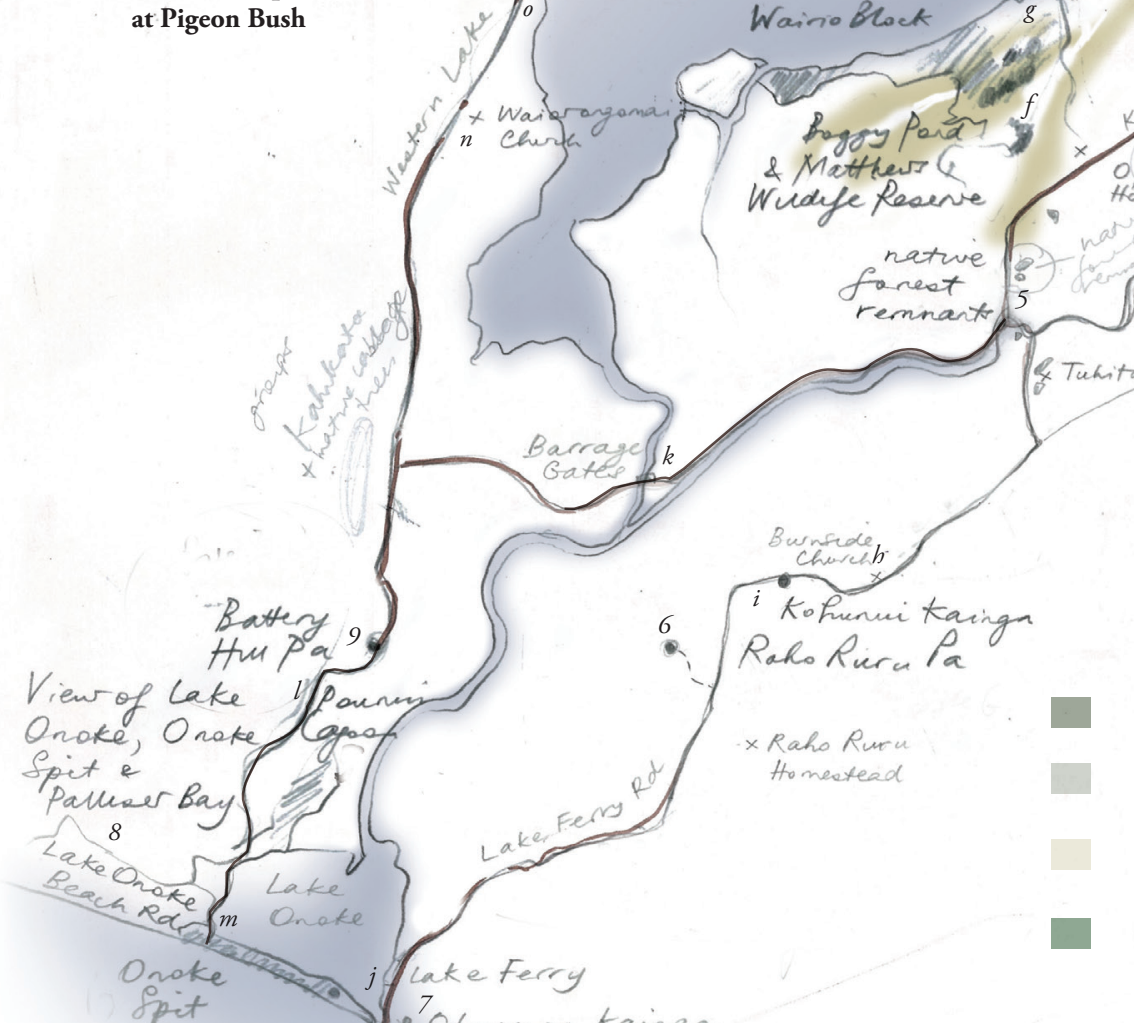

Featherston Military Training Camp

FMTC training grounds and satellite camps

(Papawai Camp not shown, approx. $12 \mathrm{~km}$ east of FMTC)

Kahutara Dunes

Native forest remnants around meeting of

Ruamahanga River and Kahutara Rd

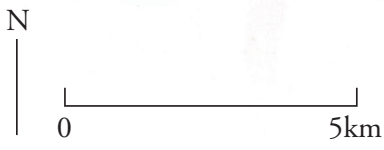

Fig. 4.31. Fourth Draft Trail Map with sites to be interpreted numbered. 


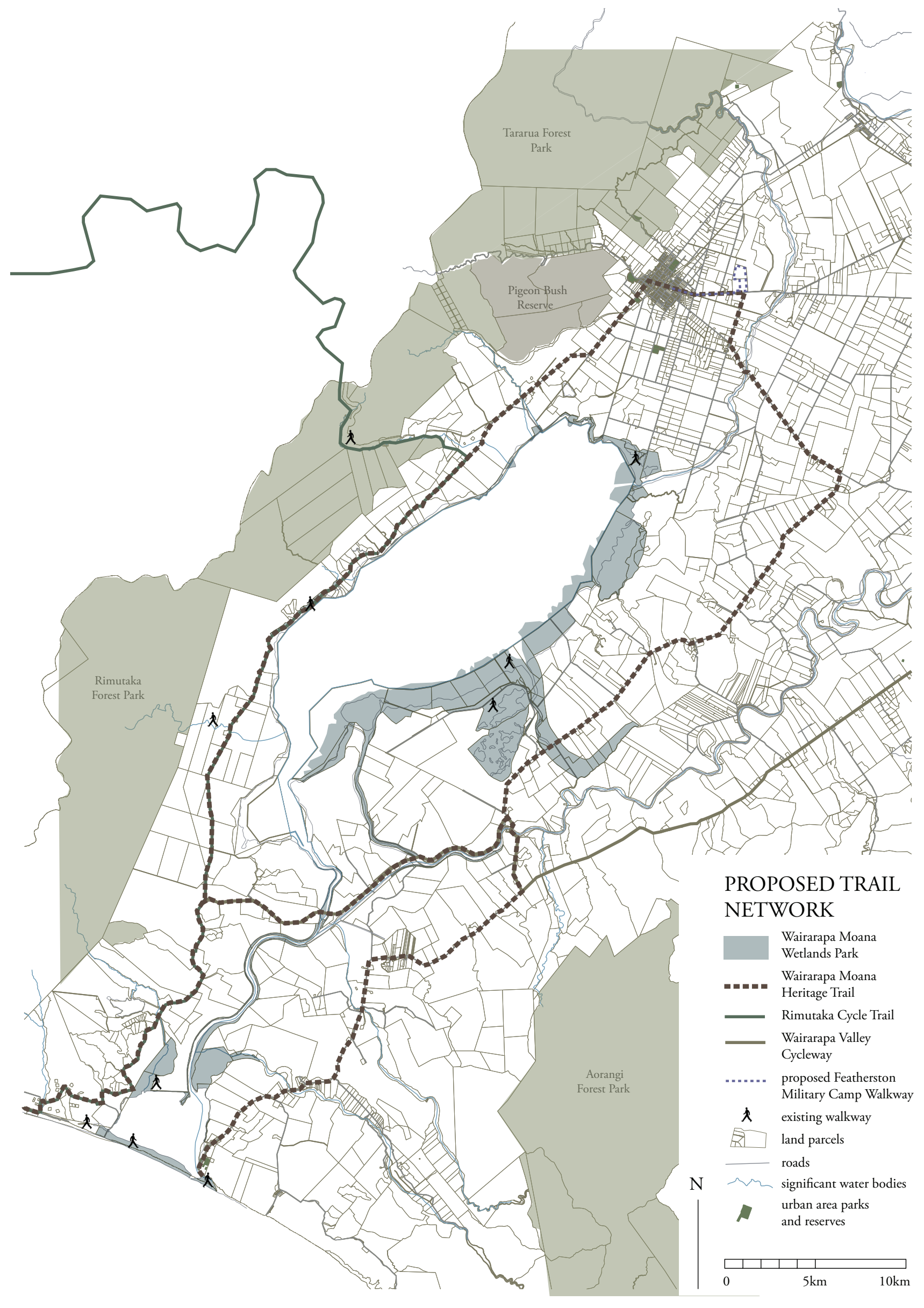

Fig. 4.32. The Proposed Trail Network - The Wairarapa Moana Heritage Trail will link with the nationally important Rimutaka Cycle Trail and the Wairarapa Valley Cycleway. It will include the proposed Featherston Military Camp Walkway and connect people to existing walkways. 


\section{FINDING}

\section{Bringing Together the Threads}

Many talk and write of layers in landscape. Perhaps rather than layers being what makes up landscape it is threads, threads woven through and with each other. On the following pages are the threads discovered for the twelve trail sites that are not readily visible (see figs. 5.01 - 5.12).

Eleven sites were to be revealed, interpreted, when the Fourth Draft Trail Map, figure 4.31, was made. Subsequently it was decided to re-instate Lake Onoke at Lake Ferry which had only been removed from this group when making the Fourth Draft Trail Map. A conversation with a Lake Ferry resident (described fully on page 138) encouraged the researcher to re-consider designing for it. Other factors reinforced this. The site is where fresh and salt water meet, so of great importance to the natural system. It is also important to Māori, particularly due to the tūna harvest that took place there. The site and its environs had a huge part to play in the story of the relationship between Māori and Pākehā in South Wairarapa. There was great tension between Pākehā settlers, who wanted to keep the mouth of the lake artificially open so as to farm the fertile lowlying land of the valley without threat of flood, and Māori, for whom the flood or hinurangi was a time of plenty, the great tūna harvest. Therefore, in order to completely set the scene for the designs that follow, this site is included in the following pages. 
Kaiwaiwai Hall

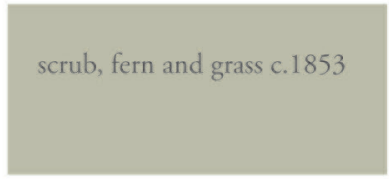

gley soils - soils strongly affected by waterlogging which occurs in winter and spring, some soils remain wet throughout the year; in NZ large areas of gley soils have been artificially drained to form productive agricultural land (Soil Orders Of New Zealand)

generally above flood hazard zone and hinurangi, protected by dunes and site location on relatively high ground

Emerging Patterns:

Kaiwaiwai Hall landing

this hall that held - at another (camp) site soldiers bravely set for war, is now sited alone and empty waiting to re-serve

Small vertical form in contrast to horizontal form
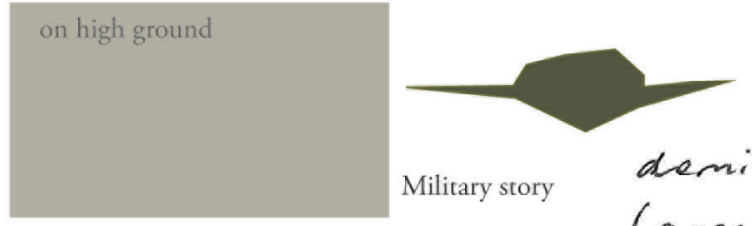

Military story

poor to moderately sorted gravels

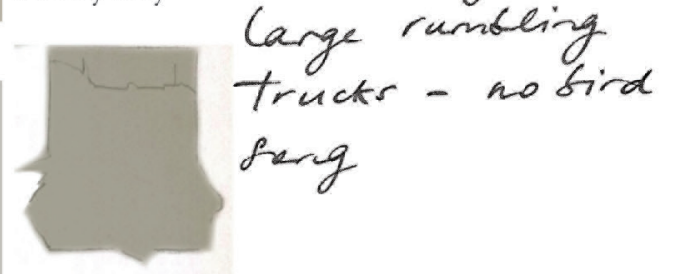

Building group

S. vast complex of tuildings and facities at Featherston. In July 1920, MajorGeneral G. S. Richardson suggested that part of Featherston Camp should be retained for storage purposes until a new depot could be built at a more suitable location. Much of the camp could be dismantled, and the buildings sold off. 14 The Department announced in October 1920 that the camp would soon close. By 1923 it planned to keep the camp in use only until the ordnance buildings at the new N $N$ garuawahia camp were completed 's

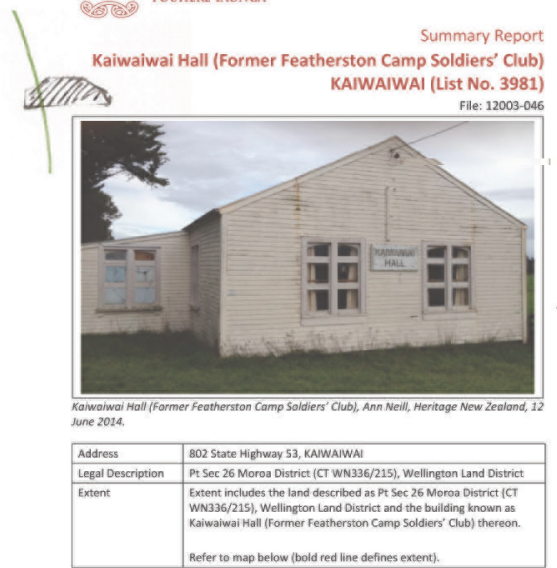

The Department decided to sell the camp buildings off in stages, retaining those needed for storage and to accommodate a skeleton administrative and maintenance staff. The buildings would be offered for tender, with government dopartments given the first option, (linwed by returned servicemen. The Public Works Department offered more than 120 政 purchased many for farm buildings, while ochers found new uses around southern Wairarapa

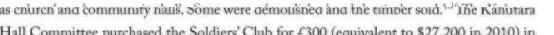
July 1922. One wing became the Kahurar Hall, another the Kaiwaivai Hall Hutrear 84 was converted into the Presbyterian Sunday School in Martintorought the same year. Chanak Crisis of late 1922 prompred the Department to halt the sale of camp buildings lest the country need to mobilise once again ${ }^{\text {1s }}$

Tim Phoelariage $n z$ hietory. net

Fig. 5.01. Kaiwaiwai Hall threads. 


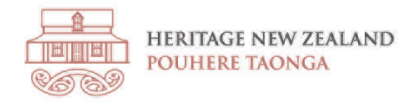

\section{South Wairarapa deficient registration project summary} April 2015

The following prioritisations have been decided based on the information contained in the preliminary Summary Reports for 23 South Wairarapa District Council deficient registrations. This includes two properties owned by South Wairarapa District Council which are denoted in bold type.

Research into these places was discontinued

\begin{tabular}{|l|c|}
\hline Name & List no. \\
\hline Hitching Rail, Featherston & $\mathbf{3 9 7 7}$ \\
\hline Te Kopura Homestead & 3991 \\
\hline Tinui Hotel (relocated to Greytown) & 4011 \\
\hline
\end{tabular}

Places given Proposal status

These 20 places are considered good candidates for entry onto the List based on aspects such as historical, social and architectural values. At this stage we are unable to specify in which year's work programme we will be able to complete a full heritage assessment for each of these places and progress them for entry onto the List.

\begin{tabular}{|l|c|}
\hline Name & List no. \\
\hline St Andrews Church & 1307 \\
\hline Roval Hotel, Featherston & 3973 \\
\hline Cottage, 24 Waite St, Featherston & 3974 \\
\hline Cottage, 22 Waite St, Featherston & 3975 \\
\hline War Memorial, Featherston & 3980 \\
\hline Kaiwaiwai Hall (Former Army Camp Building) & 3981 \\
\hline St Francis Church (Non-Denominational) & 3982 \\
\hline Oporua Homestead & 3983 \\
\hline Burnside Church & 3984 \\
\hline Raho Ruru Homestead & 3985 \\
\hline Tuhitarata Homestead & 3986 \\
\hline Tuhitarata Stabte/Barn & 3987 \\
\hline Rototawai Stable block/coach) house & 3988 \\
\hline Rototawai Machine Shop & 3989 \\
\hline Pithautea Station Former Store & 3992 \\
\hline Ongaha Homestead & 3993 \\
\hline Pihautea Homestead & 3994 \\
\hline Kahutara Schoot Building & 4042 \\
\hline Pihautea Stable & 4043 \\
\hline Tahora Homestead & 5450 \\
\hline
\end{tabular}

Thora Homestead

Historic Homesteads + Kahutara Dunes landing

Fig. 5.02. Historic Homesteads and Marine Sediments threads. dunes weave between the homesteads built by those who cleared and drained and farmed

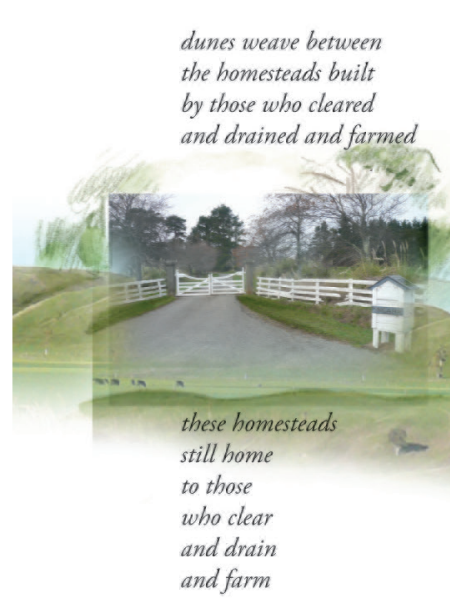

a quieter road, birds singing

\section{Hill group}

Emerging Patterns: structure and high density, in places that are dry in summer and wet in winter due to slow Horizontality in the landscape - linear fomealand)

Pakeha settlement story protected by dunes and site limited (Soil Orders Of New

the soils - soils with weak

Marine Sediments
Maric Homesteads

rub, fern and grass c.1853
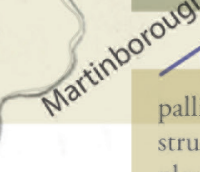

(1)

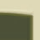

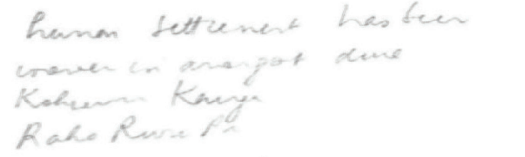

generally above flood hazard zone and hinurangi, location on relatively high ground

on high ground
Quaternary deposits, marine sediments (from when lake was part of the sea) - in general shallow water deposits of sand and mud with shell beds and some limestone (barnacle coquina limestone specifically here) (Quaternary) 
Kahutara
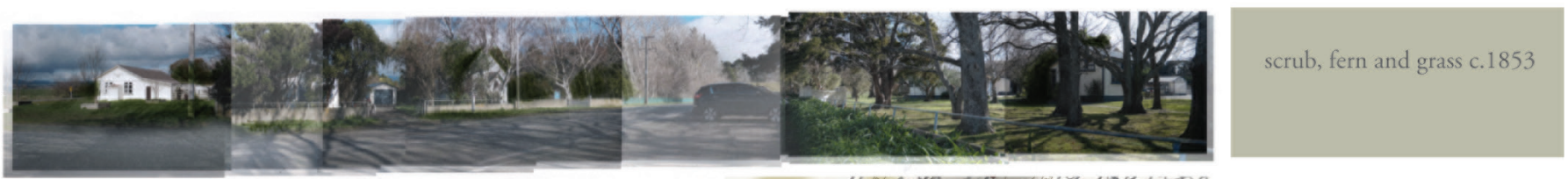

\section{Kahutara landing}

church + school + hall the condset birdseng
- birds wi the Cange gathered in the crook of a dune birds wi the Carye aged trees and

aged buildings,

still welcome gatherings

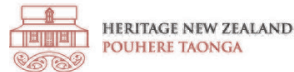

Summary Report

Kahutara School Building, Kahutara (List No. 4042)

File: 12015-137

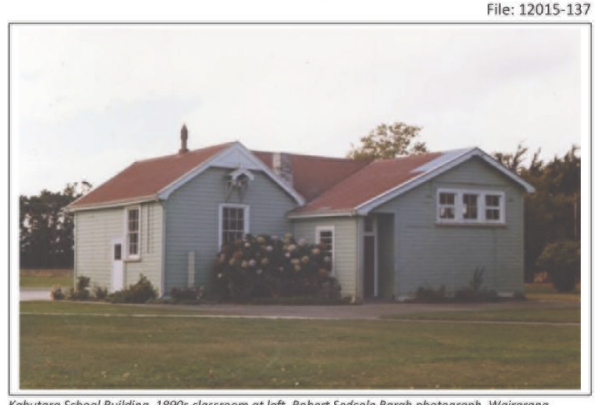

Kahutaro School Building, 1890s classroom ot left Robert Sedcole Bargh photogreph, Woirarapa

\begin{tabular}{|l|l|l|}
\hline Address & 990 Kahutara Road, KAHUTARA \\
\hline
\end{tabular}

\begin{tabular}{|l|l|}
\hline Address & 990 Kahutara Road, KAHUTARA \\
\hline Legal Description & Pt Sec 1 Kahutara District (N2 Gazette, 1989, p.5689). Wellington \\
\cline { 1 - 1 }
\end{tabular}

Pr Sec 1 Kah
Land District \begin{tabular}{|l|l}
\hline Extent & Extent inctudes part of the land described as Pt Sec 1 Kahutara \\
District (NZ Gozette, 1989, p.5689), Wellington Land District and the
\end{tabular} building known as Kahutara School Building thereon. Extent excludes the later classroom block and all other buildings and structures on 列

See figure 1 for detailed site plan

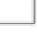

\section{,}

角四 (ब)

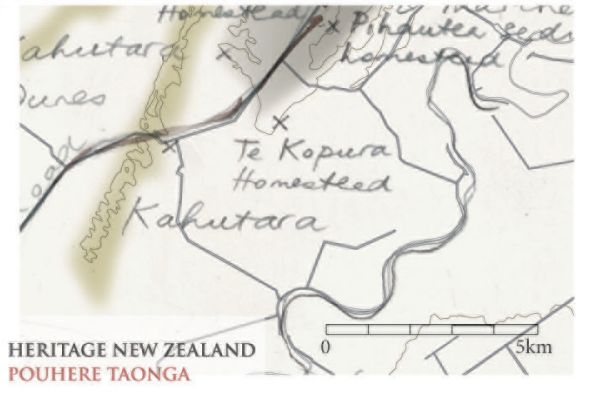

South Wairarapa deficient registration project summary April 2015

The following prioritisations have been decided based on the information contained in the preliminary Summary Reports for 23 South Wairarapa District Council deficient registrations. This includes two generally above flood hazard properties owned by South Wairarapa District Council which are denoted in bold type.

Research into these places was discontinued

\begin{tabular}{|l|c|}
\hline Name & List no. \\
\hline Hitching Rail, Featherston & $\mathbf{3 9 7 7}$ \\
\hline Te Kopura Homestead & 3991 \\
\hline Tinui Hotel (relocated to Greytown) & 4011 \\
\hline
\end{tabular}

Places given Proposal status historical, social and architectural values. At this stage we are unable to specify in which year stahutara Dunes and area of work programme we will be able to complete a full heritage assessment for each of these placestaternary deposits, but and progress them for entry onto the List.

Name

\begin{tabular}{|l|c|}
\hline Name & List no. \\
\hline St Andrews Church & 1307 \\
\hline Royal Hotel, Featherston & 3973 \\
\hline Cottage, 24 Waite St, Featherston & 3974 \\
\hline
\end{tabular}

\begin{tabular}{|l|c|}
\hline St Andrews Church & 1307 \\
\hline Royal Hotel, Featherston & 3973 \\
\hline Cottage, 24 Waite St, Featherston & 3974 \\
\hline
\end{tabular}

Cottere, 22 Waite St, Featherston War Me, 22 Waite st, Feathers Kaiwainai Halltformer Army Gamp Building St Francis Church (Non-Denominational) STr

Bporatiomeste

Raho Ruru Homestead

Tuhitarata Homestead

Tuhitarata Stable/Barn

\begin{tabular}{|l|l|}
\hline Rototawai Stable block/coach house & 3987 (a) \\
\hline Rot
\end{tabular}

\begin{tabular}{|l|l|}
\hline Rototawai Machine Shop & 3988 \\
\hline
\end{tabular}

zone and hinurangi, protected by dunes and site location on relatively high ground

pallic soils - soils with weak and wet in winter due to slow drainage; root extension limited (Soil Orders Of New Zealand)

作

Ongaha Homestead

Pinautea Homestead

Kahutara School Building ?

Pinautea Stable

[D] (64 4) 4948320 a Central Regional Office, Level 7, 69 Boulcott Street a PO Box 2629
HERITAGE NEW ZEALAND

alluvial deposits, well sorted floodplain gravels

higher than the lake side of dunes

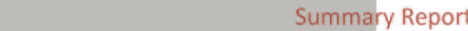
3993

(List No. 3982)

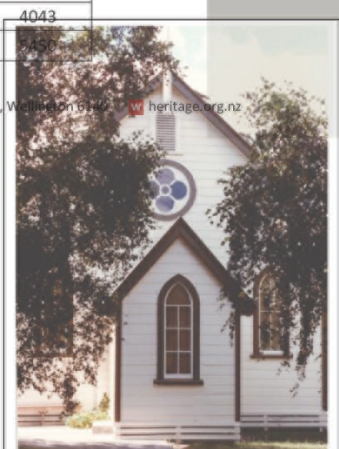

File: $12004-480$

St Froncis Church, Kahutara, Chris Cochron, December 1984, token for NZHPT Buildings Classification committee

Address 991 Kahutara Road, KAHUTARA

Legal Description Lot 6 DP 6671 (CT WN327/209), Wellington Land District

Natasha Naus, Vivienne Morrell and Christine Whybrew, Heritage New Zealand Pouhere Taonga, 15 May 2014

Fig. 5.03. Kahutara threads. 


\section{Kahutara Dunes}

scrub, fern and grass c. 1853

brown soils - summer dryness

uncommon and not

waterlogged in winter, rain

usually $1000 \mathrm{~mm}+$

most extensive NZ soil (Soil

Orders Of New Zealand) Emerging Patterns:

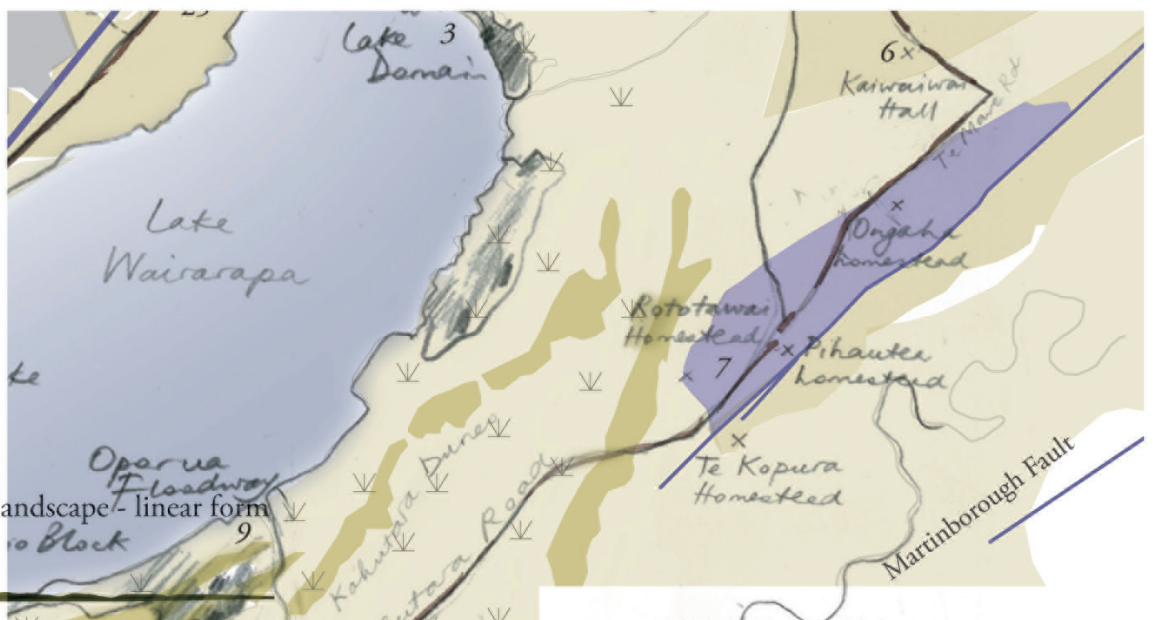

Horizontality in the landscape - linear form

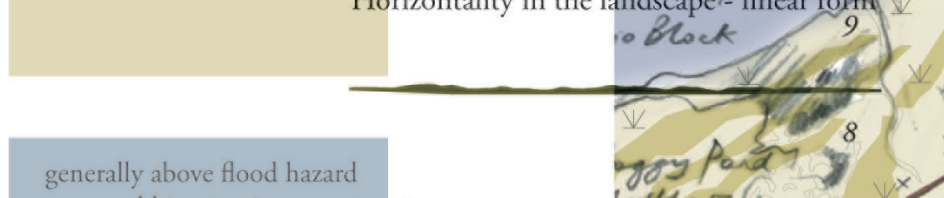

zone and hinurangi, Landscape remnant stóry thears

protected by dunes and site

location on relatively high

ground

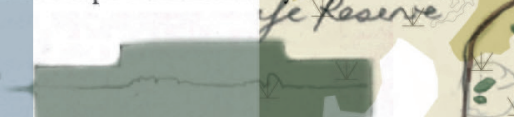

- Vparva V

GEOLOGY

relatively high ground

compared to surrounding Hill group

land

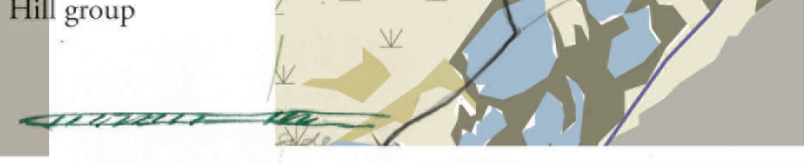

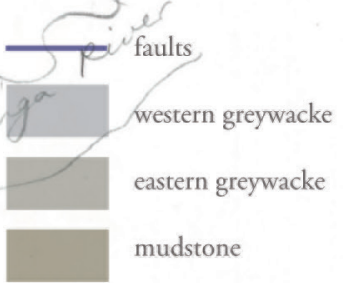

mudstone

alluvial deposits

well sorted floodplain gravels

poor to moderately sorted gravels
Aoelian dunes - formed through wind action

"non-coastal dunes formed by wind-deposited fine sediments exposed through fluctuating lake levels"

(Extent and Significance of Wairarapa Moana Wetlands and Lake Pounui)

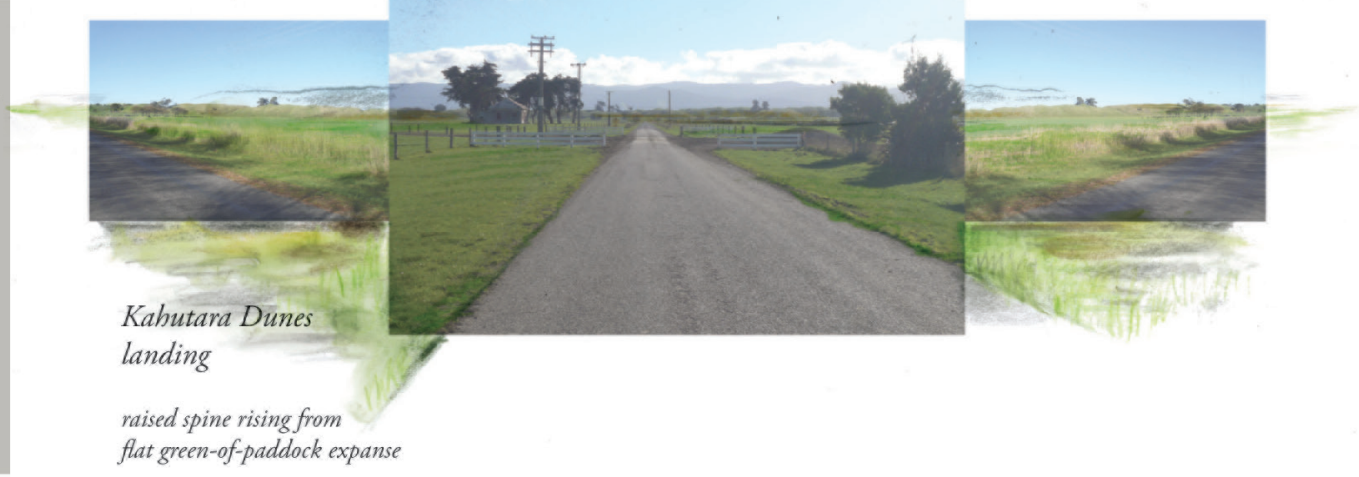

Fig. 5.04. Kahutara Dunes threads. 
Native Forest

Remnants
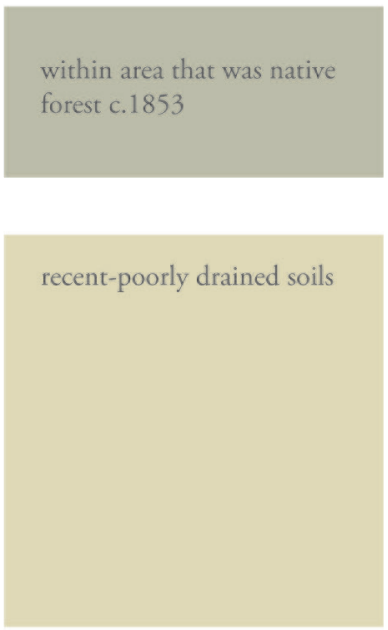

Ruamahanga River + native forest remnants

there is a gathering,

a coming together here.

of remnants of

what in the past

clothed this land

it is as if

they feel safer close

Emerging Patterns:

prior to the Lower Wairarapa Valley Development Scheme the remnants were part of a swamp/wetland

Horizontality in the landscape - linear form
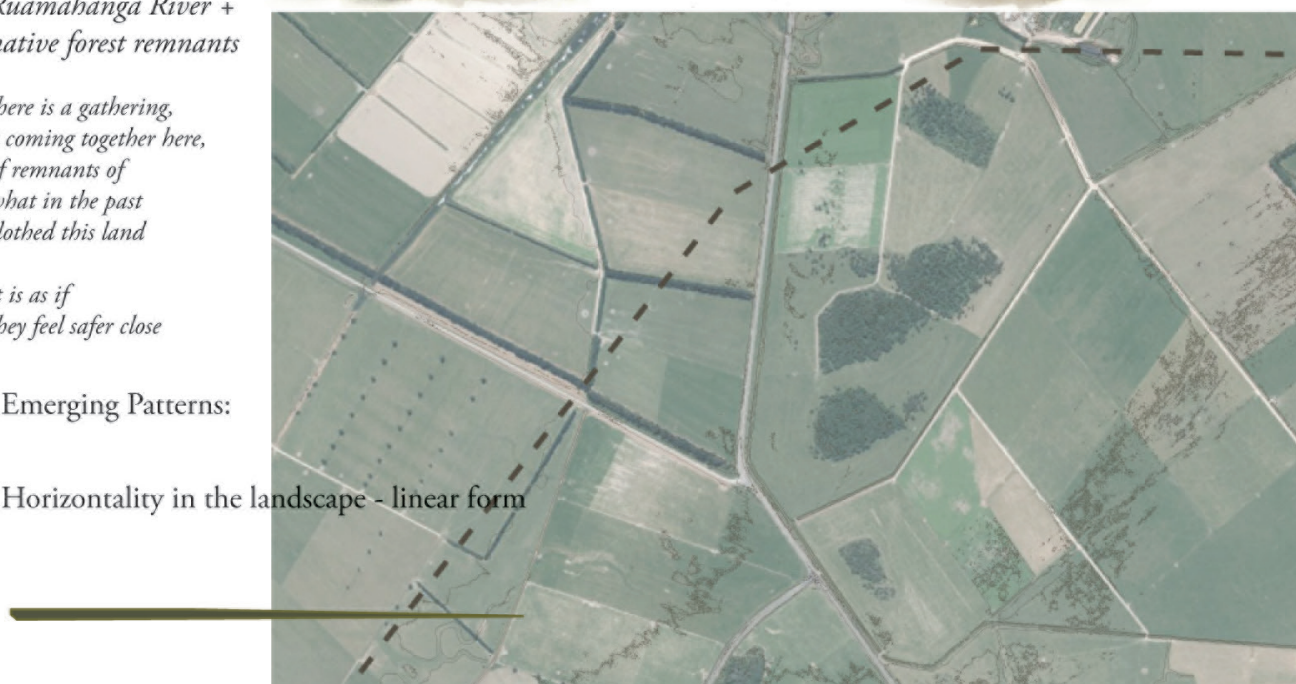

Landscape remnant story,

low-lying land

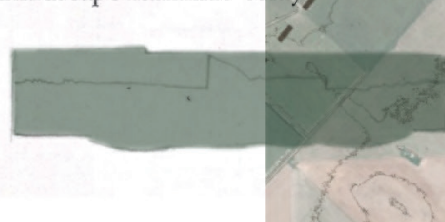

alluvial deposits, well sorted floodplain

gravels
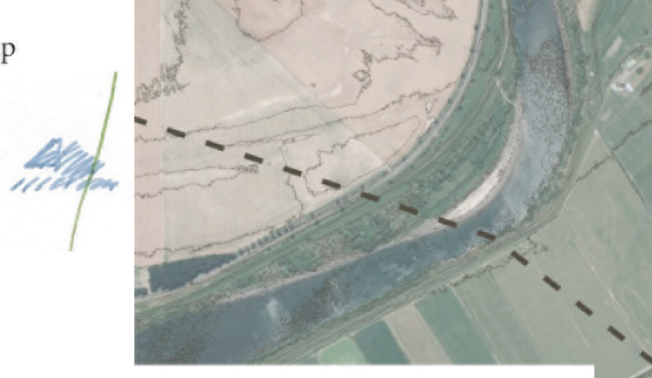

Native Swamp Forest Remnants Scale 1:10,000

Key:

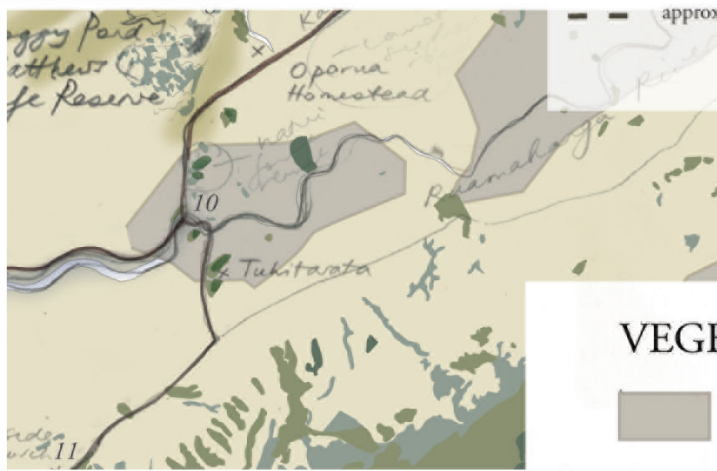

aprox. extent

of forest c. 1853

$$
\text { - the ratural syetemo }
$$

Fig. 5.05. Native Forest Remnants threads. 
Raho Ruru Pa

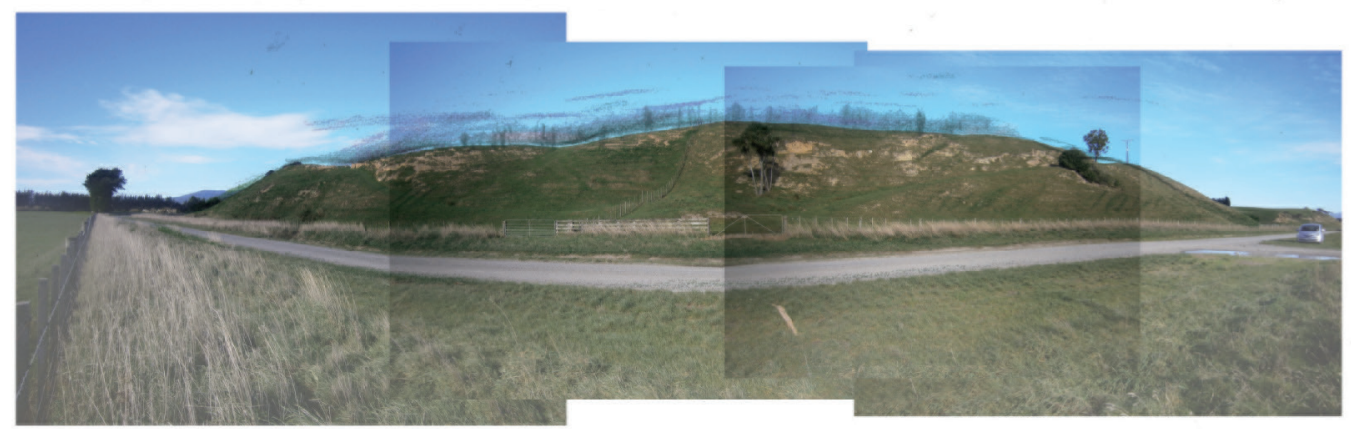

Emerging Patterns:

Horizontality in the landscape - linear form

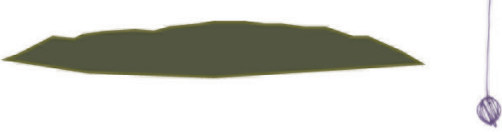

Māori, military and human traces of past use stories

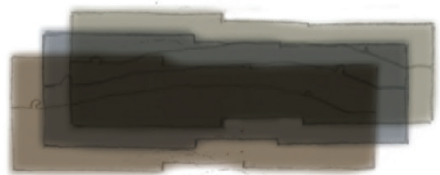

\section{Hill group}
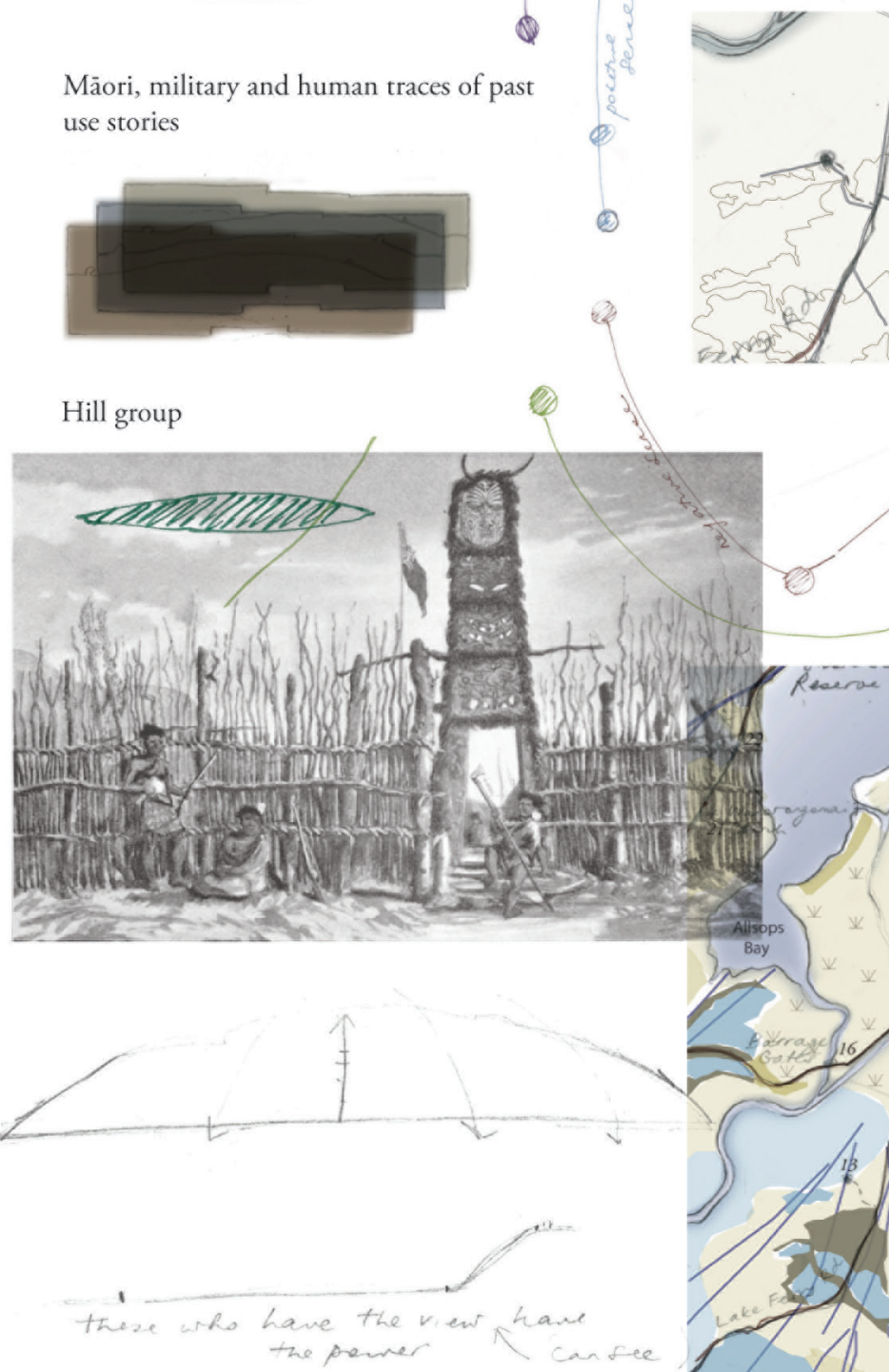

Raho Ruru Pa landing

bidden from my roadside view

those who held this high ground look down still

(2)

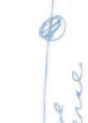

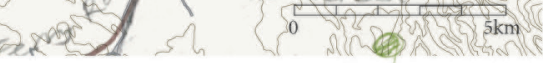
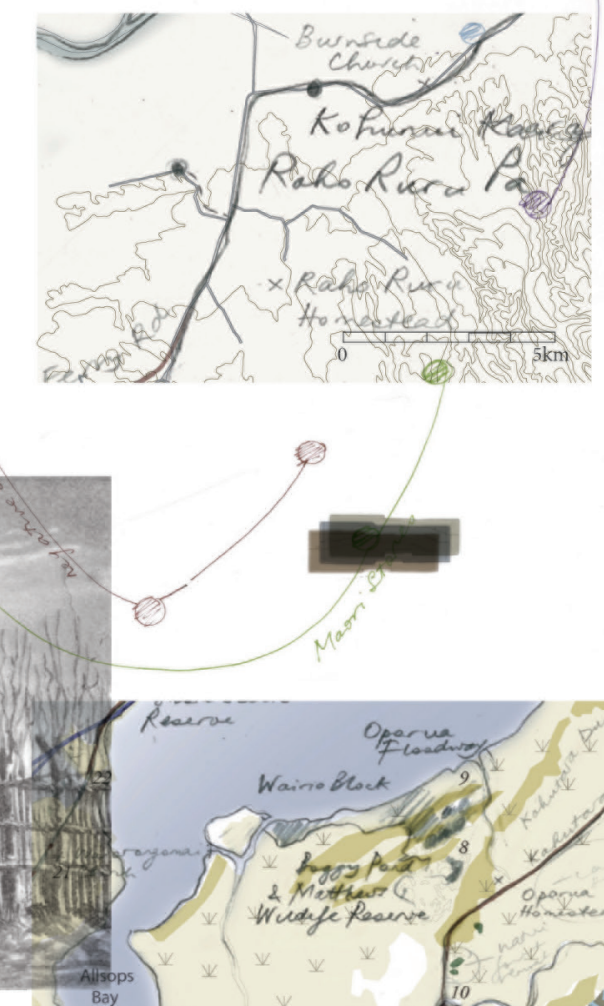

on edge of high ground adjacent to plain/low lying ground

on or close to edge between pallic and recent-poorly drained soils

above hinurangi on high ground
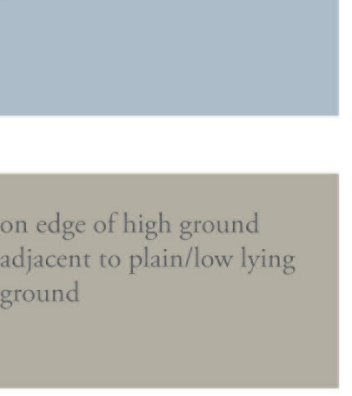

on edge between alluvial deposits and beach deposits

Fig. 5.06. Raho Ruru Pa threads. 


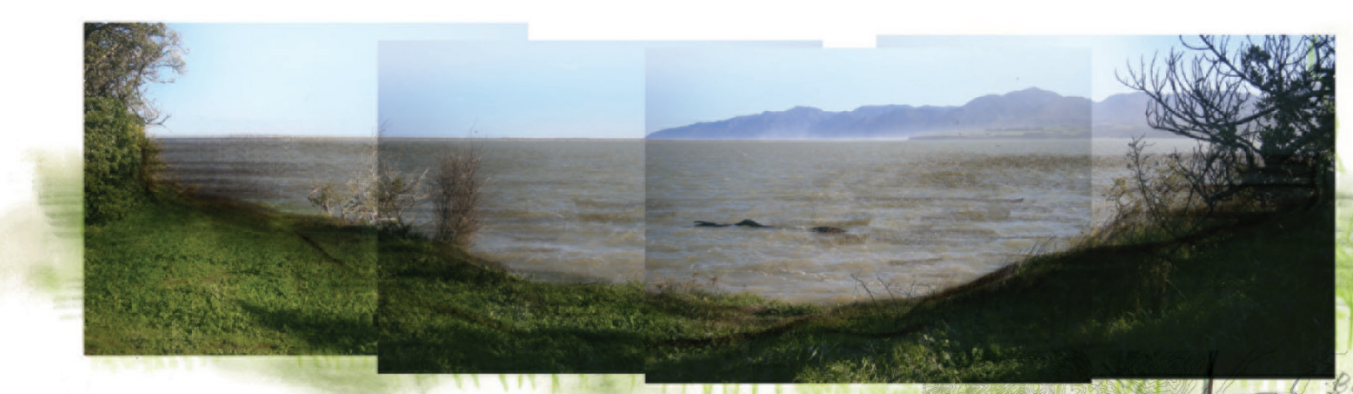

Lake Onoke, at Lake

Ferry

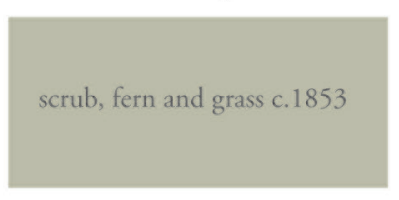

on or close to edge between pallic and recent-poorly drained soils

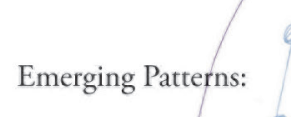

Horizontality in the landscape - linear form

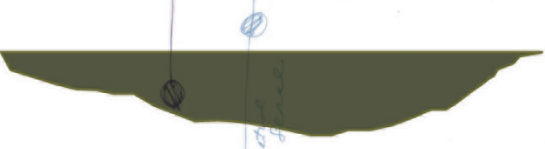

'Negative sense' story
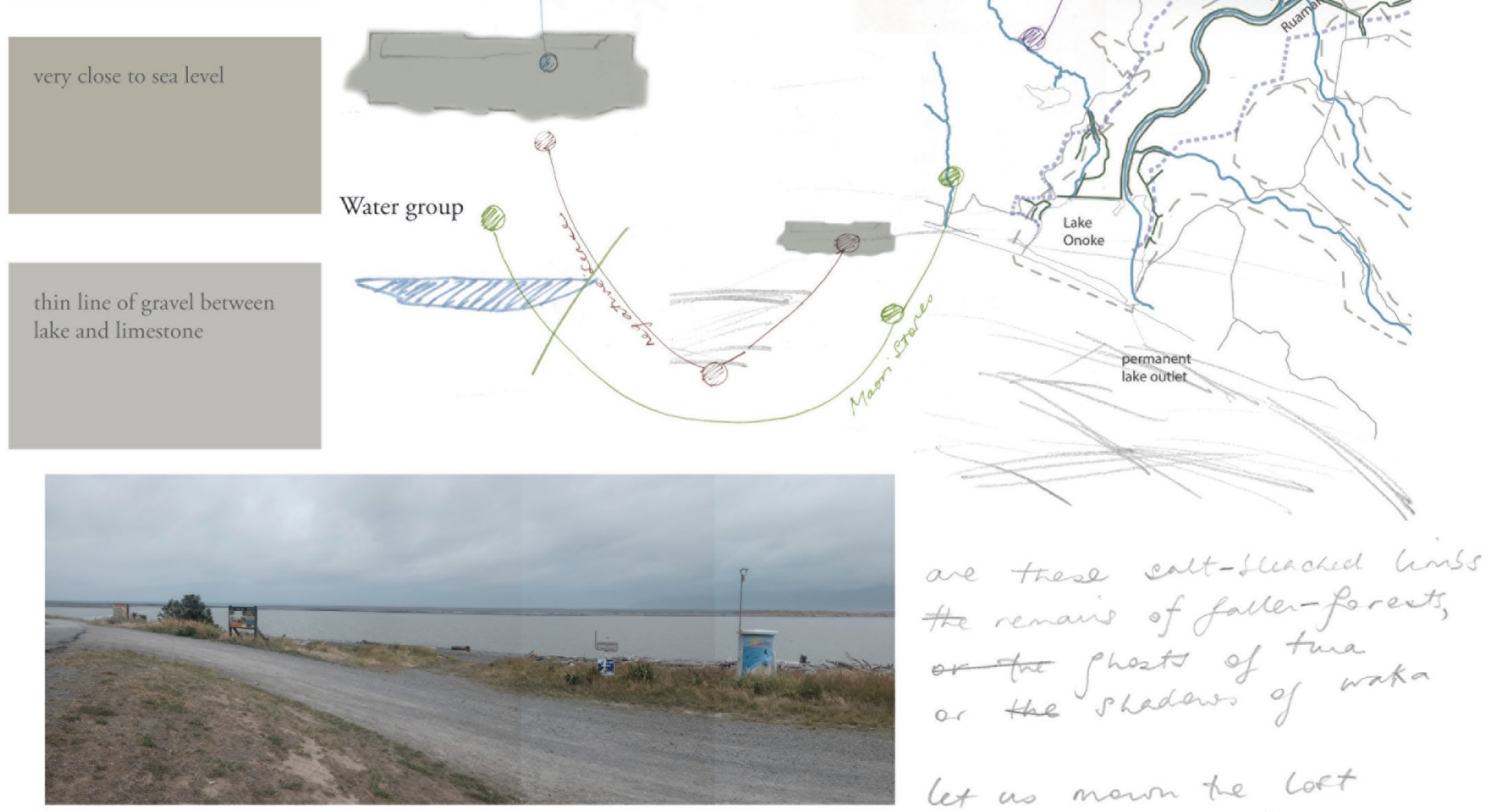

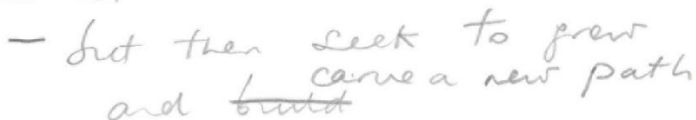

$$
\begin{aligned}
& \text { and prot waver acoos }
\end{aligned}
$$

Fig. 5.07. Lake Onoke, at Lake Ferry threads. 
Okorewa kāinga
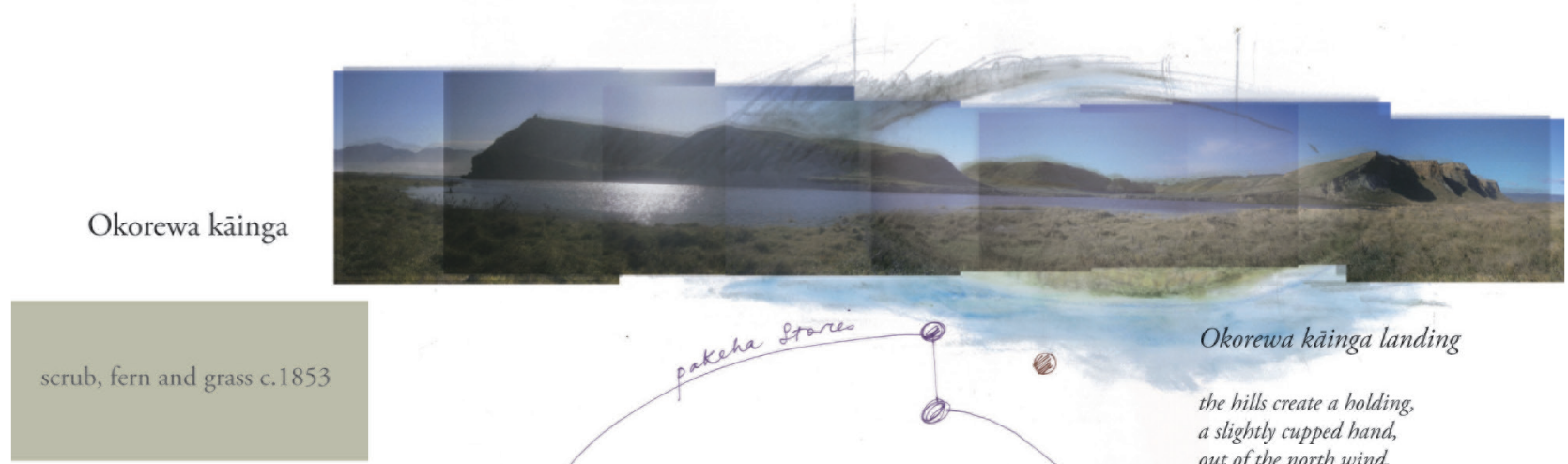

on or close to edge between pallic and recent-poorly drained soils

Emerging Patterns:

Horizontality in the landscape - linear form
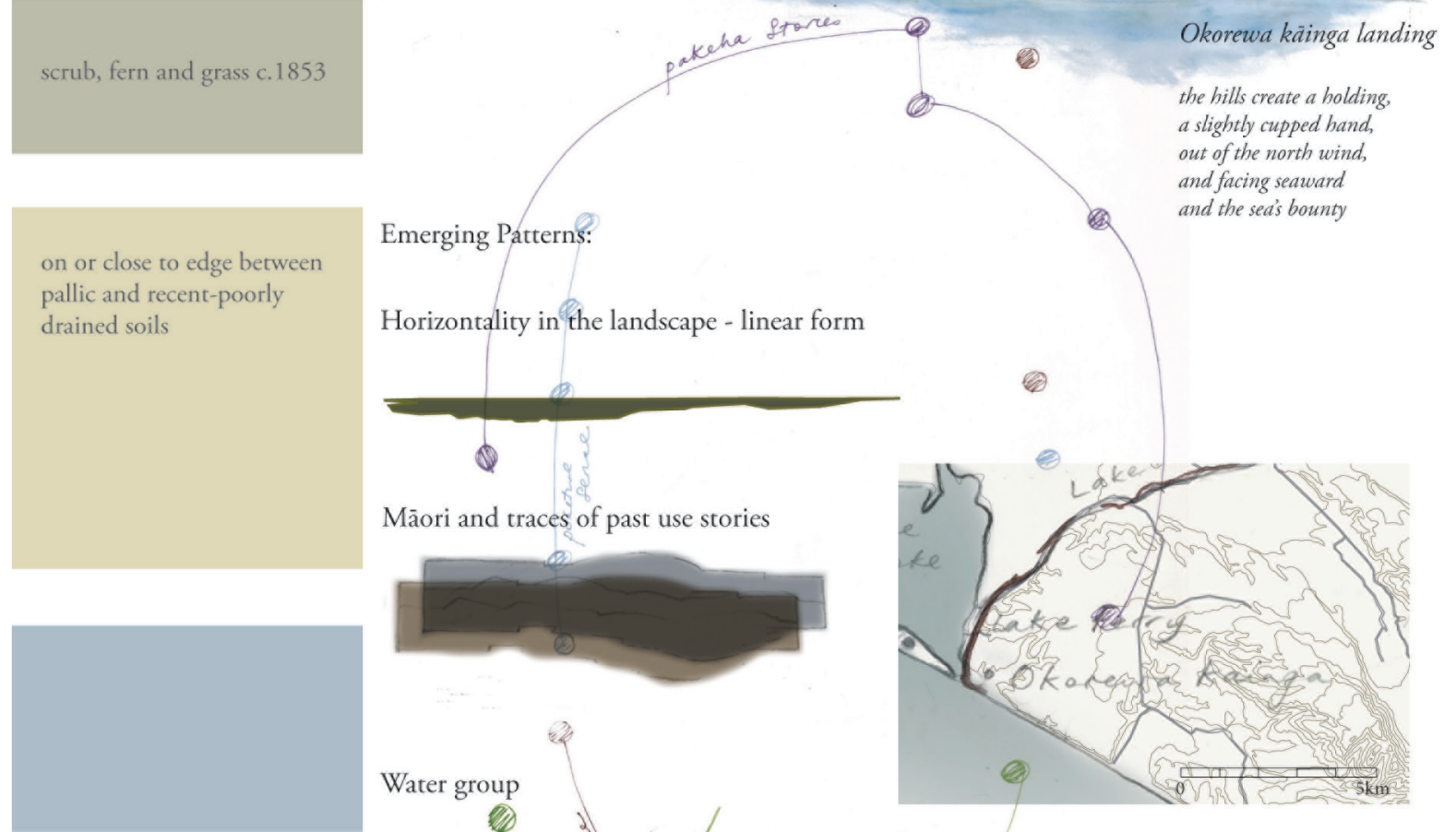

Māori and traces of past use stories
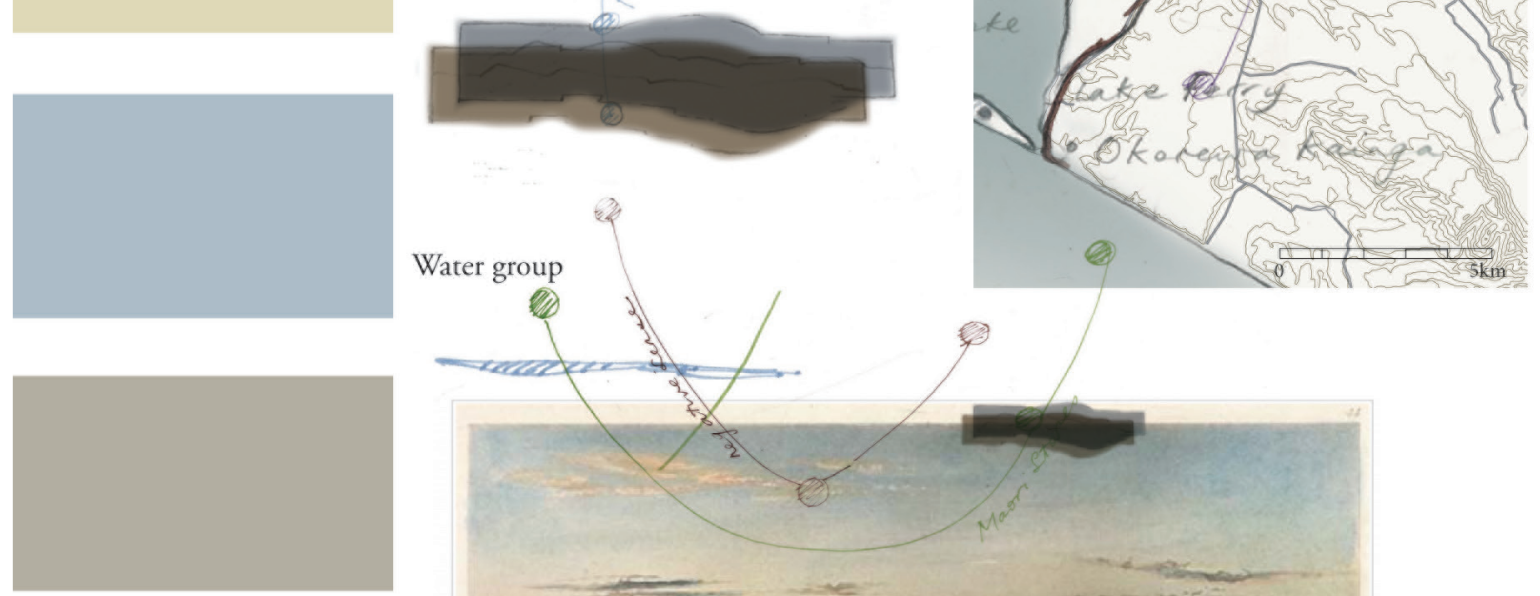

on terrace overlooking coast

on limestone, surrounded by beach deposits including marine gravel
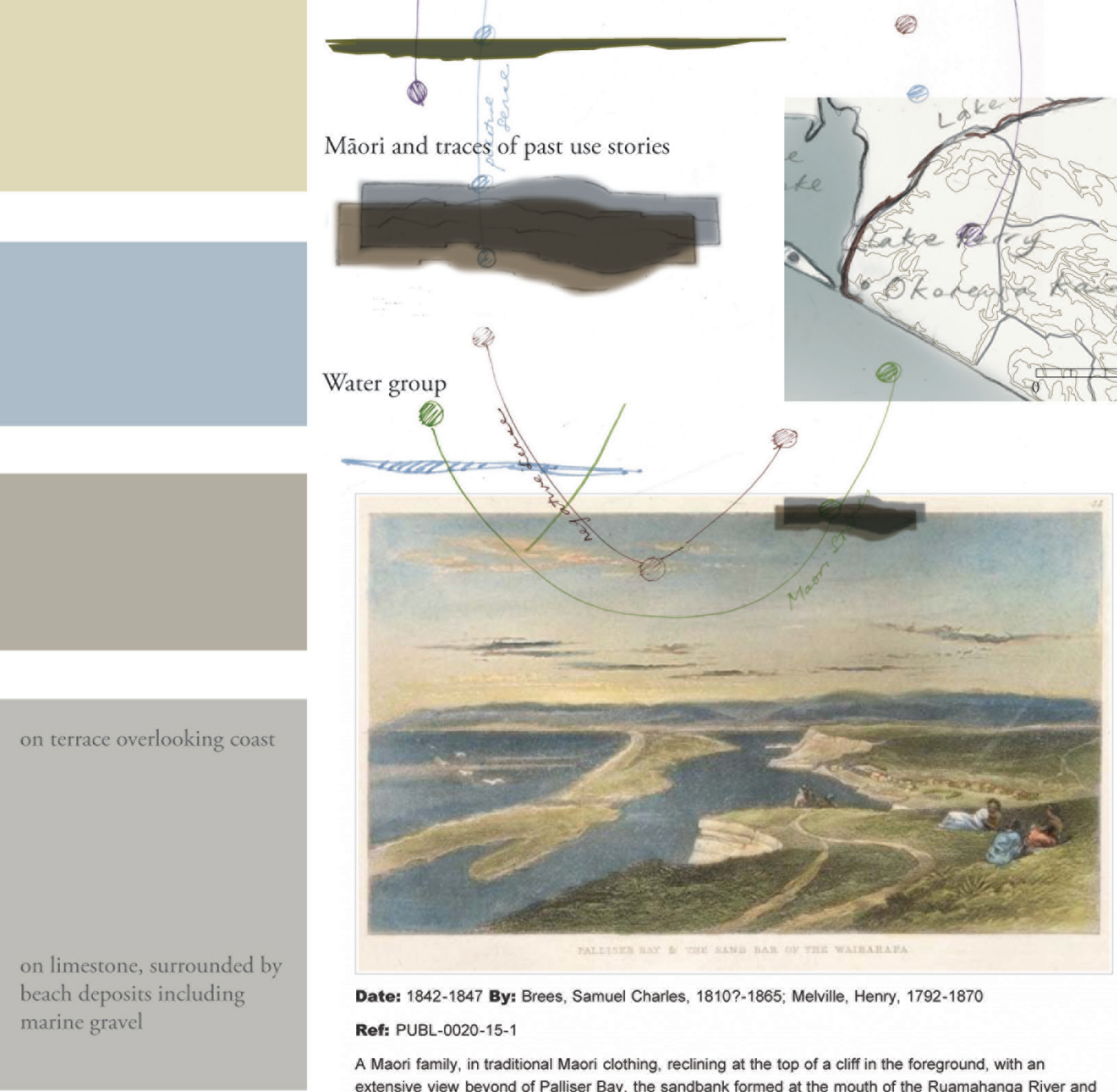

Date: 1842-1847 By: Brees, Samuel Charles, 1810?-1865; Melville, Henry, 1792-1870

Ref: PUBL-0020-15-1

A Maori family, in traditional Maori clothing, reclining at the top of a cliff in the foreground, with an extensive view beyond of Palliser Bay, the sandbank formed at the mouth of the Ruamahanga River and Okorewa $\mathrm{Pa}$, also at the mouth of the river on the flat land below.

https://natlib.govt.nz/collections

Fig. 5.08. Okorewa Kāinga threads. 


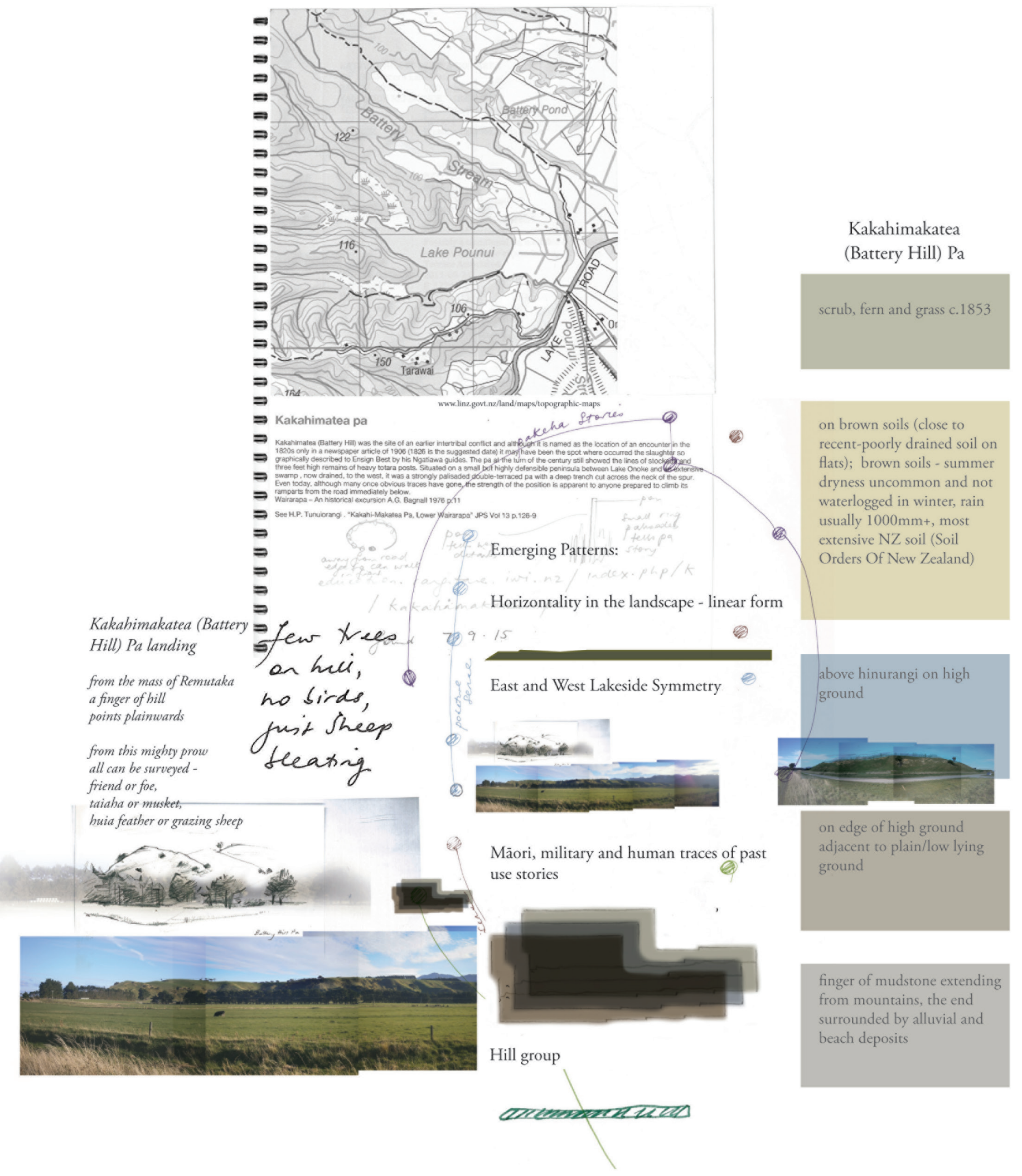

Fig. 5.09. Kakahimakatea (Battery Hill) Pa threads. 
View of Lake Onoke, Onoke Spit and Palliser Bay, Wharekauhau Road

scrub, fern and grass c. 1853

pallic soils - soils with weak structure and high density, in places that are dry in summer and wet in winter due to slow drainage; root extension limited (Soil Orders Of New Zealand)

above hinurangi on high ground

high ground, uplifted marine terrace (Boffa Miskell Ltd., 84)

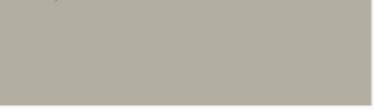

alluvial deposits, well sorted floodplain gravels

\section{Emerging Patterns}
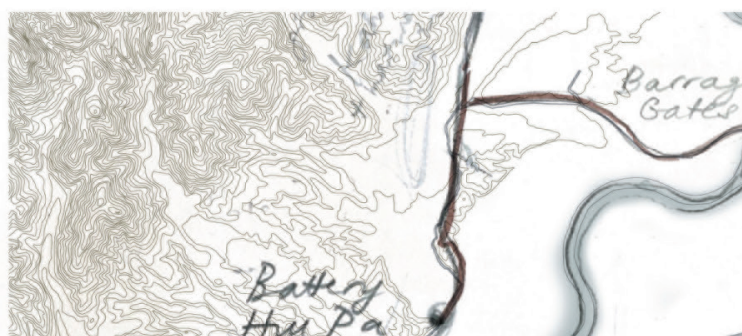

Horizontality in the landscape - linear form
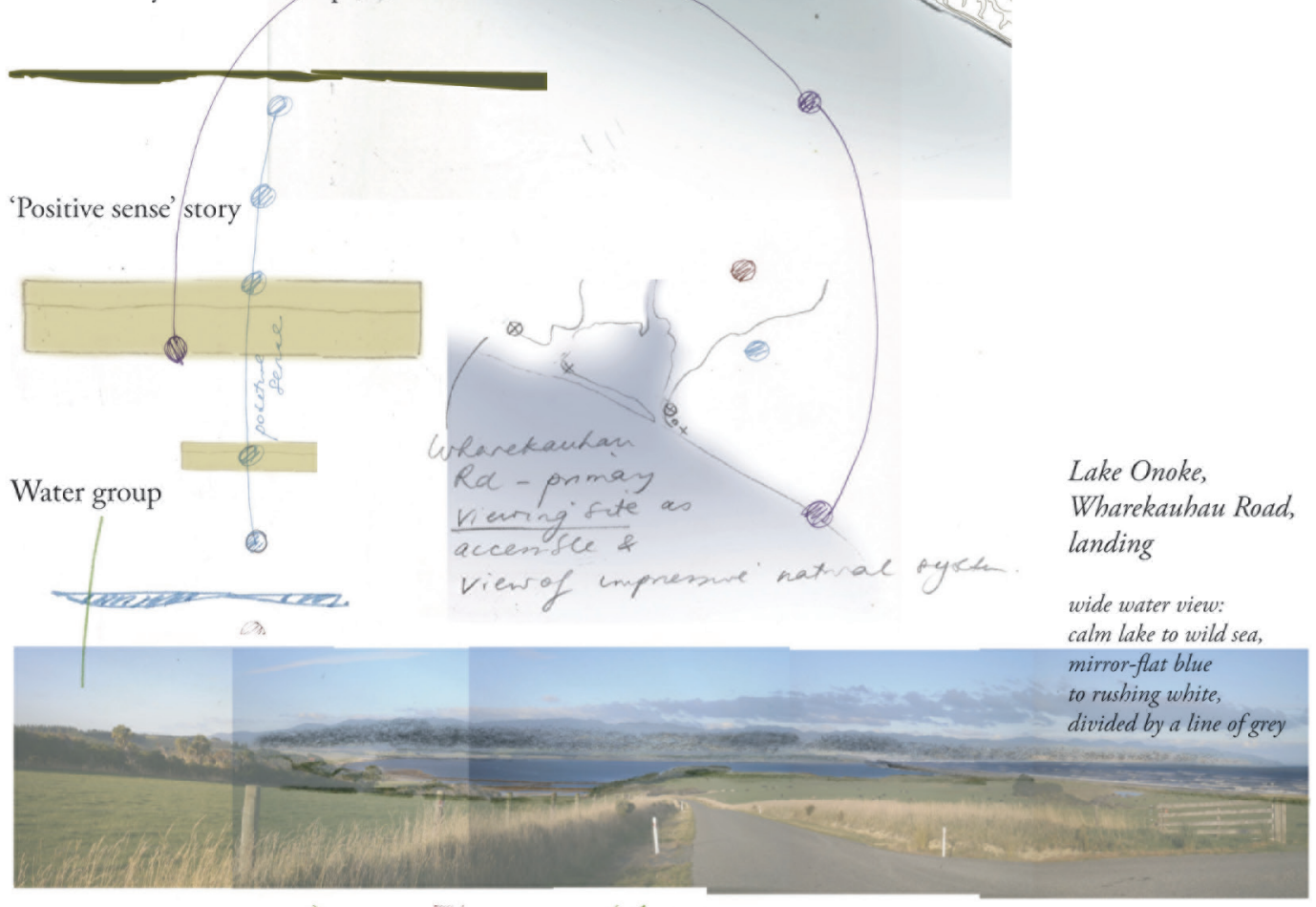

e

Fig. 5.10. Wharekauhau Road Viewpoint threads. 
Pigeon Bush
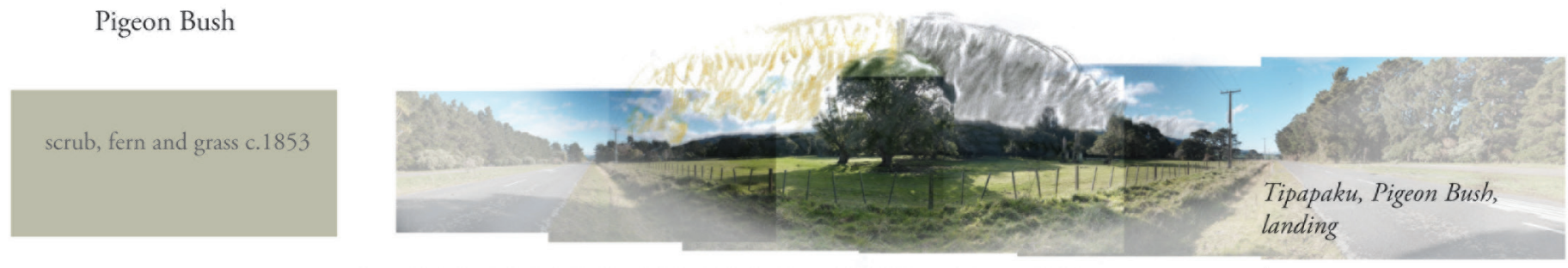

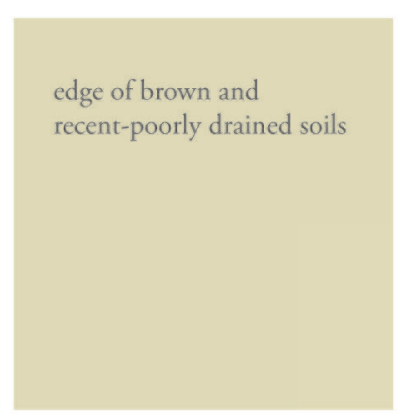

above hinurangi on high ground

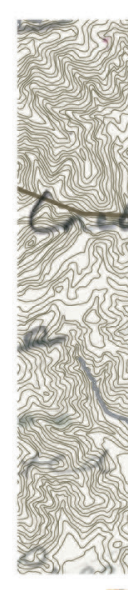




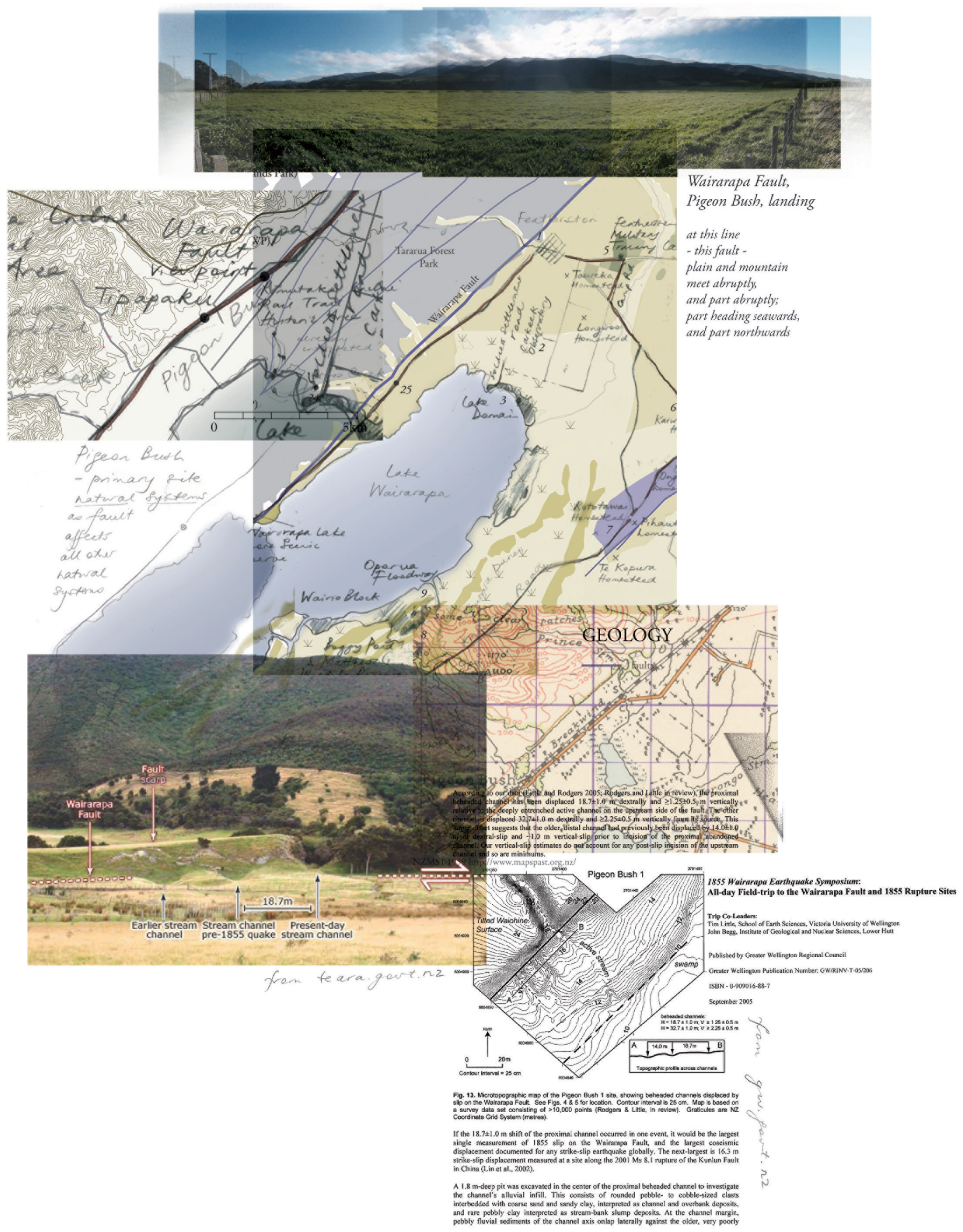

Fig. 5.12. Wairarapa Fault, Pigeon Bush, threads. 


\section{Finding/weaving}

Finding is the weaving together of discoveries made in the first two trace concepts, landing and grounding. It is "the act and process of searching as well as the outcome, the thing discovered" (Girot 63). As part of seeking what to design, project specific design principles were established and precedents sought which used similar principles. They are depicted alongside design iterations they influenced. Further design iterations appear in Appendix E.

\section{Design Principles and Precedent Examples}

1. Interventions are to expose and enable the seeing of the heritage site and show the dependent relationship of heritage on the landscape.

In 'Homage to a Duck Decoy' the path extends out like a jetty into what was the pond. The text cut into the end of the path encourages pause and reflection (see fig. 5.13). This principle was explored in the design for Bidwill Green (see figs. 5.14 and 5.15).

2. Create small scale interventions, with a light touch, that are economically feasible.

Landscape architect Georges Descombes has written, "I believe that the largest of territories can be irreducibly restructured through small, laconic interventions as opposed to an unbearable excess of everything - objects, forms, materials ("Shifting Sites" 80). An example of this is Parc en Sauvy, where he designed simple interventions in unplastered concrete (see figs. 5.16 and 5.17). 


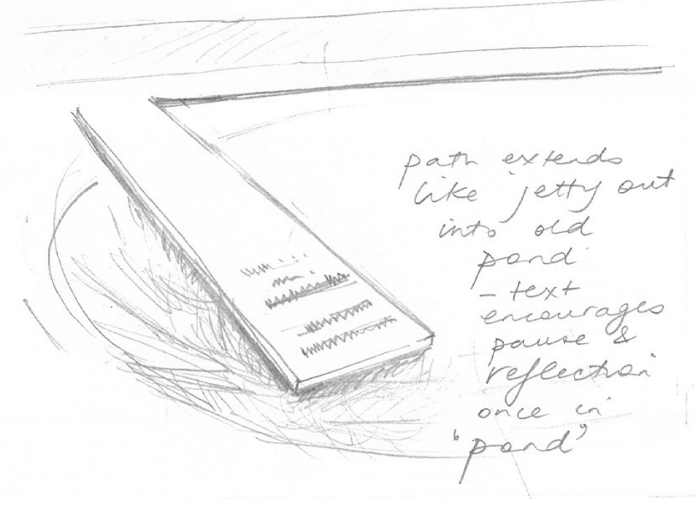

Fig. 5.13. 'Homage to a Duck Decoy' by MD

Landschapsarchitecten.

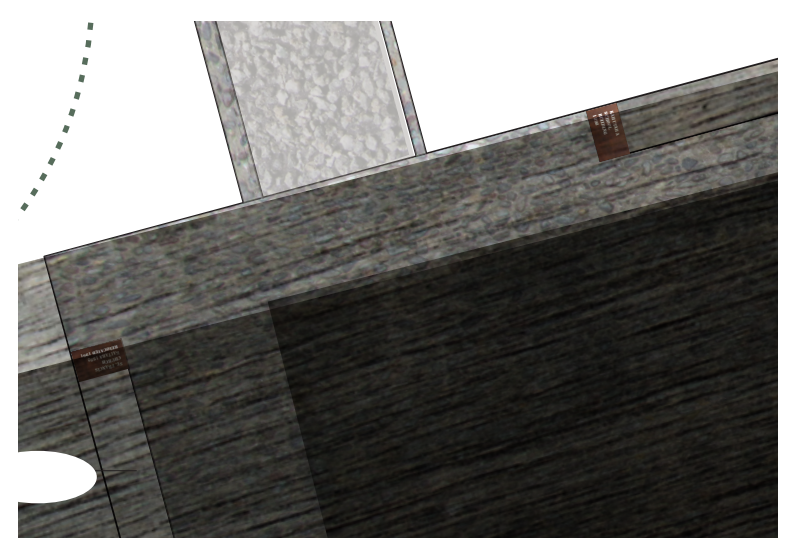

Fig. 5.14. A close-up view of one of the first iterations for Bidwill Green with corten plaques featuring text set into the benches.

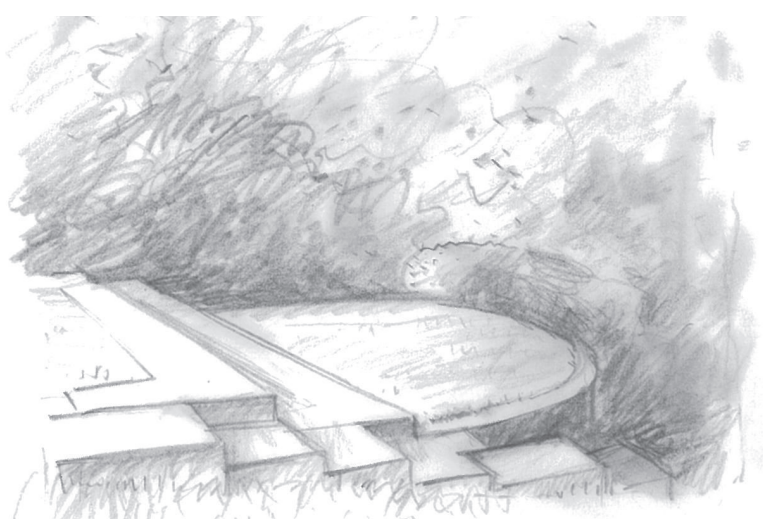

Fig. 5.16. Part of 'Parc en Sauvy', Lancy, Switzerland by Georges Descombes.

\section{ST. FRANCIS \\ CHURCH \\ KATYARA 1882 \\ BELOCAYYID 1961 \\ KAHUTARA \\ SCHOOL. \\ BUIIIDING \\ 1898 \\ KAHUTARA HAM \\ SOUDIRRS CUUB \\ FMTC 1916 \\ RELOCAYED 1921}

Fig. 5.15. The corten plaques.

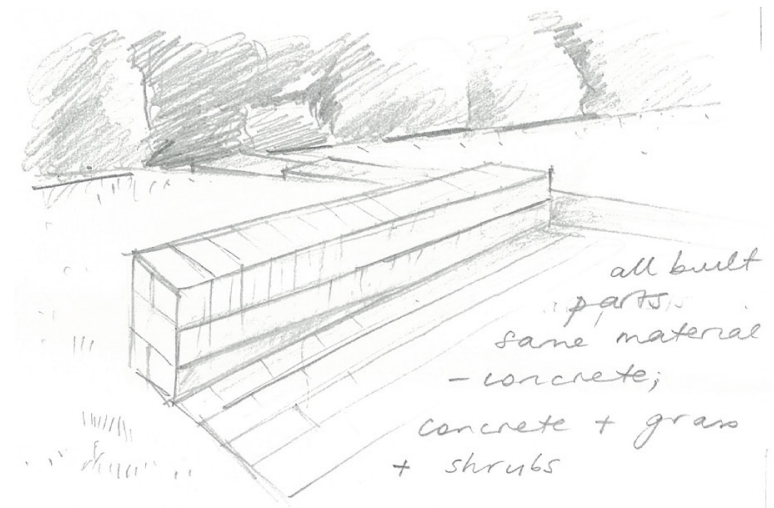

Fig. 5.17. Another area of 'Parc en Sauvy'. 
In 'Twickel Estate' and 'Kasteel Groeneveld' (see figs. 5.18 and 5.19), the small size of the intervention and the limited choice of materials enable the landscape to remain dominant. The interventions still focus attention and attract viewers to them. The same principle has been employed in the Wairarapa Fault interpretation (see fig. 5.20).

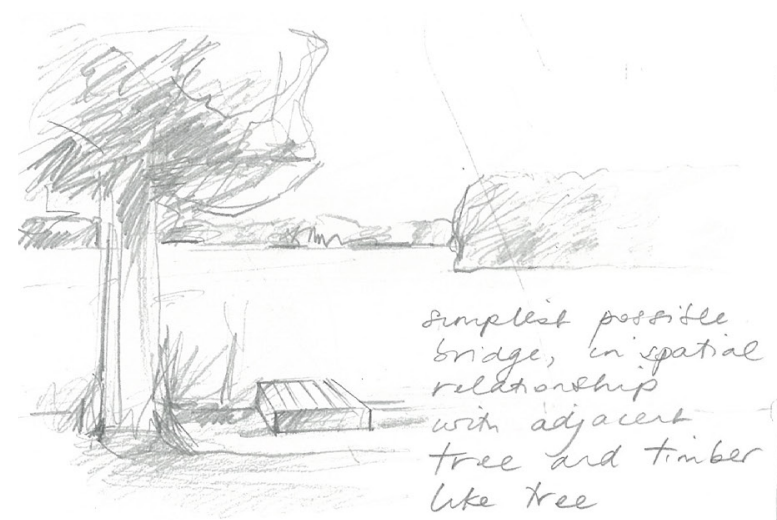

Fig. 5.18. Michael van Gessel's 'Twickel Estate'.

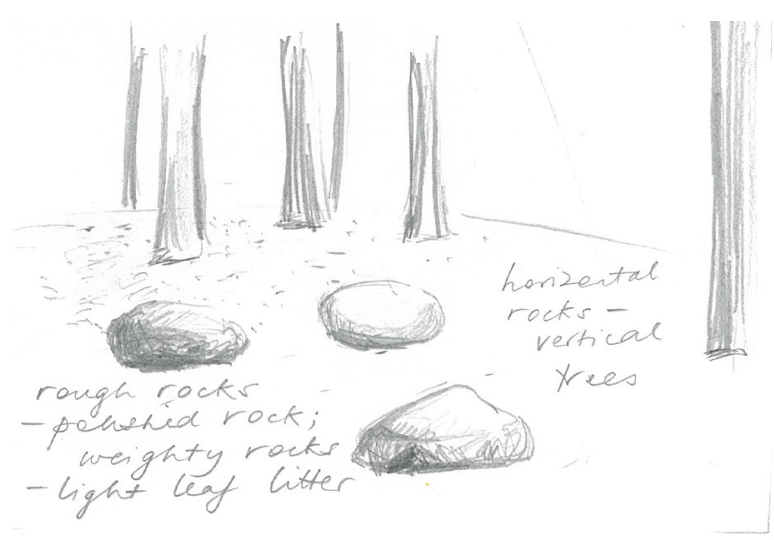

Fig. 5.19. Michael van Gessel’s 'Kasteel Groeneveld'.

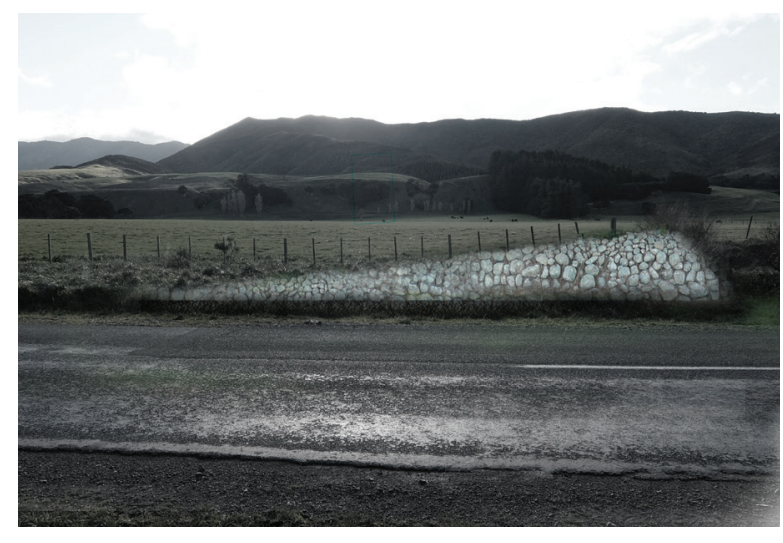

Fig. 5.20. Wairarapa Fault intervention - an early image. 


\section{Create a sense of intrigue}

'Sheep Seats', 'Stronghold Grebbeberg' and 'The Infinite Bridge' (see figs. 5.21, 5.22 and 5.23), are surprising and intriguing insertions into the landscape. They draw viewers to interact with them, to sit on them, walk through them and walk along them. The markers on the trail will create intrigue as they are unexpected objects in the landscape.
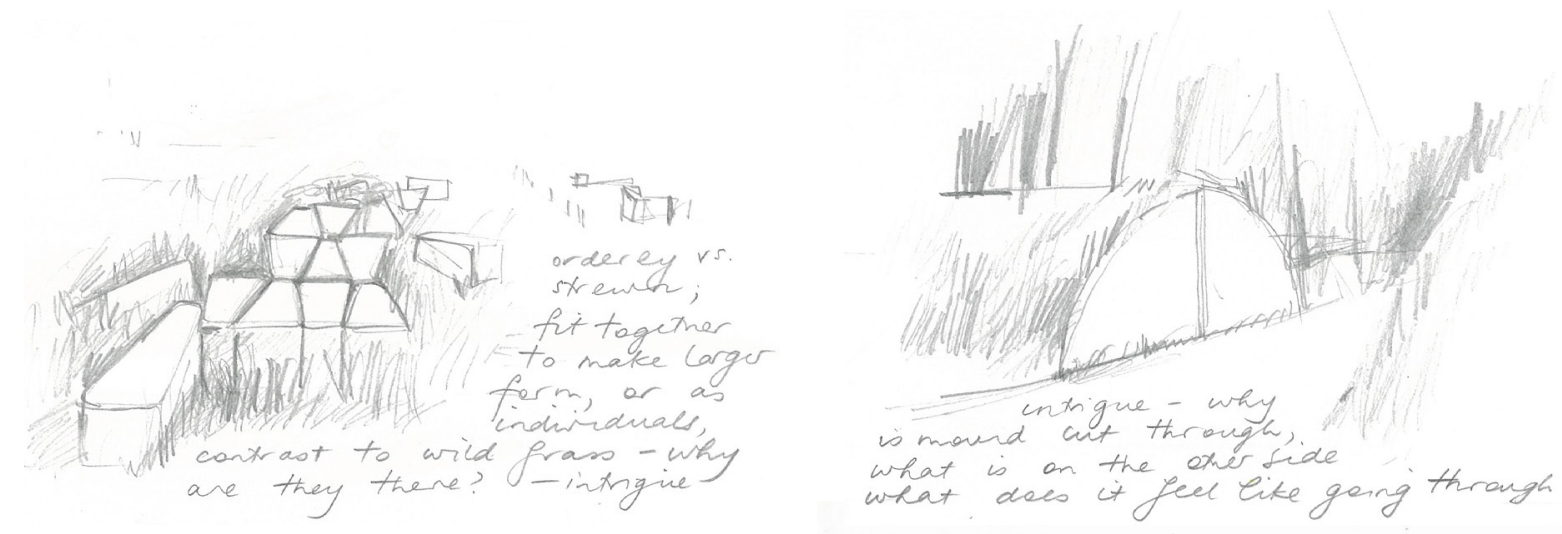

Fig. 5.21. Peter Beard's 'Sheep Seats'.

Fig. 5.22. Michael van Gessel's 'Stronghold Grebbeberg'.

Fig. 5.23. 'The Infinite Bridge' by Gjøde \& Povlsgaard Arkitekter.

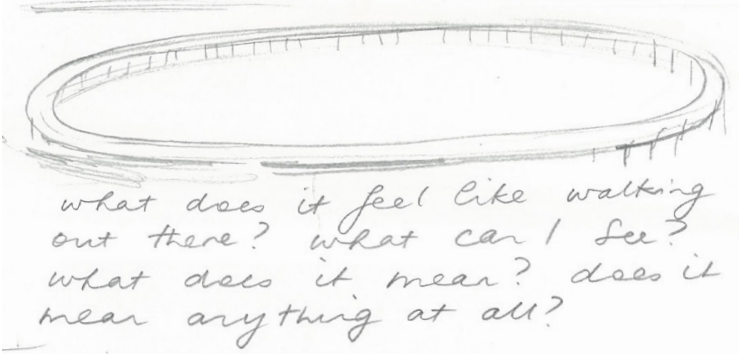


4. Create a new experience within the landscape

Replicate in some way the discovery experience undergone in this research so other people can experience it. This will increase their relationship with the landscape and weave more people into the landscape fabric making it richer. An example of this is EMF Landscape Architecture's 'Cap de Creus' project in Catalunya, which went further than the restoration brief and created an experience (see fig. 5.24).

It is especially important that more people experience the landscape in our current world. John Robert Stilgoe, professor in the History of Landscape at the Visual and Environmental Studies Department of Harvard University wrote in 1998: "Get out ... not just outside, but beyond the trap of the programmed electronic age so gently closing around so many people at the end of our century" (Oles, Timmermans, and Abelman, 35). This is even more the case eighteen years later. In a presentation by the researcher to the
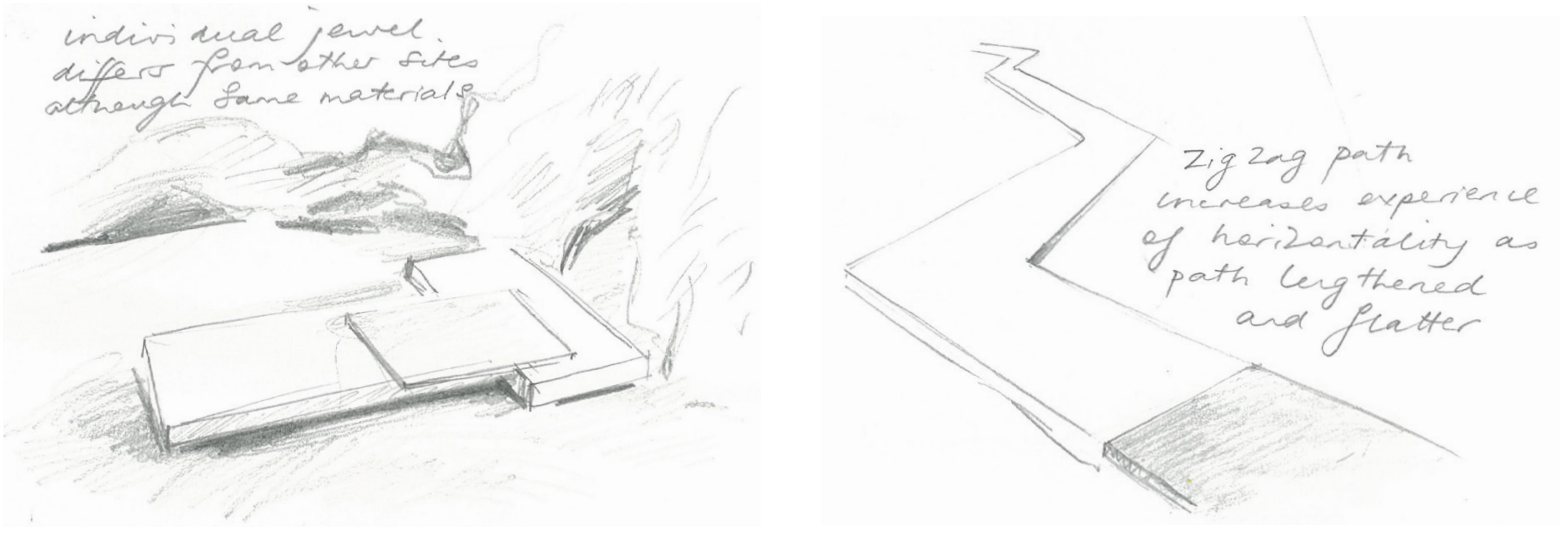

Fig. 5.24. 'Cap de Creus' by Marti Franch's EMF Landscape Architecture.

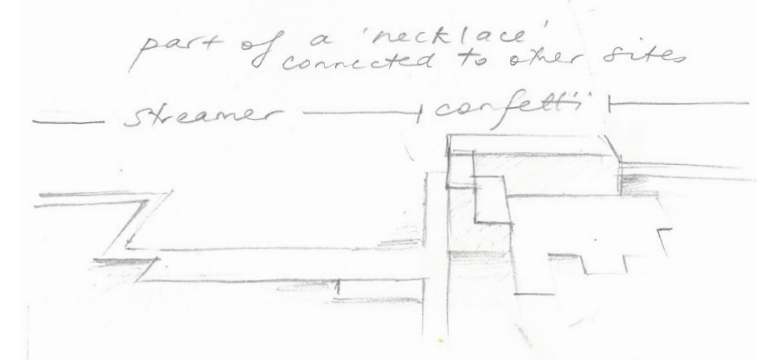

Fig. 5.25. 'Germanetes Viladomat' by EMF Landscape Architecture.

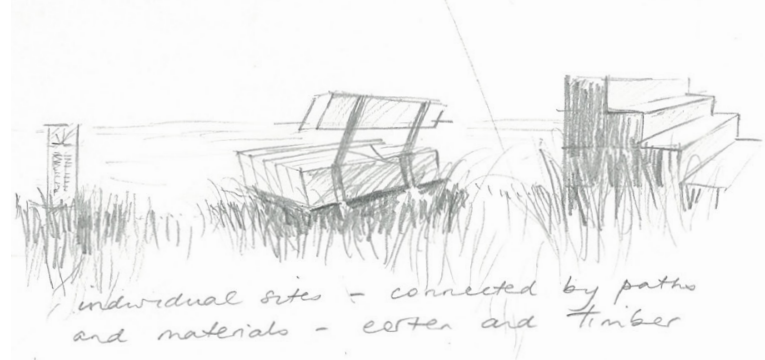

Fig. 5.26. 'Belvederes Drentsche Aa' by Strootman Landscape Architecture. 
Wairarapa Moana Management Team it was suggested that the trail could become an app. However, the aim of this research is to increase association with landscape in a world increasingly viewed and interpreted through screens and apps. Disassociation with landscape can also happen with traditional methods of interpretation. New Zealand landscape architect Wendy Hoddinott, in her article 'Passing Time: A Phenomenological approach to Heritage Design', wrote:

the expression of time in the landscape ... has frequently been treated in a very prosaic and interpretive fashion, seeking to educate the visitor. However, such approaches can switch off people's association with the landscape, because their attention is focused only on captions, signs and displays. $(51,52)$

5. With the Wairarapa Moana Wetlands Park sites forming an 'inner necklace', the interpreted sites can be viewed and experienced as individual 'jewels' or as part of a connected 'necklace'.

The sites can be different from each other and not dependent on each other. The precedents illustrated show parts of a whole with the parts differing from each other: 'Germanetes Viladomat' (see fig. 5.25) and 'Cap de Creus' (fig 5.24) and 'Belvederes Drentsche Aa' (fig. 5.26).

\section{Individual interventions are to be like Marti Franch's 'confetti', "objects and moments of intensity".}

Marti Franch is a Catalan landscape architect who explores how history can be expressed and interpreted by a design. In an article published in 2014 he discusses his "two tactical abstractions" (5). Confetti are "objects and moments of intensity" (Franch 5), used to choreograph movement through space, give cadence and aid narrative, for example, the rest stops, view framing devices and lookout points in the 'Cap de Creus' and 'Nummulites Walk' projects (see figs. 5.25 and 5.27). Streamers connect the confetti and are, for example, the paths connecting lookouts. The confetti concept has helped him "distribute economically and strategically available resources" (Franch 9). This concept will be useful to apply in this research as one of the aims is for the design proposals to be economically feasible. Confetti-like iterations are shown in figs. 5.29 and 5.30. 


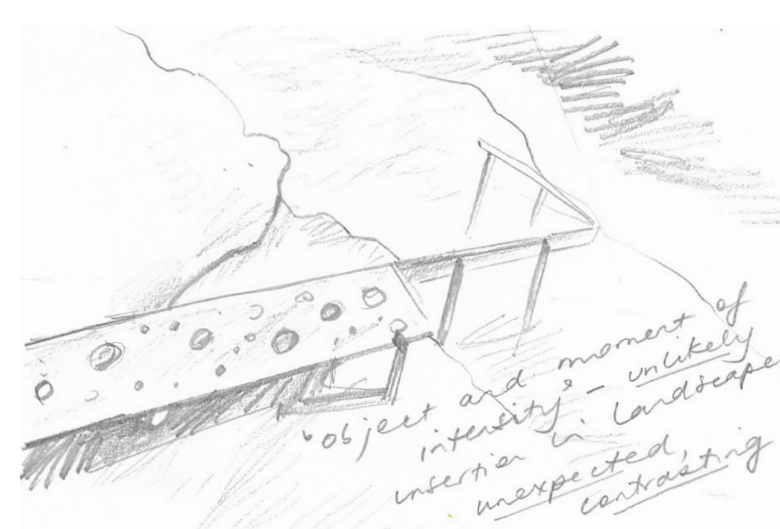

Fig. 5.27. 'The Nummulites Walk' by EMF Landscape Architects.

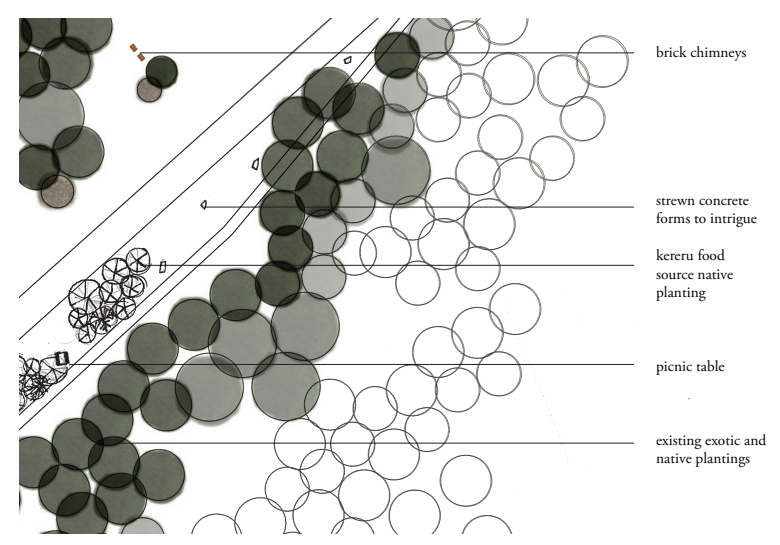

Fig. 5.29. Early iteration for Tipapaku (Pigeon Bush).

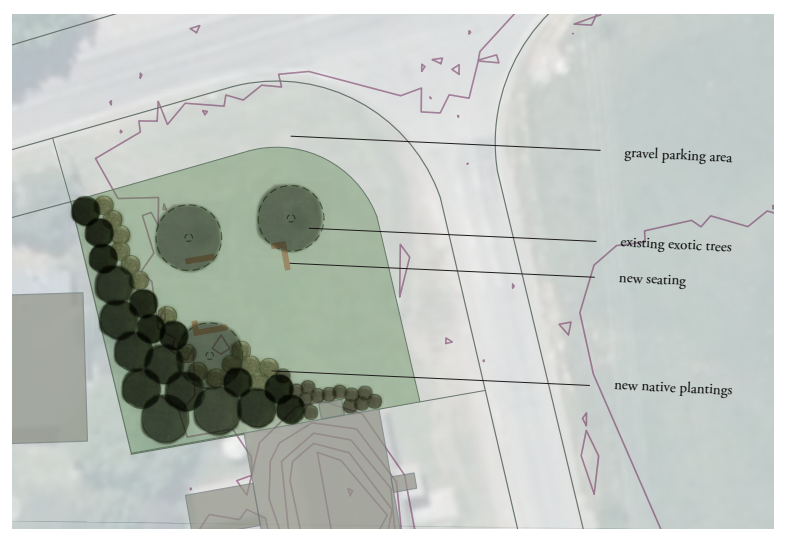

Fig. 5.28. Early iterations for Kahutara.

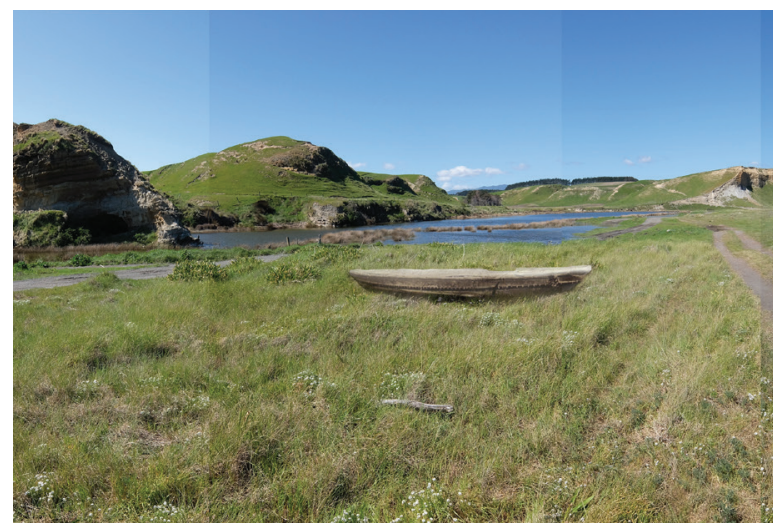

Fig. 5.30. An early image siting the waka tētē form in the landscape to reveal Okorewa Kāinga.

7. Materials and forms are to be drawn from the landscape, from the shapes and colours of the surroundings and from remnants of past land uses, re-organised or re-presented, to capture 'South Wairarapa-ness'.

Gini Lee discusses Taylor Cullity Lethlean's work in the Flinders Ranges National Park and the signs that mark the crossing from farm land to national park (see fig. 5.31):

These signs utilise materials drawn from the landscape (stone) or from the forms and colours of the surrounding groundscapes and ruins of past occupation (rusted steel forms). Coming across them causes a pause, as they are other to this landscape and obviously 
works of careful design in places that usually bear more utilitarian and handmade craftsmanship.... So often, these landscapes are inhabited by the awful generic that lacks local 'fit' to site - the infrastructure that are conceived and sited through pragmatic and corporate programming to keep the landscape from harm by taming public behaviour. As counterpoint, an attitude to site specificity is at the heart of TCL's park orientation sites dotted along the road. (99) This differs to the lack of site specificity usually employed in New Zealand's heritage sites, such as in the instantly recognisable DOC green and yellow signage (see fig. 5.32). Materials used on the trail are to be drawn from materials present in the surrounding landscape such as macrocarpa timber, manuka poles, local stone (see fig. 5.33) and corten steel (see fig. 5.34), referring to the rusting farm machinery a feature of many farms.

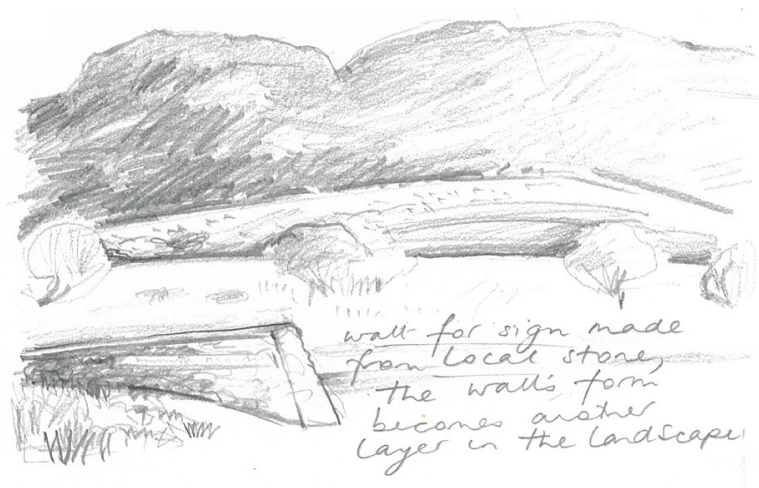

Fig. 5.31. 'Flinders Ranges National Park' Australia, by Taylor Cullity Lethlean.

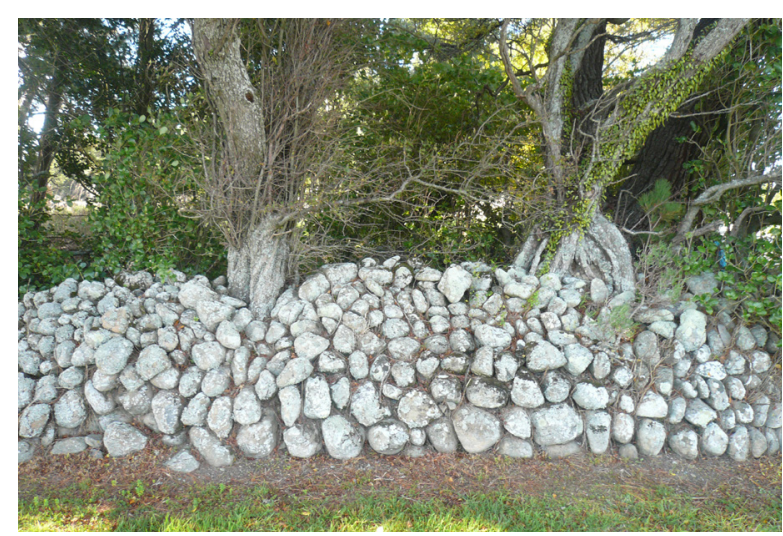

Fig. 5.33. An old stone wall on the road side near Featherston became inspiration for the Wairarapa Fault intervention.

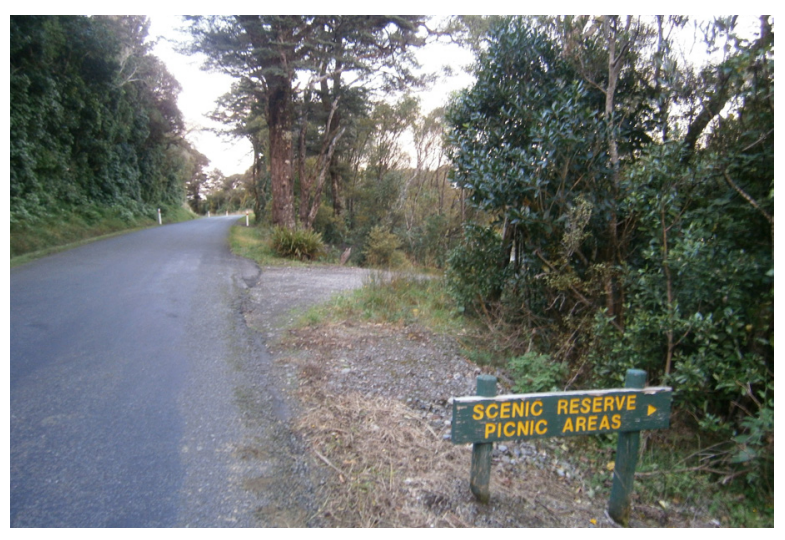

Fig. 5.32. The old Wairarapa Moana Scenic Reserve sign.
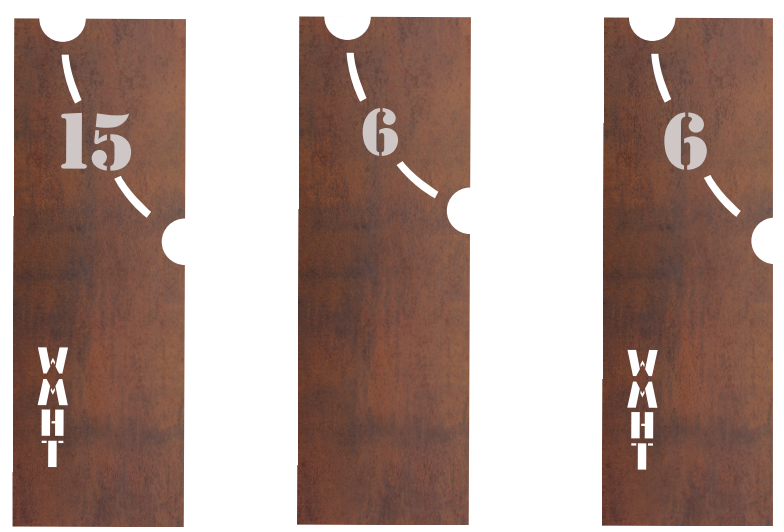

Fig. 5.34. Iterations of the corten steel trail markers. The numbers are stainless steel and cut outs frame small views of the landscape. 
8. Plants are one of the materials drawn from the landscape with which to interpret the site.

Rob McGowan spoke at the 2015 NZILA conference about the importance of using endemic and locally sourced plants. He said they survive better and that the species of an area are part of its mauri, defined as "vital essence [or] special nature" (Definition of Mauri). Introducing species not of the area decreases mauri. McGowan told conference delegates "your job as landscape architects is to restore mauri”".

Nelson, Byrd, Woltz Landscape Architects in their design for Nick's Head Station used planting as one of the layers to tell the stories of the past. The Endeavour Garden was inspired by the collections Joseph Banks made on Captain Cook's 1769 expedition. In the garden are 30 plants that were identified and collected at Young Nick's Head, including scurvy grass and New Zealand spinach, which became part of the staple diet for Cook's crew. The Earth Works Garden (see figs 5.35 and 5.36), with earthworks and broad sweeps of planting, references nearby hills and remnants of Māori defensive structures. Designs that use plants to help interpret the sites are Bidwill Green (see fig. 5.37) and Tipapaku (Pigeon Bush) Picnic Area (see fig. 5.38).

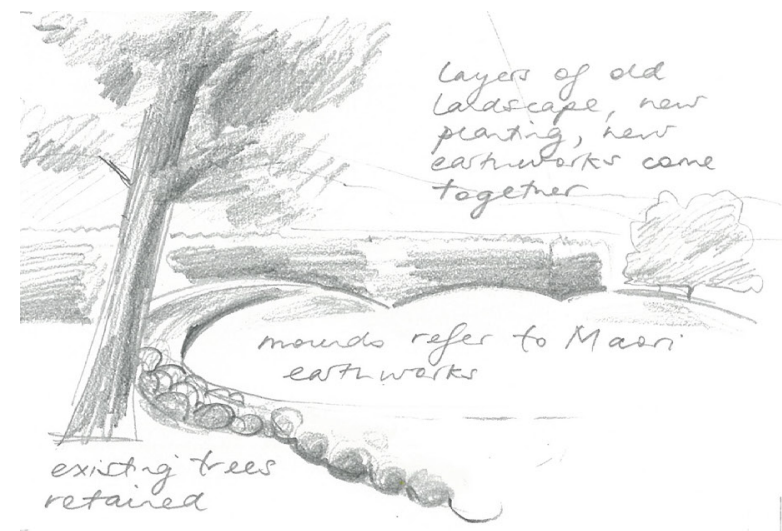

Fig. 5.35. 'The Earth Works Garden' at Nick's Head Station by Nelson Byrd Woltz Landscape Architects.

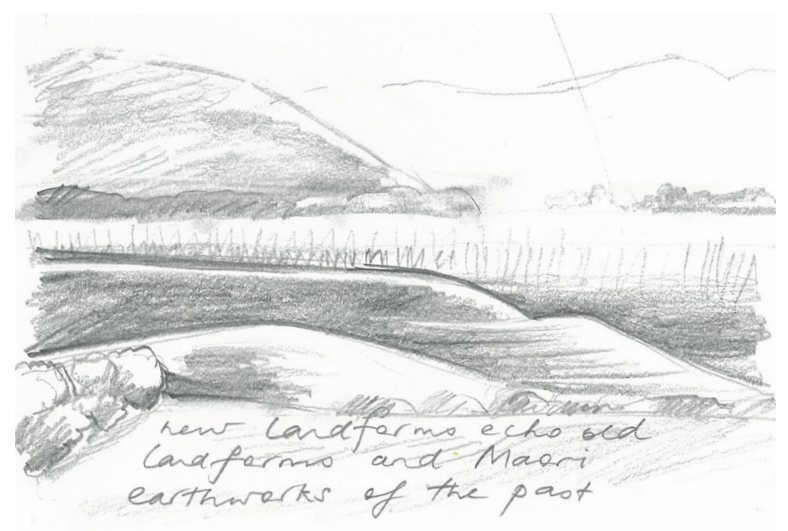

Fig. 5.36. Another view of 5.35. 


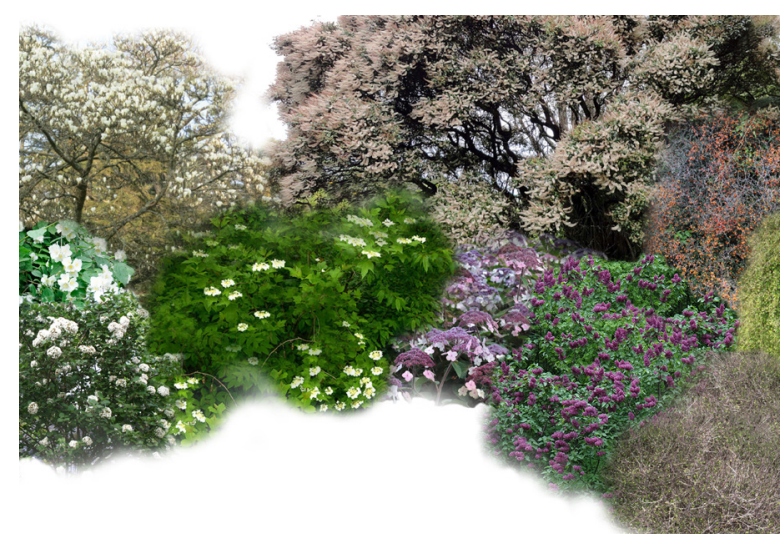

Fig. 5.37. In the design for Bidwill Green exotic flowering shrubs typical of Victorian gardens that would have been familiar to WE Bidwill have been used, as well as native plants from the surrounding landscape, to signify the gathering of people at Kahutara, Māori and Pākehā.

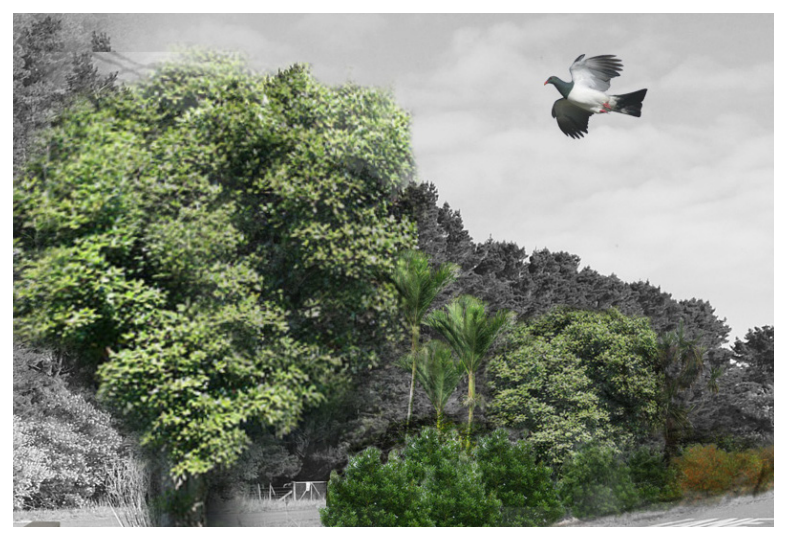

Fig. 5.38. The planting at Tipapaku (Pigeon Bush) has been chosen to attract kererū, wood pigeon.

9. Involve the community and engender community ownership.

All local people spoken to about this project have been enthusiastic. If the trail was to eventuate there would need to be community involvement to create a sense of community ownership. As local government maintenance may be limited, ongoing community involvement in the care of sites may be needed to ensure their continued ability to reveal heritage.

Local iwi may be involved, for example, in the design and carving of pou for the pa sites (see fig. 5.39). Residents may be asked to bring stones for the Wairarapa Fault wall. Māori and Pākehā may come together to plant trees at Tipapaku (Pigeon Bush).
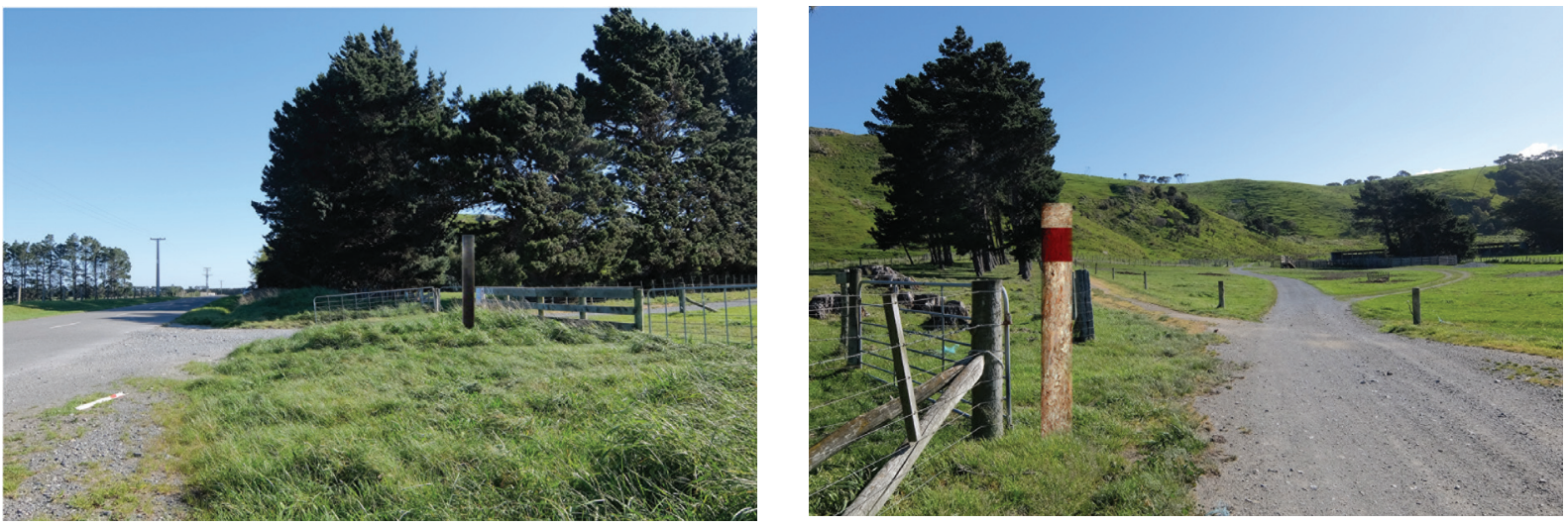

Fig. 5.39. An exploration of the possible siting of pou and markers to show the way to the Kakahimakatea Pa site. 


\section{Enable space, landscape, to become a place; to create a sense of place}

As Hunt has written "knowing something about the history of a landscape ... can ... transform it into a very different place" (29). The aim of this project is to make the landscape and space meaningful to people. As Tim Creswell has written, place is "a meaningful location" (7). In figure 5.40 the two images show the effect of placing an unexpected element, a simple pou, in the landscape - a place is made from space.
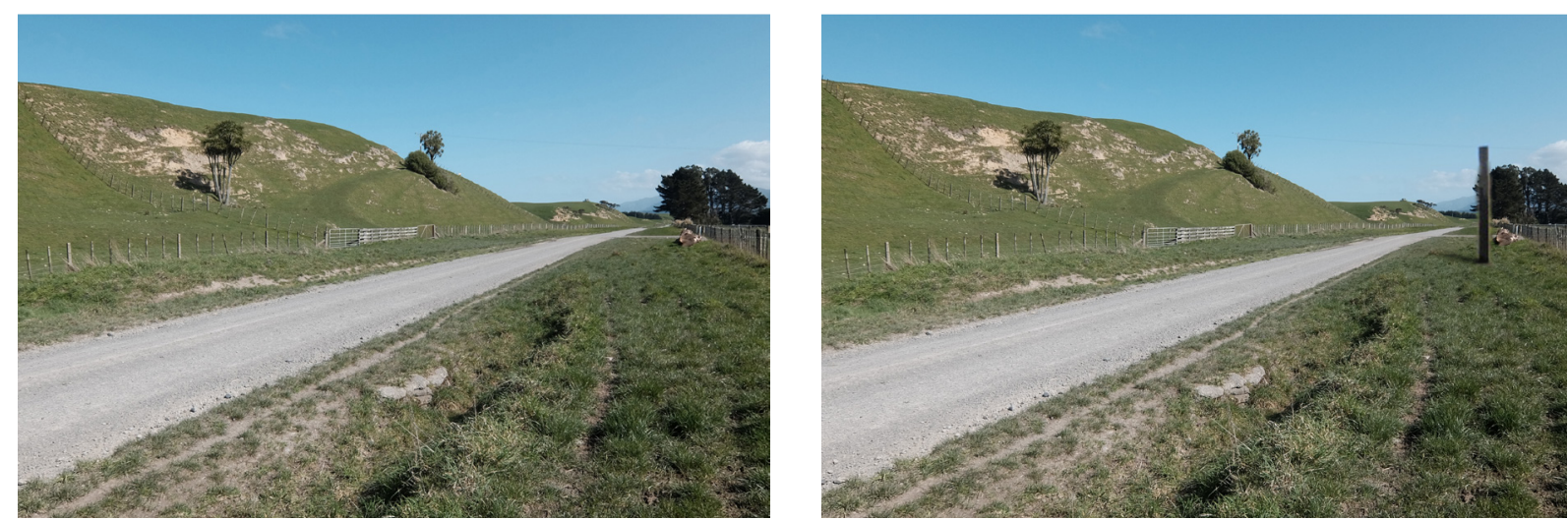

Fig. 5.40. An early iteration, a pou, at Raho Ruru Pa. 


\section{Design Ideas Explored and Precedent Examples}

Specific design ideas are explored below. These followed the design principles laid out in the previous section.

\section{Threshold, 'set apart'-ness}

Examples of this design idea are 'The Infinite Bridge'(see figs. 5.24) and 'the Nummulites Walk' (see fig 5.41) and the 'Cultural Landscape Path' (see fig 5.42). An early design exploration for Raho Ruru Pa, with a palisade setting an area apart from the surrounding landscape, is an example of using a threshold (see fig. 5.43) as is the hedging in Bidwill Green (see fig. 5.44).

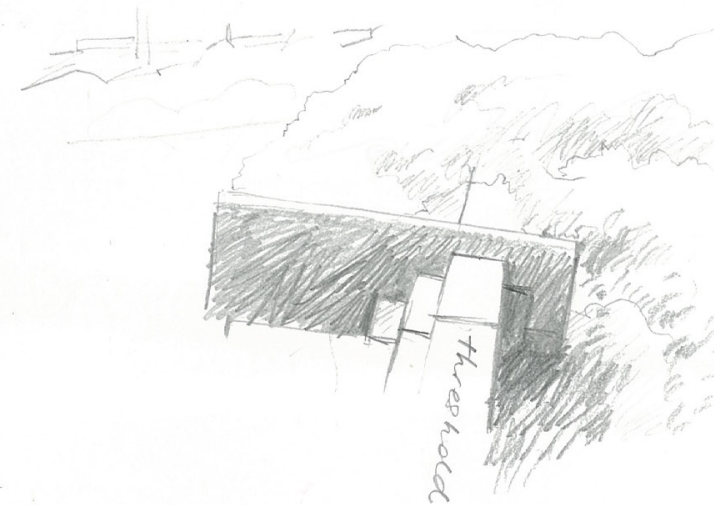

Fig. 5.41. 'The Nummulites Walk' in Girona, Spain, by EMF Landscape Architects.
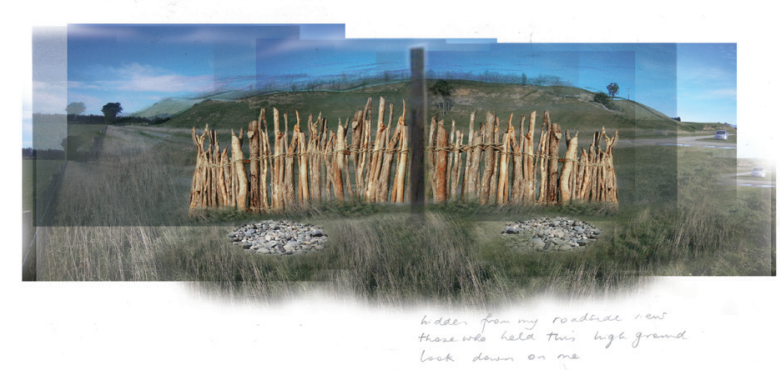

Fig. 5.43. An early design exploration for Raho Ruru Pa.

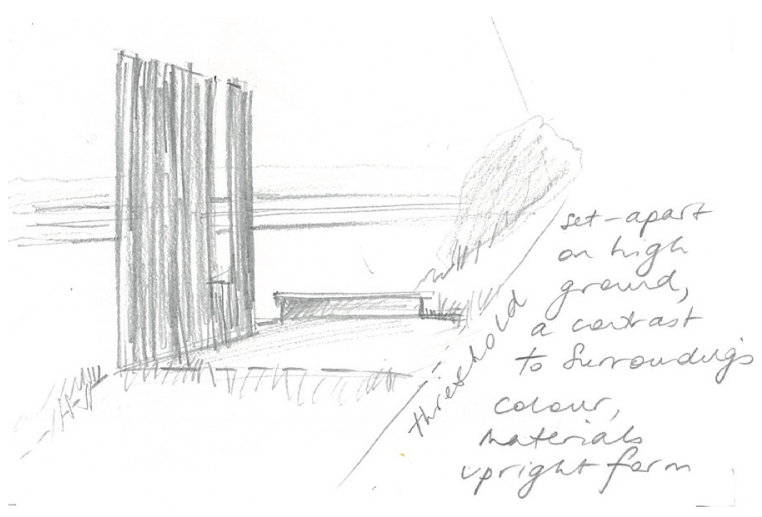

Fig. 5.42. 'The Cultural Landscape Path' by Archiplan.

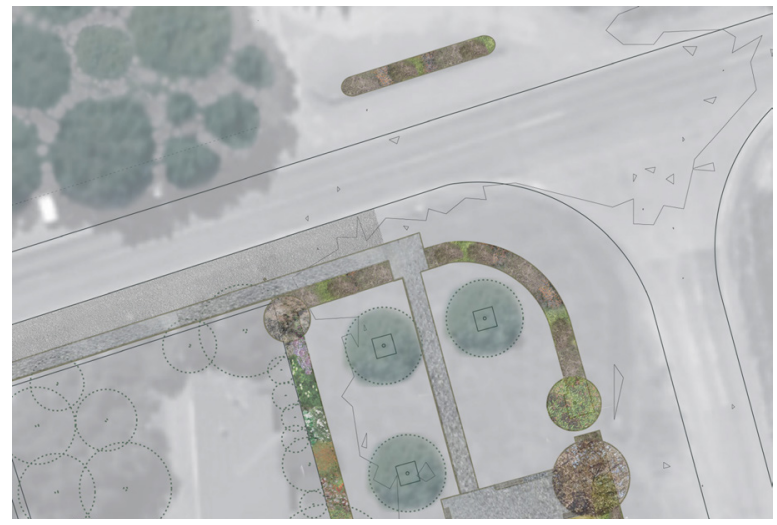

Fig. 5.44. Bidwill Green - hedges create a sense of 'set apart'ness and the path widening creates a threshold. 


\section{Small verticality amidst horizontality}

Design diary explorations of how verticality and horizontality can be expressed through light touch elements, specifically, post, bench, step and path, are shown in fig. 5.47. Examples of small verticality amidst horizontality are the signs at 'Belvederes Drentsche Aa' (see fig. 5.45) and 'Pedra Tosca Park' (see fig. 5.46). The form and materiality of these have influenced the design of the trail markers, shown in figure 5.34, and the use of pou, as in figs. 5.43 and 5.48. The researcher attended the NZILA 'Making the Culturally Shared Landscape' wānanga in 2015. There was much discussion about the issue of 'pou-ification', overuse of pou, when there is a desire to incorporate Māori culture into a design. The presenters concurred that the use of pou was acceptable if they told a story of that particular place, if the story could not be told anywhere, such as the story of Rangi and Papa, or if pou was the only layer.

Different ways horizontality and verticality can be expressed were put into practice in a number of designs, for example the 'waka' bench (see fig. 5.51), the directional connecting path in Bidwill Green (see fig. 5.44) and the steps in the Wharekauhau Road Viewpoint (see fig. 5.56).

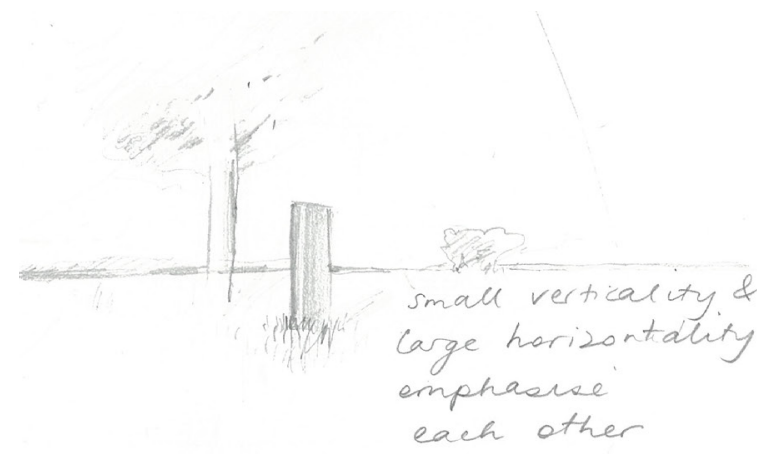

Fig. 5.45. 'Belvederes Drentsche Aa', in the Netherlands, by Strootman Landscape Architecture.

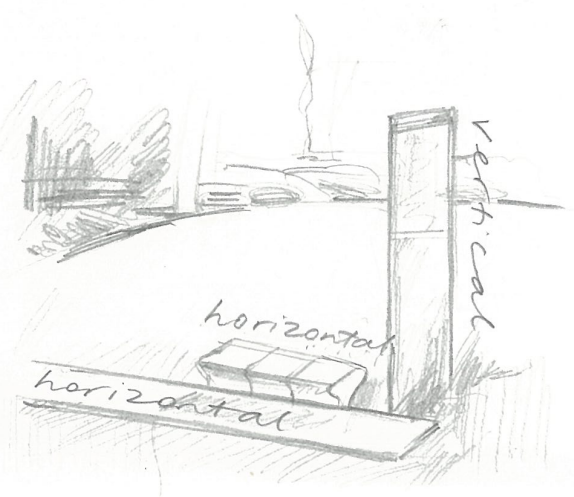

Fig. 5.46. 'Pedra Tosca Park', in Spain, by RCR Arquitectes. 


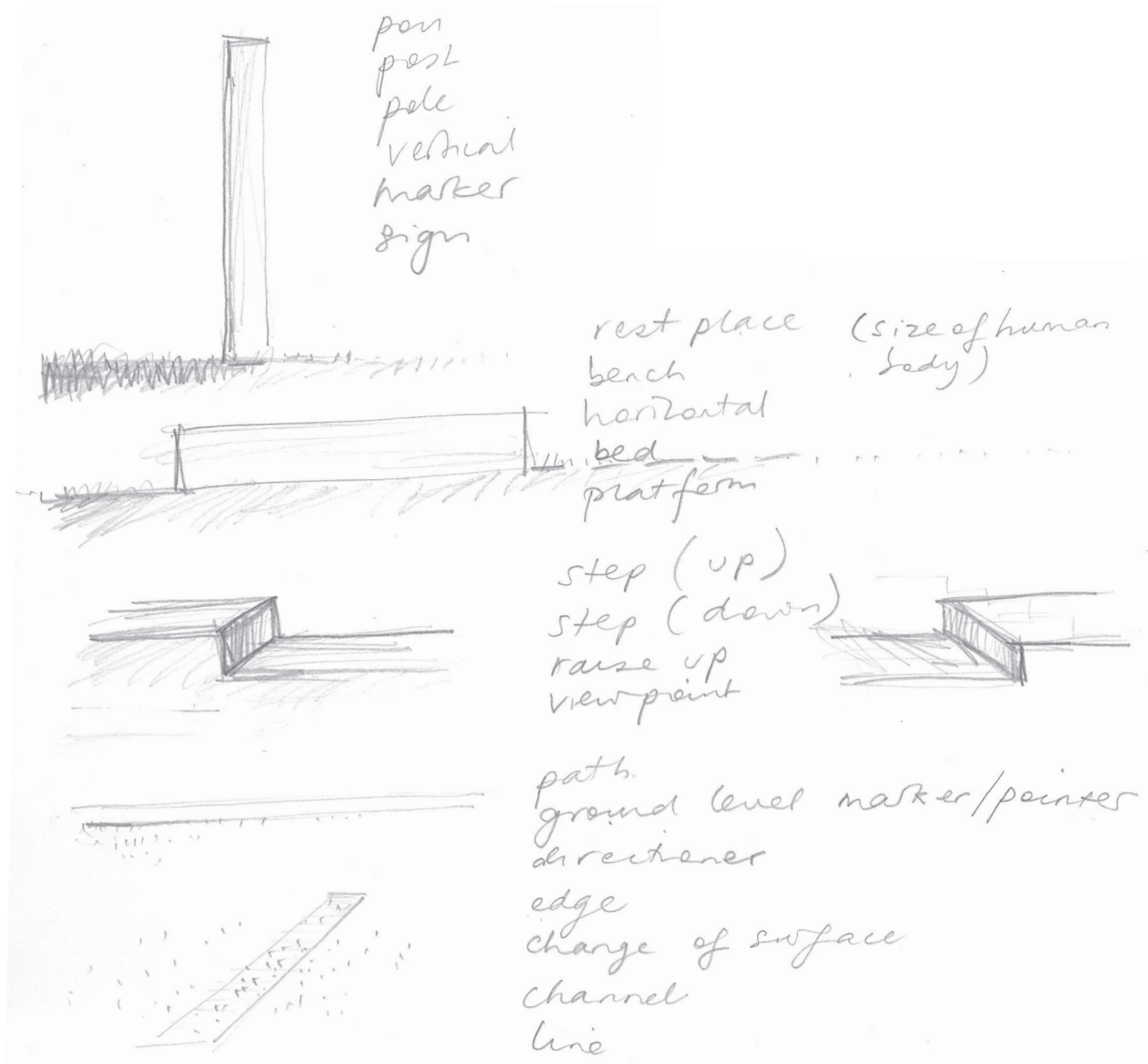

Fig. 5.47. Exploration of elements.

Fig. 5.48. Early iterations of a marker for Kahutara Dunes sited on the road's high point where it crosses the dune. The curved marker echoes the curve of the lake edge and the dominant wind direction - the material the dunes are made of has been carried by the wind from the lake.

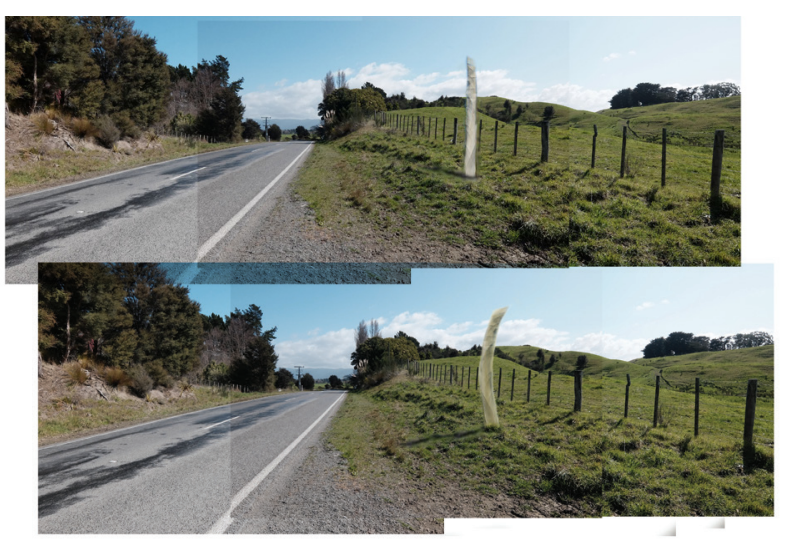


3. Horizontality underlined and emphasised

This design idea is exploited in 'Cap de Creus' (see fig. 5.49) and 'Innes National Park' (see fig. 5.50). It has been adopted in the interventions revealing Okorewa Kāinga and the Wairarapa Fault (figs. 5.51 and 5.52).

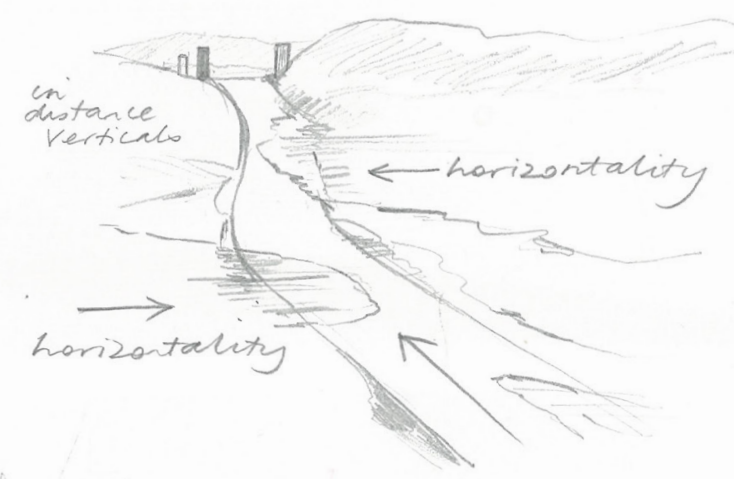

Fig. 5.49. 'Cap de Creus', in Catalunya, by EMF Landscape Architects.

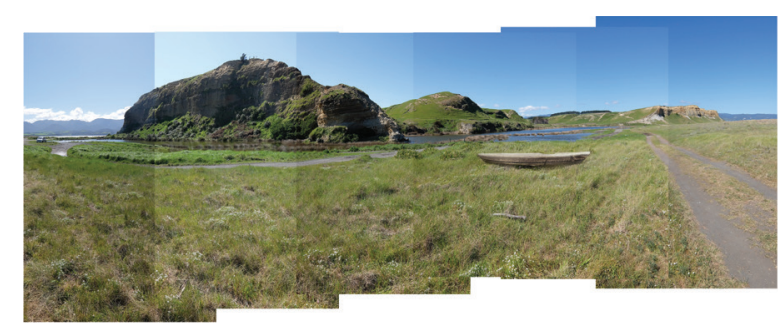

Fig. 5.51. The intervention revealing Okorewa Kāinga.

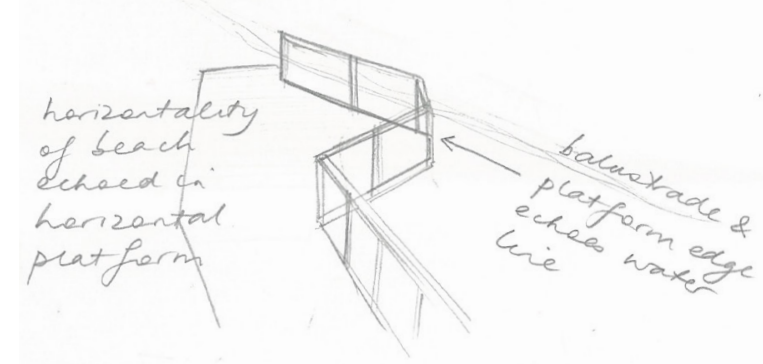

Fig. 5.50. 'Innes National Park', in Australia by Taylor Cullity Lethlean.

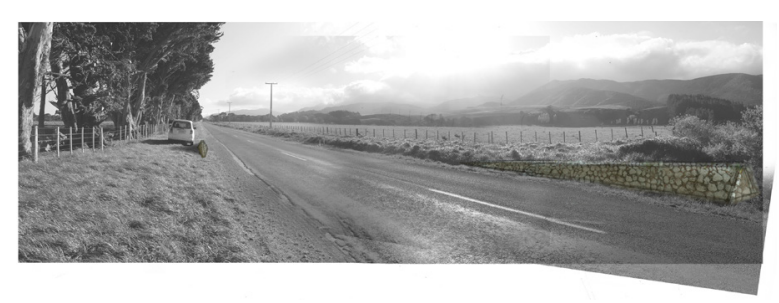

Fig. 5.52. The Wairarapa Fault intervention. 


\section{A structure may enable a different view}

The steps up in 'Belvederes Drentsche Aa' (see fig.5.53) enable different views. 'The Cultural Landscape Path' (see fig. 5.54) frames the view. On 'the Nummulites Walk' a corten steel sheet with circles cut into it frames fossils (see fig. 5.55). An improved view of Lake Onoke and the water bodies it connects to is enabled with the raised viewing platform of the Wharekauhau Road Viewpoint (see fig. 5.56). Once on the top of the platform the corten sign with place names cut into it informs the viewer.

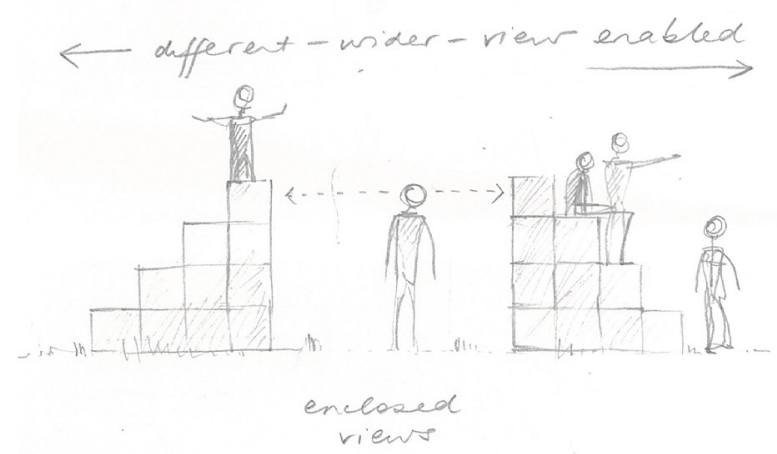

Fig. 5.53. 'Belvederes Drentsche Aa' by Strootman Landscape Architecture.

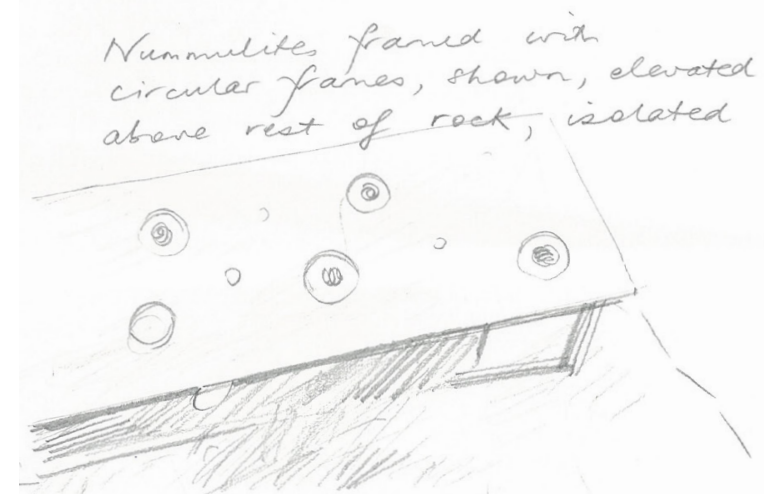

Fig. 5.55. 'The Nummulites Walk' by EMF Landscape Architects.

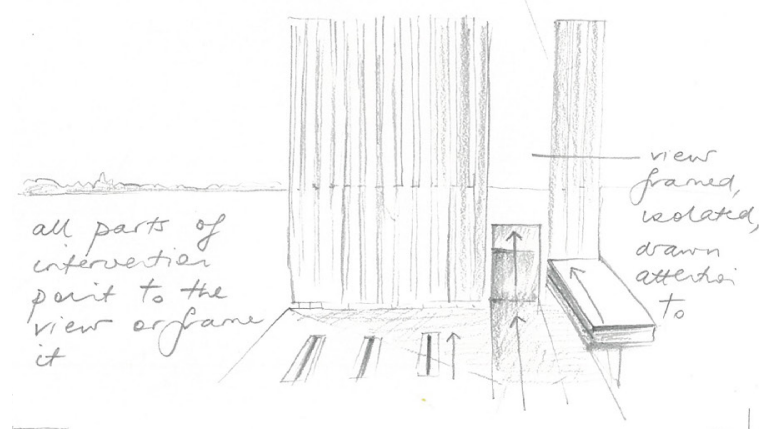

Fig. 5.54. 'The Cultural Landscape Path' in Italy, by Archiplan.

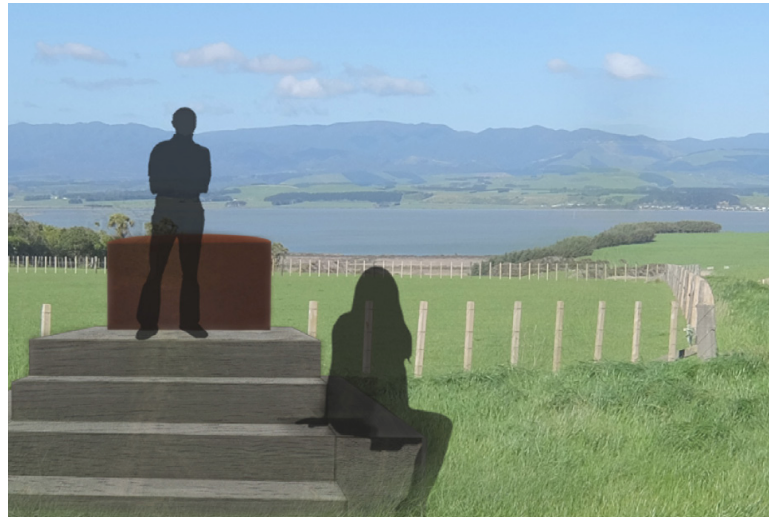

Fig. 5.56. An early image of the Wharekauhau Road Viewpoint. 


\section{Consider the removal of things}

Georges Descombes writes about how cleaning some of the boulders on the Swiss Path 'intensifies them':

Carmen Perrin, an artist with whom we collaborated, cleaned several of these boulders of moss and dirt with the help of art students from Geneva. Cleaning intensified their visual presence as well as revealing their beauty - and their history. Washing uncovered memory. Nothing more was needed. ("Displacements"129)

Pruning trees and removal of signs are moves that were employed in the trail (see figs. 5.57 - 5.59).

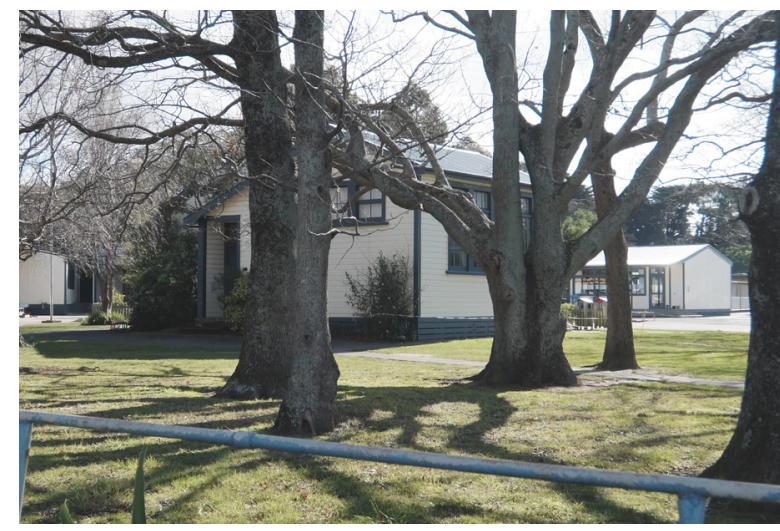

Fig. 5.57. The view from the road of the Kahutara School Building in winter; when the trees are in leaf it is barely visible.

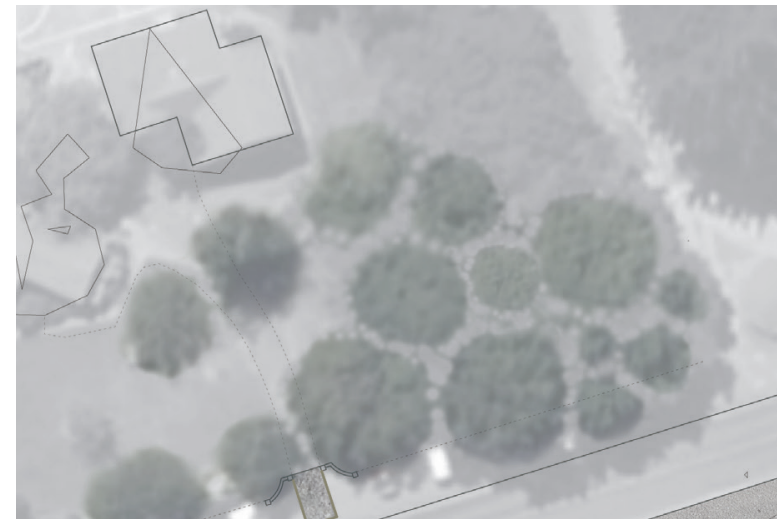

Fig. 5.58. Judicious pruning of the trees' branches will enable the historic school building to be seen from the road visually connecting it with the other historic buildings gathered in Kahutara.

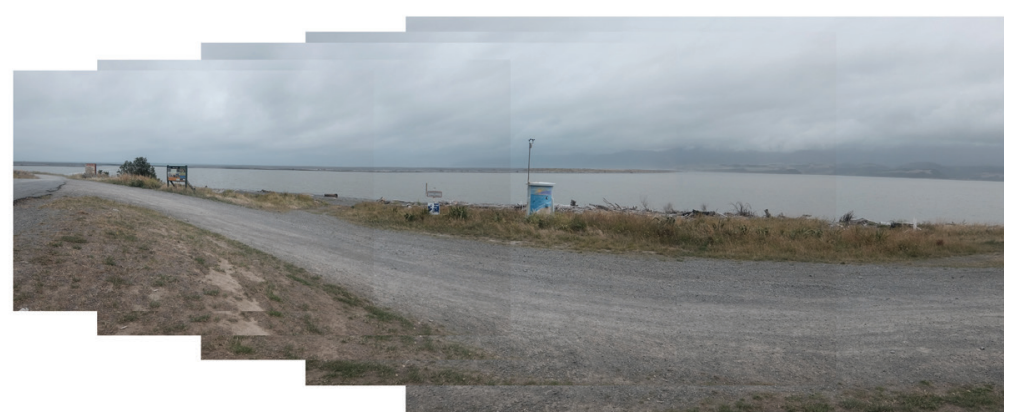

Fig. 5.59. The view of Lake Onoke, Onoke Spit and the Rimutakas shrouded in mist punctuated by signs and structures. 
8. Use naming as a layer in the interpretation

Hunt considers Bürgi "is content to stimulate us with names ('geological observatory', 'ludic path')" (Hunt 29). This research aims to provide pointers to history and to reveal heritage sites rather than tell the whole story. Māori use naming to point to what has gone before. Brain Murton writes that for Māori:

Place names are imagined as the "footsteps of the ancestors" and are sign posts, survey pegs of memory, to the events and processes by which the world was created. ... The daily use of place names means that history is always present, always available. (94)

Examples in the trail are Bidwill Green, Tipapaku (Pigeon Bush) Picnic Site and Nga Rākau Pūrākau - Raho Ruru Pa.

\section{Repetition of elements}

Repeating of elements can give direction, emphasis and connection as in the Sharpeville Memorial shown in fig. 5.60. Repetition is used in the palisadelike fence that bridges the two solid masses of planting in the Tipapaku (Pigeon Bush) Picnic Area (see fig. 5.61).

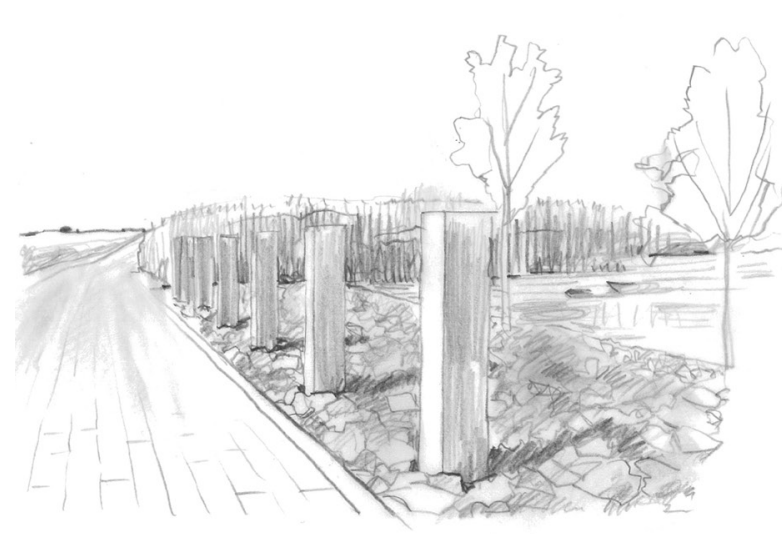

Fig. 5.60. 'Sharpeville Memorial', South Africa by GREENinc Landscape Architecture.

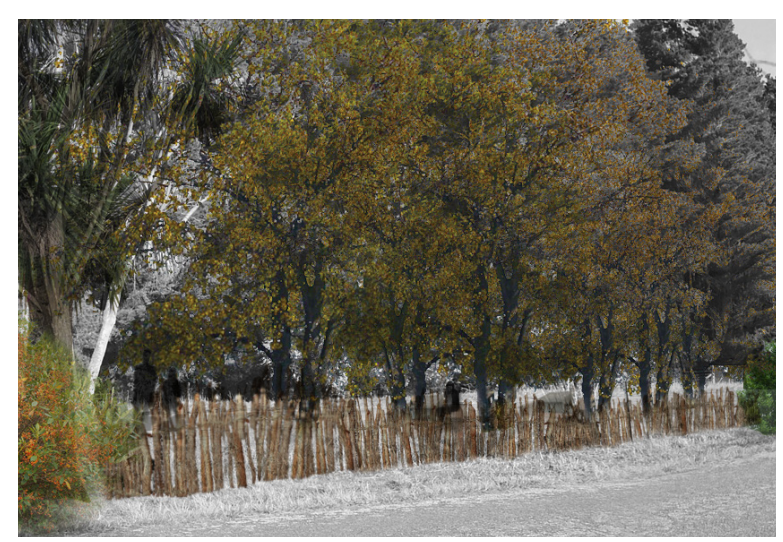

Fig. 5.61. The palisade-like fence in the Tipapaku (Pigeon Bush) Picnic Area. 


\section{After Girot's Method}

As the design process began to culminate in 'designs' the designer/researcher reflected on the method used to reach this stage, this trace concept that Girot calls grounding. Girot's 'Four Trace Concepts in Landscape Architecture' had been used as a starting point, but was adapted and shaped by the researcher's previous experience, previous designing, research for this thesis, and by relationships to the sites and the people associated with them. The result was the 'Four Listening Acts in Landscape Architecture' diagrammed in figure 5.62. Hence the title of the next chapter is a combination of Girot's fourth trace concept, founding, and the researcher's equivalent, retelling. 


\section{Four Trace Concepts in Landscape Architecture - Christophe Girot}

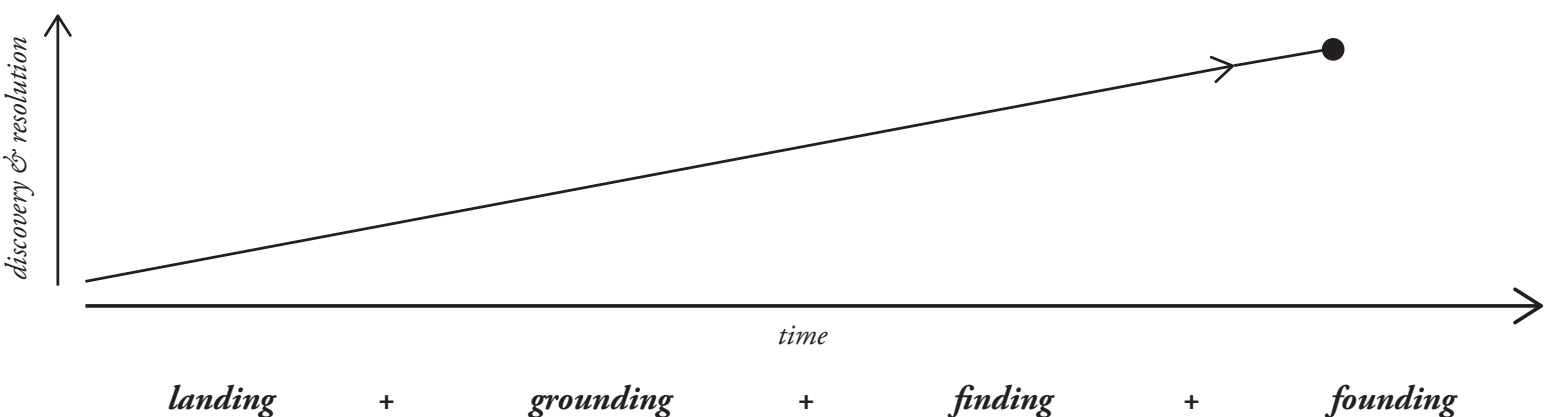

meeting the site the first time reading $\&$ understanding the site

- first impressions
- intuitions
- sensorial experiences
- happens only once

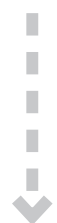

bearing

hearing the land speak the first time

- starting the conversation

- initial impression, intuition, hunch

minimal site research before site visit

- mindfully going to site, recording first impressions, intuitions in sketches, words

- landing images + text

- generally happens only once (1)

- what has led to the evolution of a place - through repeated visits

+ research

+ analysis

- recurs indefinitely

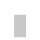

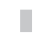

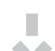

gathering

gathering all the stories revealing the threads

- what has led to the site being the way it is

- researching landscape processes + history + present day - how do these come together in the site + what connections are between them

- recurs indefinitely
$+$

\section{finding}

landing + grounding

$\begin{array}{rll}\text { verb } & + \text { noun } \\ \text { act \& process } & + \text { outcom }\end{array}$
of search

activity + insight

through a surprise discovery or methodical search

finding "conveys a distinct quality to a place", a unique identity

\section{$+$} weaving

weave 1 and 2 together make new discoveries

- finding out what will be designed pulling together all gatherings, tangible + intangible

- what does the coming together of

these factors generate: how space is shaped, materials, planting

- creates a unique identity
$+$

\section{founding}

a synthesis

landing + grounding + finding

- "a new and transformed

construction of the site"

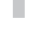

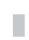

西

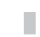

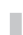

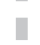

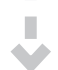

retelling

the design

- a passing on of the story - writing a new chapter - enabling others to hear + see

+ experience

Four Listening Acts in Landscape Architecture - Maria Rodgers after Christophe Girot

Fig. 5.62. Diagram comparing Girot's method and the researcher's method based on it. 


\section{FOUNDING/RETELLING}

The last stage of the 'Four Listening Acts in Landscape Architecture' is called retelling. This can also be seen as 'the design', the passing on of the story, the writing of a new chapter or enabling others to hear, see and experience. In this research this is the Wairarapa Moana Heritage Trail.

The trail can be reached via the Wairarapa Line (Masterton - Wellington) rail route, as well as by road, making it accessible for cyclists (see fig. 6.01). In addition to providing another cycle route, the trail creates a strong connector to the existing cycleways.

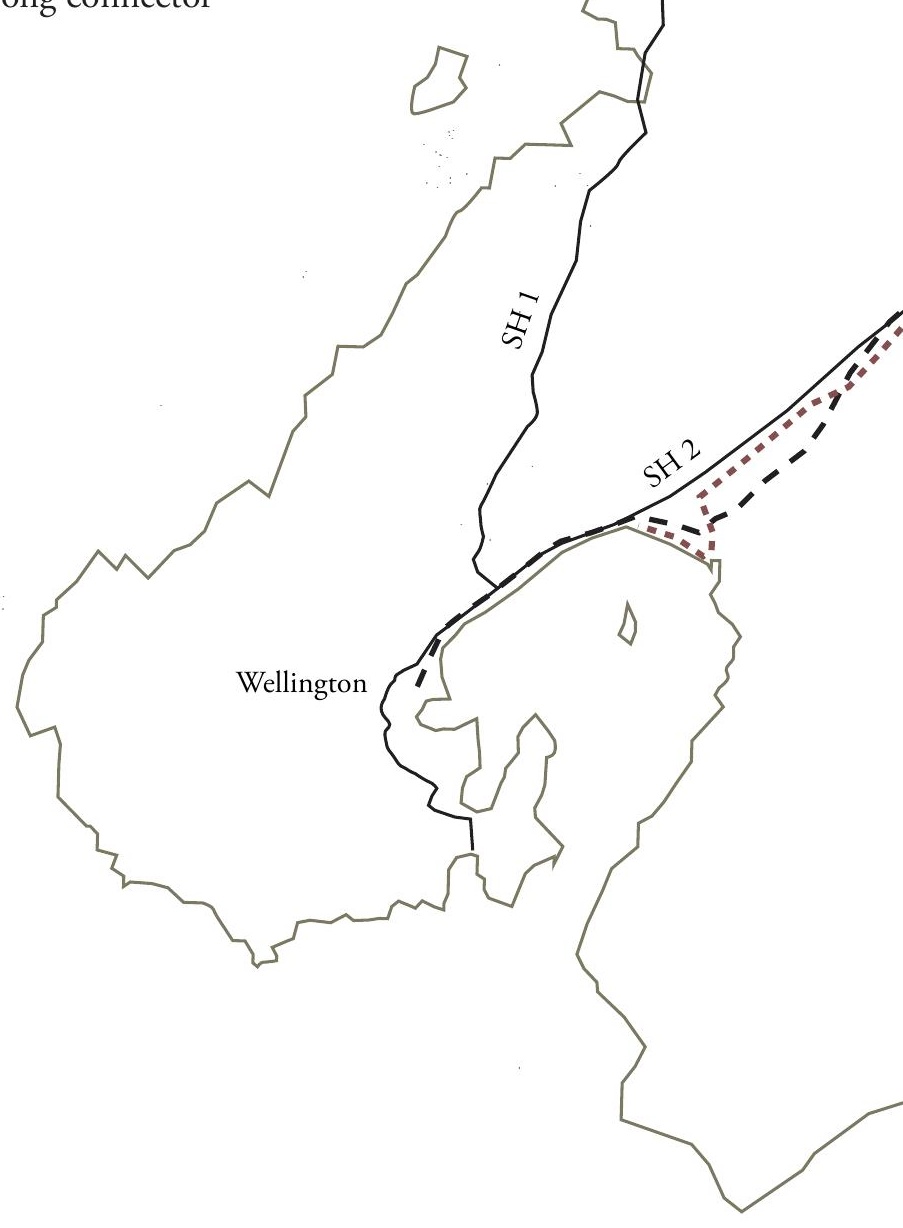

TRANSPORT CONNECTIONS TO TRAIL

Wairarapa Moana Heritage Trail

road

- - - rail

------ Rimutaka Cycle Trail

Wairarapa Valley Cycleway

Fig. 6.01. Transport Connections to the Wairarapa Moana Heritage Trail. 


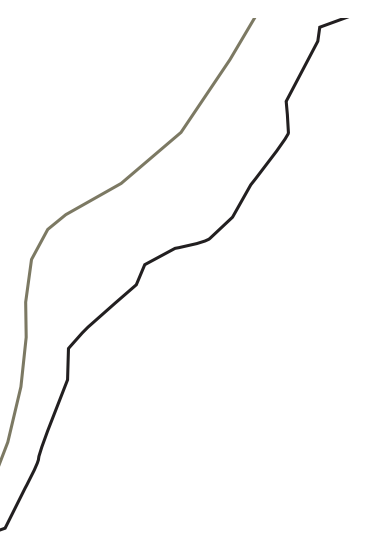




\section{The Trail Markers}

A marker makes you look differently at a space, shows there is significance there and space becomes place. Some of the revealed sites have only a marker as there is nowhere to park a car and the site can be seen from the road. Corten steel was chosen as the material for the markers due to its readily aged appearance, as it is already present on the trail in the Lake Domain sign (see fig. 6.14) and as rusting steel is present in the landscape with many farms having old machinery on site. The markers will have the necklace motif cut into the top which connects back to the initial hunch and shows the site is part of a greater whole. The initials WMHT, for Wairarapa Moana Heritage Trail, will be cut into the steel. Stainless steel numbers will be fixed to either side of the marker so they can be viewed from both directions (see figs. 6.02 - 6.04). The exact location of the markers will be determined after discussions between the designer and stake holders.

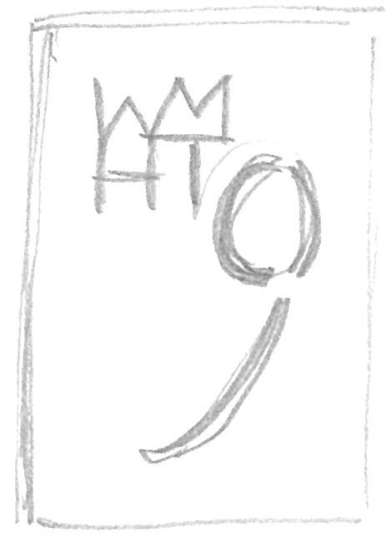

Fig. 6.02. Initial sketch for the trail marker. 


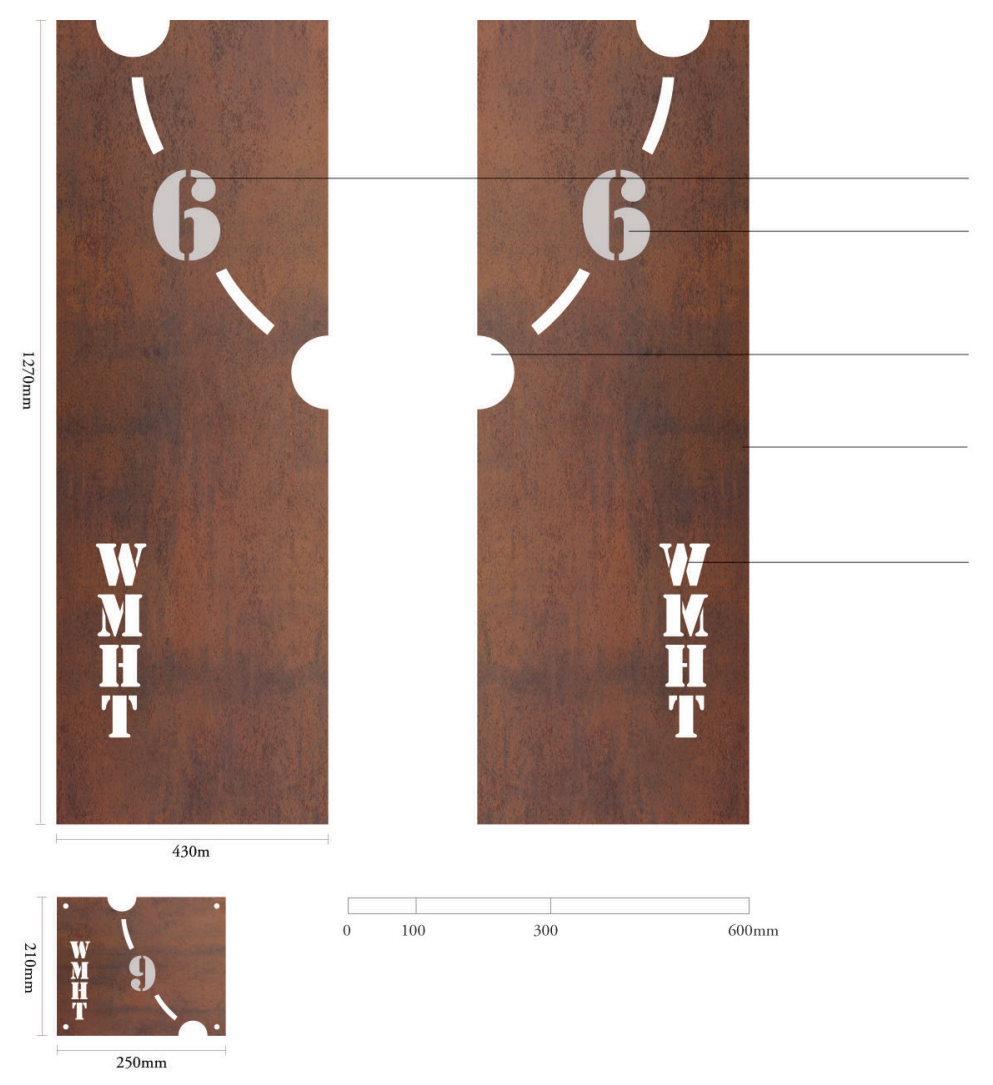

site numbers are fixed to either side of the marker so they are legible; they are made of stainless steel and fixed with stainless steel rivets as this is compatible with corten steel and better able to withstand the coastal environment

the landscape can be seen through the cut outs integrating the sign and the landscape

$8 \mathrm{~mm}$ corten steel

the initials of the trail name are in a single column so as to be legible from either side

Fig. 6.03. Above, the corten steel trail markers for the uninterpreted sites, below, the markers that will be fixed to existing signs - their size may alter depending on the existing sign.

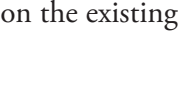

Fig. 6.04. Construction details for the large trail markers: vertical section through marker, bottom left, horizontal section.

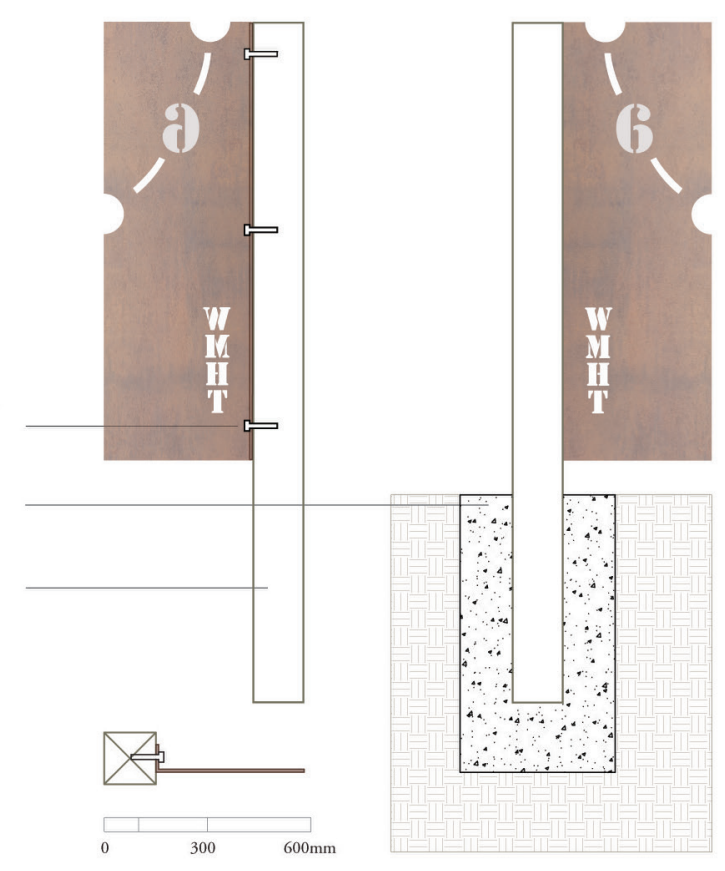


Featherston

2. Wairarapa Lake Domain (Wairarapa Moana Wetlands Park)

3. Featherston Military Training Camp site

4. Kaiwaiwai Hall, via Camp Rd

5. Historic homesteads + marine sediments

6. Bidwill Green, Kahutara

7. Kahutara Dunes

8. $\quad$ Boggy Pond \& Matthews Wildlife Reserve (WMWP)

9. Wairio Block (WMWP)

10. Native swamp forest remnants

11. Burnside Church

12. Kohunui Marae

13. Nga Rākau Pūrākau - Raho Ruru Pa

14. Lake Onoke, at Lake Ferry (WMWP)

15. Okorewa Kāinga Waka Tētē

16. Barrage Gates

17.

18.

19.

20.

21.

Kakahimakatea (Battery Hill) Pa

Pounui Lagoon (WMWP)

Lake Onoke, Beach Road, and Onoke Spit (WMWP)

Wharekauhau Road Viewpoint

Waiorongomai Church

Wairarapa Lake Shore Scenic Reserve (WMWP)

Cross Creek, Rimutaka Incline Rail

Trail Historic Area

24.

Tipapaku (Pigeon Bush) Picnic Area

Wairarapa Fault Viewpoint

Featherston Cemetery

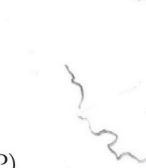

$$
\text { ২. }
$$
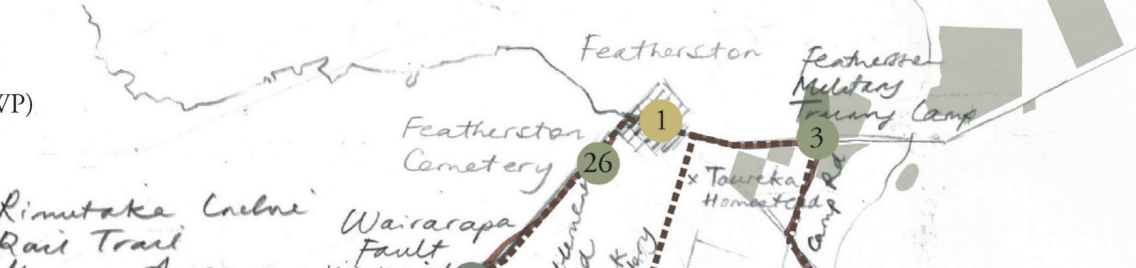

Rimutate Cnclne Wairarapa
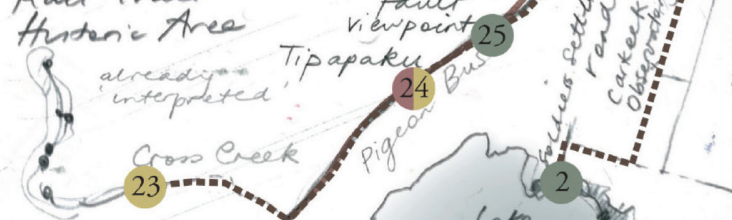

Longwer
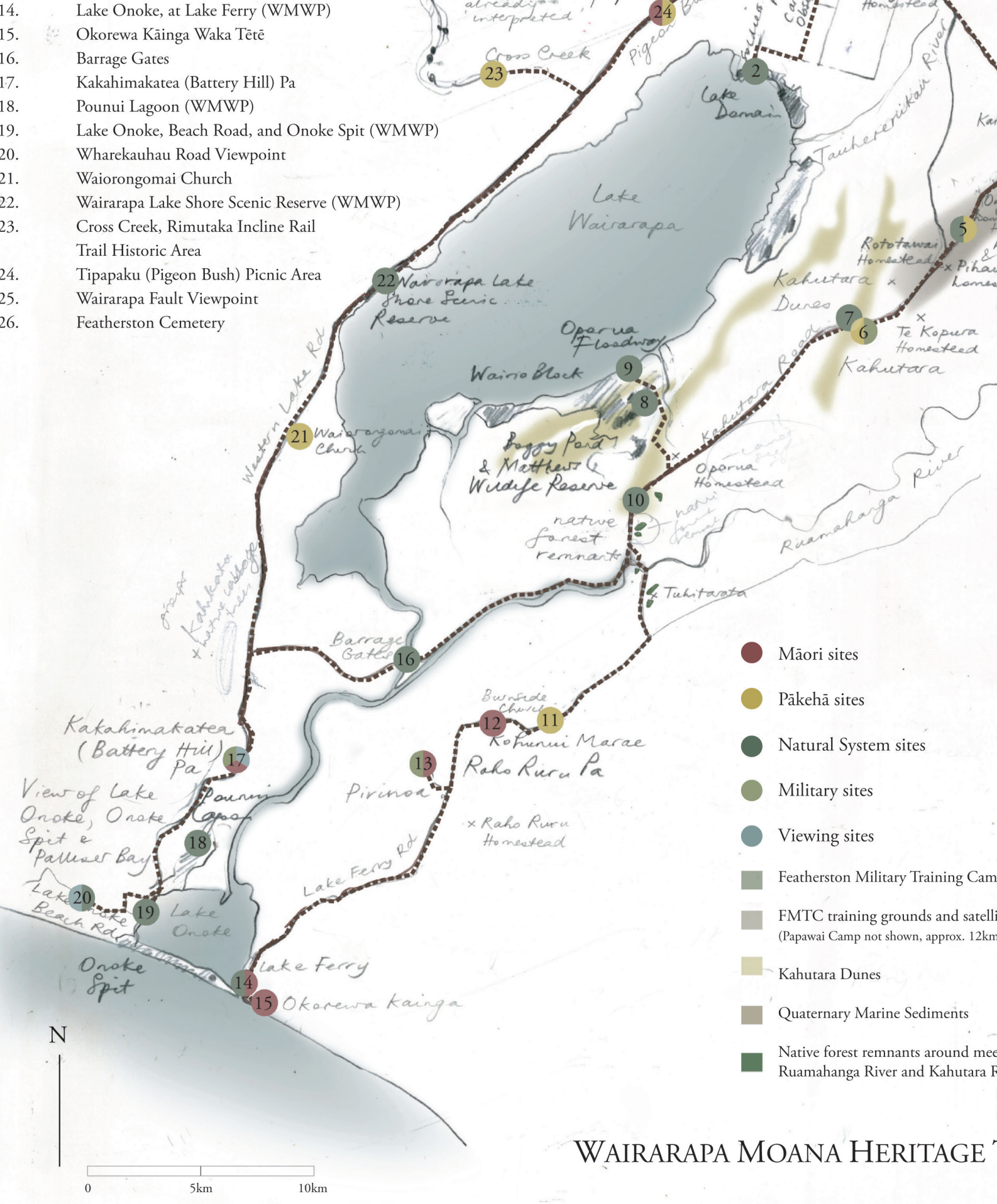

WAIRARAPA MOANA HERITAGE TRAIL

Fig. 6.05. The final Wairarapa Moana Heritage Trail map. 


\section{Wairarapa Moana Heritage Trail}

Of the twenty six trail sites most are already revealed, named or marked in some way and eleven are unmarked (see fig. 6.05). Research into how to reveal these sites has seen three different approaches used. The first approach is that sites with spaces, and which are considered primary sites (see table 3.01), have had their essence intensified and become places, for example, Bidwill Green and Nga Rākau Pūrākau - Raho Ruru Pa. (The full plant list for these sites is in Appendix F.) The second sees two sites which have objects designed for them that are directly related to the landscape, Okorewa Käinga Waka Tètē and the Wairarapa Fault Viewpoint. The significance of the rest of the sites is shown with a numbered marker. The sites that are already revealed or named will have a smaller version of the marker fixed to their existing sign.

For some sites the images on the following pages will be the first time they appear in this document. This is to replicate in the reader the sense of discovery the researcher experienced and will also be replicated in the journey of those using the actual trail. 


\section{Featherston}
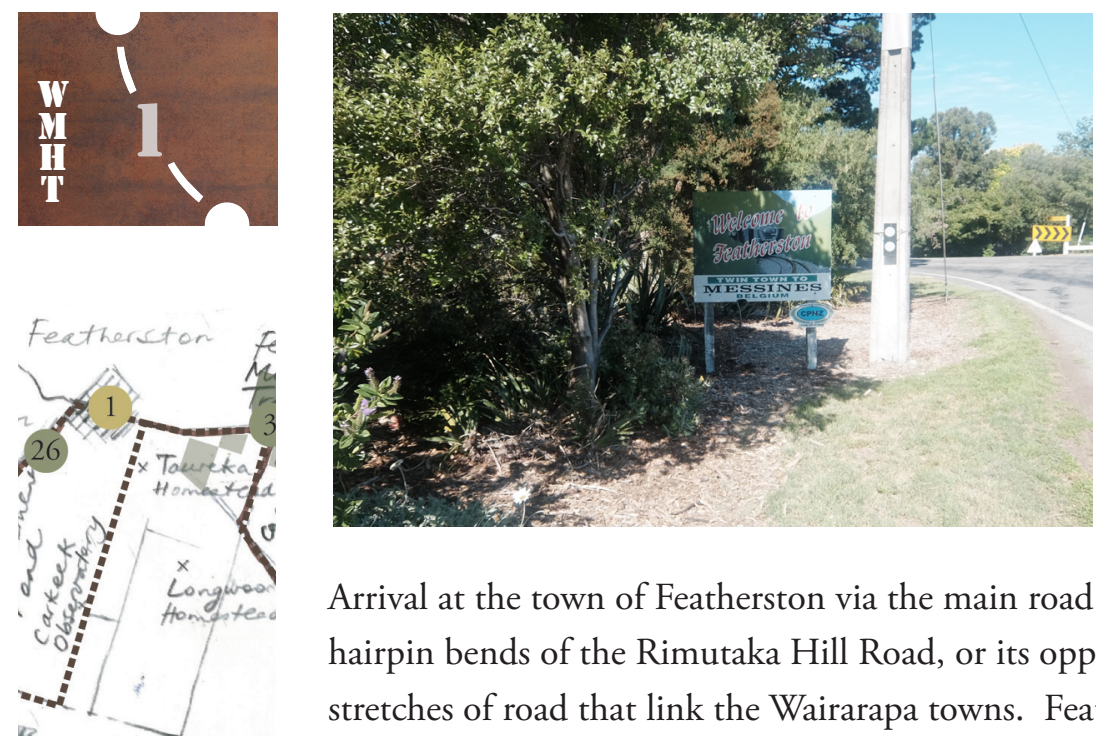

Fig. 6.06. The sign greeting visitors entering Featherston from the east.

Arrival at the town of Featherston via the main road is preceded either by the hairpin bends of the Rimutaka Hill Road, or its opposite, the long straight stretches of road that link the Wairarapa towns. Featherston sits at the very foot of the Rimutaka Range, its situation due to the need of nineteenth century travelers from Wellington for rest and sustenance.

Featherston does not have a 'welcome to Featherston' sign at the western entrance to the town. The sign at the eastern entrance is old, unattractive, too close to a concrete pole and partly hidden (see fig. 6.06). New signs are planned by the community and are much needed at both ends of the town to create a more positive first impression for visitors.

Fig. 6.07. Marker and location on Trail Map for Site No. 1. 


\section{Wairarapa Moana Lake Domain Reserve (WMWP)}

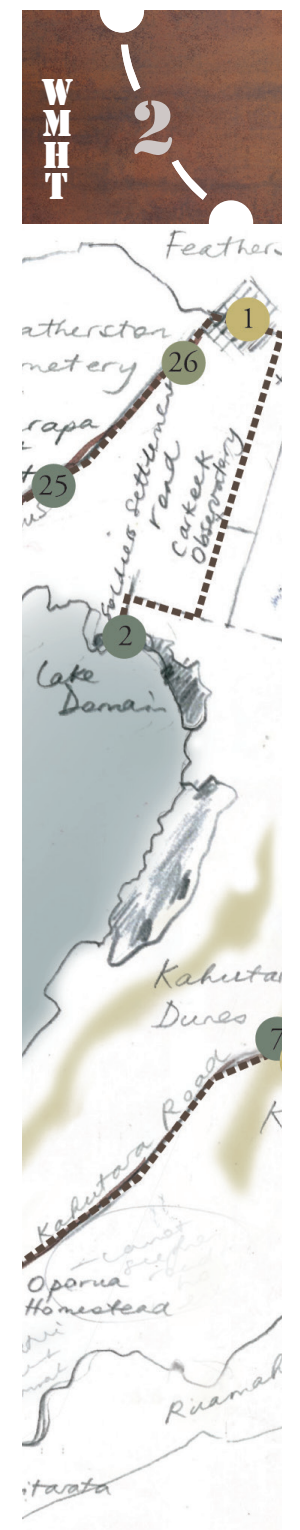

Fig. 6.09. Marker and location on Trail Map for Site No. 2.

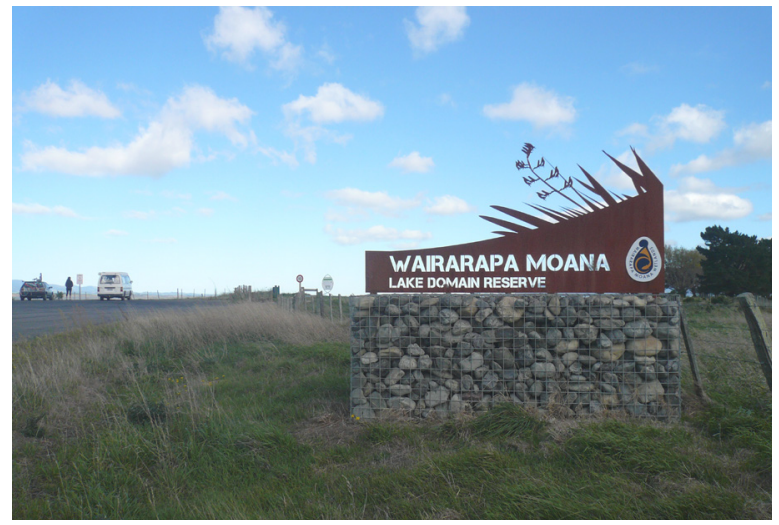

Fig. 6.08. The corten steel sign announcing arrival at site 2 .

Just outside Featherston's eastern edge the aptly name Boundary Road points in the direction of the unseen lake. Crossing SH53 the road becomes Murphys Line and continues arrow straight through farmland parallel to the Rimutaka Range. The Aorangi Range becomes visible to the east and one gets the sense for the first time of being in a place between, held by, the ranges. A right turn onto Lake Domain Road and then left onto Soldiers Settlement Road leads down to Lake Domain Reserve. The wide expanse of the water is suddenly revealed when almost at the lake. Just beyond the sign shown in figure 6.08 the road ends abruptly in a carpark, which is close to the lake edge and facing south, towards the unseen coast (see fig 6.10).

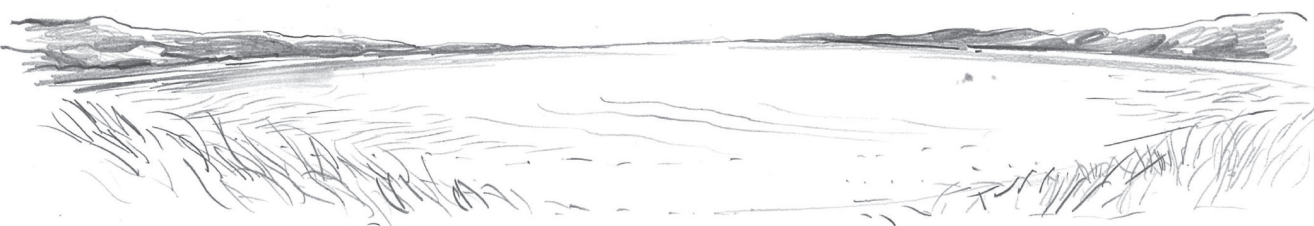

Fig. 6.10. Lake Wairarapa looking south, flanked by the Aorangi and Rimutaka Ranges. 


\section{Featherston Military Training Camp site}
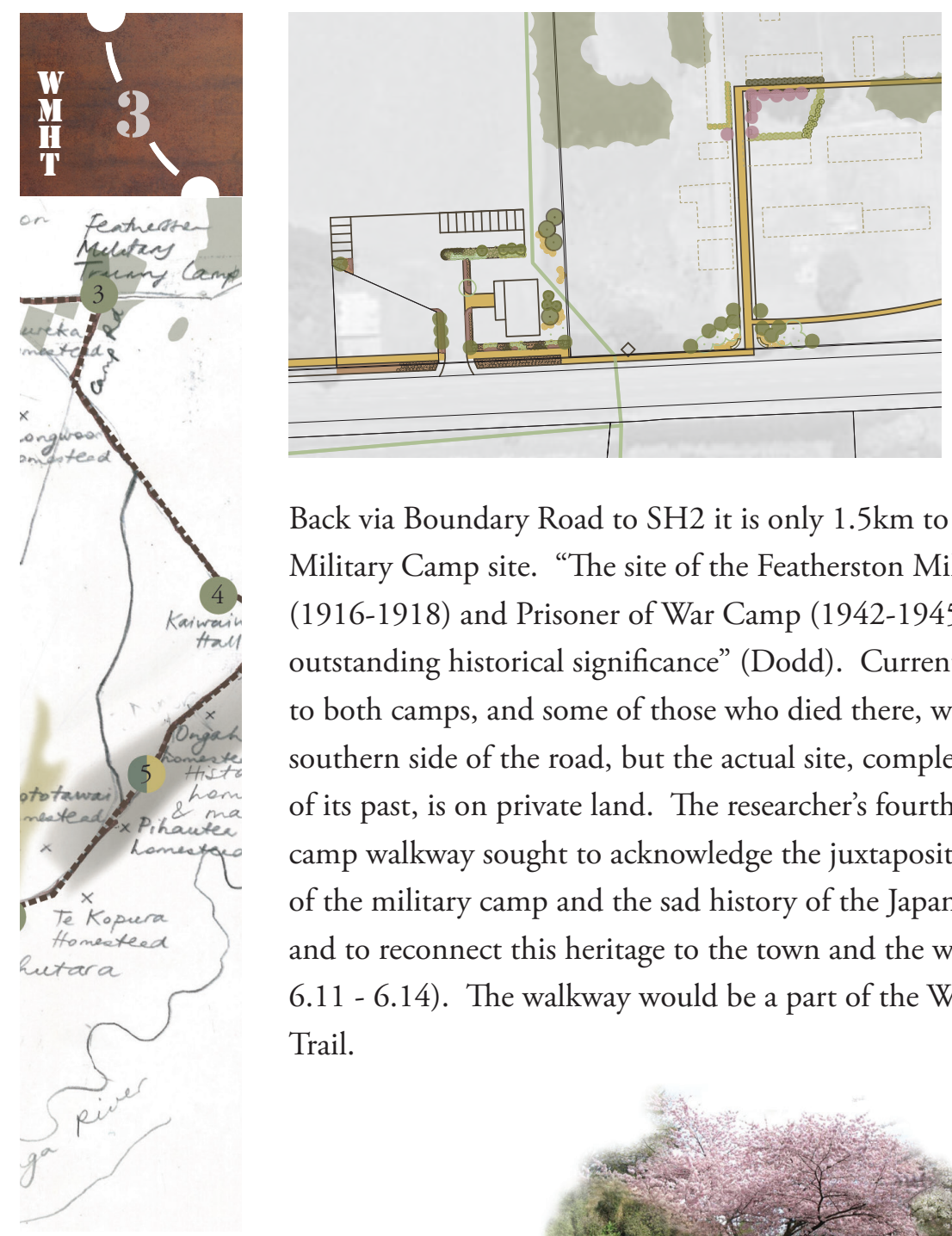

Fig. 6.11. The plan for the visitors' centre, entrance and gathering area.

Back via Boundary Road to $\mathrm{SH} 2$ it is only $1.5 \mathrm{~km}$ to the Featherston Military Camp site. "The site of the Featherston Military Training Camp (1916-1918) and Prisoner of War Camp (1942-1945) in the Wairarapa is of outstanding historical significance" (Dodd). Currently there are memorials to both camps, and some of those who died there, within a rest area on the southern side of the road, but the actual site, complete with many remnants of its past, is on private land. The researcher's fourth year project for the camp walkway sought to acknowledge the juxtaposition of the proud history of the military camp and the sad history of the Japanese prisoner of war camp and to reconnect this heritage to the town and the wider public (see figs. 6.11 - 6.14). The walkway would be a part of the Wairarapa Moana Heritage Trail.

Fig. 6.12. Marker and location on Trail Map for Site No. 3.

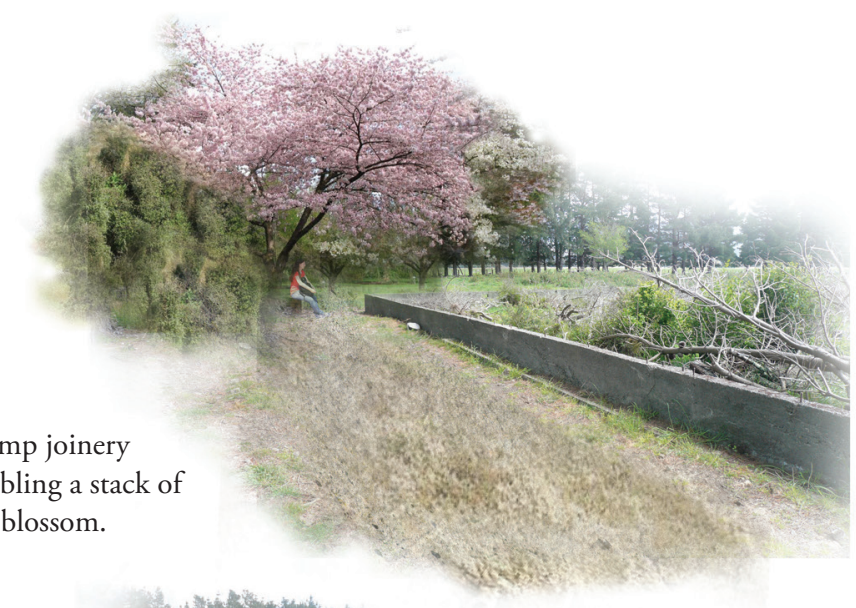

Fig. 6.13. The World War II POW camp joinery workshop is marked with a seat resembling a stack of timber and planting including cherry blossom.

Fig. 6.14. The rifle range is screened from view by divaricating coprosma species, which also frame the view once the corten seat is reached.

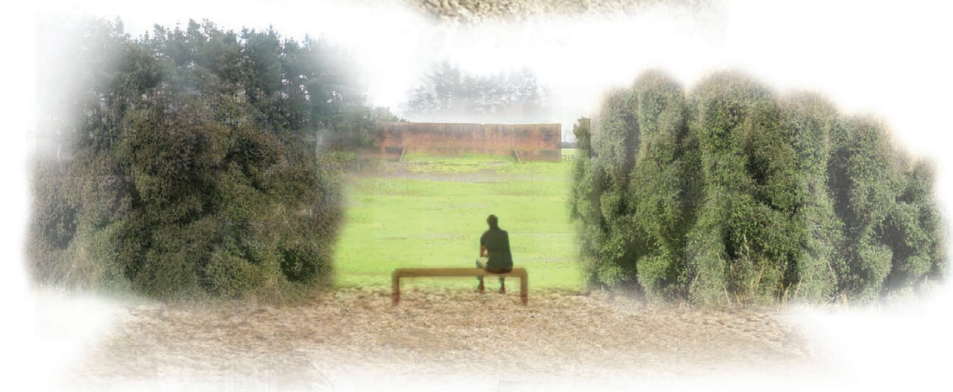




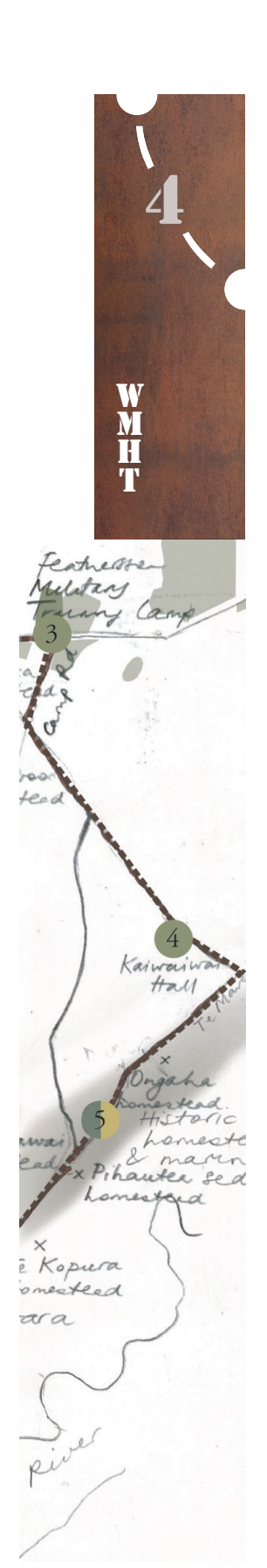

Kaiwaiwai Hall, via Camp Rd
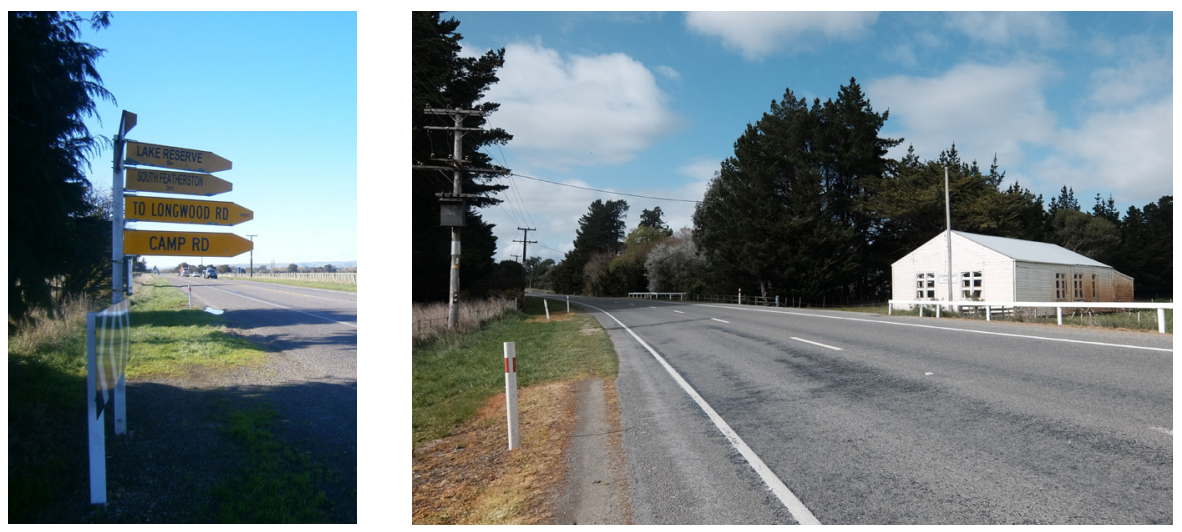

Fig. 6.15. The Camp Road sign on $\mathrm{SH} 2$.

Fig. 6.16. Kaiwaiwai Hall on SH53.

Just east of the camp site along SH2 Camp Road heads south (see fig. 6.15), so named as it was within the military camp. The trail then joins SH53 which bends to cross Tauherenikau River, on its way to feed into Lake Wairarapa. At the end of a straight stretch of road, with a backdrop of macrocarpa shelter belt, sits Kaiwaiwai Hall (see fig. 6.16). The now unused hall, once part of the Soldiers' Club at the military camp, was moved when the camp closed, like many other redundant buildings, to its current site in 1921.

Fig. 6.17. Marker and location on Trail Map for Site No. 4. 


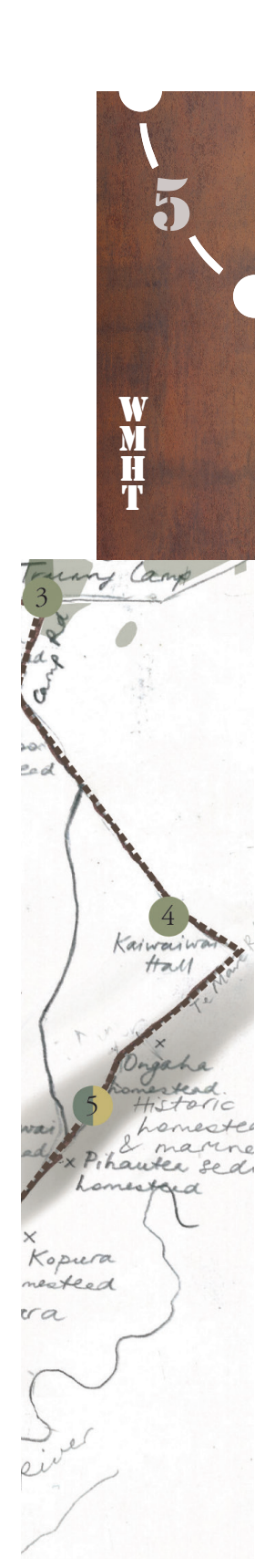

Fig. 6.20. Marker and location on Trail Map for Site No. 5.

\section{Marine sediments + historic homesteads}

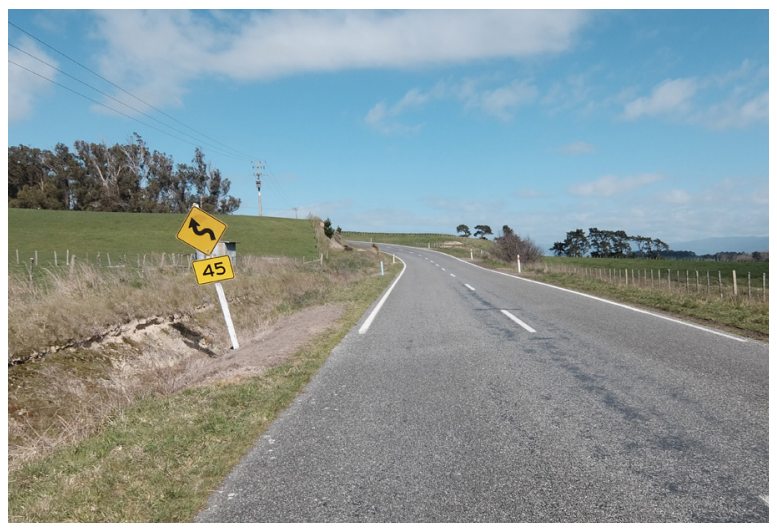

Fig. 6.18. Te Maire Road rises up onto the marine sediment terrace.

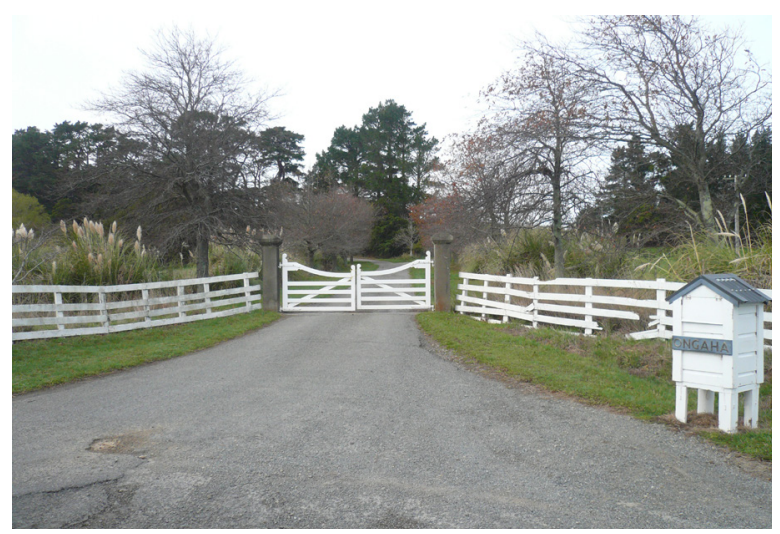

Fig. 6.19. Ongaha Station is the first the trail passes with an historic homestead.

After Kaiwaiwai Hall the road turns sharply and heads towards gently sloping hills. The trail turns right onto Te Maire Road and aligns itself with the low hills for $3 \mathrm{~km}$ before rising up onto them (see fig. 6.18). These low hills are marine sediments which form a terrace in the landscape, a reminder of when the sea came up as far as Carterton. A series of historic homesteads, built by early Pākehā settlers, sit along this high ground safe from the floodwaters of Lake Wairarapa and the Ruamahanga and Tauherenikau rivers. The undulating road passes intriguing gateways (see fig. 6.19) and there are often glimpses through the trees of grand houses. 


\section{Bidwill Green, Kahutara}

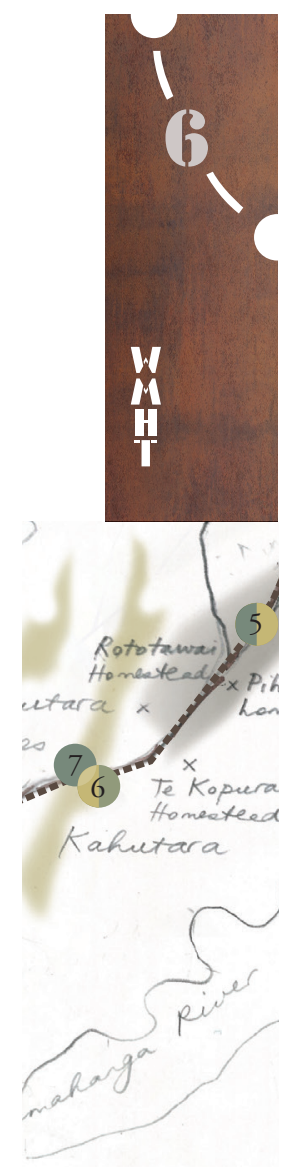

Fig. 6.21. Marker and location on Trail Map for Site No. 6.
At the bottom of the gentle slope descending from the marine terrace sits the small settlement of Kahutara. Gathered together, with a handful of houses, on land donated to the community by William Bidwill (son of C. R. Bidwill, the first Pākehā settler west of the Ruamahanga River) are three heritage buildings, a school building, church and hall. Kahutara is sheltered from flooding due to the proximity of the Kahutara Dunes and the marine terrace. The road rises and turns on leaving the settlement to ascend the dunes. 
In this design the aim is to increase the sense of gathering that the landscape has facilitated (see figs. $6.22-6.34)$. The hedge wraps around Bidwill Green as the dunes wrap around Kahutara. The planting in the Green is of native and endemic plants and flowering shrubs grown in Victorian times (see figs. 6.24 and 6.25). (The plant list for the whole trail is in Appendix E.) The new name Bidwill Green acknowledges William Bidwill's gift of the land and the gathering possible in a village green. The repetition of kämahi at the corner of Bidwill Green and in front of the church, pruning, additional hedging, and the extension of gravel areas, will accentuate the gathering together and enable views of the historic school building (see fig. 6.22). Brief text about each building is routered into the seating close to the hall (see figs. 6.29 - 6.34) as images are routered into the posts of the Wairarapa Moana

Wetlands Park signs (see fig. 6.37). An exterior door in the hall was reinstated to open out onto the paved seating area (see fig. 6.27).

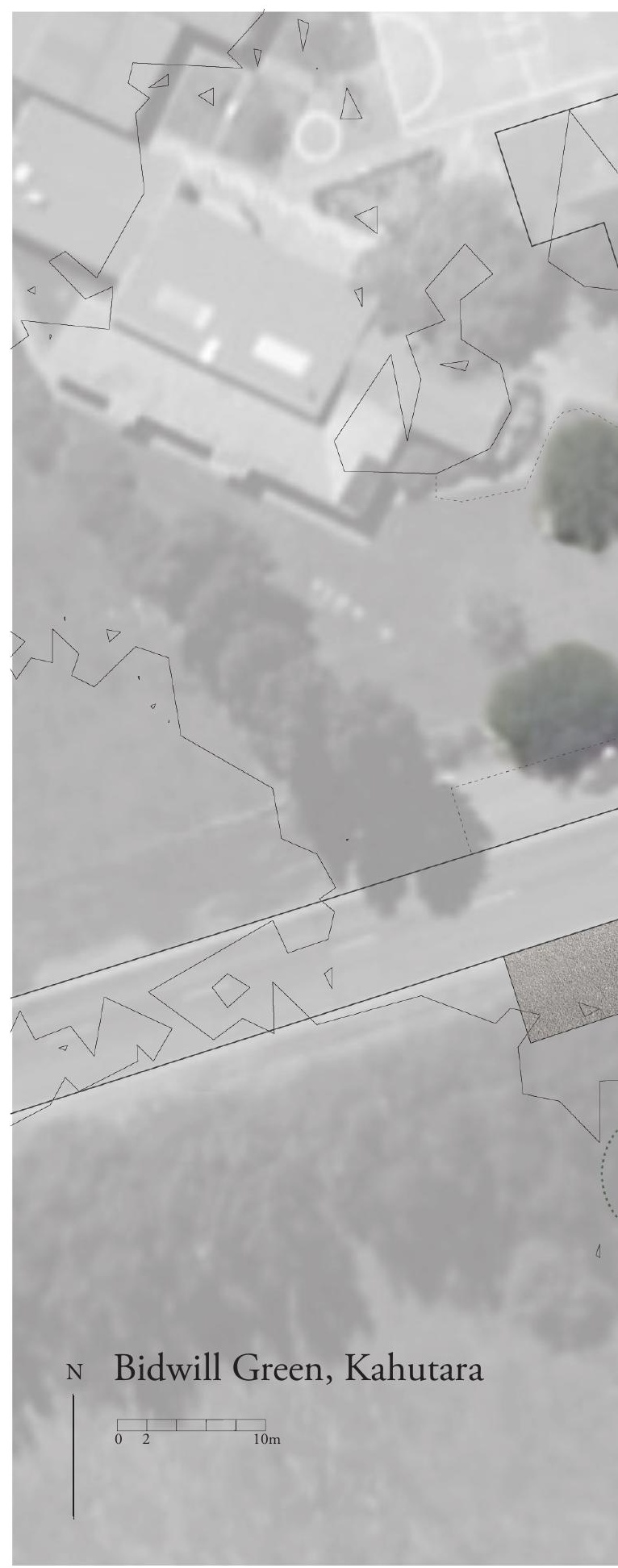

Fig. 6.22. Site Plan for Bidwill Green, Kahutara. 


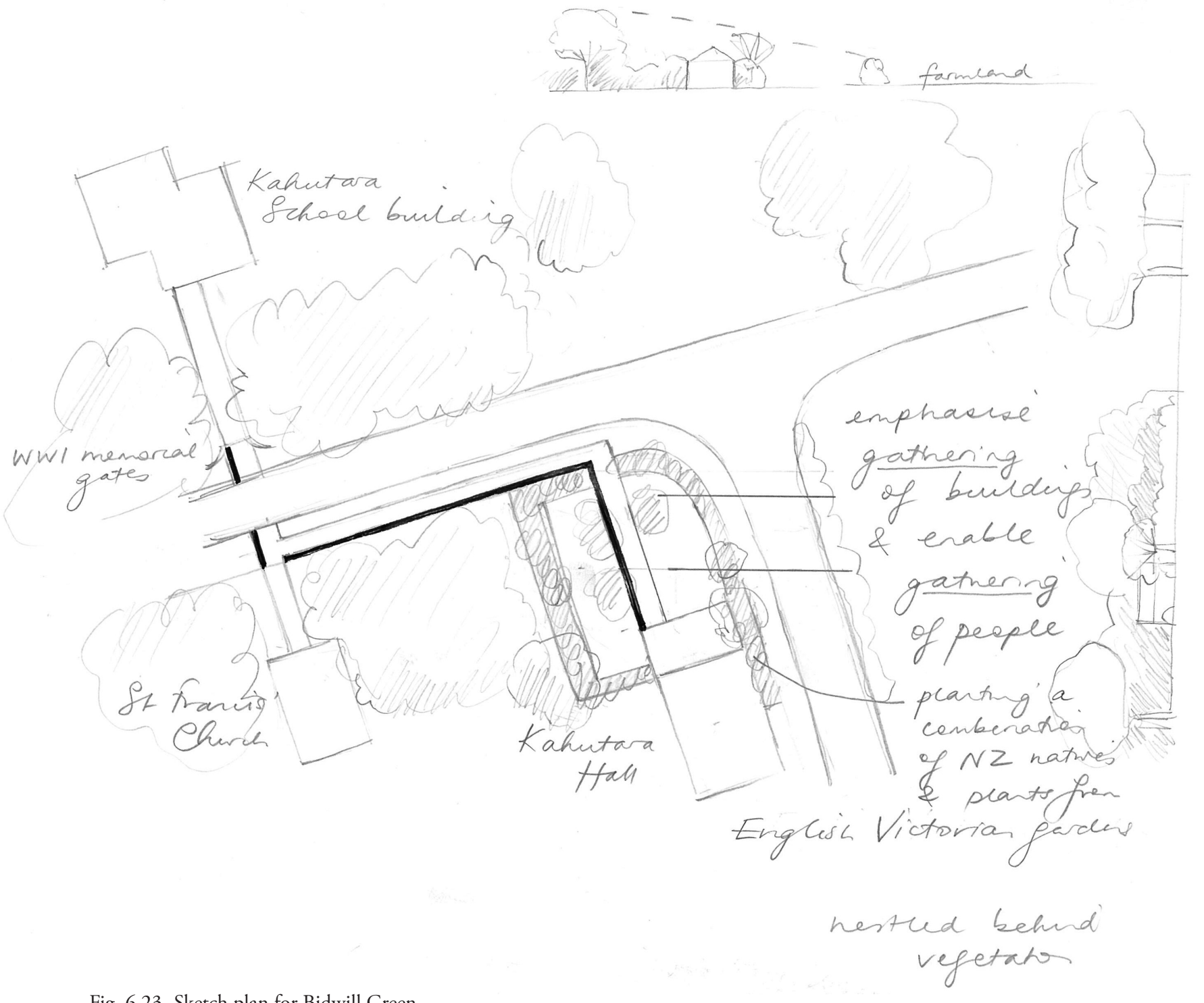

Fig. 6.23. Sketch plan for Bidwill Green.

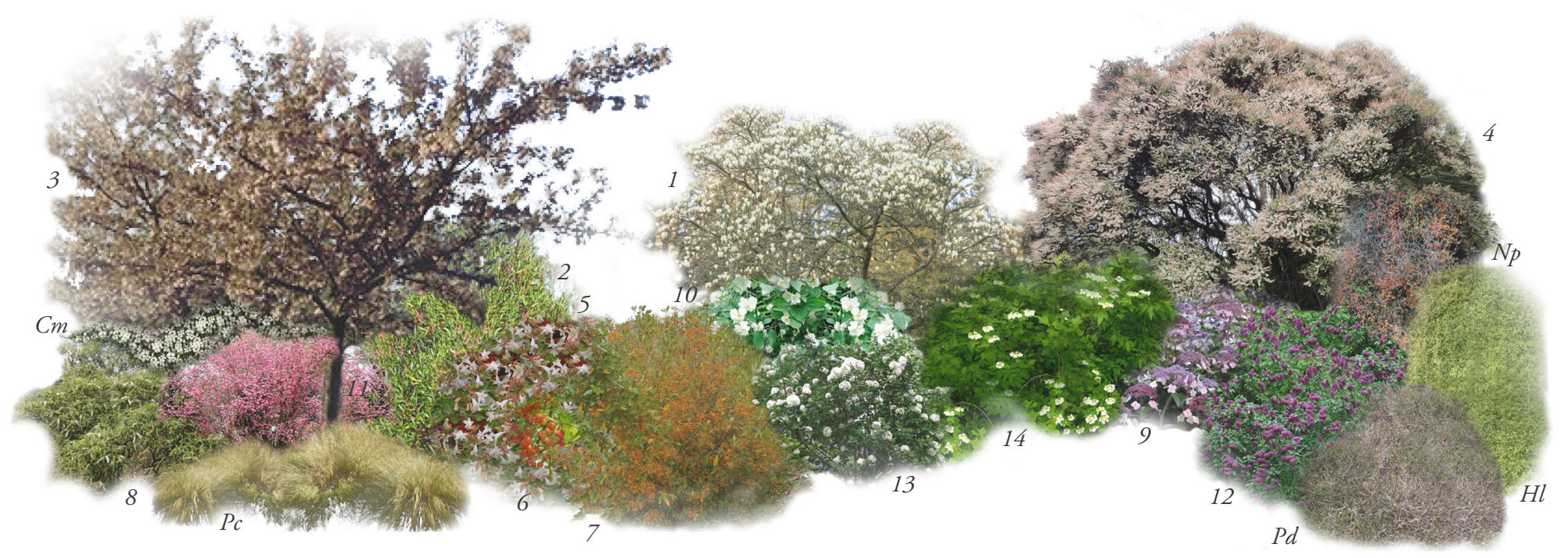

Fig. 6.24. Planting collage for Bidwill Green. 


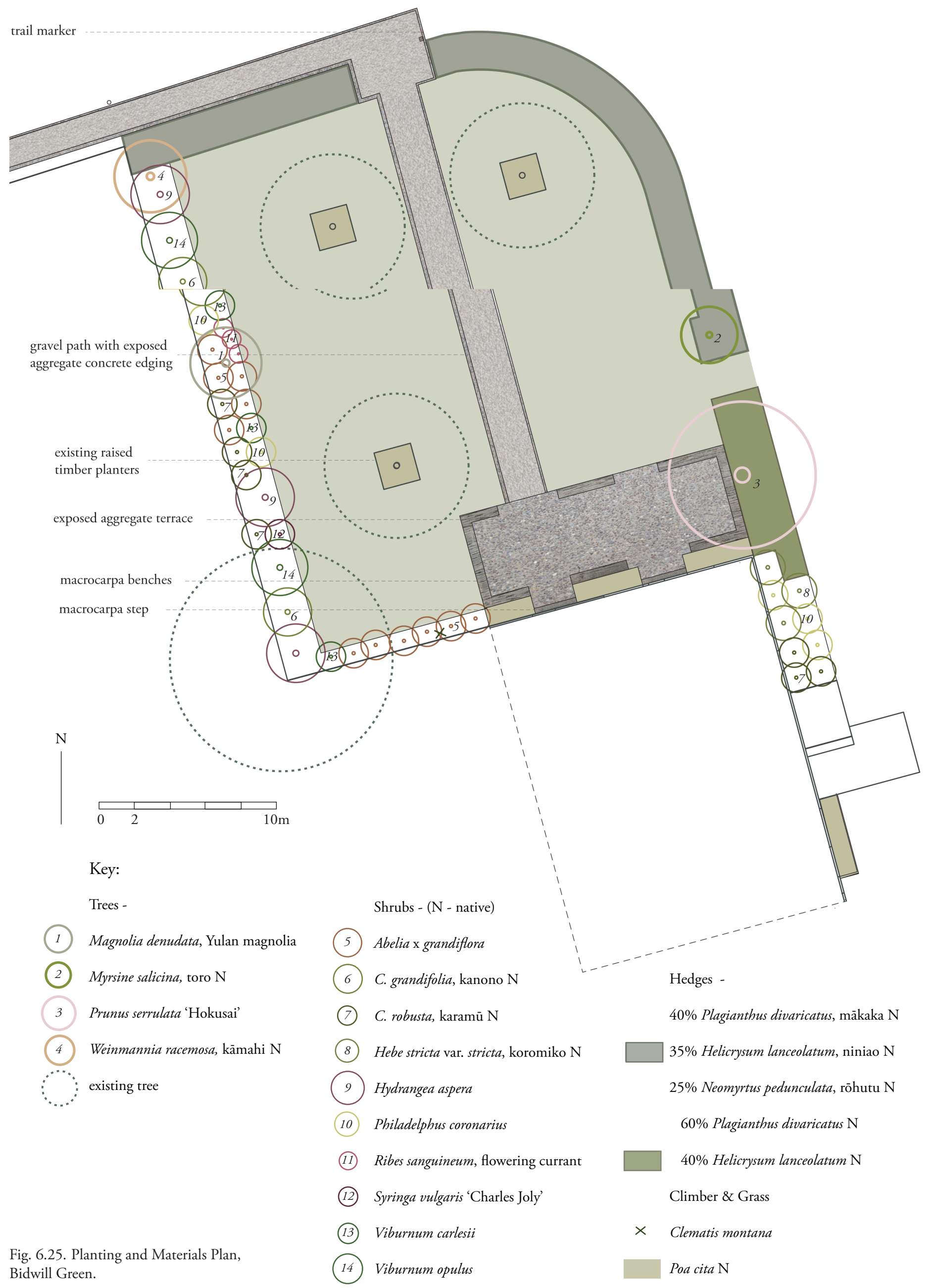




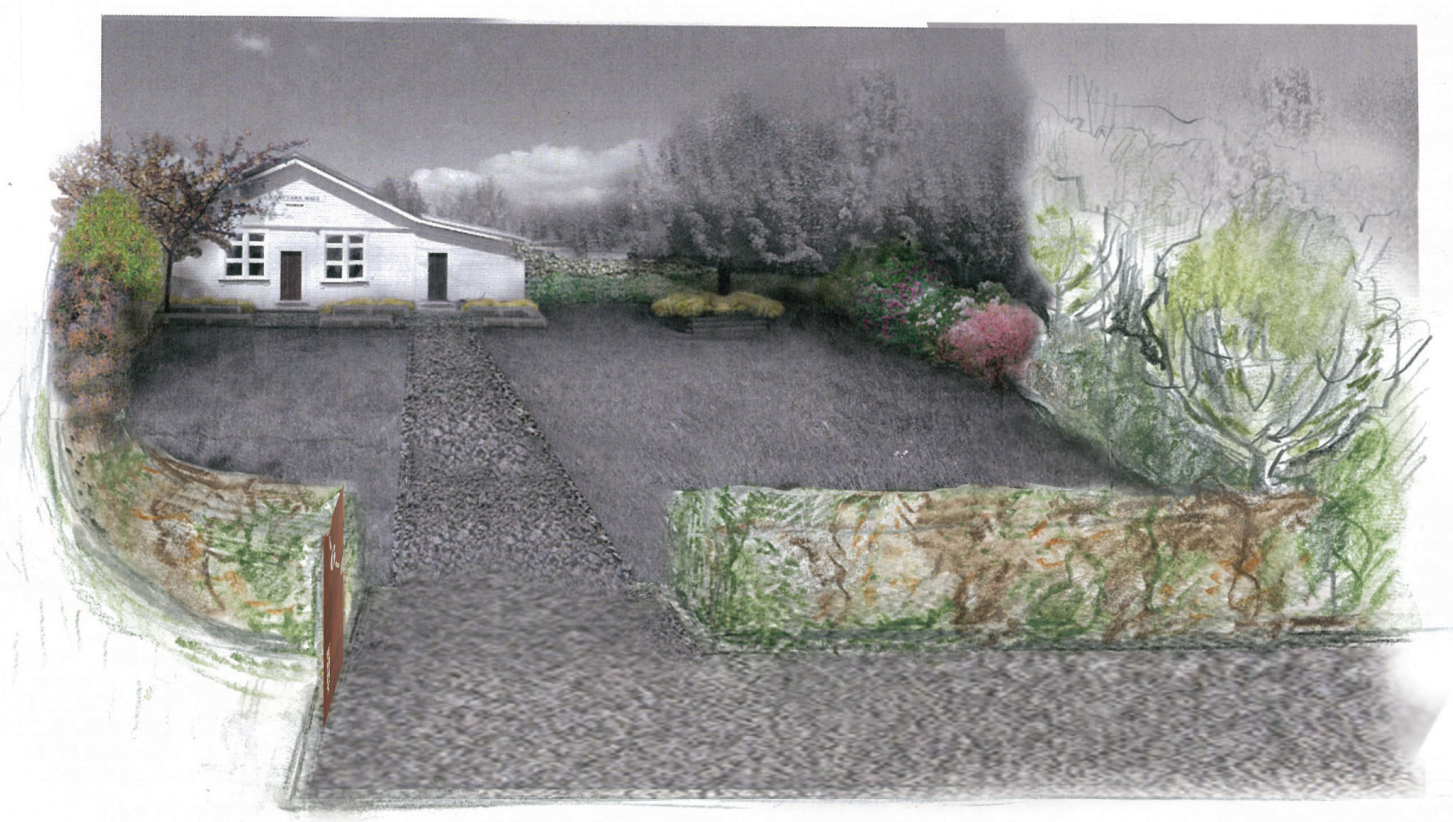

Fig. 6.26. The view of Bidwill Green from the road.

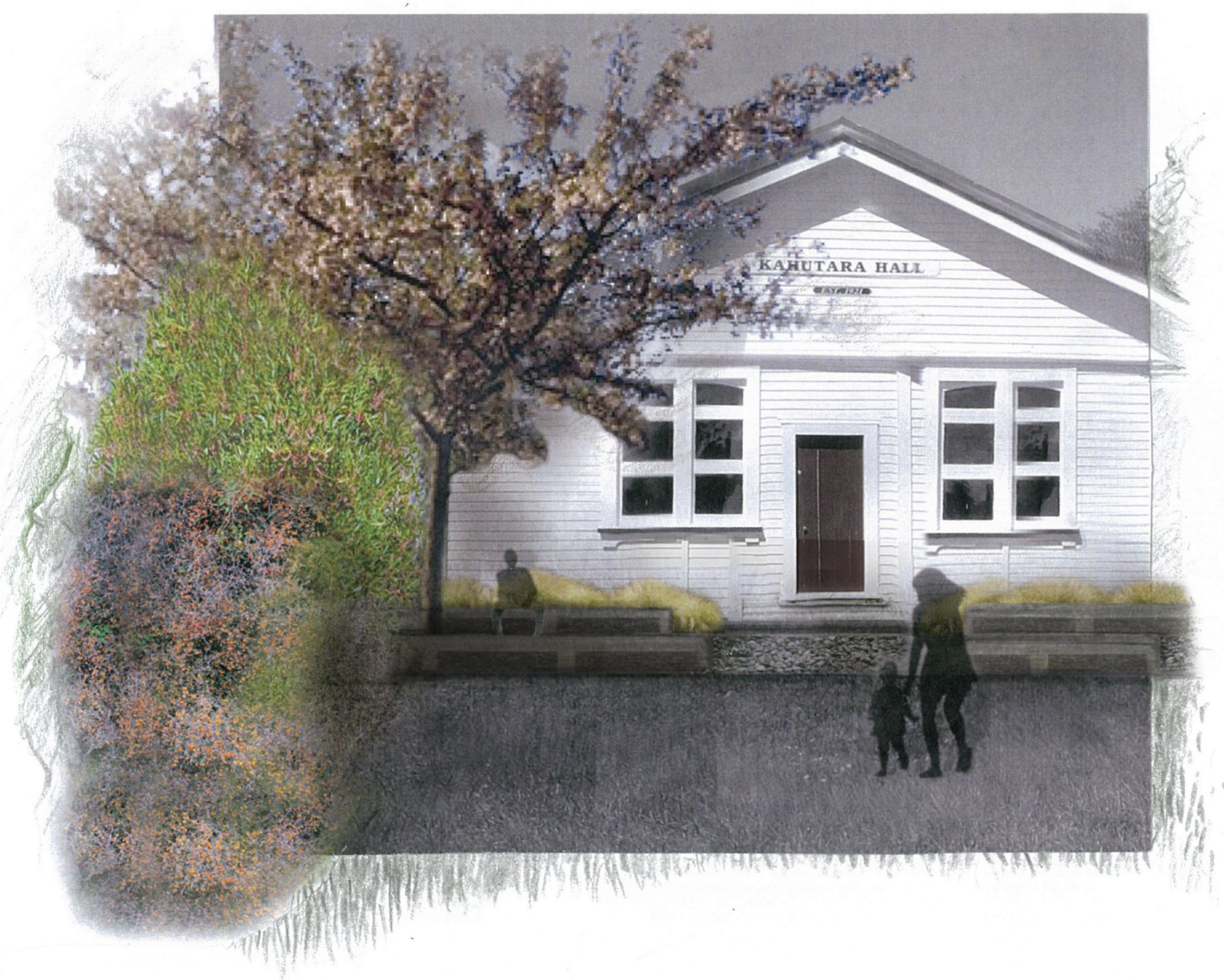

Fig. 6.27. The planting, paving and seating create a welcoming area. The Prunus serrulata 'Hokusai' echoes the cherry blossom planted as part of the Featherston Military Camp Walkway as the hall building was from the camp. 


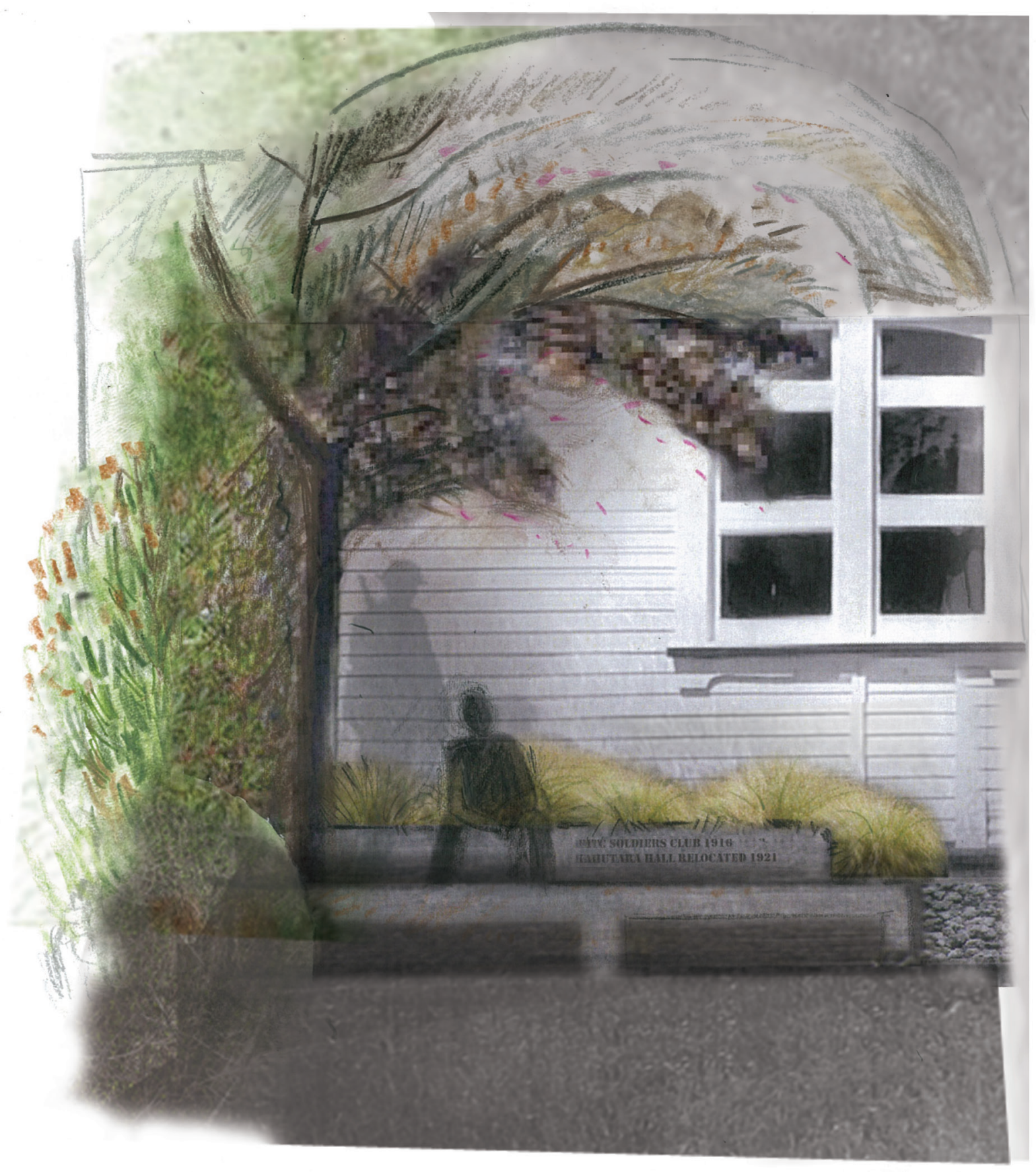

Fig. 6.28. The macrocarpa seat has text routered into it that remembers the past life of the hall. 


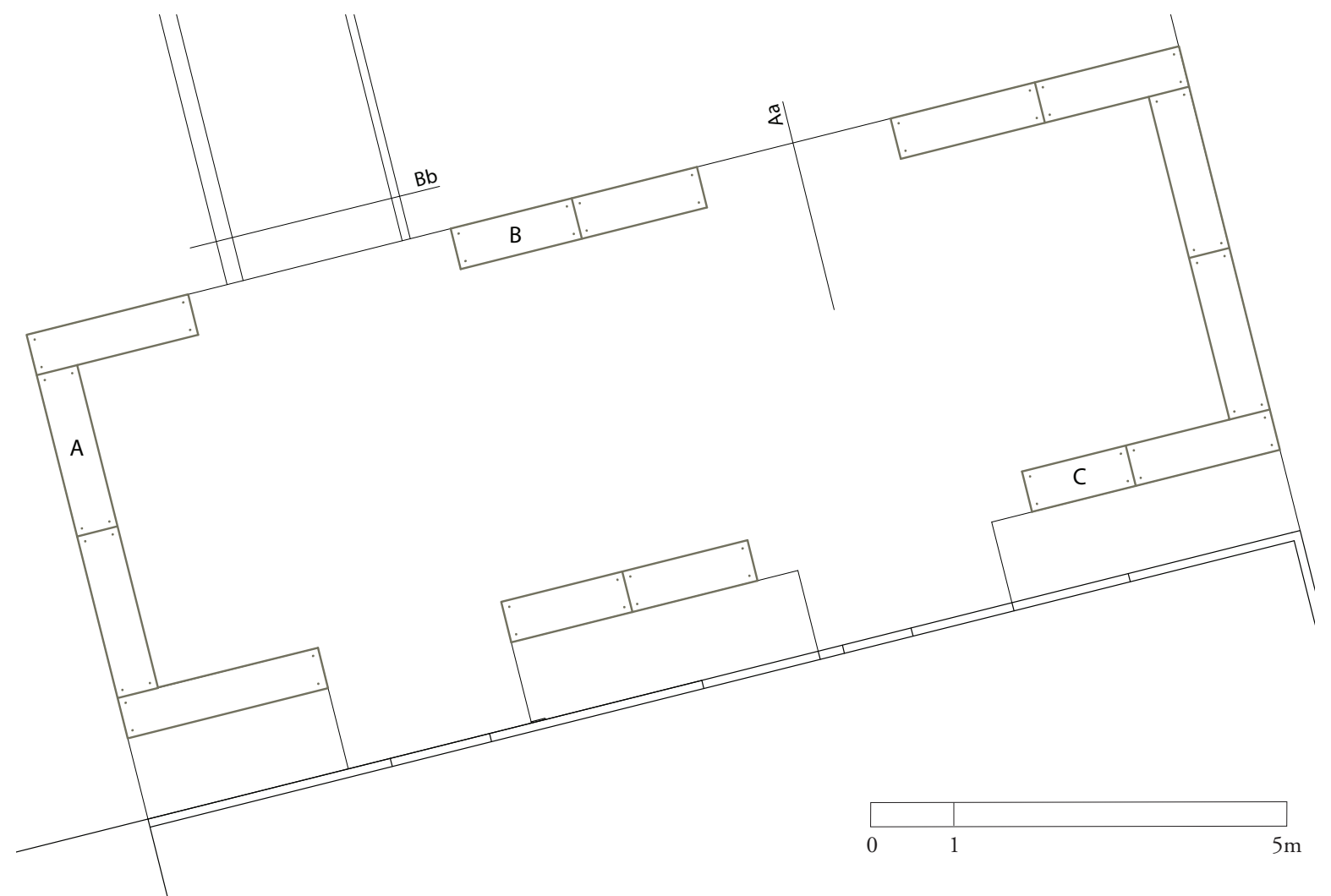

Fig. 6.29. Plan of Bidwill Green seating.

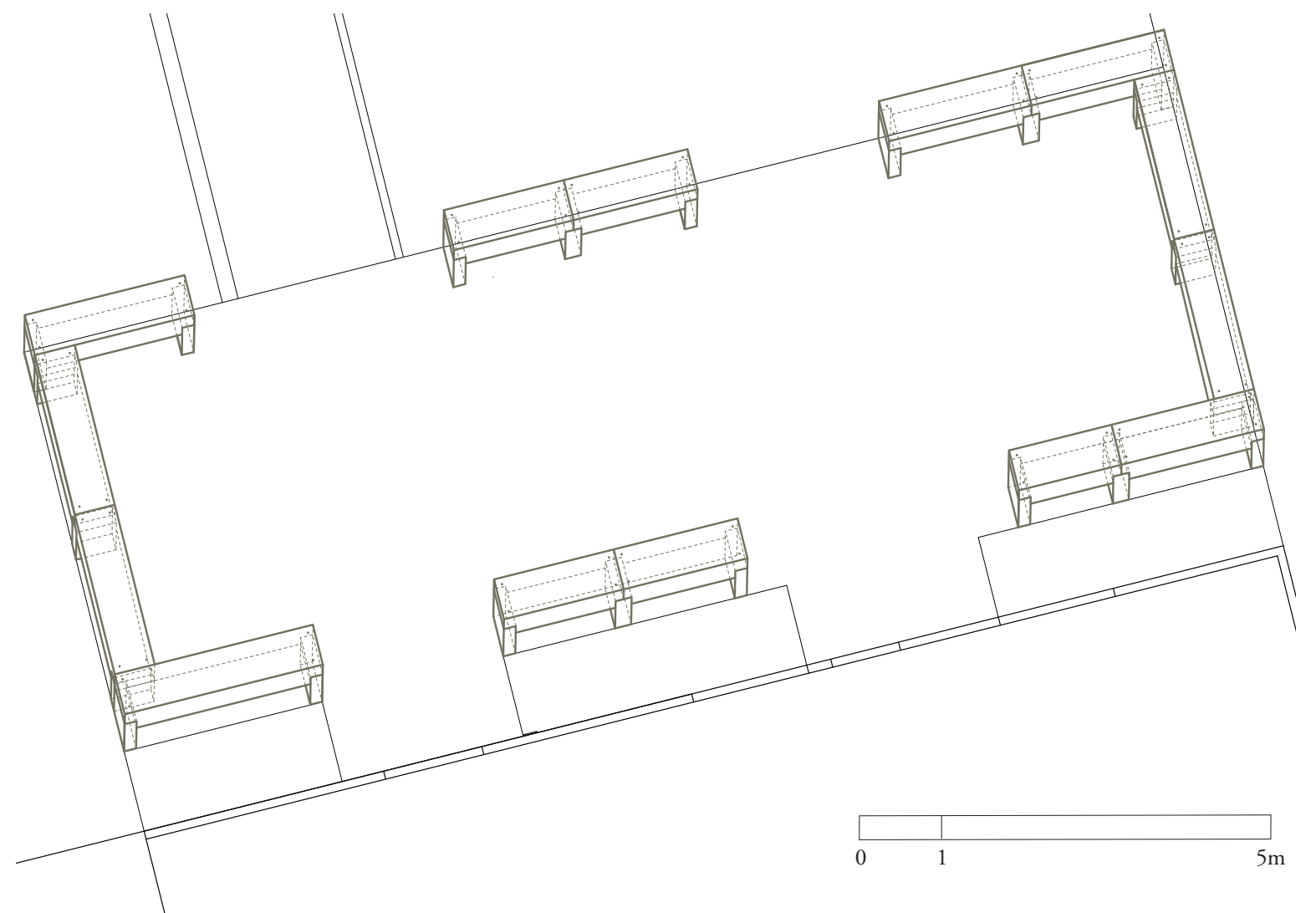

Fig. 6.30. 3D representation of Bidwill Green seating.

126 

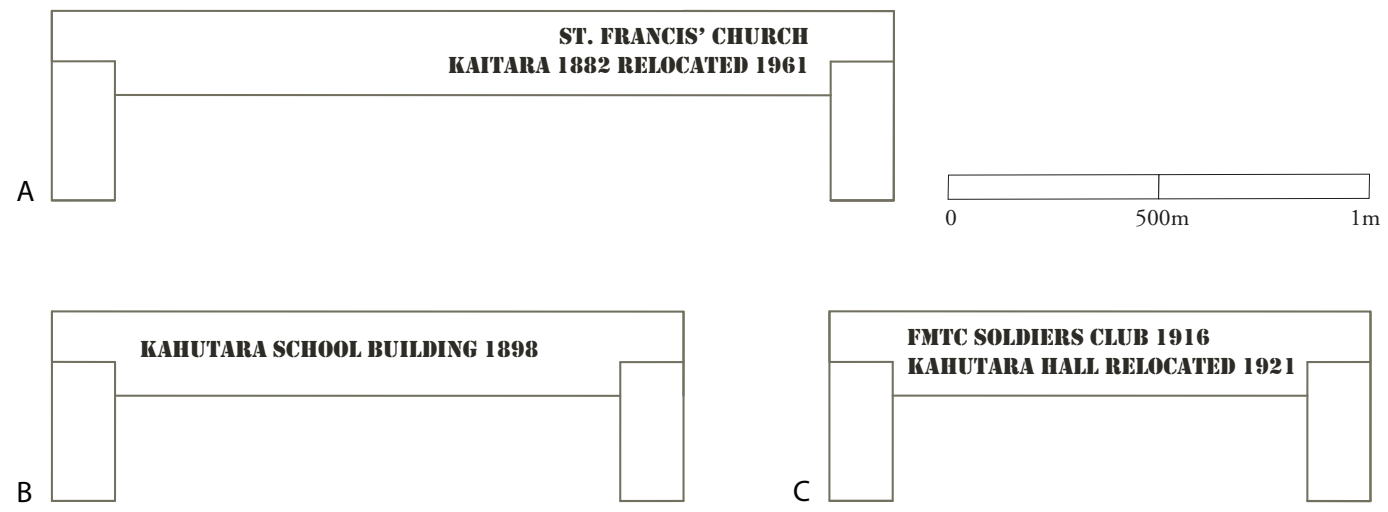

Fig. 6.31. The text routered onto the benches.

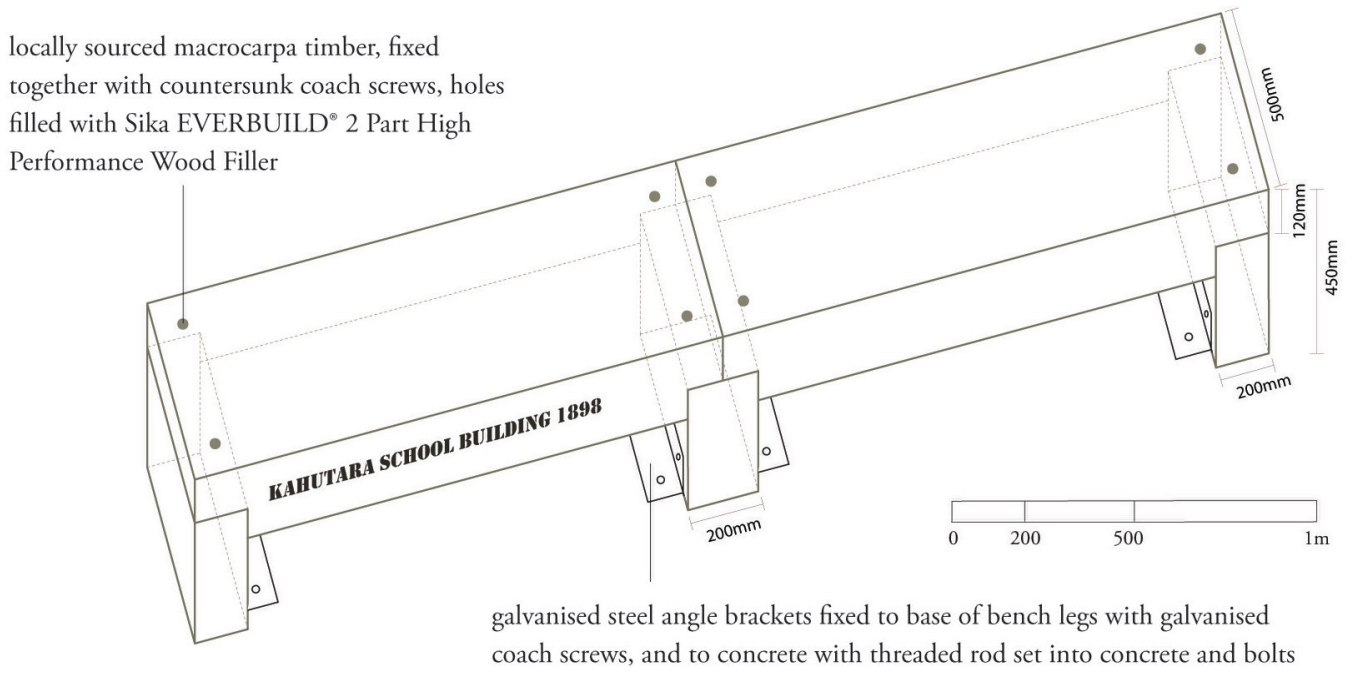

Fig. 6.32. 3D representation of Bench B. 


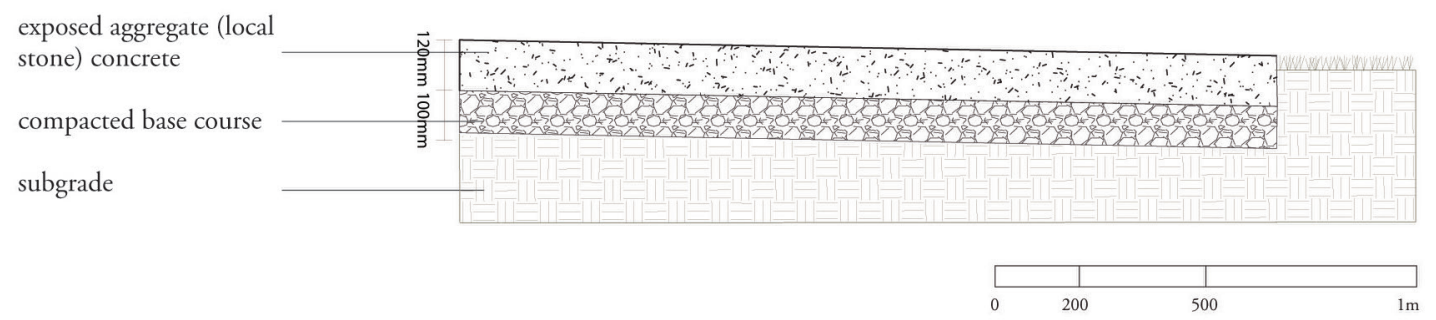

Fig. 6.33. Section Aa through concrete paving adjacent to Kahutara Hall.

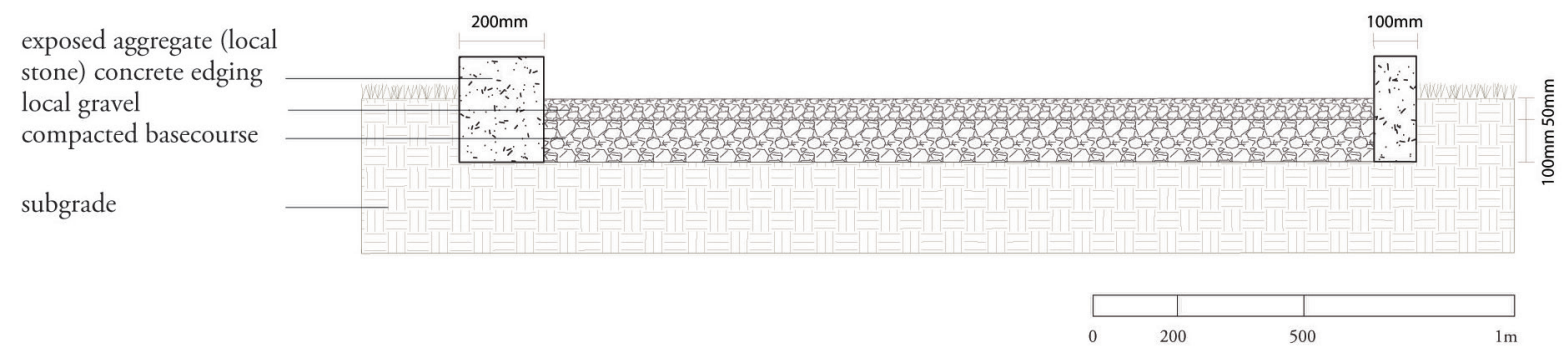

Fig. 6.34. Section $\mathrm{Bb}$ through path - the wider edging emphasises the link to the other two historic buildings. 


\section{Kahutara Dunes}

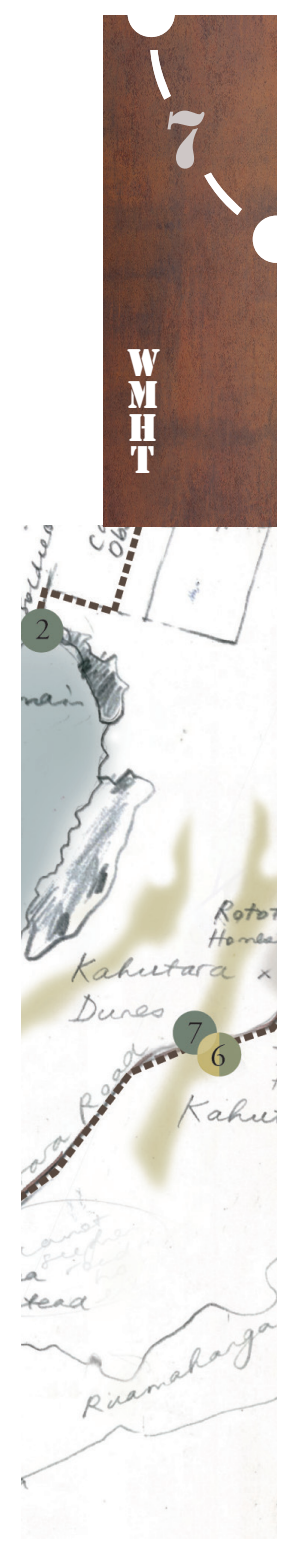

Fig. 6.35. Marker and location on Trail Map for Site No. 7.

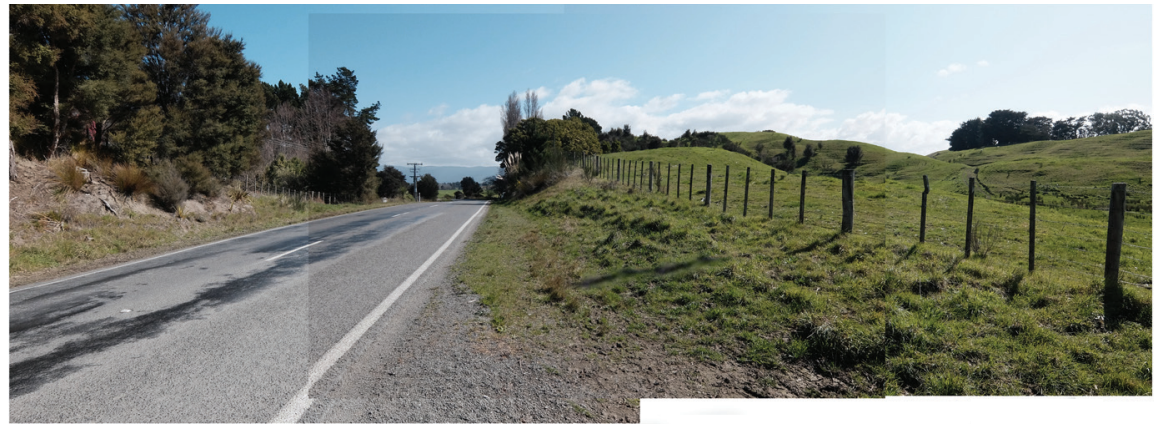

Fig. 6.36. Montage of the section of Kahutara Road passing across the dunes.

The road rises and turns on leaving Kahutara to ascend the dunes. A marker sits alongside the road atop the dune's crest (see fig. 6.36). These are aoelian dunes, formed by the wind blowing material from the lake to the west. Their sinuous form weaves through paddocks and continues to accompany the road before diminishing, resserting themselves close to the next site. 


\section{Boggy Pond (WMWP)}
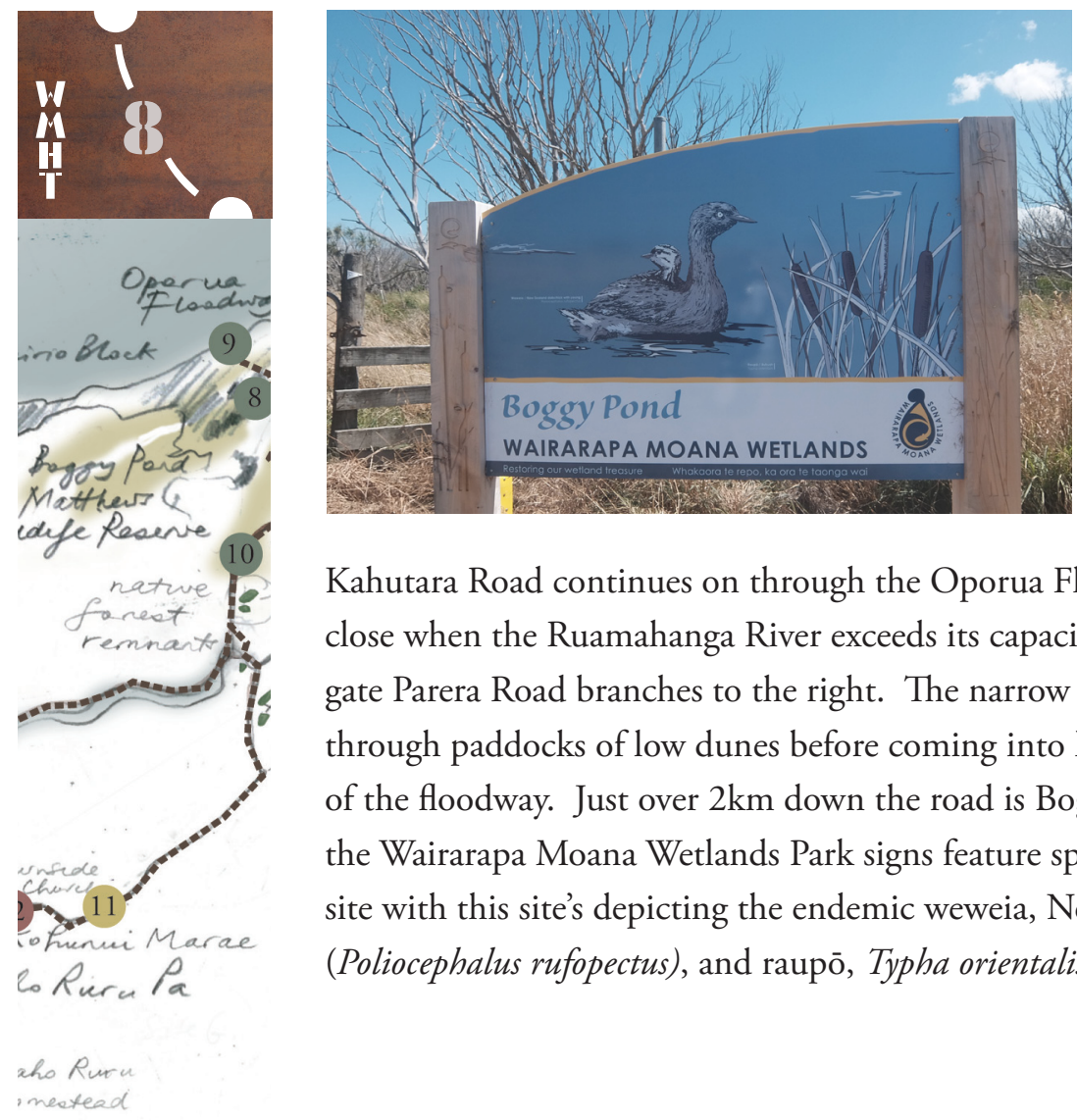

Fig. 6.37. The Boggy Pond sign features the dabchick and raupō.

Kahutara Road continues on through the Oporua Floodway gates, which close when the Ruamahanga River exceeds its capacity. Just past the south gate Parera Road branches to the right. The narrow gravel road winds through paddocks of low dunes before coming into line with the stopbanks of the floodway. Just over $2 \mathrm{~km}$ down the road is Boggy Pond. Each of the Wairarapa Moana Wetlands Park signs feature species significant to the site with this site's depicting the endemic weweia, New Zealand dabchick (Poliocephalus rufopectus), and raupō, Typha orientalis (see fig. 6.37).

\section{Wairio Block (WMWP)}

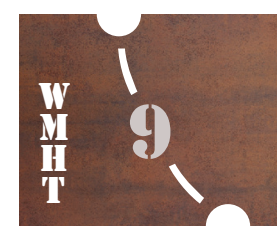

Fig. 6.38. Markers and location on Trail Map for Sites No. 8 and 9.

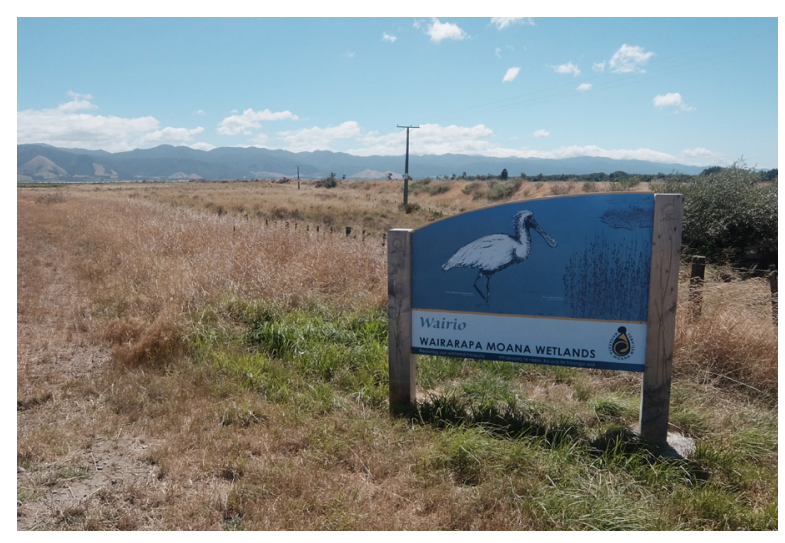

Fig. 6.39. The WMWP sign for Wairio displays the kōtukungutupapa and oioi.

Two hundred metres from Boggy Pond is the sign for Wairio (see fig. 6.39) depicting the kōtuku-ngutupapa, Royal spoonbill (Platalea regia) and oioi, jointed wire rush (Apodasmia similis). From here a walkway leads along the stopbank to the lake edge. 


\section{Native swamp forest remnants}
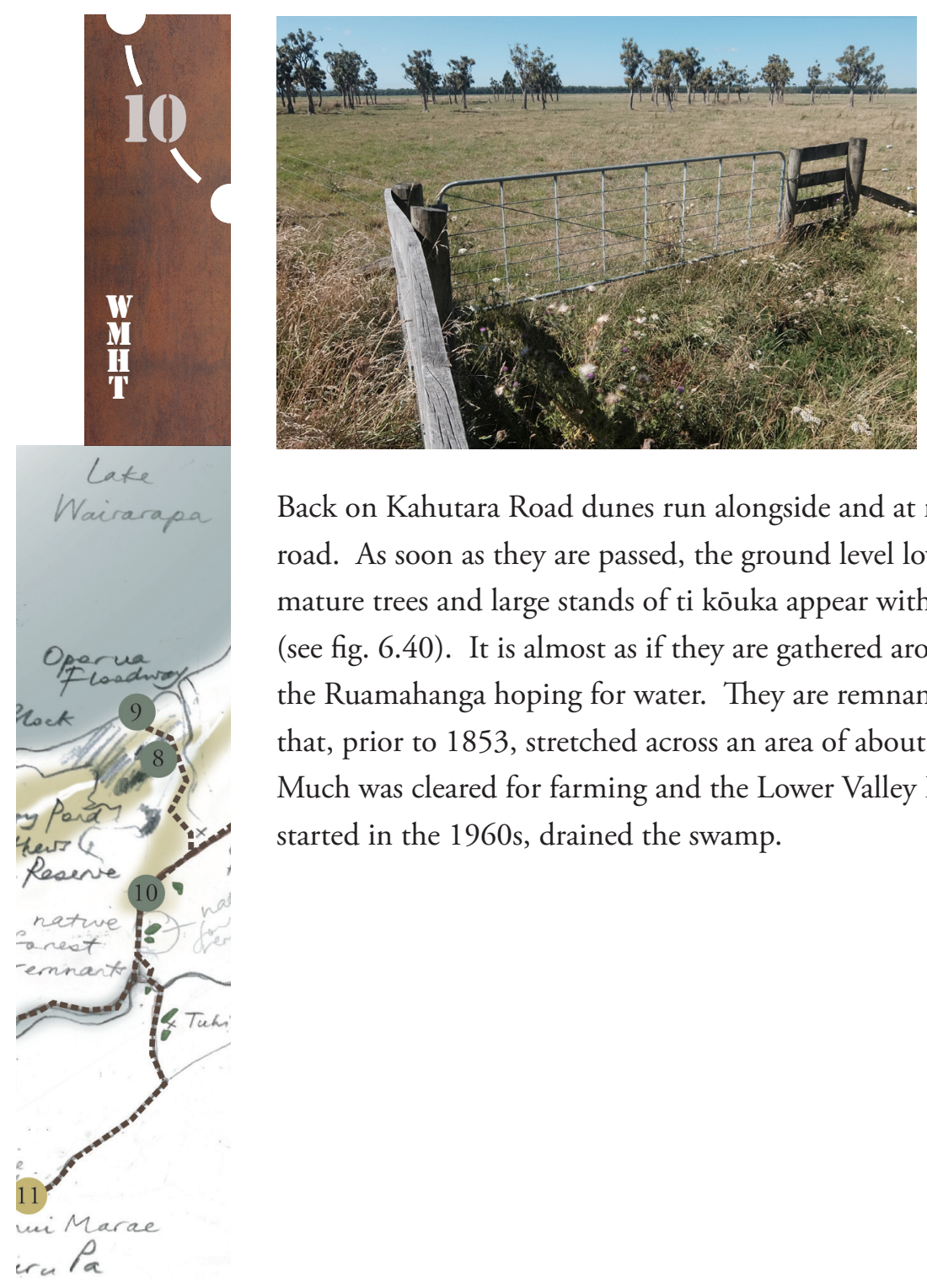

Fig. 6.40. A stand of ti kōuka or ti rākau, Cordyline australis, close to the bridge over the Ruamahanga River.

Back on Kahutara Road dunes run alongside and at right angles to the road. As soon as they are passed, the ground level lowers and dark groups of mature trees and large stands of ti kōuka appear within the green paddocks (see fig. 6.40). It is almost as if they are gathered around the bridge over the Ruamahanga hoping for water. They are remnants of the swamp forest that, prior to 1853 , stretched across an area of about eight by five kilometres. Much was cleared for farming and the Lower Valley Development Scheme, started in the 1960s, drained the swamp.

Fig. 6.41. Marker and location on Trail Map for Site No. 10. 


\section{Burnside Church}

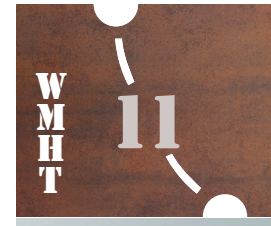

a Lake

ic.

Operu

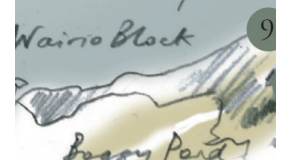

Rogoy porar
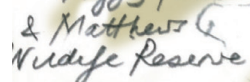

farest
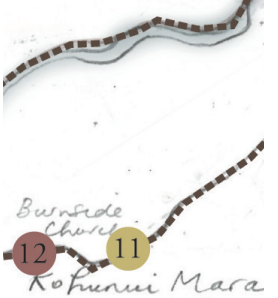

Pako Rura Pa

Raho Ruru

Ho meatead

Fig. 6.44. Markers

and location on Trail

Map for Sites No. 11.
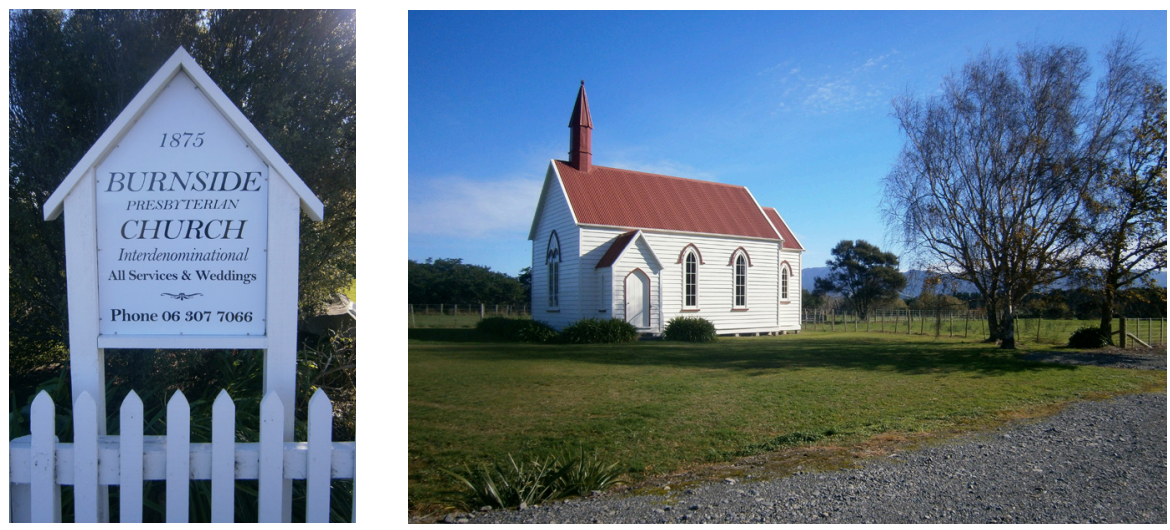

Fig. 6.42. The roadside sign for Burnside Church.

Fig. 6.43. Burnside Church with the Rimutaka Range behind.

Kahutara Road joins Lake Ferry Road and heads to the sea. After about $4 \mathrm{~km}$ of gently undulating farmland a small picturesque church comes into view. Built in 1875 by early Pākehā farmers Burnside Church is a popular wedding venue (see fig. 6.42 and 6.43). 


\section{Kohunui Marae}
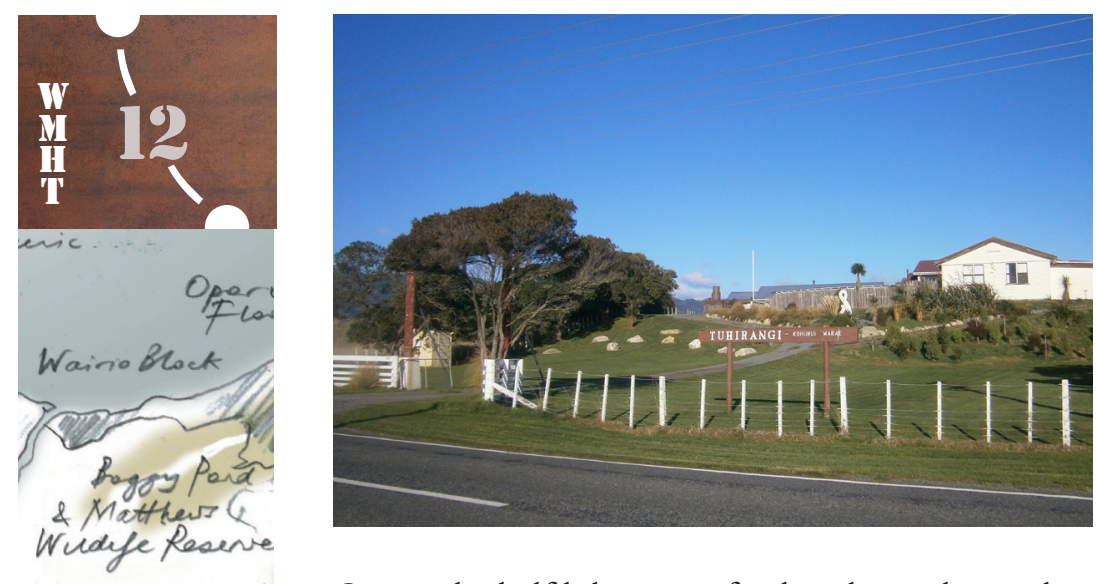

Fig. 6.45. Kohunui Marae.

natwe fareet

One and a half kilometres further down the road, and on a ridge above it, sits Kohunui Marae (see fig. 6.45). Strung along the top of the ridge are the marae buildings and an urupa. Kohu nui means big fog. Fog settled when the hinurangi spread over the plain the marae looks down on.

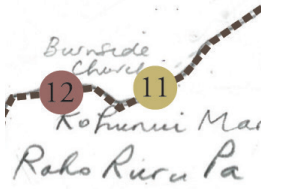

$\times$ Raho Ruru

Homestead

Fig. 6.46. Markers and location on Trail Map for Sites No. 12. 


\section{Nga Rākau Pūrākau - Raho Ruru Pa}
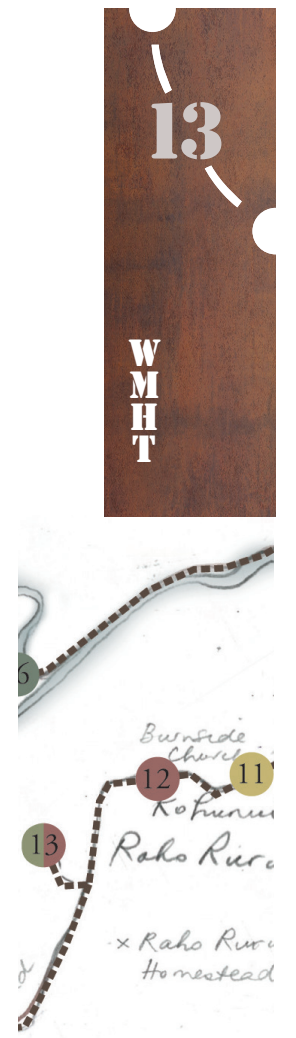

Fig. 6.47. Marker and location on Trail Map for Site No. 13.
Just before the small settlement of Pirinoa a sign points down a side road to Raho Ruru. The quiet gravel road winds through paddocks before turning a corner around a low hill and the view to the plains opening out. The road straightens and runs beneath the hill on which Raho Ruru Pa was sited. It sat atop the northern end of the raised finger of alluvial soils that juts out into a low lying area of beach deposits. The raised site has extensive views over the surrounding plain.

The intervention, foreshadowed by a ti kōuka at the beginning of the straight stretch of road, sits directly below an existing ti kōuka on the slopes beneath the pa (see figs. 6.48 - 6.53). When approaching the site on foot, planting screens views of the wider landscape. Walking between the rows of palisades, the shape of which echoes the shape of the hill, the eye is drawn to the pou and then to the hill behind. The palisades enclose a story telling place with a simple timber bench, enabling reflection on what has gone on here. The name of the place 'Nga Rākau Pūrākau', or storied trees, was given to the researcher by Rawiri Smith, a great storyteller. It came from his sister, Member of Parliament Marama Fox, a descendant of the tribes of Ngāti Kahungunu, Ngāti Porou, and Rangitāne, also of Te Ikaroa Rāwhiti.

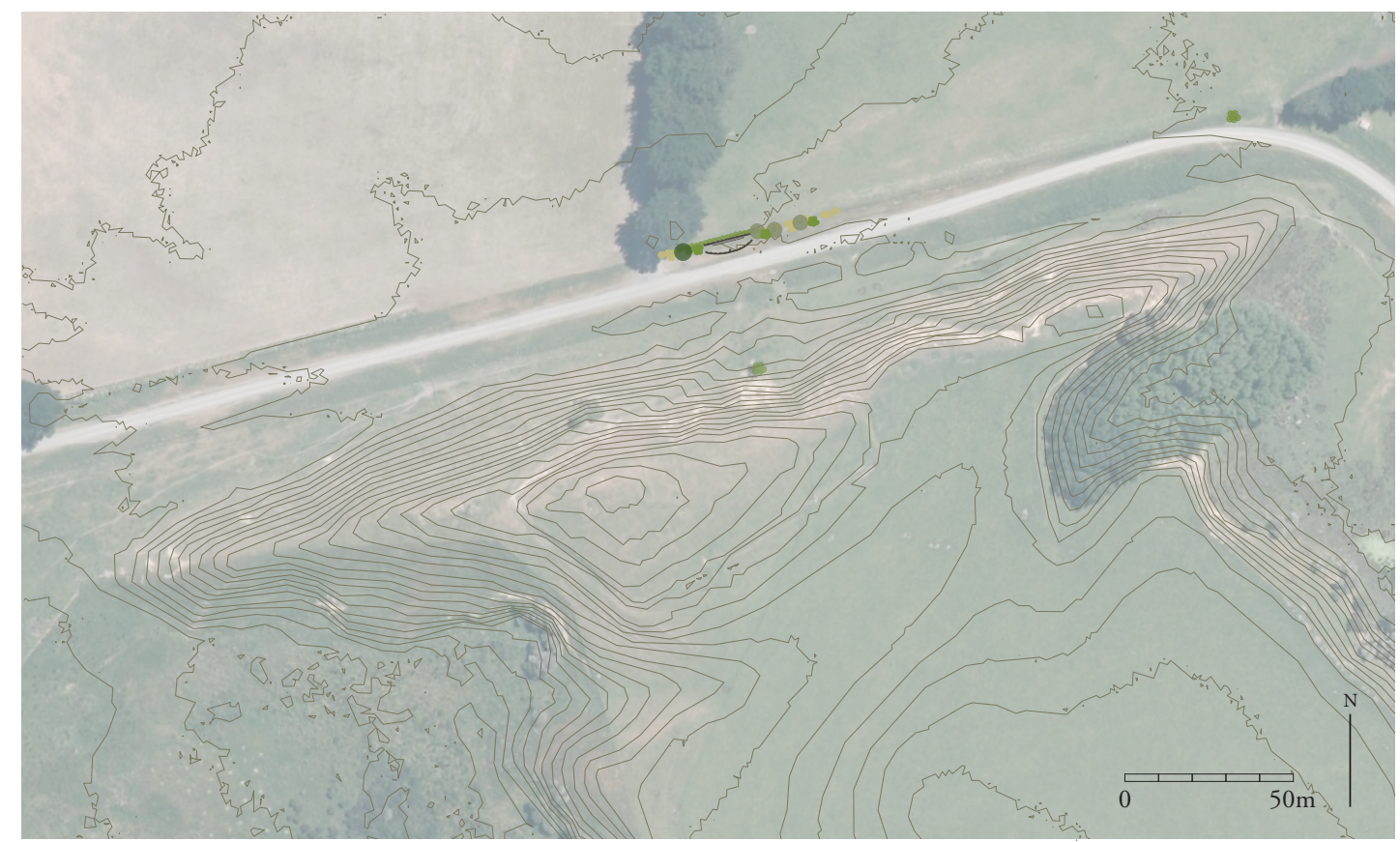

Fig. 6.48. The location of Nga Rākau Pūrākau and the pa site. N.B. the shelter belt to the left has been removed. 
Detailed construction plans are not included here as the construction method is to be determined by the whānau of the nearby marae, Kohunui, with the aim of revitalising traditional construction techniques. It is also the researcher's hope they will carve the pou and maintain and use the site.

To give some shelter, possible sustenance and to welcome the birds, the native plants are to be edible. "In Māori tradition, the morepork or ruru was often seen as a watchful guardian. ... Its occasional high, piercing call signified bad news, such as a death, but the more common 'ruru' call heralded good news" (Hutching). Rawiri Smith, Ngāti Kahungungu, in conversation about Raho Ruru Pa and its name, said the name ruru is significant as it is a bird of the night, a bird of prey, and associated with death and life. He considered this to be a dying place that can be brought to life again. This intervention seeks to do this by creating the storytelling place; the telling of the place's stories will renew it and give it voice again, as will the planting of trees and encouraging of birds. Rob McGowan, at the NZILA conference, said, "birds are the voice of the landscape".

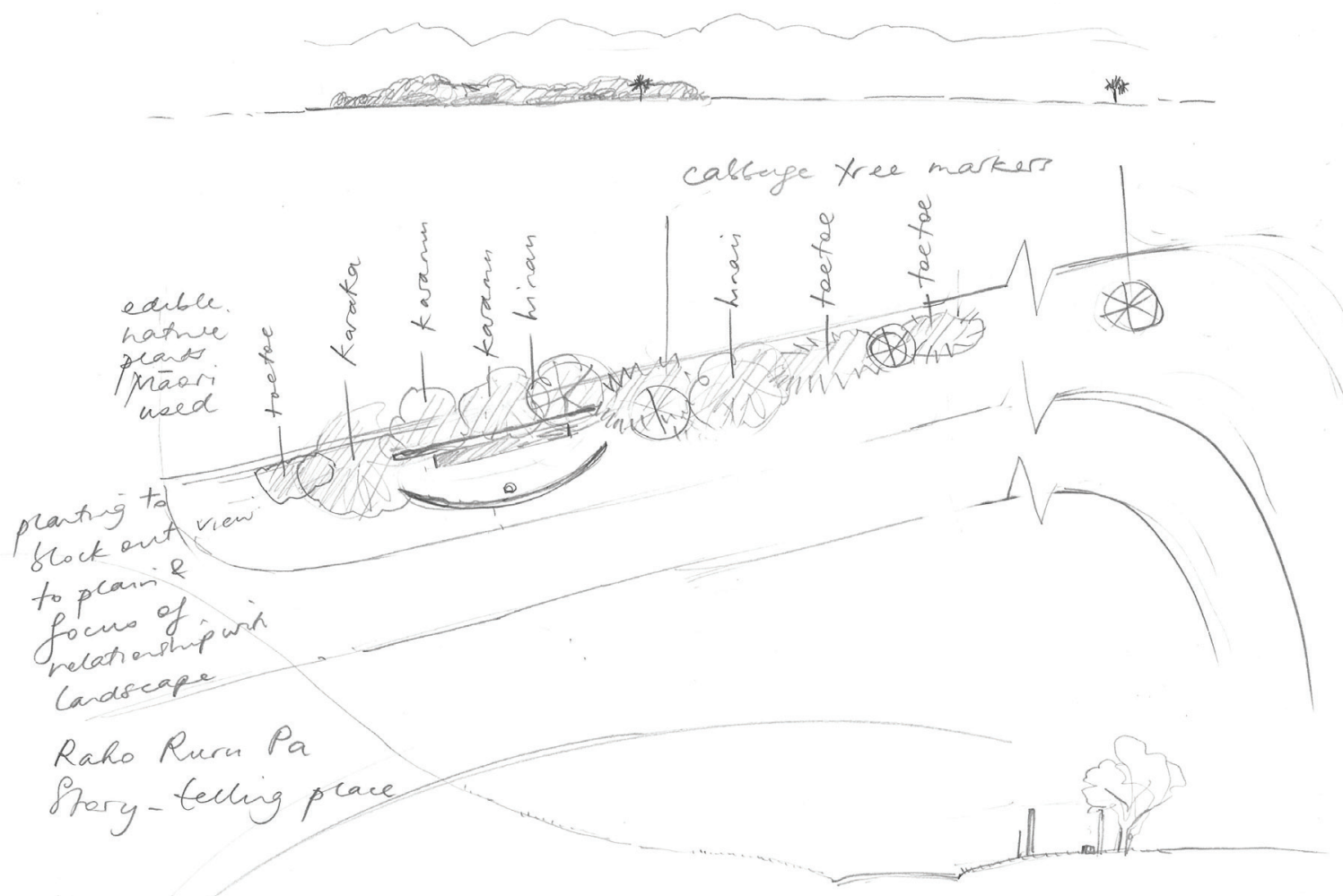

Fig. 6.49. Early design sketch. 


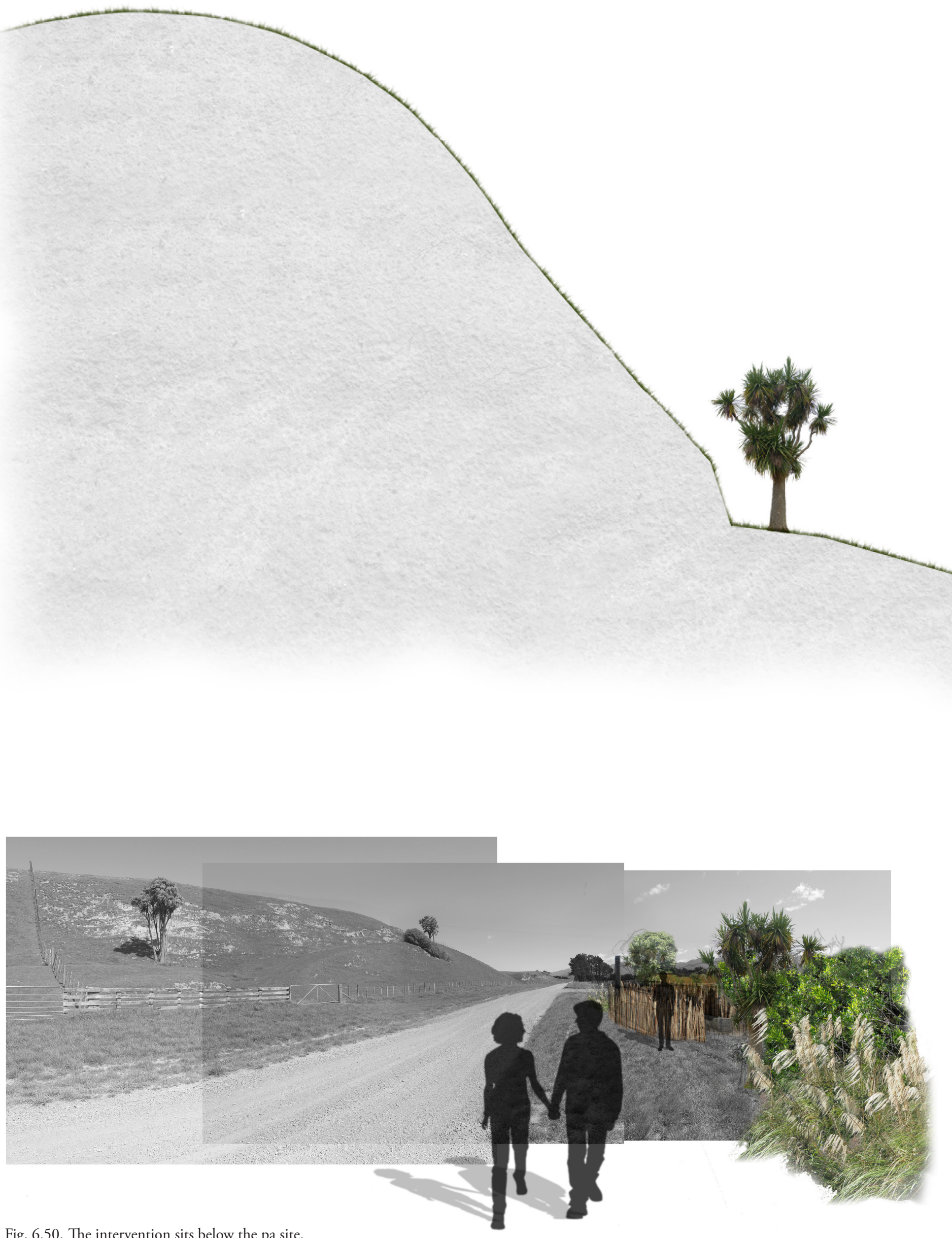

Fig. 6.50. The intervention sits below the pa site. 


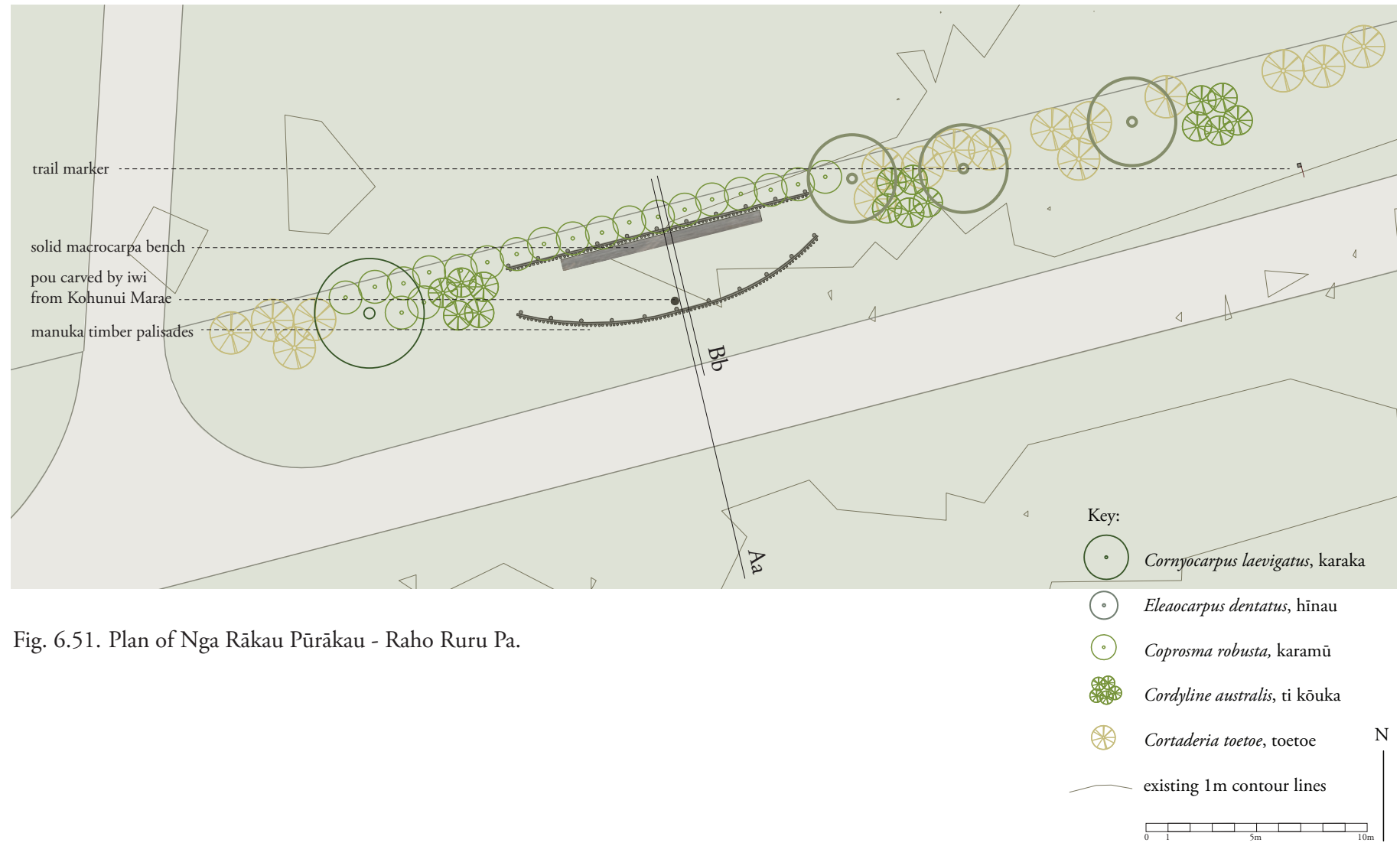

Fig. 6.52. Section Aa through Raho Ruru Pa site and intervention, Scale 1:200.

Fig. 6.53. Section $\mathrm{Bb}$ through intervention,

Scale 1:50. 


\section{Lake Onoke, at Lake Ferry (WMWP)}

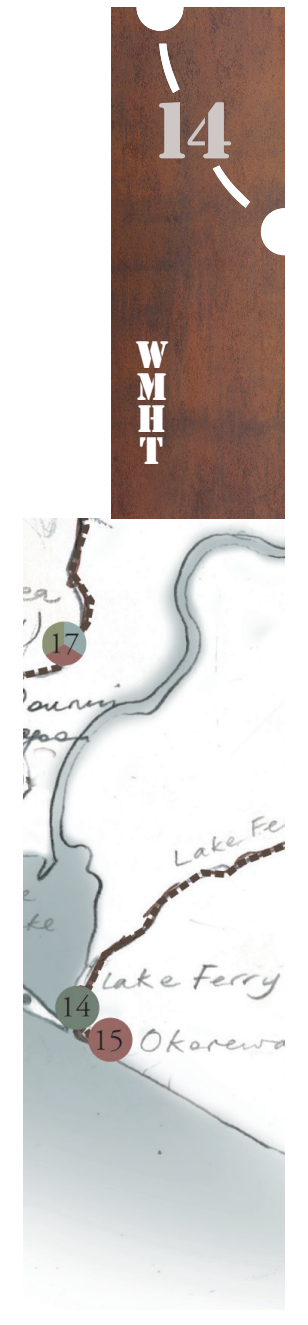

Fig. 6.55. Marker and location on Trail Map for Site No. 14.

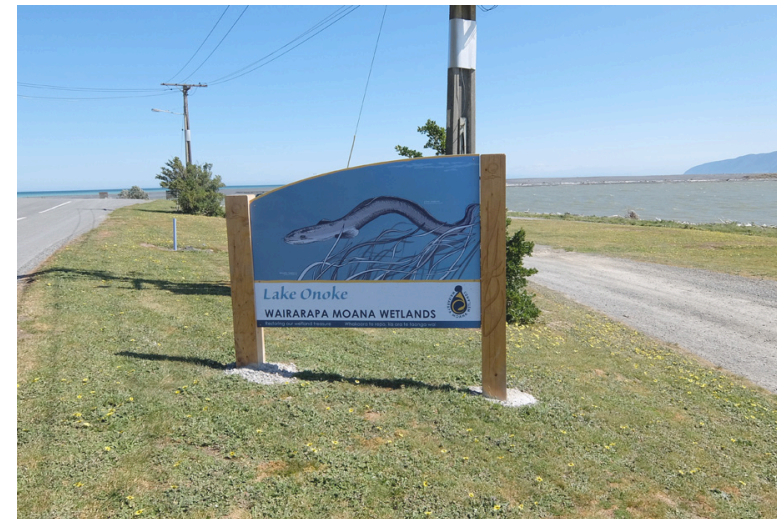

Fig. 6.54. The WMWP sign features tūna, the long fin eel, Anguilla dieffenbachii, and rimurehia, seagrass.

From Pirinoa Lake Ferry Road wends its way through farmland to the coast. As the settlement of Lake Ferry is approached, the land west of the road empties of trees and Lake Onoke can be seen beyond the gently sloping fields.

When one arrives at the end of the road outside the Lake Ferry Hotel the view of the spit, lake, lake mouth and distant ranges is punctuated by signs and a structure housing equipment that monitors the lake level and weather (see fig.6.56). Removing these, as in the following image (see fig.6.57), will restore emphasis to this unique landscape and the processes that have formed it.

Designing an intervention for this site was initially stopped due to the new signage, as described on page 75 (see fig. 6.54). However, late in the research process the researcher revisited a concept that had been discussed with local entrepreneur Reuben Raihania Tipoki. He has a dream of seeing waka back on Lake Onoke and catching tūna when the lake mouth closes, as was done in the past during the hinurangi. While reviewing research, the idea resurfaced of somehow including reference to heritage practices in the design (see fig. 6.61). Tim Benton in his book 'Understanding Heritage and Memory' calls this intangible heritage "heritage that exists in action" (Benton, 219). On Lake Onoke this could be using waka on the lake and catching tūna at the lake mouth in autumn. Doing so will renew connections to the past and renew relationships with the landscape as the landscape is integral to these practices.

The lake shore is laden with bleached driftwood logs. To formalise and frame 
the existing access to the shore for catching tūna and paddling waka, some of these $\operatorname{logs}$ are to be re-sited and become seats (see fig. 6.62). Planting will include Phormium cookianum and other suitable coastal species (see fig. 6.58 - 6.60). The seats also frame the view and encourage people to sit and take time to experience it more fully. They will also provide a vantage point for watching the lake and whatever takes place in and on it.

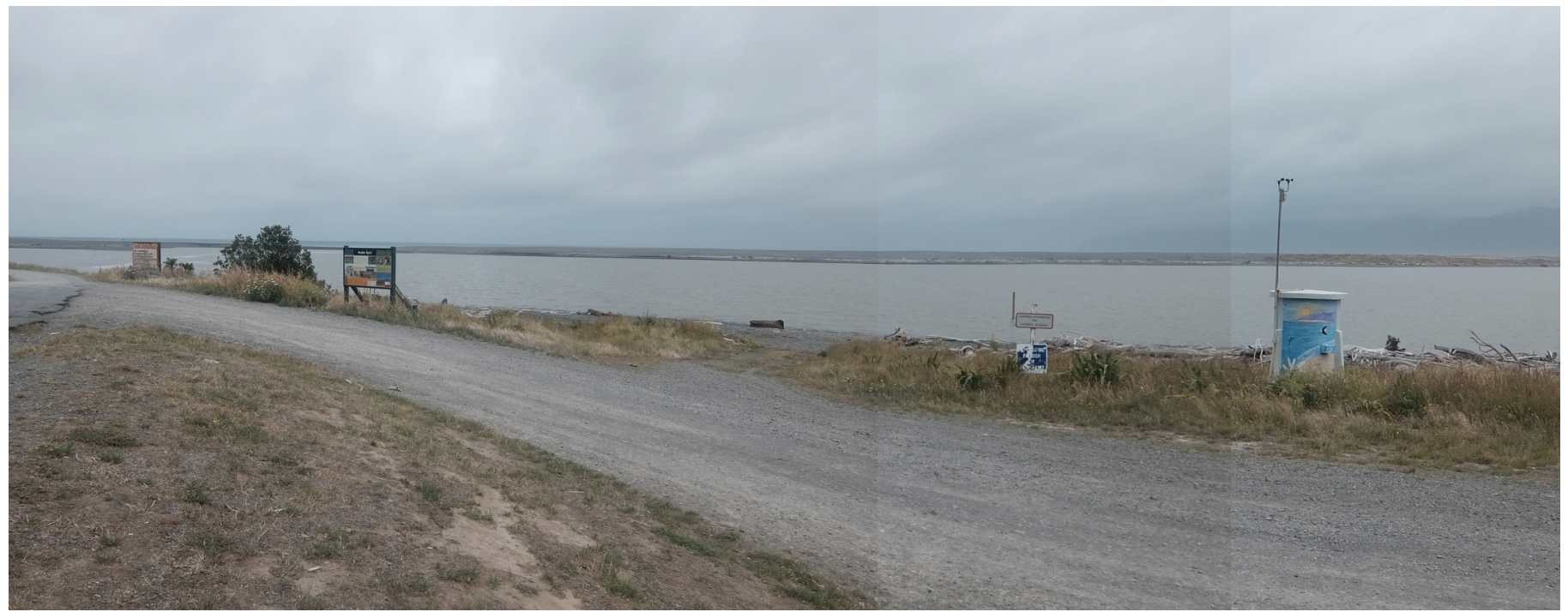

Fig. 6.56. The current view across Lake Onoke towards Onoke Spit with lake edge access in the centre of the image. To the right is the structure housing equipment to monitor the lake level, wind speed, etc. It belongs to the GWRC Environmental Monitoring Department.

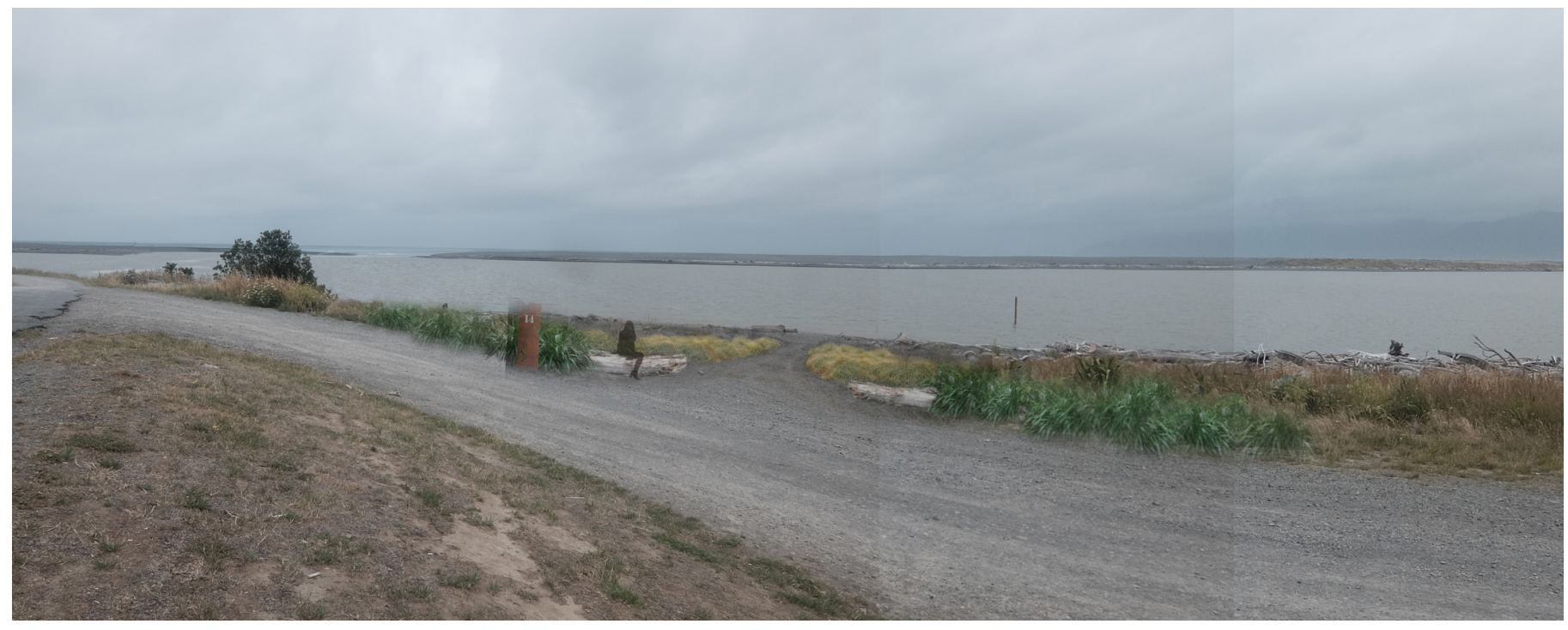

Fig. 6.57. The same view as figure 6.61, with the signs and structures removed and the intervention in place. 


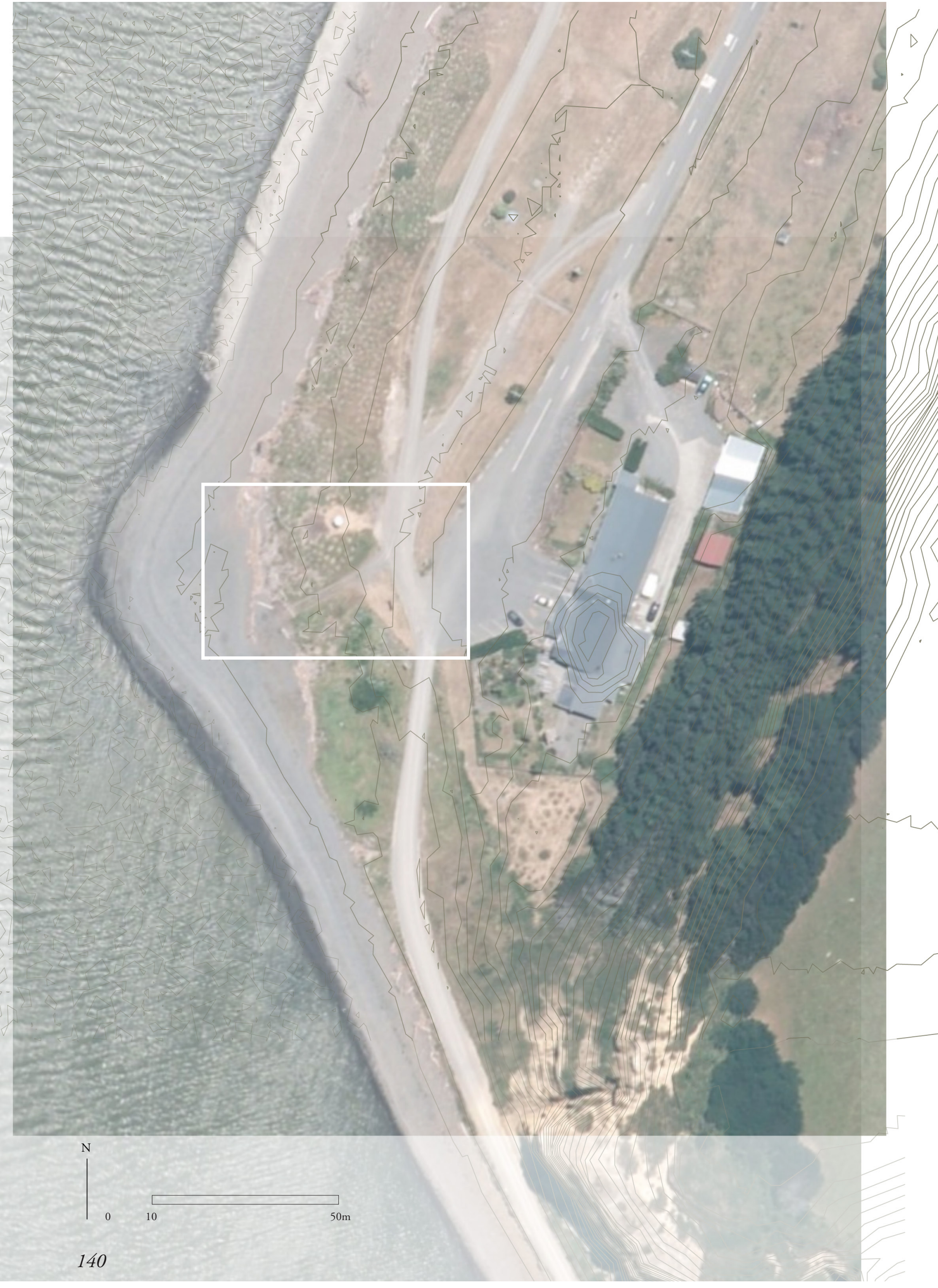




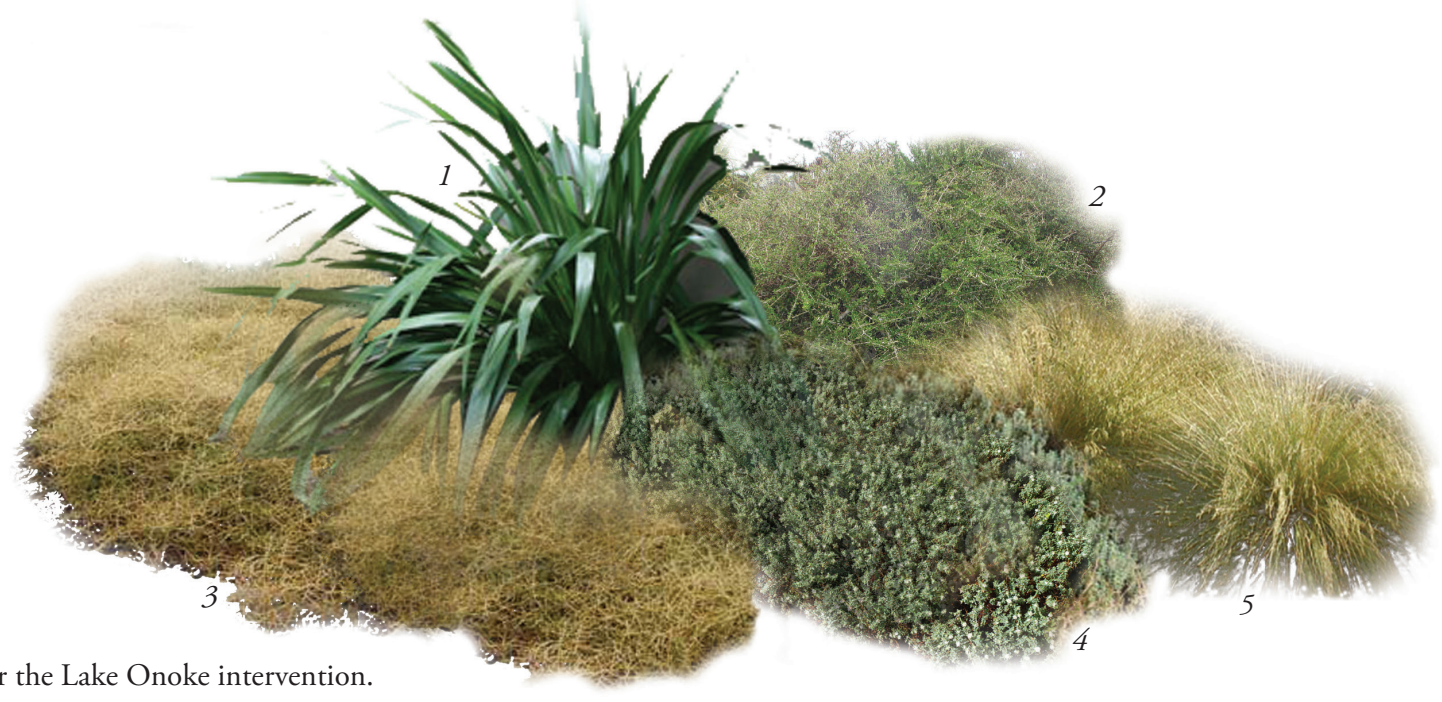

Fig. 6.58. Planting collage for the Lake Onoke intervention.

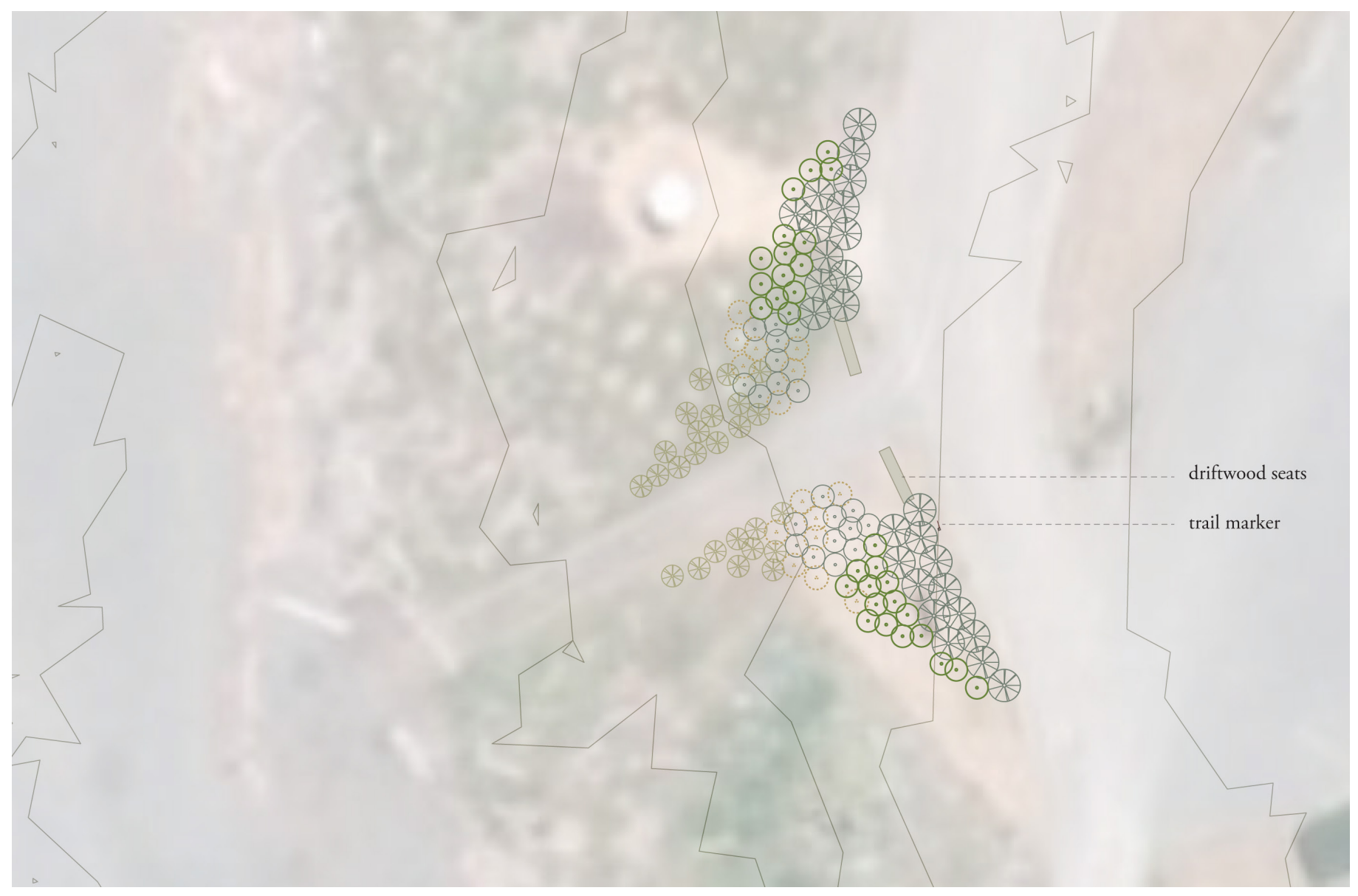

Fig. 6.59. Planting plan for the Lake Onoke intervention. The planting will blend into those of recent revegetion schemes. The trail marker is sited south of the pathway.
Key:

A Phormium cookianum

(2) Melicytus crassifolius

3 Coprosma acerosa, sand coprosma

(4) Pimelia arenaria, sand daphne

(5) Poa cita, silver tussock

Fig. 6.60. The location of the intervention - the sealed road terminates in front of the Lake Ferry Hotel.

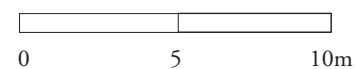




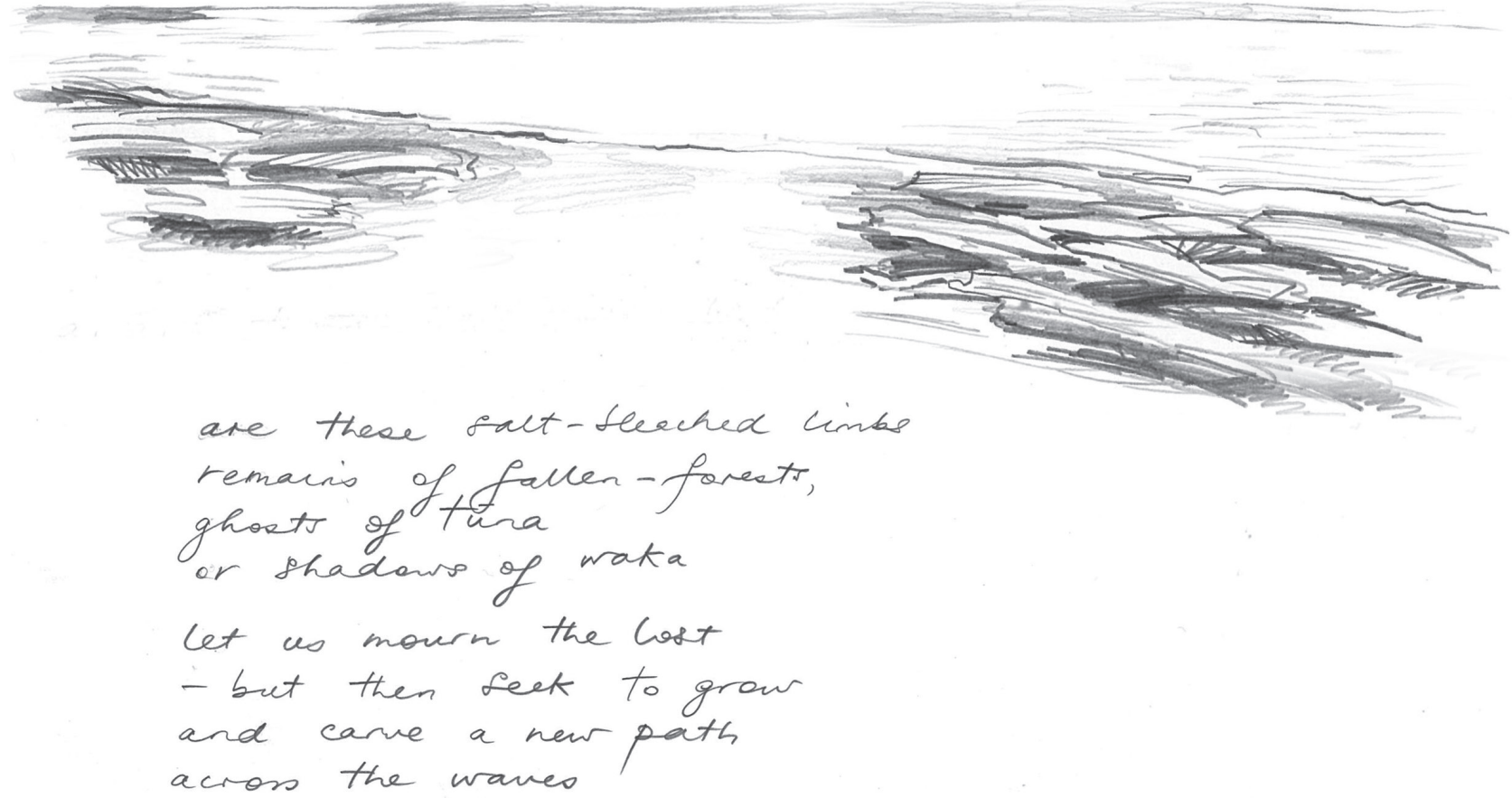

Fig. 6.61. Sketch and text made after a visit to the Lake Onoke site towards the end of the research process.

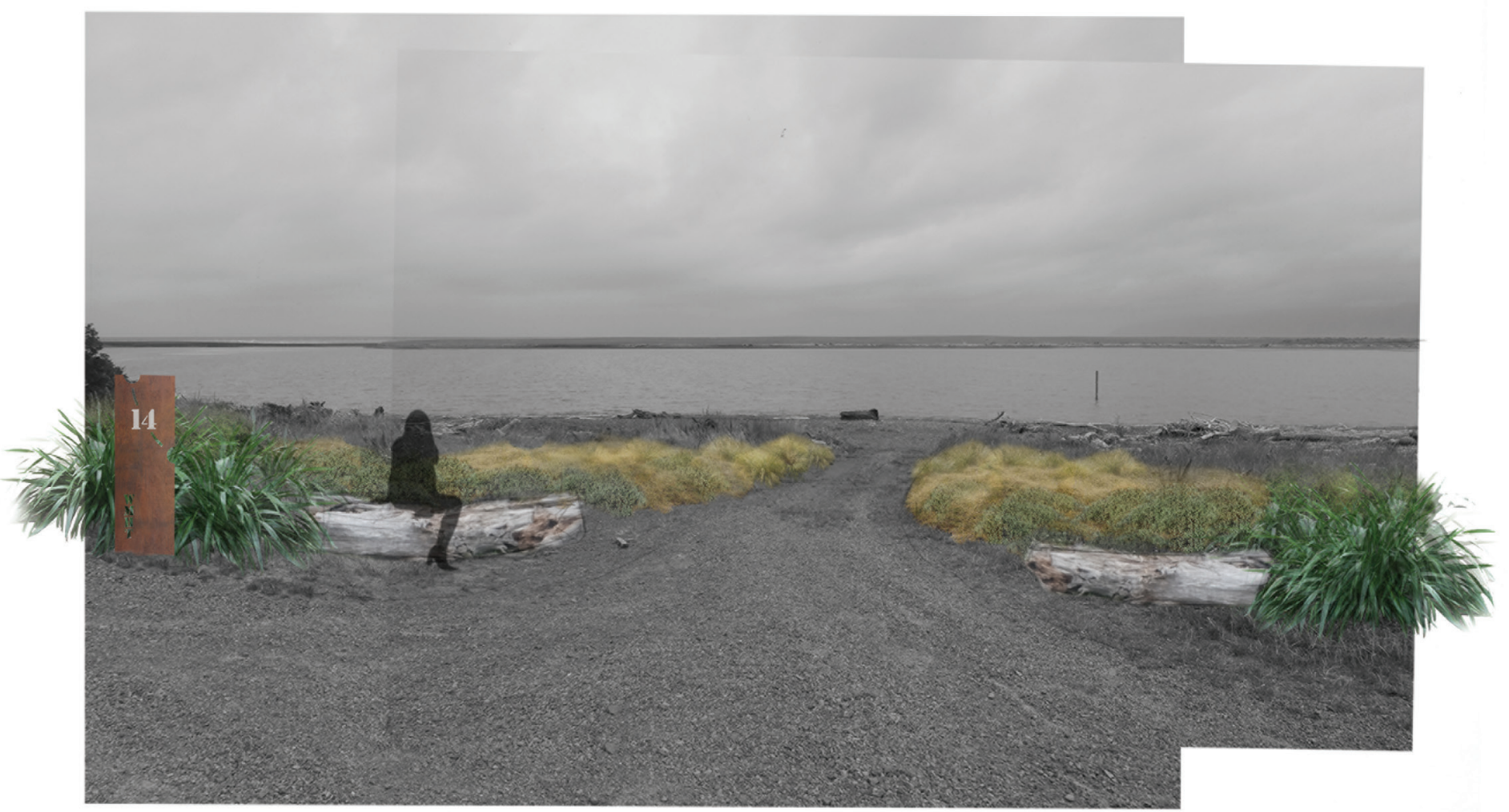

Fig. 6.62. The lake edge access and view across Lake Onoke is framed by driftwood seating and planting. 


\section{Okorewa Kāinga Waka Tētē}

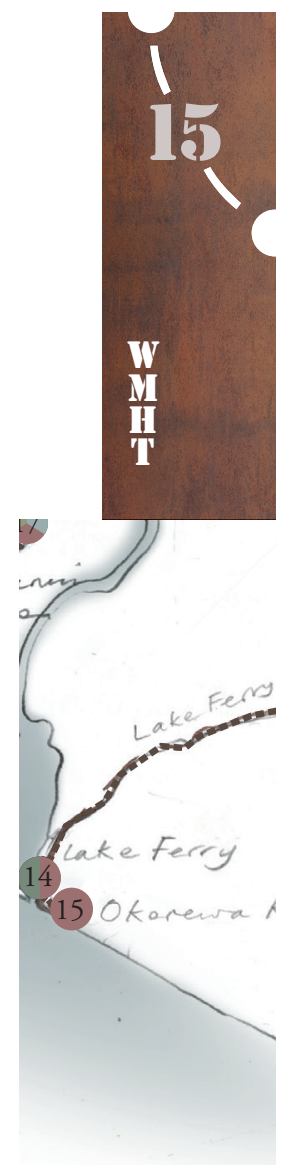

Fig. 6.63. Marker and location on Trail Map for Site No. 15.
The road to the east of Lake Onoke becomes gravel after the Lake Ferry Hotel and curves under the headland onto a wide expanse of grasses and gravel under a huge sky. No buildings can be seen. Following a short track west, cars can be parked close to a lagoon and a trail marker. Walking westward, drawn towards a large waka form, the view soon opens up. Nestled in the depression between the two jutting headlands is the site of Okorewa Kāinga, a fishing village (see fig. 6.65 - 6.69). The actual site is not accessible but its sheltered position is evident and idyllic. The intervention resembles a large waka tētē, a fishing waka, carved by local iwi, its curve echoing the gently holding shape of the land the käinga sat within (see fig. 6.64). The structure can be climbed and sat upon.
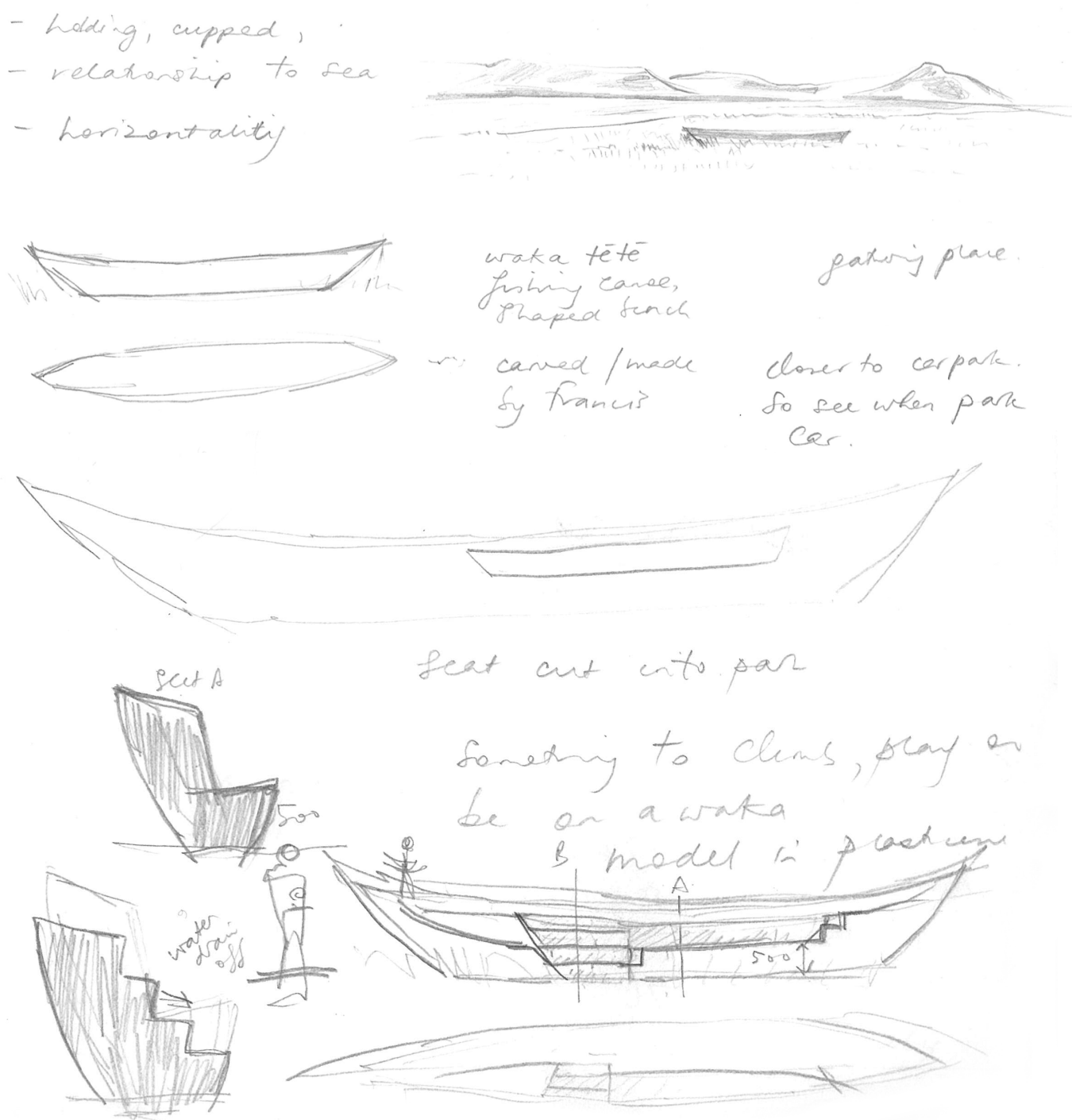

Fig. 6.64. Design diary sketches. 


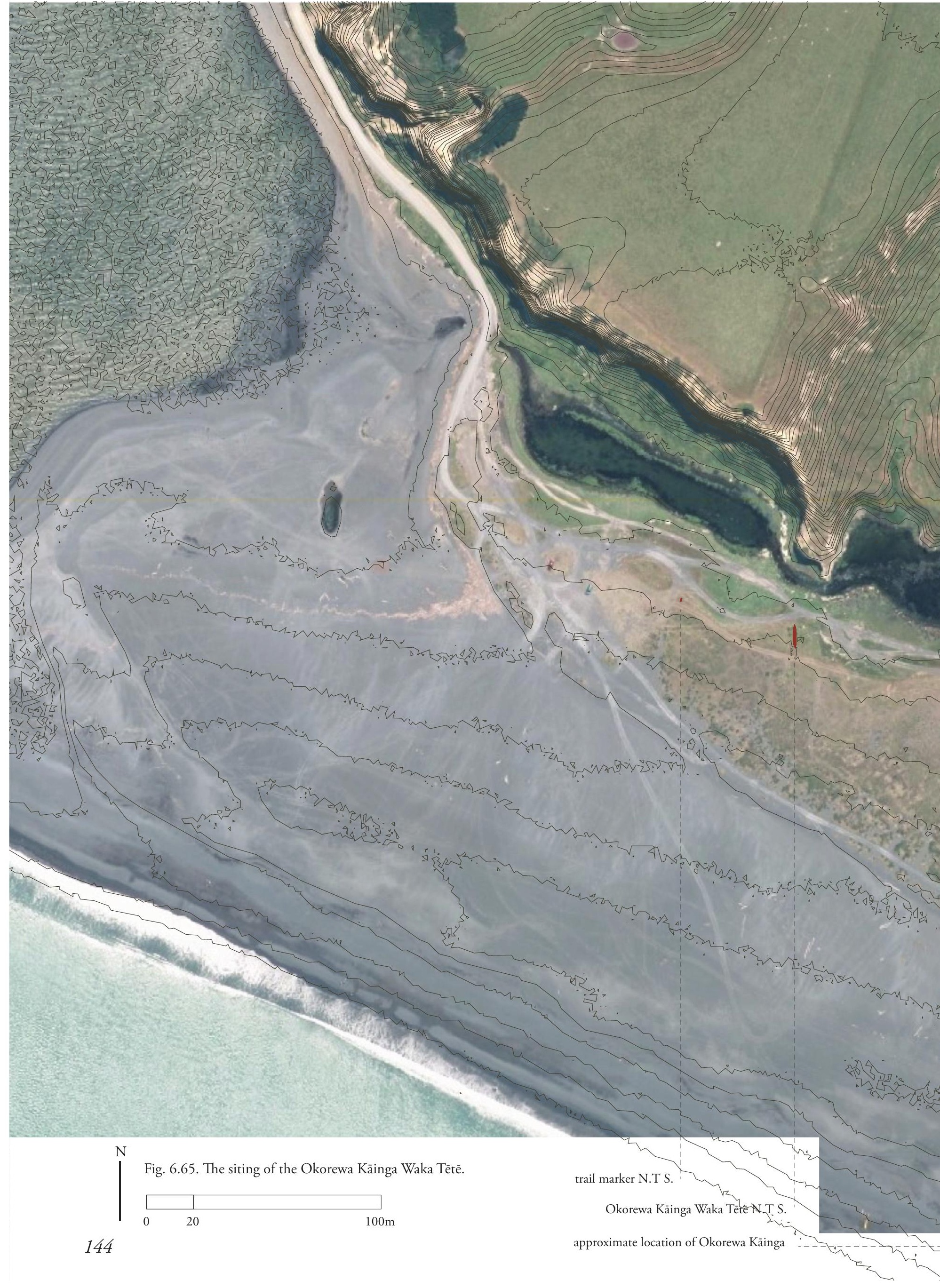



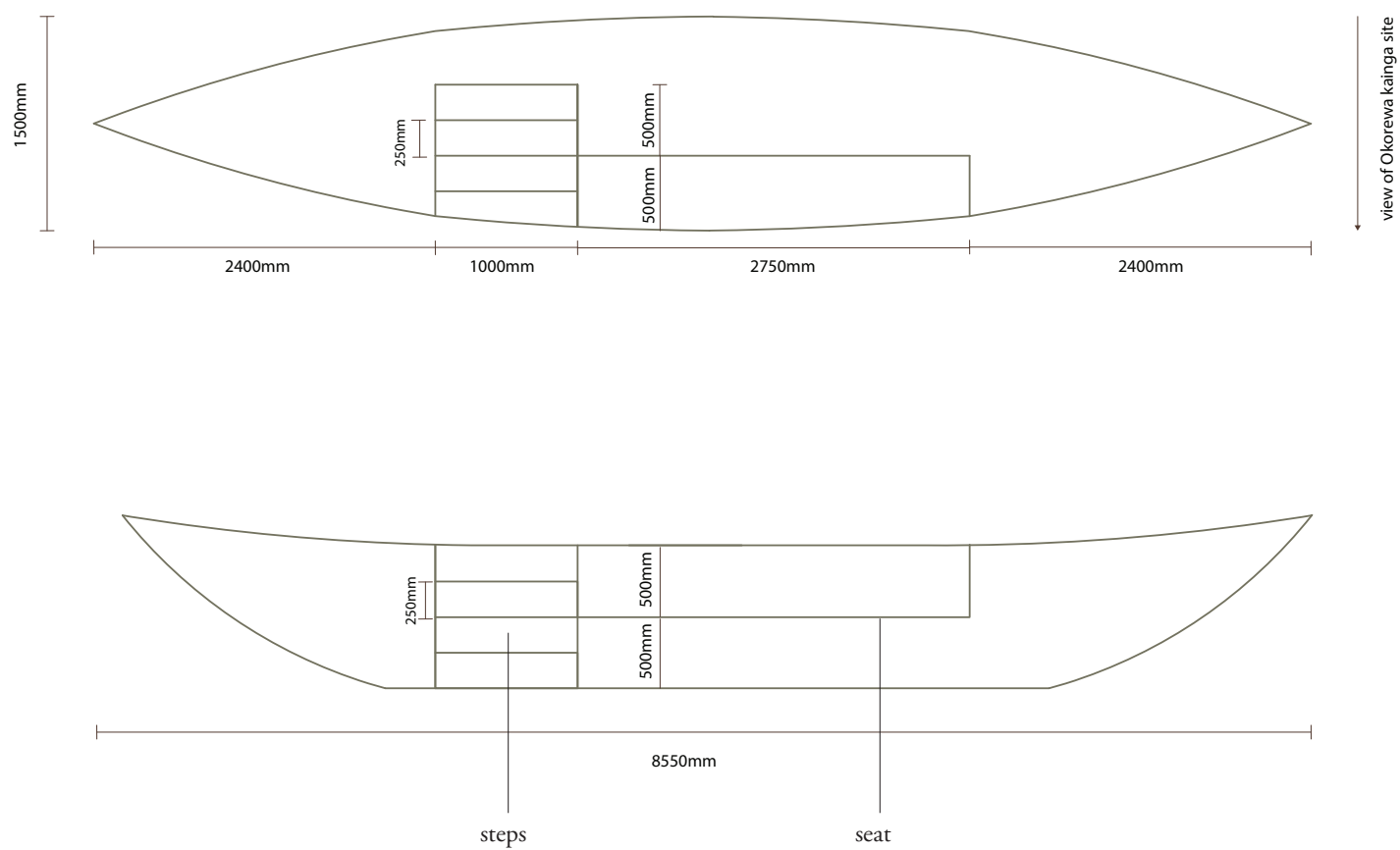

Fig. 6.66. Okorewa Kāinga Waka Tētē

- Plan and Elevation.

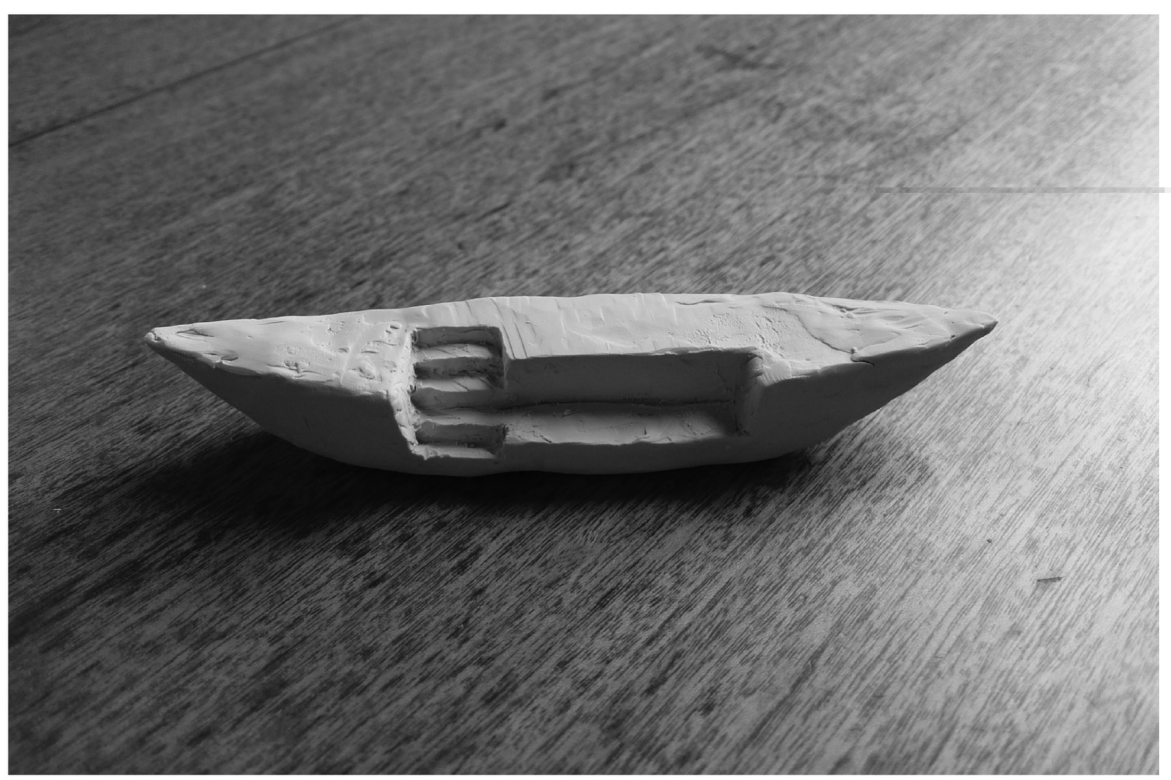

Fig. 6.67. Plasticine model for the Waka Tètē. 


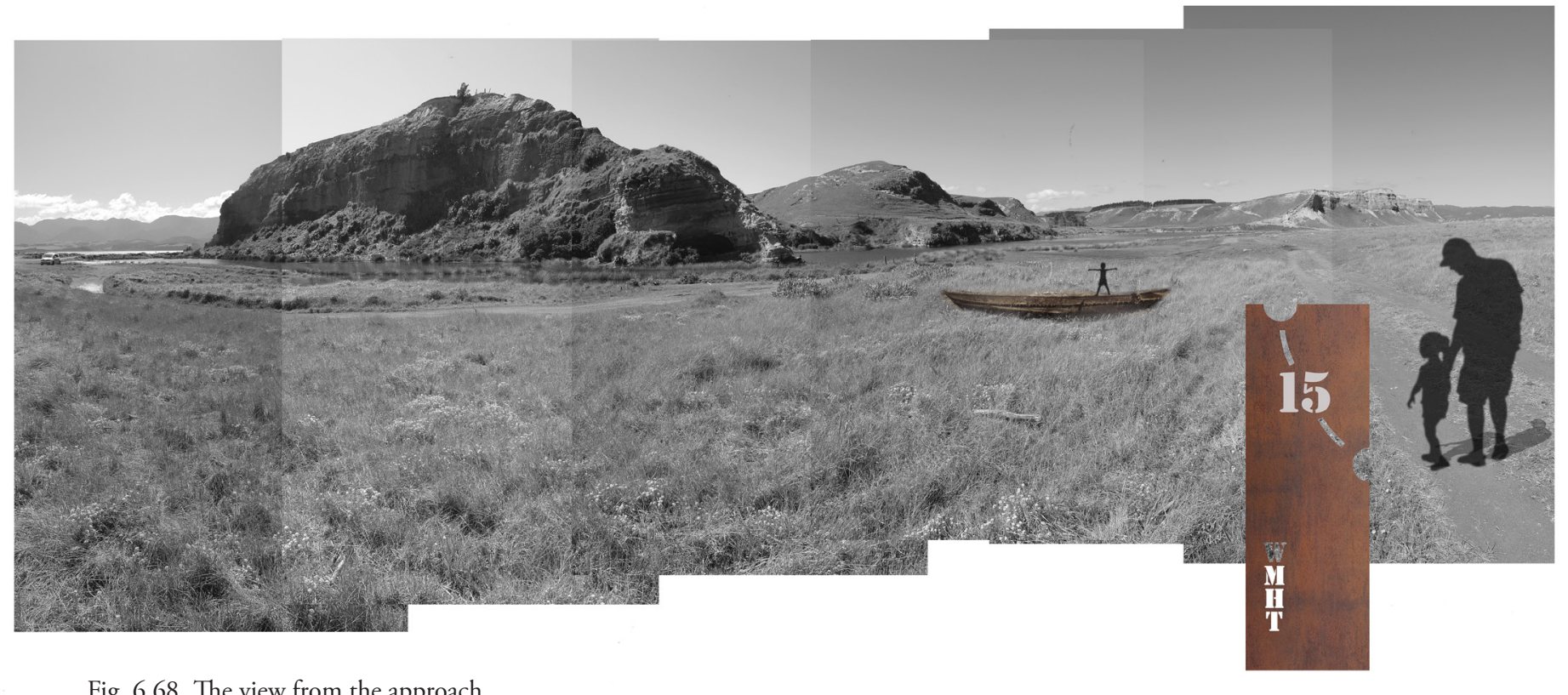

Fig. 6.68. The view from the approach path to the Okorewa Käinga Waka Tètè.

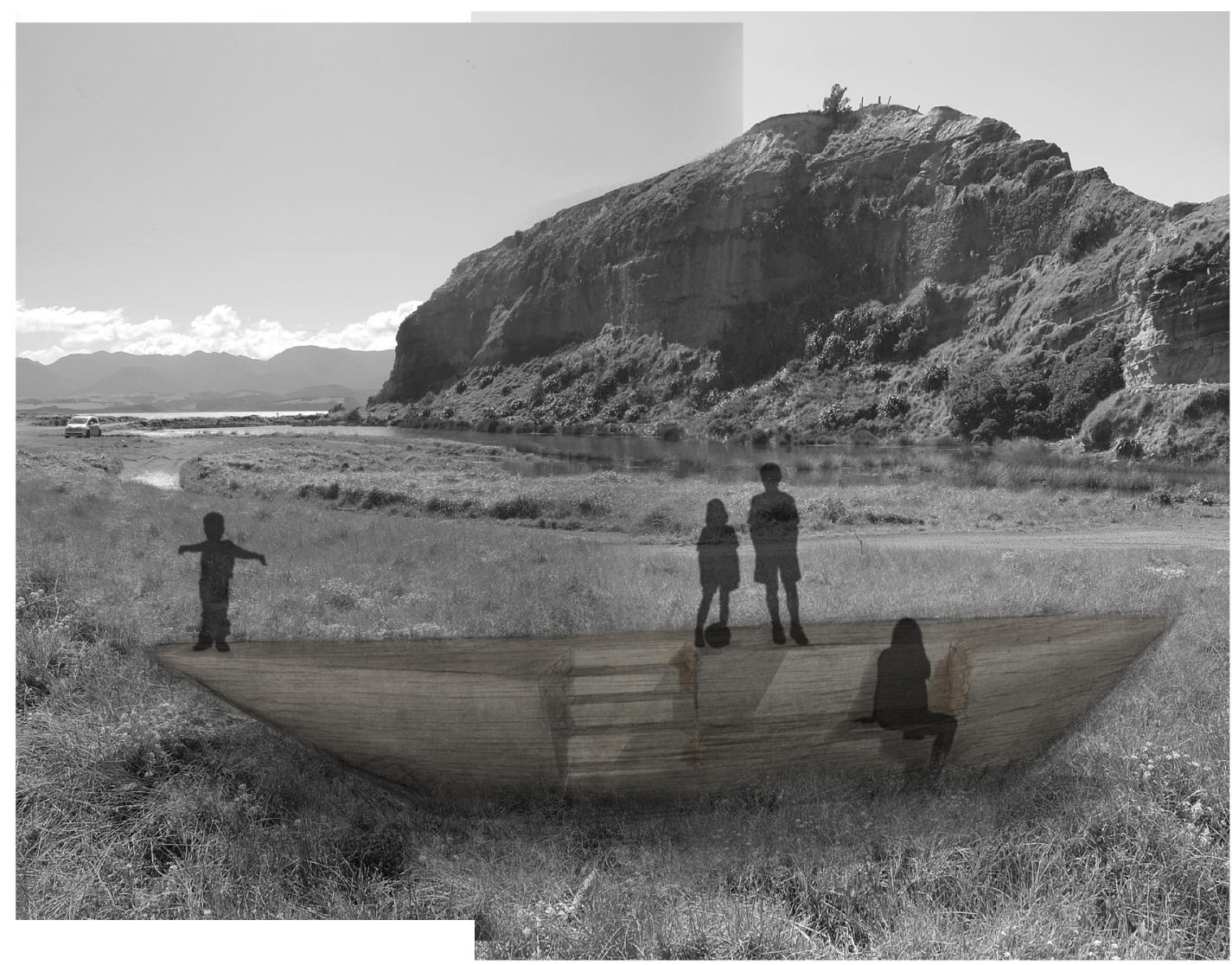

Fig. 6.69. Okorewa Kāinga Waka Tētē the familiar re-imagined. 


\section{Barrage Gates}

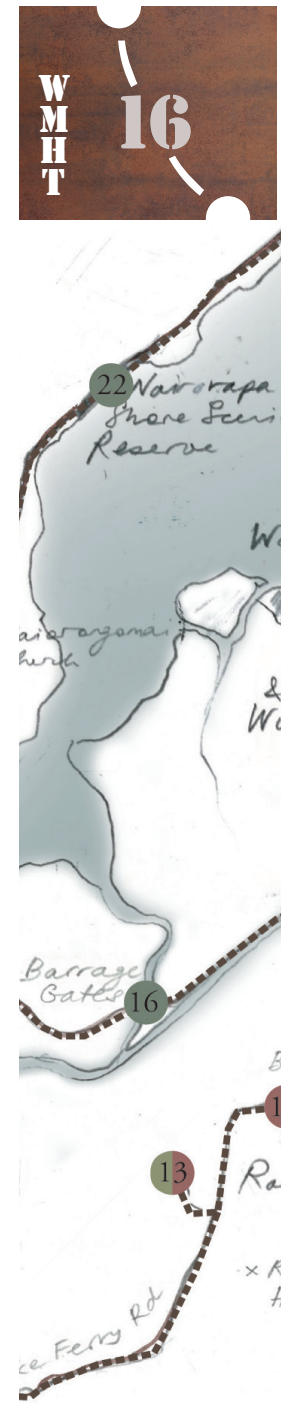

Fig. 6.71. Marker and location on Trail Map for Site No. 16.

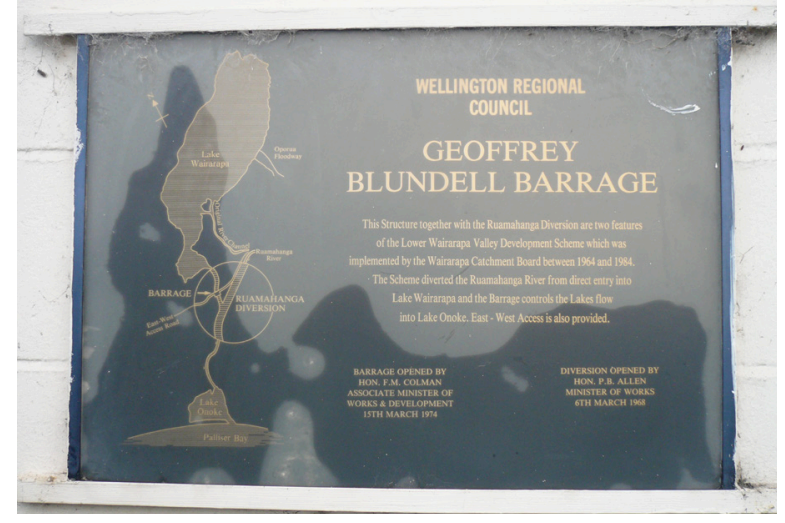

Fig. 6.70. The sign on the Barrage Gates.

The trail doubles back via Lake Ferry and Kahutara Roads until just past the bridge over the Ruamahanga. Then the East West Access Road takes the trail to new territory. The road firstly passes the EC Holmes Memorial Scenic Reserve. In 2013, historian Bruce Stirling compiled the report 'E C Holmes and the Māori Education Foundation Land at Te Hopai'. In it he wrote, "In 1962 Edward Carlton Holmes gifted 739 acres of his Te Hopai farm to the recently formed Māori Education Foundation, in order for the income to be used to educate Wairarapa Māori” (Mapunaatea). This has recently been the cause of much grief for iwi as the farm was sold to private owners.

The East West Access Road is a byproduct of the flood protection scheme. It follows the river, hidden from view behind the stopbank and willows until the ates (see figs. 4.20-22). The sign on the gates (see fig. 6.70) reads, "This Structure together with the Ruamahanga Diversion are two features of the Lower Wairarapa Valley Development Scheme which was implemented by the Wairarapa Catchment Board between 1964 and 1984. The Scheme diverted the Ruamahanga River from direct entry into Lake Wairarapa and the Barrage controls the Lakes flow into Lake Onoke. East - West access is also provided." 


\section{Kakahimakatea (Battery Hill) Pa}

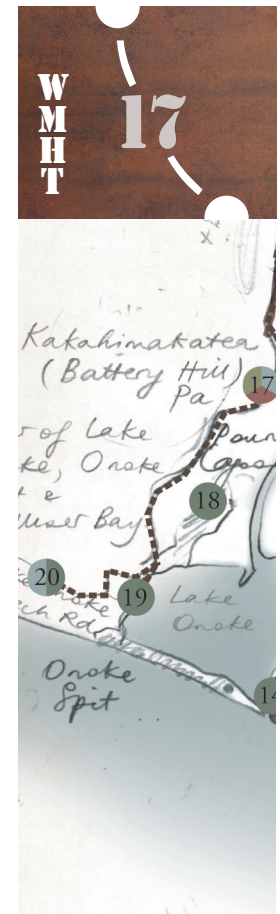

Fig. 6.73. Marker and location on Trail Map for Site No. 17.

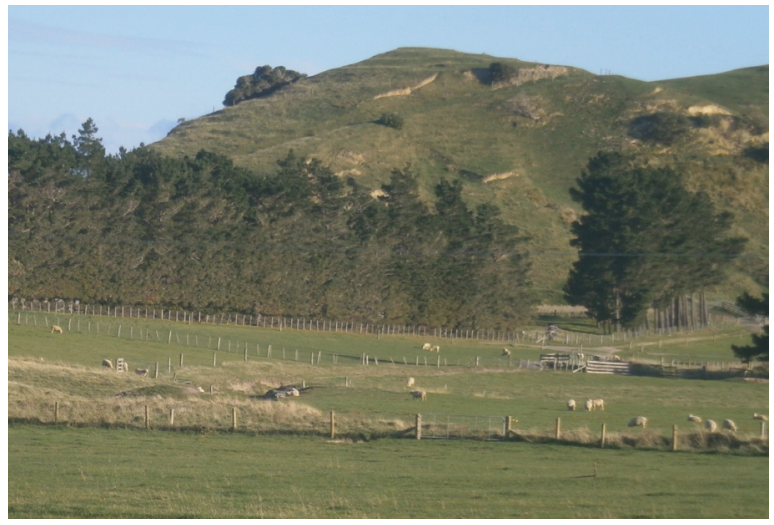

Fig. 6.72. The view of the pa site and its terraces from the north.

Past the Barrage Gates the trail continues until it meets Western Lake Road when it carries on southwards. The road winds along beneath a snaking low hill parallel to the much taller range. Gradually more of a long finger of hill is revealed extending out from the range, pointing towards the Ruamahanga River. On the prow of the promontory-like landform, terracing can be seen (see fig. 6.72). This is the remains of Kakahimakatea Pa. The site is to be marked close to the road by a pou carved by local iwi with a curved corten trail marker near the base. As the pa site is accessed through a network of farm roads the way will be shown by markers (see fig. $6.74-6.76$ ).
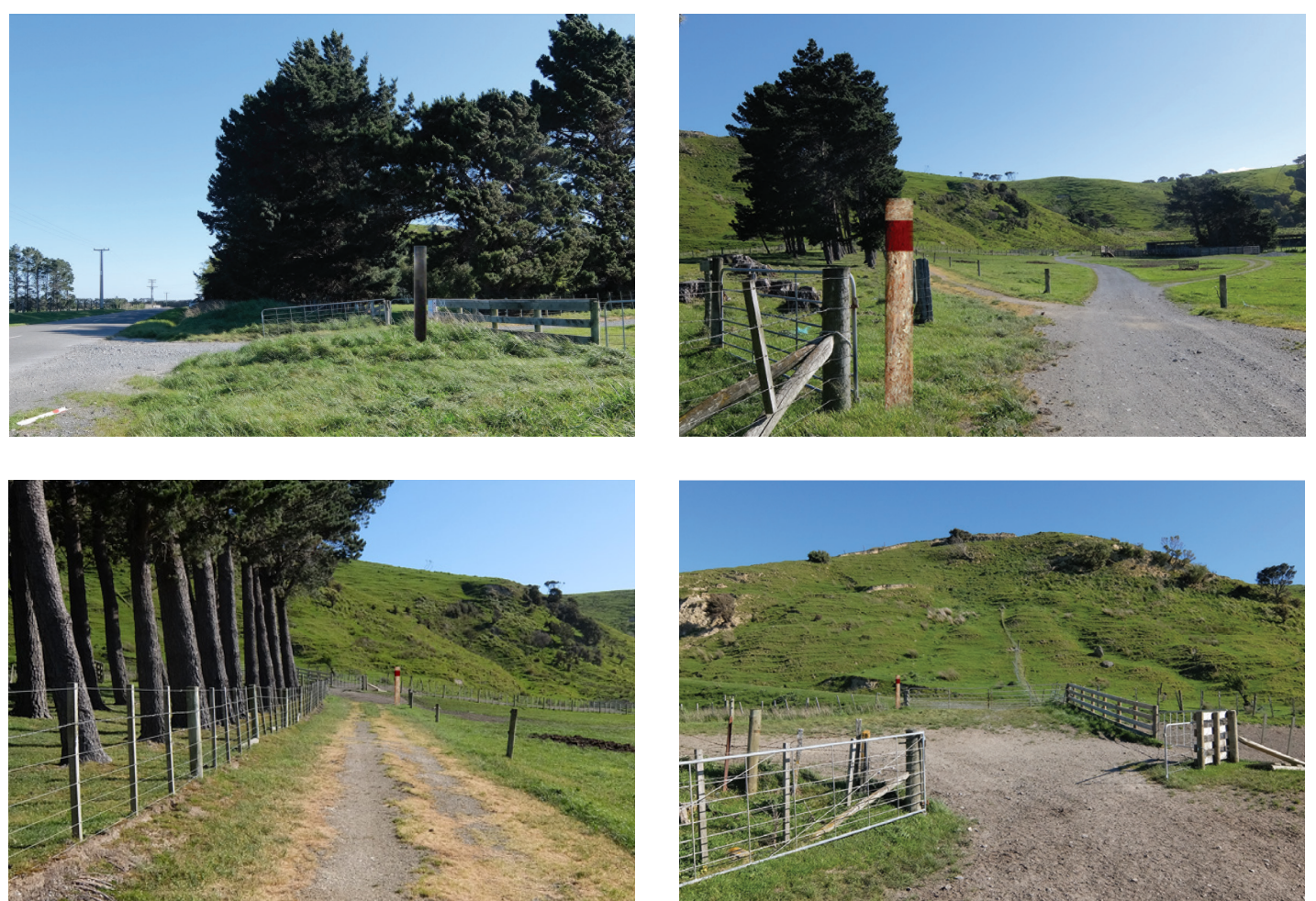

Fig. 6.74. Sequence of pou and markers leading to the Kakahimakatea Pa site. 


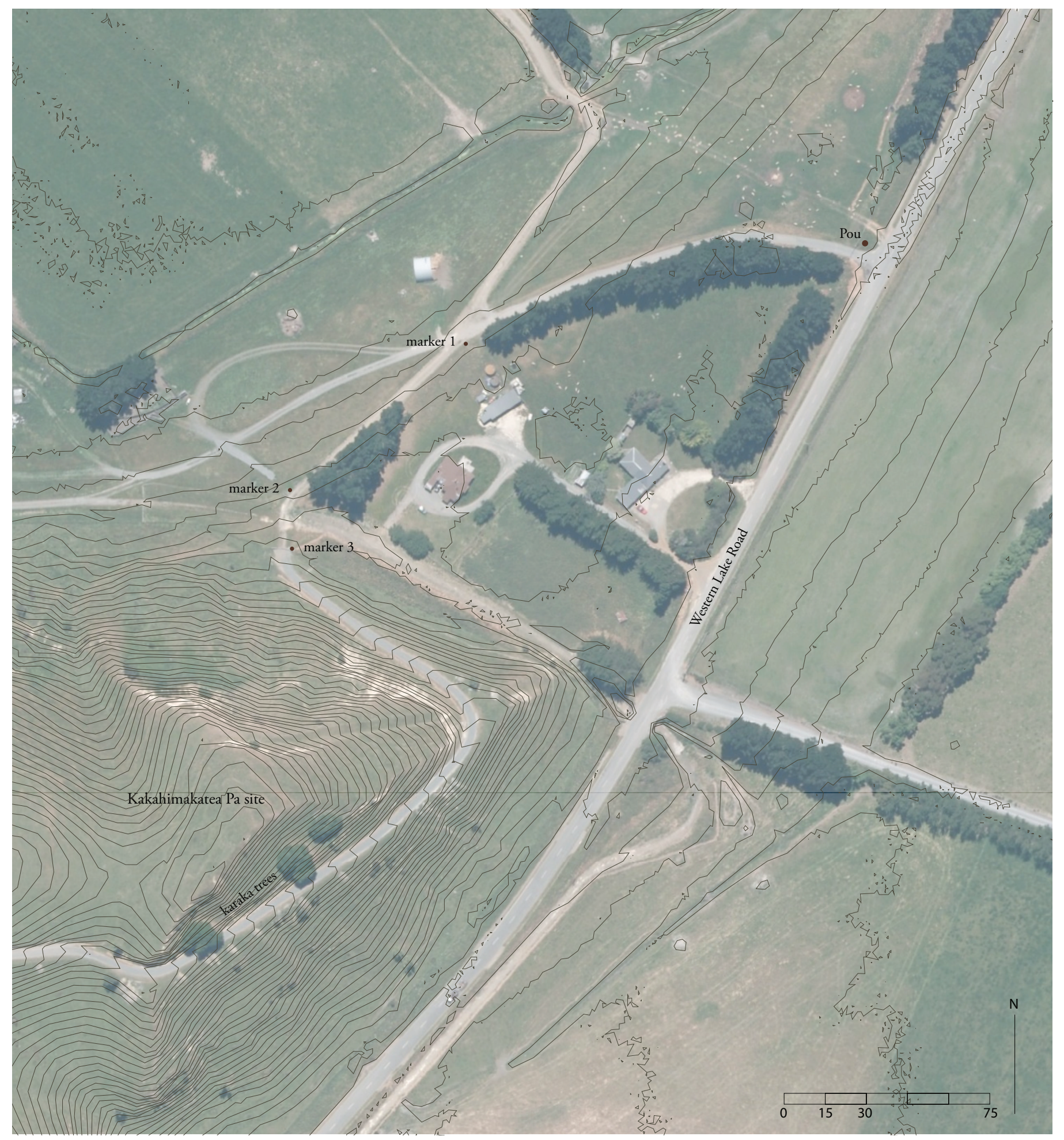

Fig. 6.75. Location of Kakahimakatea Pa pou and markers.
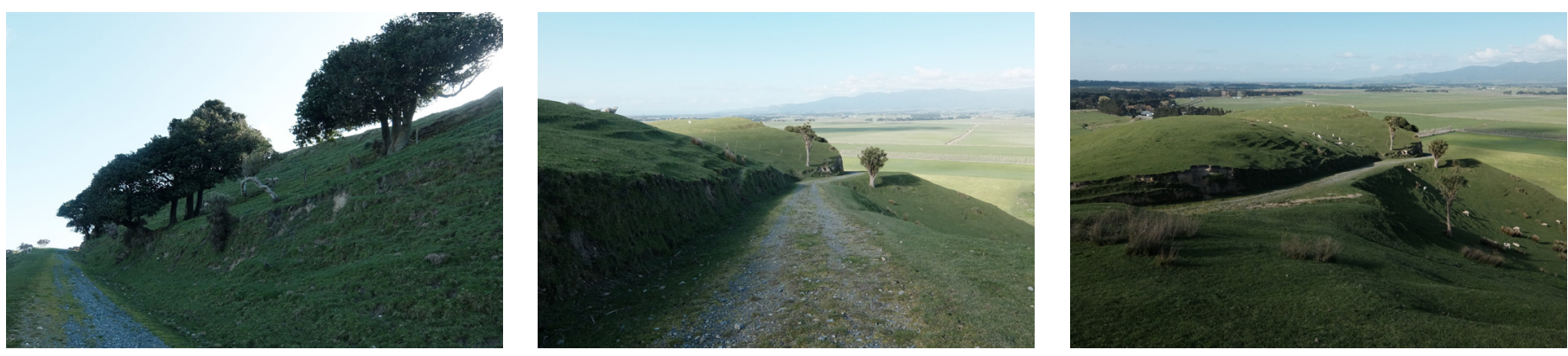

Fig. 6.76. Sequence of views of the Kakahimakatea Pa site: karaka trees, the pa site and the pa site and valley from the highest point of the hill. 


\section{Pounui Lagoon (WMWP)}
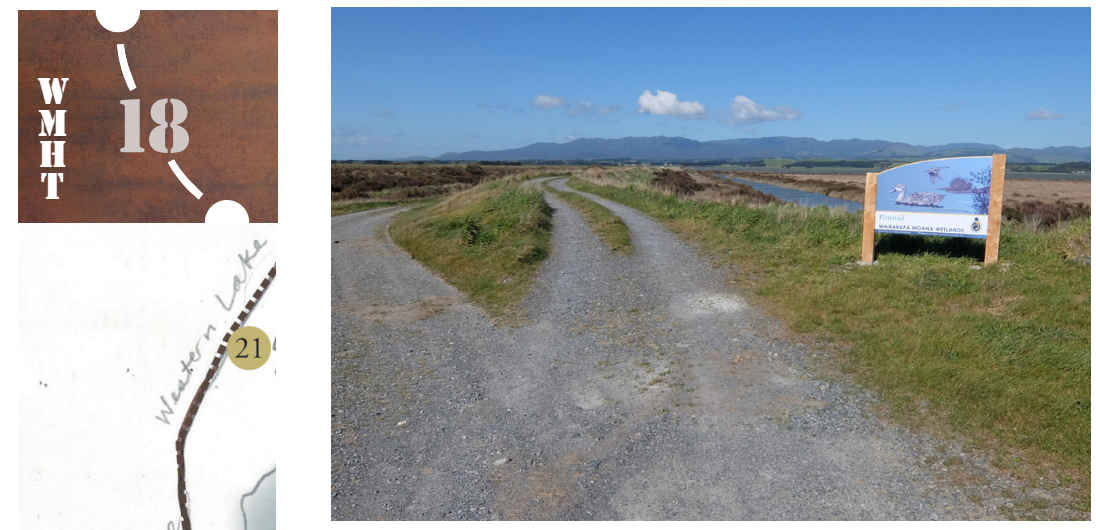

Fig. 6.77. The WMWP sign depicts grey teal and salt marsh ribbonwood.

The road continues south, now curving along the edge of the flat land against the foothills. The Lake Ferry settlement comes into view sandwiched between the waters of Lake Onoke and the hulk of the Aorangi Range. At Pounui, wetlands extend like a skirt out from the gate. Behind the gate the sign features tètē moroiti, the grey teal duck, or Anas gracilis (see fig. 6.77). The plant is mākaka, salt marsh ribbonwood, or Plagianthus divaricatus. The view to Palliser Bay is blocked by Onoke Spit.

Fig. 6.78. Marker and location on Trail Map for Site No. 18. 


\section{Lake Onoke, Beach Road and Onoke Spit (WMWP)}

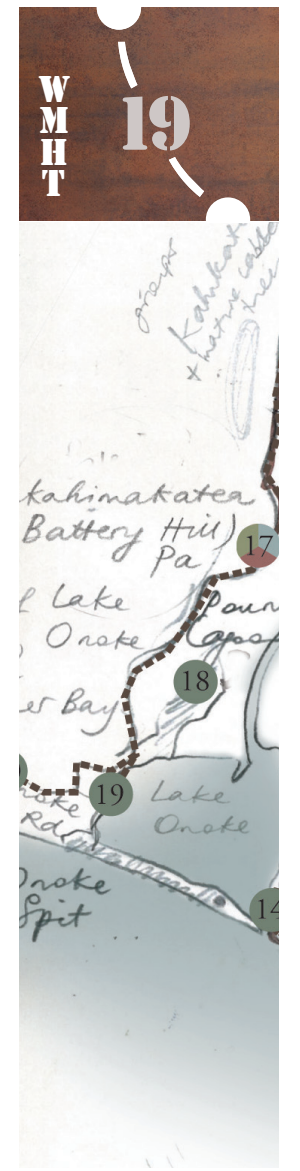

Fig. 6.80. Marker and location on Trail Map for Site No. 19.

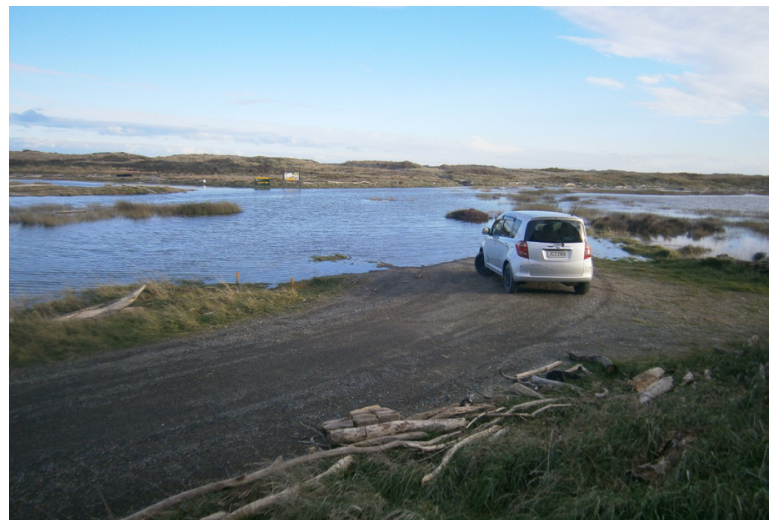

Fig. 6.79. The access to Onoke Spit in May requires wading.

The road continues in the same fashion until, just before curving up the hill and into a stand of mānuka, there is a sign to Onoke Spit Access. The narrow gravel track winds, at times very close to the lake edge, to the point in figure 6.79 . 


\section{Wharekauhau Road Viewpoint}

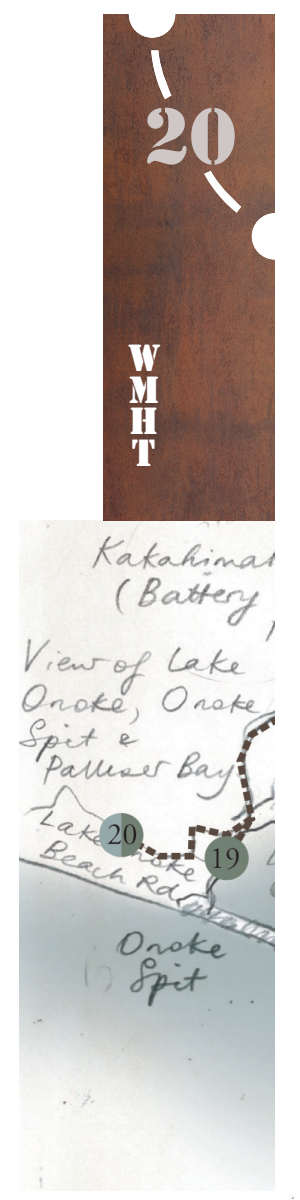

After the turnoff to Onoke Spit the road suddenly veers away from the lake and zigzags up onto the uplifted marine terrace flanking the south eastern end of Wairarapa Moana. The road straightens and continues to climb gradually. At the top of the rise the trail sign and planting signal a place to stop. The overall form of the planting echoes nearby bands of native vegetation that sits amongst farmland and also contains mānuka and ti kōuka (see figs. 6.82, 6.86 - 6.89).

The viewpoint is hidden from the road, the opening to it marked by ti kōuka. Inside is a clearing and the viewing platform. Steps up invite climbing, which is rewarded by the dramatic view of Lake Onoke, Onoke Spit and Palliser Bay (see fig. 6.83). A corten steel sign points out the various bodies of water in the view, telling the story of the water's journey southwards from lake to sea, from fresh to salt (see figs. 6.84 - 6.85).

Fig. 6.81. Marker and location on Trail Map for Site No. 20.

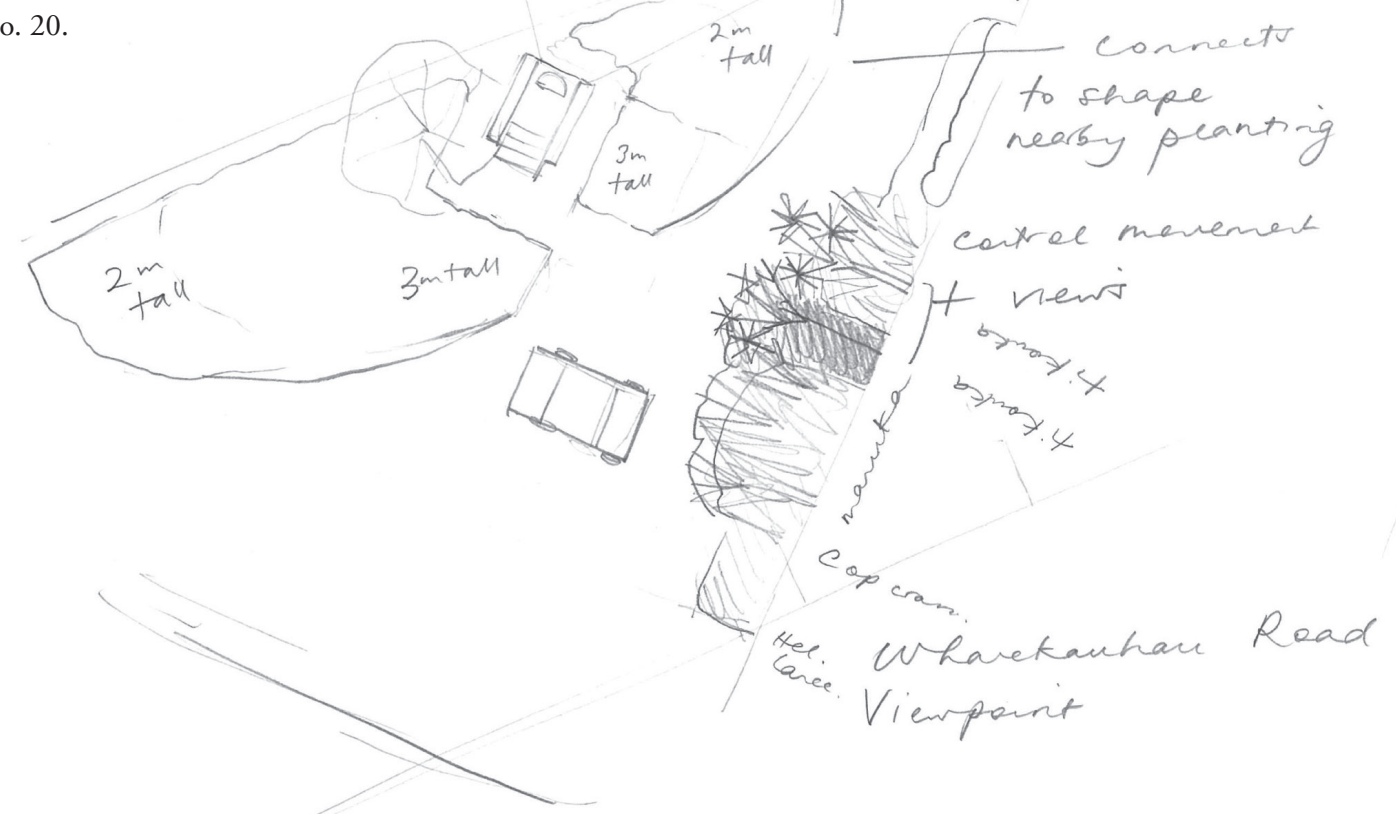

Fig. 6.82. Early design sketch. 


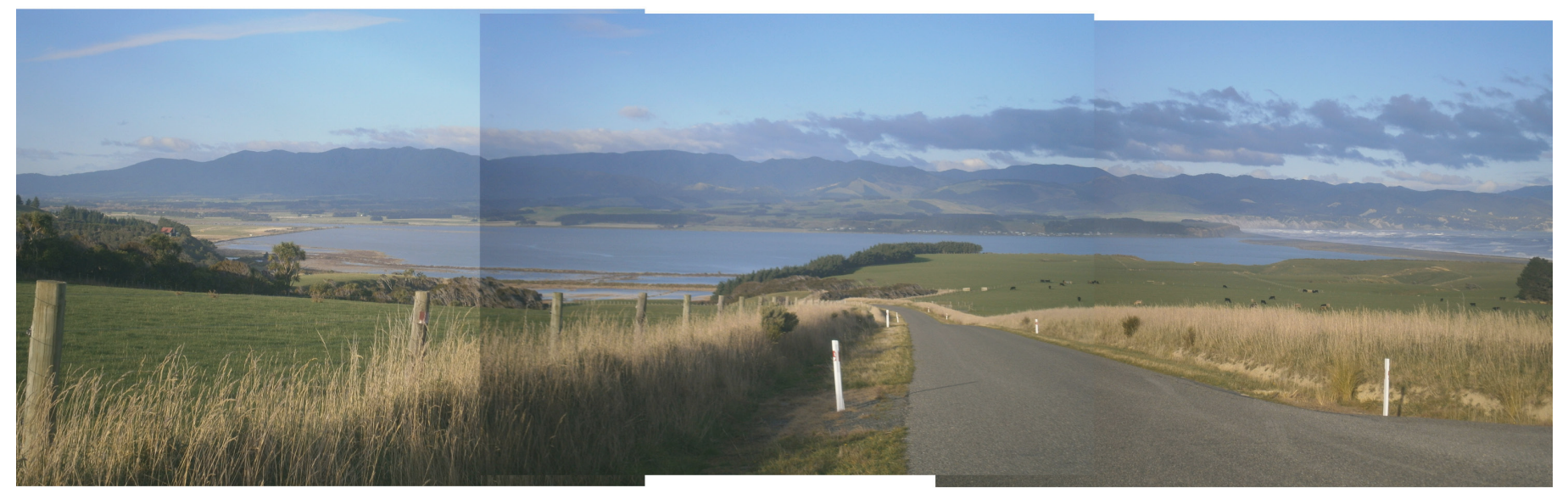

Fig. 6.83. The view from the road adjacent to the viewpoint site.

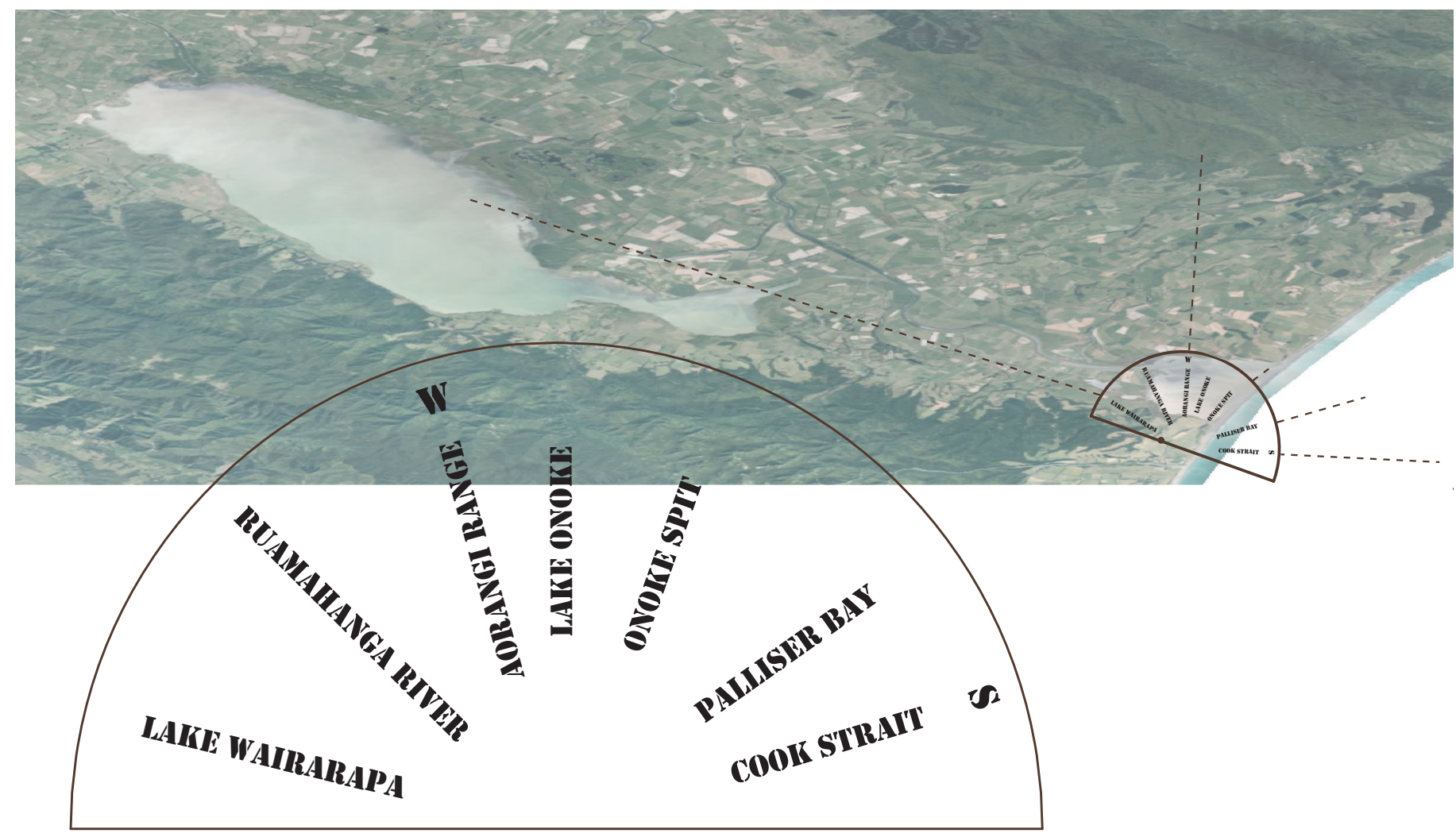

Fig. 6.84. The corten steel sign with names cut into it. The aerial image above indicates the water bodies it points to and

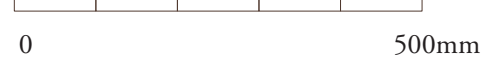
shows the water's journey seawards. 
corten steel sign with place names cut into it, fixed with stainless steel coach screws to timber

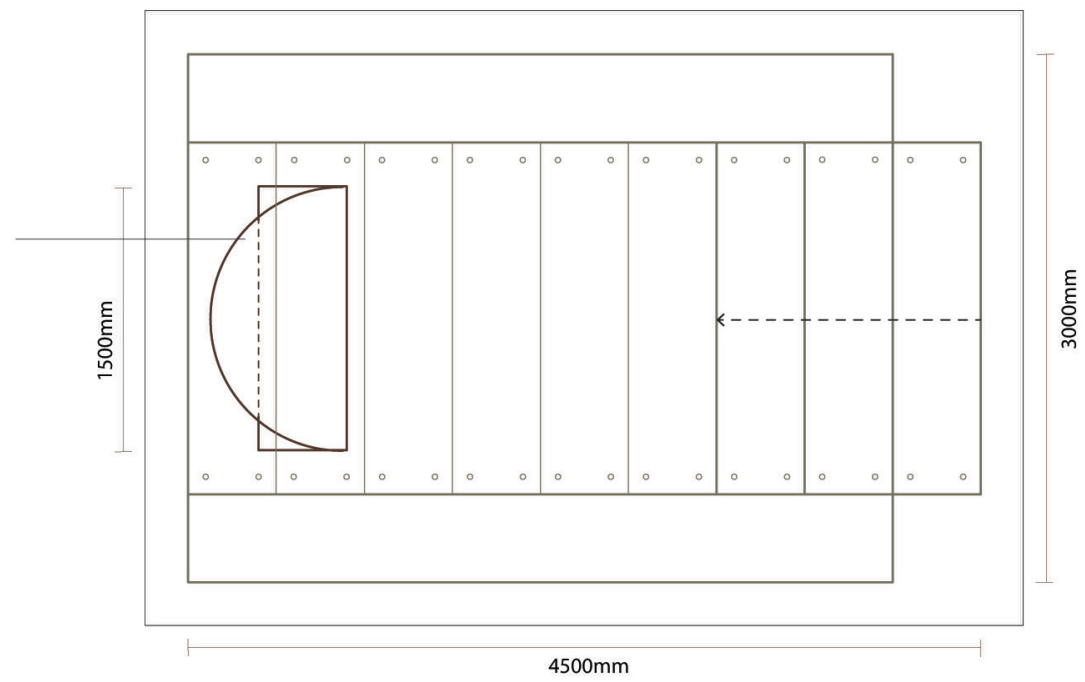

locally sourced macrocarpa timber, fixed together with countersunk coach screws, holes filled with Sika EVERBUILD ${ }^{\circ} 2$ Part High Performance Wood Filler

concrete footing to be specified by engineer

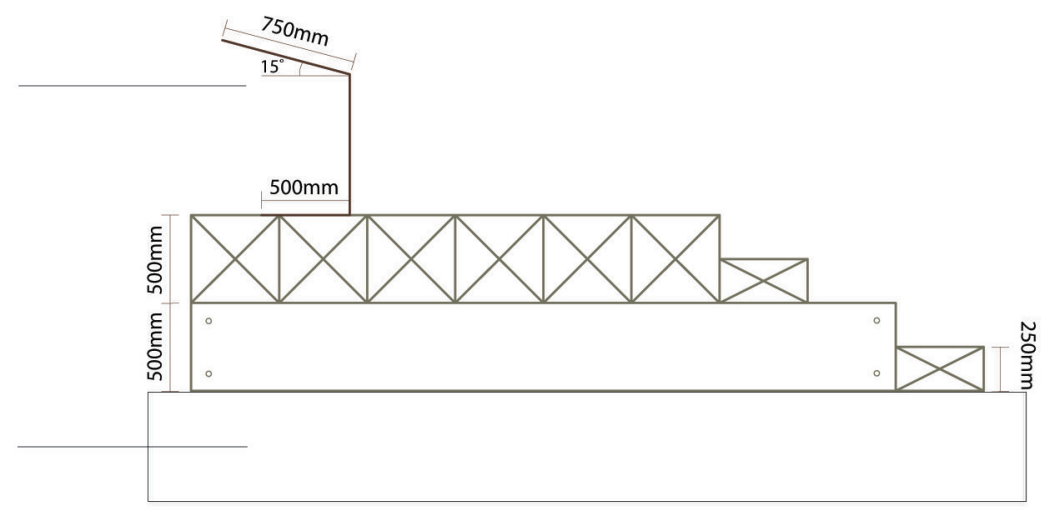

$8 \mathrm{~mm}$ corten steel sign

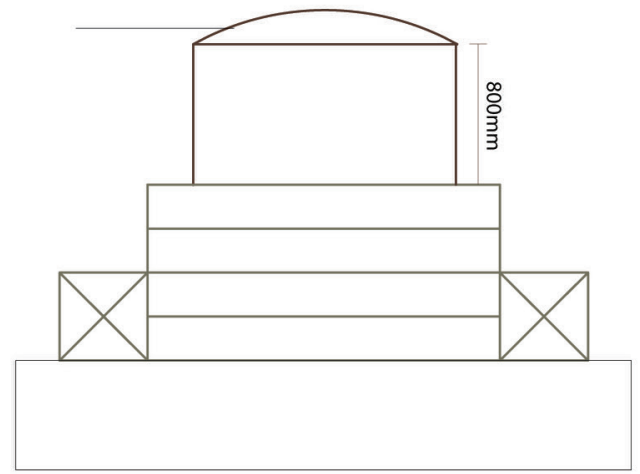

Fig. 6.85. Plan and elevations of Wharekauhau Road Viewpoint.

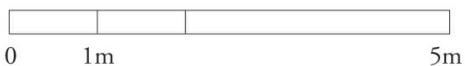




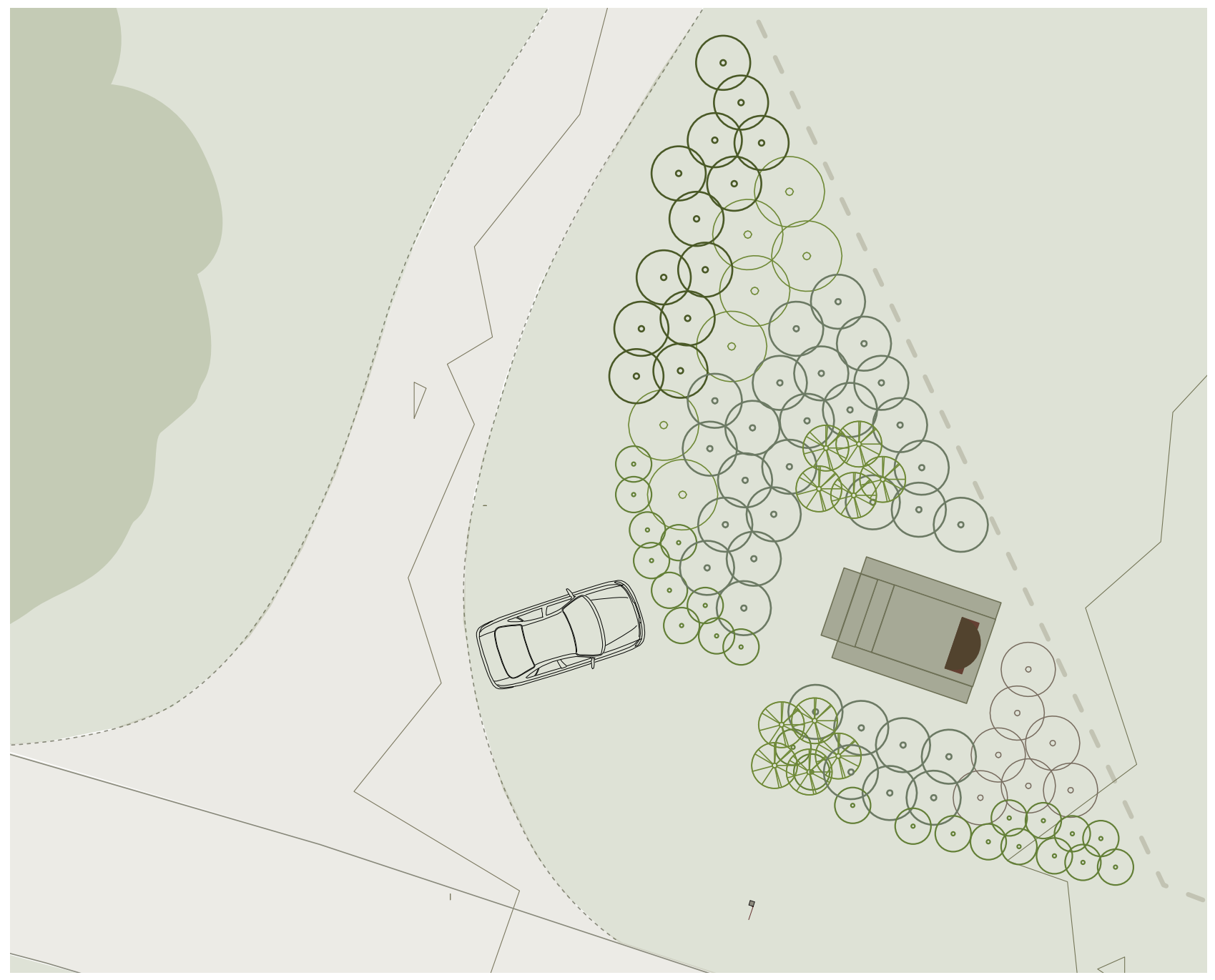

Key:

Fig. 6.86. Planting Plan for the Wharekauhau Road Viewpoint.

Cordyline australis, ti kōuka

(2) Leptospermum scoparium, mānuka

(3) Coprosma crassifolius

(4) Helicrysum lanceolatum, niniao

(5) Plagianthus divaricatus, mākaka

(6) Melicytus crassifolius

घ trail marker

existing trees

existing $1 \mathrm{~m}$ contour lines

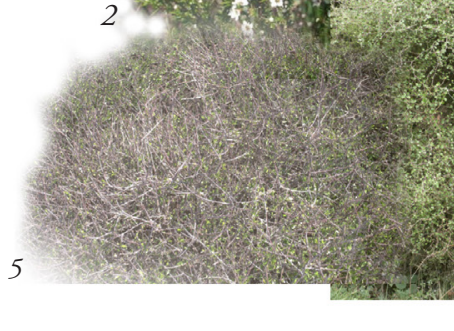

3

Fig. 6.87. Planting collage for the Wharekauhau Road Viewpoint. 


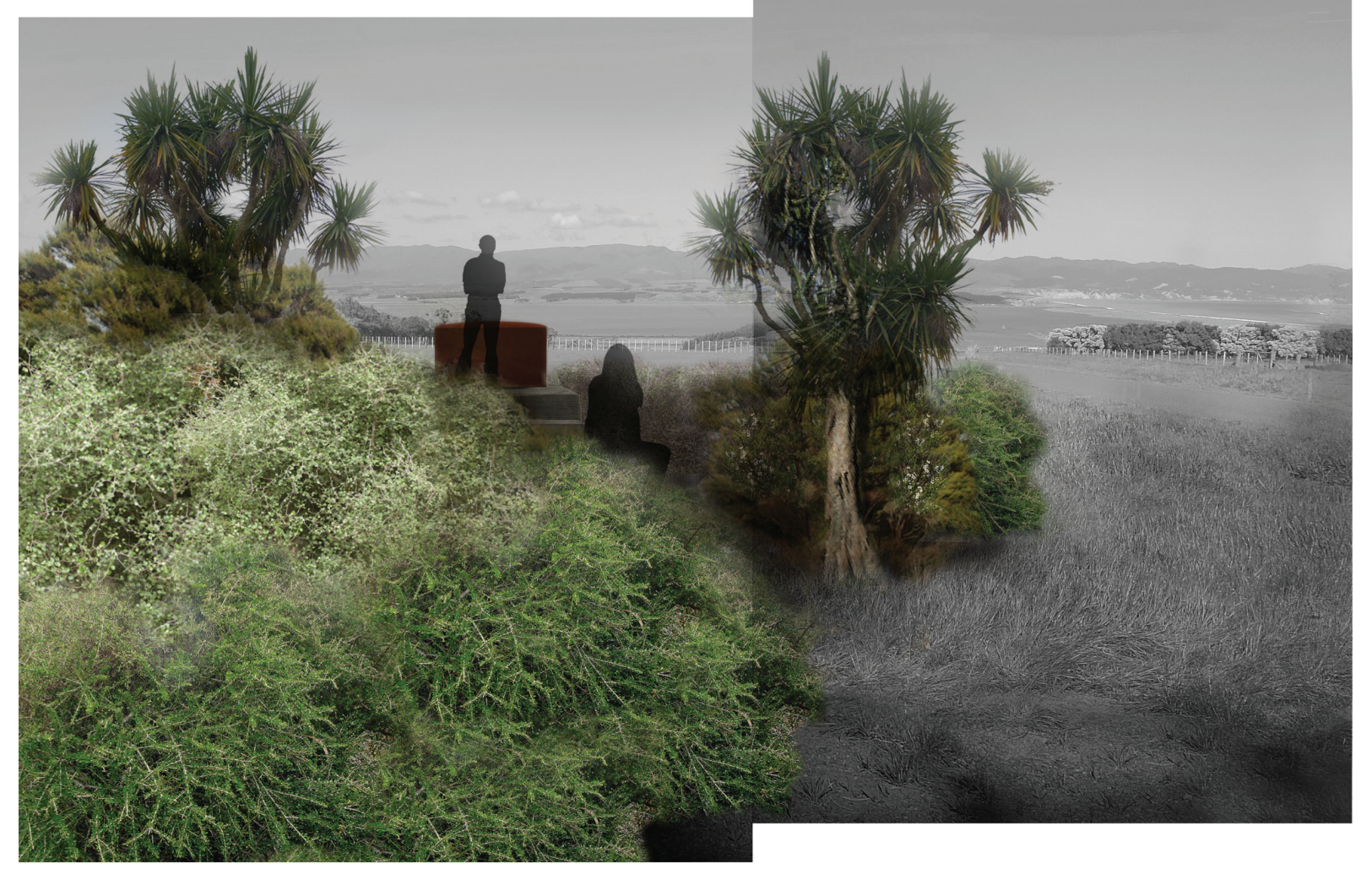

Fig. 6.88. The Wharekauhau Road Viewpoint.

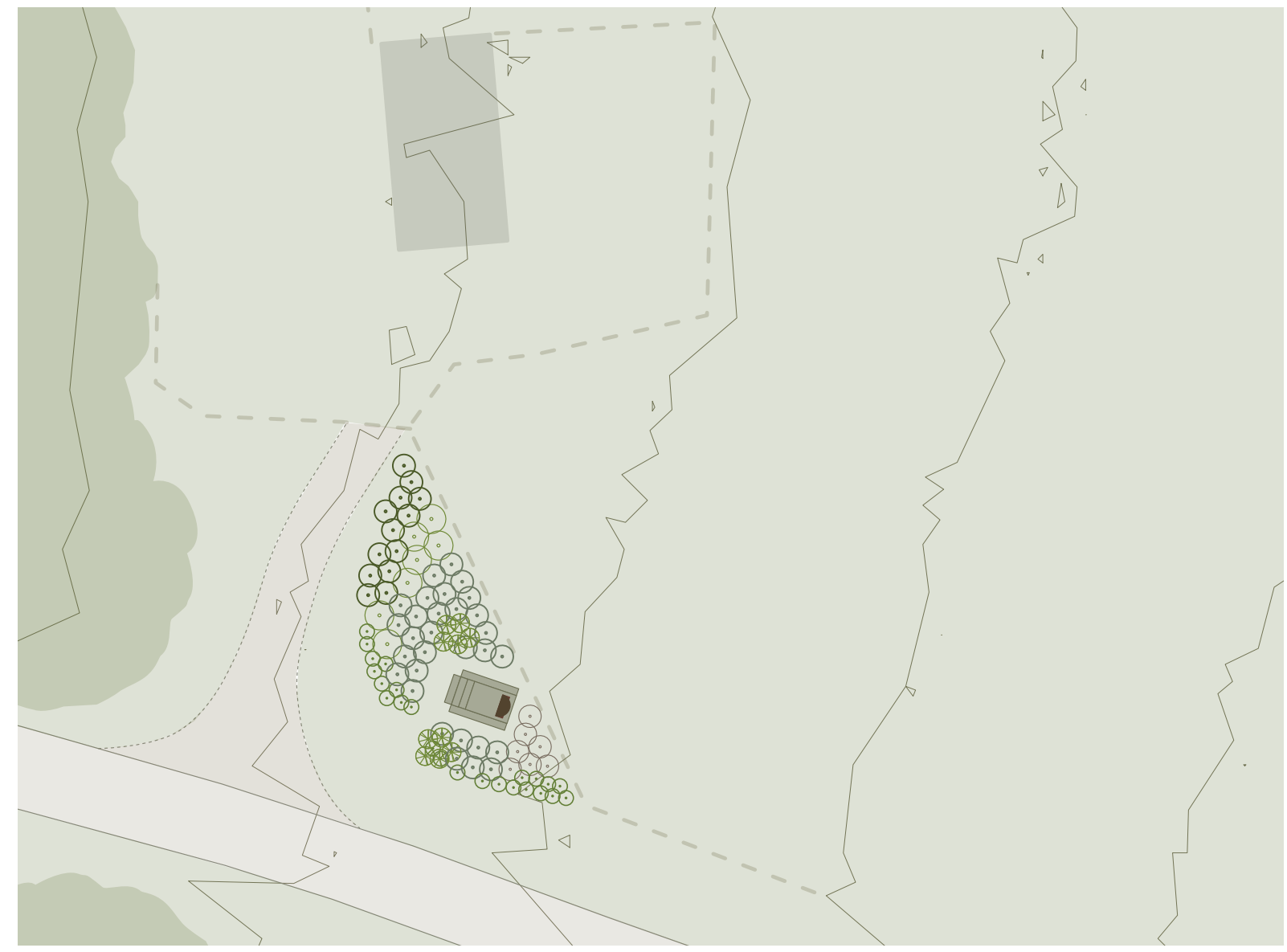

Fig. 6.89. Plan showing location of the Wharekauhau Road Viewpoint.

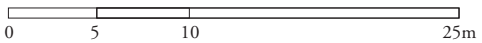


Waiorongomai Church
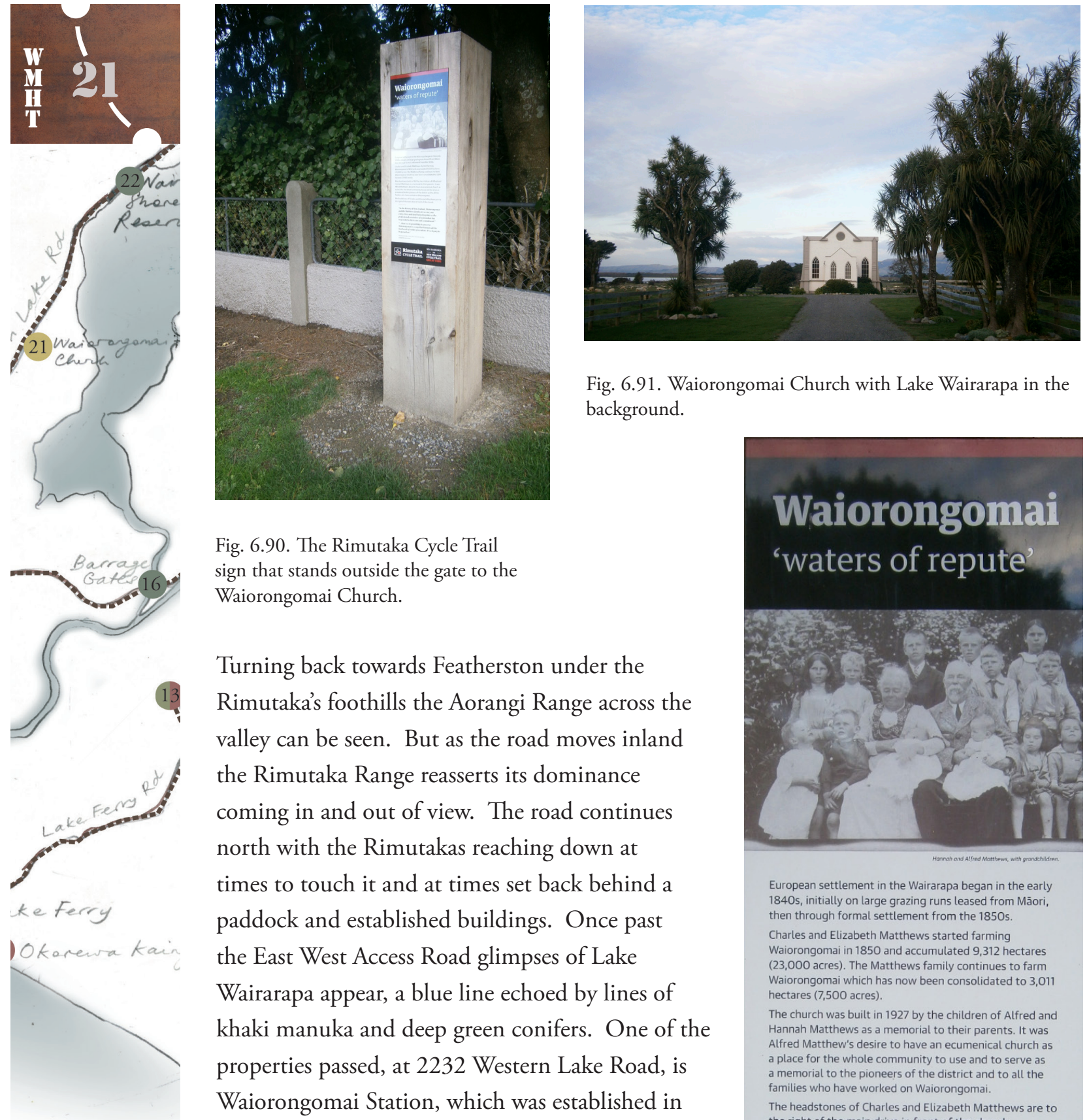

Fig. 6.91. Waiorongomai Church with Lake Wairarapa in the background.

Fig. 6.90. The Rimutaka Cycle Trail sign that stands outside the gate to the Waiorongomai Church.

Turning back towards Featherston under the

Rimutaka's foothills the Aorangi Range across the valley can be seen. But as the road moves inland the Rimutaka Range reasserts its dominance coming in and out of view. The road continues north with the Rimutakas reaching down at times to touch it and at times set back behind a paddock and established buildings. Once past the East West Access Road glimpses of Lake Wairarapa appear, a blue line echoed by lines of khaki manuka and deep green conifers. One of the properties passed, at 2232 Western Lake Road, is Waiorongomai Station, which was established in 1850. A kilometre to the north of the homestead is Waiorongomai Church (see fig. 6.91). The

Fig. 6.92. Marker and location on Trail Map for Site No. 21.

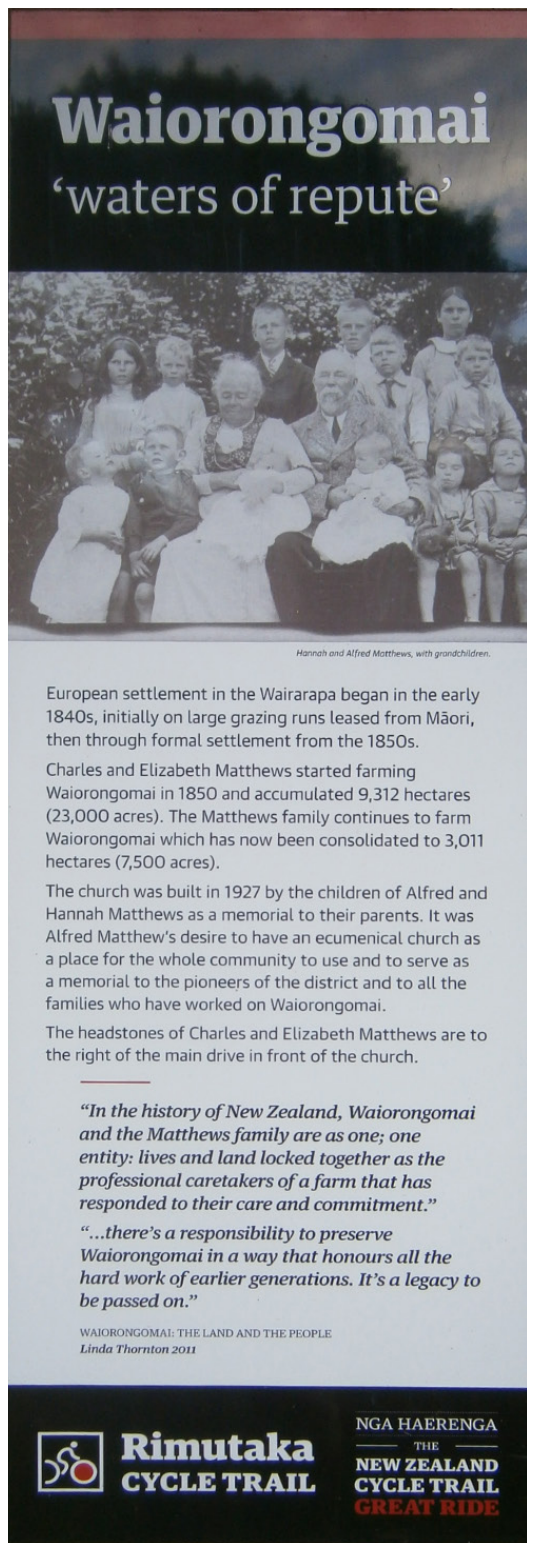

Rimutaka Cycle Trail sign tells something of the story of the Matthews family and its deep and long connection to this land (see figs. 6.90 and 6.93).

Fig. 6.93. A closer view of fig. 6.93. 
Wairarapa Lake Shore Scenic Reserve (WMWP)

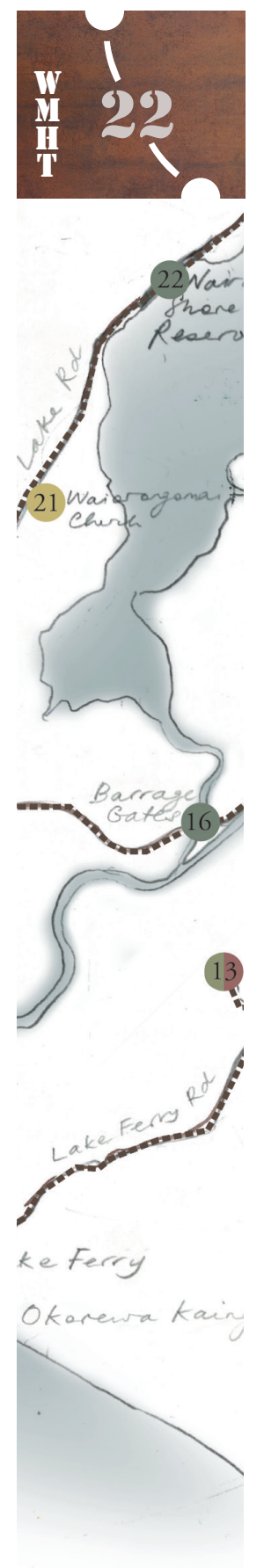

Fig. 101. Marker and location on Trail Map for Site No. 22.

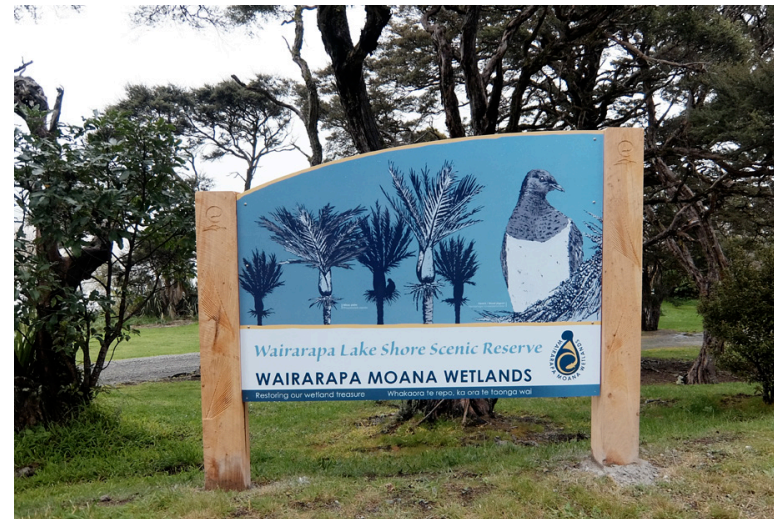

Fig. 6.94. This WMWP sign depicts kererū and nīkau.

Traveling along the road north of the church the lake edges closer. The dark bush clad hills move closer too until they seem to cross over the road, touching the lake edge, with the narrow road forcing its way through. Where the vegetation is most dense is the Wairarapa Lake Shore Scenic Reserve. The sign for the reserve shows two species that strongly feature there, the nīkau, Rhopalostylis sapida, and kererū or New Zealand pigeon, Hemiphaga novaeseelandiae (see fig. 6.94). 


\section{Cross Creek, Rimutaka Incline Rail Trail Historic Area}

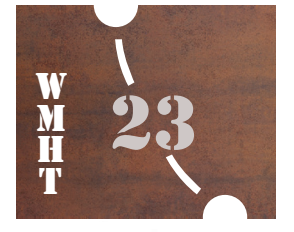

Rimutake Cneh Race Trace Hutenic Area f. interpineted - Crossereek a. $23=\cdots+\cdots$ (2)

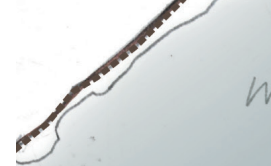
airorapa lake une ficuic. ure

Op

Waino Block

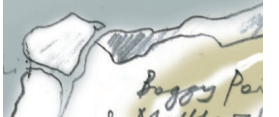
\& Matthers Wudefe Res
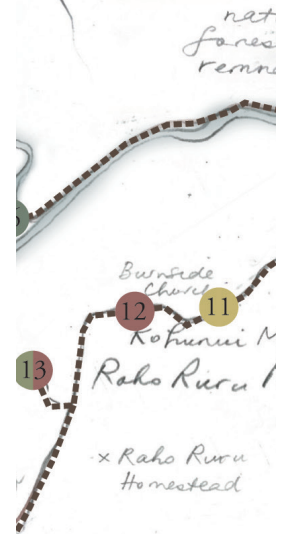

Fig. 6.96. Marker and location on Trail Map for Site No. 23.

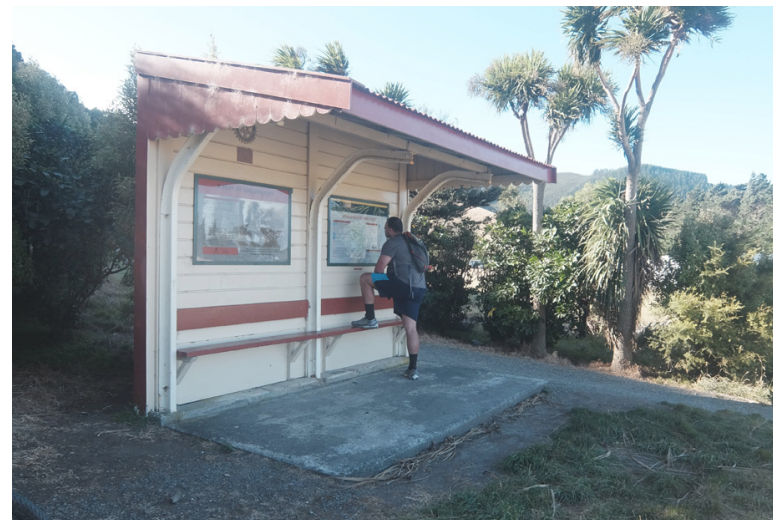

Fig. 6.95. Information panels are displayed in a railway station-like structure at the start of the trail.

As the road continues north the hills and the lake edge separate. A side road to the left, after passing a scattering of houses, leads to the start of the walking and cycling track to Cross Creek and the Rimutaka Incline Rail Trail, which is part of the Rimutaka Cycle Trail (see fig. 6.95). "A gently graded $18 \mathrm{~km}$ walk or mountain bike ride, the Trail features restored railway bridges and historic tunnels" (Rimutaka Rail Trail). Cross Creek Station shown in figures 6.97 6.99 is "A registered Historic Site ... once occupied by several cottages, a hall, school, library, locomotive depot and a turntable" (Rimutaka Rail Trail). The walk from the end of the road to Cross Creek takes about 30 minutes.

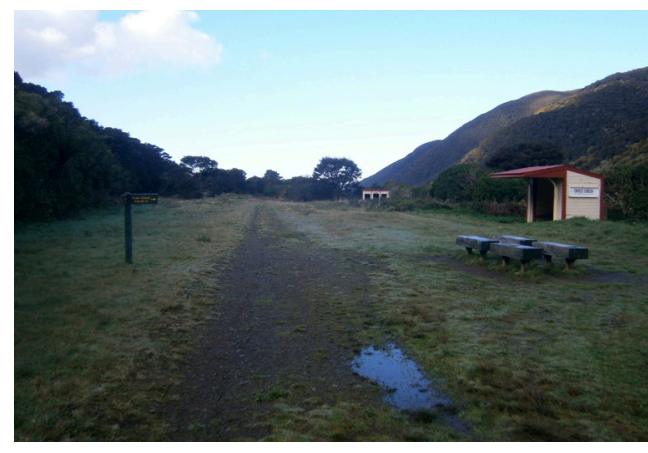

Fig. 6.97. Cross Creek Station.

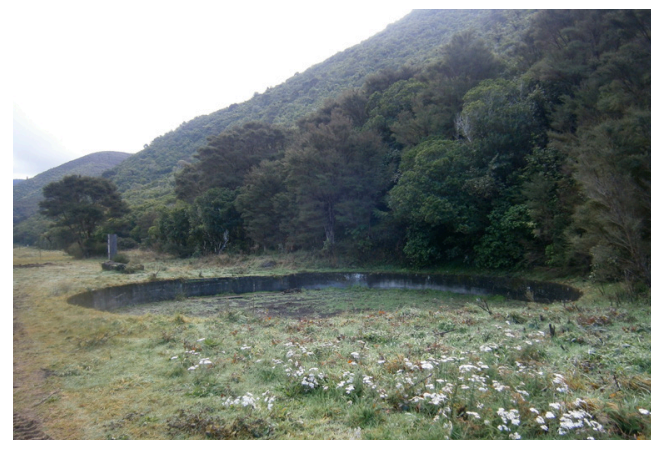

Fig. 6.98. The remnants of Cross Creek turntable.

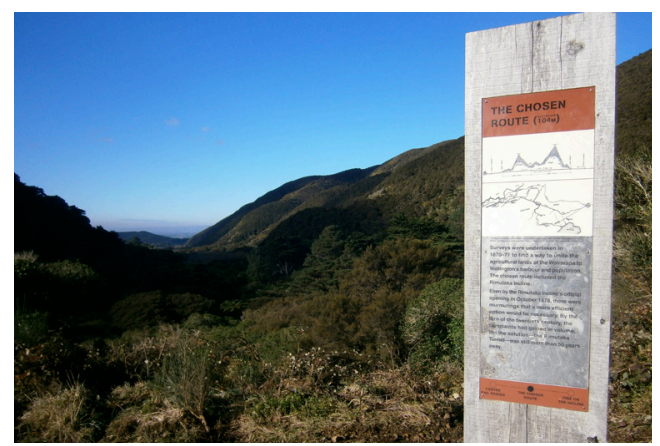




\section{Tipapaku (Pigeon Bush) Picnic Area}

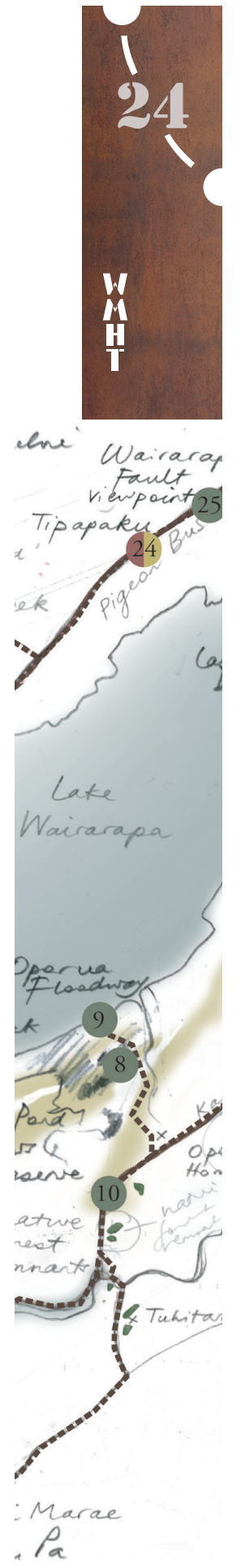

Fig. 6.100. Marker and location on Trail Map for Site No. 23.

A metre wide off-road lime chip trail was recently laid for cyclists alongside the eastern side of Western Lake Road to connect the Rimutaka Cycle Trail to Featherston. Heading north, $3 \mathrm{~km}$ after Cross Creek, a disused road branches off the western side of the road at an oblique angle and runs parallel to it for 200 metres. This road was once the main road that deviated to skirt the Pigeon Bush Railway Station. On 18th January 1896 local Māori invited politicians and local Pākehā to a hākari Fat Tipapaku (Pigeon Bush) to mark the gifting of Wairarapa Moana by iwi to the Crown. "Local settlers duly hosted a return 'picnic' for Māori two weeks later at the same place, which was an even larger affair and which was also attended by Seddon and Carroll" (Stirling and Barnett). Māori were promised their fishing rights would be protected and reserves set aside for them. However, these promises were not honoured.

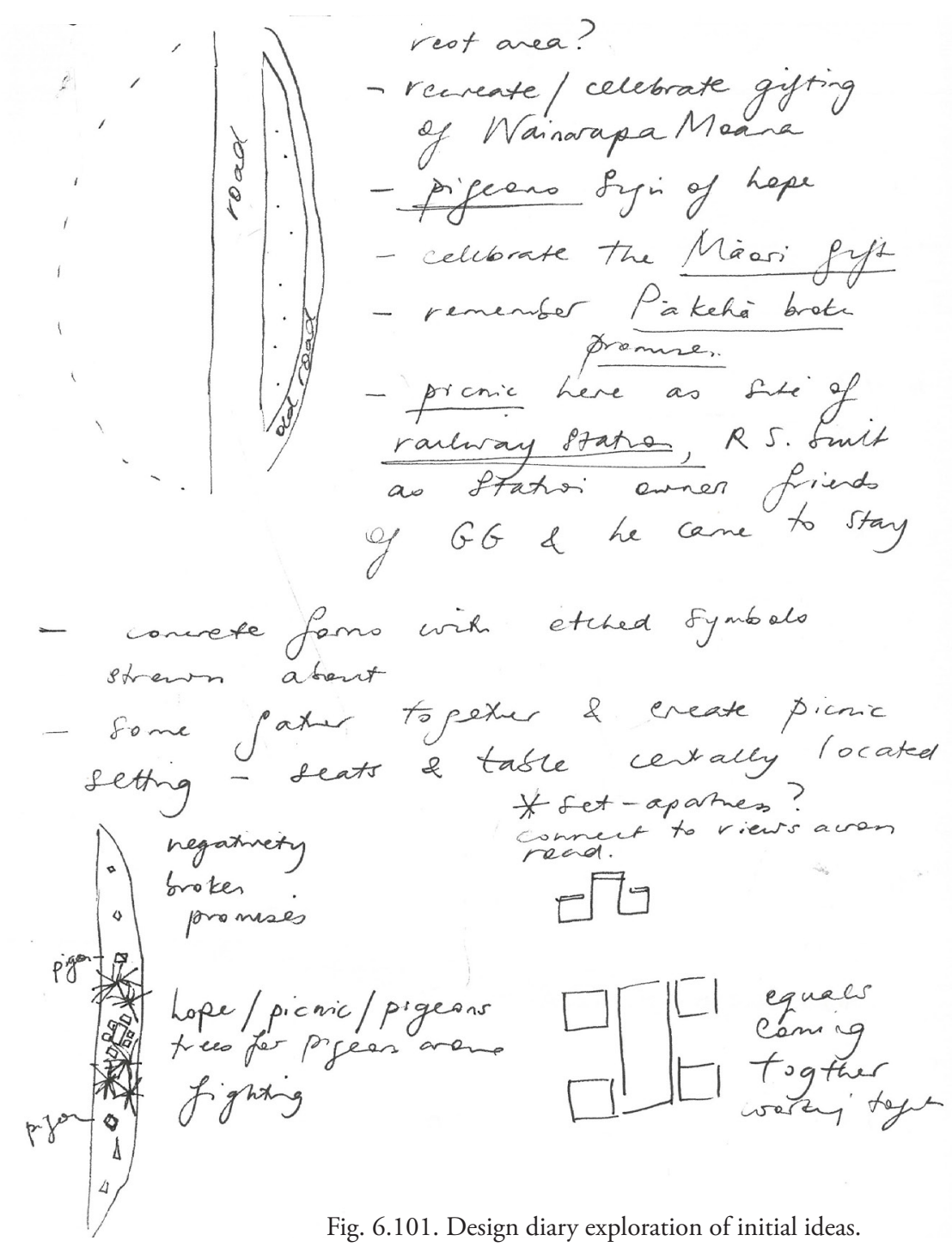


A picnic area has been designed for the strip of land enclosed by the old and present road (see figs. 6.101 - 6.109). Native plants that kererū, wood pigeon, feed on, are planted to attract these birds whose presence is seen by iwi as tohu. The researcher has driven along this road often accompanied by the swoop of kererū, particularly when vegetation is close - this has given much pleasure and indeed felt like a good sign. Rob McGowan's words, that birds are the voice of the landscape, ring true.

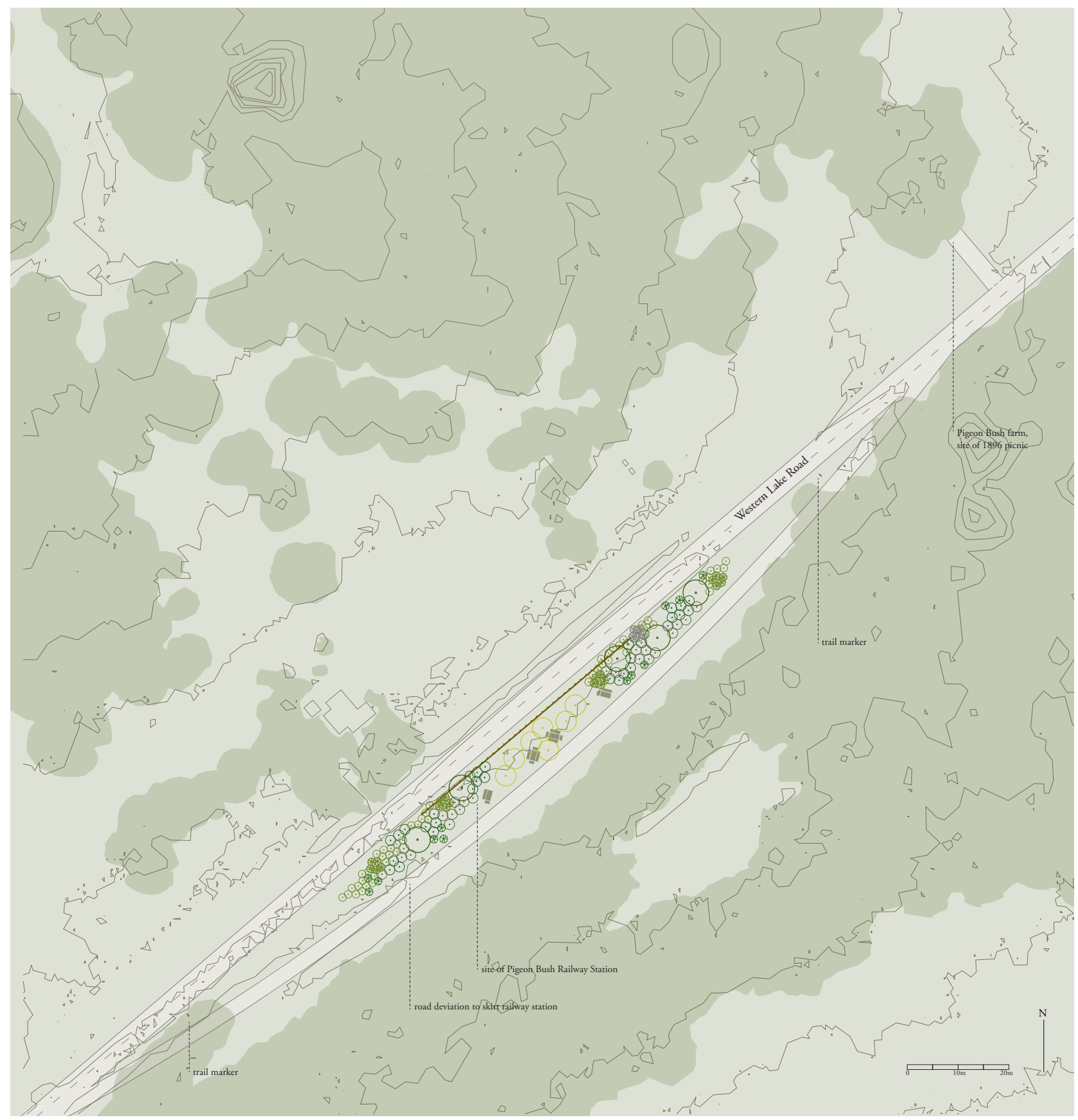

Fig. 6.102. This plan shows the relationship between the intervention, planting and the adjacent landscape spaces. 


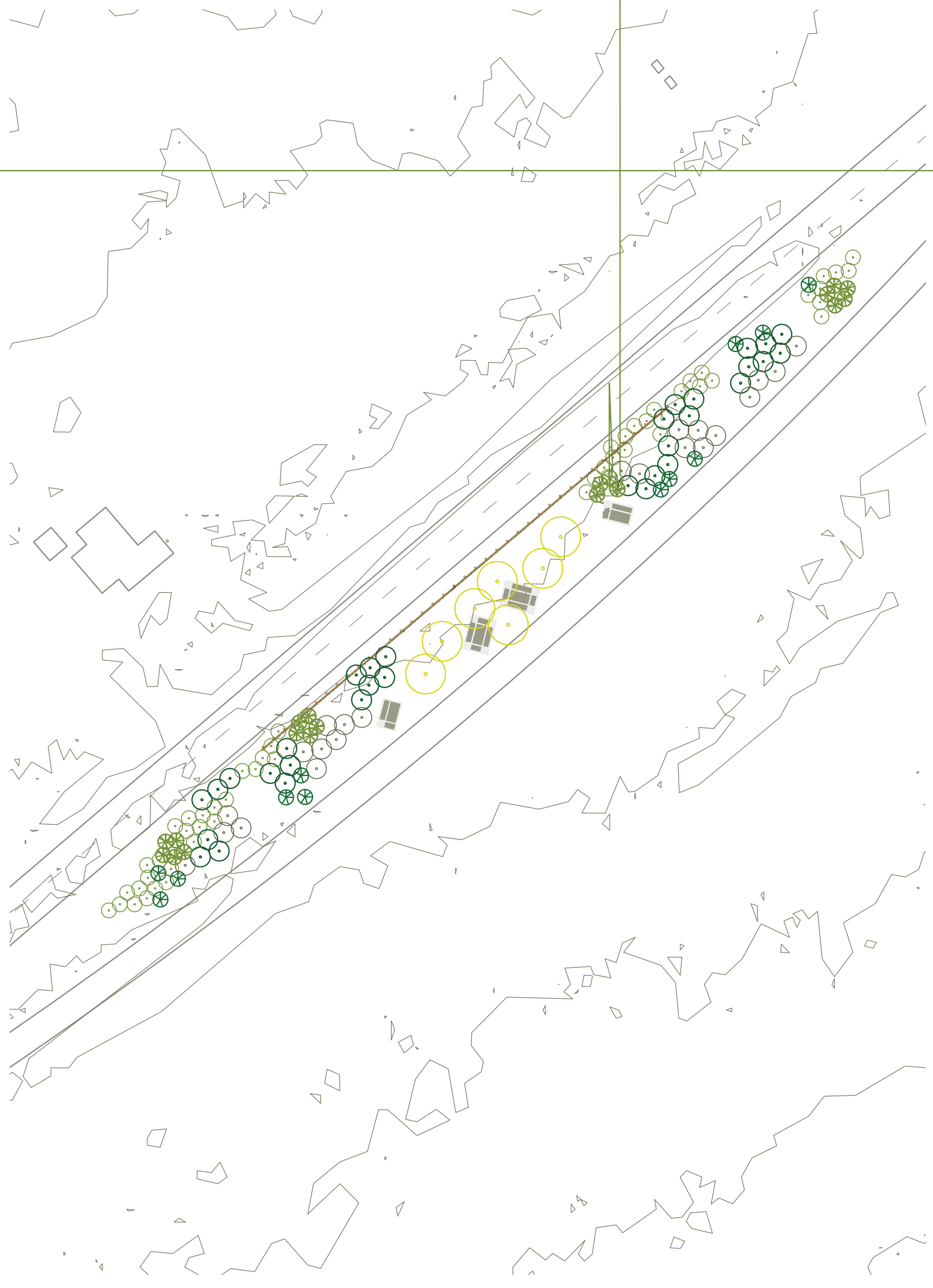




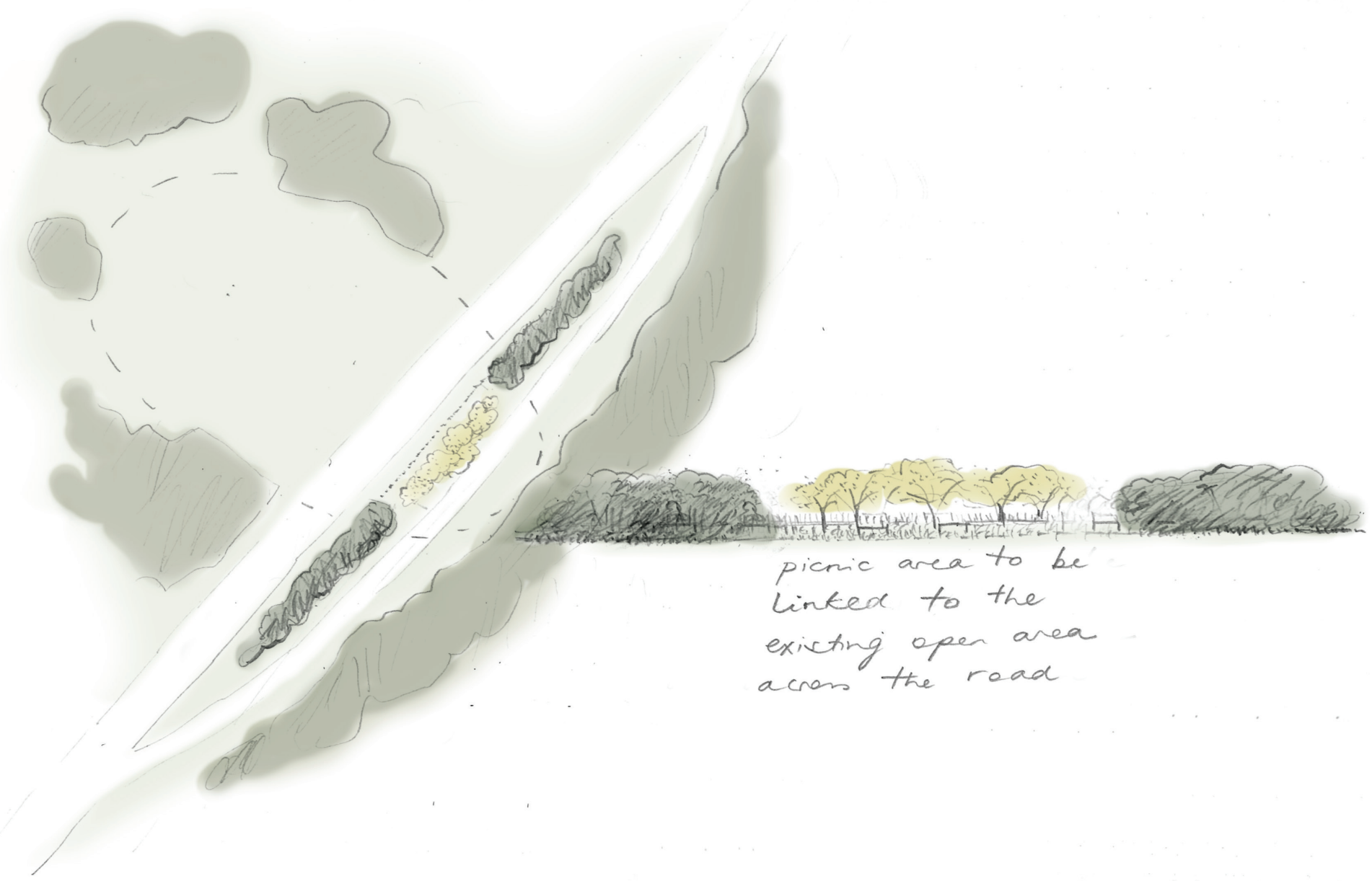

Fig. 6.104. Design development sketch.

Of the four picnic tables only the central ones have seats all around them to represent a new coming together of Māori and Pākehā. A palisade-like fence made of local manuka bridges the gap, literally and figuratively, between the two dense groups of vegetation as well as providing a barrier between the picnic area and the road (see fig. 6.106). The picnic tables are under a gathering of kōwhai, whose golden blooms in spring are a sign of hope. This more open area contrasts with the dense bands of vegetation either side it, and connects to the open areas in the adjacent landscape (see figs. 6.102 and 6.104).

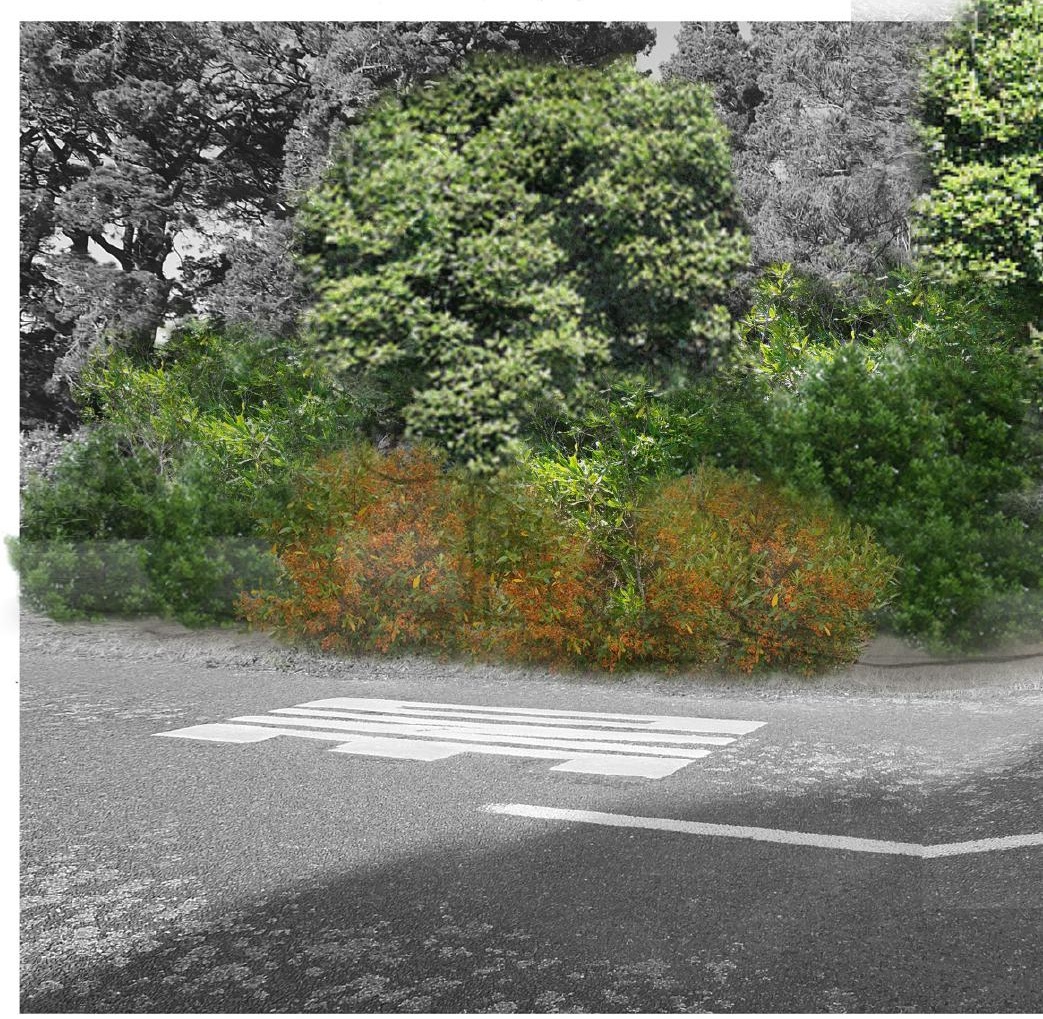




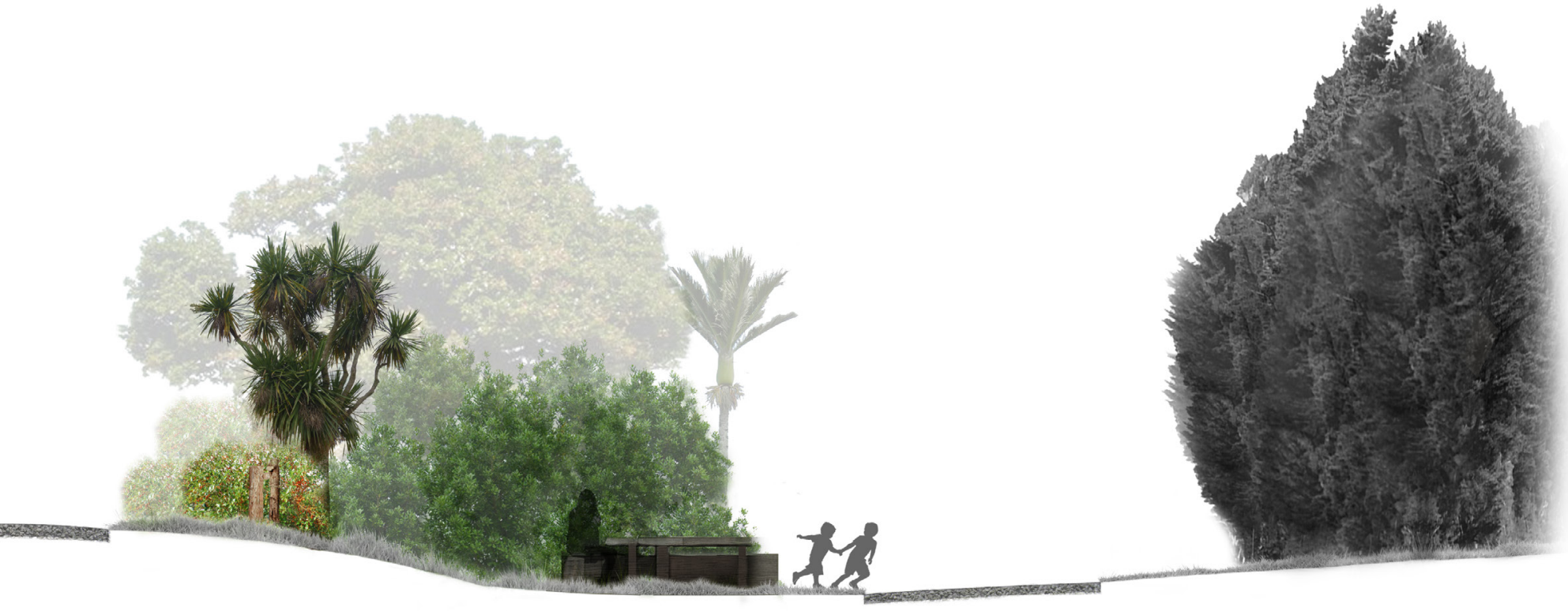

Fig. 6.105. Section Aa through the picnic area. Scale 1:100.

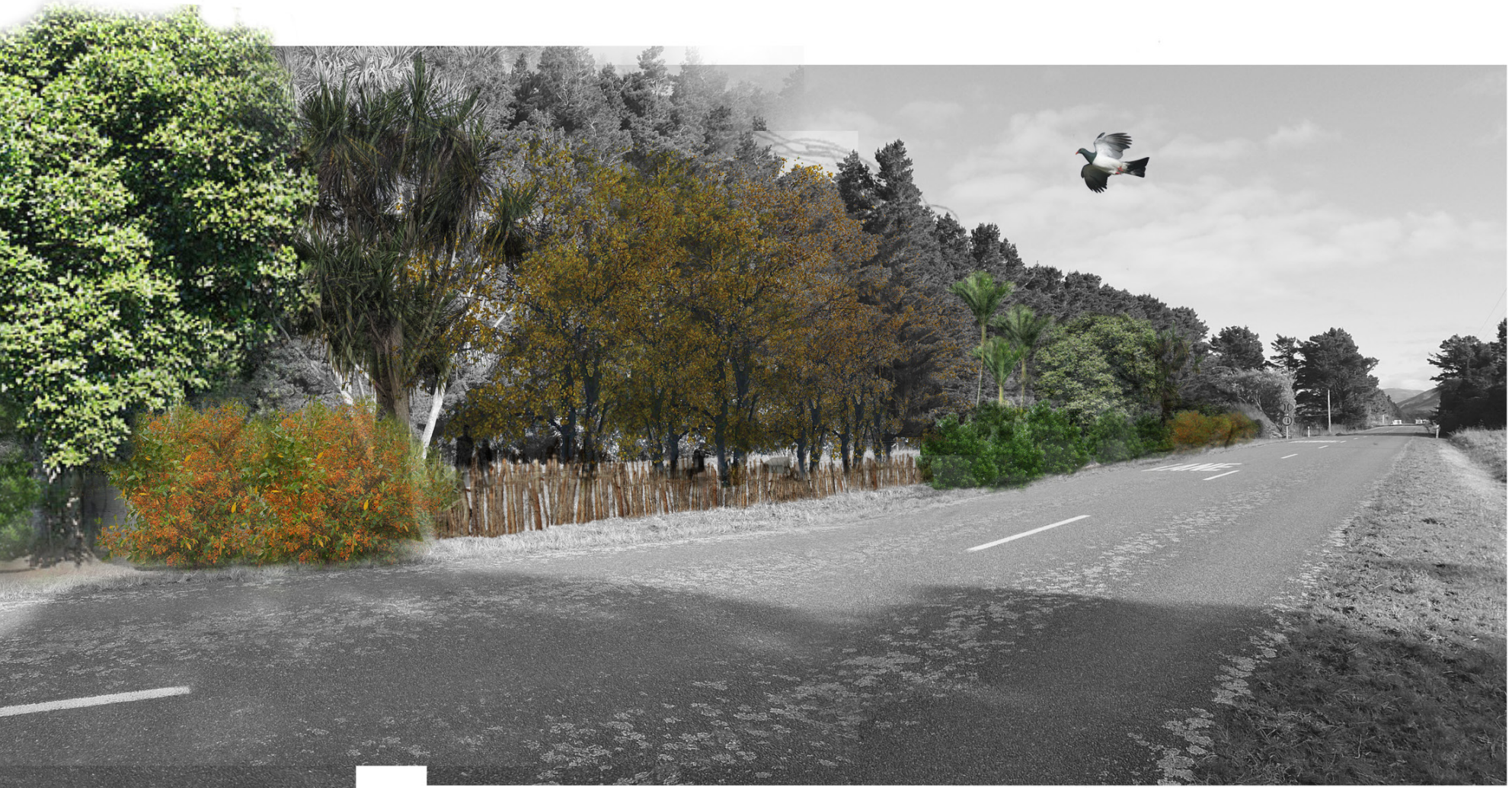

Fig. 6.106. Tipapaku (Pigeon Bush) Picnic Area viewed from Western Lake Road. 


\begin{tabular}{|llll}
\hline-4 & & \\
\hline 0 & & 0 & \\
\hline & & & \\
\hline
\end{tabular}
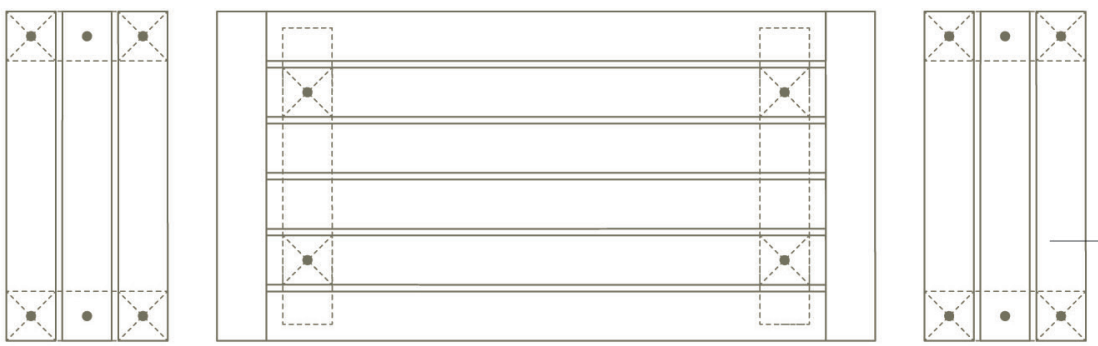

\begin{tabular}{|c|c|c|}
\hline$\circ$ & $\therefore$ & $\therefore$ \\
\hline$\bullet$ & - & • \\
\hline$\therefore$ & 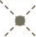 & $\because$ \\
\hline
\end{tabular}

locally sourced macrocarpa timber, fixed together with countersunk coach screws, holes filled with Sika EVERBUILD ${ }^{\circ} 2$ Part High Performance Wood Filler

concrete footing to be specified by engineer

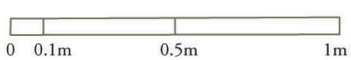

Fig. 6.107. Tipapaku (Pigeon Bush) Picnic area - plan view of table and bench seats.

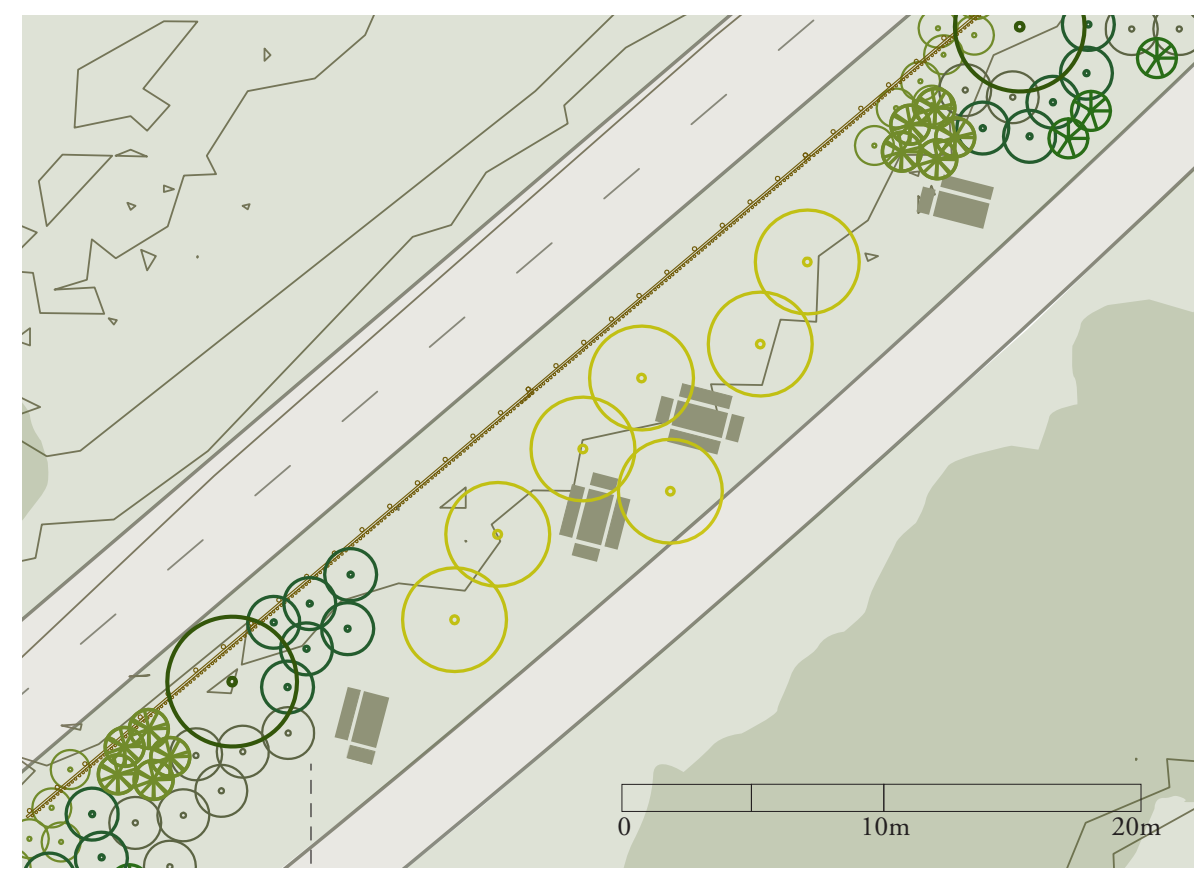

Fig. 6.108. Location of seating - the two outer tables have two benches. 


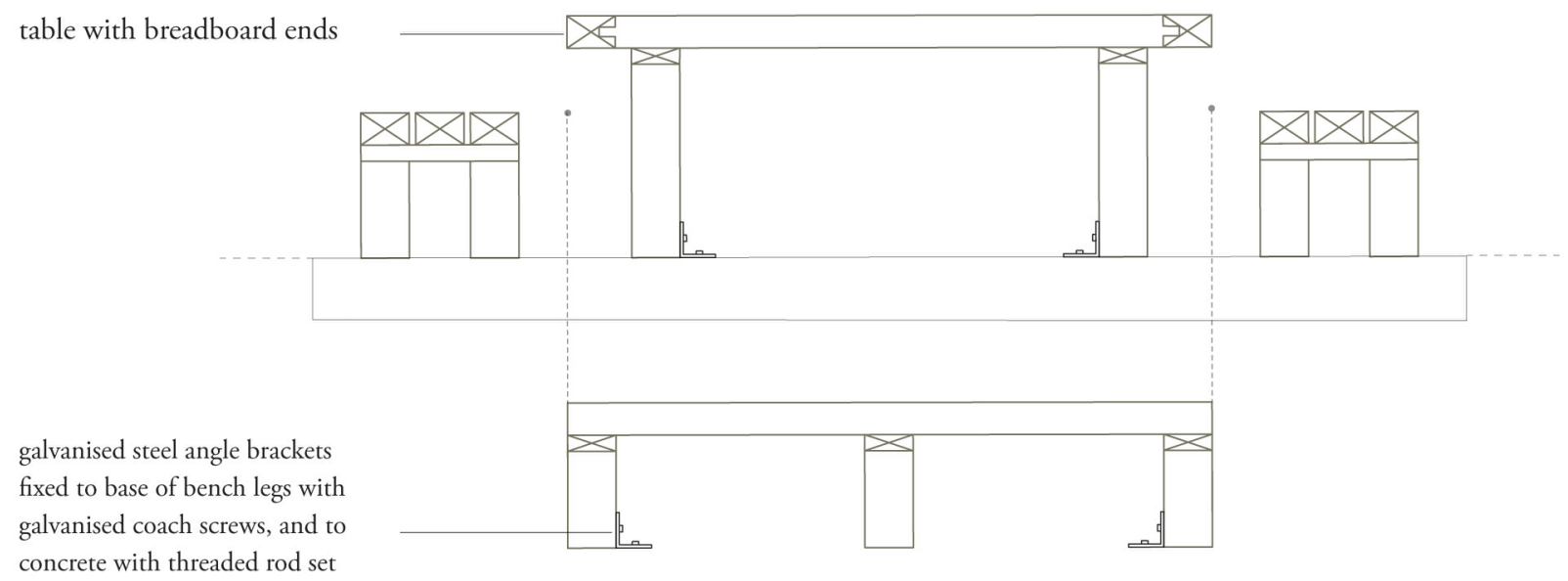
concrete with threaded rod set into concrete and bolts

Fig. 6.108. Tipapaku (Pigeon Bush) Picnic area - elevation with long side of table.

concrete footing to be specified by engineer

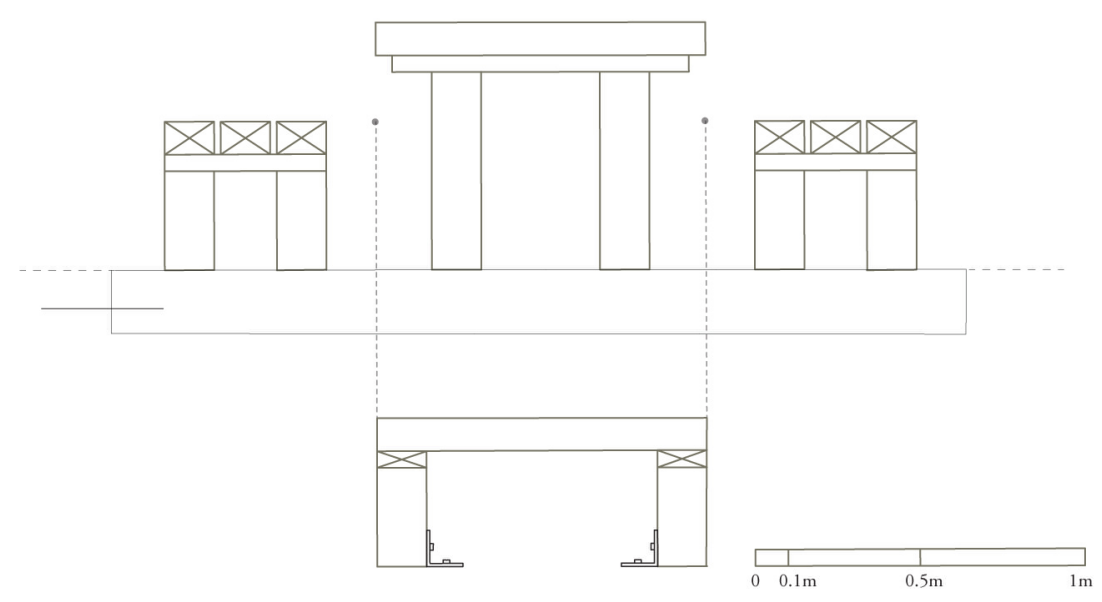

Fig. 6.109. Tipapaku (Pigeon Bush) Picnic area - elevation with short side of table. 


\section{Wairarapa Fault Viewpoint}
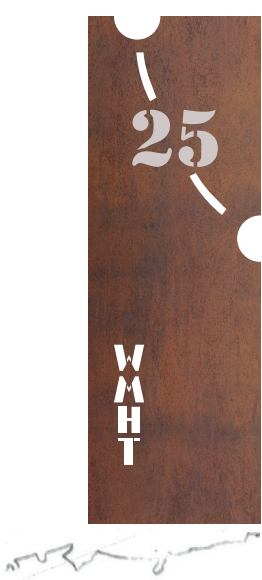

Feather

Cemet.
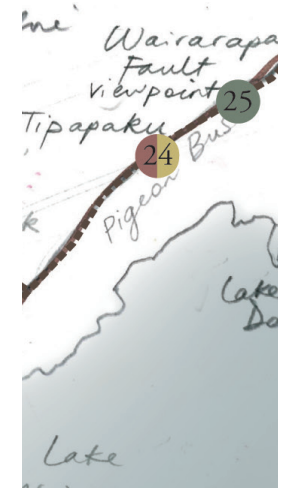

Vairarapa

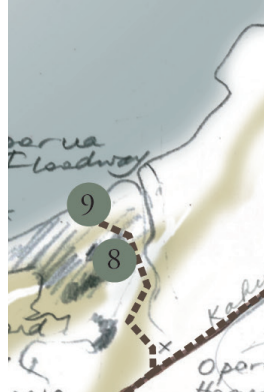

ene

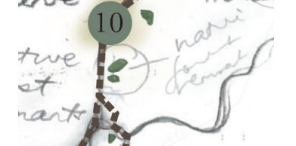

Tukitarax

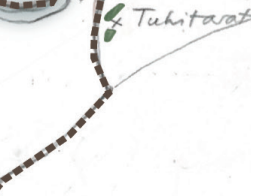

Marae

Pa

Fig. 6.111. Marker and location on Trail Map for Site No. 23.
After the picnic area the road straightens and begins to travel in parallel to the distinct line made by the transition from plain to foothills. This abrupt change in landform sits directly over the Wairarapa Fault, which is causing the shift of the mountains northward and the plain south (see fig. 6.110 - 6.117). The 1855 Wairarapa earthquake was along this fault. The intervention 1 kilometre from the Tipapaku (Pigeon Bush) picnic area seeks to echo the movement along the fault. The two walls are to be made from local stone. Their slope repeats the slope of the fault-formed landscape behind them (see figs. 6.115).

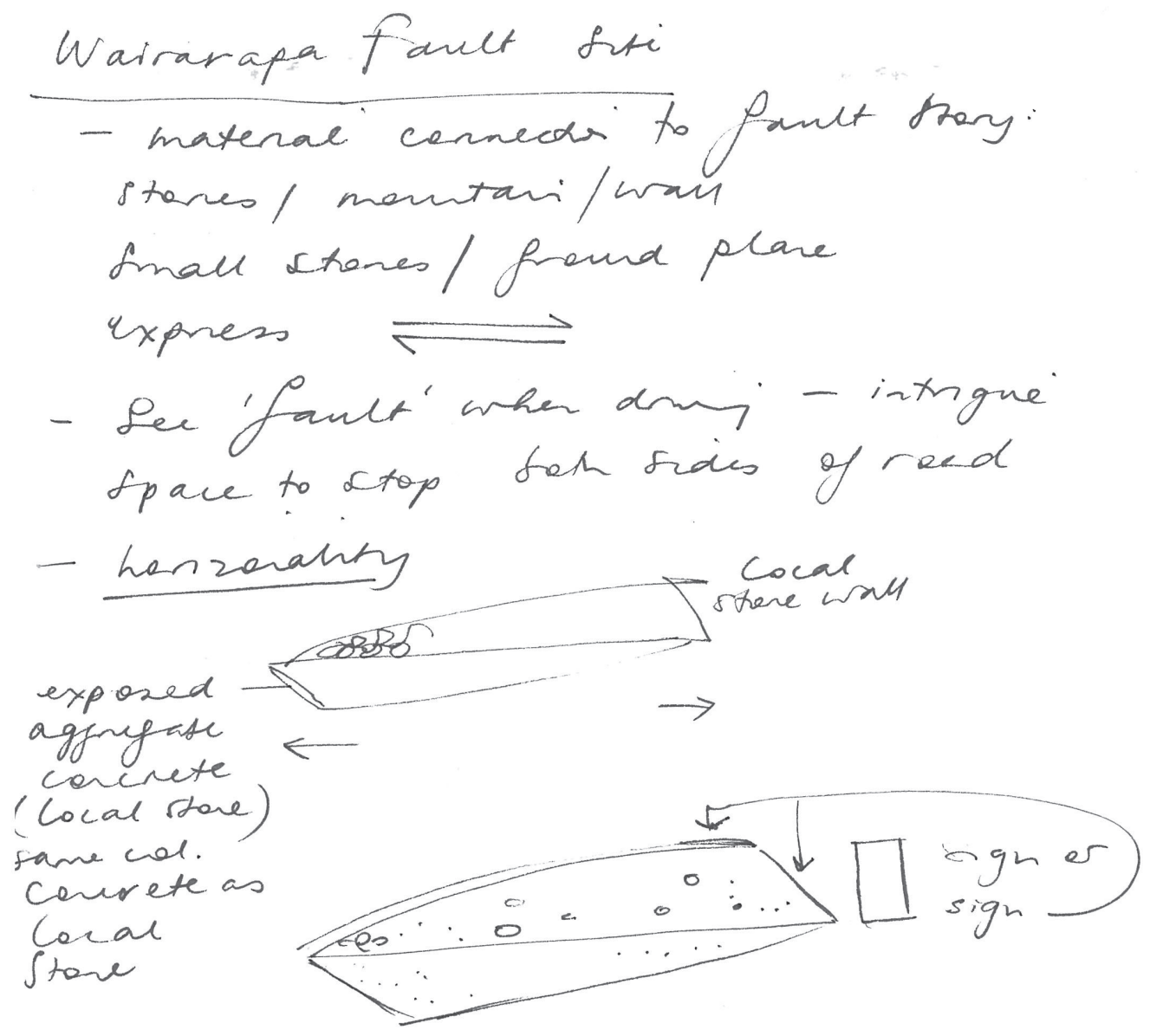

Fig. 6.110. Design diary exploration of initial ideas for interpreting Wairarapa Fault. 


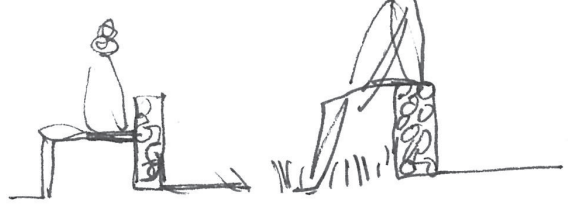

unterventi extur side of read

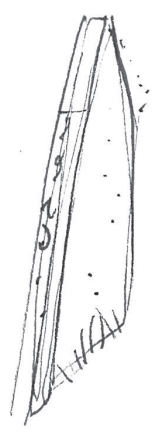

area franel pathici
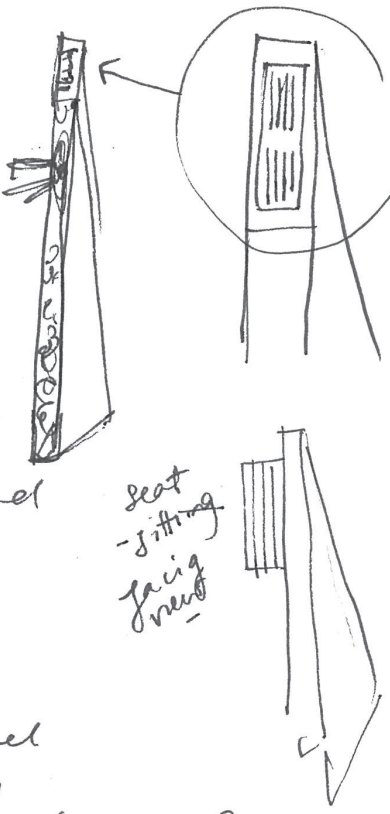

size of tins pak

$$
12 \times 12.5 \mathrm{~m}
$$

Finding = landiry 't frounding'

$\longrightarrow$ fault mavement

- plan \& mentan' meet

- fault where thy meet

- mantaris headij herm.

planis Eent

read

Safer en same fide Lajer seat? on Wrde
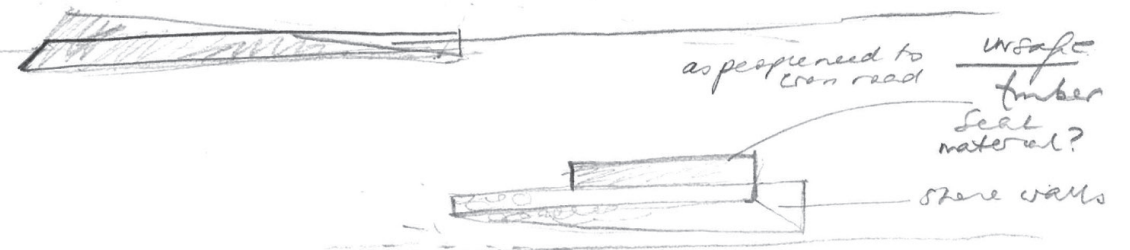

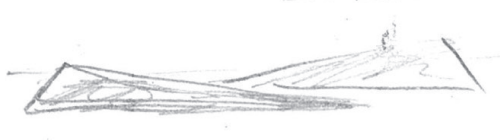

can wallo actracly do Semething.?

be semething mere -

- bamier for parked car run aloy.

lager rond

enen read?

mosaligned

plogue WAIRARAPA FANMT
Mired a i $N 2$

logest cq iano + heds meet

pinot hids meet earpark

need scaled drany' to corfer.

Fig. 6.112. Further design diary exploration.

169 


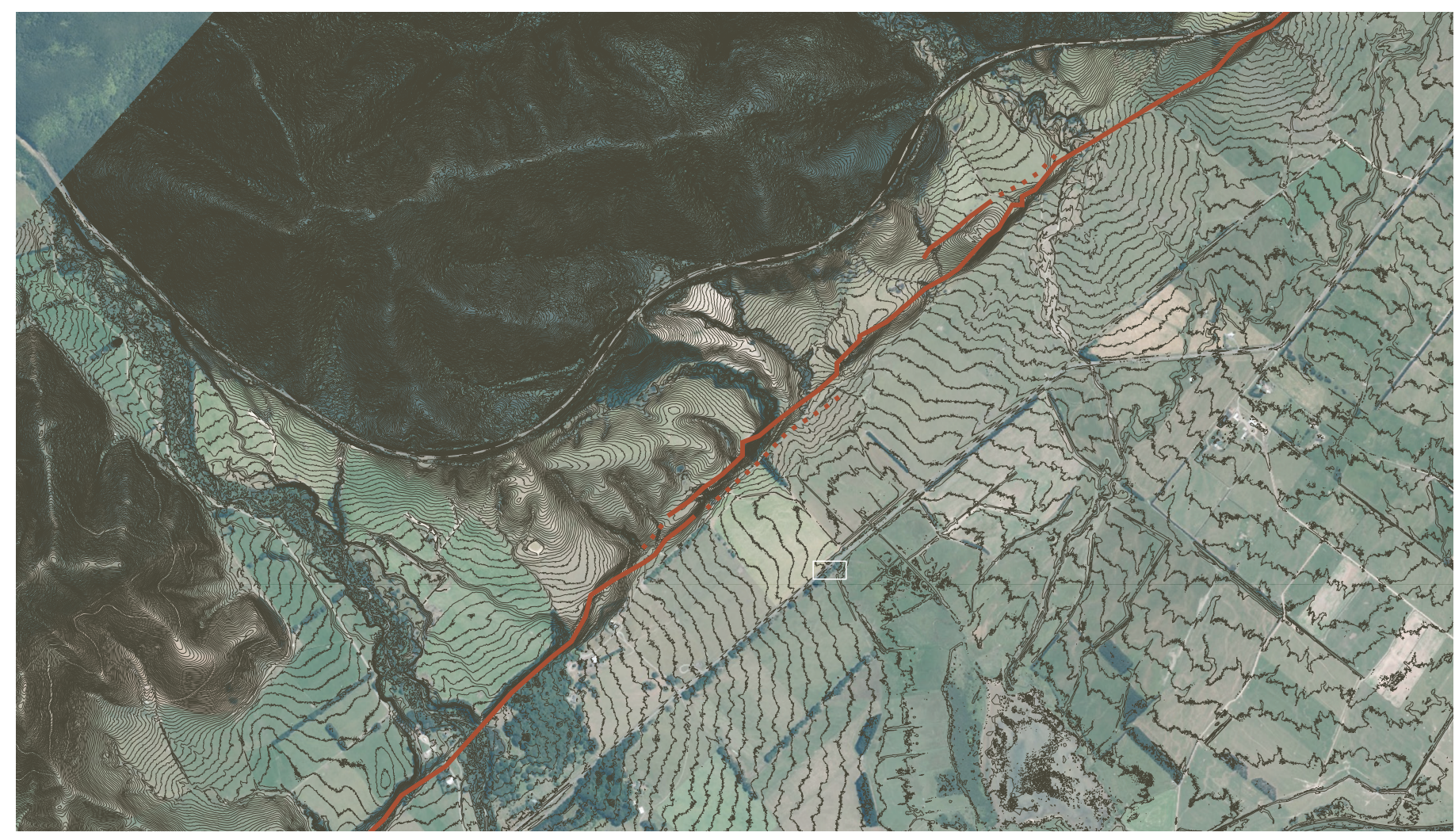

Fig. 6.113. The Wairarapa Fault and the location of the intervention.

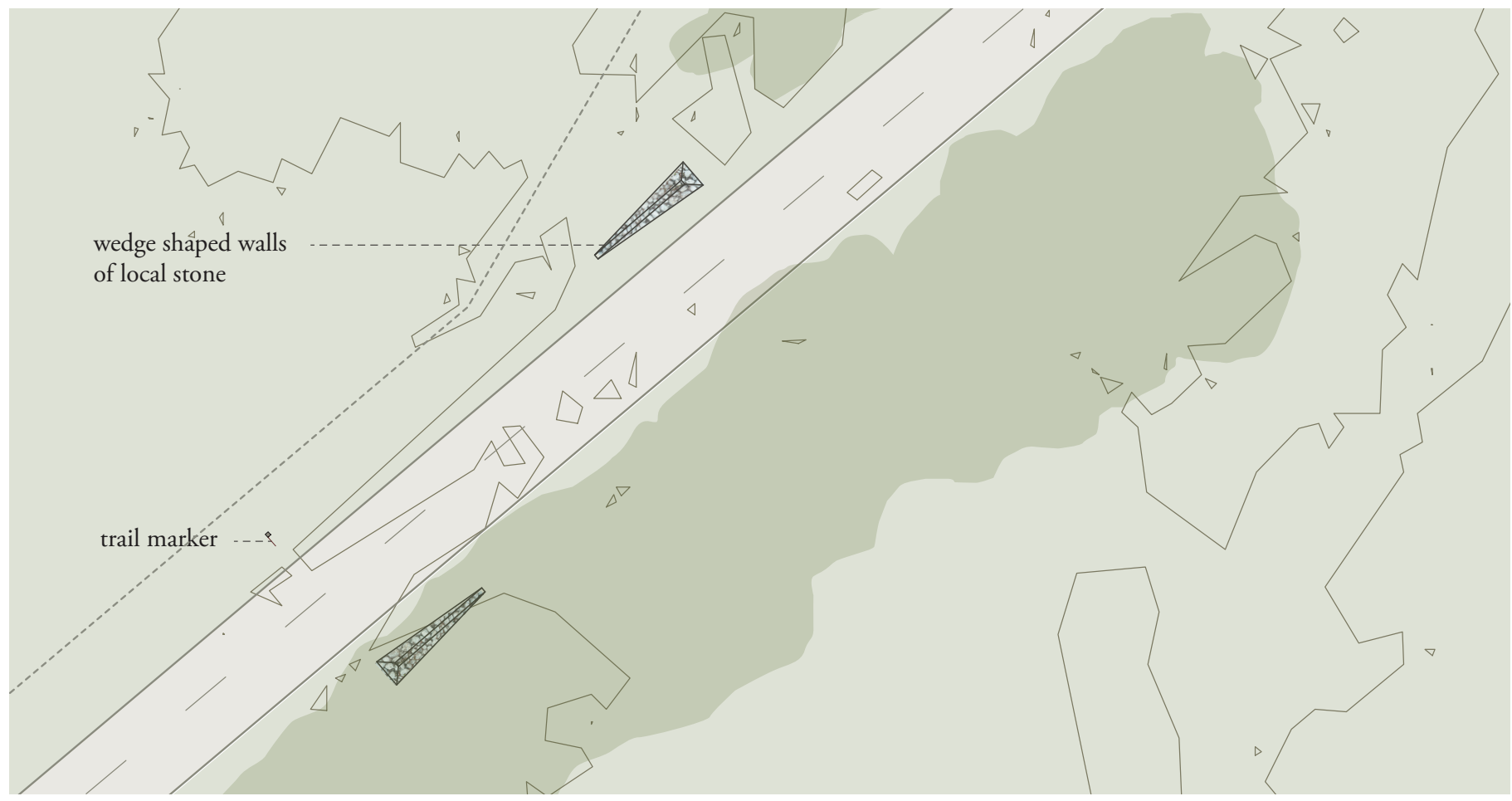

Fig. 6.114. Plan of the Wairarapa Fault Viewpoint.

Key:

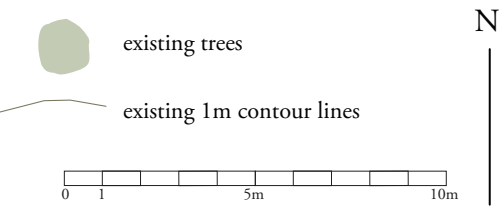




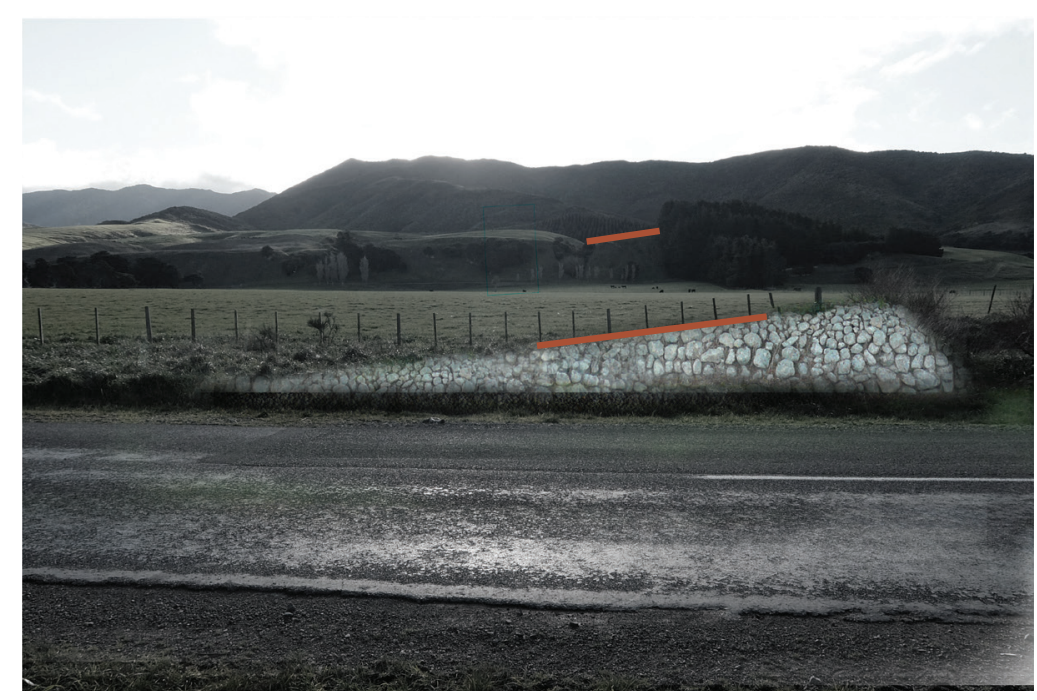

Fig. 6.115. How the upper slope of the walls in the intervention was determined.

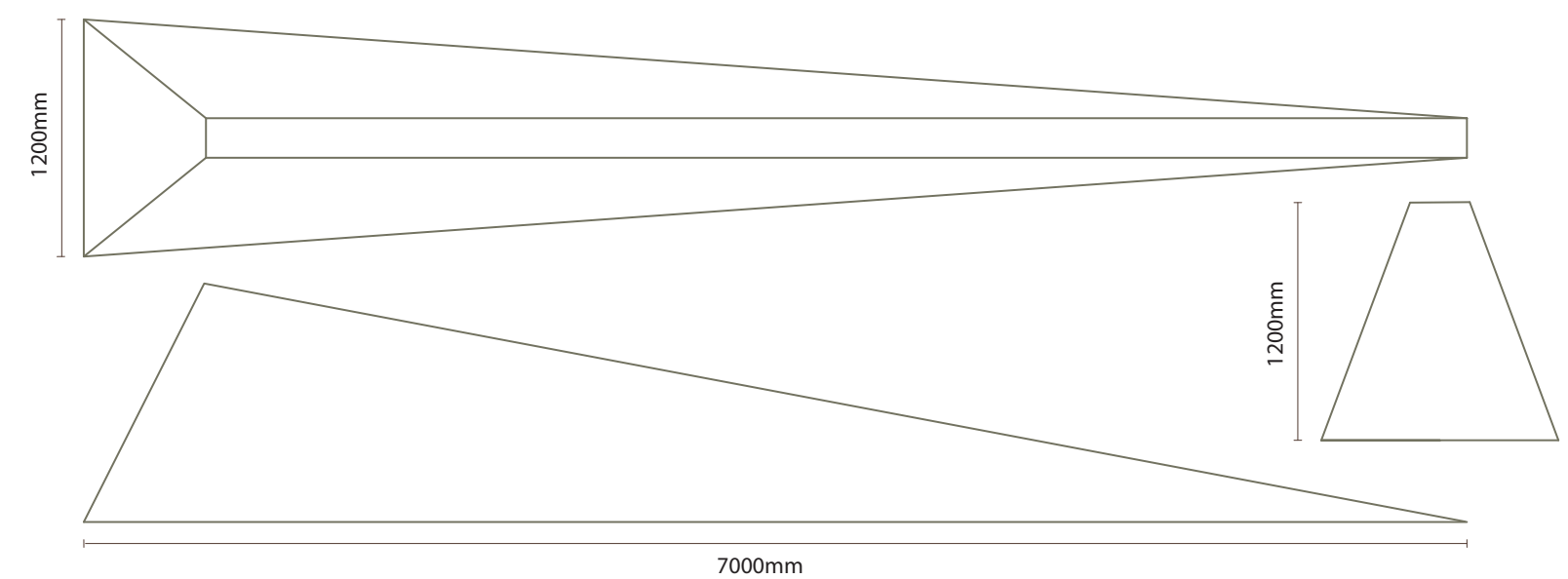

Fig. 6.116. The dimensions of the stone walls - the sides are angled to accentuate the feeling of uplift and to reference traditional stone walls.

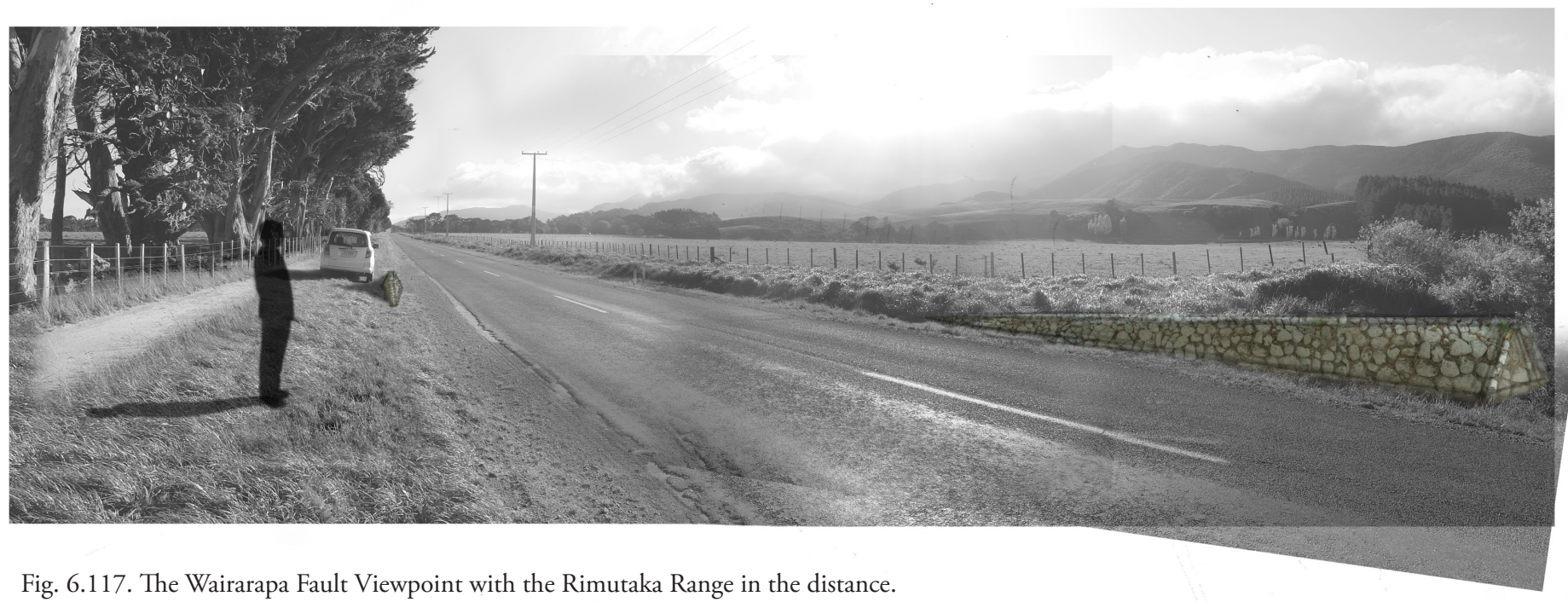




\section{Featherston Cemetery}

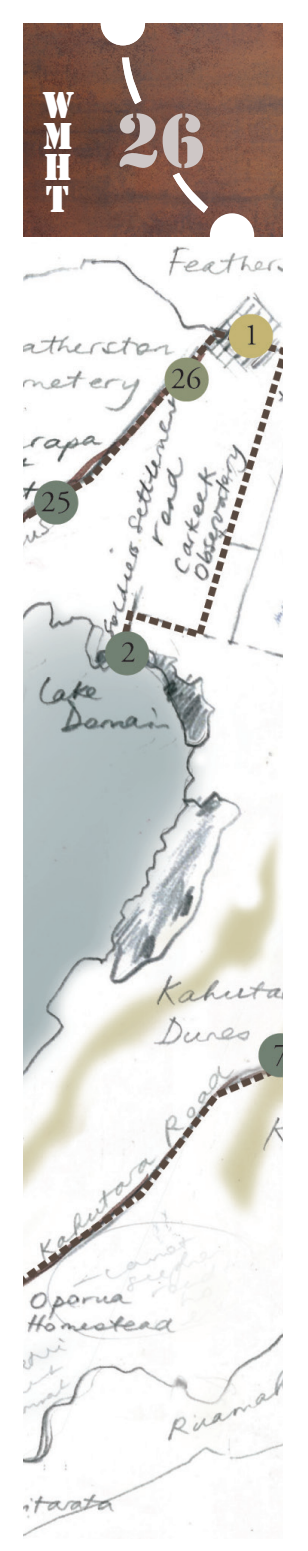

Fig. 6.119. Marker and location on Trail Map for Site No. 26.

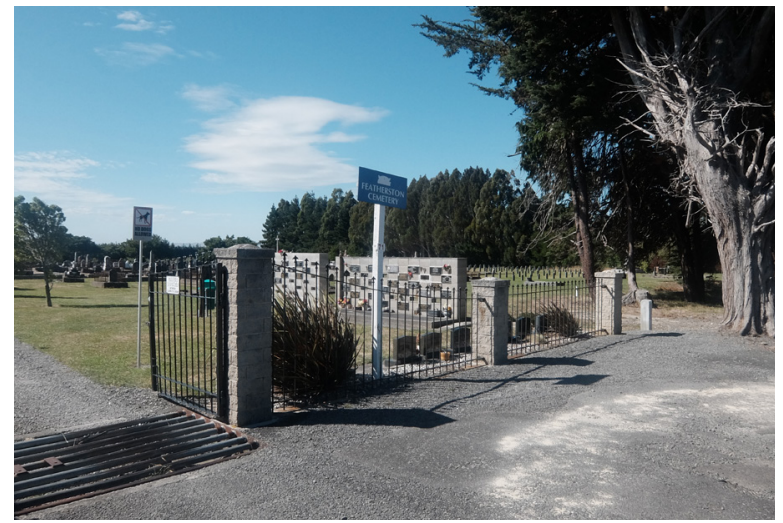

Fig. 6.118. The entrance to Featherston Cemetery.

Close to Featherston, just before the speed limit reduces to $50 \mathrm{~km}$, is Featherston Cemetery (see fig. 6.118). Fittingly this is the end of the trail, but the cemetery also brings trail followers back to the beginning, the Featherston Military Training Camp. "The war graves in this cemetery are of servicepeople who died in the great Reinforcement Camp at Featherston, established in January 1916, where a maximum of 4,500 men could be accommodated in huts and 3,000 under canvas. At Featherston the training of the Mounted Rifles, the Artillery and the specialists was carried out, as well as part of the Infantry training. An obelisk has been erected in the Cemetery, commemorating the men who died at the Camp; and a cross of Sacrifice is erected. The large number of deaths during the influenza epidemic in November, 1918, will be noticed (Featherston Cemetery). 


\section{Trail Routes}

As one of the aims of the trail is for it to interact with and attract a variety of people - Māori, Pākehā, tourists, car drivers, families with children, locals, cyclists and groups of adults of different ages - the trail can be experienced in a variety of ways. When exploring the patterns in the landing images the sites were classified according to their different stories (see fig. 3.18). Some of the sites were in more than one group, for example Raho Ruru Pa is in the Māori and military groups. Grouping the sites aligned with feedback on an early draft of the trail from David Hancock, Destination Wairarapa General Manager. He wrote:

You have identified 'varied stories' and experiences' yet the product [the trail] seems to be one story and one experience. The consumer needs to have a story to follow that will interest them. A story with a theme that they can identify with and that will generate an emotion .... I think the contents of the route needs to be broken up into smaller stories. (Hancock)

The groups became the story clusters shown in figures 3.20 and 3.22 and table 3.01 and later the four trail routes, Māori, Pākehā settlement, natural systems and military, shown in figs. 6.120 to 6.123 . These routes, designed to appeal to people with particular interests, each include a place to walk and, or, picnic. The trail can also be used to explore the area over different time periods (see fig. 6.124), different sides of the lake can be discovered, the journey of water from the lake to the sea followed and bird life focussed on (see fig. 6.125). 


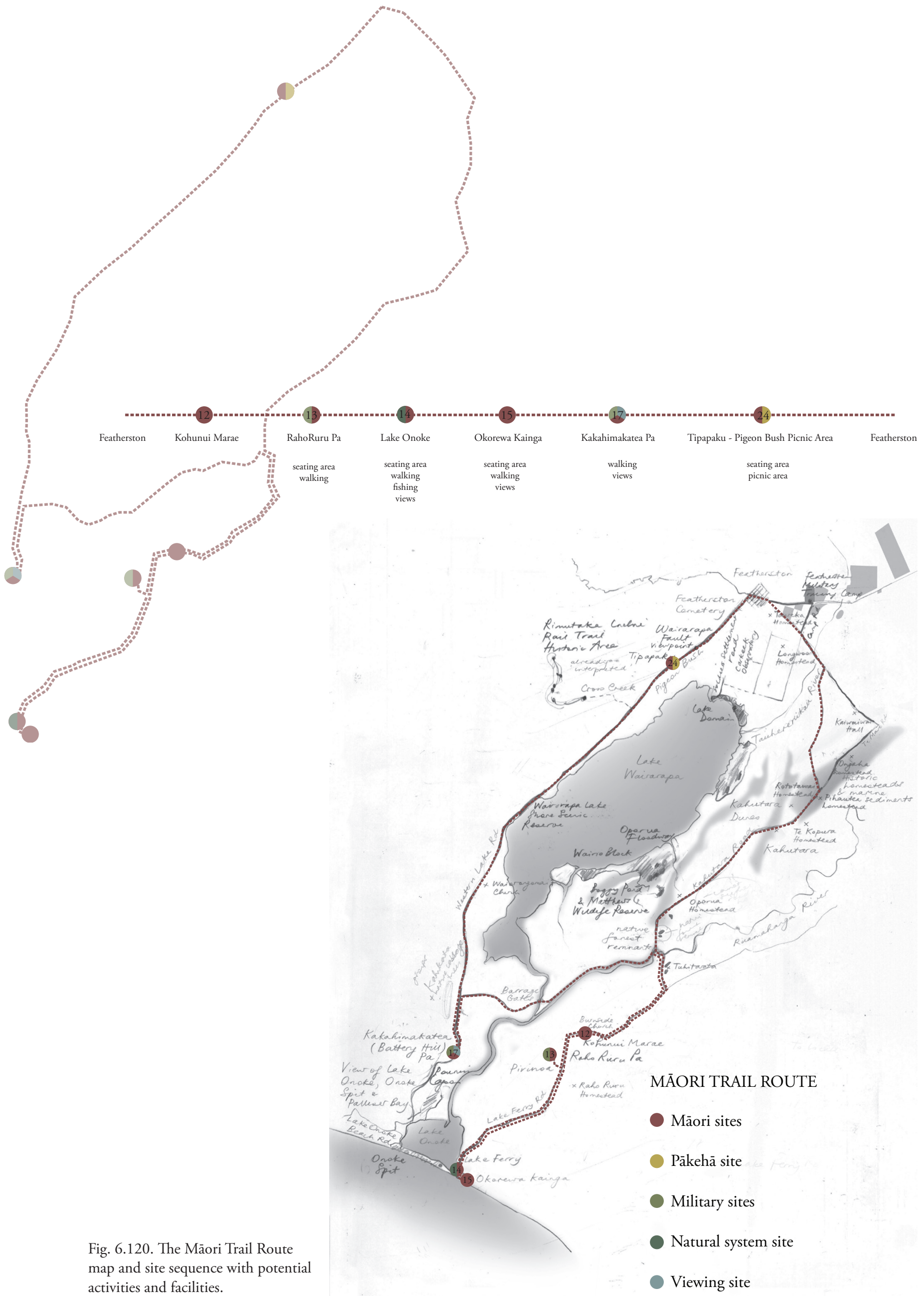




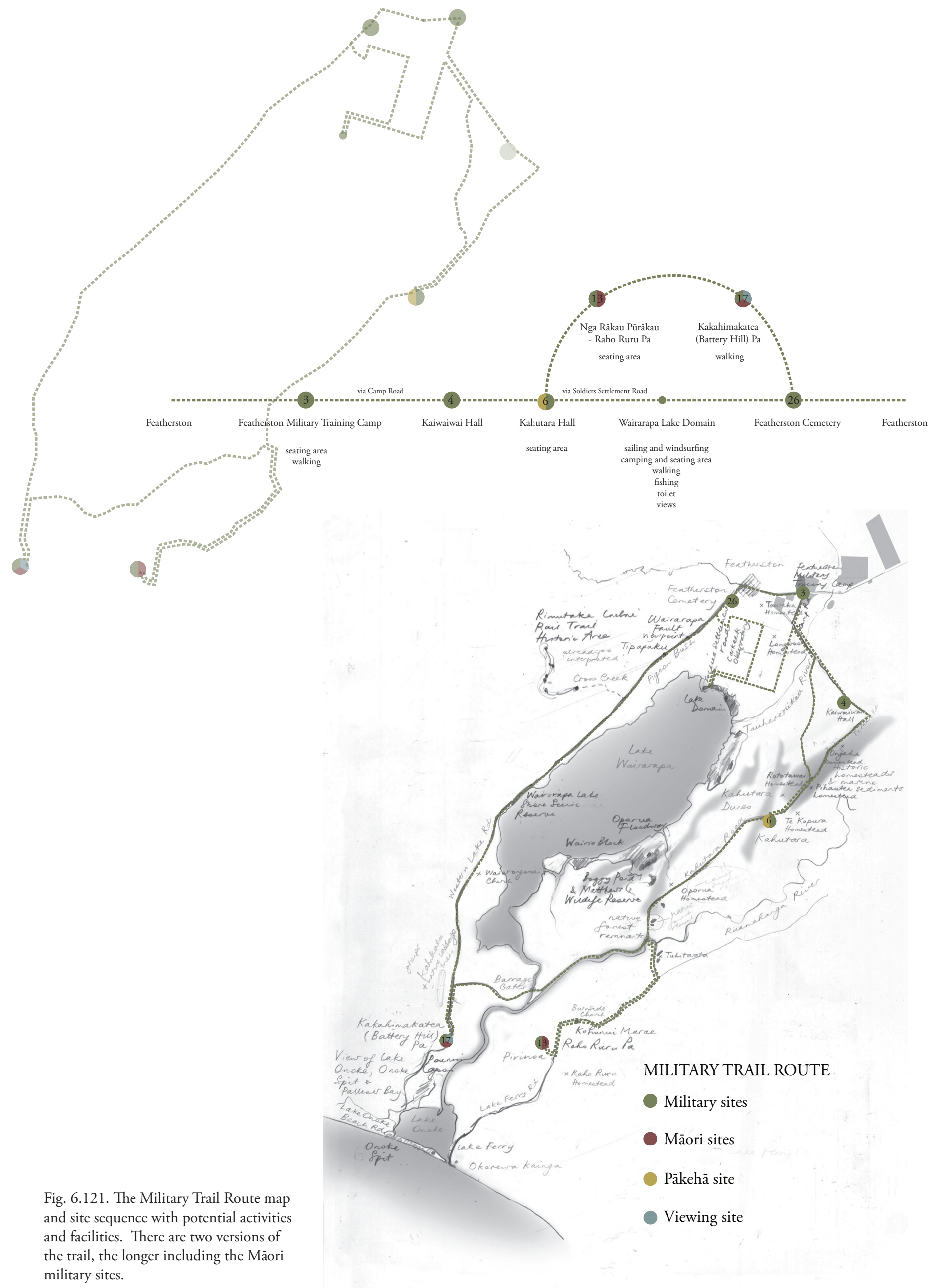




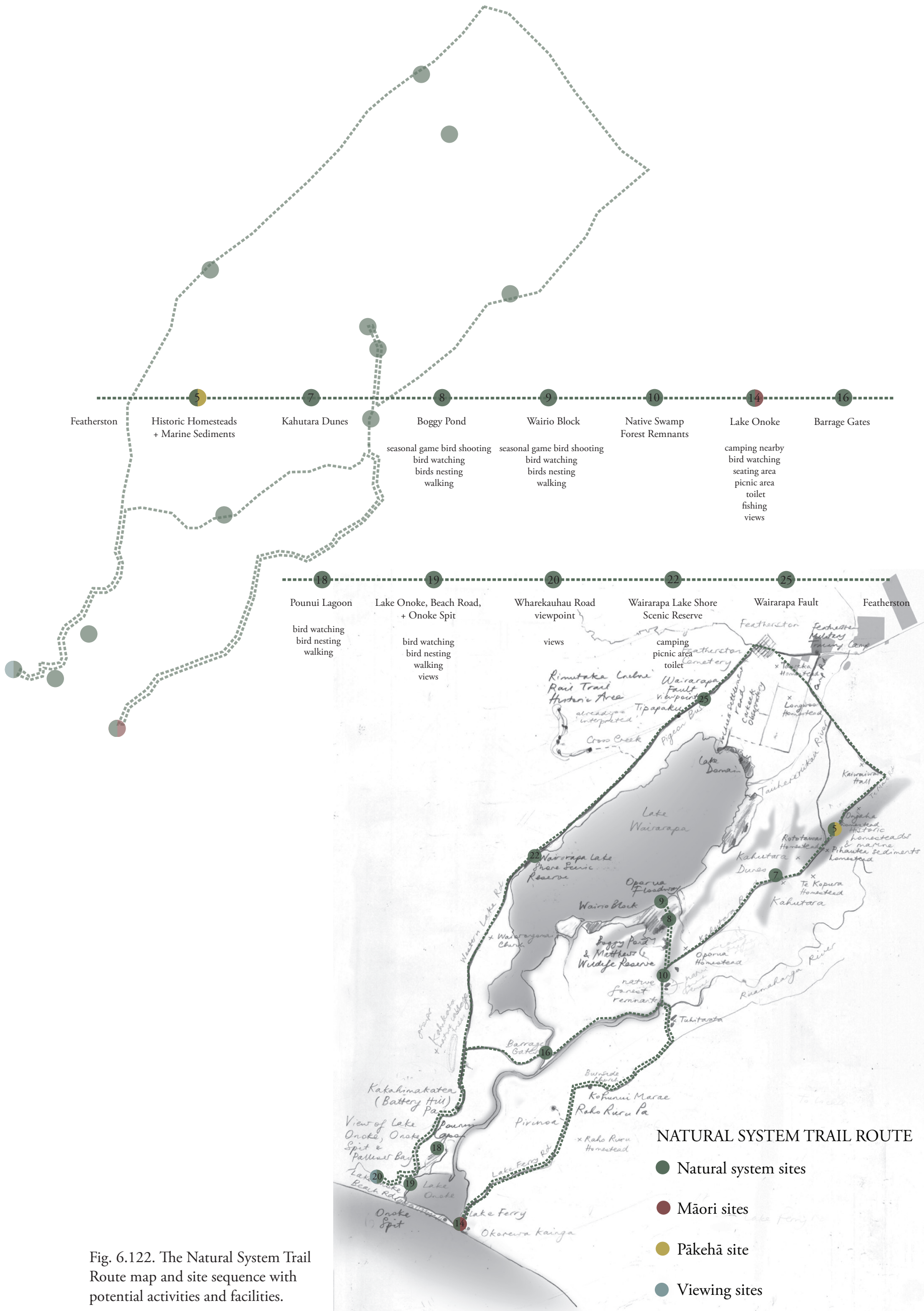




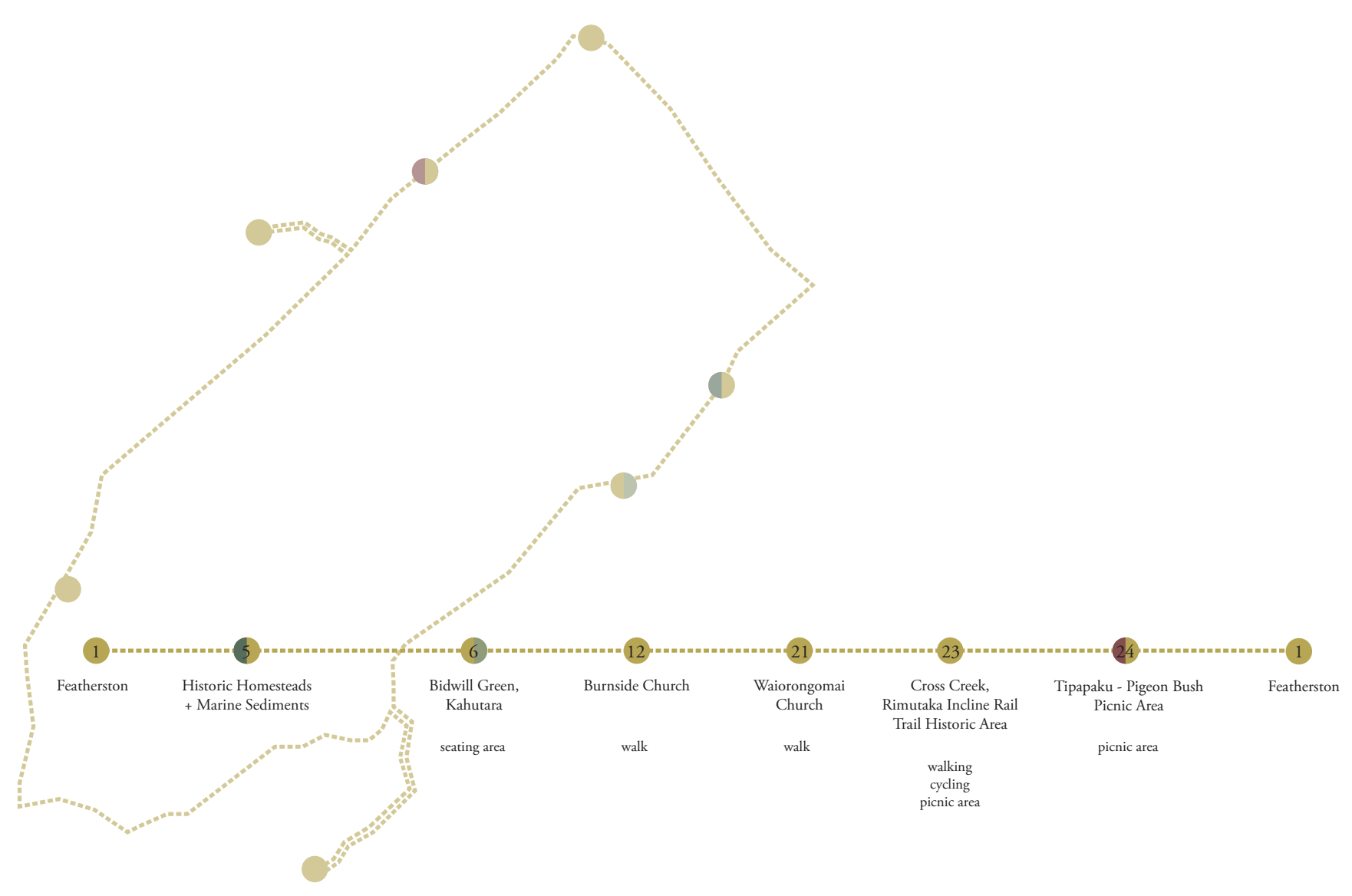

Fig. 6.123. The Pākehā Settlement Trail Route map and site sequence with potential activities and facilities.

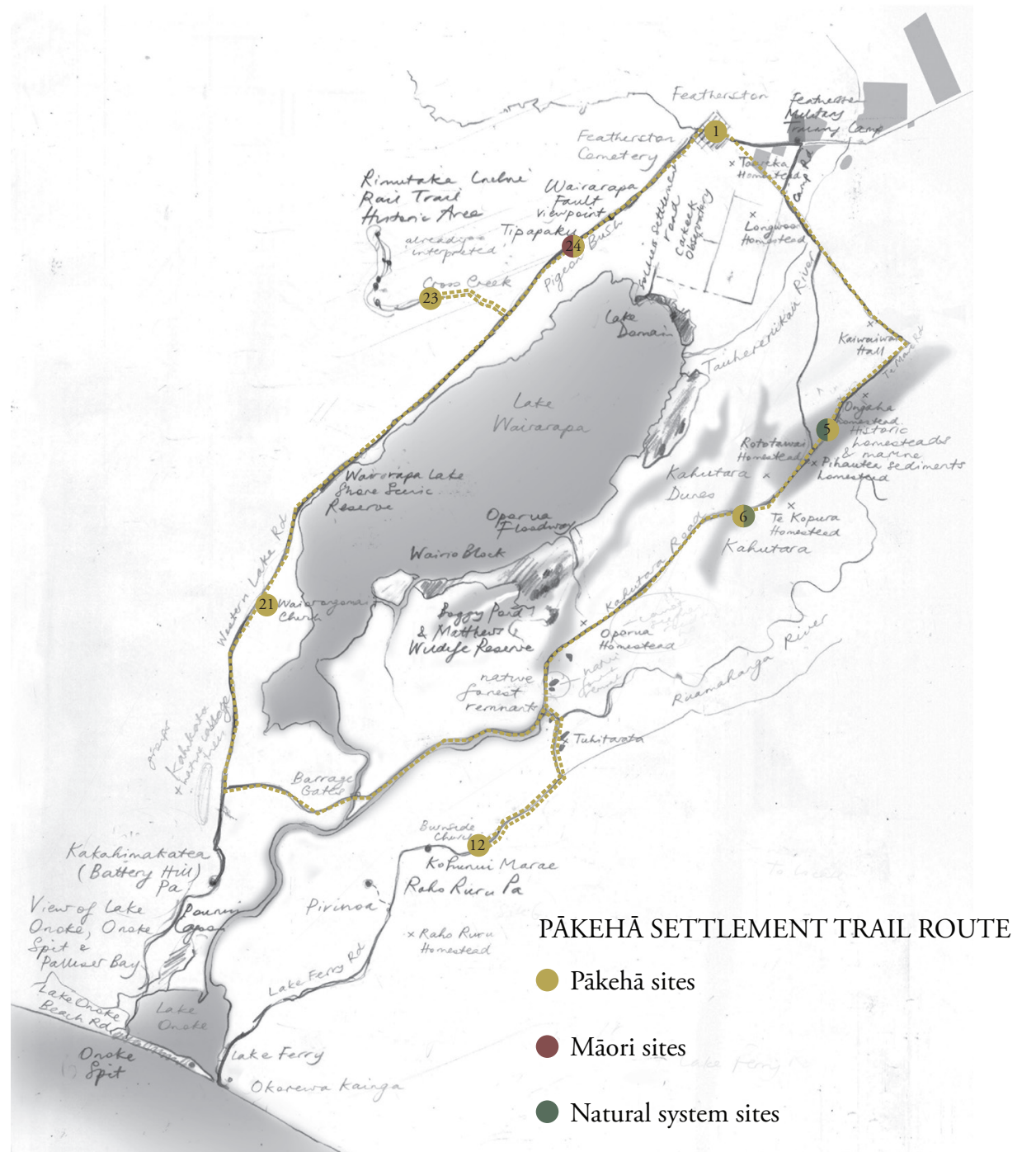

Military sites 
In an afternoon

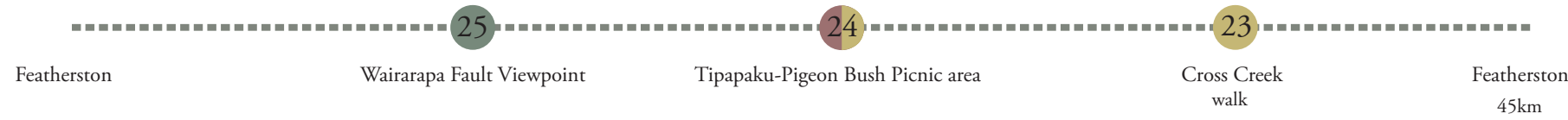

For a full day

Featherston

entire trail excluding site 8

$55 \mathrm{~km}$

Lunch at Lake Ferry Hotel

entire trial excluding site 23

Featherston

$78 \mathrm{~km}$

total $133 \mathrm{~km}$

Over a weekend

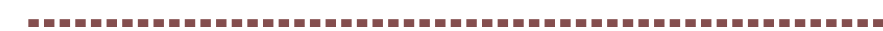

Featherston

trail sites 1 to 15

overnight at Lake Ferry Hotel

or Lake Ferry Motor Camp

trail sites 16 to 26

total $138 \mathrm{~km}$

Over a long weekend

overnight at Featherston

trail sites 1 to 15

or Lake Ferry Motor Camp

$55 \mathrm{~km}$

intervening day explore lake and south

trail sites 16 to 26

$83 \mathrm{~km}$

Featherston

coast on foot or in waka

Fig. 6.124. More ways to explore South Wairarapa through the trail - routes tailored to different lengths of time. 


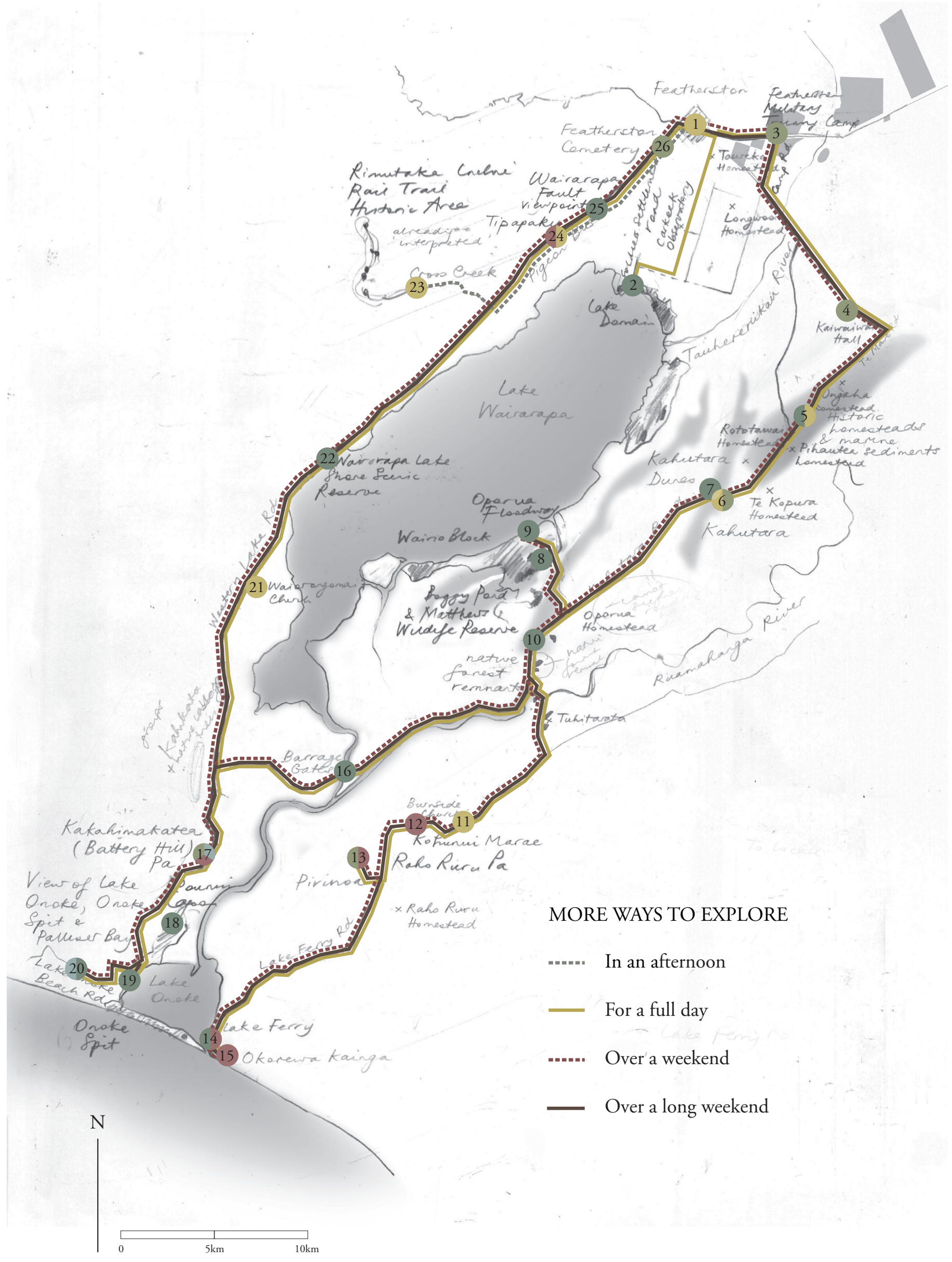


The western side of Wairarapa Moana

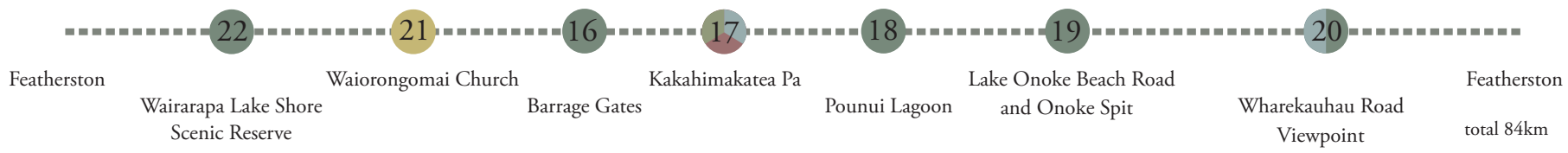

The eastern side of Wairarapa Moana

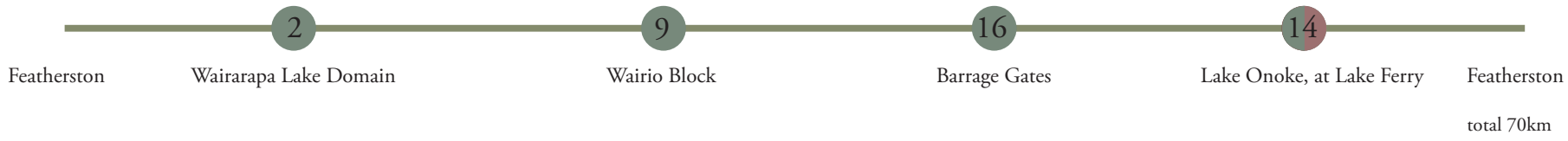

From the lake to sea

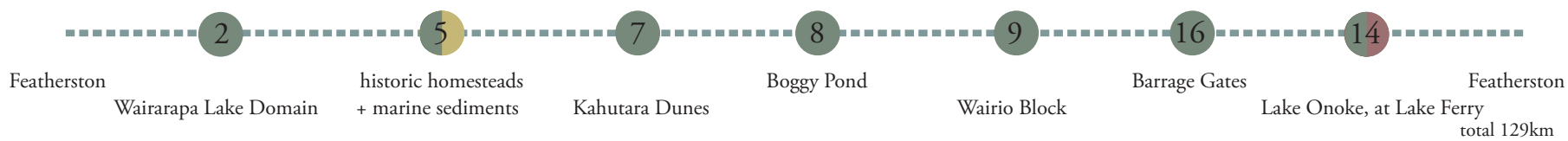

For a birding weekend

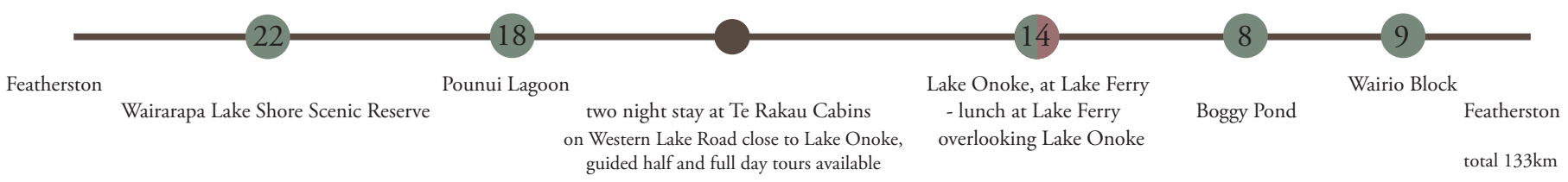

Fig. 6.125. More ways to explore South Wairarapa through the trail. 


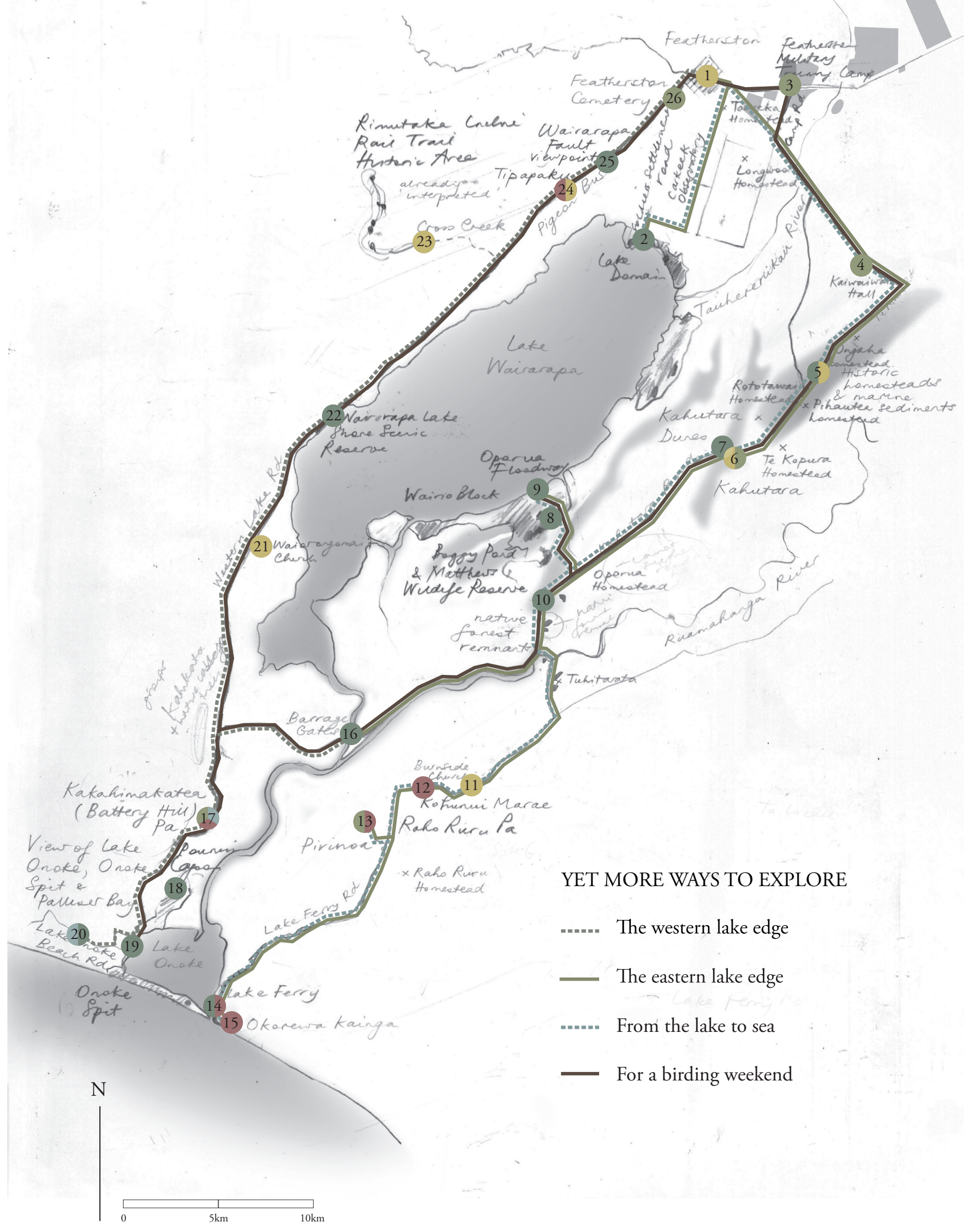




\section{Community Inhabitation of the Trail}

As well as being something to travel along, the trail can be a setting for cultural and community events. Arbor Day could be celebrated with tree planting at appropriate trail sites. "New Zealand's first Arbor Day planting was in Greytown in the Wairarapa on 3 July 1890 .... Since 1977, New Zealand has celebrated Arbor Day on June 5, which is also World Environment Day" (Arbor Day). There could be Matariki celebrations at the pa or kāinga sites; Wairarapa is known for its night sky.

Reuben Raihania Tipoki plans to involve local people in bringing back the traditional tūna harvest. This would potentially occur when the Lake Onoke outlet to the sea closes and before the council artificially opens it. He plans to involve experts to help construct hinaki and drying racks and identify short and long fin eel. Recently there was an event to celebrate tūna called 'Tūna, Return of the Eel'. As part of the Glistening Waters Storytelling Festival in 2013 a symbolic journey from Masterton to Lake Ferry was organised with stories and fish and chips by the sea (Glistening Waters Presents - Tuna, Return of the Eel). Reuben has also started to enthuse local people in seeing waka on Lake Onoke again. His ultimate dream of sailing waka on the lake is further away.

Story telling could take place at many of the sites, not just at the Raho Ruru Pa site, for example, at Tipapaku on the anniversary of the picnic. On ANZAC Day many different military stories could be told, not just those on foreign soil, such as Māori stories and stories of how peace was achieved in Wairarapa. This could take place on days of significance or as part of the Biennial Kokomai Creative Festival.

Community gatherings could take place at Bidwill Green, which could also be the setting for wedding receptions after the ceremony in the nearby church. A community picnic could take place at Tipapaku (Pigeon Bush) every 18th of January, the anniversary of the 1896 picnic, to remember and revive the spirit of the giving of the lake and the promises made.

The first Featherston Booktown Festival was held in October 2015:

a Booktown was a small rural town or village, close to major cities, in which second-hand and antiquarian bookshops were concentrated. 
Most Booktowns had developed in villages of historic interest or of scenic beauty. Their residents set up events around books .... The first Booktown was set up in Hay-on-Wye in Wales, in 1961 (Gastmeier). The trail could be included in the celebrations with readings from books at sites they connect to. At Featherston Military Training Camp there could be readings from Neil Frances' 'Safe Haven', Vincent O'Sullivan's play 'Shuriken' and Michael Nicolaidi's 'The Featherston Chronicles'. At Waiorongomai Church excerpts from 'Waiorongomai: The Land and the People' by Ian Fraser Grant and Linda Thornton could be read.

The march by soldiers trained at the military camp to Trentham was commemorated in 2015 by those who walked for 4 hours from Featherston to the top of the Rimutaka Hill Road. This is heritage existing in action (Benton, 219). ANZAC Day could see an annual walk from the camp site to the Featherston War Memorial and then on to the cemetery. 


\section{REFLECTION}

\section{On Method}

Before reflecting on the 'designs' that developed out of this research, or what Girot would call founding, it is necessary to ascertain what this thesis sees as design. In this research the method used to create the final product is integral to what has been produced. When does the design start to be created? With the decision to take on a project? With the initial journey to the site or the first site visit? When pen first meets paper? When site analysis begins? When a decision is made on what will be designed? All decisions and choices influence the final product, as well as other factors: the designer's previous experience, the weather and season of site visits, the nature of site visits, solitary or as part of a group - the list goes on. The designs that have come out of this research had their source in the initial impressions gained and intuition felt on the first visit to site and in the initial marks and words on paper these evoked. This was when a relationship began.

Establishing a relationship should be a part of a design method. However, the method is not what enables a relationship with site or landscape rather a willingness on the part of the designer, 'a right spirit'. A landscape architect would not use Girot's method if they did not want to enter into a relationship with site, if they did not want their design to be site-led, if they did have something of the 'right spirit'. Through Girot's method the prime importance of design 'for' the site is reinforced. There are connections between how Māori can hear the land speak, reading the landscape, consulting the genius loci and having 'a right spirit'.

The researcher believes the landscape designer needs to connect to the landscape so they can design interventions that connect with people and enable people to have a relationship with the landscape or site. Following Girot's method and adapting it is a way of finding a method with 'personalised fit', a way of finding 'a right spirit'. The researcher created 
landing images and text as an initial response to the sites and these have had an ongoing influence on the design process. The researcher discovered, however, that while the initial impression of a site, the relationship established at the first 'meeting', can be all important to the final design, other meetings are also important. They build a deeper relationship with site, and enable hearing the land speaking in different voices, in different moods, seasons and weather.

Many people have lost their connection with the land. People do not grow their own food, tend animals to eat, and have lost their need to hear the land speak. People are more connected to their hand held devices and through them to people and things not present than the place they are in. Connection today means virtual connection through a cell phone or computer. Stilgoe calls this: "the trap of the programmed electronic age so gently closing around so many people at the end of our century" (Oles, Timmermans, and Abelman, 35). Many indigenous people have retained their unique relationship or connection with the land. In Aotearoa/New Zealand this connection is called being tangata whenua.

All people need to reconnect with the land in order to best care for it, care desperately needed given the state of climate change. Rawiri Smith's statement that we as New Zealanders can all be tangata whenua is inspiring. All landscape architects should aspire to be tangata whenua and hear the land speak, to draw life from the land, so to be best able to design with the land and for the landscape and its people. Through Girot's method, or methods derived from it such as 'Four Listening Acts in Landscape Architecture', landscape architects can work towards growing their relationship with the land and becoming tangata whenua. 


\section{Leaving a Trail}

This research asks how landscape architectural interventions can connect Māori and Pākehā to the land and to the past in rural Aotearoa New Zealand. A trail was decided on as a way to do this and to reveal a variety of sites. Within the trail there are three different ways to enable connection which are dependent on the site and adaptable to different situations - space, object, marker. These three are threaded together into a series, a necklace, creating the trail experience.

This trail is unique as it is of this place, of Wairarapa Moana, of South Wairarapa. It is a unique combination of heritage, Māori, Pākehā, farming, military, transport and natural systems heritage.

This trail not only reveals sites and their heritage that were previously hidden, but reveals the richness of the warp and the weft that together weave into the fabric that is the landscape of the South Wairarapa. Into this fabric the researcher has woven a new thread, their own experience of this landscape. A trail showing such rich fabric has the potential to create a cultural and recreational asset for both locals and tourists of South Wairarapa. 


\section{AFTERWORD}

It was with a slight, yet strange and wistful, sadness that the researcher set out for her final trip around the trail to take the last photographs and to polish the last text for this thesis document. Why feel this way?

A relationship had been established with this place, these places, and it was coming to an end, or rather, was about to change. There will always be a relationship, and visiting this place again will be like visiting an old friend. 


\section{Glossary of Māori Language - Papakupu o te Reo Māori}

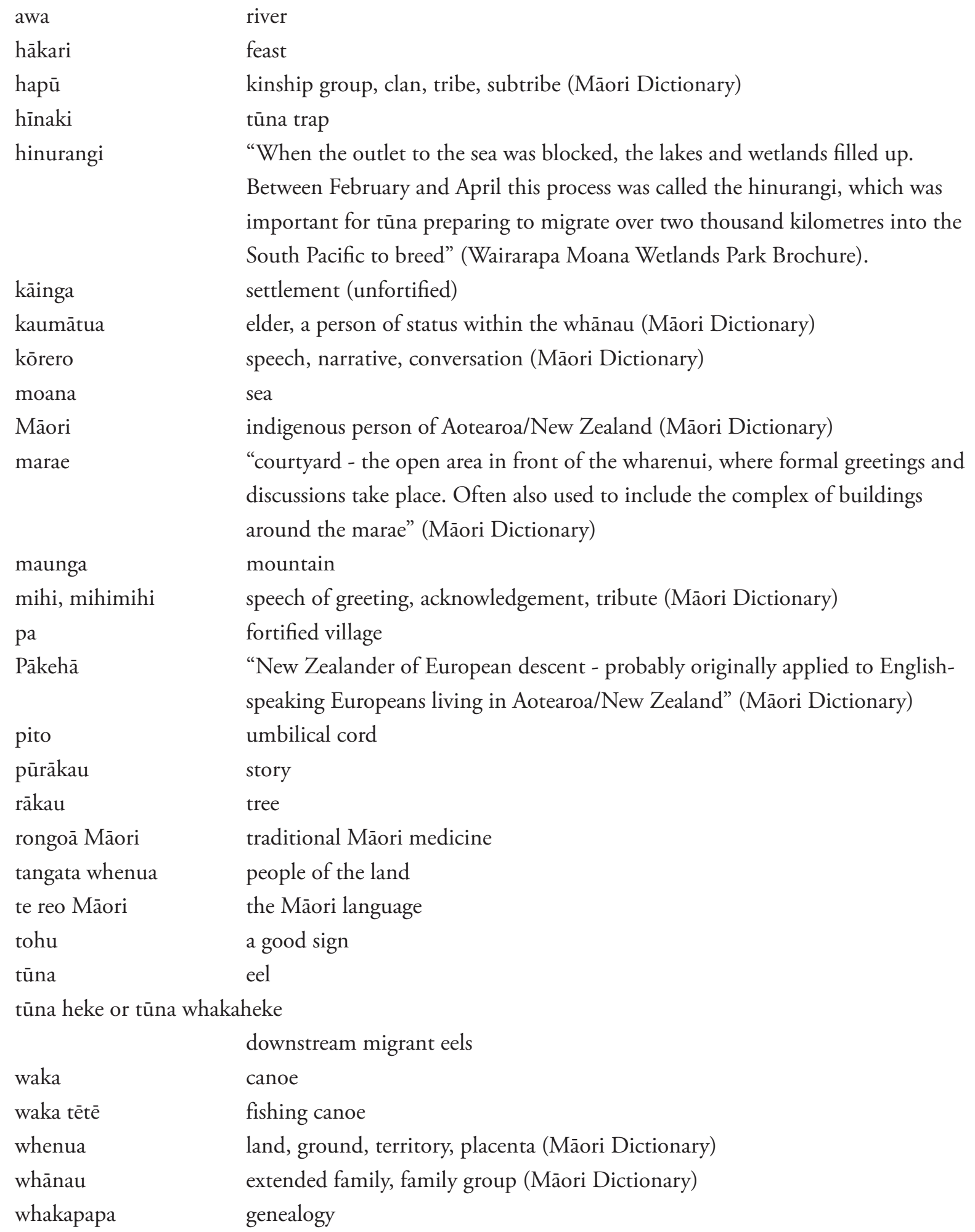




\section{LIST OF REFERENCES}

“About the ICOMOS NZ Charter.” ICOMOS• New Zealand. N.p., 2010. Web. 24 Mar. 2015.

“Arbor Day.” Wikipedia. Wikimedia Foundation, n.d. Web. 14 Nov. 2015. <https://en.wikipedia.org/wiki/ Arbor_Day\#New_Zealand>.

Barber, Ian, and Gavin McLean. "Heritage and the Big Picture - Reading a Cultural Landscape." Common Ground? Heritage and Public Places in New Zealand. Ed. Alexander Trapeznik. Dunedin, N.Z.: U of Otago, 2000. 91-105. Print.

Barnett, Christine. Personal interview. 3 March 2013.

"Booktown | Featherston, New Zealand." Booktown | Featherston, New Zealand. N.p., 2015. Web. 14 Nov. 2015. <http://www.booktown.org.nz/>.

Byrd, Warren T. Nelson Byrd Woltz. Garden, Park, Community, Farm. New York: Princeton Architectural, 2013. Print.

Claramunt, Marc, and Catherine Mosbach. "Nature of a Landscape Project." Pages Paysages: Landscape Review 7 (1999): 55-62. Print.

Clemmensen, Thomas Juel. "The Garden and the Machine." Revising Green Infrastructure: Concepts between Nature and Design. Boca Raton: CRC, 2014. 137-52. Print.

Connolly, Peter. "An Affirmative Open Systems Conception of How to Design Landscape." Thesis. RMIT University Melbourne, 2012. Research Repository. RMIT University, 20 Sept. 2013. Web. 6 July 2015. <https://researchbank.rmit.edu.au/eserv/rmit:160484/Connolly.pdf>.

Cresswell, Tim. Place: A Short Introduction. Malden, MA: Blackwell Pub., 2004. Print.

“Definition of Genius Loci in English.” Genius Loci. N.p., n.d. Web. 03 Sept. 2015. <http://www. oxforddictionaries.com/definition/english/genius-loci>.

“Definition of Mauri." Maori Dictionary Online. N.p., n.d. Web. 08 Sept. 2015. <http://www. maoridictionary.co.nz/search?idiom $=\&$ phrase $=\&$ proverb $=\& l o a n=\&$ keywords $=$ mauri $\&$ search $=>$. 
“Definition of Trail in English.” Trail. Oxford University Press, 2015. Web. 07 Sept. 2015. <http://www. oxforddictionaries.com/definition/english/trail>.

Descombes, Georges. "Displacements: Canals, Rivers, and Flows." Spatial Recall: Memory in Architecture and Landscape. New York: Routledge, 2009. 120-35. Print.

Descombes, George. Shifting Sites: The Swiss Way, Geneva. (1999). In James Corner (Ed.). Recovering Landscape. New York: Princeton Architectural Press.

"Destination Wairarapa Strategic Plan 2014-16". Destination Wairarapa. Web. 25 Jan. 2016. \&lt;http:// www.wairarapanz.com/sites/default/files/image_library/PDF/Tourism\%20Strategy\%202014-2016. pdf\&gt;.

"Extent and Significance of Wairarapa Moana Wetlands and Lake Pounui." (2013): Greater Wellington Regional Council, 2013. Web. 25 Jan. 2016. <http://www.gw.govt.nz/assets/Our-Environment/ Environmental-monitoring/Environmental-Reporting/Draft-Report-Extent-and-significance-of-WairarapaMoana-wetlands-and-Lake-Pounui-March-2013.pdf>.

"Featherston Cemetery." CWGC. Commonweath War Graves Commission, n.d. Web. 28 Jan. 2016. http://www.cwgc.org/find-a-cemetery/cemetery/70924/Featherston\%20Cemetery

Franch, Marti. "Confetti and Streamers in the Celebration of Landscape." Paisea 28.April (2014): 4-11. Print.

Fuller, Piers. "Remutaka Correct Spelling, Says Iwi." Stuff.co.nz. The Dominion Post, 23 Apr. 2014. Web. 18 Feb. 2016. <http://www.stuff.co.nz/dominion-post/news/wairarapa/9967900/Remutaka-correctspelling-says-iwi>.

Gastmeier, Hayley. "Town Uniting Book Lovers.” Wairarapa Times-Age. NZME. Publishing Limited, 26 Sept. 2015. Web. 14 Jan. 2016. <http://www.nzherald.co.nz/wairarapa-times-age/news/article.cfm?c_ id $=1503414 \&$ objectid $=11519083>$.

Giannetto, Raffaella Fabiani. Paolo Bürgi Landscape Architect: Discovering the (Swiss) Horizon: Mountain, Lake, and Forest. New York, NY: Princeton Architectural, 2009. Print. 
Girot, Christophe. "Four Trace Concepts in Landscape Architecture." Recovering Landscape: Essays in Contemporary Landscape Architecture. New York: Princeton Architectural, 1999. 59-67. Print.

“Glistening Waters Presents - Tuna, Return of the Eel.” Eventfinda. N.p., 2013. Web. 23 Feb. 2016. $<$ http://www.eventfinda.co.nz/2013/glistening-waters-presents-tuna-return-of-the-eel/masterton>. Hancock, David. "Re: South Wairarapa Thesis.” Message to the author. 16 Sept. 2015. E-mail.

Hoddinott, Wendy. "Passing Time: A Phenomenological Approach to Heritage Design.” Landscape Review 11.2 (2007): 42-53. Journals.lincoln.ac.nz. Lincoln University, 2007. Web. 15 July 2015. <http:// journals.lincoln.ac.nz/index.php/lr/article/view/244>.

Hoskins, Rau. “Te Aranga Māori Design Principles.” NZILA Conference 2015. Rotorua. 19 Mar. 2015. Address.

Hunt, John Dixon. Historical Ground: The Role of History in Contemporary Landscape Architecture. London: Routledge, 2014. Print.

Hunt, John Dixon. “Something Behind the Horizon.” Paolo Bürgi Landscape Architect: Discovering the (Swiss) Horizon: Mountain, Lake, and Forest. New York, NY: Princeton Architectural, 2009. 133-36. Print.

Hutching, Gerard. 'Birds of prey - Morepork: New Zealand's native owl', Te Ara - the Encyclopedia of New Zealand, updated 28-Jan-15. Web. 6 July 2015.

URL: http://www.TeAra.govt.nz/en/birds-of-prey/page-2

“John R. Stilgoe.” Wikipedia. N.p., 30 Dec. 2015. Web. 18 Feb. 2016. <https://en.wikipedia.org/wiki/ John_R._Stilgoe>.

Kahn, Andrea. "Defining Urban Sites." Site Matters: Design Concepts, Histories, and Strategies. New York: Routledge, 2005. 280-96. Print.

Lee, Gini. "South Australian National Parks - Shifting Presence: Of and for the Material Landscape." Taylor Cullity Lethlean: Making Sense of Landscape. Washington: Spacemaker, 2013. 98-100. Print.

"Lower Wairarapa Valley Development Scheme." Greater Wellington Regional Council. N.p., 23 Dec. 2014. Web. 25 Jan. 2016. \&lt;http://www.gw.govt.nz/lower-wairarapa-valley-development-scheme/\&gt;. 
McGowan, Rob. “Ecological Landscapes.” NZILA Conference 2015. Rotorua. 20 Mar. 2015. Address.

"Mapunaatea". Ngati Kahungungu ki Wairarapa-Tamaki Nui a Rua Trust, Kawerongo, June 2015. Web. 22 Feb. 2016. <http://www.kkwtnr.org.nz/wp-content/uploads/NKKWT-Pānui-June-2015.pdf> Māori Dictionary. N.p., n.d. Web. 18 Feb. 2016. <http://maoridictionary.co.nz/search?idiom=\&phrase=\& proverb $=\&$ loan $=\&$ histLoanWords $=\&$ keyword $s=[$ word meaning sought for $]>$.

Marot, Sébastien. “The Reclaiming of Sites." Recovering Landscape: Essays in Contemporary Landscape Architecture. New York: Princeton Architectural, 1999. 44-57. Print.

Meyer, Elizabeth K. "Landscape Architecture as Modern Other and Postmodern Ground." The Culture of Landscape Architecture. Melbourne, Vic.: Edge Pub. in Association with the Dept. of Planning, Policy and Landscape, RMIT, 1994. 12-34. Print.

“Mihimihi.” Mihimihi - Kōrero Māori. N.p., n.d. Web. 22 May 2014. <http://www.korero.maori.nz/ forlearners/protocols/mihimihi.html>.

Murton, Brian. "Embedded in Place." Landscape in Language: Transdisciplinary Perspectives. Amsterdam: John Benjamins Pub., 2011. 73-100. Print.

Oles, Thomas, Marieke Timmermans, and Jacques Abelman. Go with Me: 50 Steps to Landscape Thinking. Amsterdam: Architectura \&amp; Natura, 2014. Print.

Olsen, Stephen. “Pipitea Marae.” Landscape Architecture New Zealand 18 (2013): 34-38. Print.

"Phenomenology (philosophy)." Wikipedia. N.p., 5 Jan. 2016. Web. 12 Jan. 2016. <https://en.wikipedia. org/wiki/Phenomenology_(philosophy)>.

Pressley, Marion. “The Landscape Architect's Guide to.” Emerald Necklace Overview. ASLA, 2015. Web. 03 Sept. 2015. <http://www.asla.org/guide/site. aspx?id=40785>.

"Quaternary." GNS Science. N.p., n.d. Web. 25 Jan. 2016. \&lt;http://www.gns.cri.nz/Home/Our-Science/ Earth-Science/Regional-Geology/The-Geology-of-New-Zealand/Stratigraphy/Quaternary-W-Q\&gt;.

"Rimutaka Rail Trail." <i>Greater Wellington Regional Council</i>. N.p., n.d. Web. 21 Feb. 2016. \&lt;http://www.gw.govt.nz/Rimutaka-Rail-Trail\&gt;. 
Royal, Te Ahukaramū Charles. 'Kaitiakitanga - guardianship and conservation - Connected to nature', Te Ara - the Encyclopedia of New Zealand, updated 22-Sep-12 URL: http://www.TeAra.govt.nz/en/ kaitiakitanga-guardianship-and-conservation/page-2

Sennett, Richard. “The Public Realm.” Quant. N.p., 2015. Web. 04 Nov. 2015. <http://www. richardsennett.com/site/senn/templates/general2.aspx?pageid=16\&cc=gb $>$.

"Soil Orders Of New Zealand (Maps)." <i>NZ Soils</i>. Waikato Regional Council, 2011. Web. 25 Jan. 2016. \&lt;www.nzsoils.org.nz\&gt;.

“Te Aranga Maori Cultural Landscape Strategy.” TE ARANGA (2008): n. pag. Auckland City Council, 28 Apr. 2008. Web. 14 July 2015. <http:/www.aucklandcouncil.govt.nz/EN/planspoliciesprojects/ plansstrategies/unitaryplan/Documents/Section32report/Appendices/Appendix\%203.16.7.pdf>.

Timmermans, Marieke. “Reading a Landscape.” Topos 88 (2014): 18-25. Print.

Treib, Marc. "Must Landscapes Mean? Approaches to Significance in Recent Landscape Architecture.” Meaning in Landscape Architecture \& Gardens: Four Essays, Four Commentaries. London: Routledge, 2011. 82-125. Print.

Treib, Marc. "Must Landscapes Mean? Revisited." Meaning in Landscape Architecture \& Gardens: Four Essays, Four Commentaries. London: Routledge, 2011. 126-32. Print.

Vaughan, Laurene. Introduction. Designing Place: An Archaeology of the Western District. Melbourne, Vic.: Melbourne, 2010. 8-9. Print.

Wairarapa Moana Wetlands Park Brochure. N.p.: n.p., 2015. Greater Regional Council, 2010. Web. 5 Mar. 2015. <http://www.gw.govt.nz/assets/council-publications/Wairarapa_Moana_Wetlands_Park_-_ brochure_.pdf>. 


\section{ADDITIONAL SOURCES}

Books:

Cave, Yvonne, and Valda Paddison. The Gardener's Encyclopedia of New Zealand Native Plants. New Zealand: Godwit, 1999. Print.

Grant, Ian Fraser. Wairarapa Moana: The Lake and Its People. Masterton, N.Z.: Wairarapa Archive, 2012. Print.

Palmer, Stanley J. Palmers Manual of Trees, Shrubs \&amp; Climbers. Runaway Bay, Qld., Australia: Lancewood Pub., 1994. Print.

Wairarapa Moana He Pātaka Kai, He Pātaka Körero - Stories about a Lake and Its People. Masterton: Aratoi, 2010. Print.

Wellington Regional Native Plant Guide. Wellington, N.Z.: Greater Wellington Regional Council, 2010. Print.

Reports:

Boffa Miskell Ltd. “Wairarapa Landscape Study”. Rep. N.p.: n.p., n.d. 2010. Web. 25 Jan. 2016. \&lt;http://www.gw.govt.nz/assets/council-publications/Wairarapa\%20Character\%20Study\%20 August\%202010.pdf\&gt;.

Shoebridge, Tim. Featherston Military Training Camp and the First World War, 1915-27. Rep. no. ISBN (web Pdf) 978-0-478-18471-6. Wellington: Manatū Taonga/Ministry for Culture and Heritage, 2011. Print.

Stirling, Bruce, and Christine Barnett. Wairarapa Moana Heritage Study. Rep. Wellington: Greater Wellington Regional Council, 2009. Print. 


\section{Unpublished Reports:}

Naus, Natasha, Vivienne Morell, and Christine Whybrew. <i>St Francis' Church (Non-Denominational), Kahutara (List No. 3982)</i>. Rep. no. 12004-80. Wellington: Heritage NZ Pouhere Taonga, 2014. Print.

Wairarapa Moana Wetlands Project Strategy for Interpretation and Visitor Facilities. Rep. no. 1448277. Wellington: GWRC \& DOC, 2015. Print.

Wairarapa Moana Wetlands Project Interpretation and Visitor Facilities 3 Year Plan 2015-18. Rep. no. 1468061. Wellington: Wairarapa Moana Wetlands Project, 2014. Print.

Whybrew, Christine. Kahutara School Building, Kahutara (List No. 4042). Rep. no. 12015. Wellington: Heritage NZ Pouhere Taonga, 2014. Print.

Web pages:

"Pigeon Bush Railway Station." <i>Wikipedia</i>. N.p., 1 Aug. 2015. Web. 5 Aug. 2015. \&lt;https:// en.wikipedia.org/wiki/Pigeon_Bush_Railway_Station\&gt;.

Eileen McSaveney. 'Earthquakes - What causes earthquakes?', Te Ara - the Encyclopedia of New Zealand, updated 9-Jul-13

URL: http://www.TeAra.govt.nz/en/photograph/4400/wairarapa-fault-scarp-pigeon-bush

New Zealand Archaeological Association's Archaeological Site Recording Scheme Website. N.p., n.d. Web. 20 Apr. 2014. <http://www.archsite.org.nz/>.

Oratia Native Plant Nursery. N.p., 2007. Web. 22 Feb. 2016. <http://www.oratianatives.co.nz/>. 


\section{SOURCES OF FIGURES}

All figures not attributed are the author's own.

\section{Chapter 1}

Fig. 1.01 Wikimedia Commons. Wikipedia, n.d. Web. 2 Mar. 2016. <https://upload. wikimedia.org/wikipedia/commons/thumb/c/c8/New_Zealand_locator_map_ blank_cropped.svg/183px-New_Zealand_locator_map_blank_cropped.svg.png>.

Fig. 1.02 Aerial image: LINZ Data Service https://data.linz.govt.nz/layer/1870-wellington-03mrural-aerial-photos-2012-2013/ and licensed by LINZ for re-use under the Creative Commons Attribution 3.0 New Zealand licence.

Population statistics: Statistics New Zealand. New Zealand Government, n.d. Web. 2 Mar. 2016. <http://www.stats.govt.nz>.

Fig. 1.03 as fig. 1.02

Fig 1.06 Wairarapa Moana Wetlands Park Brochure. N.p.: n.p., 2015. Greater Regional Council, 2010. Web. 5 Mar. 2015. <http://www.gw.govt.nz/assets/councilpublications/Wairarapa_Moana_Wetlands_Park___brochure_pdf>. (permission to reproduce obtained)

Fig. 1.14 Wikimedia Commons. Wikipedia, n.d. Web. 2 Mar. 2016. <https://upload. wikimedia.org/wikipedia/commons/4/4b/Olmsted_historic_map_Boston.png>.

Fig. 1.16 Wikimedia Commons. Wikipedia, n.d. Web. 2 Mar. 2016. <https://upload. wikimedia.org/wikipedia/commons/9/9f/Preveli_Strand.jpg>.

Fig. 1.17 Wikimedia Commons. Wikipedia, n.d. Web. 2 Mar. 2016. <https:// en.wikipedia.org/wiki/File:Pieter_Bruegel_der_\%C3\%84ltere___Landschaft_mit_ der_Flucht_nach_\%C3\%84gypten.jpg>.

\section{Chapter 3}

Fig 3.01 as fig. 1.06

Archaelogical Data: Arch Site Archaeological Site Recording Scheme. New Zealand Archaeological Association, 20 Mar. 2015. Web. <www.archsite.org.nz/>. (permission to reproduce obtained) 


\section{Chapter 4}

Fig 4.05 Geological Data: Wellington Geological Map. N.p.: Institute of Geological and Nuclear Sciences, 2000. Print

Fig 4.10 Contours: LINZ Data Service https://data.linz.govt.nz/search/?q=contours $+20 \mathrm{~m}$ and licensed by LINZ for re-use under the Creative Commons Attribution 3.0 New Zealand licence.

Fig. 4.13 Soil Data: Boffa Miskell Ltd. “Wairarapa Landscape Study”. Rep. N.p.: n.p., n.d. 2010. Web. 25 Jan. 2016. <http://www.gw.govt.nz/assets/council-publications/Wairarapa\%20Character\%20 Study\%20August\%202010.pdf>

Fig. 4.18 Land Parcels: LINZ Data Service https://data.linz.govt.nz/search/?q=land+parcels and licensed by LINZ for re-use under the Creative Commons Attribution 3.0 New Zealand licence.

Fig. 4.23 Hinurangi and Flooding Extent: Grant, Ian Fraser. Wairarapa Moana: The Lake and Its People. Masterton, N.Z.: Wairarapa Archive, 2012. Print.

Other Data: Wairarapa Combined District Map Viewer. Masterton, Carterton, and South Wairarapa District Councils, 10 June 2015. Web. <http://mapping.gw.govt.nz/wairarapa/>.

Fig. 4.28 Vegetation Extent c.1853: Hill, R. D. "The Vegetation of the Wairarapa in MidNineteenth Century." Tuatara 11.2 (1963): 83-89. Web. 2 Mar. 2016.

Other Data: Wairarapa Combined District Map Viewer. Masterton, Carterton, and South Wairarapa District Councils, 10 June 2015. Web. <http://mapping.gw.govt.nz/wairarapa/>.

Fig. 4.32 "Wairarapa Valley Cycleway." NZ Cycle Trail. NZ Cycle Trail Inc., n.d. Web. 01 Mar. 2016. <http://nzcycletrail.com/trails/wairarapa-valley-cycleway/>.

"Rimutaka Cycle Trail.” Wellington Absolutely Positively. Wellington Regional Economic Development Agency, 2016. Web. 2 Mar. 2016. <http://www.wellingtonnz.com/rimutaka-cycle-trail/>.

Other Data: Wairarapa Combined District Map Viewer. Masterton, Carterton, and South Wairarapa District Councils, 10 June 2015. Web. <http://mapping.gw.govt.nz/wairarapa/>.

Chapter 5 - N.B. within some of the threads images sources have been given

Fig. 5.02 as fig. 4.05 
Fig. 5.03 as fig. 4.10

Fig. $5.04 \quad$ as fig. 4.05

Fig. $5.05 \quad$ as fig. 4.28

Fig. $5.06 \quad$ as fig. 4.05 and 4.10

Robley, General. Carved Gateway of Maori Village. Digital image. Hellenica World. N.p., n.d. Web. 30 July 2015. <http://www.hellenicaworld.com/NewZealand/Literature/WilliamPemberReeves/ en/img/image09.jpg>

Fig. $5.07 \quad$ as fig. 4.10 and 4.23

Fig. $5.08 \quad$ as fig. 4.10

Brees, Samuel Charles, 1810?-1865. Brees, Samuel Charles 1810-1865 :Palliser Bay

and the sand bar of the Wairarapa / Drawn by S C Brees. [Engraved by Henry Melville. London, 1847]. [No] 44, Plate 15.. Brees, Samuel Charles, 1810-1865 :Pictorial Illustrations of New Zealand. London, John Williams and Co., Library of Arts, 141, Strand, 1847.. Ref: PUBL-0020-15-1. Alexander Turnbull Library, Wellington, New Zealand. http://natlib.govt.nz/records/23178946

Fig. $5.10 \quad$ as fig. 4.10

Fig. $5.11 \quad$ as fig. 4.10

"NZMS1 1959." MapsPast | Current and Historical Topographic Maps (topomaps) of New Zealand. Web. 10 Aug. 2015. <http://www.mapspast.org.nz/>.

Fig. $5.12 \quad$ as fig. 4.05 and 4.10

“NZMS1 1959." MapsPast | Current and Historical Topographic Maps (topomaps) of New Zealand. Web. 10 Aug. 2015. <http://www.mapspast.org.nz/>.

\section{Chapter 6}

The aerial images and contours used in the plans in this chapter are from the same source as fig. 1.02 and 4.10 
APPENDIX A: $\quad$ Fourth year Featherston Design Project

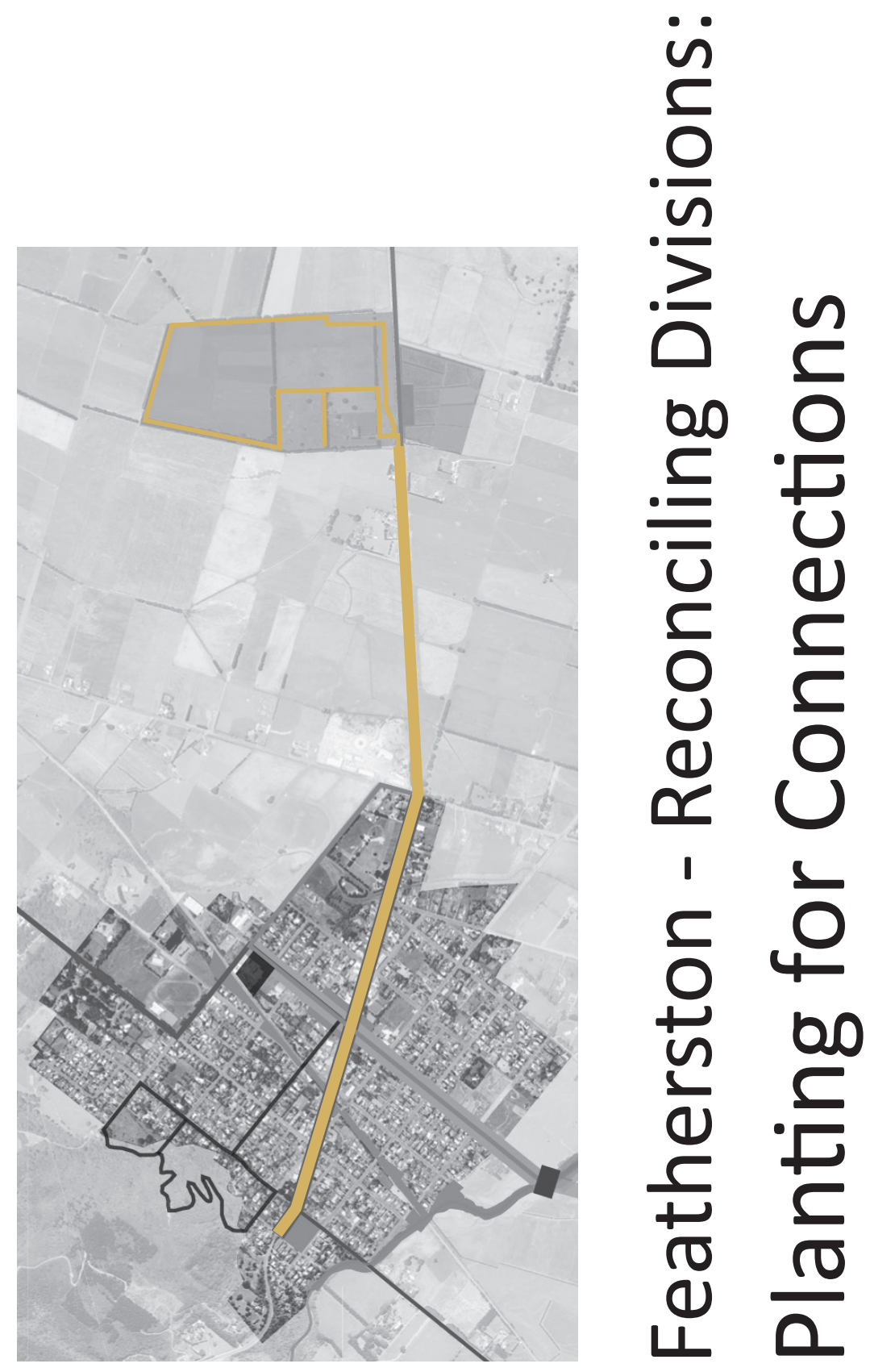




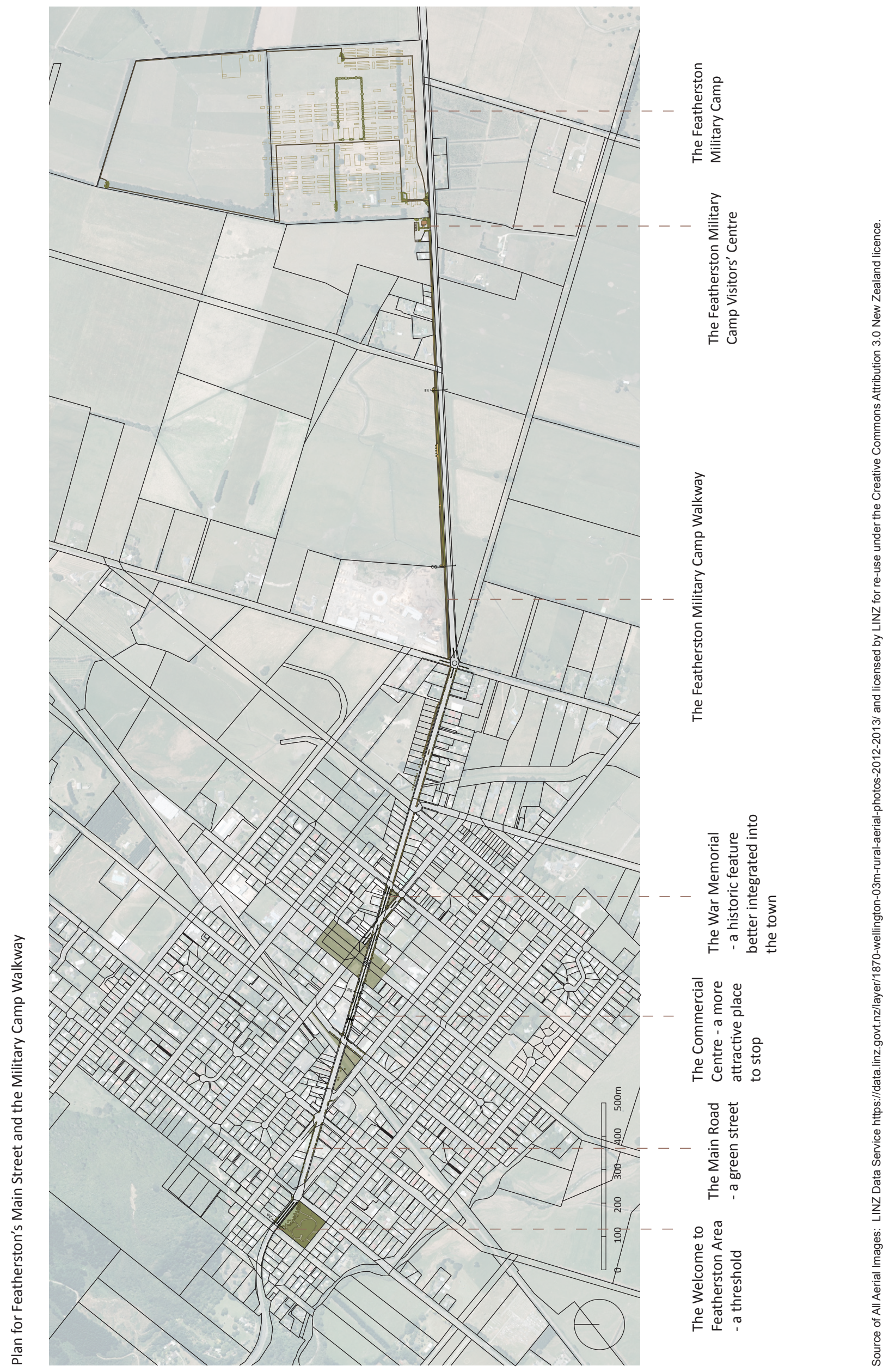



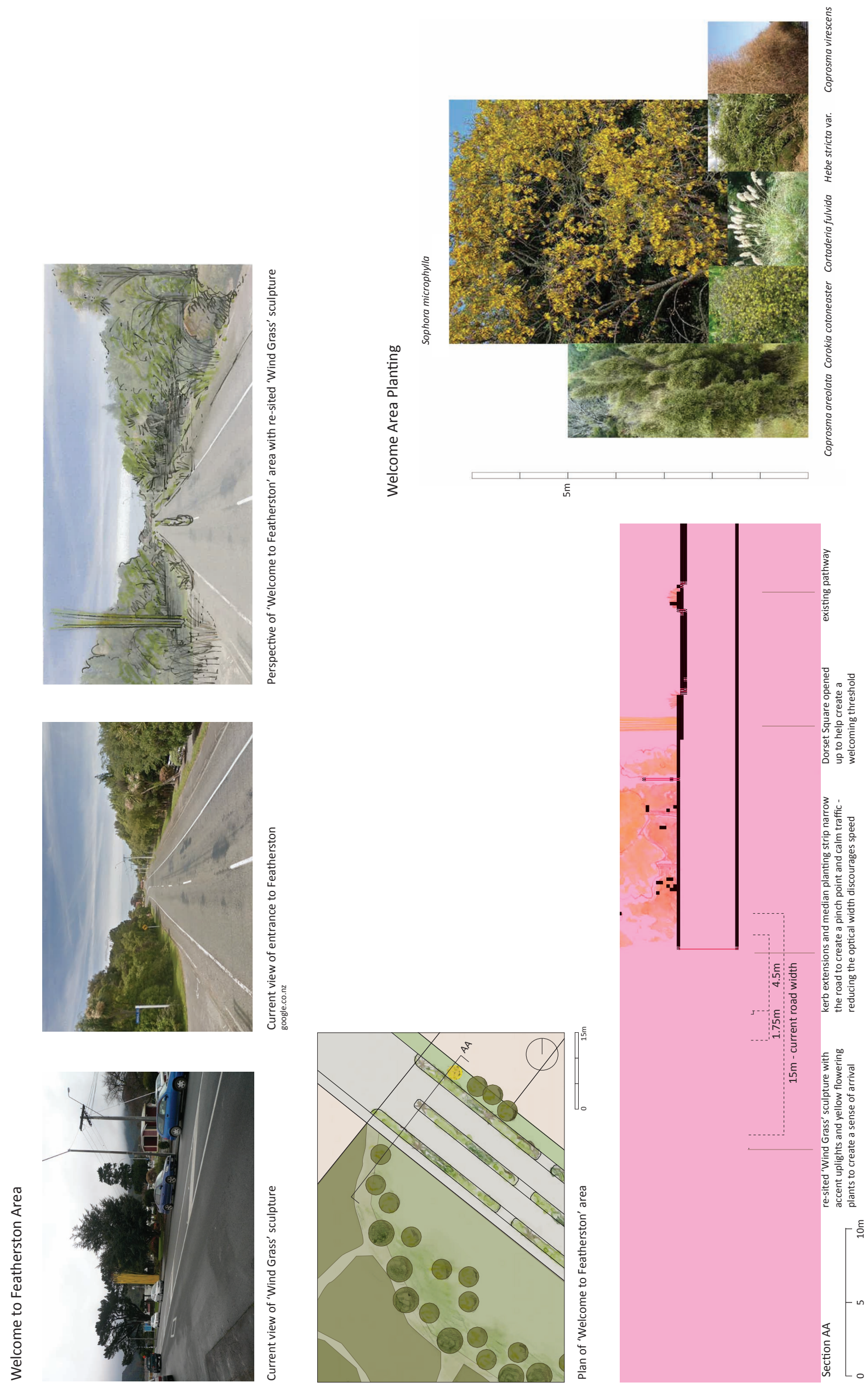


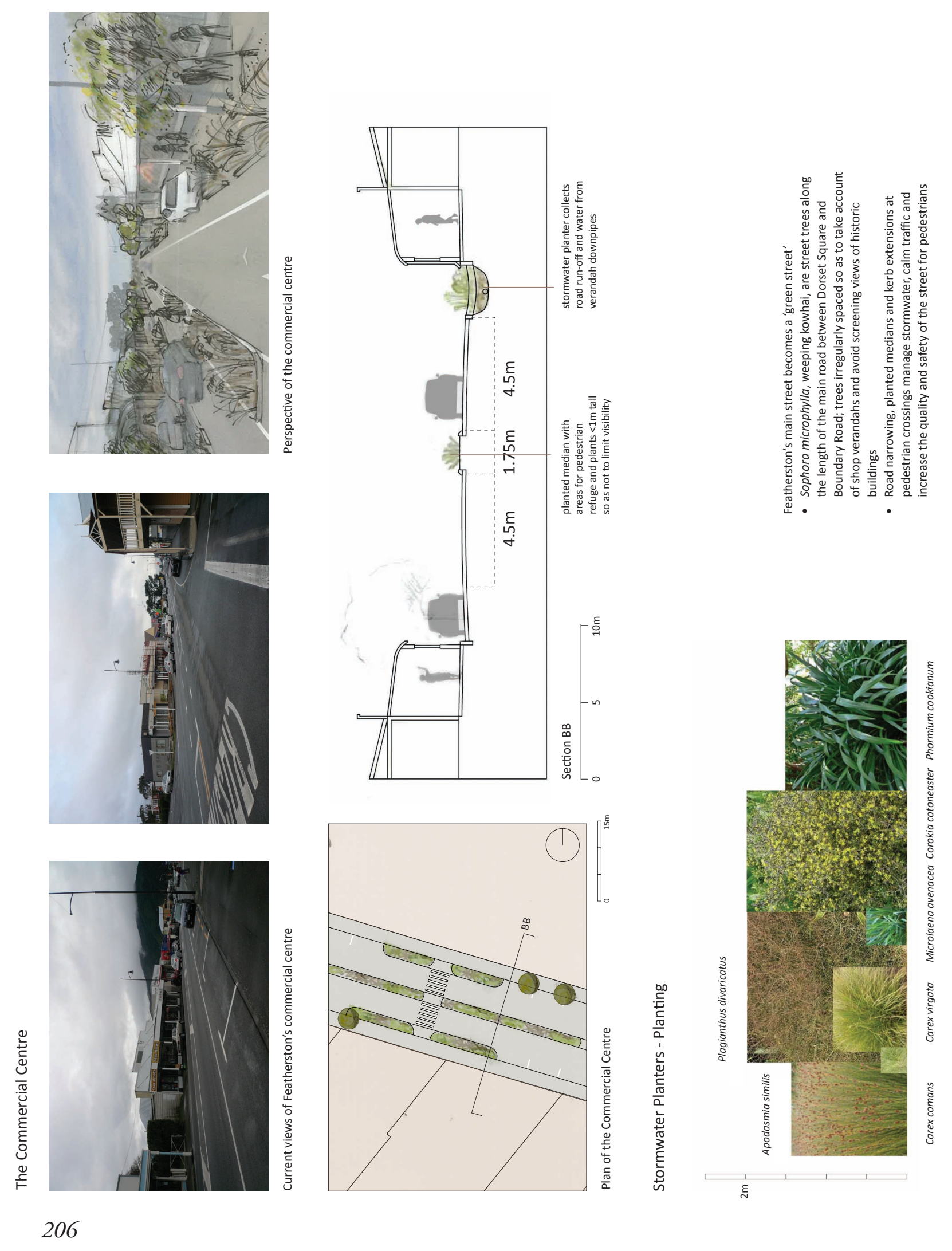



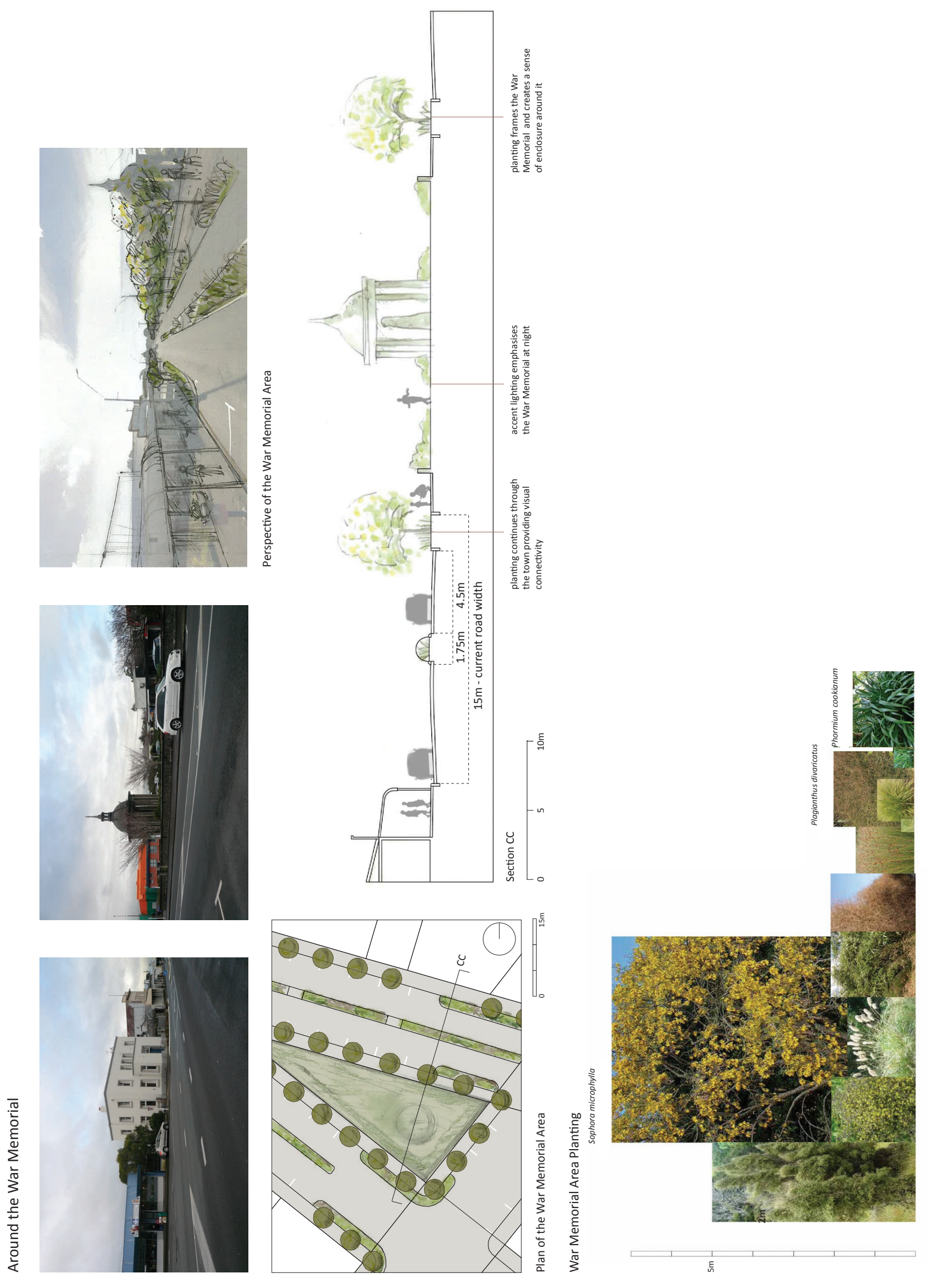

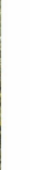

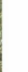

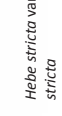

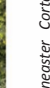




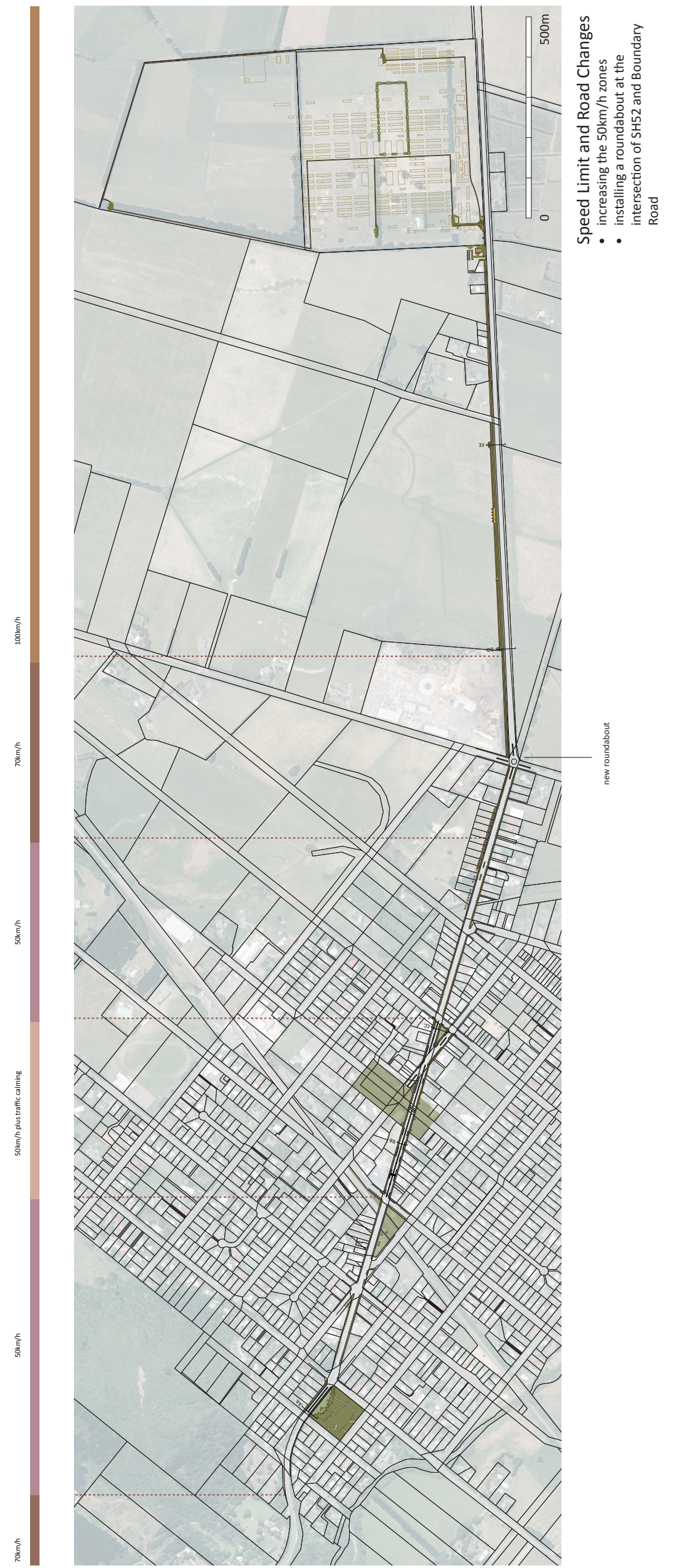




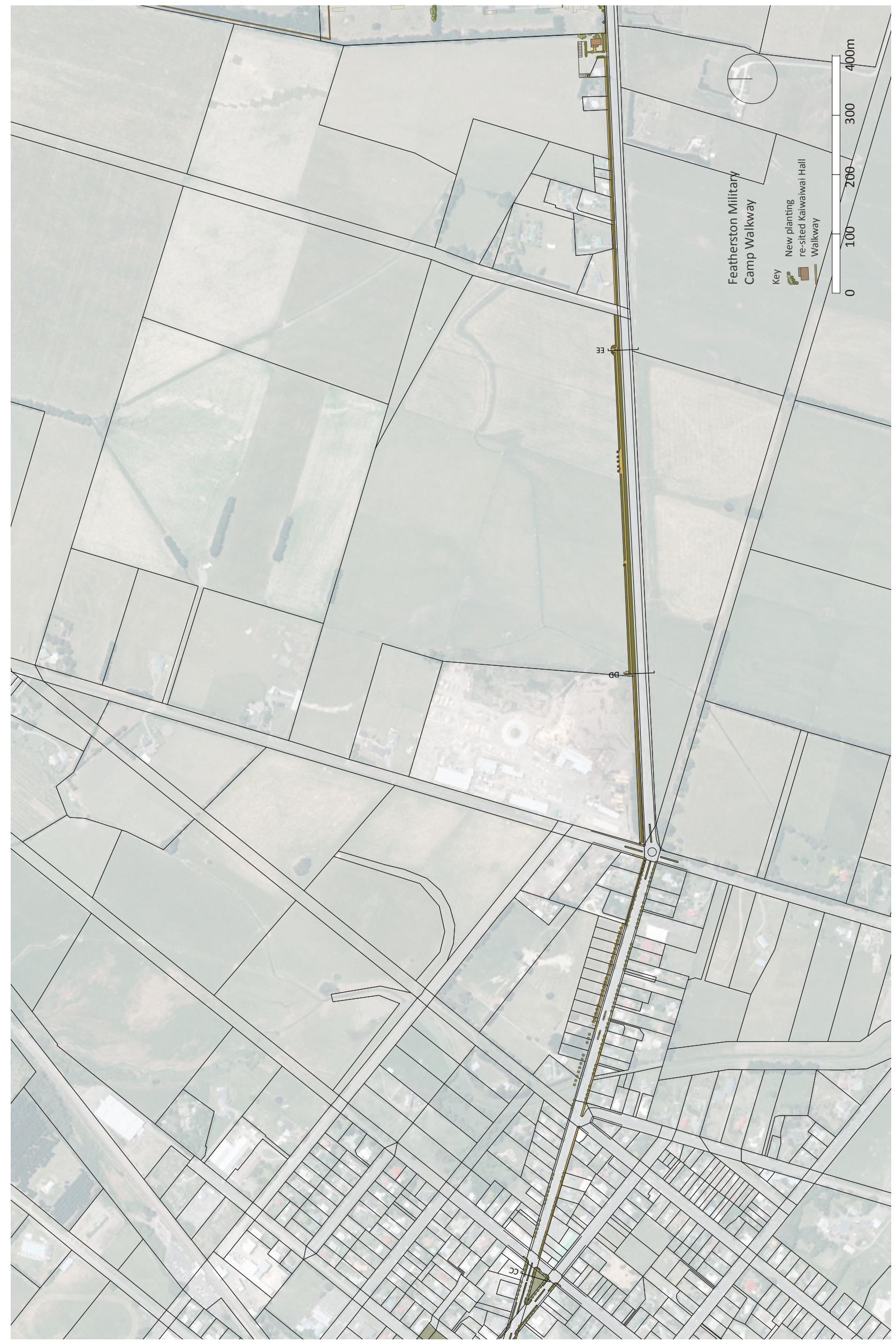



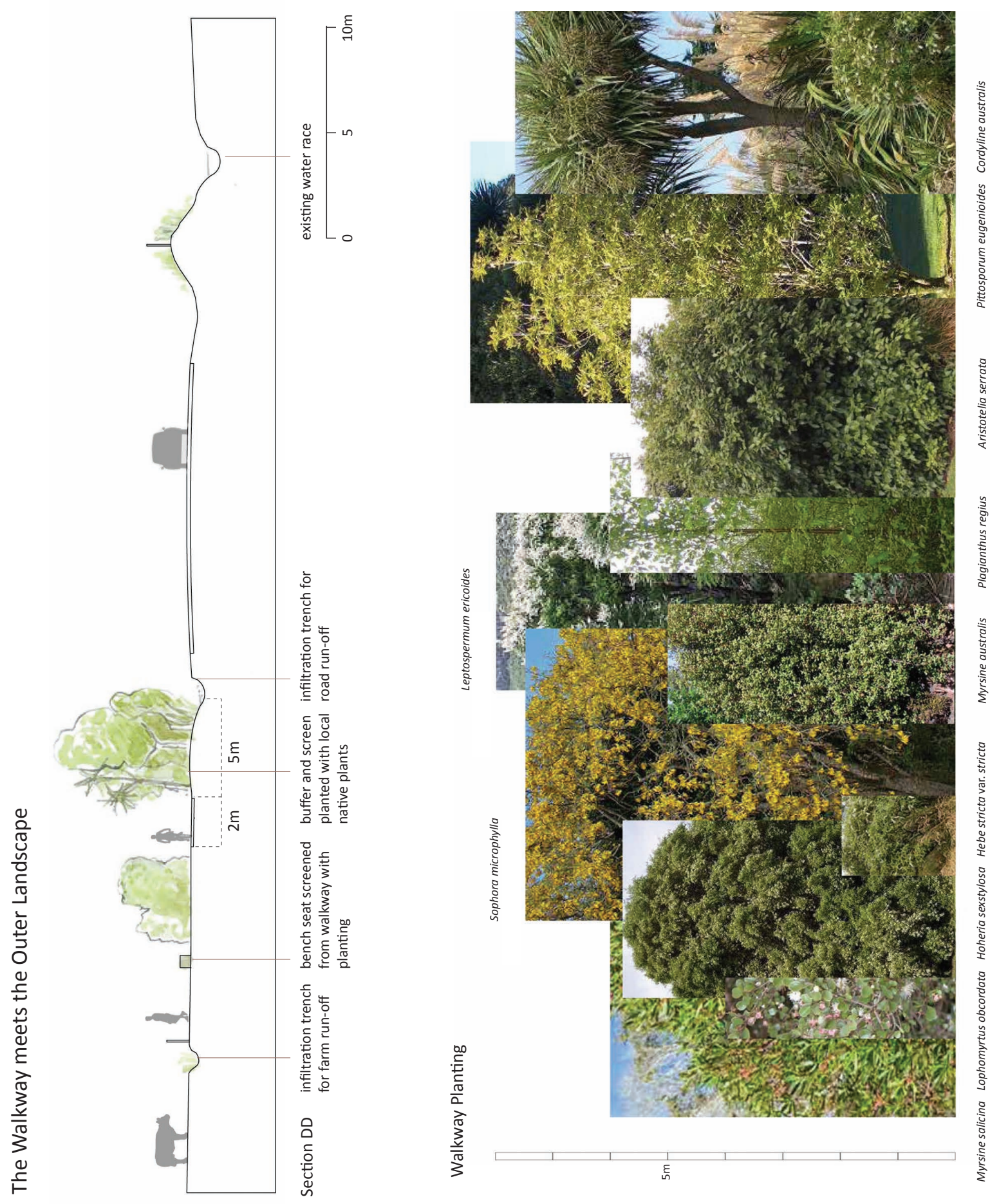

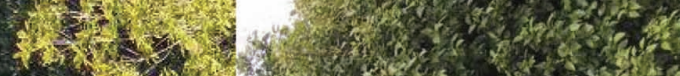

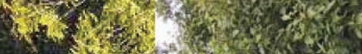

(5) $(2,2)$

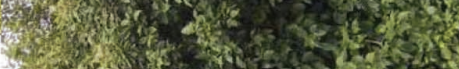

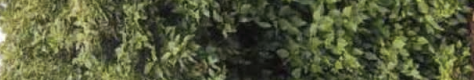

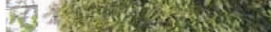

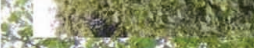
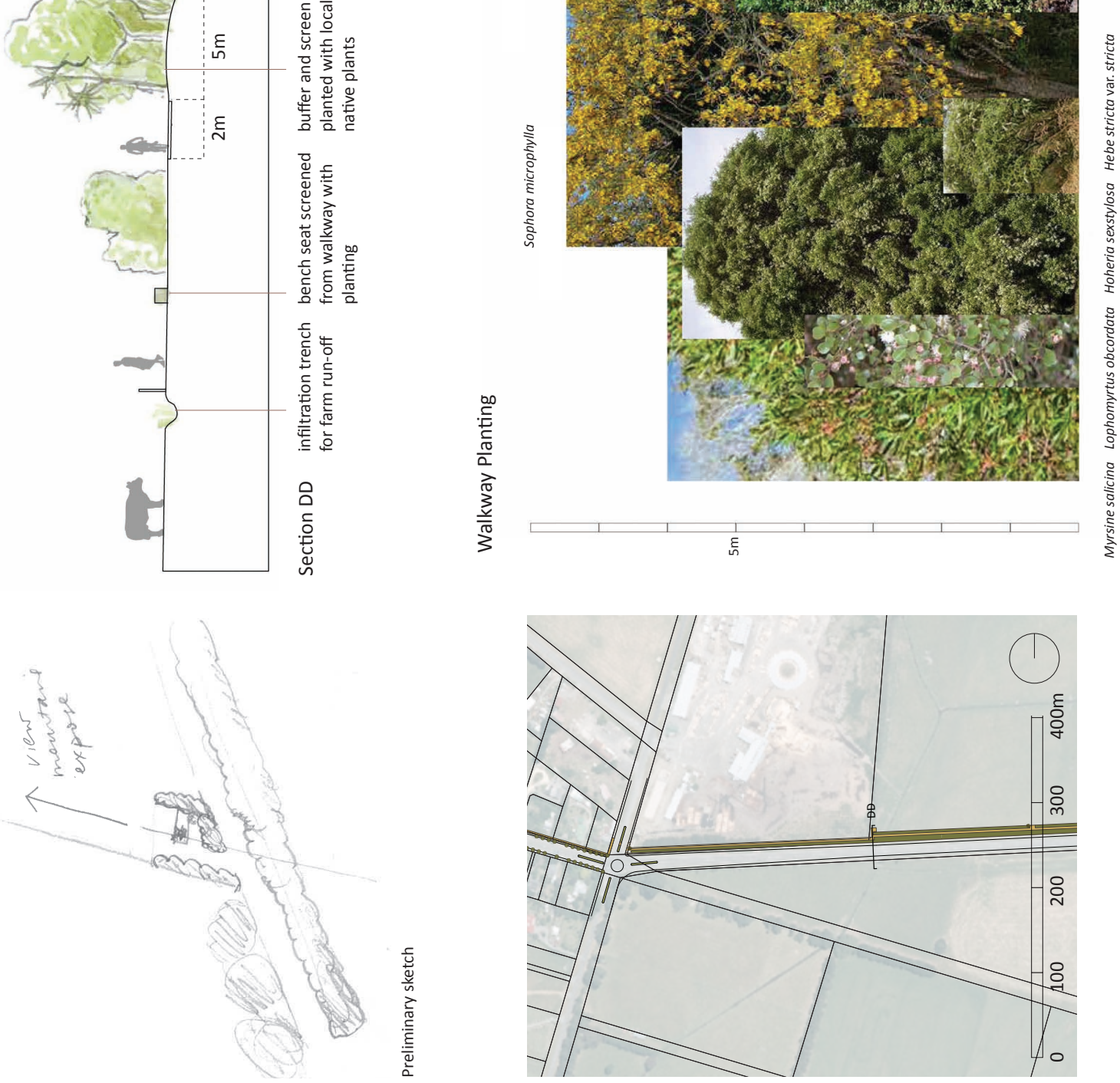


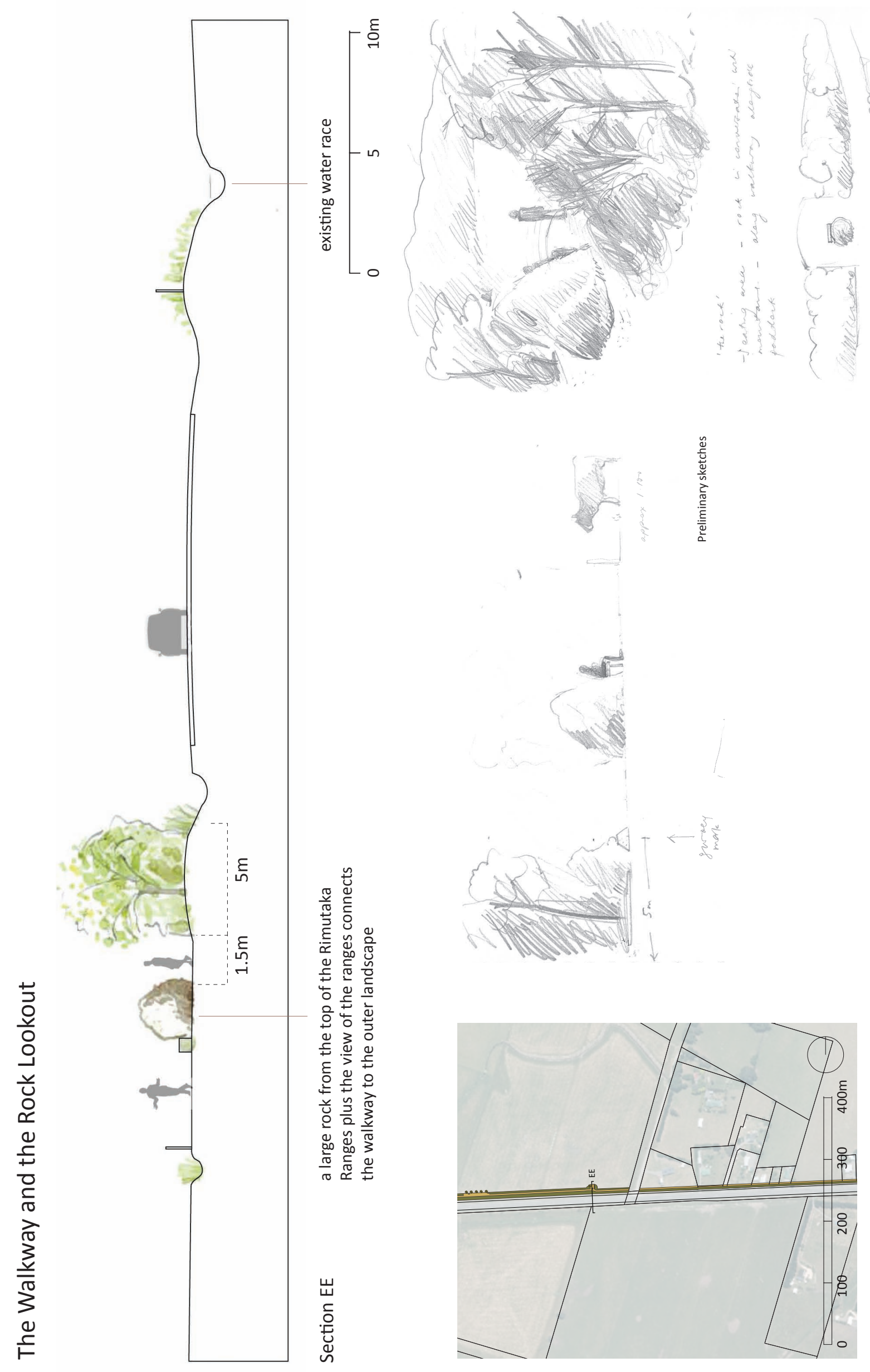



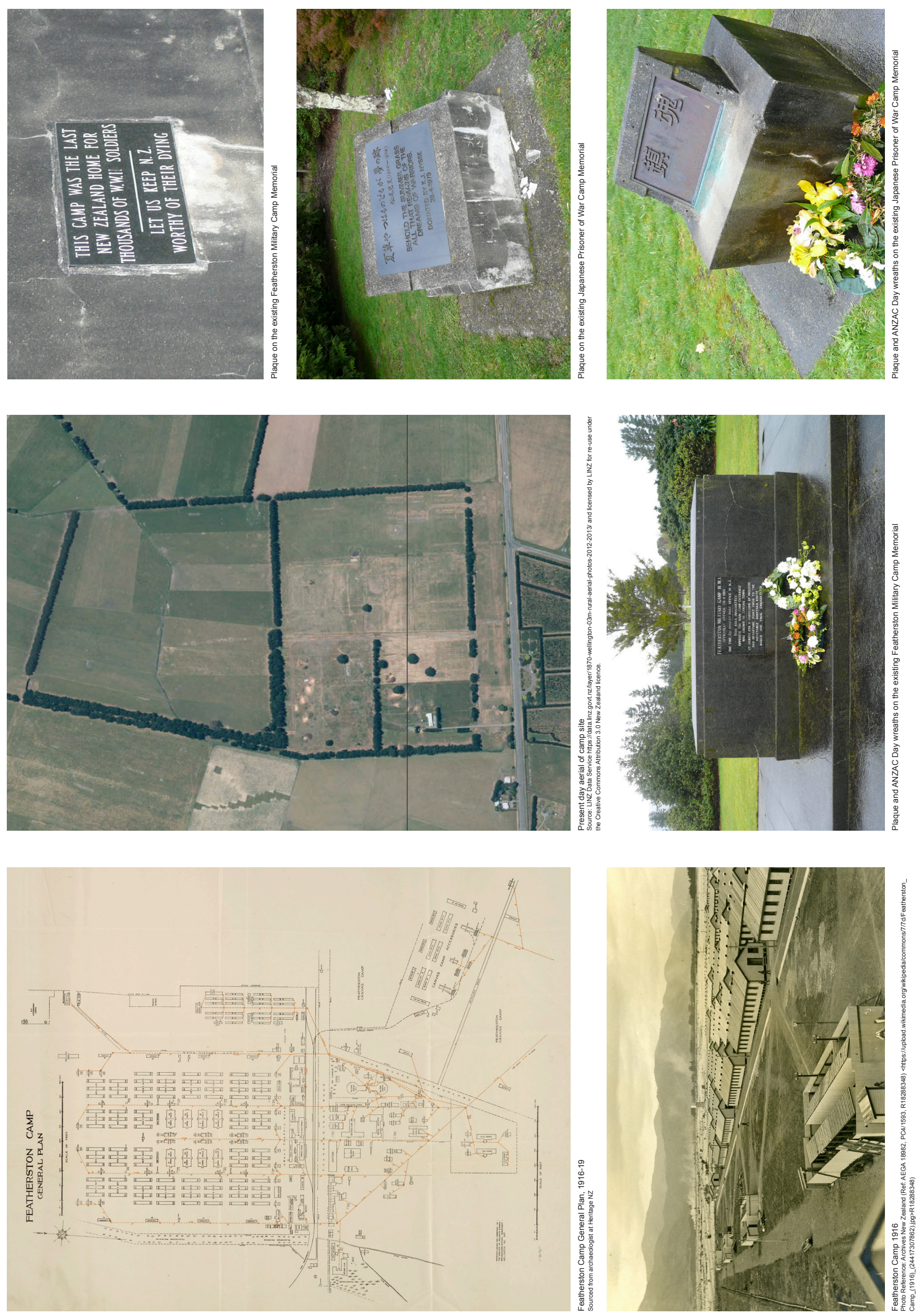

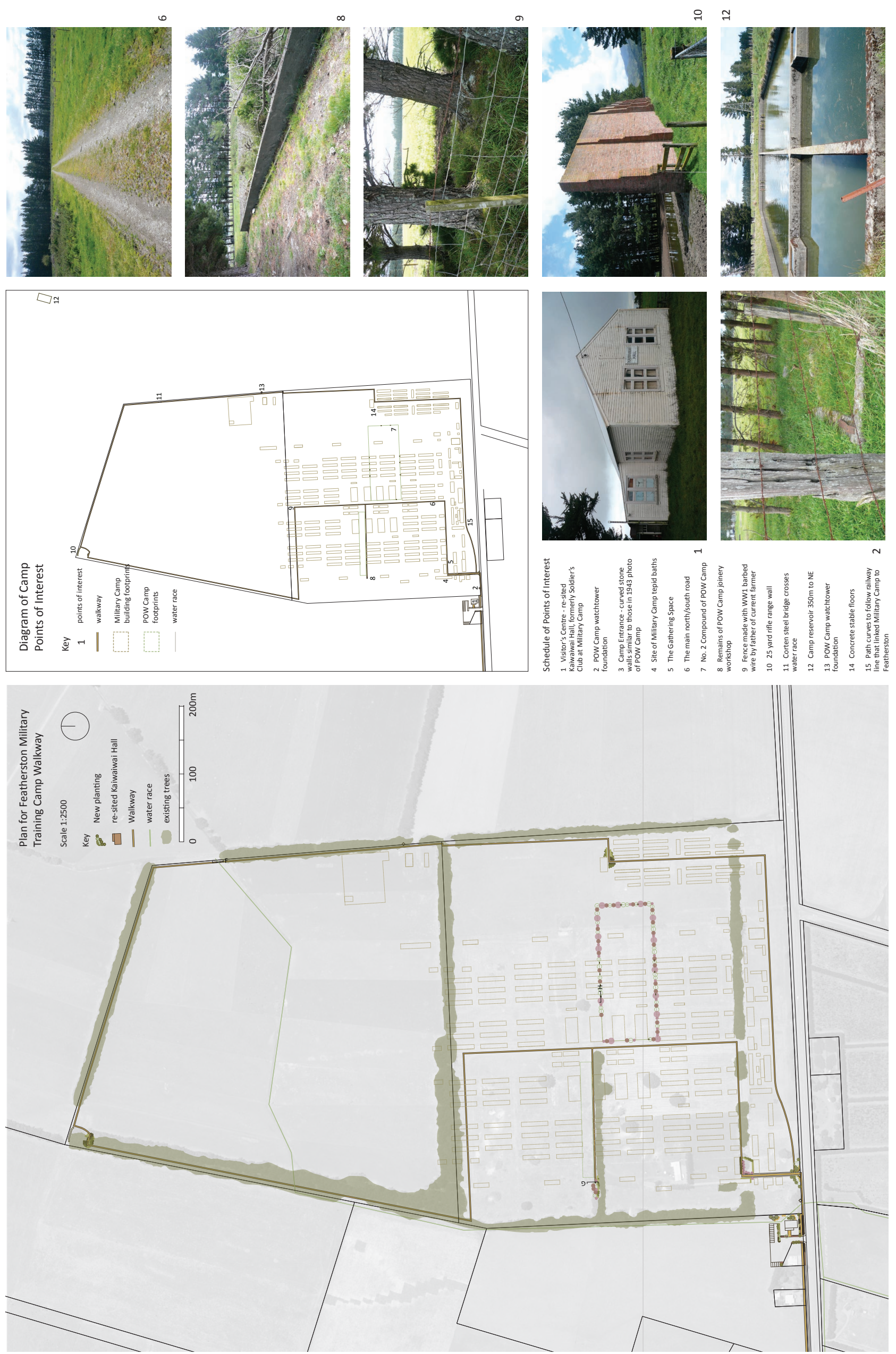

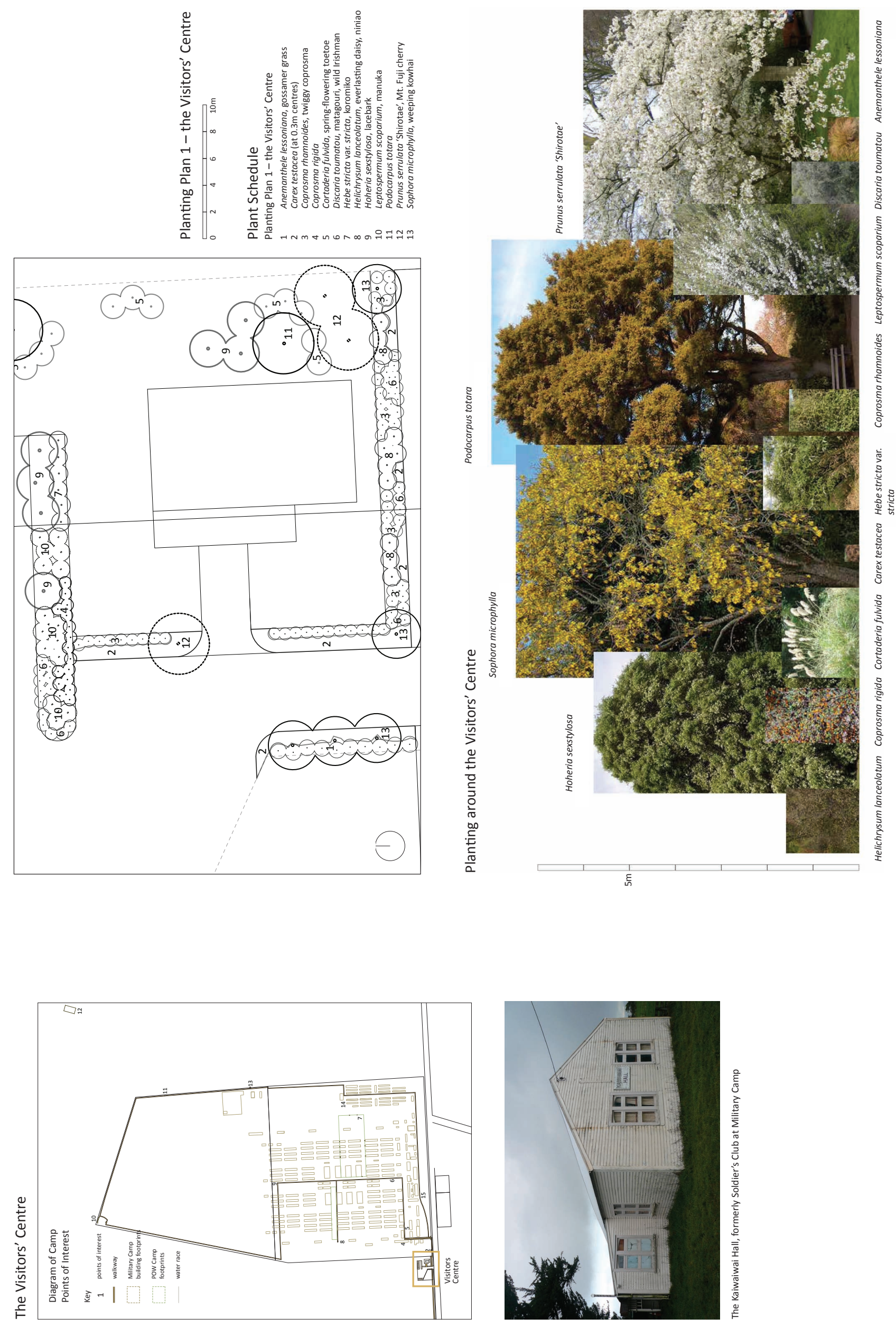


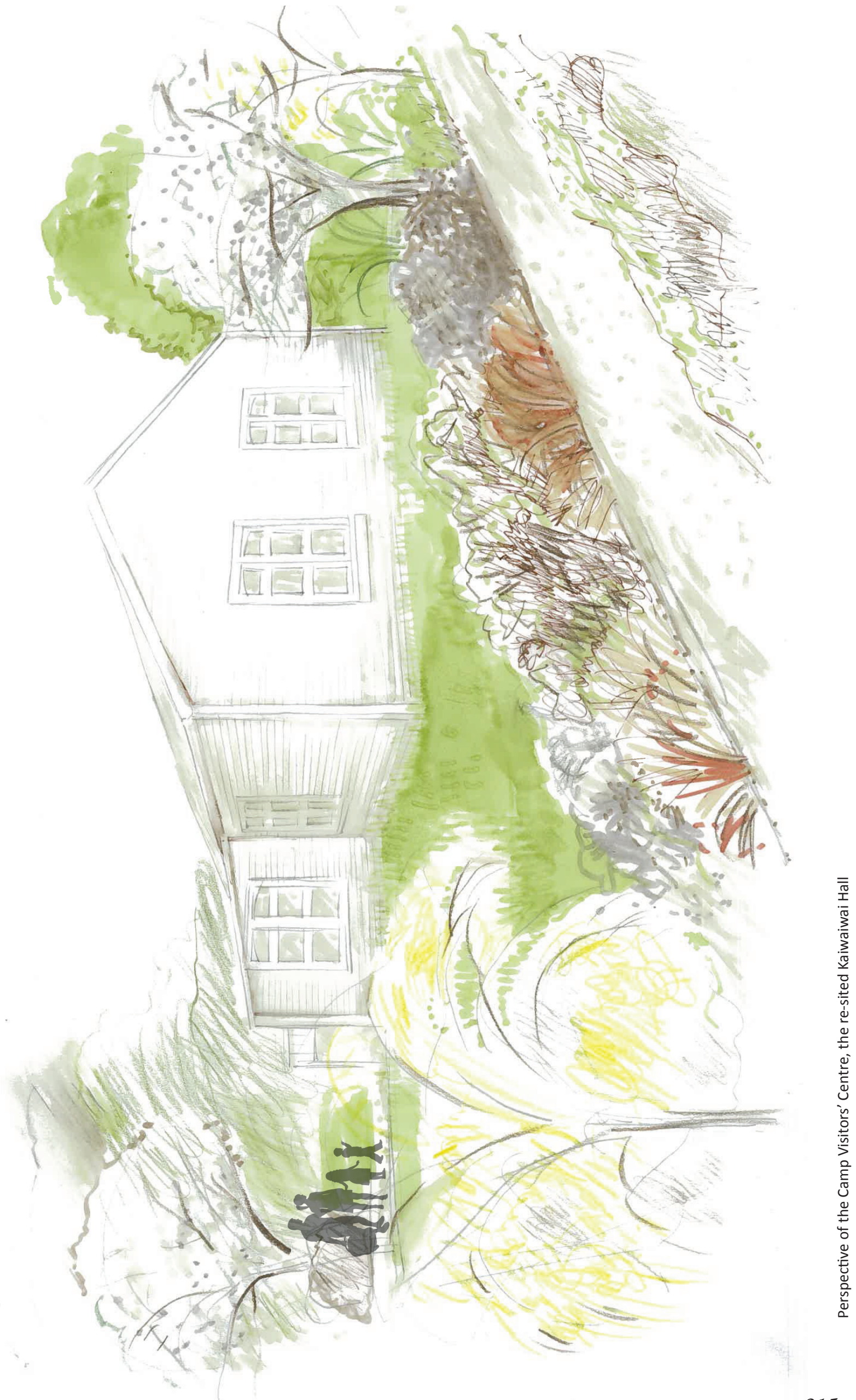




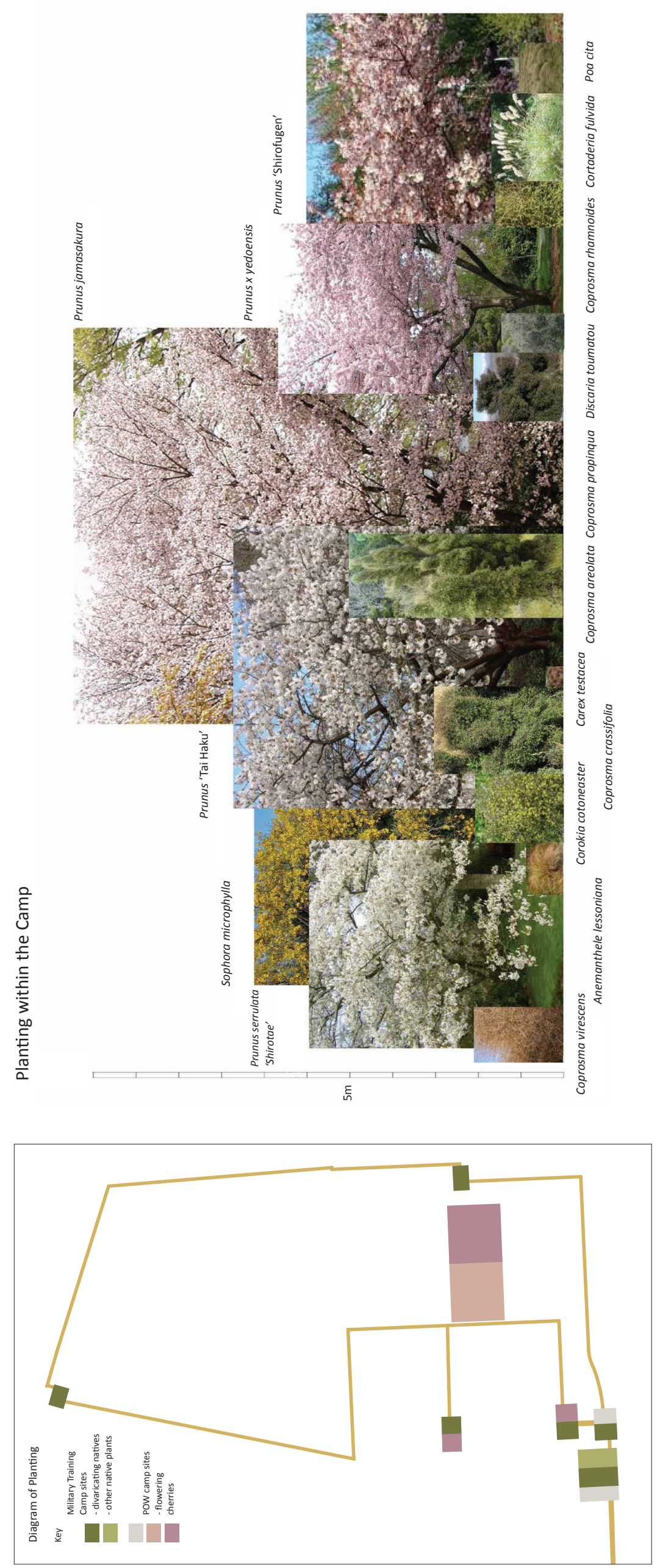



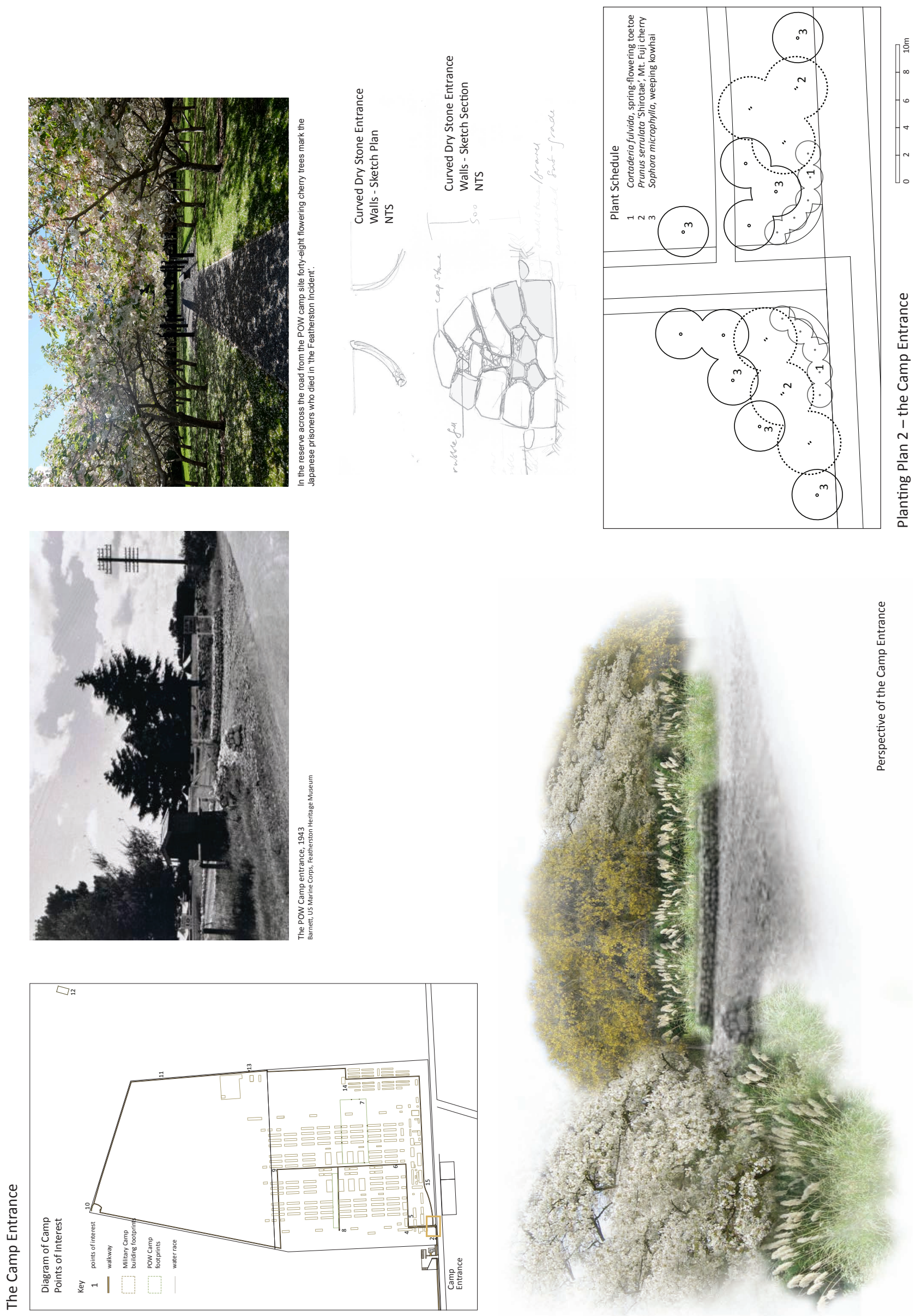

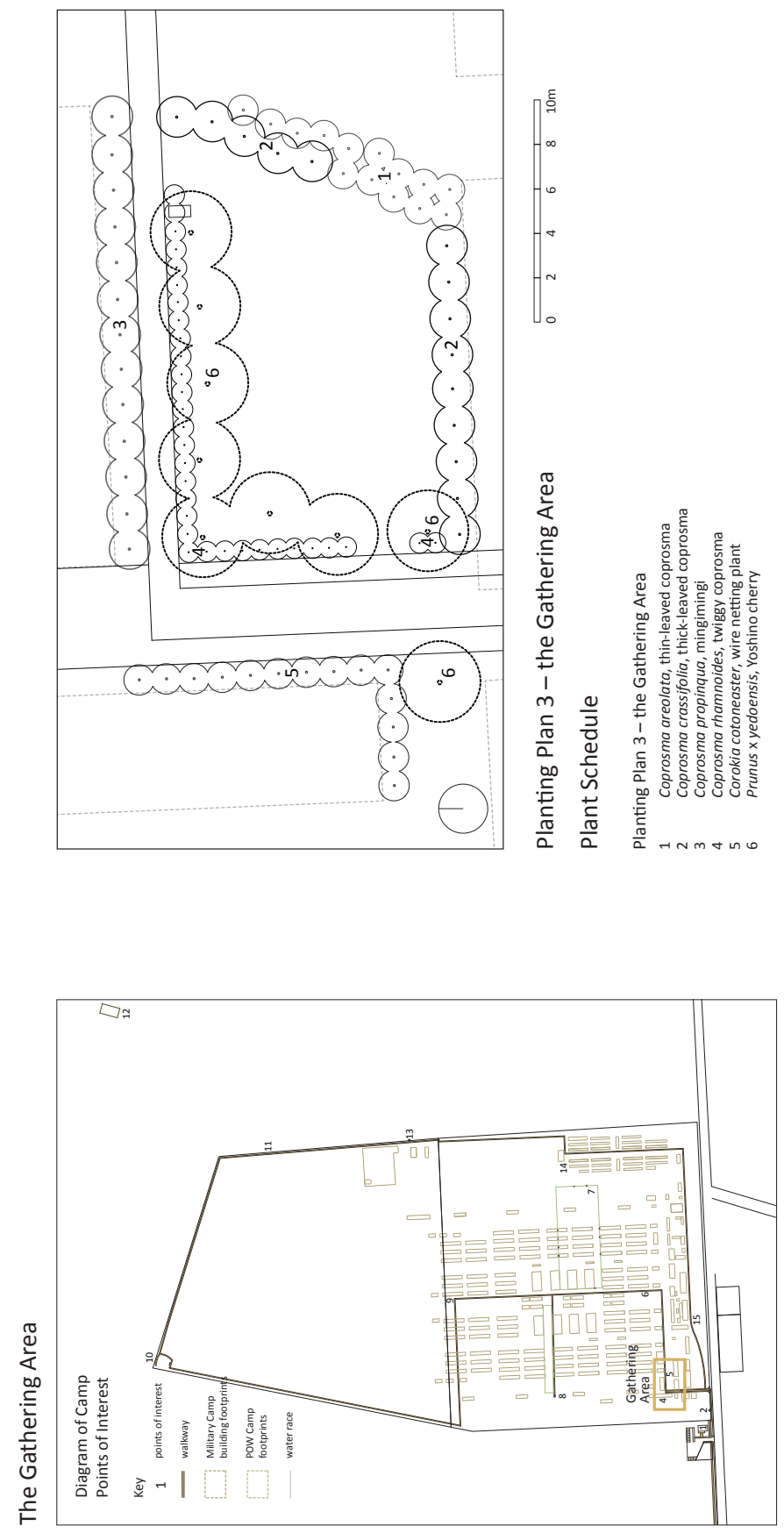

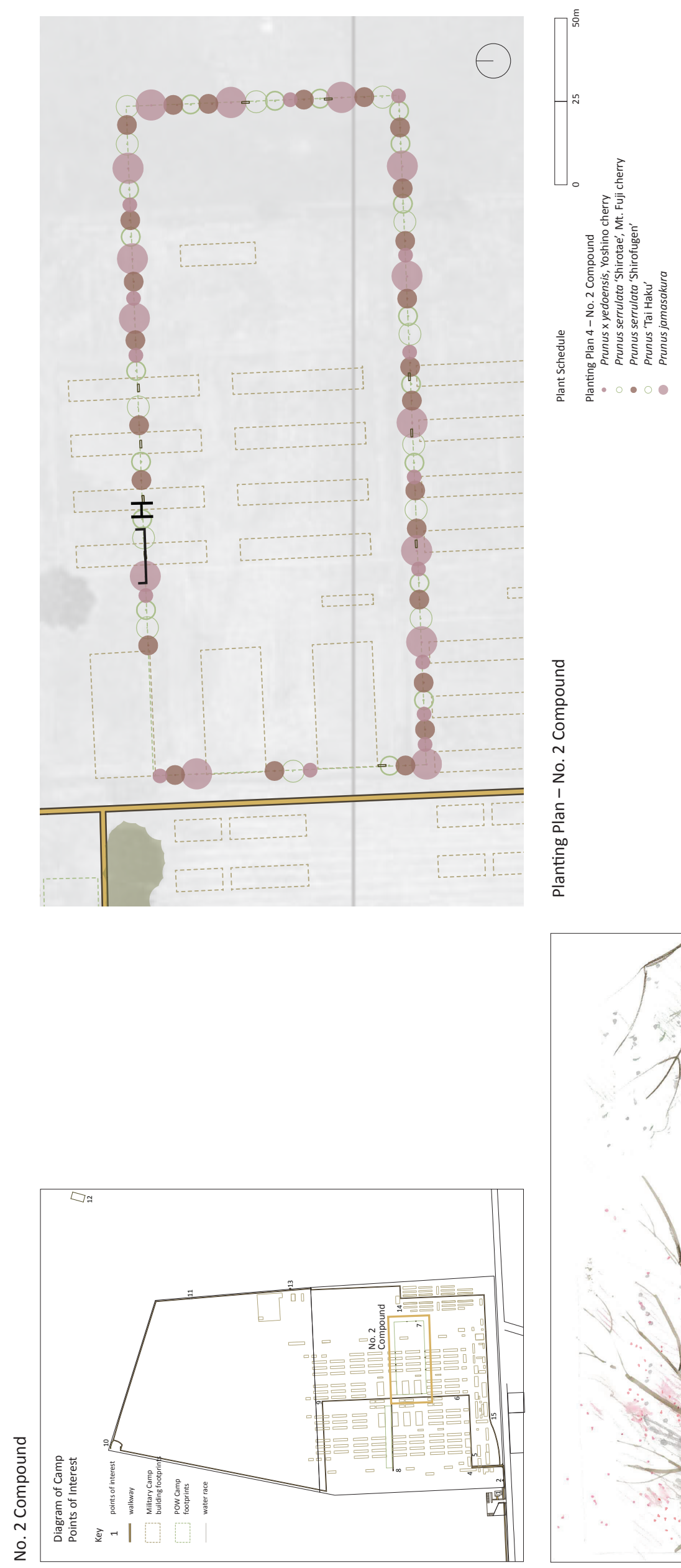

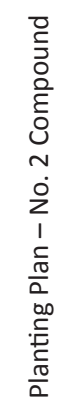

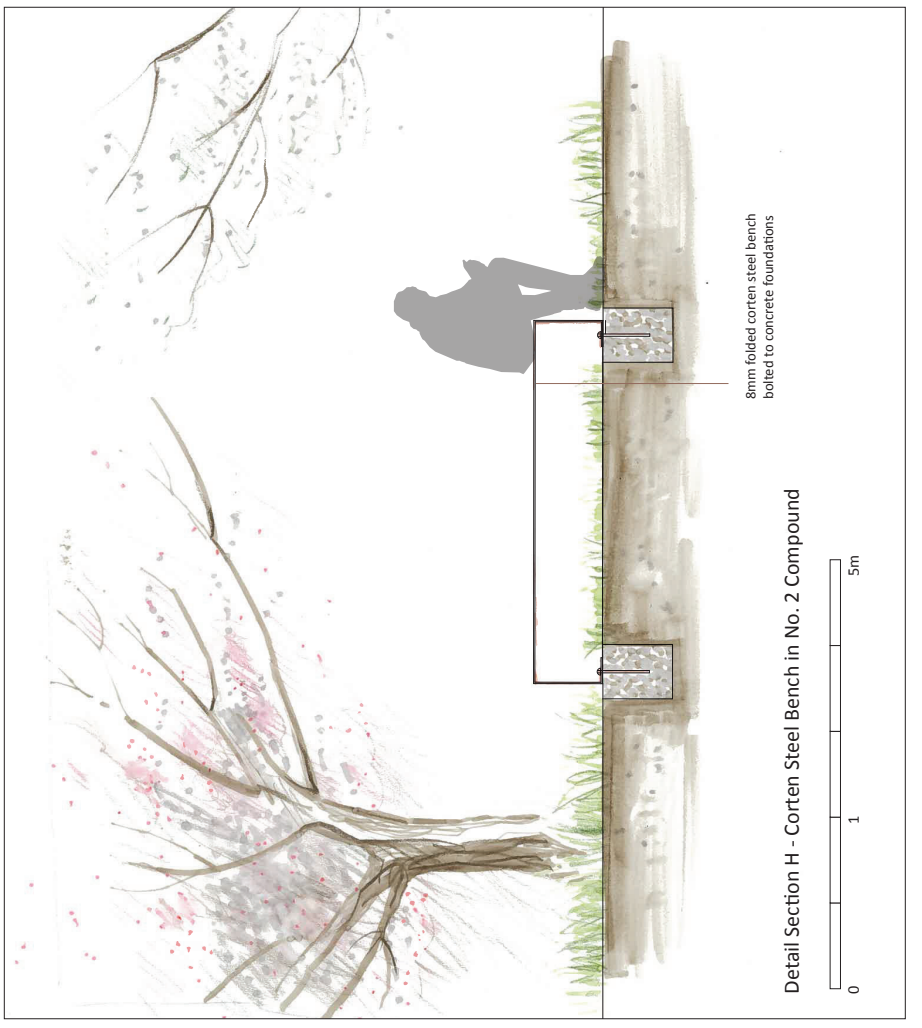



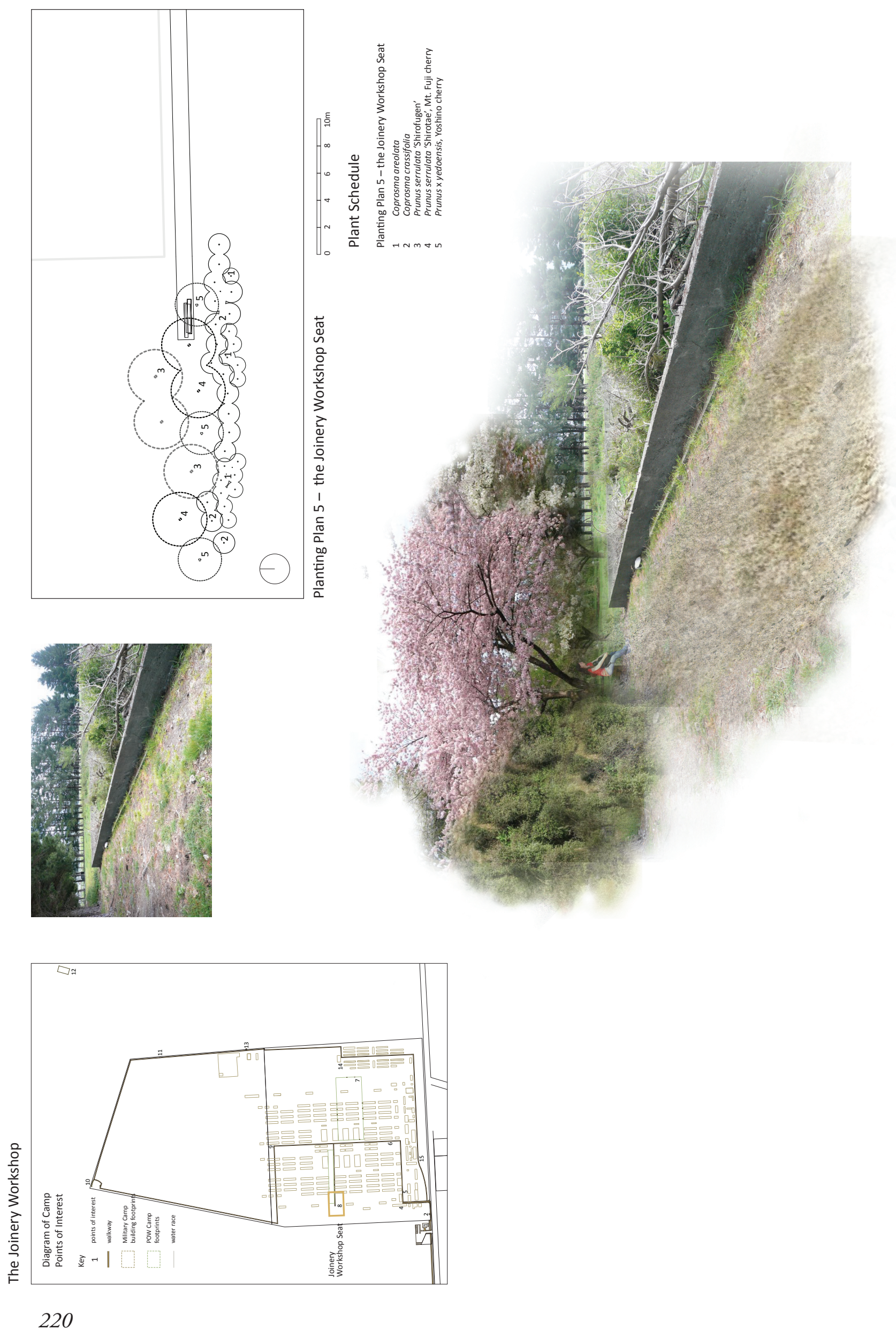

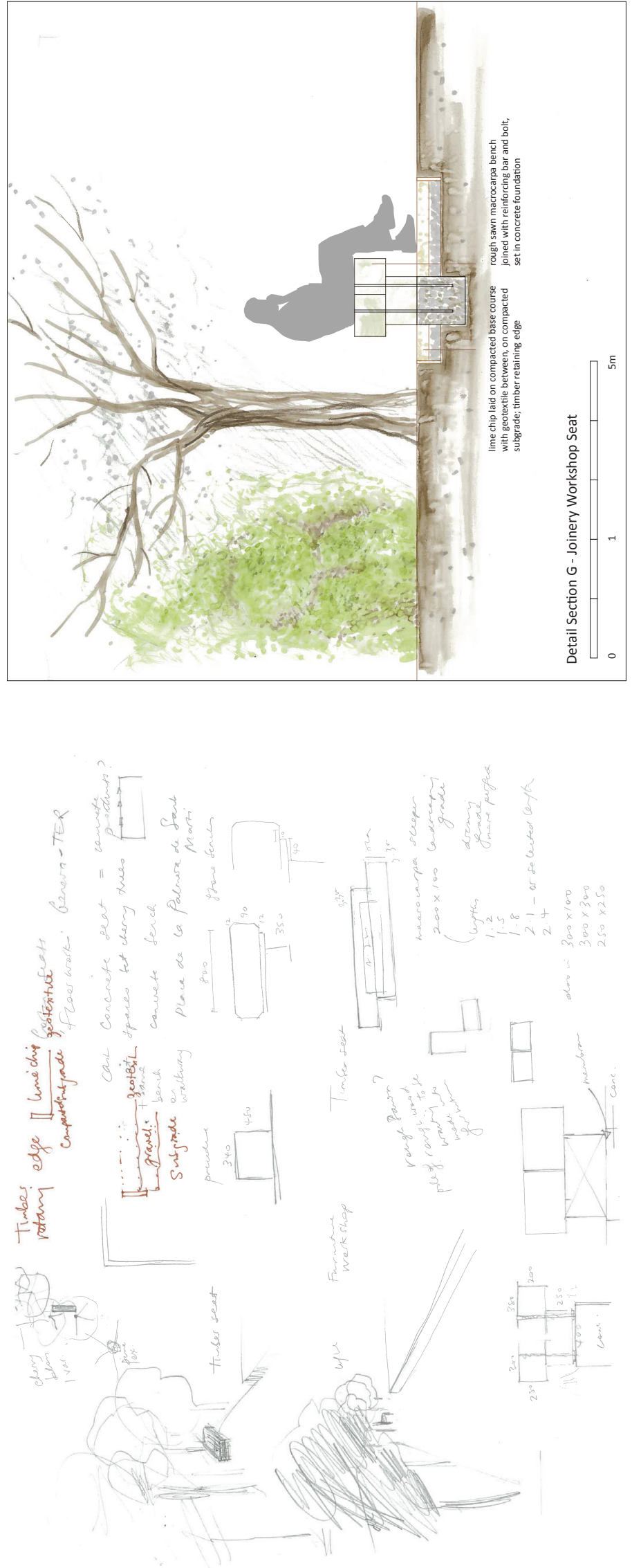

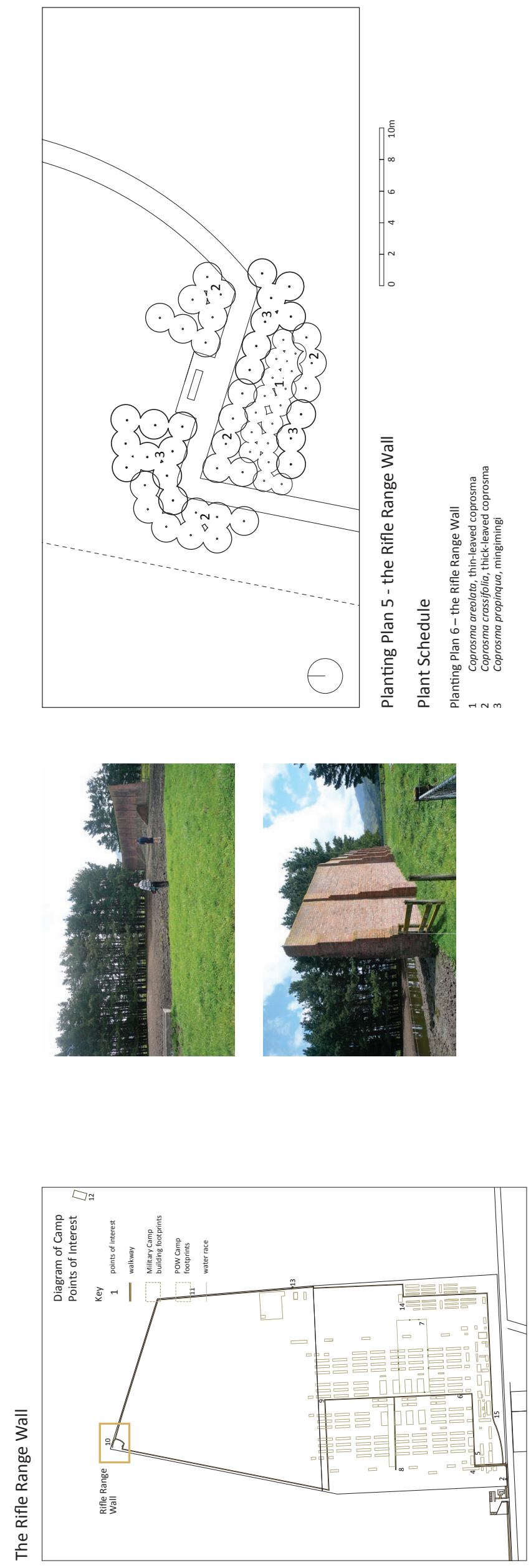

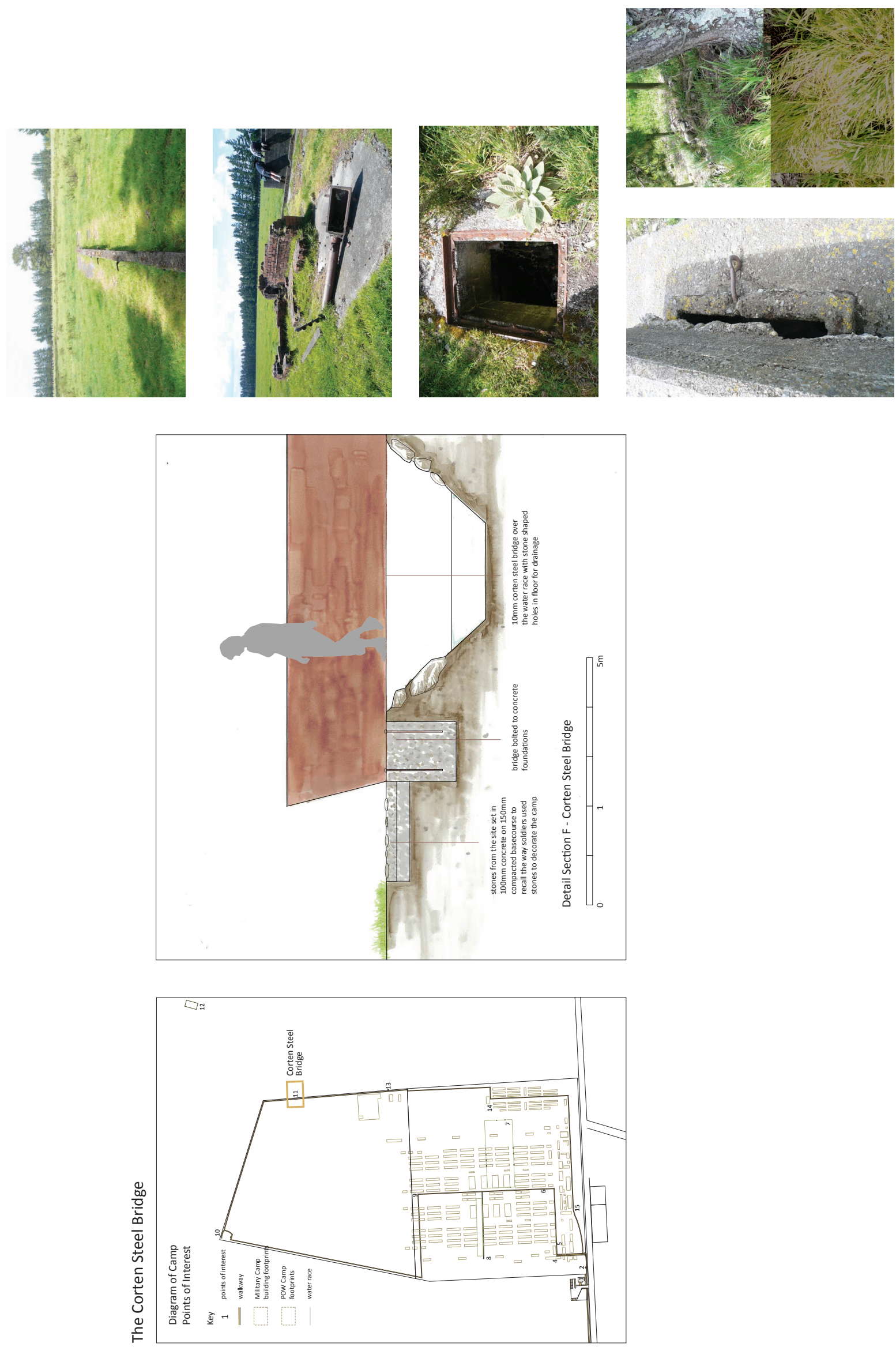

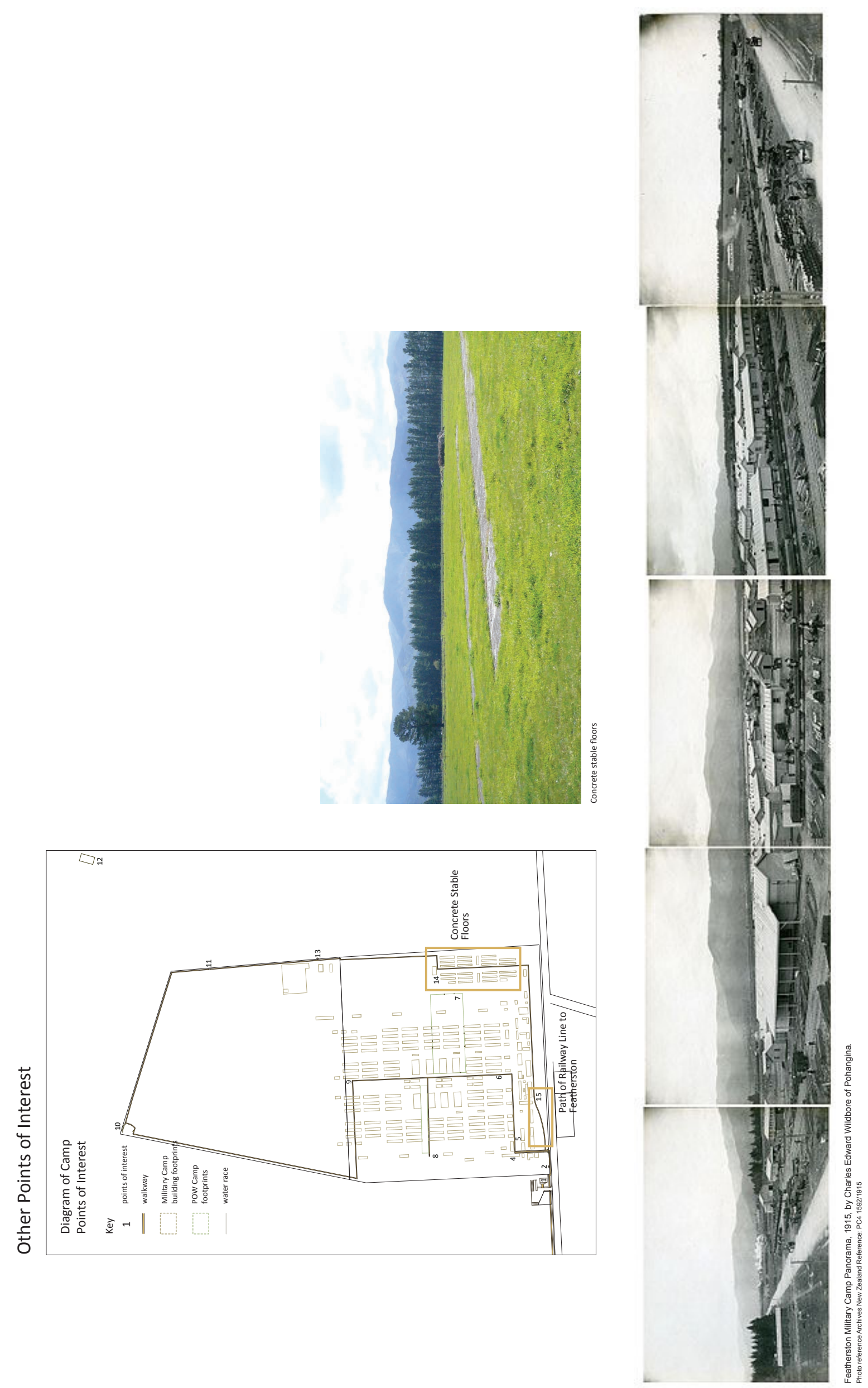

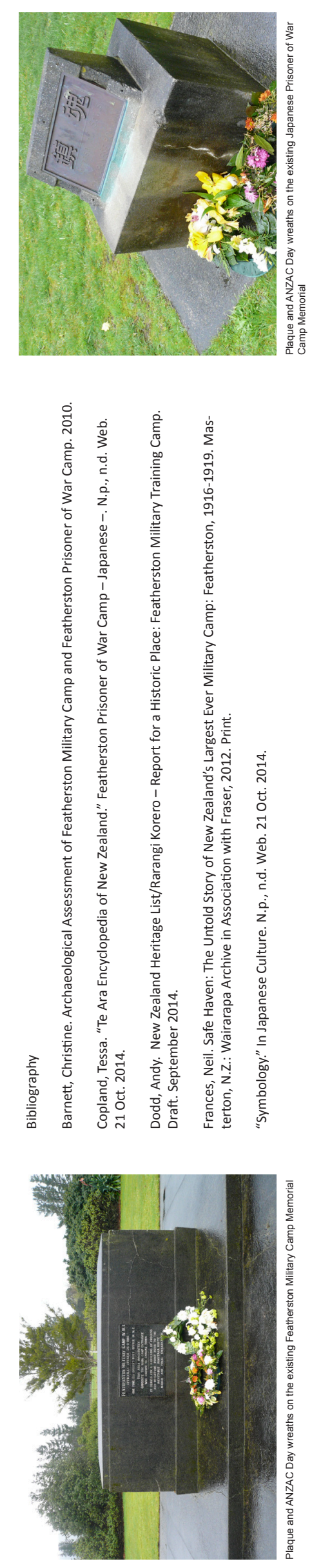


\section{APPENDIX B: $\quad$ Arch Site Maps}

Maps sourced from the New Zealand Archaeological Association's Archaeological Site Recording

Scheme website - www.archsite.org.nz - joined together to create larger maps of the study area

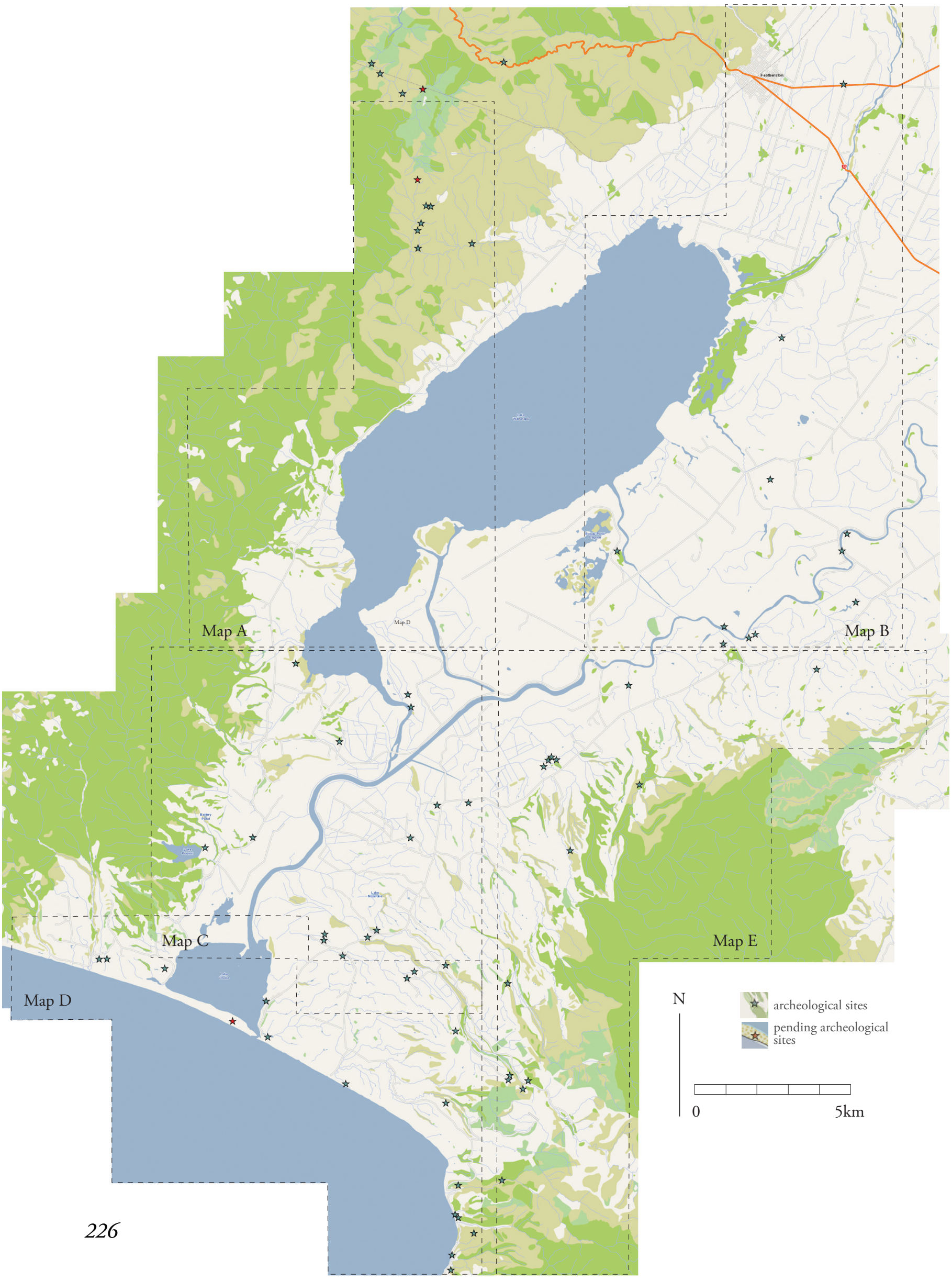


Heritage NZ Listing

Rimutaka Incline Rail Trail

Historic Area

List no. 7511

\section{KEY:}

Site information:

1. NZAA Id

2. Description and Name (if applicable)

3. Period:

Site Types:

$\begin{array}{ll}\text { A } & \text { Artefact find } \\ \text { B/C } & \text { Burial/Cemetery } \\ \text { BE } & \text { Botanical evidence } \\ \text { H } & \text { Historic - domestic } \\ \text { I } & \text { Industrial } \\ \text { M } & \text { Marae } \\ \text { Mil } & \text { Military } \\ \text { MH } & \text { Maori horticulture } \\ \text { M/O } & \text { Midden/Oven } \\ \text { P } & \text { Pa } \\ \text { P/T } & \text { Pit/terrace } \\ \text { TC } & \text { Transport/Communication }\end{array}$

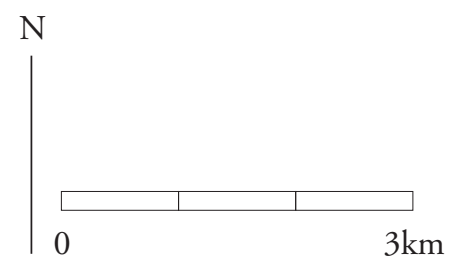

\section{Map A}

S27/35 TC

Railway Tunnel

Summit Tunnel and Settlement Rimutaka Incline

Colonial 1840-1900

S27/36 TC

Railway Tunnel

Siberia Tunnel

Colonial 1840-1900

S27/37 I

Water intake. Concrete water drop shaft/drainage inlet column

Colonial 1840-1900

S27/38 TC

Railway Tunnel

(no more info.)

S27/40 T C

Railway Workers' Shelter

(Northern side of former railway track. SW bend of

Rimutaka Incline)

Colonial 1840-1900

S27/39 I

Brick kiln

(no more info.)

S27/41 TC

Railway workshop and settlement (foundations) (Sited on the Rimutaka Incline - now an extension of Cross Creek Road; $2 \mathrm{~km}$ west of junction with

Western Lake Road.)

Colonial 1840-1900

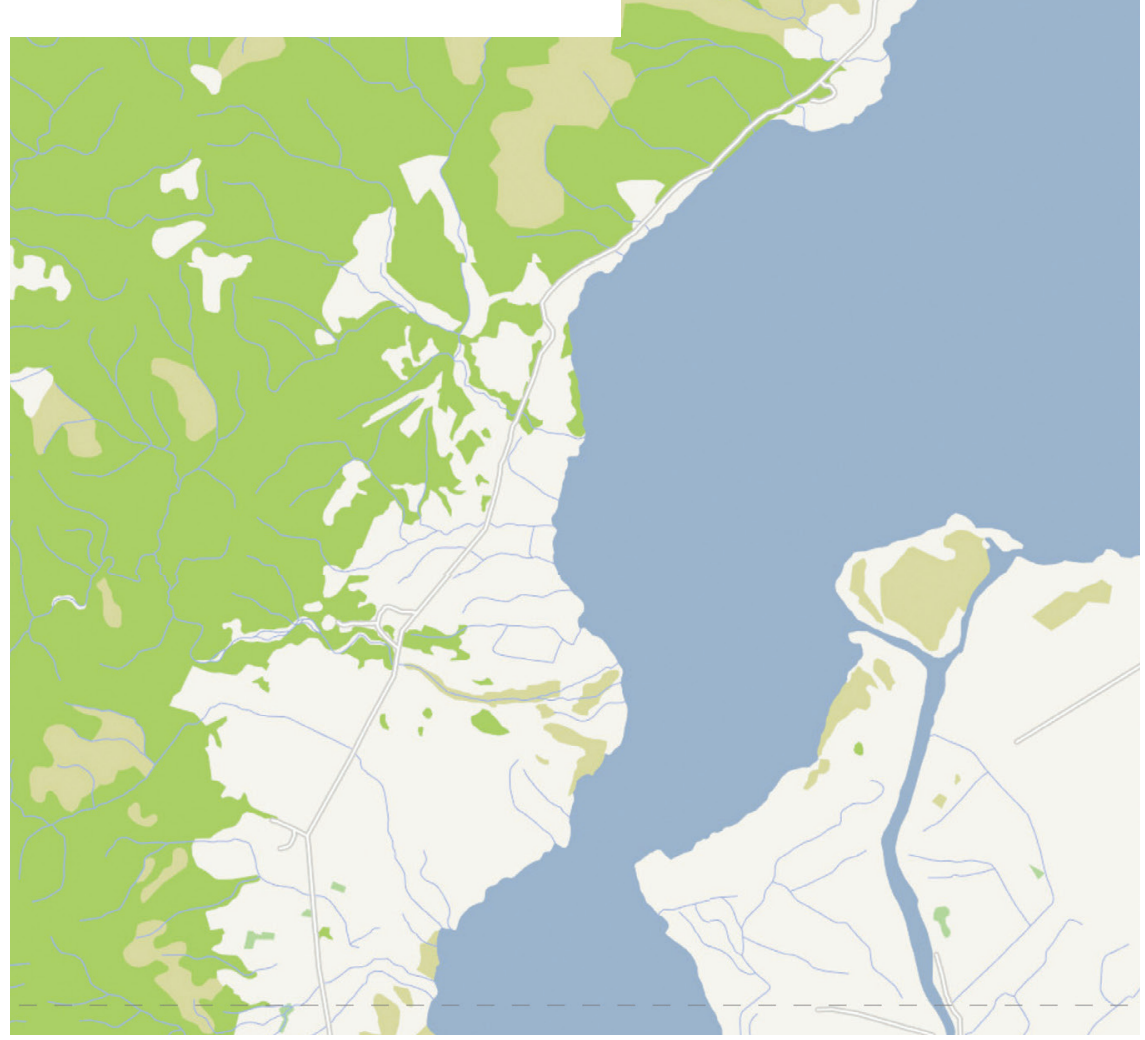




\section{KEY:}

Site information:

1. NZAA Id

2. Description and Name (if applicable)

3. Period:

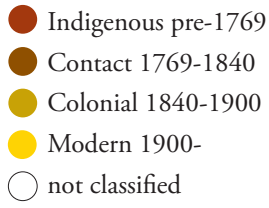

Site Types:
A Artefact find
B/C Burial/Cemetery
BE Botanical evidence
$\mathrm{H} \quad$ Historic-domestic
I Industrial
M Marae
Mil Military
$\mathrm{MH}$ Maori horticulture
M/O Midden/Oven
$\mathrm{P} \quad \mathrm{Pa}$
$\mathrm{P} / \mathrm{T} \quad \mathrm{Pit} /$ terrace
TC Transport/Communication
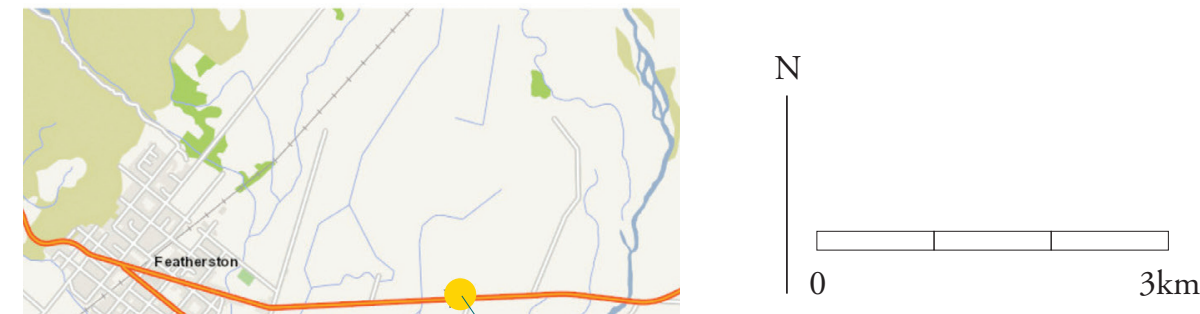

Map B

S27/42 Mil

Military Camp, extent of site $1 \mathrm{x} 1 \mathrm{~km}$ (on north and south side of $\mathrm{SH} 2,2 \mathrm{~km}$ east of Featherston)

Modern 1900-

Heritage NZ Listing:

Featherston Military Training Camp

Historic Place Category 1

List no. 9661

S27/47 A

Greenstone adze find spot

Indigenous pre-1769

S27/29 MO

Ovens

Indigenous pre-1769

S27/17 MO

?Ovens

Maori

Period not listed

S27/30

Burials and ovens B

Historic site and possibly Otaraia Pa

Extent of site $60 \times 30 \mathrm{~m}$

Contact 1769-1840

S27/15 P/T

Pits and terraces, extent of site

100x $100 \mathrm{~m}$

Indigenous pre-1769

S27/18 P/T

Pits

Indigenous pre-1769

S27/19 A

Findspot for canoe

Indigenous pre-1769

S27/14 B

Burials

Indigenous pre-1769

S27/20 A

Findspot for canoe

(no more info.)

S27/13 P

Pa site

Otaraia Pa

Colonial 1840-1900

Heritage NZ Listing

- Rototawai Homestead

Historic Place Category 1

List no. 3954 
Map C

S27/8 M/O

Ovens - site not found

Indigenous pre-1769

S27/5 A

Findspot for canoe.

Single totara log waka (approx.. 3m long).

Canoe in storage in Masterton.

Indigenous pre-1769

S27/24 M/O

Ovens - site not found

(no more info.)

S27/7 M/O

Ovens. Artefact findspot

Indigenous pre-1769

S27/22 P/T

Eight raised rim pits

Indigenous pre-1769

S27/121 M/O

Ovens (not found recently)

Indigenous pre-1769

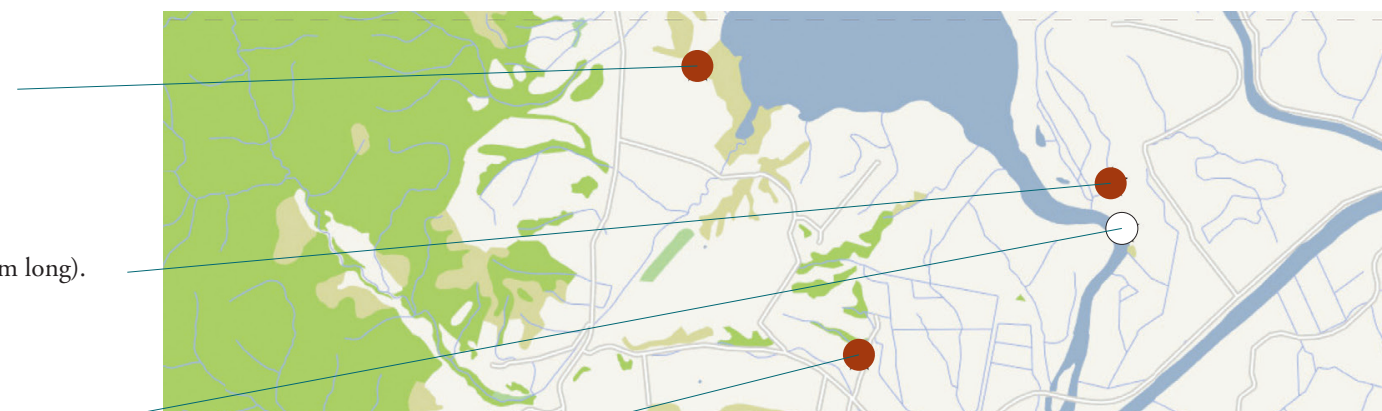

R27/122 P

Pa with terraces. Possibly a traditional pa, modified in 1820 s for musket wars.

Extent of site approx. 80x25m

Battery Hill

Indigenous pre-1769

Heritage NZ Historic Place Category 2

List no. 6160

S27/26 P

Ring ditch pa. A number of

interior/exterior pits

Raho Ruru

Colonial 1840-1900

Heritage NZ Historic Place Category 2

List no. 6236

S27/23 M

Kainga. Extent of site at least 200x50m along sand dune. School site - native school closed no later than 1900. Ngat Porou urupa. Old Whare Tupuna site Kohunui

Colonial 1840-1900

S28/171 P/T

Three or four lines of pits, at least 13 pits Indigenous pre-1769

\section{$\mathrm{S} 28 / 19 \mathrm{P} / \mathrm{T}$}

Raised rim pits

Period not listed

$\mathrm{S} 28 / 20 \mathrm{M} / \mathrm{O}$

Oven and buried charcoal soil (destroyed) Period not listed

S28/18 U

Kainga. Various house sites, orchards and a urupa (no name listed)

Colonial 1840-1900

S27/28 P/T

Raised rim pits

Indigenous pre-1769

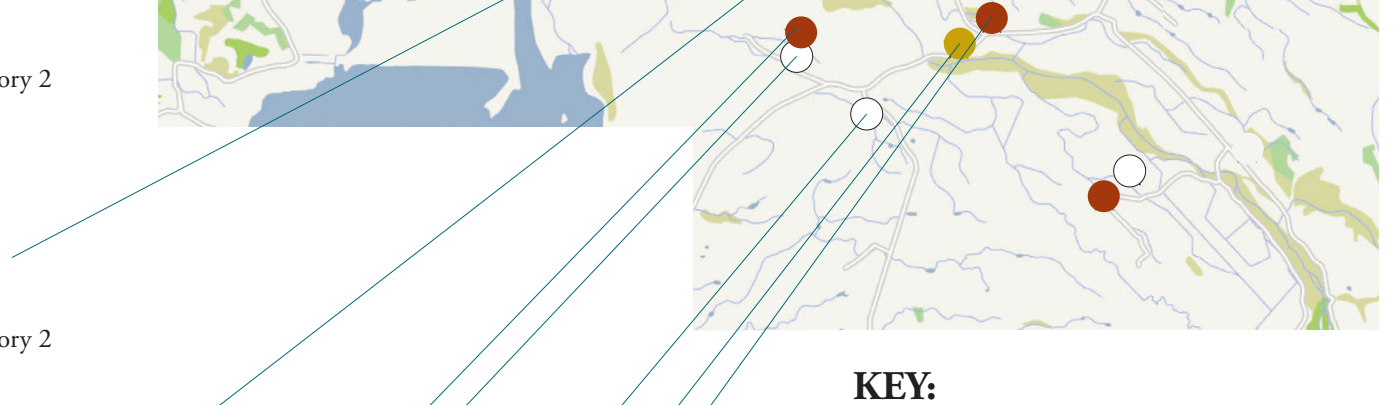

Site information:

1. NZAA Id

2. Description and Name (if applicable)

3. Period: Indigenous pre-1769

Contact 1769-1840

Colonial 1840-1900

Modern 1900-

not classified

Site Types:

A Artefact find

B/C Burial/Cemetery

BE Botanical evidence

$\mathrm{H} \quad$ Historic - domestic

I Industrial

M Marae

Mil Military

$\mathrm{MH}$ Maori horticulture

M/O Midden/Oven

$\mathrm{P} \quad \mathrm{Pa}$

P/T Pit/terrace

TC Transport/Communication 


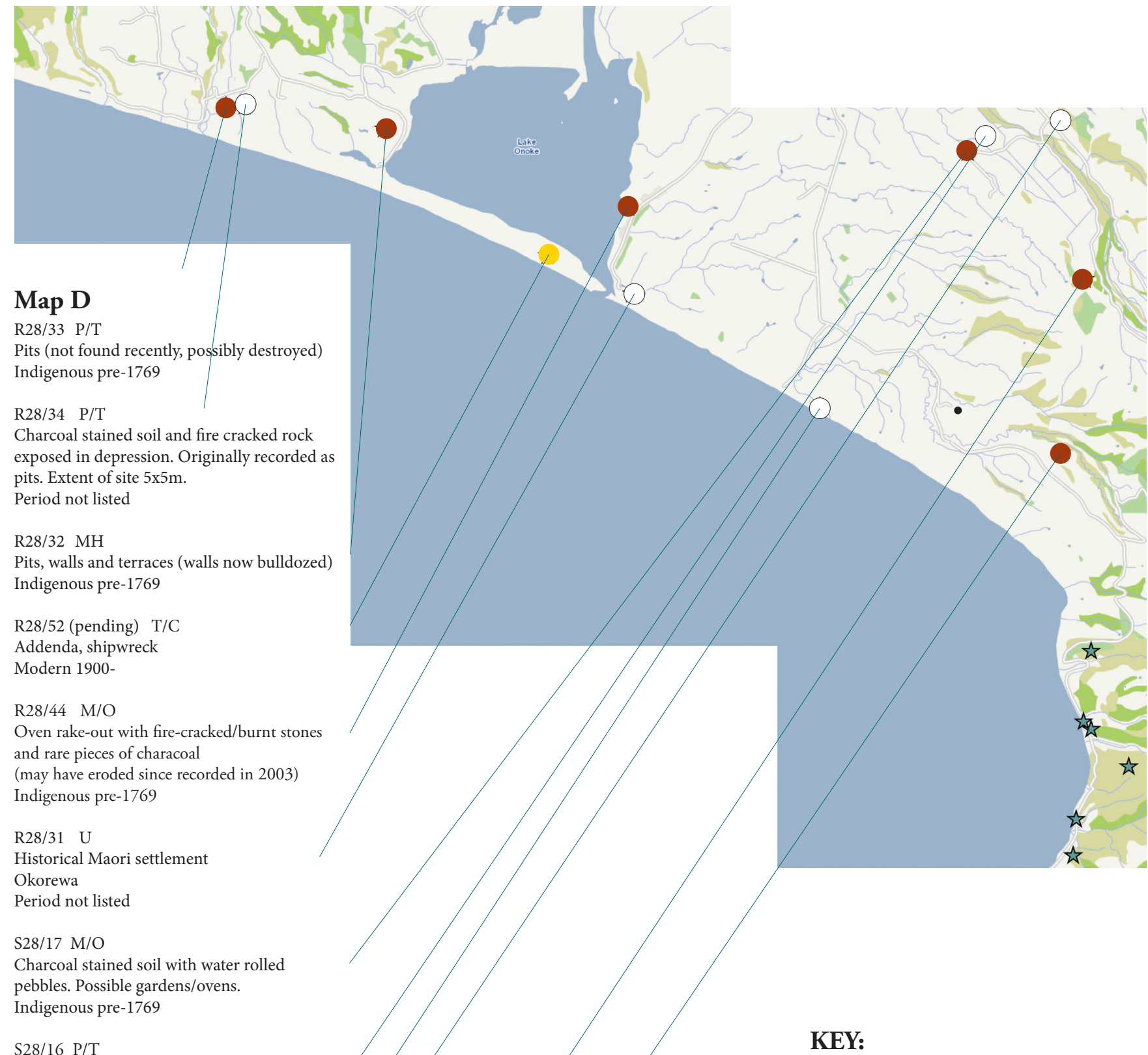

S28/16 P/T

Pits

Period not listed

S28/10 M/O

Oven and midden (site not found, eroded or hidden by vegetation)

Period not listed

S28/14 P

$\mathrm{Pa}$ - Parikarangaranga

Period not listed

Heritage NZ Historic Place Category 2

List no. 6238

S28/15 P/T

One raised rim pit, two other pits, and 6-8 possible depressions.

Indigenous pre-1769

$\mathrm{S} 28 / 9 \quad \mathrm{P} / \mathrm{T}$

Settlement site with house floors, pits and stone rows/gardens (very good condition) Moikau

Indigenous pre-1769

Whangaimoana Station Homestead Heritage NZ Historic Place Category 2 List no. 1315 


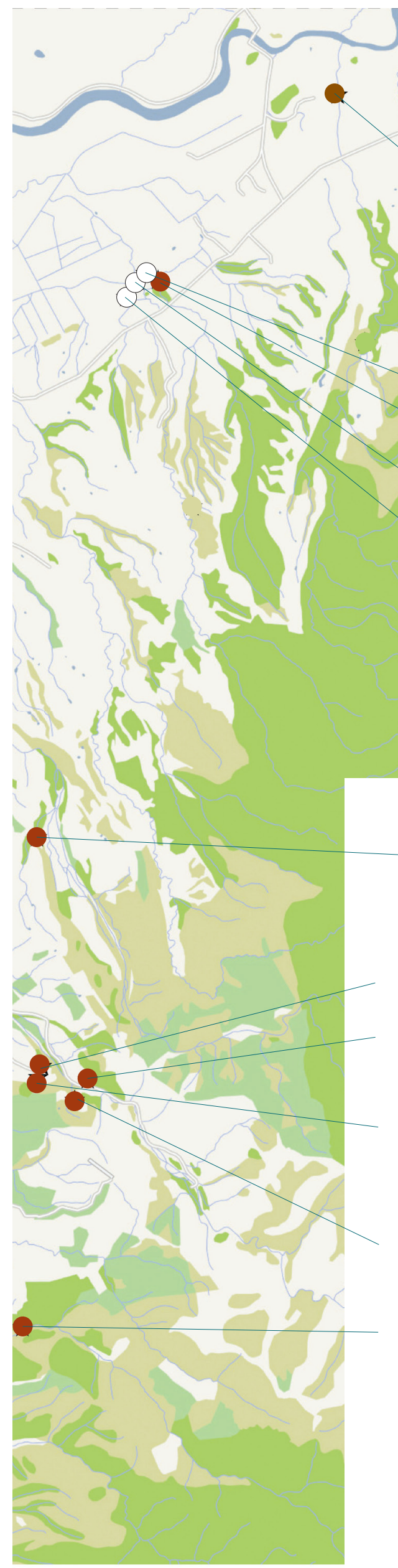

S28/21 P/T

Raised rim pits, extent of site $15 \times 5 \mathrm{~m}$

Indigenous pre-1769

S28/13 P/T

Complex of pits

Indigenous pre-1769

\section{S28/11 $\mathrm{P} / \mathrm{T}$}

Two raised rim pits, amongst remnant karaka. Black charcoal-rich soil and fire cracked rock visible in erosion $30 \mathrm{~m}$ to west. Small terrace $4 \times 2 \mathrm{~m}$ Indigenous pre-1769

S28/12 P

Ridge pa site, approx. 90x10m

Indigenous pre-1769

$\mathrm{S} 28 / 2 \quad \mathrm{BE}$

Karaka grove

Indigenous pre-1769

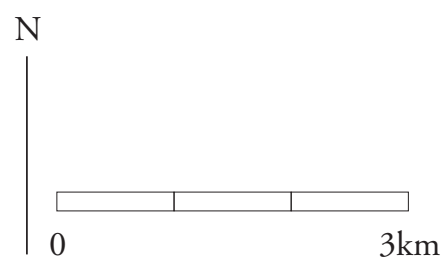

Site information:

1. NZAA Id

2. Description and Name (if applicable)

3. Period:

Indigenous pre-1769

Contact 1769-1840

Colonial 1840-1900

Modern 1900-

not classified

Site Types:

A Artefact find

B/C Burial/Cemetery

BE Botanical evidence

H Historic-domestic

I Industrial

M Marae

Mil Military

$\mathrm{MH}$ Maori horticulture

M/O Midden/Oven

$\mathrm{P} \quad \mathrm{Pa}$

$\mathrm{P} / \mathrm{T} \quad$ Pit/terrace

TC Transport/Communication 
Arch Site Maps for individual interpreted trail sites
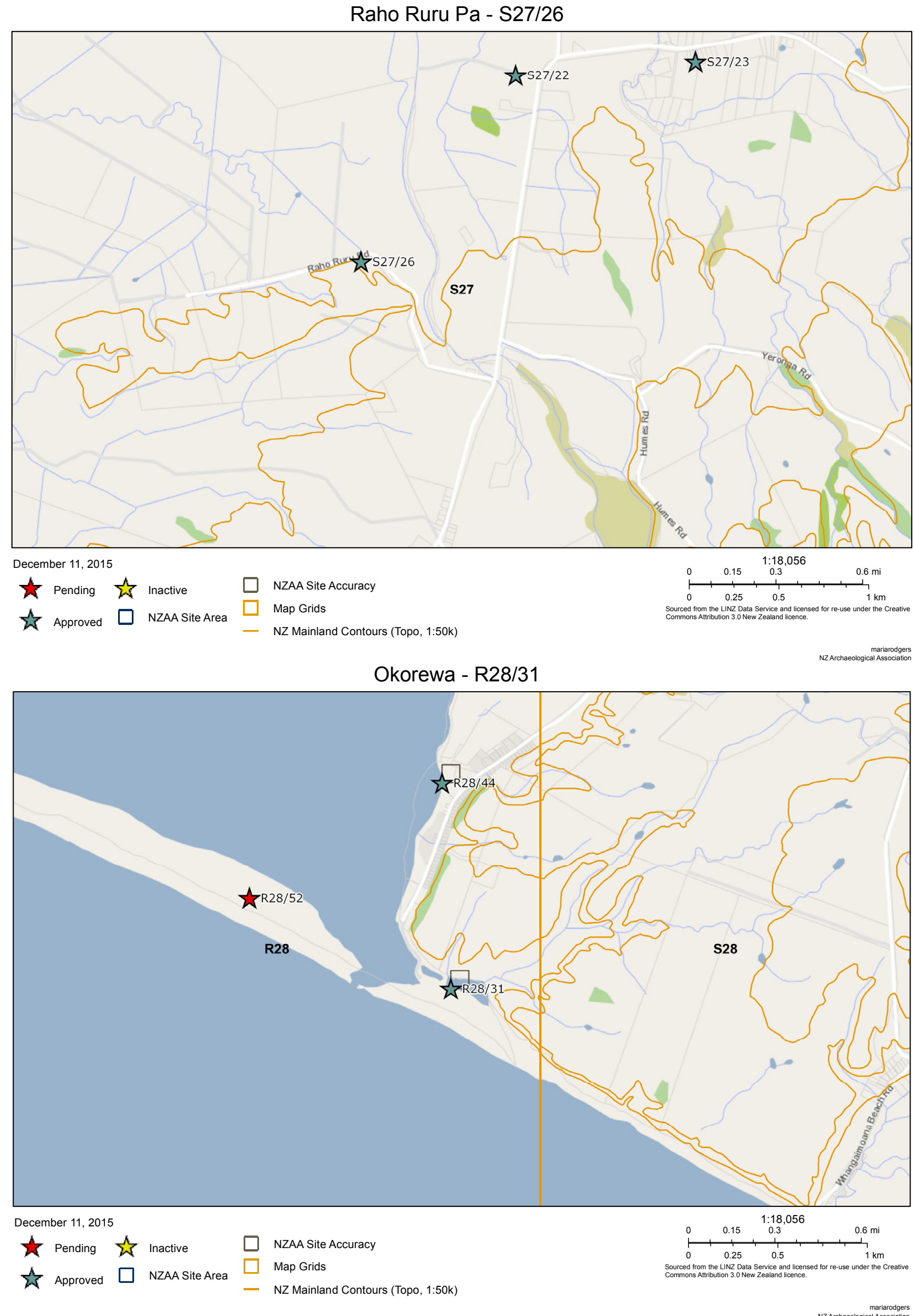
Kakahimakatea (Battery Hill) Pa - R27/122

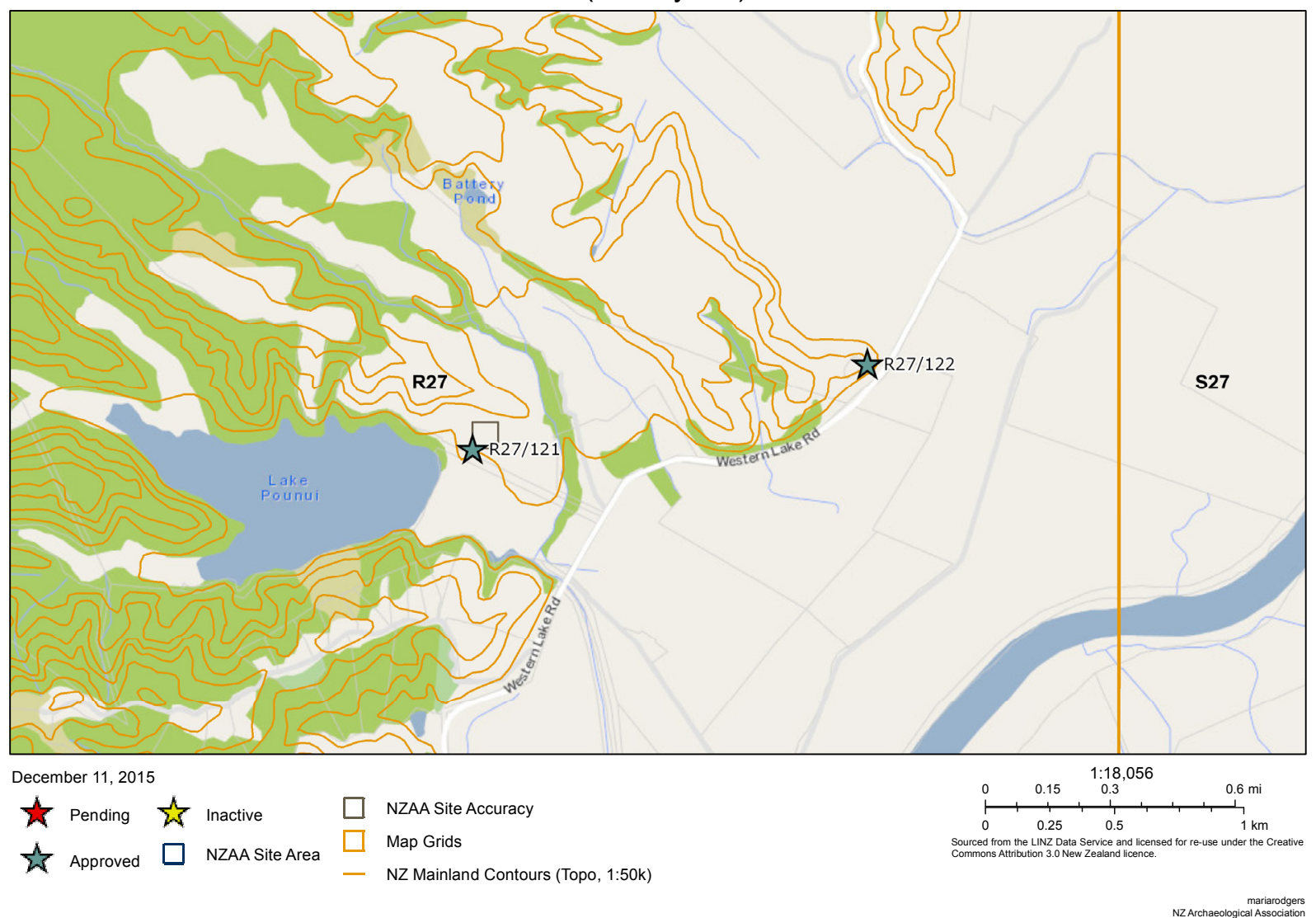




\title{
APPENDIX C: NZ Heritage South Wairarapa Deficient Registration Project Summary List
}

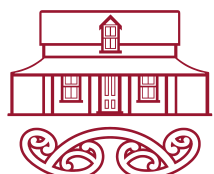

\author{
HERITAGE NEW ZEALAND \\ POUHERE TAONGA
}

\section{South Wairarapa deficient registration project summary}

April 2015

The following prioritisations have been decided based on the information contained in the preliminary Summary Reports for 23 South Wairarapa District Council deficient registrations. This includes two properties owned by South Wairarapa District Council which are denoted in bold type.

\section{Research into these places was discontinued}

\begin{tabular}{|l|c|}
\hline Name & List no. \\
\hline Hitching Rail, Featherston & $\mathbf{3 9 7 7}$ \\
\hline Te Kopura Homestead & 3991 \\
\hline Tinui Hotel (relocated to Greytown) & 4011 \\
\hline
\end{tabular}

\section{Places given Proposal status}

These 20 places are considered good candidates for entry onto the List based on aspects such as historical, social and architectural values. At this stage we are unable to specify in which year's work programme we will be able to complete a full heritage assessment for each of these places and progress them for entry onto the List.

\begin{tabular}{|l|c|}
\hline Name & List no. \\
\hline St Andrews Church & 1307 \\
\hline Royal Hotel, Featherston & 3973 \\
\hline Cottage, 24 Waite St, Featherston & 3974 \\
\hline Cottage, 22 Waite St, Featherston & 3975 \\
\hline War Memorial, Featherston & 3980 \\
\hline Kaiwaiwai Hall (Former Army Camp Building) & 3981 \\
\hline St Francis Church (Non-Denominational) & 3982 \\
\hline Oporua Homestead & 3983 \\
\hline Burnside Church & 3984 \\
\hline Raho Ruru Homestead & 3985 \\
\hline Tuhitarata Homestead & 3986 \\
\hline Tuhitarata Stable/Barn & 3987 \\
\hline Rototawai Stable block/coach house & 3988 \\
\hline Rototawai Machine Shop & 3989 \\
\hline Pihautea Station Former Store & 3992 \\
\hline Ongaha Homestead & 3993 \\
\hline Pihautea Homestead & 3994 \\
\hline Kahutara School Building & 4042 \\
\hline Pihautea Stable & 4043 \\
\hline Tahora Homestead & 5450 \\
\hline
\end{tabular}




\section{APPENDIX D: $\quad$ Balance of Landing Images and Text}

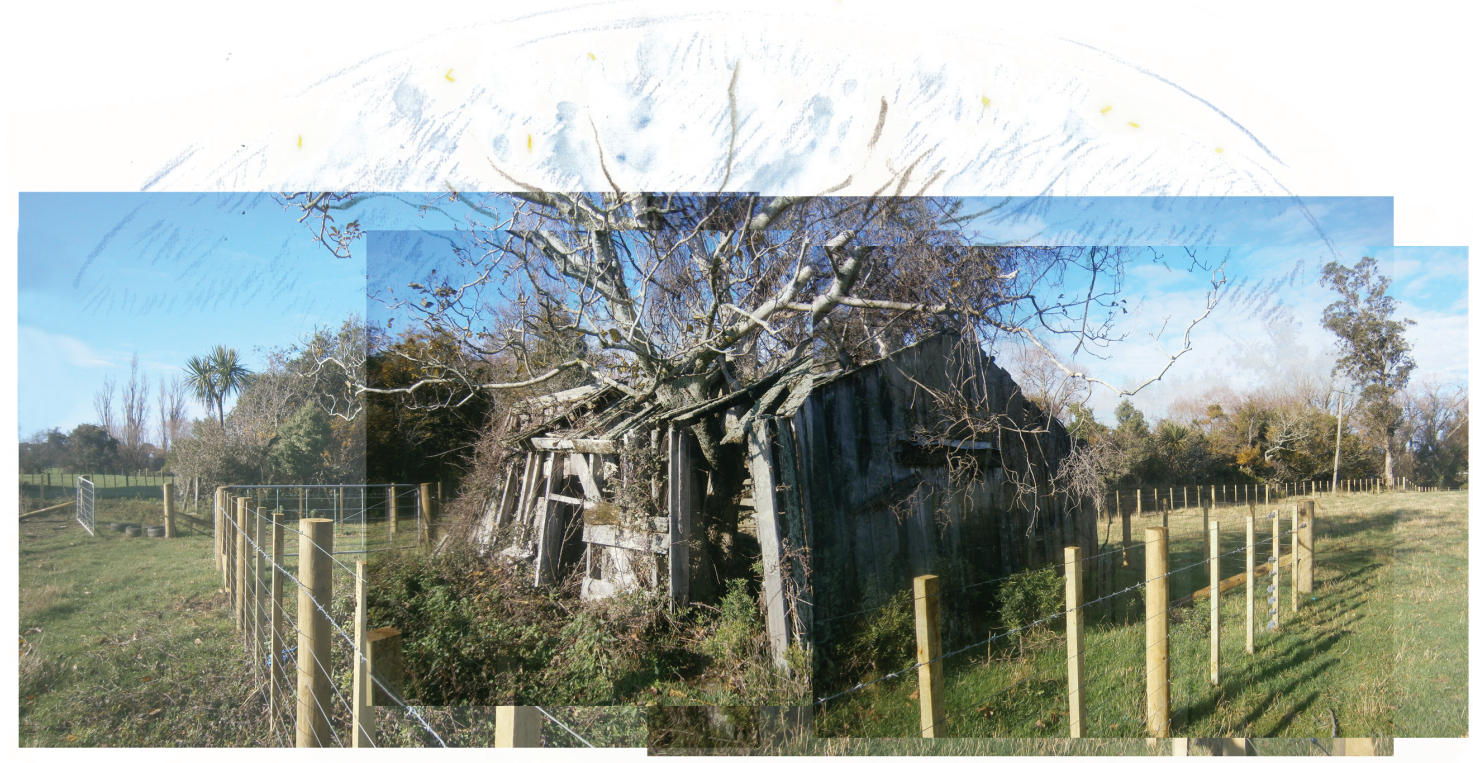

Carkeek Observatory landing

once, a star-seeking telescope looked out from this roof-

now, a walnut tree

reaches up, skywards

holding together

roof and wall

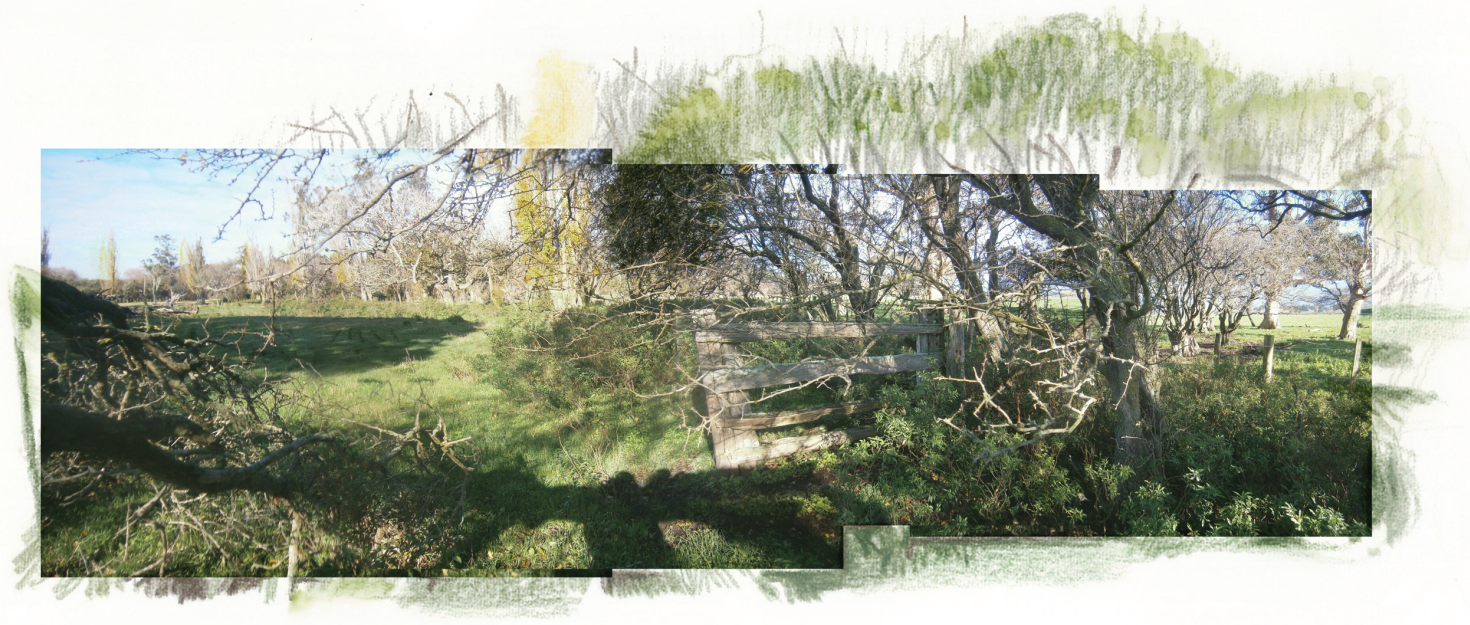

Carkeek house site

landing

all that is left are the trees

- these poplars once lined a driveway

and these pears once fed a family

now they stand in solemn memorial

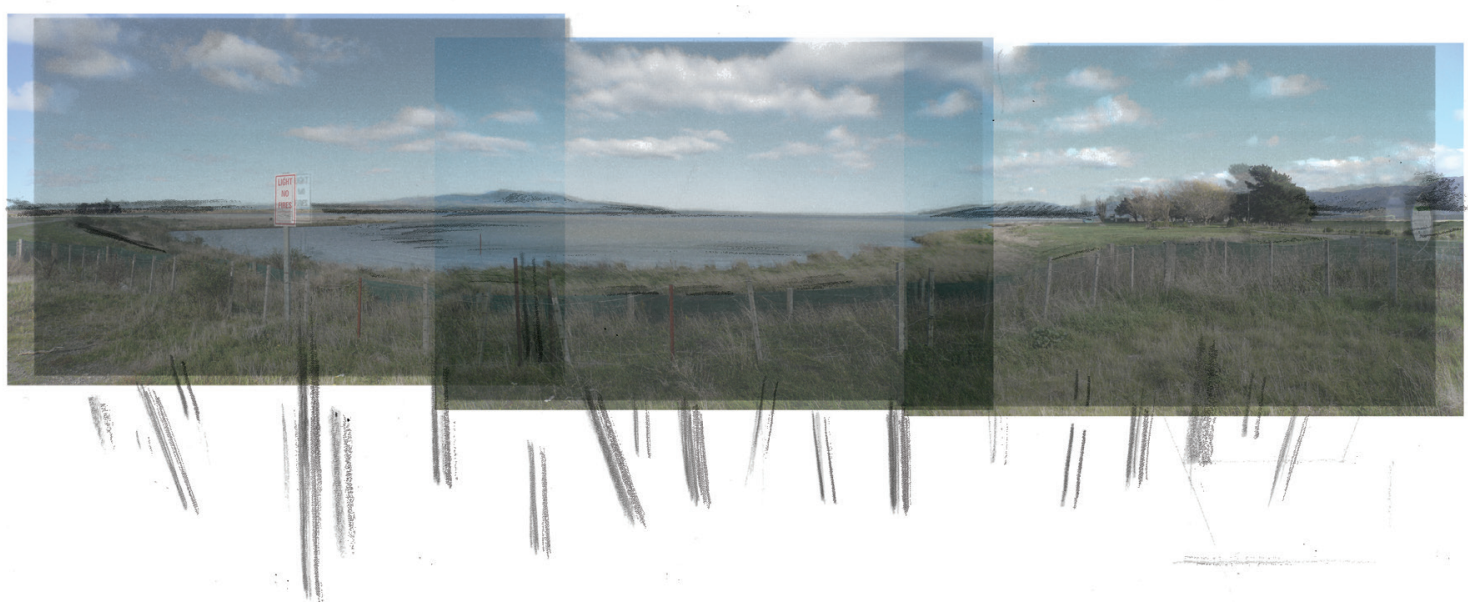

Wairarapa Lake Domain landing

needing

mending,

directionless,

exposing,

emptiness

- although barriers and signs

punctuate/interrupt/

the view

- everywhere I can see looks more inviting than where I am 


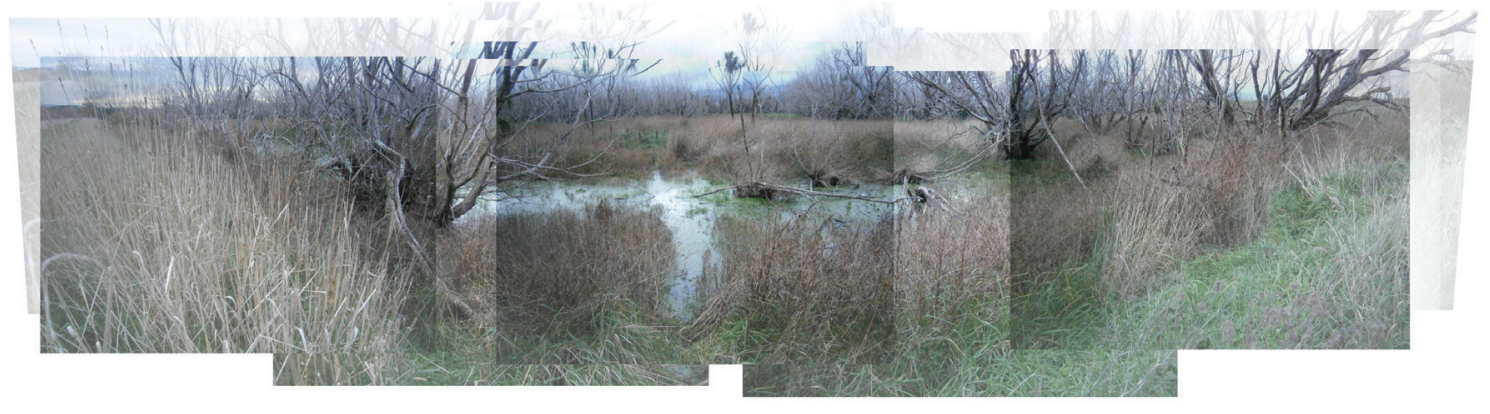

Boggy Pond landing

the willows are grey and their order fading the returning order

has yet to colour -

the water is green,

yet not the plants

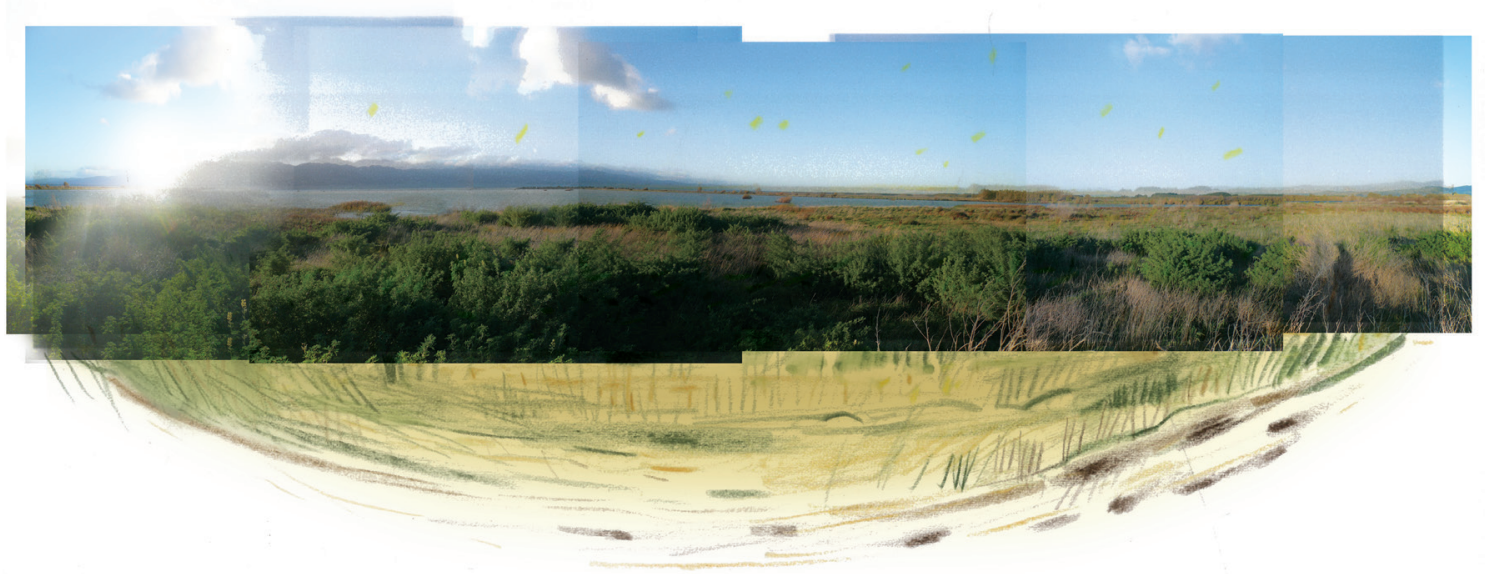

Wairio Wetlands landing

free-dom

barrier-less

life-full

the lake

has a

magnetic pull

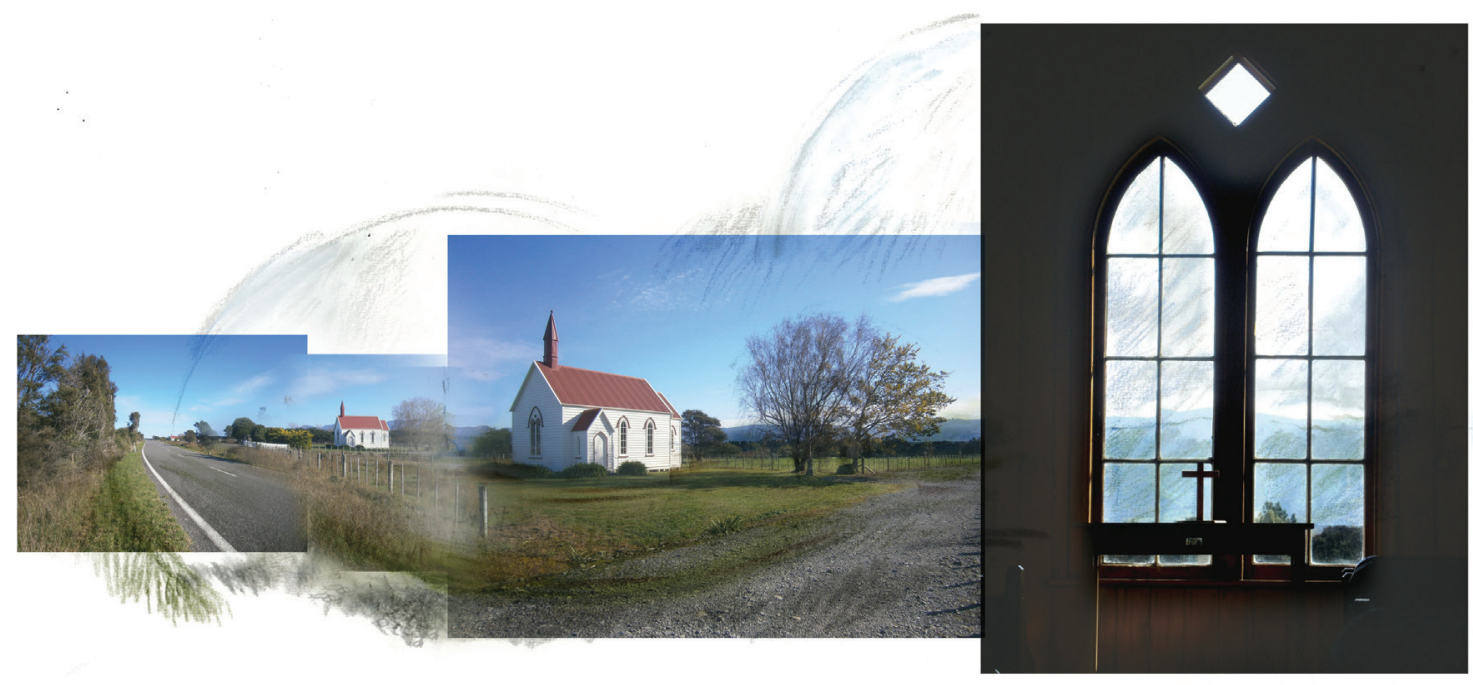

Burnside Church

landing

the church bears witness

to its builder's faith

140 years on

its altar window

frames the Remutaka Range

- a witness long

before faith's arrival 


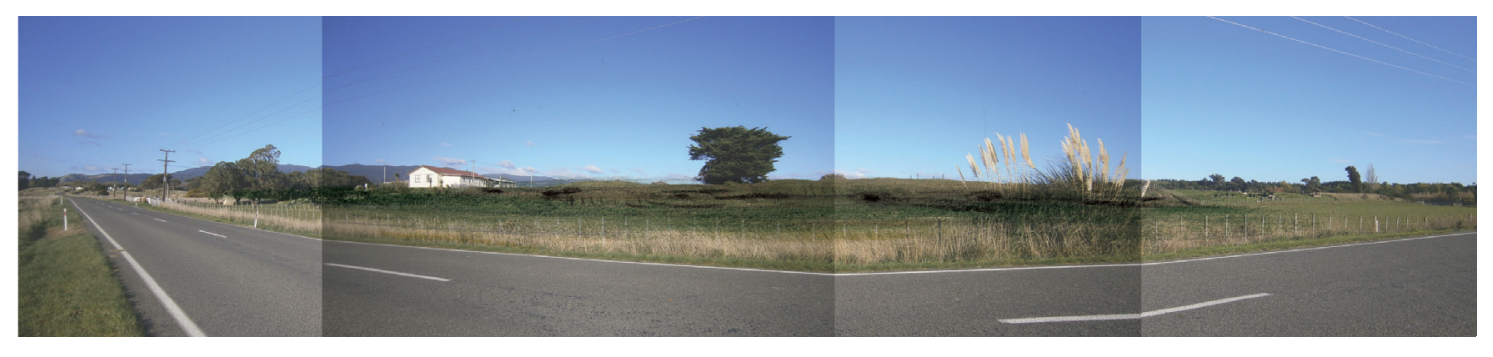

Kohunui Marae landing

a string of past places

strung along the dune crest

- strung between

their present echoes

marae and urupa,

present and past

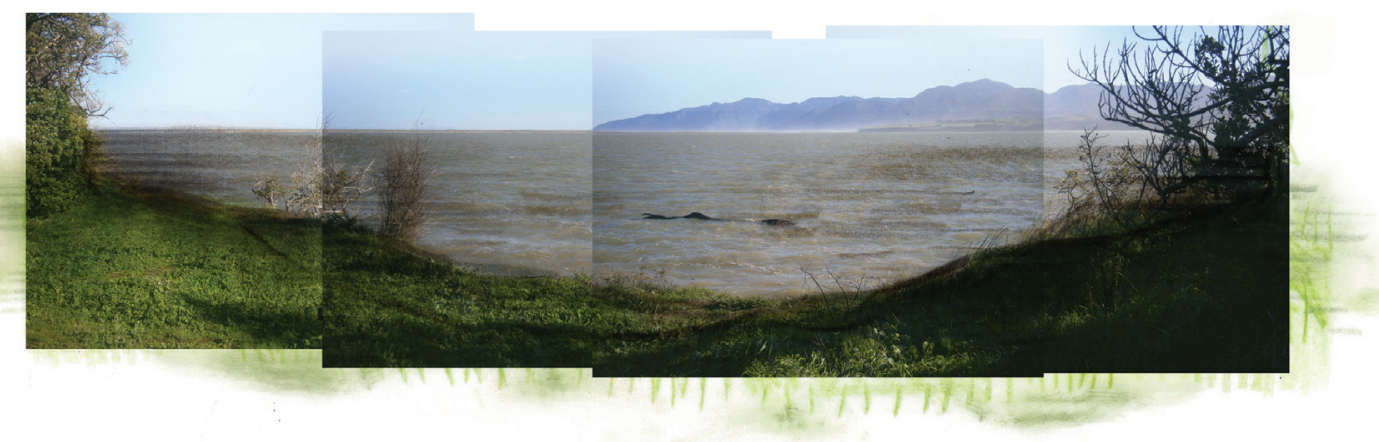

Lake Onoke, at Lake Ferry, landing

land drops away as if not pleased to meet

brown waters

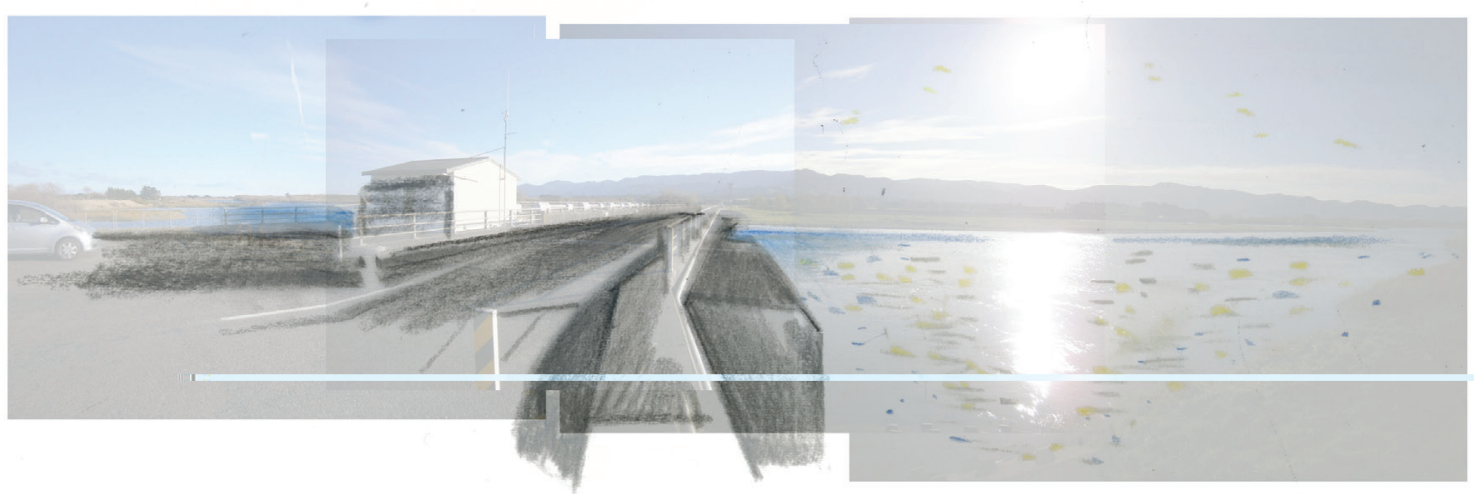

Barrage Gates landing

a static bulk

laid across

the gistening waters 


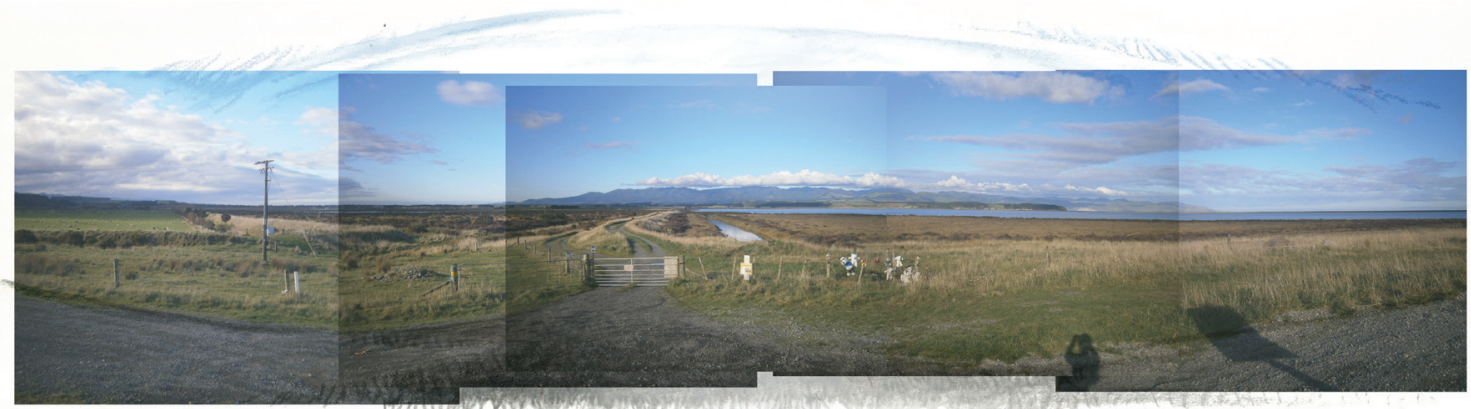

Pounui Lagoon landing

you are not welcomed -

instead greeted by

faded creatures,
hardly meant for wind and

rain

the richness of calling

and flying

and swimming things

and swimming things
remains hidden behind

a gate

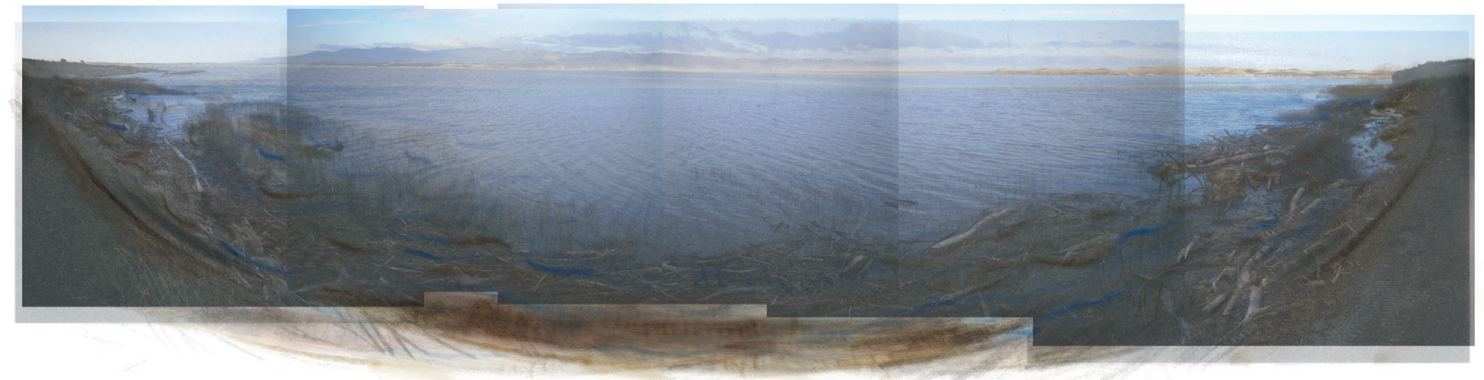

Lake Onoke, Beach

Road, landing

here lake and land

intertwine

with each other

Waiorongomai Church landing

faith

in family

in family

this whenua,

firmly rooted

here 


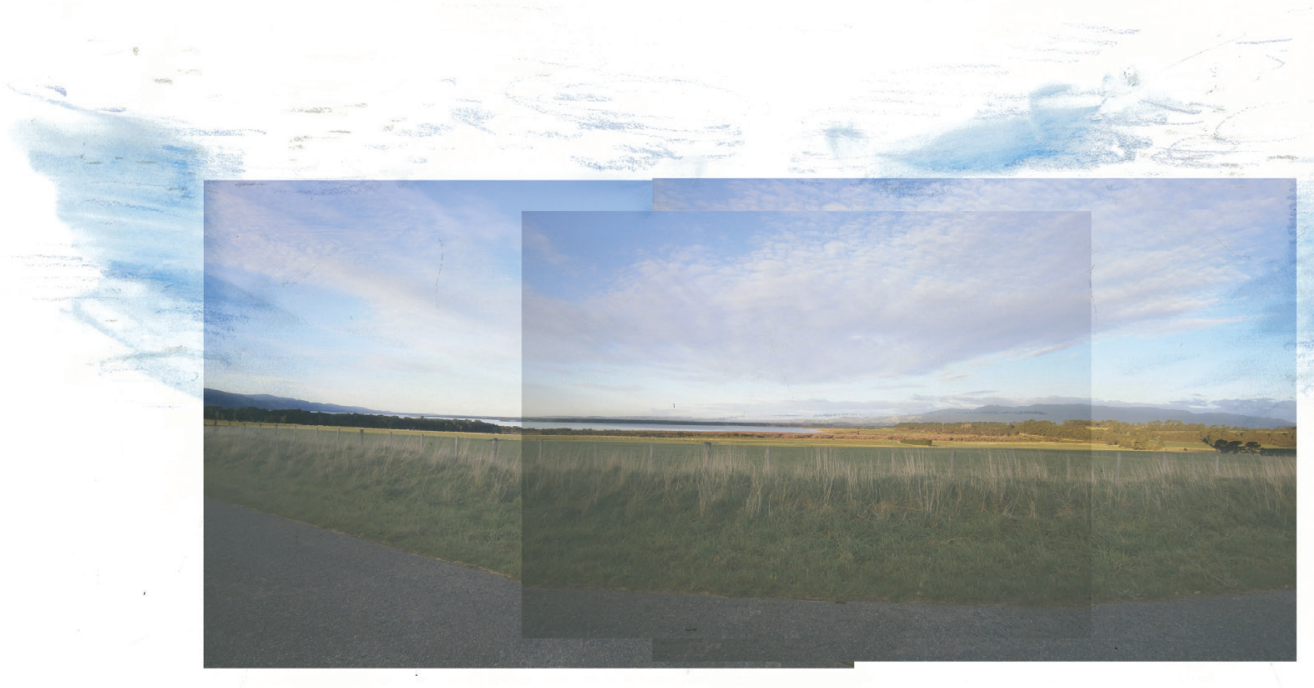

Western Lake Road (travelling north and first view of lake) landing

the lake appears

- a blue underlining

beneath the big sky

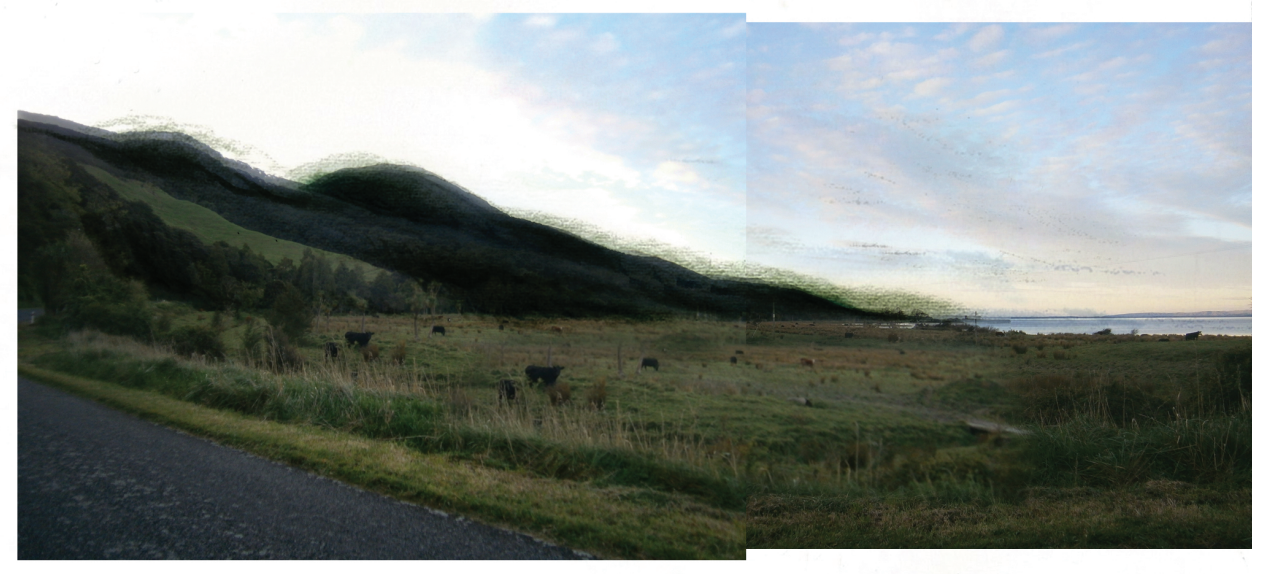

Forest Meets Lake landing

the mountain

clad in mountain clothes

reaches out

to touch the lake 


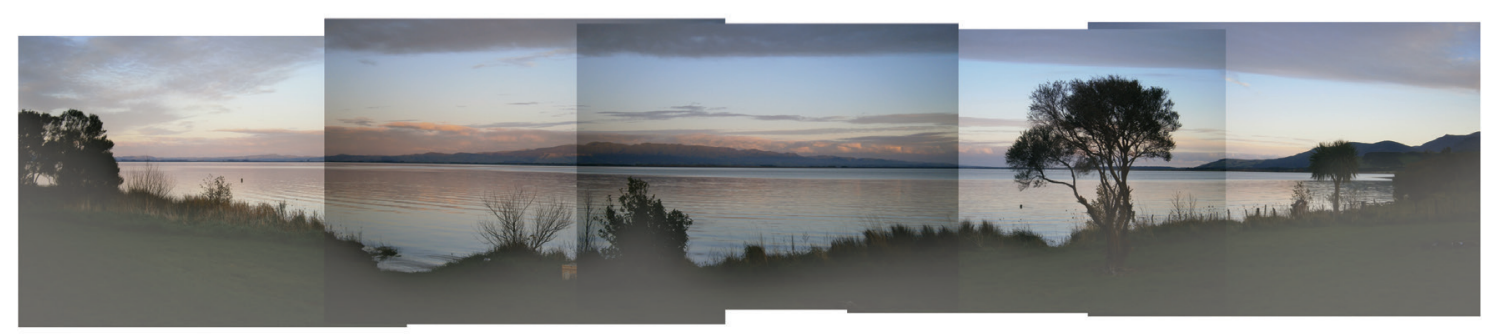

Wairarapa Lake Shore Scenic Reserve landing

this humble edge where

land meets lake

lit meets dark

solid meets fluid

where the mountains,

clad in mountain clothes, and kereru,

reach down to touch the lake

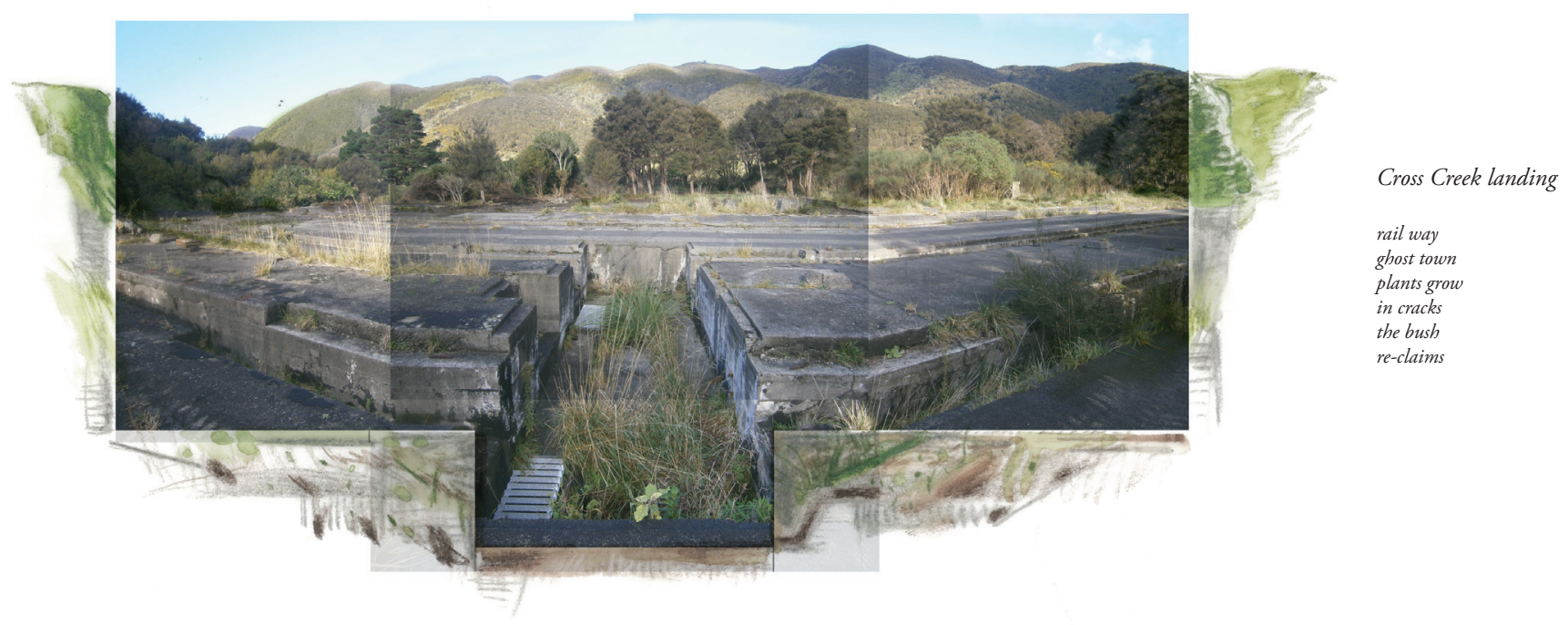


APPENDIX E: Initial Iterations that do not appear elsewhere in thesis document

4. Kaiwaiwai Hall
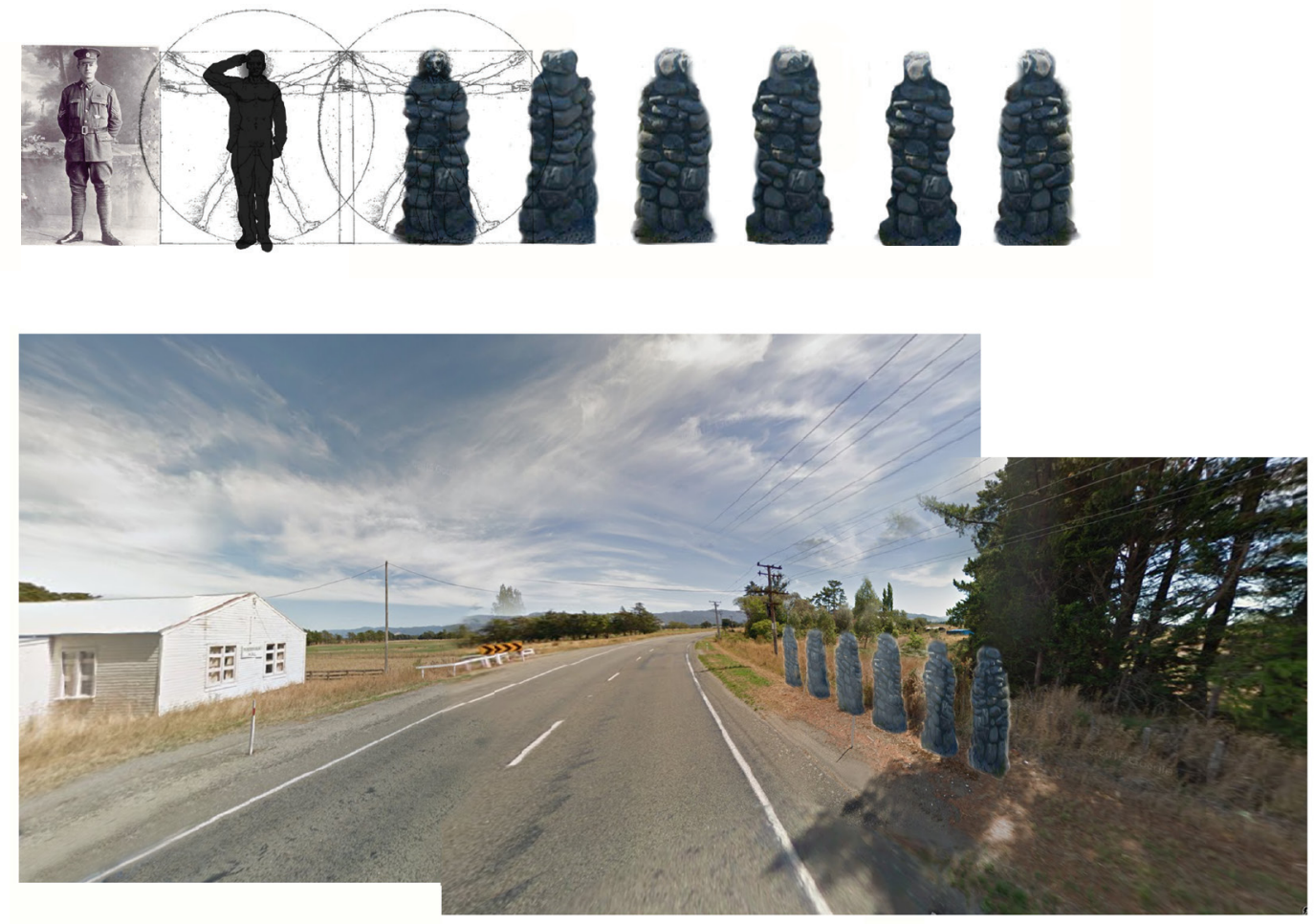

5. Historic homesteads + marine sediments
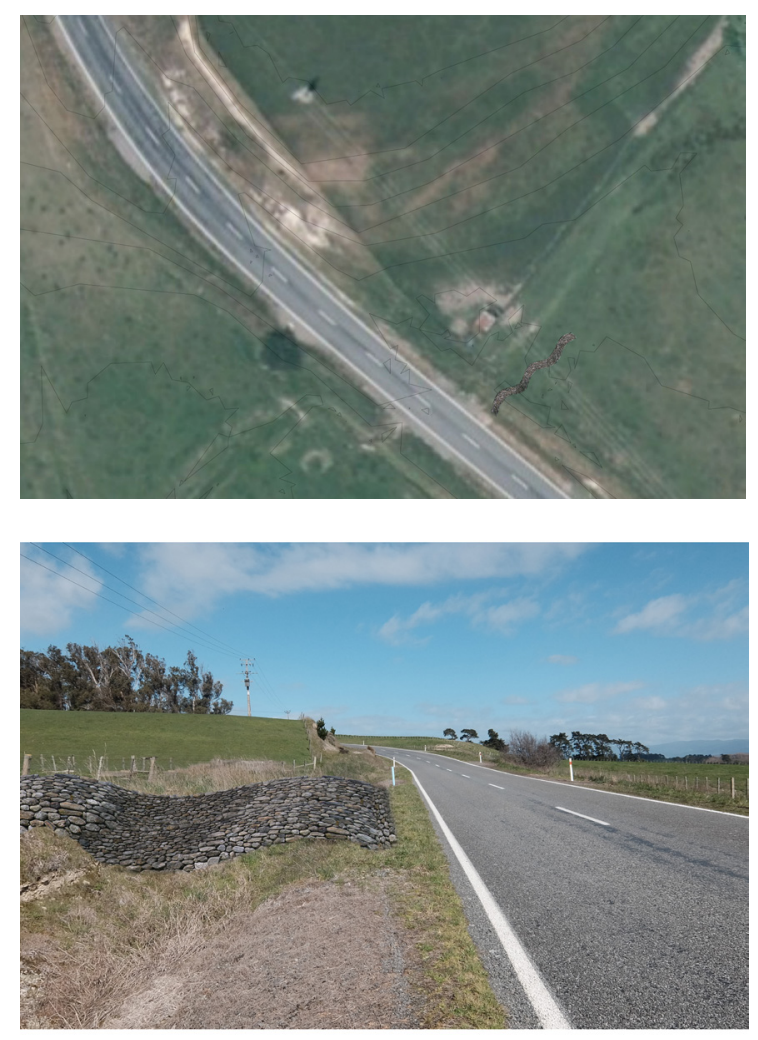
6. Bidwill Green, Kahutara
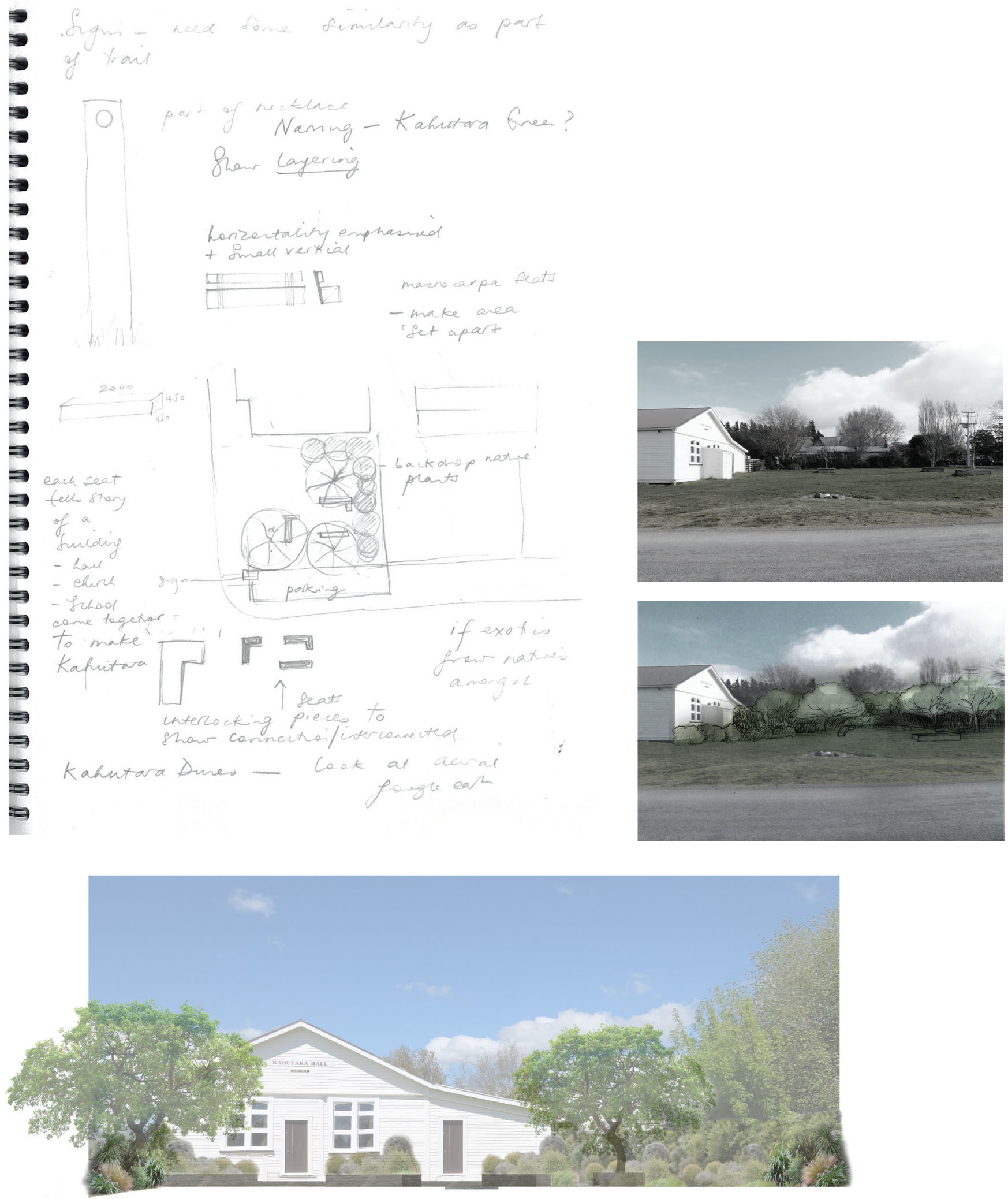
10. Native swamp forest remnants
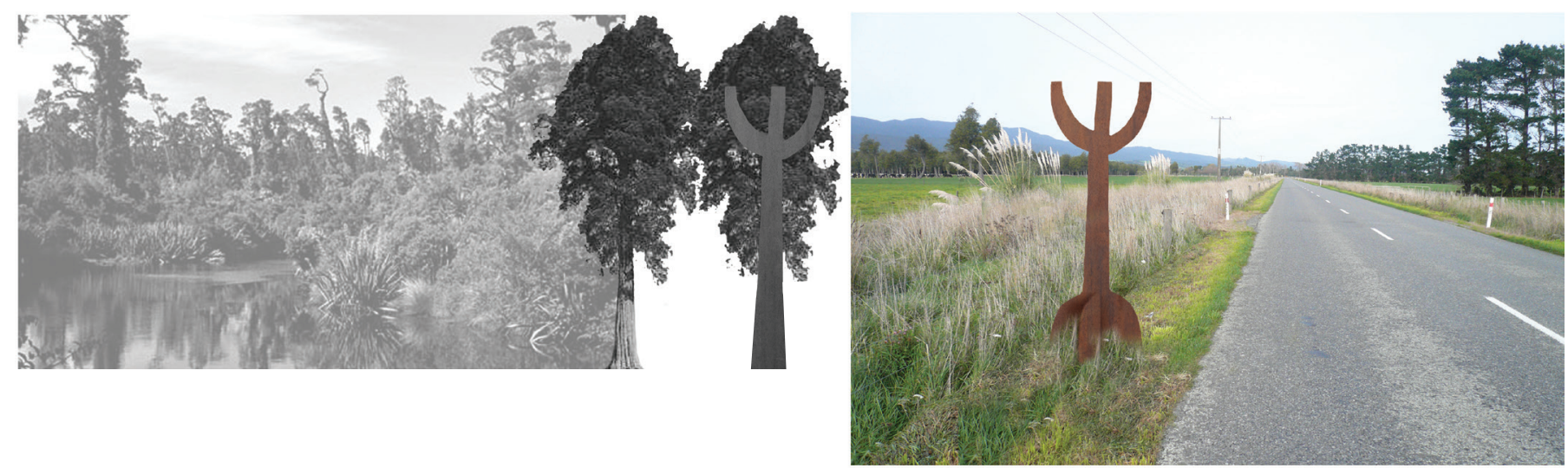

13. Raho Ruru Pa
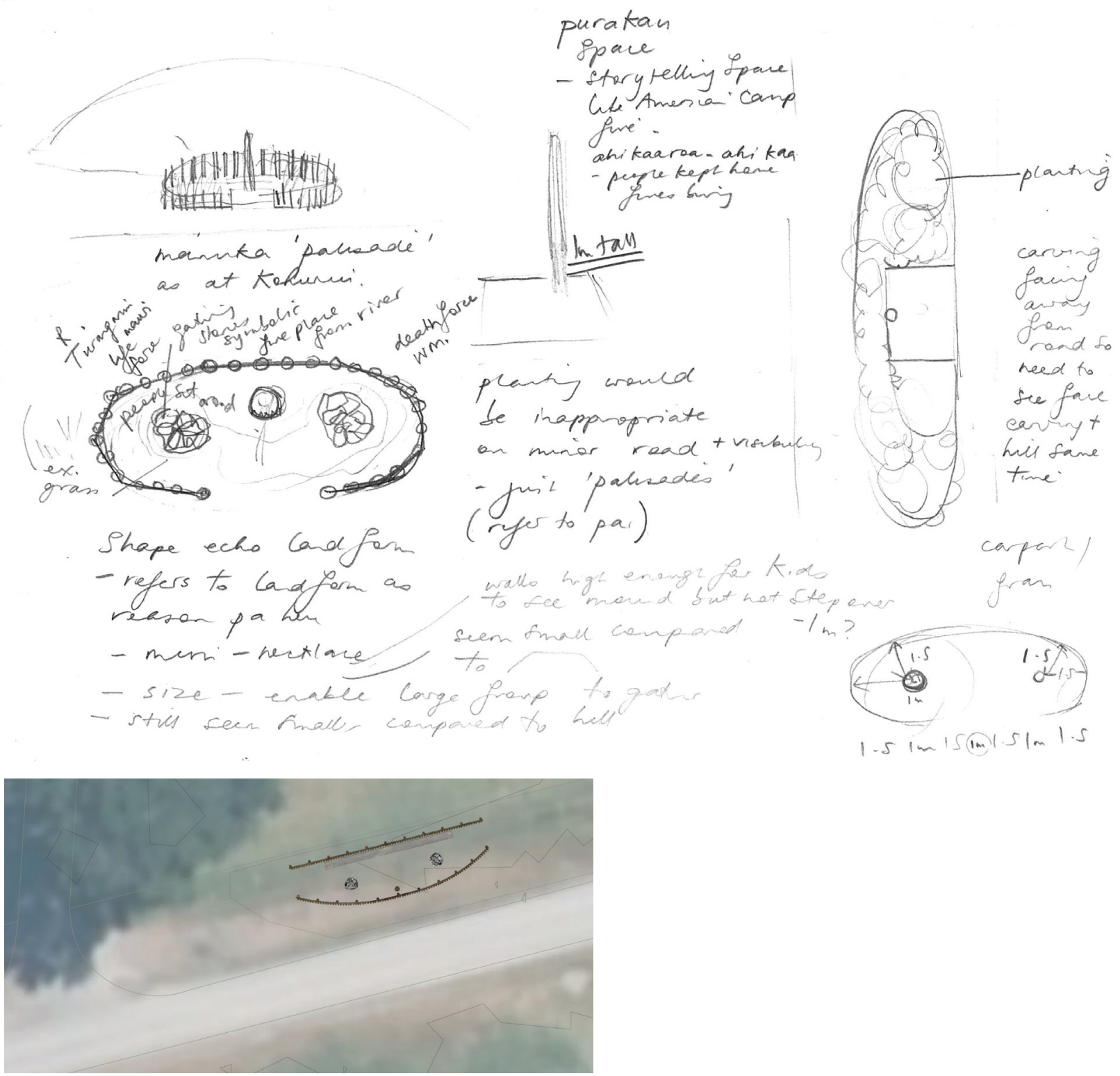
24. Tipapaku (Pigeon Bush) Picnic Area

- Sheep seats

hasarder rest stop

Plotare Simall herzortals

$\Delta$

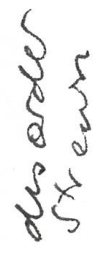

此

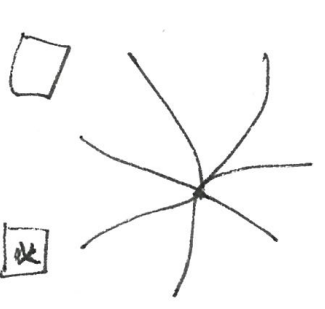

- whace collectrai of afjects steurn, spread, horizentally

+ smallintersptors un the horisontale

Trees kereru hke

- pigeonwood, karaka thinas miro, fawa, puriri, taraire, Kahikatea, mkain + Loprosma (t kowhai leaves withen fruit scarce)

- chak with WRgPI. Gunde

- incidental-look inte objerts ahrays feen there

- hatuing in aligurnet with road

" meet halfuray

244 
APPENDIX F: Plant List

\begin{tabular}{|c|c|c|c|c|c|}
\hline Plant name & $\begin{array}{l}\text { Common } \\
\text { name }\end{array}$ & $\begin{array}{l}\text { Native } \\
\text { /exotic }\end{array}$ & $\begin{array}{l}\text { Plant characteristics, } \\
\text { height x spread } \\
\text { (evergreen unless stated) }\end{array}$ & $\begin{array}{l}\text { Flowering/fruiting } \\
\text { time }\end{array}$ & site \\
\hline Abelia $\mathrm{x}$ grandiflora & glossy abelia & $\mathrm{E}$ & $2 \times 1.5 \mathrm{~m}$, shrub & $\begin{array}{l}\text { mid-summer to } \\
\text { autumn flowering, } \\
\text { white/pinkish }\end{array}$ & BG \\
\hline Clematis montana & $\begin{array}{l}\text { Anemone } \\
\text { clematis }\end{array}$ & $\mathrm{E}$ & $\begin{array}{l}\text { climber, } \\
\text { deciduous }\end{array}$ & $\begin{array}{l}\text { early spring flowering, } \\
\text { white }\end{array}$ & BG \\
\hline Coprosma acerosa & sand coprosma & $\mathrm{N}$ & $0.4 \times 1 \mathrm{~m}$, ground cover & smoky blue berries & LO \\
\hline Coprosma crassifolia & & $\mathrm{N}$ & $3 \times 2 \mathrm{~m}$ shrub & & WV \\
\hline Coprosma grandifolia & kanono & $\mathrm{N}$ & $4 \times 2.5 \mathrm{~m}$ shrub or small tree & late summer berries & BG \\
\hline Coprosma robusta & karamū & $\mathrm{N}$ & $2-4 \mathrm{~m}$ shrub or small tree & late summer berries & RR, BG, TPB \\
\hline Cordyline australis & $\begin{array}{l}\text { ti kōuka } \\
\text { cabbage tree }\end{array}$ & $\mathrm{N}$ & $8 \times 3 m$ tree & $\begin{array}{l}\text { late spring/summer, } \\
\text { cream flowers }\end{array}$ & RR, WV, TPB \\
\hline $\begin{array}{l}\text { Cornyocarpus } \\
\text { laevigatus }\end{array}$ & karaka & $\mathrm{N}$ & $\begin{array}{l}\text { size } 10 \text { years } 6 \times 5 \mathrm{~m} \text {, } \\
\text { maturity } 12 \times 5 \mathrm{~m} \text {, tree }\end{array}$ & $\begin{array}{l}\text { late summer and } \\
\text { autumn fruiting, } \\
\text { orange }\end{array}$ & $\mathrm{RR}, \mathrm{TPB}$ \\
\hline Cortaderia toetoe & toetoe & $\mathrm{N}$ & $\begin{array}{l}1.5 \times 2 \mathrm{~m} \text {, up to } 4 \mathrm{~m} \text { tall when } \\
\text { in flower, grass }\end{array}$ & $\begin{array}{l}\text { spring and summer } \\
\text { flowering }\end{array}$ & RR \\
\hline Eleaocarpus dentatus & hīnau & $\mathrm{N}$ & $\begin{array}{l}5 \times 4 \mathrm{~m} \text {, eventually up to } 8 \mathrm{~m}, \\
\text { tree }\end{array}$ & spring flowering & RR, TPB \\
\hline $\begin{array}{l}\text { Hebe stricta var. } \\
\text { stricta }\end{array}$ & koromiko & $\mathrm{N}$ & $2 \mathrm{~m}$ shrub & $\begin{array}{l}\text { white flowers, } \\
\text { summer }\end{array}$ & BG \\
\hline Hedycarya arborea & $\begin{array}{l}\text { porokaiwhiri, } \\
\text { pigeonwood }\end{array}$ & $\mathrm{N}$ & $\begin{array}{l}\text { size at } 10 \text { years } 2.5 \times 2 \mathrm{~m} \text {, } \\
\text { maturity } 12 \times 3 \mathrm{~m} \text {, tree }\end{array}$ & berries, orange-red & TPB \\
\hline $\begin{array}{l}\text { Helicrysum } \\
\text { lanceolatum }\end{array}$ & niniao & $\mathrm{N}$ & $\begin{array}{l}1.5 \times 1.5 \mathrm{~m} \text {, semi-prostrate to } \\
\text { shrub }\end{array}$ & spring, tiny flowers & WV, BG \\
\hline Hydrangea aspera & star hydrangea & E & $3 \times 3 \mathrm{~m}$, deciduous shrub & $\begin{array}{l}\text { summer flowering, } \\
\text { pink/purple/blue }\end{array}$ & BG \\
\hline $\begin{array}{l}\text { Leptospermum } \\
\text { scoparium }\end{array}$ & mānuka & $\mathrm{N}$ & $4 \times 1.5 \mathrm{~m}$ tree & spring, white flowers & WV \\
\hline Magnolia denudata & Yulan magnolia & E & $5 \times 4 m$ tree & $\begin{array}{l}\text { early spring flowering, } \\
\text { white }\end{array}$ & BG \\
\hline Melicytus crassifolius & $\begin{array}{l}\text { thick leaved } \\
\text { mahoe }\end{array}$ & $\mathrm{N}$ & $1 \times 1 \mathrm{~m}$ shrub & & WV, LO \\
\hline Myrsine salicina & toro & $\mathrm{N}$ & $6 \times 3 m$ tree & $\begin{array}{l}\text { pinkish flowers and } \\
\text { berries }\end{array}$ & BG \\
\hline $\begin{array}{l}\text { Neomyrtus } \\
\text { pedunculata }\end{array}$ & rōhutu & $\mathrm{N}$ & $3 \times 1.5 \mathrm{~m}$ & $\begin{array}{l}\text { summer white } \\
\text { flowers, autumn } \\
\text { orange-red berries }\end{array}$ & BG \\
\hline $\begin{array}{l}\text { Philadelphus } \\
\text { coronarius }\end{array}$ & $\begin{array}{l}\text { sweet mock } \\
\text { orange }\end{array}$ & E & $2 \times 1.5 \mathrm{~m}$ deciduous shrub & $\begin{array}{l}\text { early summer } \\
\text { flowering, white }\end{array}$ & BG \\
\hline
\end{tabular}




\begin{tabular}{|c|c|c|c|c|c|}
\hline $\begin{array}{l}\text { Phormium } \\
\text { cookianum }\end{array}$ & wharariki & $\mathrm{N}$ & $\begin{array}{l}\text { 1.2-1.5m height and width, } \\
\text { clump-forming perennial }\end{array}$ & yellow-orange flowers & LO \\
\hline Pimelia arenaria & sand daphne & $\mathrm{N}$ & $0.5 \times 1 \mathrm{~m}$ prostrate shrub & & LO \\
\hline $\begin{array}{l}\text { Plagianthus } \\
\text { divaricatus }\end{array}$ & $\begin{array}{l}\text { mākaka, salt } \\
\text { marsh } \\
\text { ribbonwood }\end{array}$ & $\mathrm{N}$ & $2 \times 1.5 \mathrm{~m}$ shrub & & WV, BG \\
\hline Poa cita & silver tussock & $\mathrm{N}$ & $50 \times 50 \mathrm{~cm}$, grass & & BG, LO \\
\hline $\begin{array}{l}\text { Prunus sato-zakura } \\
\text { 'Hokusai' syn. } \\
\text { Prunus serrulata } \\
\text { 'Hokusai' }\end{array}$ & $\begin{array}{l}\text { Hokusai Japanese } \\
\text { flowering cherry }\end{array}$ & E & $\begin{array}{l}5 \times 4 \mathrm{~m} \text { after } 10 \mathrm{yrs}, 6 \times 8 \mathrm{~m} \text { after } \\
20 \mathrm{yrs} \text {, deciduous tree }\end{array}$ & spring flowering & BG \\
\hline Rhopalostylis sapida & nīkau & $\mathrm{N}$ & $\begin{array}{l}10 \text { years } 1.5 \times 1 \mathrm{~m} \text {, maturity } \\
10 \times 3 \mathrm{~m} \text {, palm }\end{array}$ & & TPB \\
\hline Ribes sanguineum & flowering currant & E & $1.5 \times 1 \mathrm{~m}$, deciduous shrub & $\begin{array}{l}\text { early spring flowering, } \\
\text { deep pink }\end{array}$ & BG \\
\hline Sophora microphylla & kōwhai & $\mathrm{N}$ & $5 \times 3 \mathrm{~m}$, tree & $\begin{array}{l}\text { spring flowering, } \\
\text { bright yellow }\end{array}$ & TPB \\
\hline $\begin{array}{l}\text { Syringa vulgaris } \\
\text { 'Charles Joly' }\end{array}$ & lilac & $\mathrm{E}$ & $\begin{array}{l}2.5 \times 1.5 \mathrm{~m} \text {, deciduous } \\
\text { shrub/small tree }\end{array}$ & $\begin{array}{l}\text { Late spring flowering, } \\
\text { purple }\end{array}$ & BG \\
\hline Viburnum carlesii & $\begin{array}{l}\text { Korean } \\
\text { viburnum }\end{array}$ & $\mathrm{E}$ & $1.5 \times 1.5 \mathrm{~m}$, deciduous shrub & $\begin{array}{l}\text { Spring flowering, } \\
\text { white/pink }\end{array}$ & BG \\
\hline Viburnum opulus & Guelder rose & $\mathrm{E}$ & $4 \times 3 \mathrm{~m}$, deciduous shrub & $\begin{array}{l}\text { Spring flowering, } \\
\text { white }\end{array}$ & BG \\
\hline $\begin{array}{l}\text { Weinmannia } \\
\text { racemosa }\end{array}$ & kamahi & $\mathrm{N}$ & $8 \times 4 m$, tree & $\begin{array}{l}\text { spring to summer } \\
\text { flowering, cream }\end{array}$ & BG \\
\hline
\end{tabular}

\section{Site Key}

BG Bidwill Green

LO Lake Onoke

RR Raho Ruru Pa

TPB Tipapaku (Pigeon Bush)

WV Wharekauhau Viewpoint

\section{Sources:}

Cave, Yvonne, and Valda Paddison. The Gardener's Encyclopedia of New Zealand Native Plants. New Zealand: Godwit, 1999. Print.

Oratia Native Plant Nursery. N.p., 2007. Web. 22 Feb. 2016. <http://www.oratianatives.co.nz/>.

Palmer, Stanley J. Palmers Manual of Trees, Shrubs Eamp; Climbers. Runaway Bay, Qld., Australia: Lancewood Pub., 1994. Print. 


\section{APPENDIX G: $\quad$ Ethics Approval Documents}

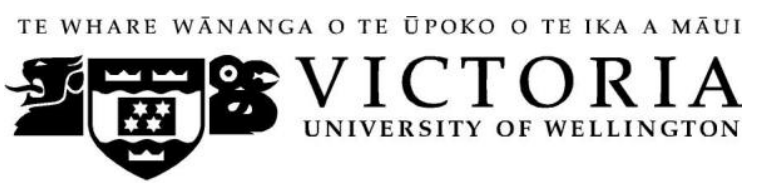

\section{MEMORANDUM}

\begin{tabular}{l|l}
\hline TO & Maria Rodgers \\
\hline COPY TO & Bruno Marques \\
\hline FROM & AProf Susan Corbett, Convener, Human Ethics Committee \\
\hline DATE & 15 May 2015 \\
\hline PAGES & 1 \\
\hline & $\begin{array}{l}\text { Ethics Approval: 21875 } \\
\text { A telling of South Wairarapa stories - interpretation of } \\
\text { archaeological and heritage sites through landscape architecture }\end{array}$ \\
\hline
\end{tabular}

Thank you for your application for ethical approval, which has now been considered by the Standing Committee of the Human Ethics Committee.

Your application has been approved from the above date and this approval continues until 16 February 2016. If your data collection is not completed by this date you should apply to the Human Ethics Committee for an extension to this approval.

Best wishes with the research.

Susan Corbett

Human Ethics Committee
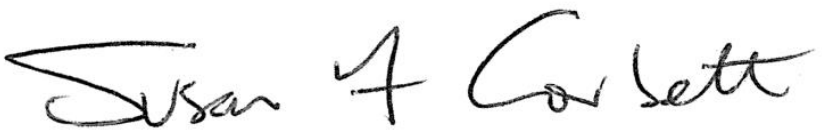


\section{PARTICIPANT INFORMATION SHEET}

Title of project: A telling of South Wairarapa stories - interpretation of archaeological and heritage sites through landscape architecture

Master's Thesis Research, LAND 591

Student: Maria Rodgers

Supervisor: Bruno Marques

Nature and Purpose of Research

Research Question: How can landscape architectural interventions connect people to the past in rural Aotearoa New Zealand?

Proposition

Our rural landscapes contain rich and varied stories, which, if interpreted and made stronger by being linked together, have the potential to create a cultural and recreational asset as well as a tourist drawcard. Telling the stories in the landscape helps to restore and build connection to the land, for all people, Māori and Pakeha. This research will consist of a set of design case studies into heritage sites in rural South Wairarapa. It will focus on six sites on the margins of the lake identified by the Wairarapa Moana Management Team as sites they wish to see developed. Additional archaeological and heritage sites will be connected to these and create an outer 'necklace' of interpreted stories. This design-led research will endeavour to connect the sites together, forming heritage trails that will contribute a cultural, recreational and tourist resource to the South Wairarapa. This research project has received approval from the Victoria University Human Ethics Committee.

Research Aims

- To add richness to experiences of the sites, and the area as a whole, by bringing to the surface the stories woven into the whenua, the land, or, in Christophe Girot's words, to "reactivate the cultural dimensions of sites" (59)

- To preserve the genius loci, sense of place, of each site

- To develop a series of design proposals that have a light touch, are small scale and economically feasible.

Collection and Use of Material

Visits by the participants and the researcher to the sites on the margins of Wairarapa Moana, and additional sites identified by the participants or researcher, will be undertaken. Conversations between the participant/s and researcher regarding the site will be recorded/taped. Photographs will be taken of the site that may include the participants. Sketches of the site may include input of the participants or representation of them. The material collected will be used, along with other information, analysis, and feedback from the participants, including the Wairarapa Moana Management Team, to inform the design of landscape architectural interventions on selected sites. Information gathered will be securely stored and kept in a locked file with access restricted to the investigator. All electronic information, data and images will be password protected and access restricted to the investigator. The participants have the right to withdraw from the research by the end of August 2015. 
SCHOOL OF ARCHITECTURE Te Kura Waihanga

FACULTY OF ARCHITECTURE \& DESIGN Te Wāhanga Waihanga-Hoahoa

VICTORIA UNIVERSITY OF WELLINGTON, PO Box 600, Wellington 6140,

New Zealand Phone +64-4-463 6200 Fax +64-4-463 6204 Email

architecture@vuw.ac.nz Web www.victoria.ac.nz/architecture

\title{
PARTICIPANT CONSENT FORM
}

Title of project: A telling of South Wairarapa stories - interpretation of archaeological and heritage sites through landscape architecture

Master's Thesis Research, LAND 591

\author{
Student: Maria Rodgers \\ Supervisor: Bruno Marques
}

- I consent to the researcher collecting data, information, stories or opinions from me.

- I consent to data, information, stories or opinions which I have given being attributed to me in any reports for this research.

- I understand I can be given, if requested, a transcript of any interviews with me.

- I understand that I will have an opportunity to check the transcripts of the interview and the text of the research before publication and that I will be consulted for my feedback on any resulting designs.

- I consent to the taking of any visual images of myself that are generated as part of the data collecting/story telling process.

- I understand these images may also to be used for student reviews and/or inclusion in the thesis, which will be stored electronically in the University Library.

- I understand that the data I provide, and images of myself, will not be used for any purpose other than research for the named thesis, or released to others, without my written consent.

- I understand that all written material will be kept in a locked file with access restricted to the investigator. I understand that all electronic information will be password protected and access restricted to the investigator.

- I understand that I have the right to withdraw from being a participant in this research by the end of August 2015 and I have the right to decline to be recorded or photographed.

- I agree to take part in this research.

Signed:

Date:

Name of participant and contact details: 